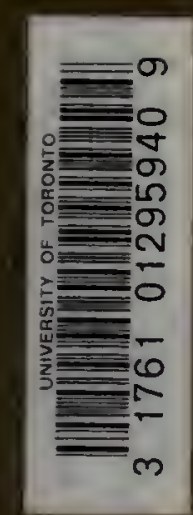

UWIY DI: ropono WBRAM 



\section{Digitized by the Internet Archive in 2008 with funding from Microsoft Corporation}




\section{TYPE AMMONITES}

III 
Additions to fauna decrease the imperfection of the zoological, but increase that of any local geological record: the gaps caused by destruction stand revealed more plainly 


\title{
TYPE AMMONITES
}

IIY

\author{
S. S. BUCKMAN, F.G.S.
}

Correspondent of the Paleontological Society (U.S.A.);

Hon. Member of the Yorkshire Philosophical Society ;

of the Cheltenham Natural Science Soc. etc.

The illustrations from photographs by

J. W: TUTCHER

and

The Author

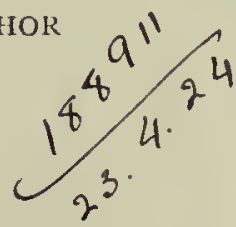

VOL. III

(Pp I 64; Plates CXXXI CCLXVIN(197); 3 Portraits

\author{
Published by the Author \\ SOLD BY \\ WHELDON AND WESLEY, LTD. \\ INCORPORATING \\ WILLIAM WESLEY AND SON \\ 28 ESSEX STREET, STRAND, LONDON, W.C. 2 \\ IgI9-I92 I
}




\section{CONTENTS}

PAGE

$\begin{array}{lllllllll}\text { Editorial } & \ldots & \ldots & \ldots & \ldots & \ldots & \ldots & \ldots & \end{array}$

$\begin{array}{llllllllll}\text { Terminology } & \ldots & \ldots & \ldots & \ldots & \ldots & \ldots & \ldots & & 5\end{array}$

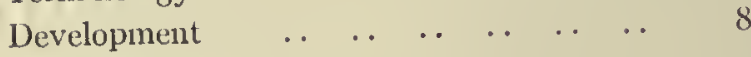

$\begin{array}{llllllllll}\text { Chronology } & \ldots & \ldots & \ldots & \ldots & \ldots & \ldots & \ldots & & 9\end{array}$

$\begin{array}{lllllllll}\text { Terminology } & \ldots & \ldots & \ldots & \ldots & \ldots & \ldots & \ldots & \text { II }\end{array}$

$\begin{array}{lllllllll}\text { Systematic } & \ldots & \ldots & \ldots & \ldots & \ldots & \ldots & \ldots & \text { I2 }\end{array}$

$\begin{array}{llllllllll}\text { Terminology } & \ldots & \ldots & \ldots & \ldots & \ldots & \ldots & \ldots & 3 \mathrm{r}\end{array}$

$\begin{array}{llllllllll}\text { Systematic } & \ldots & \ldots & \ldots & \ldots & \ldots & \ldots & \ldots & 32\end{array}$

$\begin{array}{lllllllll}\text { Corrigenda } & \ldots & \ldots & \ldots & \ldots & \ldots & \ldots & \ldots & 55\end{array}$

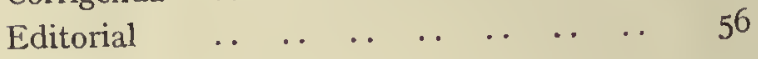

$\begin{array}{llllllllll}\text { Index } & \ldots & \ldots & \ldots & \ldots & \ldots & \ldots & \ldots & \ldots & 57\end{array}$

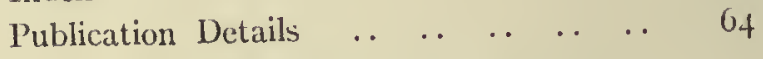

With 177 . Plates and 3 Portraits 


\section{vol. 3. $4^{4}$}
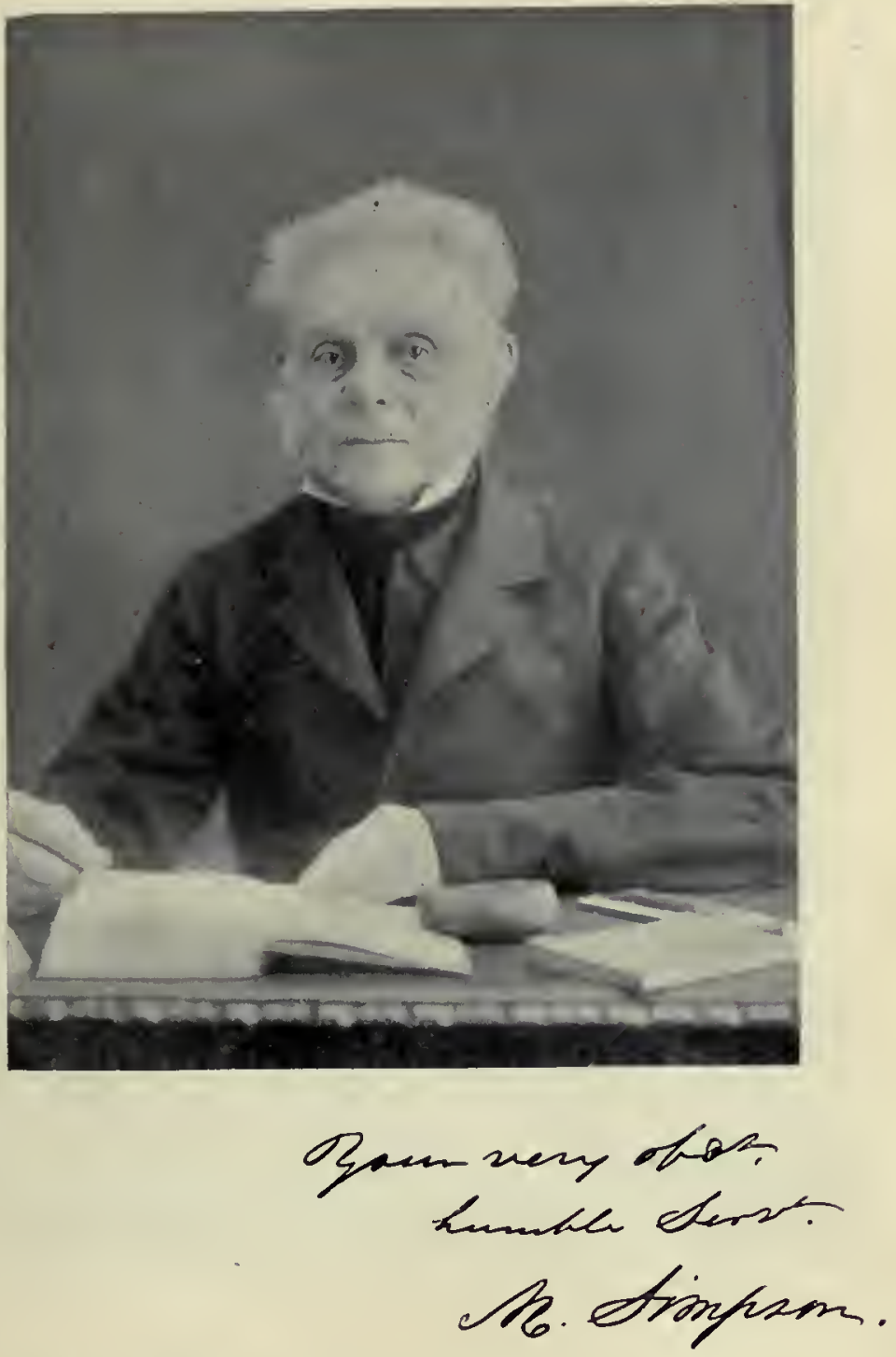

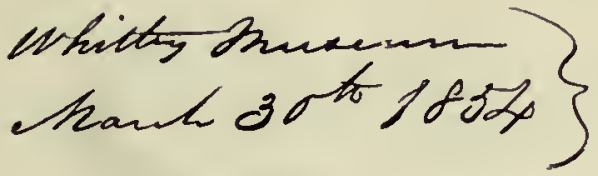



vol. 3

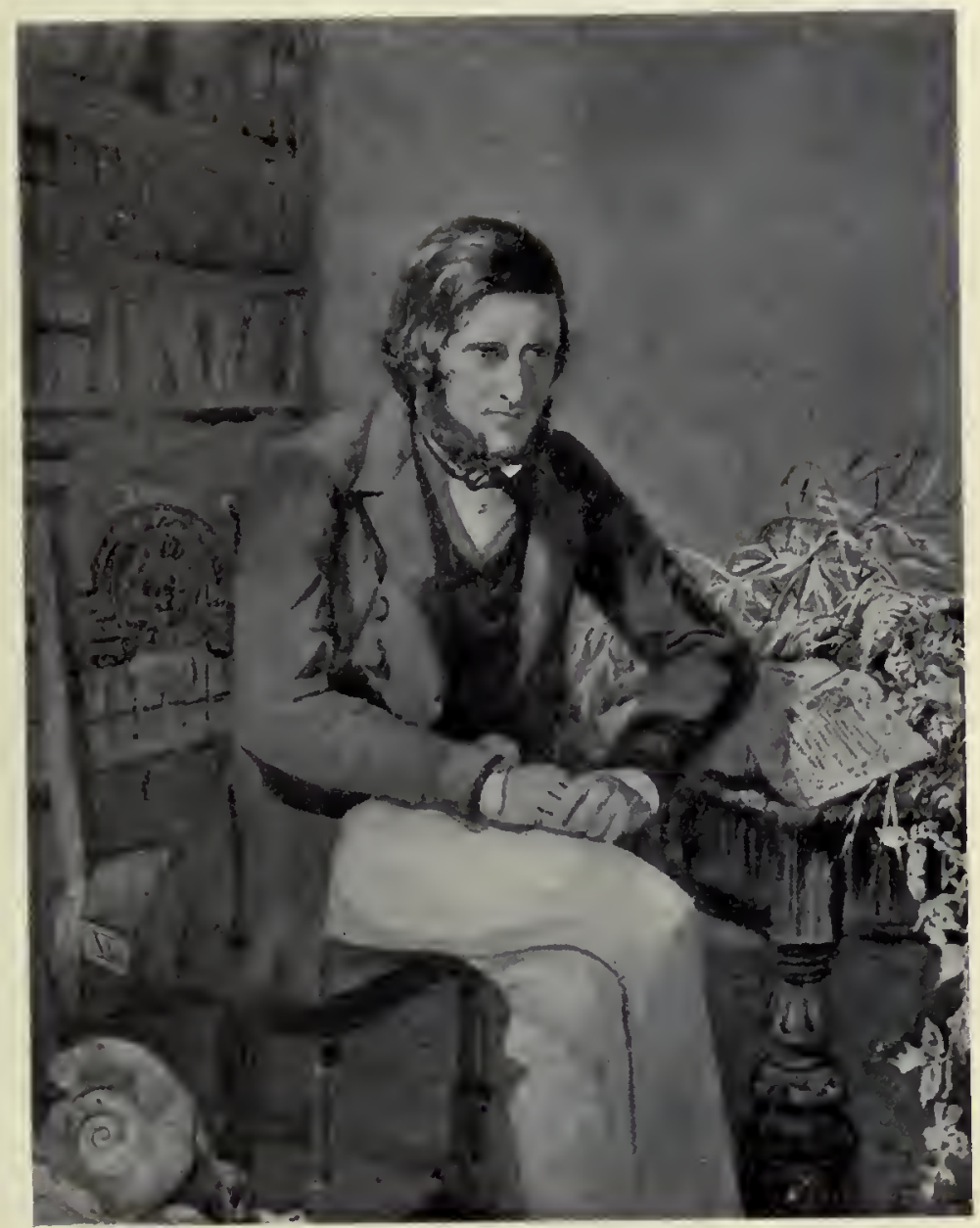

JAMES BUCKMAN, iet. c. 30

From portrait painted by Miss P. N. Marshall, Cheltenham, c. I844 [Ammonites strangwaysii; J.B., Geol. Chelt. I844, 90 ; "Dumbleton, Glos." "U.L." F. 240? (35), 30, - 46 ; Harp. cf. mulgra vium, Y.\&B. See IV] 



$$
\text { voc. 3. } \quad 4^{3}
$$

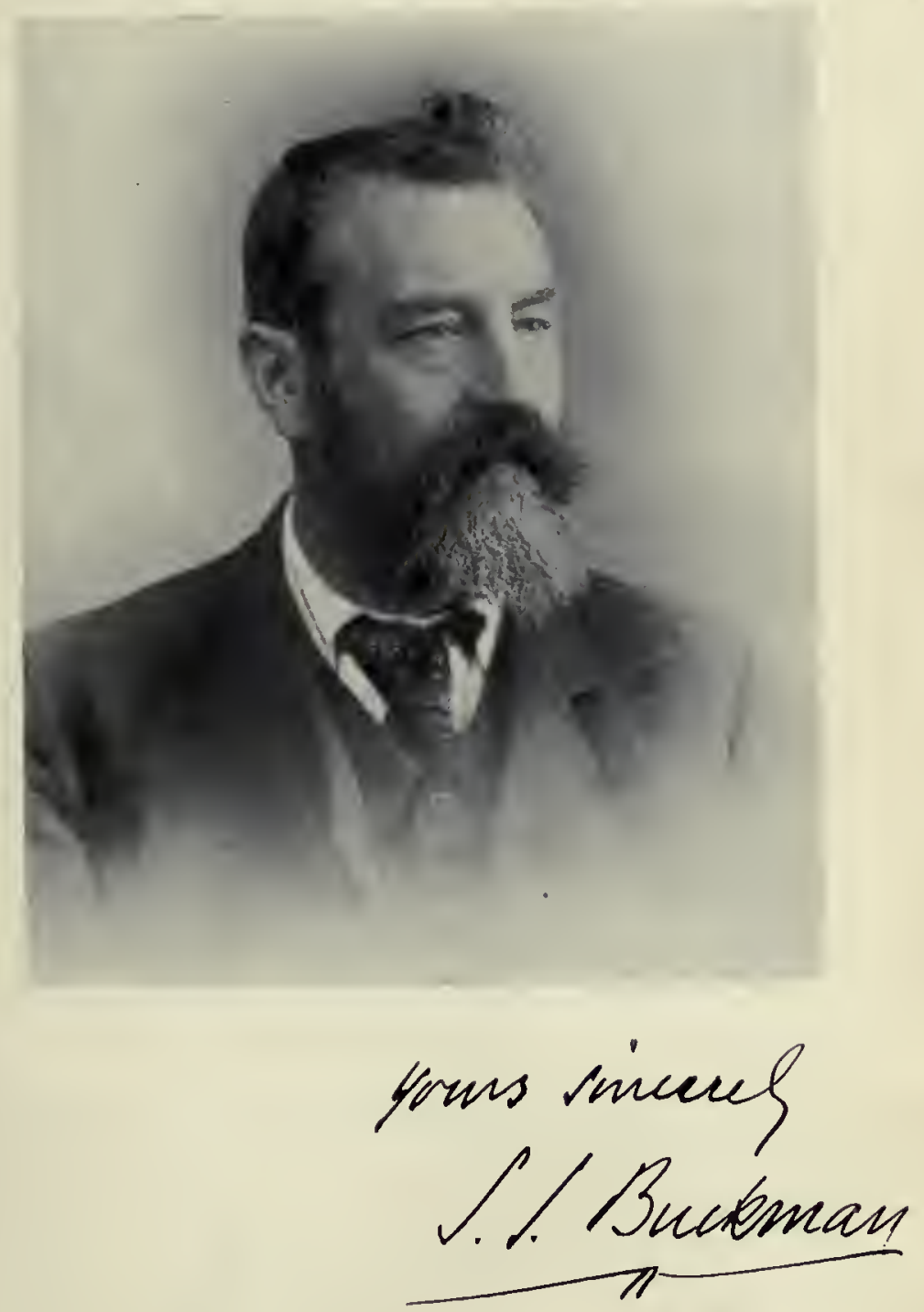

Sydney S. Buckinan, at. 46 Maull \& Fox, Ltd., Photo. Igors

S. S. BUCKMIAN, I860- 



\section{TYPE AMMONITES}

BY

S. S. BUCKMAN, F.G.S.

The illustrations from photographs mainly by

J. W. TUTCHER

\section{Part XIX}

Pp. 5, 6; 9 Plates and a Portrait

Published by The Author

Sold By

WILLIAM WESLEY AND SON,

28 ESSEX STREET, STRAND, LONDON, W.C. 2.

August, JgI9 


\section{CONTENTS}

PART XIX

Text :- $\quad$ Page

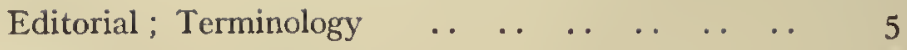

Illustrations :-

Plate

I3I. Ammonites bucklandi

(Coroniceras bucklandi) $\ldots \quad \ldots \quad$ CXXXI

132. Nautilus ammonoides

(Goliathiceras ammonoides).. CXXXII A

133. Cadicone Coronoid

(Docidoceras cylindroides).. CXXXIII A

134. Sphæroceras perexpansum)

(Labyrinthoceras perexpansum) CXXXIV A

135. Sphæroceras perexpansum

(Labyrinthoceras intricatum)

CXXXV

136. Ammonites victoris

(Victoriceras victoris) $\quad \ldots \quad \ldots \quad$ CXXXVI A, B

137. Am. victoris, Homœomorph of

(Tutchericeras perfoliatum) CXXXVII A

138. Argonauta serpentinus

(Hildoceras serpentinum) $\quad$.. CXXXVIII A

And a portrait of

Martin Simpson paged $4^{a}-$ 


\section{EDITORIAL}

Part XIX of Type Ammonites, commencing Vol. III of the series, is now presented to subscribers. The courtesy of Mr. T. Sheppard, M.Sc., F.G.S., allows the addition of a portrait of Martin Simpson which has appeared in Proc. Yorksh. Geol. Soc. XIX, 1918, Xxxv. This has not now been headed, so that subscribers may place it as a frontispiece to whichever volume of the series they choose.

As in the present volume the text must be very strictly limited, it is intended to supply deficiencies of description by detail (diagrammatic and otherwise) in the illustrations. This has the advantage of not only inducing greater strictness of observation, but of presenting the results pictorially, that is, in a language which is universal. If the plates themselves were perfect they should, with their legends, give all necessary details: descriptions should be superfluous. There will, however, be descriptive matter; but it will be held until depicted species have accumulated.

The legend of the plate is designed to give the following information : name or other identification; status as type, if it has such ; references to protolog and protograph or other bibliographic details; locality and horizon according to original information-in quotation marks ; collection; proportional formula; see Q.J.G.S. LXXIII, I9I9, 3I5. At foot of plate will be given present name, presumed date and status. The date is to be read as-age, in Roman, hemera, in italic type. This dating system accords with a very detailed scheme, not yet complete : the Liassic portion is given in the Journal cited above, but even that may requirc elaboration. Two hemeral names with / between them imply that the species possibly occupied an intermediate date, which may be added in brackets.

\section{TERMINOLOGY}

In the legend is a further innovation-there is given in millimetres as "max. c. xyz" the presumed maximum size of the specimen with complete body-chamber added; this within square brackets indicates information from another, a more complete, example.

This information prepares for a scheme of recording the great variation which adult Ammonites make at different dates in regard to sizefrom a few to several hundred $\mathrm{mm}$. Thus there are certain dates when Ammonites of large size flourished, and others when small forms livedthe maxima rising and falling like waves; and there are further cases of large and small Ammonites occurring in the same stratum - the juxtaposition may not necessarily imply synchronism.

In connexion with these data a concise Terminology is necessary, particularly in regard to small Ammonites. Specimens may be small as a matter of growth; but they may also be small because they have been reduced (I) by breaking off of outer whorls before deposition, (2) by similar breakage in the process of extraction, (3) by both causes combined. In practice it may seldom be possible to say which of these causes has operated; but distinction could be made by qualifying the 
technical term by (I) geological, (2) artificial. Then Ammonites which are small by growth require much further analysis. The following technical terminology is proposed, applicable also to other organisms :-

Colomorph-small because reduced by breaking off of outer whorls by geological or artificial agents (кúdos, docked).

Micromorph-small by growth-auxologic diminutive (Hudleston, Jur. Gaster. Pal. Soc. I888, 6I)-subdivided :-

Brephomorph-small because young, ontogenetically immature

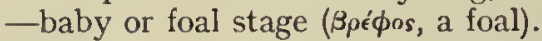

Anamorph - small because phylogenetically immature Eohippus stage-Amioceras miserabile, flavum, etc. stage (Ana- of Anagenesis).

Phaulomorph-small because stunted, phylogenetically mature, but under-sized-Donkey stage ( $\phi$ aì os, paltry, mean).

Catamorph-small because pliylogenetically degenerate (? tarpan stage); Schlotheimia lacunata (and allies) stagc; Criocone stage (Cata- of catagenesis).

Nomomorph - of normal, average, or customary size; hackney horse

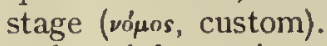

Megalomorph-of large size; shire-horse stage; giant stage ( $\mu \dot{\epsilon}$ great).

When the distinction between phaulomorphs and catamorphs is in doubt, it is suggested that they be referred to as nannoids (vávvos dwarf). The distinction is that the former are presumed to be derived directly from anamorphs, not having passed through a nomomorph stage, while the latter are the degenerate descendants of nomomorphs, or, like the cited Schlotheimia group, the final expression of a nomomorph stock. The African pygmies, the cat and the donkey, are respectively human, feline and equine nannoids: it is for zoologists to say if I read them aright as phaulomorphs and not catamorphs.

Among Lias Ammonites phaulomorphs are rare-Cheltonia is an instance, Oxynoticeras being the nomomorph.

Among Inferior Oolite Ammonites phaulomorphs abound, and many are unillustrated. They are usually incipient scaphiticones with fine development of the mouth-border, especially in regard to lateral auricles. The following are a few examples, with their respective nomomorphs:-

Nomomorphs
Cadomites
Lissoceras
Stepheoceras, etc.
Emileia

Phaulomorphs

Polyplectites

Cadomoceras

Normannites

Otoites

The theory that the forms now called nomomorphs are the females, and the phaulomorphs the males (Munier-Chalmas, I892, Hang, I893), encounters serious objections (I) that various periods lack phaulomorphs, (2) that they are not always found in the same localities as the supposed females, and (3) that there are not enough " husbands" to go round (Buckman \& Bather, I894); to which may be added (4) that they do not always occupy the same horizons.

Among the species now illustrated Coroniceras bucklandi and Goliathiceras ammonoides are megalomorphs, Docidoceras cylindroides, at present the geologically earliest of the Stepheoceratacea, is a nomomorph : its corresponding phaulomorph is to be figured; Labyrinthoceras perexpansum and $L$. intricatum are colomorphs, but the latter is also, in comparison with the former in its complete state, an incipient catamorph, much on 


\title{
TYPE AMMONITES
}

Hi

S. S. BUCKMAN, F.(i.s.

The illustrations from photographs mainly by

J. W. TUTCHER

$$
\begin{gathered}
\text { Part XX } \\
\text { Pp. 7, 8; } 44 \text { Plates }
\end{gathered}
$$

\author{
Published by The Author \\ SOLD BY \\ WILLIAM WESLEY AND SON, \\ 28 essex StreEt, Strand, London, w.c. 2. \\ October, 1919
}




\section{CONTENTS}

\section{PART XX}

Tert:-

Terminology

Illustrations :-

Plate

I32. Nautilus ammonoides

(Goliathiceras ammonoides) $\quad$. CXXXII B, C

I34. Sphæroceras perexpansum)

(Labyrinthoceras perexpansum) .. CXXXIV B

I36. Ammonites victoris

(Victoriceras victoris) $\ldots \quad \ldots \quad \ldots \quad$ CXXXVI c

I38. Hildoceras serpentinum

CXXXVIII B

139. Am. biplex, Homøomorph of

(Dichotomoceras dichotomum) CXXXIX A

I40. Docidoceratan phaulomorph

(Trilobiticeras trilobitoides) .. CXI

I4I. Sphæroceras contractum

- (Otoites delicatus) ..

142. Ammonites ferrugineus

(Amauroceras ferrugineum) . . . . . CXLII

I43. Ammonites oxynotus

(Oxynoticeras oxynotum) . . . $\quad$ CXLIII A

I44. Cf. Phylloceras buvigneri

(Fastigiceras clausum) .. . . C CXIIV

I45. Ammonites reversus

(Rursiceras reversum) $\quad \ldots \quad \ldots \quad \ldots \quad$ CXLY

I46. Ammonites centaurus

(Beaniceras centaurus) $\quad \ldots \quad \ldots \quad \ldots$ CXI.VI

I47. Ammonites planicostatus

(Beaniceras crassum) .. .... . CXLYH

CHEI.TENHAM

NORMAN, SAWYER AND CO. L'ID., PRINTERS

ST. GEURGE'S HAI.I. 
the down grade in regard to size. Victoriceras victoris and Tutchericeras perfoliatum are nomomorphs, somewliat reduced, however, in size by the loss of more or less outer whorl, but not so reduced as to be colomorphs. The same applies to the megalomorphs mentioned above: as species these and the oxynotoids are megalomorphs or nomomorphs ; as specimens they are docked or truncated megalomorphs or nomomorphs respectively. $D$. cylindroides is a nomomorph requiring no qualification; hut the examples of the species usually found are so much reduced that they are colomorphs.

There seems to be general agrement that the cone-terms initiated by Hyatt, revised and expanded in this work (I, p. xi, II, p. ix) are particularly useful, making for much brevity of expression. Experience shows that some cases of peculiar contour are not properly covered by the terms now in use, and further additions are therefore proposed as follow :-

Contracticone. The terminal portion of the cone contracts in thickness, not merely to proportionally less than a preceding part, but to actually less. The character is especially marked in certain phaulomorphs, as, for instance, in Trilobiticeras trilobitoides now figured (Pl. CXL), which in earlier whorls is a stout cadicone. But it is not confined to pliaulomorphs: it is shown by the nonomorph cadicone Emileia crater (1I, ix).

It is also a feature of sphærocones. Of necessity it is a character which requires a reasonably stout whorl for its basis.

Ellipticone. The regular increasing spiral of the outer edge of the volute is not maintained : it is accelerated and then reduced, making an ovoid or ellipsoid figure. This is shown in the platycone phaulomorphs Cadomoceras cadomense (d'Orbigny) and Cyrtosiceras macrotelus (Oppel). It is also to be observed in spherocones of the genus Otoites, and slightly in Sutneria.

Goniocone. This is an exaggeration of an elliptocone. The outer edge of the conch runs out as if it intended to make a baculicone ; but the inner edge is conservative to the sphæroconc. The latter tendency prevails, and the outer edge is brought sharply back. The result is a conch with an angle-it is a pointed conch, be it noted, in the direction in which the animal would dart away from an encmy. The typical instance of a goniocone is Ecoptychius refractus (de Haan) of the Callovian. Not quite so gonioconic a form is (Ecoptychius grossouvrei Brasil, "Bajocien supéricur," Normandy. A similar form (S. B. Coll. 382) has been obtained from Broad Windsor, Dorset, from upper beds of Inferior Oolite (Vesulian, c. truellii or later).

Dr. A. Morley Davies, whose questions are most stimulating, asks whether it is correct to use the same cone-term for shapes which, though similar, have been arrived at along different routes. Logically it is not ; and such distinction has been carried out in the terms for cone-stages proposed in Vol. I. : an ophiocone and a serpenticone express the same coiled form, but the former is pre- and the latter post-spheroconic. So a sphærocone developed from a serpenticone, as in the Liparoceratidæ, and a sphærocone developed from a cadicone, which will presently be shown to be the origin of Labyrinthoceras, are two distinct phenomena. A persistent cadicone, as in the case of various Bajocian Coronates, is very different from the cadicone, with inner whorls platycone, of Cadoceras. But with our present knowledge, or rather, with the backwardness in the publication of what has been awaiting illustration this many years, it will be inadvisable to attempt too much analysis of terms relating to these subsidiary cycles (Vol. I, p. xii). It is always possible, 
and will be fairly concise, if special particularity is thought essential, to describe, say, Cadoceras as platycone to cadicone, as short for commencing as platycone and changing sooner or later to cadicone; but it would not be correct to describe Labyrinthoceras as cadicone to sphærocone, for the cadiconc stage has dropped out owing to tachygenesis, just as in much specialized Liparoceratids the serpenticone stage has done (Y.T.A. I, p. xiv). It would, however, be possible to describe Labyrinthoceras as sphærocone post-cadicone, and thus distinguish it from Liparoceratids described in certain cases as serpenticonc to sphærocone, or in the abbreviated cases as sphærocone post-serpenticone. It is these abbreviated cases (saltative palingenesis, I, p. xiv) which may lead astray and give trouble in too fine analysis, until ammonite genealogy is much more fully illustrated.

On the other hand, it may be pleaded that some cone-terms in changeable species refer to no more than the outer whorl of the specinen under consideration. Such, at any rate, is the case with those now proposed : Ellipticone and Goniocone are only concerned with phenomena belonging to the last whorl of full-grown specimens; while Contracticone is usually concerned with the difference between the last part of the last whorl of a full-grown specimen and that of the preceding part, though there are cases where the reduction began earlier even than the last whorl.

Not all contracticones, it may be remarked, are incipient scaphiticones or scaphitoids : some are ; and, on the other hand, many scaphitoids are not contracticones.

\section{DEVELOPMENT}

With the above and other terms for shape, and with the terms for size which have been proposed (III, 6), it is possible to make concisely some remarks on the supposed habits and development of Cephalopods, and especially of Ammonoids.

The early Orthocones utilising the gas-effusion, which resulted from temporary indigestion under the nervous apprehension of danger, found that a cone thus made more buoyant was a help in rapid retreat from foes. They brought the feature to perfection-a systematic gas-gencrator and containing chambers. But retreat from foes was only incidental: bottom-crawling in search of food was the normal occupation. As the orthocones increased in size fear of foes was less insistent; but the gasplant was still of service to lighten the load of the supcrincumbent conch. Now progress through the water would cause a certain amount of drag on the vertical conch, giving it a slant: there would then be tendency to absorb test on the lower edge and to make more deposition on the raised edge. Persistence of this tendency would give some curvature to the conch, and would convert an orthocone into a cyrtoconc, then to a gyrocone. As both these stages would be inconvenient for bottomcrawling or for darting away, there was good reason to hurry development into the ophiocone: then the conch, coiled in contact, would be more compact, and would be carried more easily, owing to the lowering of the centre of gravity. Darting away would still be possible, and, when ill circumstances coming again brought reduction in sizc and made such a habit again more frequent, it may be surmised that the cut-water peripheries of oxycones would be developed to facilitate rapid movement. Sharpened peripheries mean strict, presumably forced, economy-the attempt to attain the largest size, and to make the greatest slow, with the smallest outlay of material.

It seems inadvisable to postulate quite the same habits for megalo- 


\title{
TYPE AMMONITES
}

BY

S. S. BUCKMAN, F.g.s.

The illustrations from photographs mainly by

J. W. TUTCHER

Part XXI

Pp. 9-16; 14 Plates

\author{
Published by The Author \\ SOLD BY \\ WILLIAM WESLEY AND SON, \\ 28 ESSEX STREET, STRAND, LONDON, W.C. 2. \\ March, J920
}




\section{CONTENTS}

\section{PART XXI}

Text:- $\quad$ Page

$\begin{array}{lllllllllll}\text { Chronology } & \ldots & \ldots & \ldots & \ldots & \ldots & \ldots & \ldots & . & & 9\end{array}$

Illustrations :-

137. Am. victoris, Homoomorple of

Plate

(Tutchericeras perfoliatum) .. CXXXVII is

139. Am. biplex, Homœomorplı of

(Dichotomoceras dichotomum) .. CXXXIX B, C

148. Ammonites placenta

(Longæviceras placenta) .. .. CXILVIII

149. Ammonites lamellosus

(Phricodoceras lamellosum) .. C.ILIX A, B, C

I50. A mammillate Sonninia

(Papilliceras papillatum) $\quad \ldots \quad \mathrm{Cl}, \mathrm{A}, \mathrm{B}$

151. Ammonites braikenridgii

(Epalxites formosus) .. .. $\quad$ CLI

152. Ammonites braikenridgii

(Masckeites densus) $\quad$. $\quad . \quad$ CLII

153. Stephanoceras zigzag

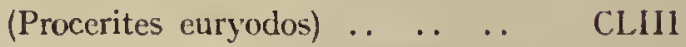

154. Ammonites lamberti

(Lamberticeras lamberti) .. CLIV

155. Ammonites serratus

(Prionoceras prionodes) $\quad . \quad \mathrm{CLV}$ 
morphs, nomomorplss and phaulomorphs: the first miglit have had 110 cause for retreat; the second might liave had to retreat occasionally, and the last might have been in a fairly constant condition of darting away. Production of phaulomorphs instead of megalomorphs might have been brought about by over-population, by decrease of food supply, by increase of competitors, other than cephalopods, for the available food. Ammonoid phaulomorphs abound during Inferior-Oolite times, when the ammonite population reached its acme in numbers of species, of specimens, and almost of diversity; for there are aberrant forms evolved-criocones, toxocones and baculicones, possible attempts to find a solution of the problem of avoiding enemies, trying to attain again to the orthoconic condition, which, at any rate, so far as small forms were concerned, must have been fairly suitable for the purposes of rapid retreat. This tendency towards tlie orthoconic seems to have been hampered by ancestral traits of coiling cones trying to assert themselves; and thus when a fairly orthoconic development had been attained, ancestral characters revive in old age, and make for curvature againthe curious walking-stick crook at the end of a straight piece.

It is in the Cretaceous that the aberrant forms show the greatest development. This cannot have been because of over-population so far as Ammonite competitors are concerned, but it might, perhaps, have relation to the greater development of some other marine organisms.

The peculiar suitability of the shape of a goniocone for darting away has been already mentioned; but now comes an interesting question: in addition to side-lappets or auricles to the conch-aperture, this form has developed a sort of cowl-shaped rostrum on the median line of the periphery. Rostra of less developed patterns are a feature of oxycones ; but many well-auriculate forms-cadicones, sphærocones, and their serpenticonic developments-lack the feature: with them the portion of the periphery connecting the auricles is neither sinuate nor rostrate, but annulate, that is, quite straight. With such periphery, or with simple rostra, there would be no interference with the action of the funnel; but the case is altered with an incurving rostrum. Is it surmisable that in such rostrate forms the funnel had been developed in duplicate, like the twin screw of a liner, acting not only for quicker propulsion, but making for more rapid turning ?

It may be noted in regard to those forms which have developed lateral lappets with annulate connecting band that, in a sense, they have reproduced something similar to the hyponomic sinus of the Nautiloids; for the plan of the lappets and band make a $U$ or sinuate curve. See Trilobiticeras and Otoites, Pls. CXL, CXLI.

Further remarks on the subject of Development must be held over until more progress has been made with the illustration of species and the naming of genera. Incidentally it may be remarked that the detailed naming of genera gives great advantage in the discussion of development, faunal distribution, chronological sequence, and other phenomena. $\mathrm{By}$ one word it is possible to lay the finger on the particular restricted lineage required, and thus to express its characters-cumbersome periphrasis is avoided, and greater precision of expression is attained with needful brevity.

\section{CHRONOLOGY}

See T.A. III, 5, Editorial ; for Chronology of Lower Oolites see Y.T.A. II, $x$, and 'Brach. Namyau'; Pal. Ind. N.S. III (2), I9I7, 236-239; for Middle Oolites see 'Kell. R.' ; Q.J.G.S. LXIX, I9r3, p. I6o. These tables are not yet satisfactory: all will require emendation and possible expansion-exact chronological work is only just beginning. 
A further upward extension is presented in the following Table; but it must be regarded as only provisional.

\section{TABLE I, ARGOVIAN CHRONOLOGY}

OLD TERMS

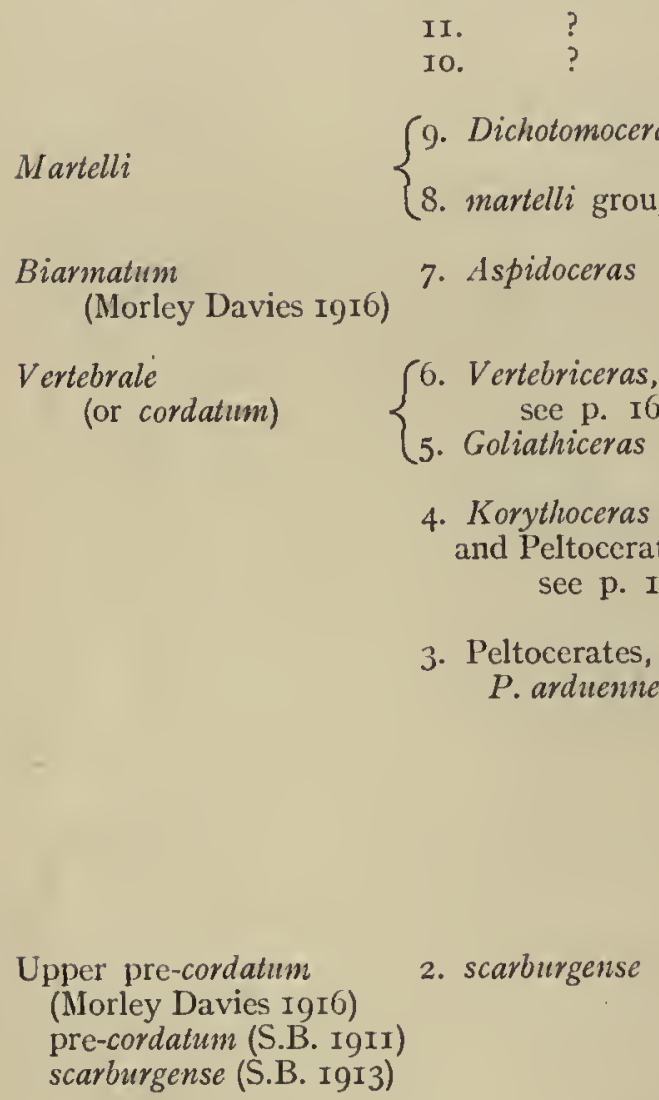

Lower pre-cordatum

(Morley Davies I9I6)

pre-cordatum, S.B. IgII

I. Cardioceras
FAUnal Horizons

StratA

The White Course.

The Coral Beds.

The Exogyra

Beds.

The Shell Bed.

Base of Shell Bed.

Lower Calc. Grit.

Loch Staffin Beds.

H. I5, Oolite

ferrugineuse

of Villers-sur-Mer,

Normandy (R.D.).

Oxford Clay, Hunts ;

Cowley, Oxford.

Borings, Kent

(Dr. Kitchin).

Oxf. Clay,

Studley, Oxon and

Brill, Bucks (A.M.D.).

Borings, Kent (F.L.K.) ;

H. 6, Villers-sur-

Mer, (partly),

(R. Douvillé) ;

Jura Bernois (Loriol).

cardia $=A$.

Oxf. Clay.

Studley Brickyard ; cordatum, Sow., (Lydlinch, Sturminster Paratype,

Newton, Dorset) ; see p. $I_{5}$
Wotton Station and

Quainton Road,

Bucks (Morley Davies);

Borings, Kent

(F.L.K.);

Jura Bernois (Loriol). 
The placing of Vertebriceras above Goliathiceras is an assumption based on the more calcareous matrix of the former, the sands passing upwards into limestones.

The term pre-cordatum was employed by me as a provisional timeterm. Subsequently R. Douvillé gave the trivial name pre-cordatum to a scarburgense-like species of about the same date.

\section{TERMINOLOGY}

See III, p. 5. It is necessary to return to this subject : such a method of work will have to be employed in other cases.

Palingenesis: Dr. W. D. Lang has published two interesting papers dealing with this and other phenomena (The Evolution of Ammonites; Proc. Geol. Assoc. XXX, I9I9, p. 49 ; Old Age and Extinction in Fossils ; Id. p. 502). In the former he suggests the term Lipogenesis instead of that of saltative palingenesis (Y.T.A., I, IgIO, p. xiii) and says that " it is a modification of tachygenesis " (p. 6o). It may be suggested that it is not so much a modification, but, rather, a specialized acceleration of tachygenesis, and that Lipogenesis (literally, genesis in which something is wanting, or skipped) scarcely expresses the phenomenon. The term seems more suitable for the phenomenon of mutations used in the sense of De Vries; and the present phenomenon is not merely genesis, but palingenesis, or recapitulation, in which something is wanting. Therefore it would seem that the term required is Lipopalingenesis. Its acceptance would involve congruous terms for the other phenomena of palingenesis-cunctative and precedentive.-Bradypalingenesis and Propalingenesis may be suggested.

Type-designation: A term of wider significance than topotype is required. A quarry only a short distance away, but in another parish, and even in another county, may show a stratum lithically the same as the original locality, with typical examples of named species. Yet these specimens would not be correctly termed topotypes, though they may be as valuable as topotypes for identification purposes. Therefore Chorotype is proposed ( $x \hat{\omega} \rho \circ$ s, a district).

The application of chorotype may in some cases be fairly wide when the stratum remains lithically constant over a considerable area, or it may be inapplicable in a short distance owing to lithic change. It should be used independently of political boundaries.

Association-term: Syntopite (oiv with, ronirns, belonging to a place": S. Buckman, Brach. Namyau Beds; Pal. Ind. N.S. III (2) I9I7, p. 234) "a stable-companion"-occurring in the same locality and same stratum. This should be a useful term. Thus Am.plicatilis and $A m$. vertebralis are syntopites in the Lower Calcareous Grit of Dry Sandford/Marcham, Berkshire (see p. I6) and Cowley, Oxfordshire. Am. plicatilis is, therefore, not a species of the Upper Corallian, as Miss Healey supposed (Q.J.G.S., LX, I904, 56 ; Pal. U. I904, 57), misled by an error long current in English geological literature.

It may be noted that $A m$. plicatilis seems to fail on the Continent just as does $A m$. vertebralis and its allies (see p. I6), whereas the goliathus group (Goliathiceras), also characteristic of the Lower Calcareous Grit of England, is wide-spread in France (d'Orbigny).

Measurement: The table designed by Mr. Tutcher (Y.T.A., App. Tab. I), is very useful, but I have now found that a slide-rule purchasable at an ironmonger's is suitable for the purpose: it allows of greater 
accuracy, care being taken in reading the lower numbers, and it can be used for any size of specimen. When dimensions have been given instead of proportions, as is the case in many works, they can be translated by simple reading of the rule.

When photograpls are measired instead of specimens the results may be slightly at variance-chiefly from the camera giving a widening of the umbilicus at the expense of the whorl. Measurements from photographs may, therefore, advisedly be marked $\phi$

\section{Systematic}

As an introduction to this subject it is necessary to make some remarks with a view to providing certain short cuts in descriptive matter.

Abbreviations: Photograph, $\phi$, see above; other abbreviations, see following paragraphs.

Tuberculation: For distinguishing Ammonite genera particular attention requires to be paid to the position of the tubercle on the side of the whorl. Thus a distinction between Trilobiticeras and Otoites is that in the former the tubercle is in the line of the lateral anricleactually in certain cases, a rare phenomenon, ( $T$. trilobitoides Pl. CXL) it is found on the auricle itself; but in Otoites the tubercle is in the line of the inside of the auricle. Then in the so-called zigzag series (or one section of it, Procerites) what is analagons to, and possibly a development of the tubercle, the parabolic curve, is found in the line of the outside of the auricle (Pl. CLIII). It becomes necessary to express these phenomena with brevity. Reading from left to right, the specimen is placed with its periphery to the left, and therefore in Procerites the tubercle (or its analogue) is O Lap.-before the lappet; but in Trilobiticeras it is (Lap.), this does not mean that it is on the lappet itself, but that it is in the line of the lappet. However, when the lappet is broad enough further particularization may be necessary. The tubercle may be in the line of the outside, of the middle, or the inside portion, which can with brevity be expressed as (Lap. I, 2 or 3) respectively. Trilobiticeras is (Lap. 2), Epalxites is (Lap. 3).

Useful, however, as observation of position with regard to the lappet may be, yet that is not a constant feature. The suture-line therefore can be taken as a guide, alone or in addition. The varying position of the tubercle with regard to the suture-line has long been recognized as a generic character, thongh it has been insufficiently employed: its different locations on the lateral area-a less satisfactory guidehave more usually been considered. Now Dr. A. E. Trueman, in an excellent study (Evol. Lip.; Q.J.G.S. LXXIV, I9I9, p. 247) has graphically illustrated (p. 258 ) the different positions of tubercle to lobes of suture-line in a detailed series of genera.

For reading the suture-line the specimen is placed in the same position, venter to left, inner part to right, that is, $\mathrm{EL}, \mathrm{L}^{1}, \mathrm{~L}^{2}$ and so on. Position with regard, say, to $\mathrm{L}^{1}$ may be $O \mathrm{~L}^{1}$, that is, before $\mathrm{L}^{1}$ is reached, $\left(L^{1}\right)$--that is in the line of the area of $L^{1}$, and $L^{x} O$, that is after $\mathrm{L}^{1}$. When lobes are wide-stemmed further precision may be attained as with the lappet-( $\mathrm{L}^{1} \mathrm{I}, 2$ or 3$)$. The saddles can be used in the same way. 
Thus some tuberculation formulas are
O Procerites
O Trilobiticeras
$\mathrm{L}^{1} \mathrm{O}$
O Otoites
(L. $\left.{ }^{2}\right)$
$\mathrm{L}{ }^{2} \mathrm{O}$

and see Trueman :-
O O Liparoceras
O 0 Becheiceras
O O Androgynoceras
O $\mathrm{O}$ Amblycoceras
$\left(\mathrm{L}^{1} 2\right) \mathrm{S}^{1} \mathrm{OL}^{2}$, that is, on $\mathrm{L}^{2}$ partition.
$\left(\mathrm{L}^{1} 3\right),\left(\mathrm{L}^{2} \mathrm{I}\right)$.
$\mathrm{OL} \mathrm{L}^{1}, \mathrm{O} \mathrm{L}^{2}$
$O L^{1},\left(S^{1}\right)$

When lobes develop laterally, expanding in some cases even to invading their neighbours' territory, attention would not be paid to these expansions for formula purposes-the main stems of the lobes would give the position.

Furcation: When the tubercle has not developed, or has declined, so that the rib shows no swelling, the place where the tubercle will arise, or where it may have been, is marked sometimes by rib-furcation. The position of this may be important, and can be noted by the same formulx, using, however, instead of $O$, the sign $V$. The signs $O V$ indicate that the tubercle is the furcation point, enclosed where necessary within the brackets to show that the position is in the line of the area of lobe or saddle.

\section{Family LIPAROCERATIDE}

See II, v, B; also Dr. A. E. Trueman, "The Evolution of the Liparoceratidxe" ; Abs. Proc. Geol. Soc. No. I022, I9I8, p. 65, Q.J.G.S., LXXIV, Igr9, p. 247.

The following new genera are proposed-Trueman, I9I8, p. 66 :-

PARINodiceras, " Genoholotype, Am. striatus parinodus Quenstedt ([Amm. Schwäb Jura], I884, pl. xxviii, fig. 6) " ;

Becheiceras. "Genoholotype, Ammonites [Agoceras] bechei Wright (Lias Amm., pl. XLI, fig. I) " ;

ANISOLOBOCERAS. "Genoholotype, Ammonites nautiliformis, J. Buckman, [Y.T.A., I, 37, Pls. XXXVII A, B.] " and see II, $x v$.

Trueman IgI9, p. 264 :

Vicrninodiceras. "Genoholotype, $V$. simplicicosta, sp. nov. [p. 289]. Pl. XxIV, fig. 4."

And in the same publication (p. 262) he discusses

Amblycoceras Hyatt, Igoo, "Genoholotype: A. capricormus Hyatt in Eastman-Zittel, 'Text-book of Palaeontology,' Ist ed. vol. i (Igoo) fig. I204, p. 578."

\section{Family AMMONITIDAE (ARIETIDAE)}

See Y.T.A., II, B and Oxynoticeras, Y.T.A., I, ii.

Oxygastric, Amblygastric: Pompeckj used these terms to denote differences in the degree of sharpness acquired by narrow peripheries of 'Oxynotes ' (Oxynotic. ; 'Comm.' Serv. Géol. Port. VI, Igo6, 7, p. 29I); more or less of a knife-edge-oxygastric ; a blunt edge or narrowly rounded venter-amblygastric. For use with oxycones and platycones. Their employment with oxycone is no more tautological in the one case 
nor contradictory in the other than the phrases sharp axe and blunt axe, when "axe" really means a "sharp implement." The terms will be useful for other families.

Radstockiceras S. Buckman I9I8, (Jur. Chron. Q.J.G.S., LXXIII, 287), "Type $R$. complicatum, [XXVII, I]". Oxygastric oxycone with highly complicated S.L.

Gleviceras, S. Buckman I9I8, (Op. cit. 289). Type, G. glevense (paratype) [xxvi11, 2]." Amblygastric oxycone, with somewhat complicated S.L. and regular ribbing.

Guibaliceras. S. Buckman I9I8, (Op. cit. 293). "Type, Am. guibalianus D’Orbigny, Pal. franç. Terr. Jur. Céph, pl. LxxıII." Suboxygastric oxycone, with somewhat simple S.L.,-EL much longer than $\mathrm{L}^{1}-$, and intermittent ribbing.

Victoriceras. S. Buckman IgI8 (Op. cit. 293). "Type, Ammonites victoris Dumortier, Bassin .Rhône ii, pl. [XIII], figs. I and 2 "; pl. XLV" is a misprint. Amblygastric oxycone, with somewhat simple S.L.,-EL and $\mathrm{L}^{2}$ about equal--, dichotomous ribbing and test radially striate with punctæ in the strix. T.A. CXXXVI.

Tutchericeras S. Buckman I9I9; Genotype $T$. perfoliatum, T.A., Legend of Pl. CXXXVIIA. Amblygastric oxycone with highlycomplicated S.L. somewhat feeble ribbing and test radially capillate, not punctate.

FAstigiceras S. Buckman IgI9; Genotype $F$. clausum, T.A., Legend of Pl. CXLIV. Amblygastric oxycone, fastigate in whorl-section and almost clausumbilicate. S.L. quite simple, ribbing obsolete.

These six genera with O.tynoticeras take the following natural order according to position marks (see op. cit. p. 296), Tutchericeras having the following marks-ES, $6, \mathrm{~L}^{1}, 7$, Periphery, I, Ribbing, 2, Umbilicus, 4 ; and Fastigiceras having I, 3, 4, I, 7 for the same:-

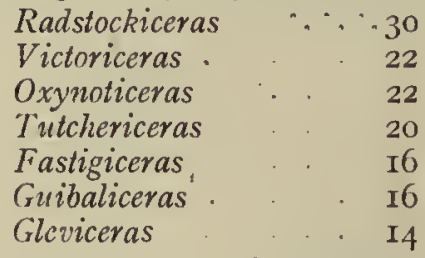

\section{Family CADOCERATIDA}

See Y.T.A., II, xiii and B.

EBoraciceras, see Y.T.A., II, xiv. The holotype of $A m$. ordinarius, Bean-Leckenby, has been kindly sent by Mr. H. Woods, F.R.S., from the Sedgwick Museum, Cambridge. The species belongs to this genus, a stage earlier than $E$. dissimile (Y.T.A., II, II8); cf. Am. lamberti pinguis, Quenstedt, I887, XC, I5.

Scotland, England, France, Germany; Divesian.

Lamberticeras, g. n. Genoholotype, L. lamberti, J. Sowerby sp. - a topotype so identified, in Mr. Tutcher's Coll. (Pl. CLIV).

Oxygastric platycone; costate, non-tuberculate, $\mathrm{V}$ on $\mathrm{S}^{2}$; periphery 2 , crenulate by $V$-ribs. Versiradii with prorsiradiate curve to mid-periphery; primaries occasionally bifurcate, usually separated by 3 unconnected secondarics. S.L. simple, with short, broad lobes; $\mathrm{L}^{1}$ just beyond guide-line, $\mathrm{L}^{2}$ just touching. Swollen stage slight, only around umbilicus. England, (Foreign?) ; Divesian. 
The topotype is from a band of argillaceous limestone in Oxford Clay, and is not pyritized; it is iron-stained: judging by the colouring of Sowerby's plate his large example is from the same source. Associated with this specimen-that is from Weymouth-are a large number of similar-looking specimens, all of which are out of clay, are dark black, and are pyritized. They are, presumably, not strictly contemporaries of the example from the band-coming, perhaps, from just above or just below the argillaceous band, or both. They all differ in suture-line-having rather long and narrow lobes: this character may also be noted in the various lamberti-like forms figured by $R$. Douville from Normandy (Cardioc. I9I2). The rarity of $\mathrm{Am}$. lamberti in contrast to the abundance of lamberti-like forms is, perhaps, to be explained by the difference in matrix-that extraction from the limestone band was difficult and subsequent cleaning tedious, whereas the pyritized specimens would be lying out on the surface washed nearly clean. Such attractive specimens would be readily collected, while what looked like the same in bad condition would be neglected. It would be interesting to know if such collection-failure accounts for the absence of $A m$. lamberti from Normandy or whether it is due to stratal failure.

Proportions of Am. lamberti, J. Sowerby, I8I9, (M.C. III, 73, CcxLII, 3)-T. and F. 63, 43, 24? 29 ; of Mr. Tutcher's specimen, S. 69, 43. 5 , $27.5,28.5$.

Cardioceras, Neumayr \& Uhlig I88I, (Amm. Hilsbild.; Palaeont. xxvir, (3) III, p. I40). A. Amaltheen mit normaler Lobenzahl .. 2) Loben verzweigt, Antisiphonallobus einspitzig (Cordati) .. Cardioceras nov. gen." No type selected, but " Cardioceras cordatum Sow." given in list of species (p. I $4 \mathrm{I}$ ), and this is evidently indicated by the name. Such has been general usage (R. Douvillé, I9I2, 26) ; the other species originally mentioned have long been allocated to other genera. But more precision is required; for the name Ammonites (or Cardioceras) cordatus has been applied to a whole series of widely-differing forms from several different strata. Therefore Card. cordatum covers various genosyntypes, and a lectotype must be chosen. As Sowerby's holotype of $A m$. cordatus is a small shell, difficult to identify with accuracyfor a little difference in so small a shell can become a big difference in more fully-grown examples-and as its suture-line is not known, it seems desirable to pass it over in favour of Sowerby's paratype, now wellknown from Miss Healey's researches (Pal. U. I 905, 94). The forms to which the name $A m$. cordatus have been given generally agree more nearly with this than with the holotype.

$\because$ Therefore CARDIOCERAS Neum. \& Uhl. I88I, genolectotype Am. cordatus Sowerby, paratype (Min. Conch, I8I3, I, p. 5I, XVII, 4) = Cardioceras cardia, nom. n., Coll. Brit. Mus. (Nat. Hist.) No. 43980 b. Proportions: T. \& F. (Miss Healey), T. 55, F. 43.5, T. 36, T. 29. Tuberculation: (ES), for keel is knotted; (SI). Suture-line (Miss Healey, Pal. U., fig. P.4), EL and $\mathrm{L}^{1}$ rather long and about equal, $\mathrm{L}^{2}$ short, well separated from guide-line. Keel distinct, bordered by depressed areas, and crossed by V-shaped ribs. "Upper Oxford Clay" [Argovian, c. scarburgense (Ärgovian I) ] ; it is about one of the earliest of the carinate Cadoceratids. Loc. "Somersetshire,". Sowerby; "Axminster, Devon," Crick, Types Ceph., Brit. Mlus. (N.H.), I898, I3. I have a recollection of examining this specimen many years ago with the late G. C. Crick, who pointed out some writing on it. This showed " . . minster" clearly; the first part, which was very indistinct, Mr. Crick made out as " $\mathrm{Ax}$ " and concluded Axminster, Devon, an impossibility. I now suggest that it is "Sturminster" for Sturminster Newton, Dorset. Specimens in the 
collection of the Geological Survey from Lydlinch, which is 3 miles W. of Sturminster Newton, show about the zone required, c. scarburgense, though examples of Sowerby's form are not among them. Lydlinch is actually about $3 \frac{1}{2}$ miles from the Somerset border, and less than 2 miles from the detached portion of Somerset around Holwell. So Lydlinch may fit in well enough with Sowerby's location of Somerset : a small mistake as to the run of county boundarics is casily made.

England, (Foreign ?); Argovian I.

Vertebriceras g. n. The vertebrale group. Genoholotype, $V$. dorsale $\mathrm{n}$. described below. Strongly carinate serpenticones becoming massive, [almost sphaeroconic, then declining to platycones], pcriphery 4 with knotted kcel, ornament $5^{* *}$. Tuberculation, (EL), $\mathrm{OL}^{\mathbf{l}}\left(\mathrm{S}^{1}+\mathrm{V}\right)$. S.L., rather long and narrow $L^{1}$, about equal to EL, $L^{2}$ short and broad.

A scries nearest to Cardioceras as now defined, but with a strong keel on a broad, almost tabulate, subsulcate periphery. Ribs about radial, but with strong sweep backward from contact-line over inner margin, less strong sweep forwards on periphery [increasing in terminal species]. Body-chamber about $3 / 4$ whorl. Depressed area alongside kecl and on line of $\mathrm{L}^{1}$.

This is the most ornate series of the Cadoceratidie: it does not attain to anything like the swollen stage of some, but it is the most massive of the distinctly carinate genera-attaining inflation of about 60 per ccnt. Early whorls of $V$. dorsale are polygyral smooth, indicating a slowly-coiled serpenticone ancestor. (Vertumniceras and Goliathiceras give evidence of similar stage). If a keelless platycone stage followed this in the phylogeny, it is omitted; and the serpenticonic stage is soon obscured in massive species by the tachygenesis of swoilcn stagc.

England (Dorset, Berkshire, Oxfordshire). Argovian 6.

The species of this genus seem to be lacking from Cuntinental strata-identifications of $A m$. vertebralis being incorrect. Card. dieneri, Neumann (Oxf. Cetechowitz; Beitr. Pal. Ocst-Ung. XX, I907, v, I6, I7) has lateral aspect of $A m$. quadratus, but its fastigate periphery excludes it from this genus. Its ribbing prevents association with Cardioceras as now defined; but it seems to range with Am. cordatus; d'Orbigny (Céph. Jur. cxcıv, 2, 3).

In Argovian I, associated with Cardioceras, are small specimens with somewhat stout whorls of Vertebriceras pattern: they are not forerunners-they lack the polygyral stagc, and differ in other respects. The species of Vertebriceras are large shells.

$V$. dorsale n. Likc $A m$. vertebralis, but whorls much less massive, ribbing not so heavy, umbilicus wider. Tuberculation and S.L. as above. S. 8o, 35, 42.5 (38), 39. Cowley, near Oxford; Lower Calc. Grit, arcnaccous limestone; Argovian 6; S.B. Coll. 2780, Holotype and Genotype.

V. vertebrale, J. Sowerby sp. I8I7, (Min. Couch, II, I47, CLXV ; Miss Healey, Pal. U. I905, 93). Proportions (Healey, fig. Ha), F. 56, $45,59,25 ; 82,39,55,3$ I ; fig. H., F. III, 35, T.4I, F. 37.5; Univ. Mus. Oxford Coll. From a quarry of Lower Calc. Grit on south side of main road from Abingdon to Faringdon, $2 \frac{3}{4}$ miles from the former; between the villages of Marcham, I $\frac{1}{4} \mathrm{~m}$. to S, and Dry Sandford, I m. to N.

Chorotype, S.B. Coll. No: 3234, L. Calc. Grit ; Cowley, near Oxford ; S $80,36,54,30 ; 98,36,47(43), 32$.

$V$. rhachis n. Like $V$. vertebrale, but decreasing thickness and expanding umbilicus earlier-decline from $V$. vertebrale; ribs not so coarse; S. 80, 35, 46, 36; max. c. 90. Cowley, near Oxford, Lower Calc. Grit, S.B. Coll. No. 2776 Holotype, 2777 Paratype. 


\section{TYPE AMMONITES}

BY

S. S. BUCKMAN, F.G.S.

The illustrations from photographs mainly by

J. W. TUTCHER

\section{Part XXII}

Pp. 17-I $8 ;$ I6 Plates

Published by The Author

SOLD BY

WILLIAM WESLEY AND SON,

28 ESSEX STREET, STRAND, LONDON, W.C. 2.

June, I 920 
CONTENTS

PART XXII

Text :

Systematic

\section{Illustrations :-}

I39. Am. biplex, Homœomorph of

Plate

(Dichotomoceras dichotomum)

CXXXIXD, E

I49. Ammonites lamellosus

(Phricodoceras lamellosum) . . . . CXLIXD

I56. Cardioceras goliathus

(Goliathiceras galeatum) .. . . .

I57. Ammonites tenuicostatus

(Dactylioceras tenuicostatum) . . . CLVII

I58. Ammonites sauzei

(Otoites contractus) . . . . . $\quad$ CLVIII

I59. Ammonites braikenridgii

(Epalxites latansatus) $\quad . \quad \ldots \quad \ldots \quad$ CLIX

r6o. Perisphinctes davidsoni

(Leptosphinctes leptus) . . . . . . $\quad$ CLX

I6I. Ammonites martinsii

(Leptosphinctes cleistus) .. . . . . CLXI

162. Perisphinctes martinsii

(Vermisphinctes vermiformis) CLXII

I63. Parkinsonia caumontii, ally of

(Caumontisphinctes polygyralis) CLXIII

I64. Emileia, cadicone stage

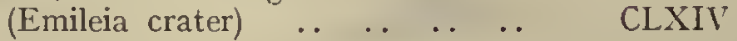

165. Am. buckii and Oxyn. oxynotum

(Oxynoticeras buckii) ..

I66. Ammonites retentus

(Retenticeras retentum) .. . . . CLXVI

I67. Macrocephalites morrisi

(Morrisiceras sphæra) .. . . $\quad$ CL.IVII 
V. quadratum, J. Sowerby, I8r3, (M.C. I, 52, xvIl, 3) ; T. \& F. 37 , 39, 30? 30; An example from Cowley, near Oxford, L. Calc. Grit, S.B. Coll. No. 2779 ; S. $96,36,27,32.5$. The somewhat polygyral inner whorls of this example match what is shown in Sowerby's figure. They persist longer than one would have expected-cunctative palingenesis?

The above species would have much the same maximum diameters -av. c. Ioo mm., about same whorl-breadth-c. 36 per cent. The differences are thickness, umbilication and size of ribbing. There should be a species between $V$. dorsale and $V$. vertebrale.

Lamberticeras, p. I4, PI. CLIV, and Prinoceras, Pl. CLV : Mr. L. F. Spath, F.G.S., kindly advises that they are pre-occupied. It is necessary to change.

Bourkelamberticeras instead of Lamberticeras-the species was named after Aylmer Bourke Lambert (J. Sow. III, 73).

Prionodoceras instead of Prionoceras.

Prionodoceras, g. n. ( $\pi$ piw, a saw). The serratum group. Genoholotype, $P$. prionodes n., Pl. CLV.

Amblygastric, convergent-sided platycone; periphery 3-fastigate, strongly carinate, carina serrate. Tuberculation-(EL) [more pronounced after loss of ribs], [(ES), $\mathrm{L}^{1}$ in costate species]. Very long projection of rad. l. on periphery. S.L. simple with short, broad lobes [longer in costate spp.], loculi short, septa crowded (degenerate?).

Distinguished by swollen stage developed on inner margin, whence whorls slope to narrow periphery; a substantial serrate keel ; excessive rostration and simple suture-lines packed close (degenerate ?). Swelling scarcely commences till ribs are much in decline. Am. serratus, J. Sow., Am. serratus, Damon (non Sow.) and many other species. Cf. Cardioceras shurarskii, Solsolov (Petschora; Mém. Comm. Géol. 76, 1912, 11, 4-6,) England; Russia? In the Midlands and eastern counties of England the species occur in Drift and have been placed in Museums as from Oxford Clay. They occur in Kimmeridge Clay (Damon), lower partthe Upper Oxfordian of Salfeld-for the present to be reckoned as Kimmeridgian, though a distinctive term is perhaps wanted.

Korythoceras, g. n. (kópvs, helmet). Genoholotype, K. korys nov., described below.

Galeatiform; periphery 3; ornament 4 ; costæ laterally slightly flexed, versiradiate, regularly bifurcate, $S^{1} \vee L^{2}$, slightly bullate, wellprojected on keel ; S.L., ES and $\mathrm{L}^{1}$ about equal, $\mathrm{L}^{2}$ short, lobes broad, saddles narrow.

A series with characters of Vertumniceras and Goliathiceras. Separable from the first by finer regular ribbing and a distinct keel; from the second by ribbing, by the more pronounced keel on which ribs form a fairly projected $V$, by radial line all behind guide-line, by suture-line with short $\mathrm{L}^{2}$. It would not attain stoutness of that genus. Scotland ; and Swiss Jura?

$K$. korys, n. (cf. Cardioceras goliathus; Loriol (non d'Orb.), Oxf. inf. ; Mém. Soc. Pal. Suisse, XXV1I, r900, 30, I1I, 7). Galeatiform, with fine, regularly bifurcate ribbing, sweeping well forward over a distinct keel ; involute; S. 42.5, 47, 52, 24 ; "Locl Staffin, Isle of Skye, Scotland, Oxford Clay" witl Peltocerates-P. cf. interscissum Uhlig (Loriol) etc.: [Argovian, post-scarburgense pre-vertebrale Argovian 4]. Mus. Geol. Surv. Engl. Coll. No. 30380 Holotype and Genotype; No. 3038r Paratype.

Goliathiceras, S. Buckman rgrg, T.A., Legend of Pls. CXXXII A-C. The goliathus group. Genoholotype Goliathiceras ammonoides, Young \& Bird sp., Plesiotype, Pl. CXXXllc. 
Galeatiform, becoming sphæroconic; periphery 2 ; ornament 4, obscurely bullate on $\mathrm{S}^{1}$; versiradii, towards periphery rursiradii with little peripheral projection. S.L., lobes long, rather narrow, $\mathrm{L}^{2}$ about to guide-line.

A massive galeatiform series in which the most inflated species, G. goliathus, attains to a swollen stage of about 100 per cent. Has usually been assigned to Cardioceras, but whorl-shape, inflation, radial line and suture-line are all distinctive. Radial line has little projection on periphery, it crosses a feeble keel by a broad V; most of its lateral portion lies beyond guide-line. Many species rising to $G$. goliathus and then declining. [Lobes not so long in declining species-septal degeneration ?] England, France; Argovian 5.

Pavloviceras, g. $n$. Genoholotype $P$. pavlovi, R. Douvillé sp., a specimen in Mr. Tutcher's Coll. which agrees with Quenstedticeras pavlovi, R. Douv., Cardioc. Mém. Soc. G. Fr., XLV, 19I2, 74, 75, xI (v), I3. Sphæroconic; periphery $I$; ornament 4 , coarse and bullate, OV L $\mathrm{L}^{2}$, ribs rounded-funiculate-rursiradiate, very slight $V$ on middle of venter. S.L., lobes rather long and somewhat narrow, $L^{1}$ not as long as $\mathrm{E} \mathrm{L}, \mathrm{L}^{2}$ about same distance from guide-line as $\mathrm{L}^{1}$.

Like Goliathiceras in inflation and suture-line, but differing in the more massive ornament and in the fact that the attempt towards a keel fails very early -it would only be found in brephomorphs and anamorphs -so that a flatly arched venter is produced.

Normandy; England (Dorset, Oxfordshire, Huntingdonshire) ; Swiss Jura; Russia. Divesian, vertummus, according to Douvillé's Normandy evidence; but it is not yet known from Yorkshire.

P. omphaloides, J. Sowerby sp. I8I9 (M.C. III, 74, CCXLII, 5. Whorls tumid, galeatiform, a little more than half-included. Ribs about radial, sometimes a little rursiradiate-the primary and forward secondary run nearly straight round whorl-the hinder secondary is rursiradiate. The $\mathrm{V}$ on periphery is feeble. There is an attempt at an angulate periphery and towards a knotted keel in youth, but this fails at about $25 \mathrm{~mm}$. diameter.

The above description is drawn up from a topotype. At the next rib after $34 \mathrm{~mm}$. diameter this shows a sudden jump in the size of the whorl-see proportions below. This explains a feature of Sowerby's plate-there the sudden jump is shown at the second primary (fifth secondary) rib from the end, before the pyritized lump-the same place as in the topotype. In the next species, $P$. bathyomphalum, the jump is shown about the same place-perhaps a rib earlier. Weymouth, Dorset; Oxford Clay, pyritized; Mus. Geol. Surv. England, No. 30569 ; S. $26,42,57,3 I ; 34.5,4 I, 57,29 ; 36,47,60,29$. Another example, Oxfordshire; same Coll. No. $30574,26 \mathrm{~mm}$. diam.

$P$. bathyom phalum, nov. Cf. Quenstedticeras sutherlandic; Loriol, Pal. Suisse, XXVII, Igoo, III, Io. Stouter than P. omphaloides, with a smaller umbilicus, which, on account of stout whorls, is quite deep. Periphery arched. Jump in size of whorl at about $34 \mathrm{~mm}$. diam. St. Ives, Hunts; Mr. Tutcher's Coll., S. 26, 44, 67, 27 ; 34, 46, 70, 26 ; $50,45,65$ ? 24 ; full size of specimen $59 \mathrm{~mm}$.; max. c. $90 \mathrm{~mm}$. A brephomorph, Great Northern Railway [Walton, Hunts], Mus. Geol. Surv. Engl. No. 30571, S. 20, 45, 60 ? 3I-certainly thicker and less umbilicate than $P$. omphaloides at the same diameter.

$P$. stibarum, nov. Cf. Cardioceras goliathus; Loriol, Pal., Suisse, $\mathrm{XXV}, \mathrm{I} 898$, II, I4. Stouter than $P$. bathyomphalum, with more flatlyarched periphery, but less stout than $P$. pavlovi, and with less flattened periphery. Ornament not so coarse as $P$. pavlovi, more in agreement 


\title{
TYPE AMMONITES
}

HI

S. S. BUCKMAN, F.G.S.

The illustrations from photographs mainly by

J. W. TUTCHER

Part XXIII

Pp. 19-24; 13 Plates and a Portrait

\author{
Published By The AUthor \\ SOLD BY \\ WILLIAM WESLEY AND SON, \\ 28 ESSEX STREET, STRAND, LONDON, W.c. 2 \\ September, 1920
}




\section{CONTENTS}

PART XXIII

Text:Page

Systematic . I9

\section{Illustrations :-}

Plate

I68. Witchellia lacviuscula

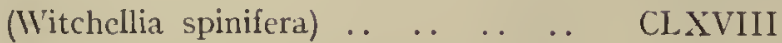

r69. Parkinsonia caumontii

(Caumontisphinctes phaulus) .. CLXIX

I7o. Quenstedticcras pavlowi

$\begin{array}{llllll}\text { (Pavloviceras pavlowi) } & \text {. } & \text {. } & \text {. } & \text { CLXX }\end{array}$

I7 I. Ammonites ordinarius

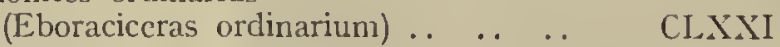

172. Ammonites ordinarius

(Eboraciceras subordinarium) .. CLXX1I

I73. Morphoceras pseudo-anceps

(Ebrayiceras ocellatum) .. $\quad$. $\quad$ CLXXIII

174. Horphoccras pseudo-anceps

(Ebrayiceras pseudo-anceps) $\quad . \quad \ldots \quad$ CLXXIV

I75. Occoptychius (sphærocone stage)

(đEcoptychoceras grossouvrei) . . . $\quad$ CL.X.XV

I76. Occoptychius grossouvrei

(CEcoptychoceras subrefractum) . C CLXXVI

177. An acmic Oppelid

(Diplesioceras diplesium) .. $\quad$. $\quad$ CLXXVII

I78. Microceras densinodum

(Crucilobiceras crucilobatum) .. CLXXVIII

I79. Hammatoceras sp.

- (Eudmetoceras eudmetum).. .. CLXXIX

I80. Hammatoceras amplectens

(Eudmetoccras amplectens) $\quad . \quad$.. $\quad$ CLXXXA

And a Portrait of James Buckman 
with $P$. bathyomphalum. St. Ives, Hunts ; Mr. Tutcher's Coll., Holotype, S. $34,48,70,23.5 ; 59,43,75,25 ;$ size $63 \mathrm{~mm}$; max. c. $90 \mathrm{~mm}$.

P. pavlowi, R. Douvillé sp. Quenstedticeras pavlowi, R. Douv., op. cit. I9I2, XI, I3. Holotype, F. 57, 39, 8I, 26 ; 70, 44, 8r, 26, not taken at end, as this seems damaged. Paratype, Russian example, R. Douv., Id. p. 74 , figs. $80-82$, F. $53,38,79,27 ; 98,45,90,25.5$. Mr. Tutcher's specimen, Genoholotype, from St. Ives, Hunts, Oxford Clay, S. 35, 40 ? 74,23 ?; $55,43,82,25 ; \mathrm{Pl}$. CLXX.

$P$. roberti nom. nov. Holotype, Quenstedticeras sutherlandice; Robert Douvillé, IgI2 (non Murchison sp.), op. cit. XI (v), 8 only. An involute development of $P$. pavlowi with the thickness beginning to decrease from that of the Russian example of that species, and the periphery becoming rounder, foreshadowed in the same form. F. 54, 4 I, 82 , I6.5; 104, 46, 82, 2I.5, Normandy.

The proportions of the last two species, especially the agreement in thickness, are fair evidence for their relationship. The next species after $P$. roberti might be more involute in youth, would be excentrumbilicate in adult - the starting indicated in the proportions of $P$. roberti given above-thinner, and perhaps attaining smoothness. It may have been confused with Am. goliathus or Am. sutherlandia in collections.

Sagitticeras g. n. Genololotype, S. sagitta nov. Serpenticonic becoming tumid ; periphery 2 to I $\mathrm{c}$; ornament 4 , coarse, ribs laminar ; crest-like bullæ, OVL?; similar bullæe less strong, EL. Like Vertebriceras - the genotype especially has resemblance to $V$. rhachis (III, p. I6) ; but a keel is not developed-instead strong ribs of Vertebriceras pattern cross the periphery with $\mathrm{V}$ curves or arrow-like, the apices rising to little transverse crests; and against these apices, leaning backwards, are little buttresses, whose bases point forwards, but die away before touching next $V$. The presence of these buttresses, with their consequent slight raising of the median line of periplery, gives a suggestion of keel bordered by feeble depressions of the Vertebriceras pattern, but only when the specimen is held at certain angles to the light. Ribbing strong, of Vertebriceras pattem, the ribs run sufficiently forward on periphery to throw radial line all behind guide line. Ribs rise nearly radial from contact-line, not with the strong backward sweep of Vertebriceras. In general characters of development the genus is between Vertumniceras and Vertebriceras. England (Dorset, Huntingdonshire) Argovian, pre-Goliathiceras, perhaps intermediate 4 and 5 .

$S$. fastigatum, nov. Whorls somewhat flat-sided, with distinct inner margin and a fastigate periphery. The periphery is like that of Vertumniceras damoni (Y.T.A. CXVIB), but ribs do not make so sharp a V. Ribs are less projected forwards than in S. sagitta-otherwise ornament is similar, but not so developed. Umbilicus is gradate. St. Ives, Huntingdonshire [Oxford Clay, grey argillaceous matrix]; Mr. Tutcher's Coll. ; S. 5 I, 44,49 (43), 33.

The question now arises whether $A m$. vertummis, Damon, I88o, I, 3 = Quenst. damoni, Nikitin, (see Y.T.A. II6 c), is the same species as the Yorkshire example (Y.T.A. CXVIB). It looks as if the Dorset species had the laminar ribs with slight forward projection of this genus: if so, it would be the species before S. fastigatum. The Yorkshire species is rightly a Vertumniceras, but would then have to take another trivial name.

2. S. sagitta, nov. Whorls tumid, rising with a somewhat gibbous curve from inner edge till they meet a flatly-arched broad periphery-at the meeting place are strong somewhat crest-like bullæ, 
the furcation point VL ${ }^{2}$. lRibs are strong, sharp, compressed, (laminar), rising very slightly ruricostate from inner edge, continuing thus to $\mathbf{V}$, then bending forwards, fairly regularly bifurcate, on a sweeping curve to middle of periphery: guide-line from this cuts tlırough next forward primary. Umbilicus somewhat cadiconic without definite inner margin. End of whorl shows complete mouth-border-quite plain, curving to a long, forwardly projected, somewliat incurving rostrum which is carinate (cf. Cardioceras cordatum; Loriol, Pal. Suisse, XXIX, II, 7). Carina presumably formed on last four or five ribs (but periphery damaged) : same distance of terminal part shows decay of ribbing and contraction of cone. Body-chamber $\frac{3}{4}$ of whorl.

Weymouth, Dorset, "Oxford Clay "-a bluisl calcareous matrix[junction of " Oxford Clay" with Lower Calcareous Grit, pre-vertebrale, Argovian, about intermediate 4, 5] ; Mus. Geol. Surv. England, 3037I ; S. 5I, 43, 63 (57), 3r.5; 68, 43, 53 (45), 30 ; max. C. 79 mm., Holotype and Genotype.

Weissermeliceras, g. $\mathrm{n}$. Genoholotype, W. longilobatum, $\mathrm{n}$. (Pl. CLXXXIII). Swelling serpenticone ; periplery 2 to I c ; ornament 4. rather small, regular, mostly bifurcate, occasionally intercalate, $V_{L}{ }^{2}$, little difference in size between primary and secondary ribs, the former versiradiate, the latter prorsiradiate, making a wide $V$ on periphery. Suture-line with particularly long and slender lobes, $\mathrm{L}^{1}$ well below guide-line, $\mathrm{L}^{2}$ just below, aux. 3 touching.

Like Eboraciceras, but distinguished by the finer, more regular ribbing and the long slender lobes.

England (Yorkshire); East Prussia?

W. longilobatum, n. (Pl. CLXXXIII). Cf. Quenstedticeras sutherlandia; Weissermel, non Murchison sp. (Zeitschr. Deutsch. geol. Ges. XLVII, I 895, XI, 3 only). The genotype is a specimen sent from Sedgwick Museum, Cambridge, witl name Quenstedticeras ordinarium, but it is well distinguished from that species. It agrees with Weissermel's figure, except that he shows more curvature of primary ribs and somewhat more spaced ribbing towards end of whorl. From iron-stained sandstone of so-called Kelloway Rock, Scarborough; Callovian, athleta ; S. 53 , $43.5,45,26.5$; size of specimen $63 \mathrm{~mm}$.; $\max . c .84 ; 2 \mathrm{~S}$ ribs on whorl to $53 \mathrm{~mm}$. diam.

Eichwaldiceras, g. n. Genoholotype, Ammonites carinatus, Eichwald, (Lethæa rossica II, I868, xxxıv, 8). Serpenticone, rapidly developing cadicone; periphery, I ; ornament, 4 ; costæ rursiradiate, bifurcate from swellings on edge of inner margin.

The serpenticone stage belongs to brephomorphs [and anamorphs], which also show an attempt towards carination: this only achieves a sequence of $\mathrm{V}$-costae, and is soon lost-swollen stage rapidly develops with a broadly-rounded periphery. A very inflated cadicone is developed, much like Cadoceras; but the genus is distinguished by the more distinct attempt towards carination in early stages, by developing a cadicone ont of a serpenticone without passing through a platycone stage.

The species figured by Weissermel (Cadoceras carinatum; Quenstedic.; Zeit. Deutsch. Geol. Ges., XIVII, IS95, XII, I) and by R. Douvillé, (Quenst. carinatum; Cardioc.; I912, X (IV), 57, 58, non cret.) are presumably the cadiconic developments of Eichwald's species, that is later developments, biologically, of Eichwaldiceras, and require new names.

Sufficient genera of Cadoceratidæ have now been described to illustrate the method of work, but not sufficient to deal properly with 
the very varicd morplology of this remarkablc family. But'a provisional analysis of the genera now named may be interesting. Three developmental features are striking-(I) the attainment of inflation: in this some genera are very successful-Cadoceras, Goliathiceras, Eichevaldiceras, and secm to cnd in it; others are fairly successful, Eboraciceras, Vertumniceras, Vertebriceras - the last passes beyond it back into platycone; others make little progress, and may be said to fail, Pseudocadoceras, Longeviccras, Bourkclamberticeras; the last drops off into oxycone; (2) the attainment of carination: in this Vertebriceras is most successful, especially in combining it with fair success in regard to inflation; Cardioceras is also successful in regard to carination, less so as regards inflation; Sagitticeras is remarkable for an attempt at carination which comes so near success and yet fails; some genera show an attcmpt abandoned as soon as inflation comes-Eboraciceras, Pavloviceras, Eichwaldiceras; otlicrs are successful because inflation takes place only around umbilicus-Chamoussetia, Korythoceras and, in a feeble degree so far as carination is concerned, Goliathiceras ; others seem to make no attempt-Cadoceras, Pscudocadoceras, Prorsiceras; (3) the attainment of tuberculate ornament: the Argovian and later genera show this-Cardioceras and Vertebriceras, which liave also knotted keels; Amoboceras and Prionodoceras, which have serrate keels. The early genera do not attain the tuberculate stage; some of the later genera, for instance Prinonodoceras, not only attain it, but lose itpass beyond it to the catagenetic stage of smoothness.

In early genera development takes place from a platycone stageCadoceras; in later genera development starts from an earlier stagethe serpenticone-Vertumniceras, Vertcbriceras, Goliathiceras, - the platycone stage being skipped; and it is to be presumed that, in the earlier genera, the scrpenticone stage has been skipped or forced into insignificance by tachygenesis of platycone.

In later genera a secondary platycone (even oxycone) stage is developed after more or less of swollen stage, which also may persist into it, though with declining intensity-Prionodoceras.

A fuller, tabular, analysis of these and other genera of the Cadoceratid family may bc attempted later.

\section{Family STEPHEOCERATIDA, Buckman, I 898}

Suture-line with tubercle, $\mathrm{OV}$, outside of $\mathrm{L}^{2}$, later, on to $\mathrm{L}^{2}$ and, in some very serpenticonic forms, inside it ; $L$ : feeble, gencrally surpassed by a lighly-developed aux. I. Suspensive lobe may become highly elaborated and long. The cadicone stage passes into serpenticones, and there are no sphrerocones.

Genera, Stepheoceras, Buckman, I 898, Normannites, Munier-Chalmas 1892, Stemmatoceras, Teloceras, Skirroceras, Epalxites, Mascke I907, Masckeites, Buckman, I920. Some other already-named genera may come here, but that has not been proved.

The family Pachyceratidæ (Y.T.A. II, xiii) is presumably a development of the early members-cadicones-of this one-whorl-shape of Erymnoceras and tubercle-position are the same. Ground for separation may perhaps be found in the simpler suture-line. 


\section{Family SPIIEROCERATIDE, nov.}

Suture-line with OV on, later inside, of a broad-stemmed, spreading $\mathrm{L}^{2}$, which is more or less unequal-sided, the suspensive lobe feebly developed, and no highly-elaborated auxiliary lobe.

Genera Sphrevoceras, Bayle, I878, Emileia, Buckman I898, Otoites, Chondroceras, Mascke I 907 , Docidoceras, Labyrinthoceras, Trilobiticeras, Morrisiceras, Buckman I9I9, I920, and Macrocephalites, to be removed from Pachyceratidx.

It seems inadvisable to employ the family name Otoitidæ, Mascke, as the present grouping is so very different. Several of these genera are distinctly spliæroconic, Emileia passes through it and becomes platyconic ; but Docidoceras is an exception : it develops serpenticones without passing through a spherocone stage.

It will be noticed that genera with lateral auricles come into Stepheoceratidæ and Sphæroceratidæ. Such forms are regarded as phaulomorphs. Suture-line is considered to be a better test of affinity than mouth-border.

Family MORPHOCERATIDE, Hyatt, Igoo.

This requires much emendation. All the genera given by Hyatt (Eastman-Zittel, Pal. I900, p. 583) must be excluded, except Morphoceras. There may be added Oecoptychius, Neumayr, and new genera, Ecoptychoceras and Ebrayiceras (see below).

The family is in origin presumably akin to the Sphæroceratidæ, and it develops sphærocones out of which come, normally, serpenticonesthe transition from spherocone to serpenticone is so rapid in some cases as to give the curious ' dimorphous ' feature-and, abnormally, goniocones-the same transition in an exaggerated form.

The difference from Sphæroceratidæ is the suture-line-comparatively simple, with $\mathrm{L}^{2}$ compact, not spreading; retraction feeble, sometimes lost-phylogerontic development.

Morphoceras, H. Douvillé, i 88I ("Am. pseudo-anceps" ; Bull. Soc. Géol. Fr. (3) VIII, 242). "Type : A. polymorphus . . . Cloisons présentant une série de lobes régulièrement décroissants."

There are 4 specimens figured in d'Orbigny (Pl. cxxIv) belonging to two, if not more, species. These are syntypes. The s.l. (fig. 7) shows the characters cited above, and from d'Orbigny's text (p. 38I) is presumably taken from fig. 4. Therefore this specimen is chosen as genolectotype.

Add-ribs, furcation twice-inside $L^{2}$ and sometimes again outside it. Periphery with smooth median line, into which fade ribs that alternate; constrictions well-marked cutting across 4 or 5 ribs. Mouth not known to be auriculate. S.l.- lobes rather broad-stemmed, E.S. narrow, E.L. and $\mathrm{L}^{1}$ approximate, $\mathrm{L}^{2}$ nearly as long as $\mathrm{L}^{1}$, all lobes touching guide-line.

EBRAYICERAS, g.n. Genoholotype E. ocellatum, n. Pl. CI,XXIII. Furcation single-on or inside $\mathrm{L}^{2}$; primaries short, swollen ; periphery sulcate, ribs thereon not quite opposite, ending as feeble nodi abruptly at interuption ; constrictions feeble, nearly parallel with ribs. Mouth 
auriculate ; S.L.-lobes narrow; E.S. wide; $L^{2}$ about half-length of $\mathbf{L}^{1}$. Vesulian (Eningenian) zigzag hemera, France (N. \& S.), England (Dorset, Somerset).

E. ocellatum, nov. P1. CLXXIlI. Thinner and more umbilicate than E. pseudo-anceps, Ebray sp. : it is also less excentrumbilicate-the umbilicus in youth being wider. The example figured shows the mouth considerably closed up, but with ocular and brachial apertures open: the same as is depicted by $H$. Douvillé for Morphoceras pseudo-anceps.

This example also shows (Fig. 2a) a great abbreviation of the last air-chamber-marked in black between the two last septa.

E. pseudo-anceps, Ebray, sp., (I 864 , Etudes géol. Dep. la Nièvre, p. 263 ; H. Douvillé, "Am. pseudo-anceps" ; Bull. Soc. Géol. Fr. (3) VIII, (I 880), 239 ; fig. 2, p. 240.) The example now figured (PI. CLXXIV) is smaller than Ebray's type as depicted by Douvillé, but agrees in proportions with his figure at the same diameter. Douville's text, however, differs from the proportions of the figure. His diameter (p. $24 \mathrm{I}$ ) is T. $38, \mathrm{~F} .36 .5$. The diameter is presumably over the shell with mouth, and then it agrees with figure. His breadth of whorl is T. I2 mm., F. I4.5, thickness T IO.5, F. II. umbilicus T. I3 mm., corresponding to his "maximum radius of umbilicus" $8 \mathrm{~mm}$., F. I2.5. These figures translated to a diam. 36.5 do not agree with the figure, and the breadth of $12 \mathrm{~mm}$. seems too small, because breadth + umbilicus $=69$ per cent. when they should be nearer 72 per cent. The breadth of whorl at end of fig. is, however, presumably exaggerated. For proportions, sec below (p. 24).

In the specimen now depicted ocular and brachial apertures are closed up-the animal has moved forwards; it will be noticed that the length of body-chamber to end of mouth is the same as to beginning in E. ocellatum. The closing up seems, from growth-lines, to have been done by the mantle working backwards, closing the hinder parts of the apertures last. There is reason to think that tubercles and parabolic excrescences have, in certain cases, been formed in the same waynot by the forward edge of the mantle, but by portions further back, extruding as if repairing an accidental break. The hinder part of closed brachial aperture is in shape just like a preceding primary rib.

At the end of the lateral part of mouth of Fig. $2 a$ is a laterallyprotruding excrescence which may be some attached foreign body: it is not on the other side (Fig. Ia).

$E$. vaschaldi, Reynès sp. in Collot, Descr. géol. . d'Aix, I880, 27 (Douvillé, 240). Professor Repelin, Director of Marseilles Museum, has kindly sent me casts of Reynès types, for which I express my best thanks. The holotype shows a species much larger than the others: it has much finer (hair-like) ribs, more closely set. Esparron, Bonches du Rhône.

$E$. jactatum, nov. Fine-ribbed like $E$. vaschaldi, but with ribs conspicuously thrown forward instead of radial. Involute and concentrically coiled in early stage, exccntrumbilicate last half-whorl. Constrictions more marked than in other species. Burton Bradstock, Dorset [zigzag], S.B. Coll. No. 3316, Holotype.

E. rursum, nov: A widely-umbilicate form, concentrically coiled, because the wide umbilicus begins early. Ribs coarser than in $E$. ocellatum, and generally in threes, mostly reclined, making an angle with the lateral nodes. Mouth present, imperfect, a large ocular 
aperture. Burton Bradstock, Dorset [zigzag], S.B., ex Darell, Coll,, No. 3365 , Holotype.

Ebrayiceras-Proportions-order of umbilication.

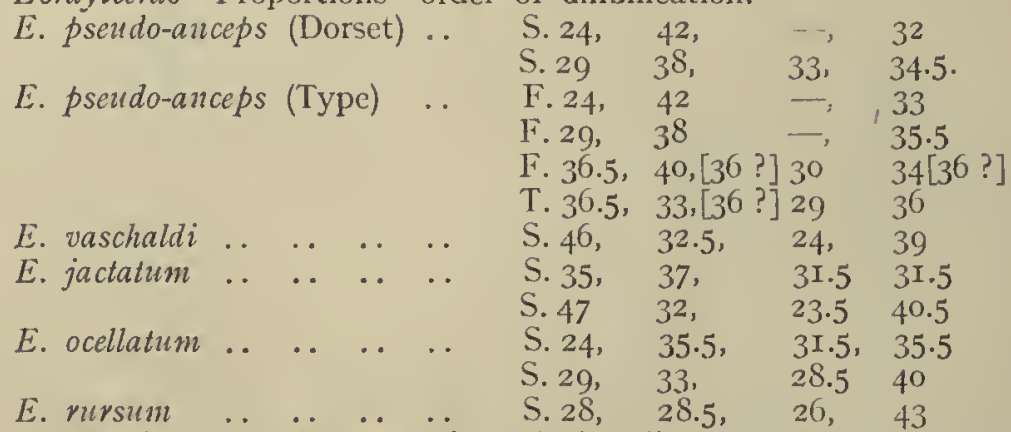

By the time $\ddot{E}$. occllatum had reached a diameter of $36.5 \mathrm{~mm}$., the size of type $E$. pseudo-anceps, it would lave something like 42 per cent. umbilication.

Okcoprychius, Neumayr, r878, Cephalopodentypen, Jahrb. k. k. geol. Reichsanstalt, XXVIII (r), 68, Genotypes " Gruppe des Ammonites refractus." Advisable to take as genolectotype Am. refractus, d'Orbigny, Terr. jur. Cépl. Clxxir, 4, 5. [S.l. lobes short and simple, EL longer than $\mathrm{L}^{2}$, trilobulate, $\mathrm{L}^{2}$ single, quite short, about one-fourth the length of $\mathrm{L}^{1}$ - from a Bavarian example].

Callovian; France, Germany.

The difficulty of placing this genus in Morphoceratidæ is the absence of connecting links-Eningenian to Callovian. But the Sphæroceratidæ slow no forms with peripheral sulcus, the Morploceratidæ do.

ECOPTYCHOCERAS, g.n., Genoholotype, Ec. subrefractum, 11. Pl. CLXXVI. A catamorph development of a sphærocone which has acquired a gonioconic outline. From Oecoptychius it differs [in mouth-border (see Brasil, Céph. nouv.; Bull. Soc. géol. Norm. XVI, I 893, p. 2I, Pl. IV, f. I2, I3)], and also in the ribs crossing the periphery with very slight weakening, making an almost indiscernible median line, not a distinct ventral interruption of ribs or sort of sulcus as in Decoptychius. At beginning of body-chamber only there is a short hidden sulcus on periphery-in cast not in test: the same is often to be seen ill Sphæroceratidæe and Morphoceratidæ.

EL and $\mathrm{L}^{1}$ about same length, $\mathrm{L}^{2}$ incipiently trilobulate, about $\frac{1}{2}$ of L1. [Lobes more developed in GEc. grossouvrei, Pl. CLXXV.]

This genus cannot be ancestor of Oecoptychius, as it is already more decadent in costation. The two genera are morphic equivalents produced by similar causes from more or less distinct sources, as the difference in periphery shows. Ecoptychoceras is perhaps connected with Morphoceras, Oecoptychius with Ebrayiceras, at least according to peripheries.

England (Dorset) ; Normandy ; Gernany ? cf. Neumayr, cit. p. 68, Vesulian (Eningenian), truellei.

Ecoptychoceras grossouvrei (Brasil), Loc. cit. Oecoptychius grossonvrei. The example figured, Pl. CLXXV, is the sphrerocone stage before the goniocone stage begins-most of body-chamber being lost.

Burton Bradstock, Dorset, truellei-the matrix is unmistakable. S. $8.5,57,76,-$, which agree with Brasil's illustration at same diam.

Ecoptychoceras subrcfractum, S.B. MS. sp., Oecoptvchius grossouvrei, S.B., Q.J.G.S., LIV, I8g8, +56 (non Brasil). This (1'l. CLXXVI) is 


\title{
TYPE AMMONITES
}

13Y

S. S. BUCKMAN, F.G.S.

The illustrations from photographs mainly by

J. W. TUTCHER

Part XXIV

Pp. 25-30; 16 Plates

\author{
Published by the Author \\ SOLD BY \\ WILLIAM WESLEY AND SON, \\ 28 ESSEX STREET, STRAND, LONDON, W.C. 2 \\ November, I920
}




\section{CONTENTS}

\section{PART XXIV}

Text:-

Systematic

Illustrations :-

Plate

ISo. Hammatoceras amplectens

(Fudmetoceras amplectens) $\ldots$.

I8I. Harpoceras fissilobatum

(Fissilobiceras fissilobatum) .. $\quad \ldots \quad \ldots$ CLXXXI $\mathrm{A}$, i

182. Haugia inæqua

(Esericeras inæquum) .. . . . CI.XXXIJ

183. Quenstedticeras ordinarium

(Weissermeliceras longilobatum) .. CLXXXII

I84. Ammonites ingens

(Dichotomoceras ingens) . . . C Cl.XXIV

I85. Ammonites poculum

(Poculisphinctes poculum) .. . CLXXXV

186. Ammonites poculum

(Poculisphinctes auricularis.. . C CLXXXVI

187. Ammunites personatus

(Agassiceras personatum) . . . C.XXXivil

I88. Ammonites erratus

(P'scudolioceras erratum) ..

I8y. An cllipticone Oppelid

(Cadomoceras costatum; .. . . CLXXXIX

I9o. Perisphinctes martinsii

(Vermisphinctes subdivisus) .. $\quad \ldots \quad \ldots \quad$ CXC

I9I. Perisphinctes martiusii

(Pseudobigotella otiophora) .. . . C. CXCI

I02. Cosmoceras caumontii

(Caumontisphinctes bifurcus .. . . CXCII

193. Ammonites gracilis

(Gracilisphinctes gracilis) . $\quad \ldots \quad \ldots \quad$ CXCIII

I94. Ammonites gulielmi

(Gulielmiceras gulielmi) . 
a thinner and smaller form than Brasil's species. His dimensions are, from beginning of depression before mouth through umbilicus, T. \& F. I5.5 (3I) $58,48,-$, and this one is much the same at a diametcr of 10.75 , taken at the same place-consequently, at this diameter Brasil's species is much thicker (see preceding species).

The prorsiradiate primary ribs bifurcate into decreasingly rursiradiate secondaries. Just before the angle the primaries nearly disappear and the secondaries pass rather suddenly into fine ribs.

Broad Windsor, Dorset-the suggested date, truellei hemera, would accord with that of the Burton-Bradstock species."

\section{Family OPPELIDE, S. Buckman I 808 .}

Oppelia, IVaagen, r 869 , (Form. Am. subradiatus; Geogn.-Pal. Beitr. II. (2), 250). Genosyntypes, O. subradiata s.l.; Genolectotype, O. subradiata, Waagen, Id. Pl. Xvi, f. I, (non Am. subradiatus, J. de C. Sowerby $)=O$. waageni nom. nov. This form shows major ribs at intervals and short minor ribs in the interspaces: these die away, leaving major ribs only, perhaps relics of the bullate ribs of Diplesioceras, sec below.

OEcotraustes, Waagen, I869, Id. p. $25 \mathrm{I}$ (Oekotraustes). Genoholotype, Oecotraustes genicularis, Waagen, Id. Pl. xx, f. 4a, b. Ribs are uniform in this genus.

DIPLESIOCERAS, g.n. ( $\delta \imath \pi \eta \eta \dot{\sigma} \leftarrow \circ$, twicc as much). Genoholotype, D. diplesium n. Pl. CLXXVII. Serpenticone ; carinatebisulcate ; costate, with, at intervals, a double-sized rib ending in a bulla on latero-peripheral border. This genus is remarkably like Dipoloceras, Hyatt, of the Lower Cretaceous, but the strong rib does not fork, instead it remains single, and swells into a strong bulla or blunt transverse knob.

This genus presumably belongs to the family Oppelidæ, and shows in its intermittently strong costation a phase through which Oppelia and like forms have presumably passed; for there remain in such forms short ribs at intervals which would correspond to the bulla and be relics of their former existence-the intermediate ribs and other part of the strong ribs having disappeared in catagenesis from serpenticone to oxycone, retained latest around the keel. If this supposition be correct, then Oppelia-like forms have had a much more varied history than has been supposed-they have rapidly dropped the serpenticone, carinatebisulcate, tuberculate stage, and have become examples of quick transformation with skipping of stages, pronounced lipopalingenesis.

England (Dorset). Vesulian (Eningenian), garantiana.

D. diplesium nov. Pl. CLXXVII, sufficiently described in generic diagnosis. Vetney Cross, near Bridport, Dorset; S. 15, 40, $53(40), 28$; S.B. Coll. No. 3265, Genotype and Holotype.

\section{Family PERISPHINCTIDE, Hyatt, Igoo.}

This was proposed for the very large series of costate serpenticones which characterize the Middle and Upper Jurassic strata; but they are of polyphyletic origin. The family diagnosis must be deferred until the genotype of the typical gcnus Perisphinctes has been selected; for 
the application of the family name depends on that and it lias not yet been done.

PERISPHINCTES, Waagen, I869 (Form. Am. subradiatus; Geogn.Pal. Beitr. II. (2), 248). Proposed for the Planulates of the Middle and Upper Jura-all named by that date are thus genosyntypes; but the author limits choice by the description-that in the young the mouth-border has auricles and the whorls have constrictions. Siemiradzli (Mon. Perisph.; Pal. XLV, I899, 78) applies generic name s. str. to certain series more or less connected with Am. martelli. As he has selected no one genotype, and still calls all the species of his six Abtheilungen by the name Perisphinctes, choice is still unfettered and should fall, if possible, on a species fulfilling Waagen's description, named before $I 869$, and, as the suture-line is very important, on an auriculate showing that fcature-a difficult condition, as sometimes suture-line and side-view have, witlout notice of the fact, been taken from different examples, whicli may be only homnomorphs.

The difficulty of such choice is well shown by the following account. It seemed that Ammonites martiusii, d'Orbigny, would be a suitable subject for type: it was doubtless one that Waagen had in mind, for both constrictions and auricles are striking. However, I put certain questions to my friend Professor Welsch. I summarize his interesting information-the result of his study of the types.

The name is Ammonites martiusii, not $A$. martinsii, as given in places by d'Orbigny and by so many authors: it was dedicated to M. de Martius, the botanist. The figures given by d'Orbigny are greatly restored, idealized from various examples which are not necessarily the same species; [they are, in fact, synthetographs]. There is no evidence for the auricle of the mouth of fig. I, Pl. cxxv of d'Orbigny, in the example which furnished the main of the figure: the auricle is taken from another specimen, perhaps another species. The month of fig. 2 is restored as regards the saddles and lobes. The mouth of fig. 3 is imagination. The suture-line is taken from another specimen rather smaller than $210 \mathrm{~mm}$. The proportions are taken from an example of $210 \mathrm{~mm}$.

With such a mix up as this identification is almost impossible, and it would be unsafe to take $A m$. martiusii as a genotype. It is advisable, however, to fix on figs. 1, 2, of d'Orbigny's plate without their months as the holotype of the species. It is presumably about of niortensis-garantiana date.

Another auriculate species, Am. defrancii, d'Orbigny, Pl. cxxix, 7 , is not now a Pcrisphinctes: it belongs to the Morphoceratida. Another auriculate, Am. bakarice, d'Orbigny, Pl. CXIIX, I, has been taken as type of the genus Siemiradzkia, Hyatt; it therefore falls out. Another candidate might be $A m$. achilcs, d'Orb., Pl. CcVI, I, 2 ; but this is excluded from the species by Dr. Siemiradzki, who gives an opinion on its identity. As this lacks s.l. and may be a synthetograph like $A m$. martiusii and as it is impossihle to go on witl the necessary investigations for each likely species, it seems advisable to return to Siemiradzki's position : this is helped by the fact that a small specimen of, or near to, Siemiradzki's Perisphinctes s. str. has been found at Cowley, near Oxford, S.B. Coll. No. 3264, showing a lateral auricle. Whether, however, this is a brephomorph or a phanlomorph is not yet certain.

For genolectotype of Perisphinctes is now selected Am. biplex, Sowerby; it is, which is important, a species figured before Waagen founded the genus. Its suture-line is partly visible: Dr. IV. D. Lang 
has kindly forwarded a sketch. The suspensive portion comes much further down the whorl than that of Dichotomoceras and the lobes are more highly developed : like those of P. martclli, Siemir., p. 268, fig. 6I.

This selection makes Siemiradzki's "Formenreihe des Per. biflex" (p. 256) the typical and perhaps only series of Perisphinctes.

The result may be thus stated :-

Family PERIsPHinctide, Hyatt (see above, p. 26). Descendants of coronates which in the catagenetic costate stage show parabolic curves (intermittent zigzag ornament) and deep constrictions. Umbilicus angulate, with fine ribs and constrictions [earlier, coronate cadicone, skipped in later forms?]. S.1. may become fairly complex. Parabolic curves fail soon and constrictions may be ultimately lost.

Genera, Perisphinctes, Dichotomoceras, Grossouvria.

Siemiradzki notices the angulate character given by constrictions to the inner whorls of his Perisphinctes s. str. (p. 78) and compares it witl Morphoceras sculpture (p. 79); cf. Dichotomoceras, CXXXIXc, I; but admits that the same character comes in small forms of the "subtilisReilie" (p. 235), which, seemingly, has a coronate-cadicone originthe cadicone obvious but the coronate lost perhaps by brady-palingenesis.

A Morphoceras origin is doubtful for many reasons-chiefly the difference in position of furcation. Somewhat of the Morphoceratan style required is shown by Vermisphinctes (PI. CLXII), but the lack of parabolic curves prevents that coming into this family.

The following corrections in nomenclature of species of Perisphinctes s.l. have usually been overlooked, and it seems advisable to note them here:-

Ammonites triplicatus, J. Sowerby, I8I5, M.C. I, p. 208, xcII, 2, [Kimmeridgian, post-virgula ?], "Portland Island, [Dorset]."

Amnonites trifidus, J. Sowerby, I82I, M.C. III, p. I94, name given to Am. triplicatus, J. Sowerby, I82I, M.C. III, I67, ccxcil and ccXciIr, 4 (non Am. triplicatus, Sow., I8I5). Holotype, ccxcII, "Pisolite formation [Argovian, c. martelli]....near Malton, Yorkshire." Am. triplex, J. de C. Sowerby, I835, M.C. VI, p. 249, name given to the two specimens of Am. triplicatus, J. Sow. I82I; but, as the holotype is already named trifidus, only the paratype is available. This is from " Marly Limestone... . probably Calciferous Grit, ... . at Shotover, near Oxford." A topotype, S.B.Coll. 2778, large adult, from Cowley, (foot of Shotover Hill), near Oxford ; Lower Calcareous Grit-Argovian, c. Goliathiceras; S. 287,2 I, $23.5(22.5), 6$ I.5.

Perisphnnctes, Waagen $x 869$, loc. cit. Genosyntypes, Planulates of Middle and Upper Jura. Genolectotype, Ammonites biplex, J. Sowerby I82I, M.C. III, I68, ccxciII, I; refigured, Miss M. Healey, I904, Q.J.G.S. I.X, 57 ; $\mathrm{x}$; Pal. U. 58. S.l. ornate, with long suspensive part whose component lobes are fairly developed. Tubercle (or furcation point) on edge of periphery, [just inside $\mathrm{L}^{\mathbf{1}}$ ] ; peripheral rilis not strong, dichotomous in young [presumably tritomons in adult, before a stage of massive ribbing is attained]. Proportions of $A m$. biplex (Dr. Lang) : S. $46.5,32,33,4 \mathrm{I}$; I20, 29.5, 29, $44 ; \mathrm{I} 60,29.5,24,48.5$. These dimensions differ from those given by Dr. Siemiradzki (p. 267) chiefly in the less thickness of the inner whorls, where there is displacement and filling in by calcite: this would not be shown in a plaster cast.

Dichotomoceras, S. Buckman 1919, T.A., III, Legend of Pl. CXXXIX.1. Genotype, D. dichotomum. Like Perisphinctes as now 
defined, but distinguished by the lower stage of development of the s.l., by stronger ribs on the periphery and perhaps by remaining dichotomous and not passing to tritomous ribbing. Subsecuently it develops similar massive ribs in old age-D. ingens Young \& Bird sp. Pl. CLXXXIV ; D. variocostatum, Buckland sp. (Healey, Q.J.G.S. LX, I904, 58 f. 2 ; XI ; Pal. U. 56).

Grossouvris, Siemiradzki, Oct. I8g8, Mon. Perisph.; Palæontographica, XLV, pp. 78, 79. “I. Abtheilung. Subgen. Grossouvria nob. A. Mutationsreihe des Per. subtilis" (p. 79).

This makes Per. subtilis the indicated genoholotype, which may be fixed with further precision on the holotype of the species, Neumayr, Balin, XIV, 3 .

Before proceeding further it is advisable to note the different methods by which costate serpenticones (Perisplinctean forms) have been produced in the Inferior Oolite; for it is here that change over is seen to advantage - the inner whorls, sometimes till quite late in life, so different from the outer, which are Perisphinctean.

A. Inner whorls.

I. Bullate cadicone, Docidoceras.

2. Tuberculate serpenticone (Skirroceratan).

3. Tuberculate serp. with sulcate venter (Parkinsonian).

4. Tuberculate serp., zigzag ornament.

5. Sphæroconic with constrictions Costate serp. No parabolic (Morphoceratau).
B. Outer whorl or zehorls.

Costate serpenticone, Docidoceras.

Costate serp.

Canmontisphinctes.

Costate serp., Procerites curves, $.4 m$. defrancii.
Costate serp.,

Differences of inner whorls, when there are several whorls before a change takes place, are good evidence for difference of origin, but differences of embryonic whorls only are not good necessarily-omission due to lipopalingenesis and modifications due to brady- and propalingenesis have to be allowed for.

The Perisphinctidæ, as now defined, showing parabolic curves, considered to be intermittent zigzag ornament, have presumably come from a later development of $4 \mathrm{~A}$, having taken a road different from $4 \mathrm{~B}-$ preserving relics of zigzag ornament and not losing all that ornament suddenly.

Of the above, I belongs to the Sphæroceratida, 2 to the Stepheoceratidæ, 5 to the Norphoceratidæ. Thus 3 and 4 are left.

\section{Family PARKINSONIDE, nov.}

Descendants of coronates which acquire more or less of peripheral sulcation and at this stage have a comparatively simple s.l. They pass on the one hand into uncoiled forms and on the other hand into costate serpenticones: these develop constrictions, lose the peripheral sulcation more or less completely and may elaborate the s.l. A stage with parabolic curves is not developed.

In the early Perisphinctean forms (costate serpenticones) the coronate stage with lateral tubercles and the sulcate stage with some- 
times peripheral tubercles bordering the sulcus are well shown in inner whorls.

Genera, Parkinsonia, (Choffatia?) Stronoceras, Garantiana, Baculatoceras, Subparkinsonia, Bigotites, Pscudobigotclla, Canmontisphinctes, (Leptosphinctes, Vermisphinctes?.).

The evidence of Parkinsonian origin-sulcate periphery - is contained in the inner whorls of Caumontisphinctes and other genera to be named: these whorls also preserve the lateral tubercles of the coronate stage. There is as yet no evidence that Choffatia, Leptosphinctes and Vermisphinctes passed through a Parkinsonian stage, though the two latter slow evidence of having been coronates : they may have to be removed. Ant. martiusii is possibly akin to Leptosphinctes.

Choffatia, Siemiradzki, I898, Op. cit. p. 79. "VI. Abtheilung. Subgenus Choffatia nob. Embryonalkammern glatt, comprimirt, ohne jede Spur von Seitenohren. Mundrand wic bei Per. Martinsi abgestutzt, ohrenlos. Seitensculptur ähnlich der Martinsi-Gruppe. Lobenlinie einfach.

"Diese Gruppe verbindet die Perisphincten mit der Gattung Proplanulites und enthält eine einzige Formenreihe: Reihe der Per. cobra Waag." (p. 79).

This marks the genoholotype and there is only one reference to that (p. 334) - "I875, Perisph. cobra Waagen, Kutch, S. I74, Taf. 45, Fig. I." And this is unique; from the zone of Reineckia anceps, Kutch, India (Siemir. p. 335).

BigoteI IA, Nicolesco IgI7 (Bull. Soc. Géol. France (4) XVI, I53), invalid through prior use.

Bigotites, Nicolesco IgI8 (C. R. somm. Soc. Géol. Fr., Jan., p. 36). To replace Bigotella. No genotype indicated in either case, and queries as to his choice addressed to the author gave no result. Therefore Bigotella therenini, Nicolesco I9I7, op. cit., P1. IV, fig. 9 with s.l. fig. 3 , p. I78, is now taken as genolectotype of Bigotites. Stout ; ribs somewhat strong, mostly bifurcate; occasional constrictions; ribs alternatc on periphery, fading into a narrow smooth band which conceals a slight furrow of cast. S.l. has EL much longer than LI, a deep ES which gives obliquity even to LI; anx 2 about as large as L2, lying across whorl nearly parallel with, but above guide-line; aux. 3 cut by guide-line.

Several of the species placed by M. Nicolesco in Bigotella (Bigotites) appear to represent, not a genus in the phylogenetic sense, but a developmental stage-members of different lineages have independently arrived at the periphery with obsolescent interruption, which may be called the Bigotitean stage of venter. If so, this should be revealed by differences of suture-line. The Bigotitean venter is transitional between the Parkinsonian with distinct peripheral interruption and the Pcrisphinctean with ribs unintcrrupted. All the Parkinsonidre which attain the Perisphinctean venter pass throngl more or less of a Bigotitean stage. But in other families which do not develop the episode of a Parkinsonian venter, the Perisphinctean venter is a continuation of the Stepheoceratan venter: peripheral interruption may appear later.

Pseudobigotella, P. Lemoine, IgI\$ (Rev. crit. Paléozool. XXVII, $(\mathrm{I}, 2)$, p. 34). 'To replace Bigotella. "M. Nicolesco n'a pas indiqué de génotype; la première espèce décrite est Pseudobigotella Haugi. . . . Je verrais dans tous les échantillons, . . . décrits par M. Nicolesco, une seule espèce . . . quui porterait le nom de Parkinsonia Haugi." The author thus makes Bigotella haugi (Nicolesco) the genotype of his 
Pseudobigotella, but condemns Pseudobigotella, as, in his opinion, an unnccessary addition to nomenclature.

Polygyral; thin; rather small ribs which cross periphery witlı a V-curve; s.l. quite simple-EL longer than LI-very little obliquity to inner part. Cf. Pl. CXCI.

Pseudobigotella has the Perispluinctean venter, presumably having passed through the stages of Parkinsonian and Bigotitean venters: but this is not yet proved: it may be inferred from evidence of other genera.

Haselbubgites, gen. nov. Like Bigotella petri, Nicolesco, 1v, 5 . Distinct from Bigotites in suture-line - ES is shorter instead of longer than LI, and it lacks a lateral brancl,; guide-line cuts above aux. 2, and therc are 4 aux. in a long hanging part which extends well below guide-line. Genoholotype, $H$. admirandus nov. Like $B$. petri, but more nassive, ornament heavier, umbilicus smaller, lateral ribs obsolesce about I70 mm. dianı. From Haselbury, Somerset (purchased); Inf. Oolite [Parkinsoni \%.] ; S. B. Coll. 654; S. I29, 33, 36, $42 ; 218,36,29$. $37 ; \max$. c. $4 \mathrm{IO}+$. Its date is presumably c. trucllei; but Strigoceras truellei appcars to be lacking from Hasclbury. A Morphoccratid of defrancii pattern occurs in the same bed-a light yellow stone, fincly oolitic, soft. ("Top bed' [I] or 'Brash' [2], Hudlleston, Mou. Gast., Pal. Soc., 1887, p. 3I).

\section{Family ZIGZAGICERATIDEE, nov.}

Descendants of those coronates whiclı have zigzag ornament-later coronates than the ancestors of the Parkinsonidæ. These lose their parabolic curves as soon as they enter the costate stagc, and they show no stage of intermittent parabolic curves like the Pcrisphinctida. Also constrictions are not developed.

The s.l. in the zigzag stage is comparativcly simple, of Stepheoceratid style; in the costate stage, or even earlicr in the stout forms, it rapidly develops to become very elaborate, distinguished by large EL, with large accessory branch, and by large aux, 2 spreading across the whorl. These characters, though there may be decay of s.l., should yet remain relatively distinguishing.

Genera, Procerites, Zigzagiceras.

Procerites, Siemiradzki I8g8 (Op. cit. p. 78.) "V. Abtheilung. Subgen. Procerites nob. C. Mutationsreihe des P. procerus Seeb." (pp. $78,79)$. The earliest whorls show lateral ornament like that of Stephanoceras zigzag-on a smooth under-surface zigzag-like coarse distant ribs which on the dorsal [ventral] margin swell up into spine-like little knobs (Siemir. p. 78).

From the character of its inner whorls Procerites is undoubtedly a descendant of the Stephanoccrata in a narrow sense (Siemir., p. 79). The development from "Stephanoceras" zigzag had been illustrated by S.Buckman, Q.J.G.S., XLVIII, I892, 447, and the likeness of inner whorls of zigzag forms to coronates ( $A m$. blagdeni-Teloceras) was also pointed out.

Unfortunately, the identification of Am. procerus scems to be incorrect, now that s.l. of zigzag costates has been worked out. M. A. de Grossouvre also points this out (Bull. Soc. géol. Fr. (4) XVIII, (IgIg), 387). Am. procerus, Siemiradzki's interpretation, is genolectotype of Procerites (Y.T.A. II, IgI $4, i x$ ). 


\title{
30 \\ TYPE AMMONITES
}

IBY

S. S. BUCKMAN, F.G.S.

The illustrations from photographs mainly by

J. W. TUTCHER

\section{Part XXV}

Pp. 31, 32; 15 Plates and a Portrait

\author{
Published by the Author \\ SOLD BY \\ WILLIAM WESLEY AND SON, \\ 28 ESSEX STREET, STRAND, LONDON, W.C. 2 \\ January, J92I
}




\section{CONTENTS}

\section{PART XXV}

Text:-

$\begin{array}{lllllllllll}\text { Terminology } & . & \ldots & \ldots & \ldots & \ldots & . & \ldots & \ldots & . . & 3 \mathrm{I}\end{array}$

\section{Illustrations :- $\quad$ Plate}

195. Ammonites omphaloides

(Pavloviceras omphaloides) .. .. $\quad \mathrm{CXCV}$

I96. Quenstedticeras sutherlandire

(Pavloviceras bathyomphalum) .. CXCVI

197. Cardioceras goliathus

(Pavloviceras stibarum) .

I98. Cardioceras aff. vertebrale

(Vertebriceras dorsale)

199. Ammonites buckmanii

(Paltopleuroceras buckmanii).. .. C CXCIX A, P

200. Perisphinctes pseudomartinsi

(Prorsisphinctes pseudomartinsi) CC

20I. Perisphinctes davidsoni

(Leptosphinctes davidsoni) $\quad . \quad \ldots \quad$ CCI

202. Perisphinctes davidsoni

(Leptosphinctes coronarius) .. $\quad$ CCII

203. Parkinsonia neufferisis

(Haselburgites admirandus) .. $\quad . \quad$ CCIII A, B

204. Lytoceras cf. sutneri

(Kallilytoceras interlineatum) .. CCIV A, B

205. A tuberculate Sonninia

(Papilliceras acantherum) .. .. $\quad \mathrm{CCV}_{\mathrm{A}, \mathrm{B}}$

And a Portrait 
Jan.

To Am. procerus, Schloenbach (Jur. Amm. Palæont. XIII, I865, $\mathrm{xxx}, \mathrm{I}$ ), he gives special attention, and this may now be definitely talicil as genolectotype. It has been named (as a syntype) $A m$. schloenbachi by Grossouvre, Ig07 (Six. Congres Assoc. Franc-Comtoise, p. 8) and Procerites schloenbachi by Grossouvre, I9I8, (Bull. Soc. G. Fr. (4) XVIII, p. 388). So this lectotype of Procerites schloenbachi, Grossouvre sp., is genotype of Procerites, which covers compressed forms of zigzag origin in which zigzag omament is soon lost.

ZigZAGICERAS, S. Buckman I902 (Y.T.A. II, I9If, $i x$ ). This covers massive forms of zigzag origin in which zigzag stage persists for some time.

The rapid development of an elaborate s.1. in Zigzagiceratidre-in small forms with zigzag ornament the s.l. is comparatively simple (S. Buckman, Q.J.G.S., XLVIII, I892, X1V, I)--is paralleled by the rapid claboration of s.l. in otler genera, Vermisphinctes, Leptosphinctes. Elaboration of s.l. may not necessarily be a reason for parting genera from those which have it poorly developed-such forms may have merely retained the original form of s.l., or they may be phaulomorphs. Again, septal degeneration has to be allowed fora phenomenon particularly noticeable in certain Perisphinctoids, Proplanulites, Pictonia. Comparison should be between what may be called the acmic forms of s.l. of different lineages.

\section{Family $A T A X I O C E R A T I D E$, nov.}

Distinct from Perisphinctidæ as defined above (p. 27) by (I) difference of inner whorls-instead of angulation and morphoceratan sculpture, delay in production of ornament (bradypalingenesis ?) : (2) longer retention of parabolic curve stage and parabolæ perhaps placed more peripherally ; (3) secondary ribs on anamorphs and brephomorphs often rursicostate, passing in later forms to versi- and then to prorsicostate; (4) s.l. comparatively simple (einfach; wenig verzweigt; Siemir.).

Genera, Biplices, Ataxioceras, Siemiradzkia, Planites, ctc. ; Poculisphinctes.

Brplices, v. Sutner-Siemiradzki I898, (Siemir. p. 77). " a. Mutationsreihe d.Per. Tiziani und Colubrinus." Now chosen as genolectotype, P. tiziani (Oppel), Siemiradzki's interpretation, (pp. I47-I49).

Ataxioceras, Fontannes 1879, (Crussol, p. 66, x, I-4); "Perisphinctes (Ataxiocerus) hypselocyclus."

"Le terme Ataxiocerus a été imprimé pour la première fois dans l'explication de la planche $\mathrm{x}$ (fig. I-q) de la Description des Ammonites des Calcaires du château de Crussol (Ardèche) par Fontannes ou il cst intercalé entre parenthése entre Perisphinctes et hypselocyclus. Cette espèce est donc le type du genre 1 taxioceras Fontannes, I879" (R. Douvillé, Bull. Soc. Géol. France (4) X, I9Io, p. 734, footnote 2). Siemiradzikis, Hyatt Igoo (Eastman-Zittel, Pal. I, p. 582). "Typc S. (A mm.) Bakerice d'Orb. sp. (Terr. Jurass. Pl. I 49, Fig. I, non Pl. I 48)." Parabolre strongly developed. The sealing of ocular apertures (Morphoceras psendo-anceps, CLXXIV) suggests a method of naking parabolie.

PLANITES, de Haan, sec Y.T.A., II, IQI3, p. iv.

\section{TERMINOLOGY}

Sec III, 5, II. Teclnical terms for well-grown and ill-grown forms are required-that which accords with the normal standard may be 
known as a Kallimorph-nomomorpl, p. 6, refers only to sizc, not to standard condition in shape and ornament; that which is not normal, kakomorph. This requires subdivision: a form awry in

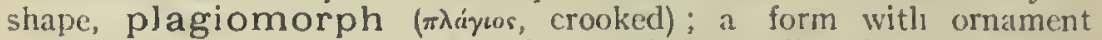
awry, distorted ribs; loss of keel in a carinate or like defects, or with exaggerations, any disturbance of ornament due to injury or disease: dysmorph (Pl. CLXXXVIII). Dysmorphy in youth may be recovered from, to sliow a kallimorpls old age, or a kallimorph youth may receivi injury and become a kakomorph adult. As Gastropods and Turrilites show, plagiomorply may become the standarized form : then it is really kallimorphy and further chance departure from that standard would be required to constitute plagiomorphy. The Turrilites of the Cretaceous are not truly plagionorplss, but the so-called Turrilites of the Lias are.

For a study of malformed or cripple Ammonites see lingel, Uebor kranker Anmonitenformen im scluwäbischen Jura; Nova Acta Ksl. Leop.-Carol. Deutscl. Akad. Naturf. I.Xl, (5), I894, 327.

A further term is required for a shell which has undergone deforma-

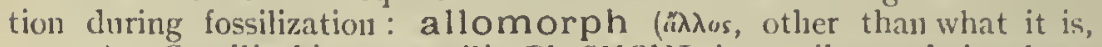
untrue). Gracilisphincles gracilis, PI. C.CCIII, is an allomorph, its shape altered by compression.

\section{Systematic}

Family PROPI.ANUI.ITIDA, $110 \mathrm{~V}$.

Heavy ribs in and around the umbilicus suggest a zigzag origin ; but style is different-stontest part near inner, instead of towards outer end; and its persistence, througl serpenticone and into platycone; also $V$ is nearer inside-about on L2 instead of nearly on LI; while the s.l. is far less developed. Species witl these characters may be surmised to have a coronate (Teloceratan) origin and to fall between the families Zigzagiceratidæe and Pachyceratidæ-s.1. much less developed than tliat of the first, rather more developed originally than that of the second, but quickly falling into a very degenerate condition : in the well-developed stage there is a spreading (palmate) ending to LI whicl is very characteristic. In Pachyceratidre the teloceratan (cadicone) stage is long retained, and there is little falling away from it; in Proplanulitidic there is rapid falling off into compressed serpenticones, cven platycones, with narrowed periphery, little sign of cadicone and nnly heavy ribs as relics of teloceratan stage: even these suffer-in some Proplanulites there is much delay in their appearance, presumably the phenomenon of bradypalingenesis. The lengtli of I.I in proportion to breadth of whorl appears, at any rate in this family, as a useful guide to genera and to series within genera. This may be stated thus: LI at $47 \mathrm{~mm}$., 42 per cent. When, in illustrations, s.l. has been traced, the length of guide-line is greater than breadth of whorl by the amount of the gibbosity of the whorl-a reduction will have to be made before stating the result: the greater the giblosity the greater the reduction. In s.l. reproduced from a photograph no correction should be required. The measurement of $\mathrm{LI}_{\mathrm{I}}$ is made from the end of the terminal lobule up the middle to a line joining ES and SI. Where one saddle is deepermore produced-than the other, the cross line may run obliquely. Up to a certain point the length of LI should increase; afterwards, as the whorl loses gibbosity and increases its breadth proportionately to diameter, the length of L.I would decrease. In aged specimens the 


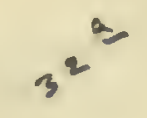

\section{TYPE AMMONITES}

แY

S. S. BUCKMAN, F.G.S.

The illustrations from photographs mainly by

J. IV. TUTCHER

\section{Part XXVI}

Pp. 33-40; I6 Plates and reprint of CCI

Published by the Author

SoLD BY

WHELDON AND WESLEY, L'TD.

INCORPORATING

WILLIAM WESLEY AND SON

28 ESSEX STREET, STRAND, LONDON, W.C. 2

March, 1921 


\section{CONTENTS}

\section{PART XXVI}

Text :-

Systematic

Illustrations :-

Plate

206. Hammatoceras aff. insigne

(Hammatoceras cappucinum) .. CCVI A, B

207. Hammatoceras sp.

(Pachammatoceras pachu) .. CCVII

208. Ammonites crassulus

(Dactylioceras crassulum) .. $\quad . . \quad \ldots \quad$ CCVIII

209. Ammonites crassiusculus

(Porpoceras crassiusculum).. $\quad \ldots \quad \ldots \quad$ CCIX

210. Ammonites incrassatus

(Cœloceras incrassatum) $\quad \ldots \quad \ldots \quad \ldots \quad$ CCX

2II. Perisphinctes cf. evolutoides

(Phanerosphinctes phanerus) .. CCXI

2I2. Ammonites alligatus

(Dichotomoceras alligatum) .. . . CCXII

213. Ammonites koenigi

(Proplanulites capistratus) . . . CCXIII

2I4. Ammonites brongniarti

(Labyrinthoceras extensum) .. CCXIV

215. A coronate Sphæroceratid

(Frogdenites spiniger) .. $\quad . . \quad \ldots \quad \mathrm{CCXV}$

216. Ammonites murleyi

(Murleyiceras murleyi) . . . . . CCXVI

217. Ammonites serpentinus

(Hildaites subserpentinus) . . . CCXVII

2I8. Ammonites serpentinus

(Hildoceratoides propeserpen-

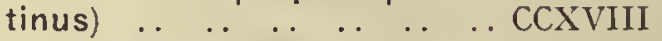

219. Ammonites huntoni

(Tragophylloceras huntoni) .. .. CCXIX

220. Ammonites robinsoni

(Tragophylloceras robinsoni) . . 
last few septa before body-ch. may show much degeneration, and should, where possible, be avoided.

Genera, Proplanulites, Teisseyre, Wagnericeras, nov., see below, Crassiplamulites, nov., see p. 41 ; Obtusicostites, nov., see p. 42 ; Kinkeliniceras, nov., see p. 42 ; Pictonia, Bayle, Rasenia, Ringsteadia, Salfeld.

$\because$ Of these genera Obtusicostites is nearest to the main stem and so to the Pachyceratidæ, while Proplanulites is farthest removed, being the most degenerate in all characters.

Am. albineus, Oppel, Per. mutans, Waagen and the series placed by Siemiradzki as "Mutationsreihe des Per. Congener Waag." possibly come into this family.

WAGNERICERAS, g.n. Genotype, Am. wagneri, Oppel (Am. planula, d'Orb., cxi.rv). Serpenticone, convergent whorls; ribs flexed, strong over venter; s.l. somewhat simple, LI at $55 \mathrm{~mm}$. est., 40 per cent. + ; Vesulian, or Bathian; France.

"Ammon. arbustigerus bildet zusammen mit Ammon. planula d'Orb. (Ammon. Wagneri Oppel non Neumayr) eine besondere Gruppe [von Proceritcs] welche den Proplanuliten nahesteht " (Siemiradzki, p. 3I5). But Am. arbustigerus is possibly a Zigzagiceratid, though s.l. is insufficiently developed.

Proplanulites, Teisseyre I887, (Amm. Baliner Ool.; Verhandl. K. K. Geol. Reichs., p. 48) "Proplanulites Könighi Sow. sp. Czerna"”; (p. 54).

"Proplanulites Koenighi Sow. sp. Das betreffende Exemplar dieser aus den Baliner Oolithen wohlbekannten Art hat einen zweispitzigen Antisiphonallobus. Doch ist dieses Merkmal schon innerhalb dieser Art unbeständig. . . Proplanulites nv. gen., welches ausser der gennanten Art noch einige andere als neu zu beschreibende Formen umfast, wird von mir an entsprechender Stelle näher charakterisirt werden."

The genus is founded on "Propl. Koenighi" (sic) from the Balin Oolite-this specimen of Teisseyre's from Czerna thus becomes the genoholotype: it is figured (with its suture-line?) by Teisseyre (Proplan.; Pamiet. mat. Akad. Krak. XIV, I887, IV, I, v, I). The two-pointed antisiphonal lobe is, perhaps, as he says, "unbeständig," inconstantpossibly an abnormality.

S.l. with EL about equal to, but often rather less than LI ; ES and SI equal in depth; L2 and aux. 11. rather degenerate. S.l. degenerates much in some series, LI passing from c. 40 per cent. of breadth of whorl to c. 20 per cent. and less. Periphery has two forms: (I) subgibbous, sides subparallel, venter full; (2) subcuneate, sides converging to a narrow venter : it carries two modes of ornament: (I) ribs cross venter, though with some weakening-(a) they cross straight, (b) secondary ribs being inclined, they cross with a feeble curve; (2) ribs fail on middle of venter, making a smooth band-a very late attempt to produce the Parkinsonian venter (p. 29) -in some degenerate forms, on cast, a fairly distinct interruption, illustrated by Phillips (Am. koenigi, Geol. Yorks. 1829, VI, 24), but exaggerated for his reduced fig. Then, in old age, forms which are subgibbous tend to acquire a subcuneate venter and those that are subcuneate, a subgibbous venter. The rib following any of the obscure Perisphinctean constrictions passes strong over venter in most series. In phaulomorphs, before end of body-ch., a few ribs show strong on venter, finishing off with a sort of collar and short rostrum.

Callovian, England, Kellaways Clay, koenigi $\eta$, Dorset, Wiltshire ; 
Kellaways Rock, post-kocnigi $\eta$. Wiltshire; "Kelloway Rock," pars, koenigi and post-koenigi, Yorkshire; Scotland, Sutherland; Roof Bed, koenigi. Also France (Normandy, Deux Sèvres and Ardennes) ; NorthWest Germany, and Poland.

$A-C$. Nomomorphs (and a megalomorph) ; body-ch. I-I $\frac{1}{4}$ whorls, not found complete; mouth not known, plain? A. S.l. subelaborate, LI, c. 40 per cent. I. Venter subcuneate, rounded, smooth. Max. c. $450+$; usually c. 200 .

P. majesticus, nov. Perisph. könighi, Neumayr (Balin, XI, 2), Pcr. obtusicosta, Petitclerc, non Waagen, (Call. I9I5, VII, 3). Large; 22 primary ribs. IVell represented in Neumayr's fig., but costation remains strong for about another half-whorl in the holotype. Umbilicus concentric, strongly ribbed; periphery narrowly rounded, smooth, but ribs may sometimes be followed across it. Approximation of s.l. to the style of Perisph. obtusicosta, Waagen, and the likeness in form, suggest a common origin for Obtusicostites and Proplanulites-Petitclerc's identification is witness.

Grol. Surv. Engl. No. 30533, Chippenham, Wilts; Kell. Clay (a) ; Holotype; S. I 33, 37, 27, 35; I. I at $47 \mathrm{~mm} ., 42.5$ per ccnt. ; max. c. 2 Io. Neumayr's spccimen, also from Chippenham; F. I27, 35, 27, 36 ; max. c. 210 ; Petitclerc's, Deux-Sèvres, France ; T. I32, 38, 26.5, 37.

$P$. basileus, nov. An involute form with heavy ribs in the umbilicus, cf. Am. könighi Neumayr, Balin, XI, 3. Smootl stage begins about Igo mm. diam., I 8 ribs in a whorl up to that, 17 ribs up to $95 \mathrm{~mm}$. Geol. Surv. Engl., 3074I ; Chippenham; Kell. Clay (b), [from a large septarian nodule]; S. I 47, 38.5, 25, 30; 236, 37.5, 25.5 . 35 ; wholly septate; $\max$. c. $465+$; LI at $56 \mathrm{~mm}$., to per cent., at 88,36 per cent. This is a megalomorph, representing perhaps the acme of size for Proplamulites.

$P$. laevigatus, nov. Bccoming smooth at about $95 \mathrm{~mm}$. ; about I5 ribs whorl before that; involute, then cxcentrumbilicate; Geol. Surv. Engl., ex Darrell, Coll., 30686; Holotype ; Rampisham, Dorset ; K. Clay (b) ; S. $83,44,26.5,26 ; 92,43^{\circ} 5,25 \cdot 5,26 ; 147,40,24,29$; according to mark on test about $I_{4}^{1}$ wh. body-ch. $=$ max. c. I90; LI at $37 \mathrm{~mm} ., 35$ per cent.

$\because A .2$. Venter subgibbous.

P. teisseyrei, Tornquist, I894, (Proplan. ; Zeit. Deutsch. Geol. Gcs., XLVI, p. 562) ; Pl. XLV, Ia-d; Holotype; Callovian; Pourcandes, Mézières, (Ârdennes), France ; 18 ribs about radial. LI at $28.5 \mathrm{~mm}$., 42 per cent.; F. 90, 39, 27, 33. P. teisseyrei; R. Douvillé, I908, (Céph. Call. d'Argences; Mém. Soc. Linn. Norm. XXIII), vili, 8, 9 ; Argences, Normandy; F. $65,37,255,35$; LI at $22.5,42$ per cent.: umbilicus is wider at a smaller size, therefore more excentric.

A. 3. Venter subcuncate, crossed by ribs.

$P$. sp. $P$. arciruga, Teiss., Iv, 9 ; v, 9c, (non Iv, 5), Czerna, Balin, Poland; F. 42, 40.5, 26, 35; 22 ribs; LI at I 2.5 est., 40 per cent.

Near this is No. 30534, Geol. Surv. Engl., "Christian Malford?" [Wilts] ; K. Clay (b) ; S. $38.5,37,28,33 ; 23$ ribs; LI at $12.5 \mathrm{~mm}$., 38 per cent.

$P$. ferruginosus, nov. Thinner than $P$. koenigi (Sow.), with forward bending ribs and more devcloped s.l. Ribbing less conspicuous than in $P$. opimus and periphery narrower. Geol. Surv. Engl., 26105; Holotype; Scarborough, Yorks.; Kell. R. (d), brown ferruginous; S. $57,40,27,26 ; 2$ ribs; $99.4 I, 26,28.5 ;$ LI at 24 mm., 33 per cent. ; at $3 \mathrm{I} \mathrm{mm.,} 37$ per cent. 
$P$. sp. $P$. subcuneatus, Teiss., IV, I3a, V, I3 b, $\mathrm{c}$, seems from its subelaborate s.l., LI at $2 I^{\prime} 5$ est., 34 per cent., to belong to this series.

A. 4. Venter subgibbous, crossed by ribs; $a$, secondary ribs curved.

$P$. curvus, nov. Ammonites koenigii; Brauns, Jura nordwest. Deutschl., I869, p. I33 ; Pl. I, f. I; Porta Westphalica ; Macrocephalenschichten; Holotype. Like P. opimus, but with a regularly concentric, umbilicus. T. $90,40,26 \cdot 5,3 I \cdot 5$.

$P$. opimus, nov. Like $P$. arcigura [arcirnga]; Tornquist, I894, xLVI, 2, and like $P$. koenigi, Sow. sp.; but ribs incline more forward and pass over venter; s.l. is well developed. Primaries I7, mostly trifurcate, one intercalate usually; ribs [in young, fairly radial], later bending more and more forward, passing over venter, somewhat weakened, making a slight U-curve. Geol. Surv. Engl., 26085, Chippenham, Wilts; Kell. Rock (d) ; Holotype; S. $55,40,30,30$; $85,40,29$, 32 ; $\max$. c. I30; LI at 25,38 per cent. No. 26095 . Id.; S. 65,40 , $3 I^{\circ} 5,32$; LI at $20^{\circ} 5,36 \cdot 5$.

$A .4, b$. Secondary ribs nearly straight.

$P$. tornquisti, nov. P. koenigii; Tornquist, I894, p. 552 ; XLIV, I, Holotype; Pourcandes, Mézières (Ardennes), France; Callovian ; F. I Io, $37,33,38$; LI at $29^{\circ} 5,34$ per cent. ; I9 ribs.

$P$. sp. P. arcigura [arcirnga] ; Tornquist, I894, XLvI, 2 ; Chippenham, Wilts ; F. 43, 37, 3I, 35 ; F. 80, 36.5, 29, 32'5;" T. 70, 38, 30, 35, size $80, "$ p. 568 . G.S.E. No. 26100 ; S. $46,39,30^{\circ} 5,30^{\circ} 5$; No. 26098 ; S. $39,42,32,29.5$; both Chippenham, Kell. R. (d), associate better here than with $P$. opimus.

$P$. cracoviensis, Tornquist, $\mathrm{I} 894$, p. 558. Name given to $P$. koenighi, Teisseyre I887, (Pam. Ak. Krak. XIV, IV, I, 2, V, I, 3, 4). These are syntypes. Take as lectotype, IV, I. Fig. Ib shows ribs crossing venter more plainly than in $P$. koenigi (Sow.), agreeing with the A. 4 series. The only difficulty is its? s.l.-LI (fig. Id) works out to no more than 3 I per cent.; but that of his $\mathrm{v}, 3 \mathrm{~b}$, is 37 per cent.

If the identification of $P$. koenighi, Teiss., as morphic equiv. of $P$. koenigi (Sow.) and a member of the present series be correct, it means that this series is the typical one for Proplanulites. Czerna; F. (Ia, b) $59,4 \mathrm{I}^{\circ} 5,30^{\circ} 5,29 ; \mathrm{F}$. (IC) $53,42,33,30$; I 8 ribs ; genoholotype.

$P$. sp., $P$. könighi, Neum., Balin, $\mathrm{x} 1,3$. Like next stage to $P$. lavigatus, widening of umbilicus beginning earlier; Balin; F. 83, $38.5,28,31 ; 16$ ribs, radial. Thickness seems too great, and ribs are depicted crossing venter; both characters are against association with $P$. lavigatus; but make it a possible terminal of this series. cuneate.

$B$. Nomomorphs; s.l. subsimple, c. 30 per cent. I. Venter sub-

$P$. polonicus, nov., $P$. arciruga, Teiss. IV, $8, v, 8$, Filipowice, Poland; Holotype (non Teiss., 1V, 5) ; F. 50, 37, 26, 34; 20 ribs ; F. 73 , $38,26,34 ; 22$ ribs ; LI at $20^{\circ} 5$ mm. est., $3 I^{\circ} 5$ per cent. Geol. Surv. Engl., No. 7693 ; Rampisham, Dorset ; K. Clay (a) ; a brephomorph ; paratype ; S. $475,37,24,34 ; 18$ ribs; LI at $13 \mathrm{~mm}$., 31 per cent.

$P$. occultus, nov. Morphic equiv. of $P$. lavigatus, but with more and smaller ribs-I8 to $78 \mathrm{~mm}$. diam.-and less developed s.l. Geol. Surv. Engl., ex Hudleston Coll., No. 30775 ; Rodborne, Malmesbury, Wilts; Kell. Clay (a) ; inner whorls and part of outer, wholly septate; S. $70,4 I \cdot 5,28,275$; I58, 39, 23.5, 30 ; LI at $3 I \mathrm{~mm} ., 3$ per cent., at $59 \mathrm{~mm} .30$; max. c. $290+$.

$P$. latus, nov. Like $P$. koenighi, Teiss, $\mathrm{IV}, \mathrm{I}$, but thinner, and with smaller, narrower ribs; like $P$. subcuneatus, Teiss., IV, II, but with 
broader whorls and smaller umbilicus. Ribs about radial, mostly trifurcate, with occasional additions, fading away on periphery. Geol. Surv. Engl., 26106 ; Scarborough ; Kell. R. (c), grey oolite with pinkish tinge, decomposing in places to ferruginous; Holotype; S. 57, 40, 27 , $26 ; 68,40,27,28 ; 2$ I ribs; LI at 17 mm., $29^{\circ} 5$ per cent. Tuteher Coll., Chippenham; K. Clay (c) ; a colomorph ; S. $53,435,28,25$; 18 ribs ; LI at 22, 27 per cent.

B. 2. Venter subgibbous. Max. c. Ioo $\mathrm{mm} .+$.

P. koenigi, J. Sowerby sp. I820 ; cclx111, 3, Holotype: F. 57, 38.5, - 32.5 , I 7 ribs on last whorl ; "Charmouth [Dorset]," III, II3; loc. not correct. Rampisham, Dorset, I3 miles N.E. by E. of Charmouth, from which fine specimens of Proplanulites were obtained by Mlr. D. S. Darell, F.G.S., in similar lithic condition to Sowerby's fig. 3, may well be original locality.

Geol. Surv. Engl., ex Darell Coll., 7688, Rampisham, Dorset ; K. Clay (a) ; Topotype? S. $57,4 \mathrm{I}, 33$ (30), 30 ; 18 ribs; specimen, $66 \mathrm{~mm}$. full ; 17 ribs ; $\max$. c. I08 mm. LI at I7, 3I per cent. G.S.E., ex Hudleston Coll., No. 30774, Chippenham, Wilts ; K. Clay (a) ; S. Iog, $4 \mathrm{I}, 30,28{ }^{\circ} 5$; I 5 ribs ; Lr at $26{ }^{\circ} 5,30$ per cent. ; about one whorl body-ch. ; max. c. 130. A mutation? G.S.E., 30537, Weymouth, Dorset ; K. Clay (b), black (nodule from clay); S. $67^{\circ} 5,38,29^{\circ} 5$ ? 3 I ; I6 ribs to $57 \mathrm{~mm}$. ; LI at $2 \mathrm{I}^{\cdot} 5,32 \cdot 5$ per cent.

C. Nomomorphs ; s.l. degenerate; LI, c. 25 per cent. I. Venter subgibbous, smooth. Max. c. I30 min. + .

$P$. laboratus, nov. Coarsely ornate; 17 ribs ; somewliat stout periphery; indication of expanding umbilicus; very likc Perisph. könighi, Neumayr, $=P$. majesticus, but umbilicus beginning to be excentric, periphery more obtuse, s.l. simple. Geol. Surv. Engl., ex Darell Coll., 7685, Rampisham, Dorset ; K. Clay (a) ; S. 7I, 39, 3I, 34 ; II7, 37, 28, 37 ; about one whorl body-ch., mark as if body-ch. continued for another whorl; $\max =I_{\frac{1}{4}}$ whorl body-ch. $=$ c. I30; I.I at 28 , c. 23 per cent.

$P$. fabricatus, nov. Like $P$. laboratus, but not quite so stout ; umbilicus wider and more excentric. Tutcher Coll., Chippenham]; K. Clay (a); S. 7I, 38, 29, 42; $\max$. c. 95 .

$P$. involutus, nov. Cf. Per. könighi, Neun., $.11,3$, but periphery more obtuse. Whorls broader, umbilicus more excentric than A. koenigi, Sow. Morphic equivalent of $P$. laevigatus, but has degencrate s.l. Geol. Surv. Engl., 3053I ; Holotype ; Chippenham, Wiltshire ; black ; S. $57,44,28,26 ; 92,39,28,30 ; 15$ ribs to $57 \mathrm{~mm}$. dianı., I 8 ribs to $92 \mathrm{~mm} . \cdot$. LI, at $2 \mathrm{I}^{\prime} 5,26$ per cent. No. 7692, Rampisham, Dorset ; S. $107,40,28,30$; I 4 ribs; signs of becoming smooth ; body-ch. showing nearly a whorl, its mark certainly another half-whorl $=$ body-ch. I 1 whorl $+=\max$. c. I $40 \mathrm{~mm} .+$; mark continued around whorl, perhaps colour-band ; No. 30538, Wilts; LI at 2I, 26 per cent. ; 30527, Chippenham; S. $65,4 \mathrm{I}^{\circ} 5,28,27{ }^{\circ}$; I3 ribs; L.I at 23.25 per cent. ; all Kell. Clay (b).

$P$. lentus, nov. A thinner development of $P$. involutus, with more numerous smaller ribs, and with umbilicus beginning to open out at a small diameter. Geol. Surv. Engl. 26092 ; Holotype: Kellaways, Wilts; Kell. Rock (d) ; S. $69,40,25.5,30$; 20 ribs to $57 \mathrm{~mm}$. dianı. ; I9 ribs to $69 \mathrm{~mm}$.; $\max$. c. I30; L.I at 25,20 per cent. strong).

C. 2. Venter subcuneate; $a$. laterally costate (secondary ribs 
$P$. apparatus, nov $P$. subcuneatus ; Tornquist, 1894, XLVI, 4 ; Pourcandes, Mćzi res, (Ardennes), France ; Callovian; Holotype ; F. 6I, $35,26,39.5 ; 92,33,23.5,42.5 ; 22$ ribs. S.l. very degenerate, Lr at $23 \mathrm{~mm} .$, I7 per cent.

C. 2 , b. laterally obscuricostate (secondary ribs feeble).

$P$. pourcandiensis, Tornquist I894, xLvI, I ; Holotype ; Pourcandes, Mézières; Callovian; F. 102, 40, 29, 30; I5 strong primaries, secondaries obscure. Lobes like those of $P$. subcuneatus $[=P$. apparatus $]$, Tornquist dixit; but great difference in style of ornament.

D. E. Phaulomorphs; body-ch., usually preserved, $3 / 4$ whorl or less; with lat. auricle, or signs of it, and short rostrum; max. not Ioo mm. and decreasing; Lr, c. 29 per cent. or less. D. I. Venter smooth, subcuneate, sometimes subtabulate towards end of body-ch.

$P$. subcuneiform is, nov. $P$. subcuneatus, Teiss. Iv, I2, (F. 71 , $35,27,3^{S} ; 22$ ribs; II at IS cst., 30 per cent. ; Poland). 'Tutcher Coll. Christian Malford, Wilts; K. Clay (a); Holotype ; S. 71, 36.5, 26, 37 ; $82,36,25,40 ; 22$ ribs; $\max$. c. 94 ; LI at 19,29 per cent. Cf. also Am. koenigi; Damon, Geol. Weym., I880, I, I ; F. ("reduced") 90? $(64 \cdot 5), 34,-, 40$; in ribs. Number of ribs agrees with next sp. luut concentric umbilicus with this; Weymouth; [K. Clay]. Colomorphs, Gcol. Surv. Engl. 30529, Chippenham, Wilts ; S. 32, 39, 25, 24 ; 30536 , "Christian Malford?"

P. subcuneatus, Teisseyre, IV, I4, V, I4b,c; Holotype ; IF. 6I, 4I, $24^{\circ} 5.345$; Lr at 25 est., 32 per cent., seems too much. Czerna, Poland.

$P$. auriculatus, nov. Coarsely ornate, 17 ribs, mostly trifurcate, occasionally extra intercalate; excentrumbilication marked. Like $P$. subcuneiformis ( $P$. subcuneatus, Teiss., IV, I2), but has $\mathrm{I}_{7}$ ribs at same diam. which are stronger, while periphery is quite obtuse towards end of last whorl; umbilicus also is smaller at first, the widening in last whorl being rapid. Geol. Surv. Engl., 30526; Holotype; Chippenlam; S. 7I, 35, 26 (23), 37; I.I, at $16 \mathrm{~mm} ., 24$ per cent.; has lateral auricle and collar. Id., No. 30528 , Chippenham; S. $72,32.5,25,38$; I. I at I 8 num., 22 per cent.; collar and base of lateral auricle: both Kell. Clay (a). A fragment (cast) comparable with this sp., Geol. Surv. Scotl., No. M.1656g., On shore, Lower Brora, Sutherland; Roof Bed; shows peripheral interruption plainly.

$P$. capistratus, nov. Small; rather coarsely ornate, 17 ribs, mostly bifurcate, one intercalate; not much excentrumb.; complete with mouth-border (auricle and collar). Geol. Surv. Engl., 30532, Holotype, Chippenham; K. Clay (a) ; S. 6I, 32, 24.5 (22), 40; LI at $14.5,21.5$ per cent. This is a smaller edition of $P$. auriculatus, with a similar number of strong primaries; but it is thinner and much more umbilicate. Paratype, G.S.E., ex Hudleston Coll., No. 30778 ; Gristhorpe, Yorkshire; Kell. R., soft, ferruginous; S. 54, 29.5, 25, 40.

D. 2. Venter subgibbous. $a$. Paucicostate.

$P$. rudis, nov. Like $P$. subcuneatus, Teiss., IV. I4, but stouter, fuller in venter, and with rather stronger ornament. Rihs mostly trifurcate, with an occasional intercalate; about radial, but slightly flexed; venter smooth. Geol. Surv. Fngl., 30525; Chippenham; K. Clay (c) ; indications of lat. auricle and collar ; S. 6I, 4I, 28 (26), 36; $88,34,26,39$; I9 ribs; LI at I9 mm., 25 per cent. A brephomorph (this sp. ?), No. 30539, Wiltshire; K. Clay. Another example? damaged; G.S.E., ex Hudleston Coll., No. 30776 ; Loudon, Chippenham ; S. $52,39,27+, 33.5$.

D. 2 , b. Multicostate. 
P. arciruga, Teisseyre, IV, 5 ; v, 5c, d ; Holotype ; Filipowice, Poland. Distinguished by the large number of fine ribs and by their crossing a rather full venter without break; F. $47.5,36,24,38 ; 32$ ribs; Lr at I2.5 mm. est., 27 per cent. A similar smaller specimen, G.S.E., ex Hudleston Coll., No. 30777; Gristhorpe, Scarborough, Yorkshire ; Kell. R. ; S. $26,34^{\circ} 5,29,42$; full size of specimen c. $30 \mathrm{~mm}$., with 27 ribs, mostly trifurcate, passing over venter.

$P$. oidaleus, nov. Inner whorls, so far as can be seen, like $P$. arcinnga, Teiss., IV, 5, but umbilicus narrower. Outer whorls more of pattern of $P$. subcuneatus, Teiss., 1V, I2, but ribs smaller and more numerous, venter broadly rounded, crossed by ribs, especially in young ; body ch. inflated, rather more than half-whorl, complete with lateral lappet and indication of short ventral rostrum. Geol. Surv. Engl., 26093 ; Holotype ; Kellaways ; S. 71, 35, 29.5, 39'5 ; 25 ribs. No. 26084, a colomorph, this sp. ?; shows signs of swelling, has a rounded venter crossed by ribs, Chippenham; S. 47, 40, 27.5, 32; LI at I8, 28 per cent. No. 26ro2, similar, Kellaways; all Kell. R. (f). Stout.

E. Phaulomorphs. Whorls subparallel, venter subtabulate, r.

P. stiphrus, nov. Am. koenigi, J. Sow. Cclxill, 2? (F. 39, 36, 34 ? 37 ; I9 ribs). Stout and crassicostate ; ribs about radial, heavy, mostly trifurcate, an occasional one intercalate, crossing rounded, later flattish venter with very faintest forward bend; umbilicus rather small, concentric. Geol. Surv. Engl. 26088; Kellaways; Kell. R. (e) ; Holotype, with beginning of body-clı.; $\mathrm{S} 4 \mathrm{I}, 37,34,34$; 16 ribs ; LI rather long and narrow ; at 13 mm., 26 per cent. ; No. 26086, Id. ; septate; S. $36 \cdot 5,39,36,345 ; \mathrm{x} 7$ ribs.

E. 2. Somewhat stout.

$P$. petrosus, nov. Primary ribs 19 , bifurcate, usually also an interpolated secondary; ribs run radial to cross periphery with a little weakening and very feeble forward turn. S.l. very degenerate, almost ceratitic; LI at $9 \mathrm{~mm}$., c. 22 per cent. Like Proplanulites haugi, Parona $\&$ Bonarelli (T. $50,35,25,40$ ), but whorl almost quadrate in shape while ribs are straight on side and not distinctly bow-shaped on venter. General likeness to Perisph. omphalodes, Waagen (see p. 42), but that has different run of coarser ribs, no intercalated ribs, and the ribs pass strong over venter. Geol. Surv. Engl., $2609 \mathrm{I}$; Kellaways ; Kell. R. (e) ; Holotype ; S. $39^{\circ} 5,33,33,43$; I9 ribs ; size of specinen, $43 \mathrm{~mm}$. ; about $\frac{5}{8}$ whorl body-ch., nearly complete.

$P$. lyprus, nov. Cf. Am. koenigi, J. Sow., cclxıI, I. Like $P$. petrosus, but thinner; ribs cross periphery with slight weakness, except just before mouth, where they are strong; they have usually no bend forward on periphery, only towards last part of body-ch. is there a slight indication of it. Body-ch. $\frac{1}{2}$ whorl; lateral auricle, c. $8 \mathrm{~mm}$. long + ? , $3 \mathrm{~mm}$. broad. Geol. Surv. Fingl., 26080 ; Holotype ; Kellaways; Kell. R. (e) ; S. $37,34,28 \cdot 5,4 \mathrm{I} ; 2 \mathrm{I}$ ribs ; No. 26 ro3, Id. ; S. 32, 36, 30, $39 ; 23$ ribs; signs of constrictions ; on cast, at beginning of body-ch., peripheral interruption strong, almost Parkinsonian (Cosmoceratan).

E. 3. Somewhat thin.

$P$. tridens, nov. $P$. teisseyrei; Douvillé Igo8 (vII, 2, 4; Argences, Normandy; F. 33, 35, 3I, 39.5; 23 ribs). Whorls not so stout and ornament less marked than in $P$. petrosus, ribs about radial, 3 secondaries to a primary, though one is not always joined up. Geol. Surv. Engl., 2609o; Holotype ; Kellaways; Kell. R. (d) ; S. 39.5, 33 , $30^{\circ} 5,40^{\circ} 5 ; 22$ ribs; about $\frac{1}{4}$ whorl body-ch. (incomplete). 
$P$. trifurcatus, nov. Cf. Am. koenigi, J. Sow., Cclxur, 2, but Sowerby seems to show a thicker shell. Cf. $P$. arcirnga, Tciss., IV, 9, but ribs morc prorsiradiate and whorls more parallel-sided than that. Ribs I9, mustly trifurcate, periphery rather obtuse, umbilicus fairly concentric. Tutcher Coll., [Kcllaways; Kell. R. (d)] ; Holotype ; S. 48, $38,29,34$; max. c. 66 ; LI at I4, 23 per cent.

$P$. excentricus, nov. Like the last, but the unbilicus up to the same size is much smaller, then it rapidly widens, becoming decidedly excentric, while primary ribs tend to become heavy. More excentric than any of the D. I series, with more obtuse periphery. Body-ch. $5 / 8$ whorl, almost complete, and from likeness of terminal part to that of D. I series may he expected with auricle. Tutcher Coll. ; [Kellaways ; Kell. R. (d)] ; S. $45,42,29,24{ }^{\circ} 5 ; 71,38,26,35$; 19 ribs; L. at 19 , I 8 per cent. A smaller, somewhat more costate example, a polished section, body-ch. 5/8 whorl with sign of lat. auricle, Geol. Surv. Engl. 26094 , Kellaways ; Kell. R; S. 62, 37, 26 ? 34 ; I7 ribs.

A similar specimen, but primaries less strong, G.S.E., ex Hudleston Coll., No. 30779 ; Gristhorpe, Yorks. ; Kell. R. ; S. 63, 35, 28, 35 ; 99 ribs ; LI at $14 \mathrm{~mm}$., I 8 per cent. This cxample has lat. auricles. It is much like $P$. teisseyrei ; Douvillé, Igog, vilı, 8, 9, except for s.l. P. pourcandiensis, Tornquist, I894, XLVI, 3 , given as $P$. teisseyrei, Tornquist, p. 562 ; Poix-Terron, Mézières ; Callovian ; F. 92, 38,-, 34; LI at $25 \mathrm{~mm}$., 22 per cent. : is much like No. 26094, but is larger.

E. 4 Thin.

$P$. partitus, nov. Cf. $P$. arciruga, Teiss., Iv, 5 ; but ribs stronger and fewer, 22 as against 32 ; cf. P. hangi, Parona \& Bonarelli, but lack of forward sweep of ribs on venter; distinct interruption on cast, beginning body-ch. Primaries, fairly marked, bifurcate, with, usually, one intercalate; ribs, almost radial, sometimes slightly flexed. Geol. Surv. Engl., 26099; Kellaways ; Kell. 1R. (f) ; S. 4I, 34, 26, 40 ; about 5,/8 whorl body-ch., nearly complete ; I.I, c. I8 per cent.

$P$. rufus, nov. Cf. Am. koenigi Phillips, (Geol. Yorks I829, v1, 24 ; F. 90 (30), 33, 27 ? 35). Lilie P. arciruga, Teiss., IV, 5, but fewer ribs and smaller, more excentric umbilicus; like $P$. subcuneatus Teiss., IV, I2 ( $=P$. subcuneiformis), but with ventral part of body-ch. flatter and more swollen. Body-ch. about 5/8 whorl; at beginning, on cast, shows peripheral interruption as depicted, but somewhat exaggerated, by Phillips. Geol. Surv. Eungl., 26104, Scarborough; Kell. R. (f), ferruginous oolite; S. $47 \cdot 5,37,21 ? 33 ; 74,32,27,40$ : about 24 ribs ; LI at I 8 mm., c. 22 per cent.

$P$. fulvus, nov. Somewhat like $P$. arcirmga, Teiss., IV, 5, but with a decidedly excentric umbilicus; like $P$. riffus, but with broader whorls and smaller umbilicus. Ribs prorsiradiate, with a slight bend forwards near venter, usually trifurcate, tending later to be bifurcate, with intercalations when primaries increase in size. Venter, up to well on in body-ch., with a distinct narrow, flat area and costal interruption. Geol. Surv. Engl., No. 26097 ; Holotype; Kellaways; Kell. R. (f) ; S. $53,38,24,30 ; 74,35,24,38 ; 23$ ribs; body-ch. over $\frac{1}{2}$ wh., nearly complete; II at I9, 20 per cent. ; No. 26083 , Chippenham; Kell. R., from top by decomposed condition; S. $67,37,24,36$; 2 I ribs ; body-ch. c. 5/8 wh., complete on inside area, with indications of lat. auricle-outer part broken. Tutcher Coll. ; [Kellaways, Kell. R.] ; S. 45, 39, 27, 33.5 ; $56,35,25$ ? 36 ; body-ch. about $3 / 4$ whorl, ncarly complete; LI at $\mathrm{I}_{3}$, 2 I per cent. ; another ex. same Coll. [and Loc.] from top K.R. by condition ; S. $39,37,25 \cdot 5,34 ; 53,34,24.5$ ? $33 ; 24$ ribs ; body-ch. just over 
l wh., almost complete; renter rather rounded; flat area not shown. (G.ol. Surv. Engl. 26087; Kellawavs ; Kiell. R. ; brephomorph (this sp. ?); No. 26ror, Id. ; colomorph (this sp. ?).

$P$. fracidus, nov. Like $\mathrm{P}$. fulvus, but has the umbilicus more closed in the young stage, conscquently the umbilical excentricity is

\section{TABLE 11, CHRONOLOGY, PROPLANULITES}

\begin{tabular}{|c|c|c|}
\hline Stratal Names & & PRE \\
\hline $\begin{array}{ll}\text { S.W. YORK- } \\
\text { ENGL. SHIRE }\end{array}$ & $\begin{array}{c}\text { SEQUENCE } \\
\text { (S.W. ENGL.) }\end{array}$ & UNA \\
\hline
\end{tabular}

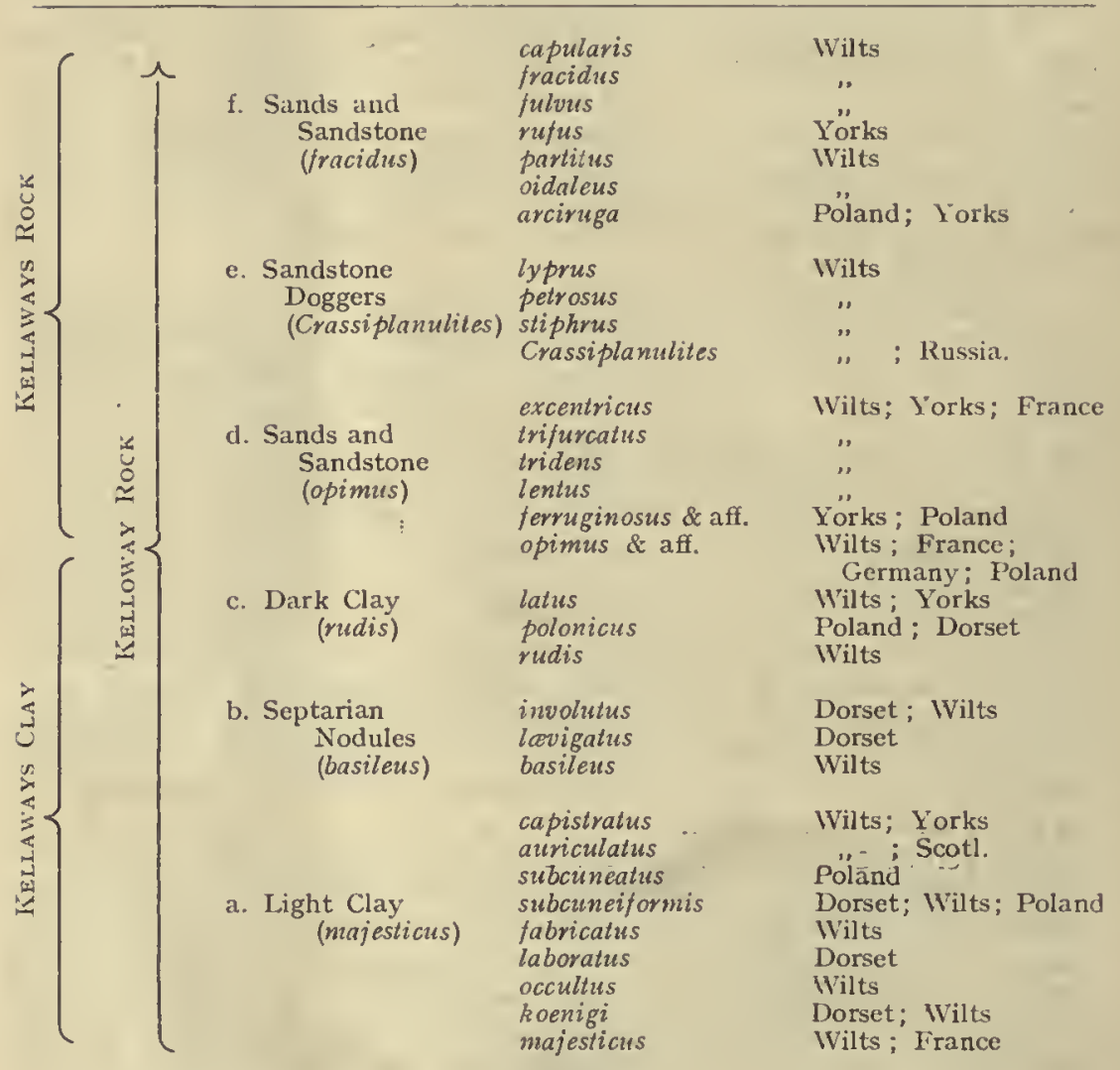

grcater. Geol. Surv. Engl. No. 26082, Chippenham; Kell: R. (f) from ncar top, judging by decomposed condition; Holotype; S. 50, $42,24,28: 76,4 \mathrm{I}, 24$ ?, 345 ; LI at I75, c. 25 per cent. - lopsided ; body-ch. c. $5 / 8$ whorl, nearly complete ; No. 30530, Id., "Oxf. Clay" [Kell. R. matrix] ; a brephomorph, this sp. ? 


$$
40^{2}-
$$

\title{
TYPE AMMONITES
}

BY

S. S. BUCKMAN, F.G.S.

The illustrations from photographs mainly by

J. W. TUTCHER

\section{Part XXVII}

Pp. $41-42 ; 14$ Plates

\author{
Published by the Author \\ SOLD BY \\ WHELDON AND WESLEY, LTD. \\ INCORPORATING \\ WILLIAM WESLEY AND SON \\ 28 ESSEX STREET, STRAND, LONDON, W.C. 2 \\ May, I92 I
}




\section{CONTENTS}

\section{PART XXVII}

Text:- $\quad$ Page

$\begin{array}{llllllllllll}\text { Systematic } & \ldots & \ldots & \ldots & \ldots & \ldots & \ldots & \ldots & \ldots & \ldots & 4 I\end{array}$

Illustrations :--

Plate

134. Sphæroceras perexpansum

(Labyrinthoceras perexpansum) .. CXXXIV c, D

221. Ammonites turneri

(Arietites turneri) $\ldots \quad \ldots \quad \ldots \quad \ldots \quad \operatorname{CCXXI~A,~B~}$

222. Ammonites scipionis

(Aetomoceras nodulatum) _. CCXXII

223. Ammonites erugatus

(Psiloceras erugatum) .. $\quad . \quad \ldots \quad$ CCXXIII

224. Ammonites oculatus

Neumayriceras oculatum _. . C CXXIV

225. Ammonites berryeri

(Rirgsteadia anglica) .. $\ldots \quad \ldots \quad \mathrm{CCXXV}$

226. Ammonites koenigi

(Proplanulites majesticus) .. .. CCXXVI

227. Ammonites koenigi

(Proplanulites subcuneiformis) .. CCXXVII

228. Ammonites bakeriæ

(Crassiplanulites crassicosta) .. CCXXVIII A, B

229. Stephanoceras humphriesianum

(Stepheoceras plagium) .. . CCXXIX

230. Stephanoceras macrum

(Kallistephanus kalus) .. $\quad . \quad$ CCXXX 
F. Phaulomorph, or catamorph--a degenerate serpenticonc.

$P$. capularis, nov. Much smallcr than $P$. fulvus, but somewhat like a dwarf of it. Ribs radial, mostly trifurcate; umbilicus fairly concentric; venter with interruption, on cast, beginning of body-ch., but, at cnd, ribs cross strongly just before mouth: this had a raised rostrum (collar) and indication of lat. auricle. Geol. Surv. Engl., $2608 \mathrm{I}$; Chippenham; Kell. R., top, by decomposed condition; Holotype; S. 43,36 , I9, $39^{\circ} 5$; c. 24 ribs ; body-ch., c. $5 / 8$ wh. ; LI, c. 22 per cent. ; No. 26096 , colomorph. this sp. ? Kellaways; Kell. R.

Perisphinctes cf. spirorbis; Neumayr, I87I, Balin, XI, 4, has much of characters of $P$. capularis; if so, it would be a biologically earlier form of this series. Ribs 23 ; F. $69,36,22,38$; Balin.

Proplanulites haugi, Parona \& Bonarclli (Call. inf. Savoie, r895, p. $157, x 1,4)$, docs not fit into any of these series. It is distinguished by arcuatc curve of ribs on venter. Other species which have been figured as Proplanulites are even more separable.

Excluding thesc, 37 species of Proplanulites have been mentioned by name, and some others have been referred to. Supposing the existence in each scries of morplic equivalents in corresponding numbers, then the possible tale of species should bc about 6o. This number seems largc, but thesc species certainly lived during two hemeræ which in Wiltshire are marked by considerable difference in deposit: it is quite possible that they may have lived during 5 or 6 hemerx; for the lack of correspondencc in the distribution of Proplamulites and Kepplerites indicates a lack of synchronization, suggesting that the so-called Kellaways Clay is of more than one date. Similarly the difference in distribution of Proplanulites and of Cadoceras and of Sigaloceras suggest that the Kellaways Rock, or its equivalent, is a polyhemeral deposit.

In Great Britain strata with Proplamilites-fauna are preserved at only a few places: on the whole Continent there seems to be only about as many localities showing the strata as in Great Britain-the wide area of almost total destruction of Continental strata with Proplanulitesfauna is thus indicated.

Table II (p. 40) gives the presumed chronology of Proplanulites and Crassiplamulites, interpreted from matrix, condition and similarity.

CRASSIPLANULITES, g. n. Genoholotype, C. crassicosta nov. Comparable with Obtusicostites (p. 42), but with less developed s.l.: it is intermediate between that of Obtusicostites and series $A$ of Proplanulites; and with ribs curving forward towards venter, which they cross in weakened condition, making a $\mathrm{U}^{\top}$-curve; [later, fading away and producing a smooth band]. Possible European equivalent and contemporary of Obtusicostites. Differs from Proplanulites in its massive proportions, more developed s.l., EL as long as LI, SI deeper than ES, greater difference between LI and L2 in size, rather more curvature to secondary ribs, and the tendency to produce a smooth band between primary and secondary ribs. I.I about 45 per cent. of whorl-breadth.

Callovian, Kellaways Rock (e); England (Wiltshire), see Table II; p. 40. Also Russia

C. crassicosta, nov. "Am. bakeria." Ribs stout, undulate, 20 primarics, mostly trifurcate; ribs carried over periphery with a slight forward sweep, and some weakening in size-the latter becomes more pronounced towards end of whorl; wholly septate; mark of another whorl; possibly only inner part of a much larger specimen, see next species. 
The general aspect is that of Perisphinctes obtusicosta, Waagen, Kutch, (Pal. Ind. I875), xxxvin, I, but with wider umbilicus, though whorls are cuite as stout: ribs not so strong over venter; s.l. more of Proplanulites pattern. Geol. Surv. Engl., 25649; Kellaways, Wilts; Kcll. IR. (c) ; Holotype ; S. $65,37,34,35$; I 4 I, 37,34 (3I), 35`5 ; I8 ribs to $84 \mathrm{~mm}$. diam.; 20 to I 4 I diam.; max. c. $250+$; LI at $33 \mathrm{~mm}$., 47 per cent.; at $45 \mathrm{~mm} ., 45$ per cent. (Pl. CCXXVIII).

C. crassiruga, nov. "Ammonites bakerice (9 ins. diam.);" H. B. Woodward (Mid. Ool. Engl.; Mem. Geol. Surv., V, I895, p. 30). Like $C$. crassicosta, but with broader, thinner whorls and smaller, more excentric umbilicus; ornament not so heavy as regards primaries; but secondaries about the same size, though rather more distant; tends to develop a smooth area between primarics and secondaries, and the latter fade into venter to produce the smooth band. Loss of ornament commences about $230 \mathrm{~mm}$. Geol. Surv. Engl., 4744; N. of turning to King's Mead Mill, S.W. of Little Somerford (Somerford Parva), near Malmesbury, Wilts (H.B.W.) ; Kell. R. (e), "calcarcous sandstone" ; S. I $4 \mathrm{I}, 39,27(25), 33 ; 22$ ribs; $238,36,28,36 ;$ c. 23 ribs; size of specimen c. 250 , with about $\frac{1}{4}$ whorl body-ch. ; max. c. 435 ; LI at 55 . 42 per cent., at 78,40 per cent. There are marks of whorl-continuation up to about a diameter of $400 \mathrm{~mm}$., witl umbilicus then c. 39 per cent.

C. lahuseni, nov. Perisphinctes koenigii; Lahusen, (Jur. Rjasan; Mém. Com. Gćol. I, I883) Pl. Ix, f. 2 , Holotype ; f. I $a, b, c$, Paratype. The s.l. which Laluusen depicts, the dimensions which he gives (p. 63) and the description (p. 94) certainly scem to fit Crassiplanulites-a species the next step onward from $C$. crassirugi. The smaller specimen (illustrated) appears to be its immature stage: it shows a smooth band on lat. area; Swistowo, (Riasan), Russia; Holotype ; T. $350,33,23,43$; LI at $72 \mathrm{~mm}$. est., $37^{\circ} 5$ per cent. ; Paratype, T. $98,375,28 \cdot 5, \mathrm{~F} .34$ ?; LI at $32 \mathrm{~mm}$. cet., 43 per cent.

OBTUSICOSTITES, g. n. Genololotype, Perisph. obtusicosta, Waagen, Kutch (Pal. Ind.), I875, Xxxvir, I. Strong ribs run straight over obtuse pcriphery; [s.l. complicated, LI with a broadened (palmate) ending, c. 5o per cent.]. Callovian, " anceps zone," India.

A. Nomomorphs. O. paramorphus, Waagen sp., Kutch, XLVI, I, lectotype ; XIVI, 2; Xlvir, 3, s.l. ; Lr at $53 \mathrm{~mm}$. est., 56 per cent. ; 0 . obtusicosta, IVaag. sp., xxxvin, I, lectotype and genotype; xxxviI, 2 , s.l. ; LI at $49 \mathrm{~mm}$. est., 5 I per cent. ; xxxvili, 3 .

$B$. Phaulomorphs. $O$. omphalodes, Waag. sp., xxxvir, 2, with lateral auricle; $O$. dhosaensis, Waag. $s p ., x x x v i n, 4$, with lateral auricle; LI at II'5 mm. est., 53 per cent.

KINKELINICERAS, g.n. Genoholotype, Proplanulites kinkelini, Dacqué, (Jura von Ostafrika; Beitr. Pal. Geol. Öst.-Ung., IgIo, XXIII, p. 36), Pl. v, f. I ; v1, 3. Primary ribs not so swollen as in Proplanulites, and thus less difference in size between primaries and secondaries, while the latter tend to run on to the inner area in between the primaries. They also pass fairly strongly over venter, with a very feeble forward curve, but without median loss of strength. [S.1. (p. 37, fig. I7) of pattern of Proplanulites majesticus, (Pl. CCXXVI), but LI not so palmate. LI, at $27^{\circ} 5 \mathrm{~mm}$. est., $43^{\circ} 5$ per cent.].

Callovian, [c. Crassiplanulites horizon ?], East Africa; India, teste Dacqué ; possibly England.

A. Nomomorphs. K. kinkelini, Dacqué sp., v, I, v1, 3, Lectotype ; VI, I, 2.

K.? sp. Dacqué cites Perisphinctes spirorbis; Waagen, Kutch, 


\section{$4^{2}$}

\section{TYPE AMMONITES}

BI

S. S. BUCKMAN, F.G.S.

The illustrations from photographs mainly by

J. W. TUTCHER'

\section{Part XXVIII}

Pp. $43-48 ; 16$ Plates and Reprint of CCXXIV

Published by the Author

SOLD BY

WHELDON AND WESLEY, LTD. INCORPORATING

WILLIAM WESLEY AND SON

28 ESSEX STREET, STRAND, LONDON, W.C. 2

July, I92I 


\section{CONTENTS}

\section{PART. XXVIII}

Text :-

Systematic

Illustrations :-

23I. Ammonites giganteus

(Titanites titan).. $\quad \ldots \quad \ldots \quad \ldots \quad \operatorname{CCXXXI~A,~B~}$

232. Ammonites koenigi

(Proplanulites laevigatus) .. ...C.CXXXII

233. Ammonites heterophyllus numismalis

(Tragophylloceras numismalis) CCXXXIII

234. Ammonites obliquatus

(Pelecoceras obliquatım) $\quad \ldots \quad \operatorname{CCXXXंIV~A,~B~}$

23.5. Deroceras leckenbyi

(Apoderoceras lobulatum) .. CCXXXV

236. Erycites cf. modestus

(Abbasites abbas) .. .. CCXXXVI

237. Erycites cf. tulcus

(Ambersites ægrotus) .. CCXXXVII

238. Ammonites humphriesianus

(Stepheoceras humphriesianum) CCXXXVIII

239. Cosmoceras subfurcatum

(Strenoceras apleurum)

CCXXXIX

240. Garantiana sp.

(Hlawiceras plytyrrimum) .. CCXI.

24I. Perisplinctes davidsoni

(Caumontisphinctes aplous) .. CCXLI

242. Parkinsonia caumontii

(Caumontisphinctes nodatus) .. CCXLII

243. Ammonites triplex

(Kranaosphinctes kranaus) .. CCXLIII A, B 
$\mathrm{XL},[\mathrm{XLI}], 2$, as synonym of his $P$. kinkelini, but specific agreement seems not quite satisfactory ; generic is possible, but without s.l. is not proved.

$B$. Phaulomorpl. $K$. pendambilianım, Dacqué sp., vı, 4, with indication of a small lateral auricle.

\section{Family TULITIDE, nov.}

Cadicones passing to serpenticonic, directly or by way of spliærocone stage. The various genera to which species have been attributed by authors indicate the changes of development and morphic equivalence. Ornament of low relief, often of distant character, knobs on junction of inner margin and venter, no real lateral area; (OVL2); costæ cross venter, usually with marked forward sweep. All ornament passing away, sooner or later, ventral ornament retained longest : the fcebleness of ornament and the passing to smoothness, even in cadicone stage, characters of the family. Suture-line simple, of pattern of simple-lobed Sphæroceratidæ, retraction of marginal portion only slight.

Teloceras, Emileia and Erymnoceras, or the coronates of the familics Stepheoceratidæ, Sphæroceratidæ and Pachyceratidæ, are comparable catagenetic development is similar. S.l. prevents association with Stepheoceratidæ; character of ribbing does not concur with Sphæroceratidæ-the sphærocones of that and of Tulitidæ are obviously independent developments; shape and s.l. have more suggestion of Pachyceratidæ, but the feebler development of ribbing, leading to smoothness, the considerable sphæroconic development and the difference of s.1.-ES and SI about equal in depth, instead of decidedly unequalsuggest the advisability of separation. The Tulitidæ and the other three families are all offshoots of a coronate cadicone radical, the Tulitidæ occupying a geological position between the Bajocian and the Callovian coronates.

England, Bathian (Falaisian), Fullers' Earth Rock of Dorset and Somerset; Great Oolite of Gloucestershire and Oxfordshire; France, Alsace (Schlippe); Deux Sèvres, Vendée, etc., (Amm. bullatus and microstoma, d'Orbigny, presumably belong to the family): Germany, Baden (Schlippe); Wurtemberg, various bullatus-like forms: Lithuania (Siemiradzki). The family is of particular interest as showing the contemporaneity of the Fullers' Earth Rock of South England with the Great Oolite of Gloucestershire-Oxfordshire, and thus that the Fullers' Earth Rock is later, not earlier, than the Stonesfield Slate. Genera of the family occur in at least two distinct deposits of the Great Oolite-the Minchinhampton Shelly Beds, which are oolitic, and another bed of the same place, which is non-oolitic. In the same way they mark at least two deposits of Fullers' Earth Rock-the brownish Milborne Beds and the white Thornford Beds (S. Buckman, Brach. of Namyau Beds; Pal. Ind. III (2), Igr8, 237).

Genera, Tulites, Tulophorites, Madarites, Pleurophorites, Rugiferites, Sphæromorphites, Bullatimorphites, Morrisites, nn., with Morrisiceras, S. Buckman, to be removed from the Sphæroceratidæ (T.A. III, Ig20, p. 22).

It is necessary to notice, as belonging to the Tulitidae, Morris \& Lycett's species, Ammonites subcontractus (Moll. Great Oolite, Pal. Soc., I850, p. II, Pl. 11, figs I, I $a$ ). The word species must be read in the plural, for their figures "are composites, drawn from two different 
species from two different matrices (two horizons) "-S. Buckman, Brach. Namyau Beds; Pal. Ind. III (2), I 918,235 . The two specimens are in the Museum of the Geological Survey of England, numbered 25610 and 25615. The first, which is mainly depicted (reduced $\times 0^{\circ} 79$ ) in fig. $I$, and has the aperture preserved, is from the Shelly Beds of Minchinhampton-a creamy coloured limestone with shell fragments and many small white oolitic grains: it bears the original label in Lycett's handwriting, "A. subcontractus, M. \& L. Gr. Ool. M-hampton." The second specimen is a much larger shell, with a depressed aperture: the general shape of the specimen is represented in fig. I $a$, but the apertural edge is taken from the small example. The large specimen is from a hard, fawn-coloured, non-oolitic limestone, presumably an carlier deposit than the Shelly Beds, but it does not seem quite to fit the descriptions either of the Wcatherstones or of the Basement Bed (Lycett, Cotteswold Hills, I857, p. 94).

In their description (p. II) of Ammonites subcontractus Morris \& Lycett give the dimensions of the large specimen-" Diameter, 5 inches. Thickness, 3 inches. Height of aperture, I $\frac{1}{2}$ inches." These figures will read as T.I27, 30, 6o, - ; their fig. r $a$ yields F. 68, 3I, 53, - ; and the large spccimen gives S. $123,36,57,33$. Their fig. I yields F. 68, $32.5,-, 4^{I}$; the small specimen gives S. 86, 35, 5I, 35-both figure and specimen being measured a little behind the aperture, which contracts rather suddenly. It may, therefore, be seen that though the authors say " the specimen from which our figure is taken," the illustrations I and $I a$ are really synthetographs-fig. I, in the main, fits the small specimen; but the height of the aperture has been reduced under the influence of the large example; while fig. I $a$ fits the large example, but the apertural margin is put in from the small specimen. Of the description, the main part fits the small shell, but the dimensions are those of the large onc. The remark, " proportion of umbilicus to diameter rather more than one-half," is incorrect, even if taken from upper edges instead of from contact-lines. The umbilicus of the small specimen is only partially excavated, not so much as is depicted in fig. I; while that of the large example had not been excavated at all. The facts pertaining to the figures and descriptions make it necessary to treat the two specimens as syntypes. As the small example shows the "subcontract " character more plainly than the large one, because it has the mouth complete, it is chosen as the lectotype.

Morris \& Lycett attribute the feebleness of ornament to the process of clearing away the original matrix. This is not the case: the small specimen shows some signs of abrasion before entombment, the large specimen does not. Ornament of very feeble relief passing to complete smoothness is a character of the 'Tulitidæ.

Tulites, g.n. (Stephanoceras, Coloceras Auctt.). Genotype, $T$. tula, n. Cadicones of Erymnoceras aspect, with funnel-shaped (craterlike) umbilicus, walls almost superimposed, only feeble gradation; walls of umbilicus make a sliarp junction with venter, and carry bullie of low relief; an earlier stage-primary costæe ending with short spines (Teloceratan) seems to be indicated. S.l. with short, narrow L2 and small aux. 2, the latter turned towards venter (askew) : cf. Siemiradzki's fig. cit. sub $T$. cadus. Distinguished from Erymnoceras by feebler ornament and by ribs curving forward over venter, also by suture-line. There is reason to conclude that Siemiradzki's figure of s.l. is taken from an example of $T$. cadus, and represents the s.l. of this genus : only the inner part observable in genotype. England; Lithuania. 
T. cadus, n. Stephanoceras m.f. coronatum, Schlotheim, Bruguière spp., Siemiradzki, (S. coronatum von Popilany; N. Jahrb. Min. I882, II, p. 255, fig. [2], p. 256). A massive cadicone of Teloceras and, later, of Erymmoceras aspect, with no sign of degeneration. [Minchinliampton] Gloucestershire, Great Oolite, Shelly Beds; S.B., ex J.B., Coll. 2 I 82 ; Holotype ; S. 77, 37, 85, 35 ; I25, 43, 86, 35: "Sherborne, Dorset " [Milborne Wick, Somerset]; Fullers' Earth Rock (Milborne Beds) ; S.B., ex Darell, Coll. 2760 ; Paratype ; S. $53,36,93,34$; 72,36 , 89 , 35; about half-whorl body-chamber: Popilany, Lithuania ; Bath[formation],(Siemiradzki),

$F$. tula, n. Like $T$. cadus, but degeneration, smoothness and reduction of whorl-incipient serpenticone stage-sets in at about \$5 mm. diameter ; body-chamber about $\mathrm{I}_{\frac{1}{4}}$ whorl ; "Sherborne, Dorset," [Milborne Wick, Somerset]; I'ullers' Earth Rock, (Milborne Beds); S.B., ex Darell, Coll. I263 ; Genotype and Holotype ; S. 56, 38, 93, 37 ? ; $80,40,73,35 ; 98,345,49,38 \cdot 5$; about $I_{\frac{1}{4}}$ whorl body-chamber, all but complete.

T. subcontractus, Morris \& Lycett sp. Am. subcontractus, M. \& L.., op. cit, p. II ; Pl. II., fig. I (pars), see above p. 43. A cadicone like $T$. tula up to about $60 \mathrm{~mm}$. diam., but with less strong ornament; then degeneration-smoothness and contraction. Test preserved, but worn ; mouth-border also preserved-a plain band preceded by a ventral ridge of low relief, and that is preceded by another still less strong; between the two presumably a thickening of test, making a constriction on cast, which should be especially noticeable on lateral area. Minchinhampton, Gloucestershire ; Great Oolite, Shelly Beds ; Geol. Surv. Engl., ex Lycett Coll. 256 Io ; Lectotype; S. 49, 37, 80, 34; 86, 35, 5I, 35 ; max. 90 .

TULOPHORITES, g. n. Genotype, $T$. tulotus, n. Somewhat of Tulites stage in inner whorls, but umbilicus distinctly gradate, with edge of umbilical wall well rounded off. Ribs on venter less strong, more approximate, and less persistent than in Tulites. [S.1. with L2 somewhat elaborate, broad, its longer part inside]. England.

$T$. præclarus, n. In shape like what would be expected between Tulites cadus and $T$. tula, but with less development of ornament. Indication of end of mouth with strong contraction on cast. Troll, near Thornford, Dorset; Fullers' Earth Rock, (Thornford Beds) ; S.B., ex J.B., Coll. I91 4 ; Holotype ; S. 82, 39, 87, 33 ; I37, 32, 50, 38 ; max. I40.

$T$. tulotus, $n$. Somewhat like $T$. tula, but with a more contracted and gradate umbilicus, and with less pronounced ornament. Endportion of body-chamber partly preserved, showing deep constriction on cast ; preceding, on ventral area, are about half-a-dozen distant, broad ribs of low relief, gradually increasing in strength-the last before constriction being fairly strong. Troll, near Thornford, Dorset ; Fullerș' Earth Rock (Thornford Beds (hard stone) ; S.B., ex J.B., Coll. I920 ; Genotype and Holotype; S. 66, 42, 88, 27 ; I10, 36, 51, 35 ; max. c. II 8.

MADARITES, g. n. (Stephanoceras, Teloceras, Auctt.). Genotype, $M$. madarus, n. Cadicones passing towards serpenticones. Slight sign of Tulites stage in inner whorls of genotype up to about $45 \mathrm{~mm}$. diam.; some undulation of upper edge of inner margin for about another halfwhorl indicates attempt to continue Tulites stage. Except for this, after about $45 \mathrm{~mm}$. diam., long before cadicone stage is complete, pronounced smoothness is established. [Anamorphs should show more distinct Tulites stage]. Umbilicus deep, contracted, funnel-shaped, with deep walls nearly superimposed in cadicone stage. S.1. simple, LI broad, not quite so long as EL; L2 expanded, longest part towards 
venter. Gloucestershire and Dorset. This genus is distinguished by the pronounced developinent of smoothness : there are no ventral ridges developed towards end of body-chamber. The direction of growth-lines across venter show that anamorphs and brephomorphs should have forwardly-arched ribs. The genus is also distinguished by the deep funnel-shaped umbilicus. Had the cadicone stage persisted with relative narrowing of umbilicus, a sphærocone would have been produced: but whorl-reduction and umbilical expansion came on too early. It shows, however, how the sphærocones of the Tulitidx (Spharomorphites and the bullatus-like forms) have been produced.

M. madarus, n. (Ammonites subcontractus, Morris \& Lycett, op. cit., p. II, dimensions; Pl. II, fig. I $a$, pars). Thin test preserved, not abraded ; body-chamber ncarly complete. Minchinhampton, Glos: Great Oolitc, a greyish, fawn-coloured, hard, non-oolitic limestone, presumably part of the Weatherstones or of the Basement Bed, or from a local deposit associated with them, but not specially noted ; Geol. Surv. England, ex Lycett, Coll., 256r5; Genotype and Holotype; S. 76, 4I, $82,30^{\circ} 5 ; 123,36,57,33 ; \max$. c. 130.

$M$. calvus, n. Like $M$. madarus, but much thinner, because reduction in thickness-incipient serpenticone stage-begins at a much smaller diameter. Test partly preserved, thin, especially on bodychamber. Troll, near Thornford, Dorset; Fullers' Earth Rock (Thornford Beds-from a hard layer, not unlike the matrix of $M$. madarus); S.B., ex Darell, Coll. I9I7 ; Holotype ; S. 63, 40, 76, 26 ; 80, 39, 65, 29 ; $99,37,56,32 ; \max$. c. 108.

$M$. pravus, n. Like $M$. calvus, but reduction in thickness of whorl commences at a smaller diameter, and is pronounced enough to produce a contracticone. Umbilical expansion also becomes considerable. Troll, near 'Thornford, Dorset; Fullers' Earth Rock, Thornford Bedsa stratum with a slight pinkish tinge, not quite so hard as the matrix of M. calvus ; S.B., ex J.B., Coll. I92I ; Holotype ; S. 6I, 4I, 69, 29.5 ; $73,33,68,35 \cdot 5 ; 92,30,44,39 ; \max$. c. 108.

RUGIFERITES, g.n. Genotype, R. rugifer, n. Cadiconic passing to incipient serpenticonic with rounded venter; costate, (not nodate), primary ribs of low relief, slightly rursicostate on inner margin, then becoming about radial; secondaries do not pursue course of primary, but start forward at somewhat of an angle, and swecp with a fairly good curve over venter; some trifurcation of primaries, sometimes by later furcation of second secondary. As umbilicus opens, primaries tend to fail ; secondaries remain, but become distant folds of low relief-somewhat of Morrisiceras-pattern. S.l. simple, but lobes somewhat long; EL. longer than Lr, L2 broad, in two branches, the outer tridactyloid, the inner simple, the incision between not deep, just deeper than between lobules of outer branch. England, Dorset.

R. rugifer, n. S.B., ex J.B., Coll. Igr6, Holotype; Troll, near Thornford, Dorset; Fullers' Earth Rock, Thornford Beds, a hard grey limestone; S. $54,46,70,26$; 9r, $38.5,49.5,35$; max. c. Ioo ; bodychamber about a whorl; S.B. Coll. 2762, ex F. H. Butler, Paratype ; "Sherborne, Dorset " [Fullers' Earth Rock, Thornford Beds], a hard, grey, crystalline limestone; S. $29,35,6 \mathrm{I}, 33 ; 38,43,7 \mathrm{I}, 3 \mathrm{I}^{\circ} 5$; c. 28 primary ribs producing about 68 secondaries; some irregularity in size of ribs and some suggestion of constrictions.

PLEUROPHORITES, g.n. (Macrocephalites, Auctt.). Genotype, $P$. pleurophorus, n. Sphæroconic passing to incipient serpenticonic; costate, primary costæ littlc larger than secondaries-the costæ begin 
with a slight backward curve, then come forward to sweep with a very slight forward arching over venter; no sign of smooth stage, nor of costal degeneration, in the two species examined, but there is the beginning of umbilical expansion. England, Dorset.

Sphæroconic shape, and ribs with regular sweep, not angulate, good distinctions from Rugiferites.

$P$. pleurophorus, n. A costate sphærocone, without any sign of umbilical expansion. S.B., ex J.B., Coll. I9I9; Genotype and Holotype ; Troll, near Thornford, Dorset ; Fullers' Eartl Rock (Thornford Beds-a rather soft bed, with a slight pinkish tinge, and also some suggestion of bluish argillaceous matrix); S. $56,45,82,23$ ?; $74,42,82,22$; size c. 95, not suitable for measurement, as the specimen is an allomorph ; about 35 primary and 75 secondary ribs; $\max$. c. I05.

$P$. polypleurus, $n$. A sphærocone commencing serpenticone by slight umbilical expansion, but without any sign of costal degeneration. About 32 primary ribs produce about 85 secondary-junction obscure, partly due to preservation, partly to intercalation. S.B., ex J.B., Coll. I 927, Holotype ; Troll, near Thornford, Dorset ; Fullers' Earth Rock, (Thornford Beds - a stratum similar to that of $P$. pleurophorus, perhaps harder, not so much sign of argillaceous resting place) ; S. 60, 4I, 69, $25 ; 92,40,55,27 ; \max$. c. I05.

BullatimoRPHITES, g.n. Genotype, Ammonites bullatus; Lycett, I863, (non d'Orbigny), Moll. Great Ool., Suppl., p. 4 ; Pl. XxxI, f. I; cf. Am. bullatusj latecentratus, Quenstedt; Amm. Schwäb. J., II, p. 658 ; Pl. LxxvII, 6 . Sphaeroconic passing to serpenticonic by excentrumbilication; costæ (at first approximate, then somewhat distant, later approximate again) of low relief, often trifurcate, some sign of angularity of Rugiferites pattern in the distant stage, later more regular curve, radial; mouth-border laterally contracted with good forward sweep ; immediately before border a fairly marked constriction in cast [not shown if test present?]; s.l. incomplete, simple? England, Gloucestershire ; (Germany, Swabia?). .

The genus is nearest to Pleurophorites, but is distinguished by its mode of coiling.

$B$. bullatimorphus, n. Am. bullatus; Lycett, cit. Geol. Surv. Engl., ex Lycett Coll., 25620, Holotype and Genotype ; "near Tiltups Inn, two miles south of Nailsworth, [Gloucestershire]; Great Oolite" (Lycett, p. 4), from a whitish, weathering ochre, hard, crystalline, limestone, feebly oolitic, but many oolite grains (?) show in cast of bodychamber ; test thin, preserved on inner whorls and part of outer; S. Ioo, $48,53+, 19$; I79, 34, 33, 39; $\max .183$; s.l., only indications; bodychamber $I \frac{1}{4}$ whorls; no sign of any smooth stage.

B. latecentratus Quenstedt sp. (Am. bullatus latecentratus, Quen. I887, LXXV1I, 6). This appears to be a smaller edition of $B$. bullatimorphus ; "Laufen, [Würtemberg] ; Brauner Jura c."

MoRRISCERAS, S. Buckman, I920, (Legend of Pl. CLXVII, T.A. III) ; Genotype, Morrisiceras sphara, S.B., Holotype $=$ Macrocephalites morrisi, Auctt. Cadicones which pass to incipient platycones through a sphærocone stage. [Primary ribs not developed into knobs, bifurcating into rather strong secondaries in cadicone stage] and becoming obsolete; sphærocone stage characterized by secondary ribs only, crossing venter with a slight forward curve, and strongest in middle of venter; [they disappear in incipient platycone stage, when complete smoothness supervenes, correlated with excentrumbilication, and whorlreduction. S.l. simple, lobes short and broad, LI about 38 per cent. of 
breadth of whorl, L2 somewhat bifid-the outer part the larger, but ratlier shorter]. England, Dorset, Somerset.

$M$. korustes, n. Cadicone passing to sphærocone; whorls somewhat galeatiform ; undulation of edge of inner margin indicates relics of Tulites-stage or its costate equivalcnt; umbilicus gradate, dcep; s.l. with short, broad lobes, LI at I9 mm., c. 40 per cent. "Somerset; Fullers' Earth [Rock] " ; J.IV.T. Coll. ; S. 44, 4I, 73, 25 ; 59, 49, 79, $2 \mathrm{I}$; size $63 \mathrm{~mm}$. ; $\max$. c. 70.

$M$. tolmerum, n. Spliæroconic, with rather heavy ventral ribs ; a less massive shell than M. sphara, with a larger umbilicus. S.B. Coll. 454 ; Holotype ; Laycock, Milborne Wick, Solnerset; Fullers' Eartl Rock (Milborne Beds) ; S. 5I, 45, 63, (I7?) ; 77, 47, 67, I6 ; max. c. 80 : S.B. Coll. 2763 , Paratype ; same loc., "top of F. E. Rock," confirmed by condition ; S. $29,4 I^{\circ} 5,65,27 \cdot 5$; inner whorls showing a costate stage analogous to that of Rugiferites; S. 50, 46, 70, 17; max. c. 66 : J.IW.T. Coll. ; [Somerset] ; S. 47, 44, 69, I75; 67, 48, 67, I7 ; $\max$. c. 70.

M. sphéra, S. Buckman I920, Legend of Pl. CLYV11. A sphærocone with a quite small umbilicus; "near Sherborne, Dorset " [Milborne Wick, Somerset] ; Fullers' Earth Rock [Milborne Beds] ; S.B., ex J.B., Coll.,, I 923 ; Holotype ; S. 65, 48, 695, —; 99, 5I, 66, Io ; max. c. I05.

$M$. homœoticum, n. The homoomorpl of Am. morrisi, Oppel, see sub Morrisites : it is distinguished by a slight difference of ribbing, by an umbilicus not gradate and not undercut, by suture-line. Subsphæroconic, with a quite small umbilicus, and a suggestion of its opening out again. S.B., ex J.B., Coll. 2758, Holotype; S. 74, 50, 64, - ; $9 I, 48.5,59$, I 2 ; max. c. I05 ; s.l. with short, broad lobes, LI at $29 \mathrm{~mm}$., c. 38 per cent. : S.B. Coll. 2757, Paratype; Milborne Wick, Som.; "F.E.R. Top" (Milborne Beds), near surface by condition; S. 45, 49, $54,(\mathrm{I} 7$ ?) ; 69, 52, 63, I2.

M. comma, n. A scaphitoid; passing from sphærocone to incipient serpenticone; a quite small umbilicus rapidly opens out, has a comma-like appearance; smooth stage attained; s.l. decidedly degenerate, with quite short, broad lobes, LI at $25 \mathrm{~mm} ., 24$ per cent.; J.W.T. Coll., Holotype; Shepton Montague, Somerset; F. E. Rock (Milborne Beds) ; S. 5I, 50.5, 69.5 (4 ?) ; 9I, 40, 45, 23; max. c. 95 ; body-chamber nearly complete, end showing tendency to renewed inflation.

M. sknipum, n. Much compressed, with a quite small umbilicus. Like $M$. comma, but much thinner in costate stage (presumed smooth stage not preserved). S.B., ex Darell, Coll. 2759, Holotype ; Milborne Wick, Somerset ; Fullers' Earth Rock, [Milborne Beds, neạr surface by condition] ; S. $62,48,53,15$.

MORRISITES, g.n. (Stephanoceras, Macrocephalites, Auctt.) ; Genotype, A. morrisi, Oppel, Geol. Surv. Engl. Coll. 256r7. Like Morrisiceras, with, presumably, similar evolution; differs internally by more elaborate s.l., externally by finer, more numerous ribbing, undercut umbilical wall and suspicion of constrictions; s.l. with lobes somewhat long and narrow, EL. about 75, and LI about 55 per cent. of whorlbreadth ; L2 in two branches, with a deep incision. England, Gloucestershire; Dorset: Germany, Baden (Schlippe), perhaps; see later, p. 49.

$M$. fornicatus, n. Like Morrisiceras korustes, but with smaller, more numerous ribbing; whorls in arch-form (fomicatus), but not quite so strong as those of $M$. korustes; S.B., ex J.B., Coll. 276I, Holotype ; marked "Sh." = Sherborne, Dorset, possibly some part of the Fullers" Earth Rock outcrop running S. of Sherborne; matrix grey, hard, some- 


$$
4^{8^{\circ}}
$$

\section{TYPE AMMONITES}

BY

S. S. BUCKMAN, F.G.S.

The illustrations from photographs by

J. W. TUTCHER

and

The Author

\section{Part XXIX}

Pp. 49-54; 16 Plates

Published by the Author

SOLD BY

WHELDON AND WESLEY, LTD, INCORPORATING

WILLIAM WESLEY AND SON

28 ESSEX STREET, STRAND, LONDON, W.C. 2 


\section{CONTENTS}

\section{PART XXIS}

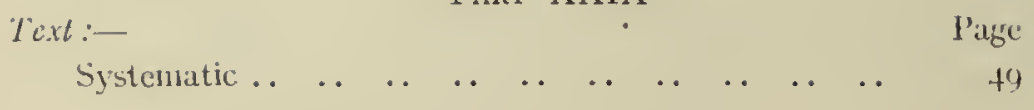

Illnstrations :- Plate

244. Anmonites fabalis

(Phymatoceras fabale)..

245. Ammonites musleyi

(Murleyiceras forte) $\quad$.

246. Erycites if. gonionotus

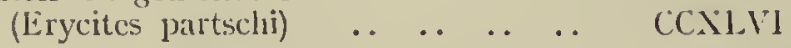

247. P'crisphinctes martinsii

(Stomphosphinctes stomphus) .. CCYLV'11

2.js. Stephanoceras baylcaunum

(Skirroceras macrum) ..

249. Skirroceras macrum

(Skolekostephanus skolex) .. CC.ILIX

250. Stepheoceras freycincti

(Rhytostephanus rhytus) $\quad . \quad \ldots \quad$.. $\quad$ CCL $\Lambda, b$

251. Ammonites kocnigi

(1'roplanulites fabricatus) $\ldots$. .

252. Ammonites kocnigi

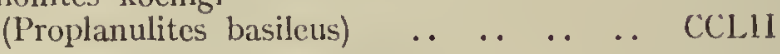

253. Ammonites bakerie

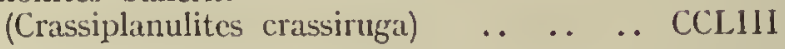

254. Ammonites gowerianus

(Gowericeras metorchum) .. $\quad . \quad \ldots \quad$ CCLIV

255. Ammonites callovicnsis

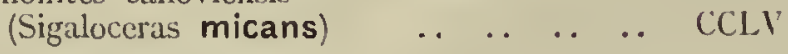

250. Anmonites gigantens

(Gigantites giganteus) . $\quad \ldots \quad \ldots \quad$ CCLVI $\mathrm{A}, \mathrm{B}$

257. Ammonites gigantcus

(Briareites polymeles) .. $\quad$. $\quad$.. $\quad$ CCLVill 
Sept.

what shelly stone, different from Milborne or Thornford Beds-more like latter, but sharp preservation of specimen differs; S. 29, 43, 67, 3I ; $45,44,77,22 ; \max$. c. 65 , presumably a brephomorph; liL at II 5 ,

c. 80 per cent., LI, c. 55 per cent.

M. morrisi, Oppel sp. (Am. macrocephalus, var., Morris \& Lycett, 1850, Moll. G. O., p. I2 ; P1. II, f. 3 ; Am. morrisi, Oppel, I857, Juraf. p. 478 ; Am. viator: Lycett, I863, Moll. G. O. Suppl., p. I2I). The specimen whicl furnished Morris \& Lycett's figure is the holotype of Oppel's species; but the original figure is misleading: it shows only about 40 ribs, which are much too strong, whereas the specimen has about 60 ribs which are quite feeble. As Morris \& Lycett's figures of Am. subcontractus are synthetographs (see above, p. 43), and as they spcak of several examples of this species, it may be suggested that their figures in this case are also synthetographs. The rib-characters which they show are those of Morrisiceras, which, however, I have not yet scen from Gloucestershire. If their figures are synthetographs, then their specimens are syntypes, and it will be necessary to choose the specimen now described as the lectotype of Oppel's species: this is in Geol. Surv. England, ex Lycett Coll., no. 256r7, from "Ninchinhampton, Gloucestershire ; base of Great Oolite," Lycett 1863 , cit.- - a soft, creamcoloured, crystalline, barely oolitic stone, perhaps the Oven-Bed of Lycett (Cotteswold Hills, I857, 93, 94); S. 45, 5I, 63, I5 5 ; 6I, 45, 66, I 5 ; max. c. $85+$, the specimen being septate to the end.

The peculiar overhanging wall of the gradate umbilicus is not shown by Morris \& Lycett: what they have is the umbilicus of Morrisiceras.

SPHAROMORPHITES, n. Macrocephalites Auctt. Genotype, S. spheroidalis, n. Sphaerocone; umbilicus narrow, deep, somewhat elliptical, walls superimposed, with tendency to become overhung: ornament fecble, some undulation on upper edge of inner margin is, presumably, relic of Tulites-stage of nodosity ; feebly undulate costulie cross the venter with a forward sweep; there are signs at intervals of something like constrictions; s.l. simple; EL longer than LI, which at $16 \mathrm{~mm}$. is about 44 per cent., $\mathrm{L}_{2}$ rather long and narrow. England, Dorset.

S. sphæroidalis, n. Cf. Macrocephalites morrisi; Schlippe, Bath. Oherrhein.; Abl. geol. Spec.-k. Elsass-Lothr., IV (4), I888, I99 : vII ; Am. bullatiss; Quenstedt, Amm. Schwäb. Jura, I887, Lxxvir, 9. like the early stage of Schlippe's species, but less costate, and certainly not possessing a concave inner margin. Quenstedt's cited figure illustrates a like, but more narrowly umbilicate, form; not congeneric as s.1. is different, especially the broad L2. S.B., ex Darell, Coll. I9I8, Holotype; Troll, near Thornford, Dorset; Fullers' Earth Rock, Thornford Beds, but a matrix distinct from that of the other species, as it is an argillaccous limestone; S. 3I.5, 4I, 92, (30 ?) ; 44, 45, 86, $27 ; 55$, $51,84,20$; max. c. 75 .

Fhere are further species of Tulitidx which do not fit these genera. For instance, Stephanoccras subcontractum; Schlippe, I888, V1, I, has the shape of Tulophorites, but ribbing comparable with Pleurophorites; lis Macrocephalites morrisi, Pl. vir, is doubtfully a Morrisites: fig. I seems to show a concave inner margin, whicl it is unlikely that Morrisitcs would develop-if correctly shown in this respect, Schlippe's form belongs, presumably, to a genus between Morrisites and Sphoromorphites. Then the bullati figured by d'Orbigny and Quenstedt seem to indicate several genera: Am. platystomus globulatus, Quen., I887, 1xxvir, 2 , is near to 
Pleurophorites: Am. bullatus; Quen., Lxxvir, 9, is near to Sphreromorphites, but differs as already mentioned.

Chronological Sequence: For the English Tulitidx this is important. There are the following data: in the Fullers' Earth Rock of Dorset-Somerset brown (ironshot) limestones (Milborne Beds); are later than the whitish, chalky limestones (Thornford Beds); in the Great Oolite of Gloucestershirc shelly, oolitic beds arc later than whitish, non-oolitic beds. Thus the genera of Tulitidæ occupy two distinct horizons. But more analysis is possible, by observation of smaller differences in the matrices of the various specimens.

Certain technical terms may facilitate this and future enquiries. For instance, the Thornford Beds, the Milborne Beds and the Minchinliampton Beds are all similar in cliaracter, in that they are limestones: therefore they may be said to be homœopetrous; but they are distinct from argillaccous or arenaceous strata: the Lower Fullers' Earth Clay and the Fullers' Earth Rock are heteropetrous. But the Milborne Beds (ironshot), the Thornford Beds (chalky, not nolitic) and the Minclinhampton Beds (the upper part, oolitic and shelly) differ from one another in a minor degree: they arc heterolithous; but any onc of these deposits shows still further differences: the Thornford Beds are not sequentially homolithous, - the matrices of the Tulitids show appreciable, differences, though these differences have not been sufficient to induce any observer to make a detailed section of the beds exposed in Troll quarry - some 5 feet: the need for such detail was not understood. But, as these beds show such differences, they must be classed as hom ceolithous; not as homolithous; while the differences are presumed to indicate differences in time of deposition-a clironological sequence: such surmise is justifiable, because the heterolithous differences between the Thornford and the Milborne Beds indicate a known sequence. The sequence within the Thornford Beds must at present be a matter of surmisc. Knowledge may be gained by noting which are isochronous deposits of different arcas-those beds which are isidophorus, yielding species equal in value (iøos. cqual, ‘idos, form, or species, фopós, bearing), being regarded as isocluronous. The yiclding of the same species is not insisted upon; but beds in two areas which yield species of, say, Tulites are reckoned as isochronous, until there be evidence to the contrary. By a parity of reasoning beds which do not fulfil such condition, beds which are anisidophorus, are, presumably, anisochronous, not equal in date. These are the arguments of similar and dissimilar faunas carried out on limited groups of organisms, like, for instance, Ammonites: therefore words compounded of species (๕̊\&os) are considered as morc desirable than any compounded with fauna: the latter should have a general application. For arguments and metliods of work with regard to the phenomena of similar (limited) faunas (isidophory) and dissimilar faunas (anisidophory) the author's papers on Jurassic Chronology (Quart. Journ. Gcol. Soc., LXXIII, I9I8, 257 ; LXXVI, I920, 62) may be consulted.

Geological SEquence: Working on the methods discussed above, the following geological sequences may be given-as regards major details the succession is known, but as regards minor details it is a case of surmise and inference. However, from what has been said above, and from what is stated in Tables IV, V, the observations upon which the work is based, and the manner in which evidence is used, may be understood. 


\section{TABLE III}

\section{FULLERS' EARTH ROCK (DORSET-SOMERSET}

STRATA

$\left\{\begin{array}{r}\text { 6. Upper part : specimens show that thcy } \\ \text { come from near surface by being } \\ \text { soil - stained and having test } \\ \text { roughened by sccondary deposition } \\ \text { from infiltration . . . . . . . Morrisiceras }\end{array}\right.$

FAUNA

4. Whitish stone; cast ironstained .. Morrisites

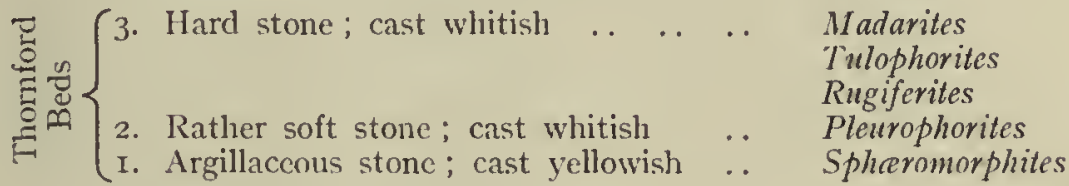

TABLE IV

GREAT OOLITE (GLOUCESTERSHIRE)

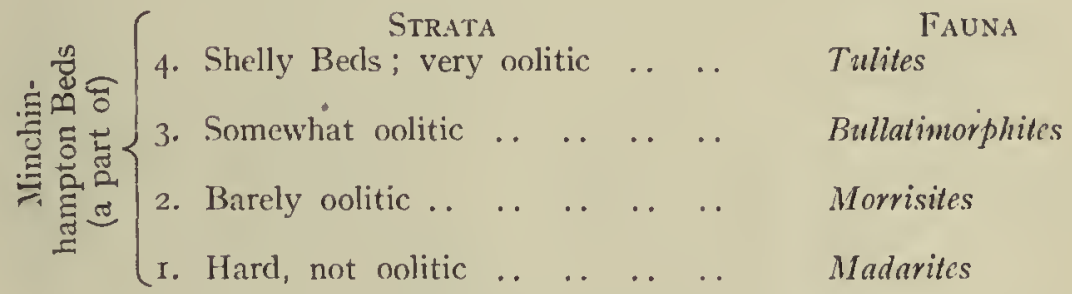

By placing together the strata which are isidophorus, and by kceping scparate those which do not correspond in species, which are anisidophorous, the following sequence is obtained:

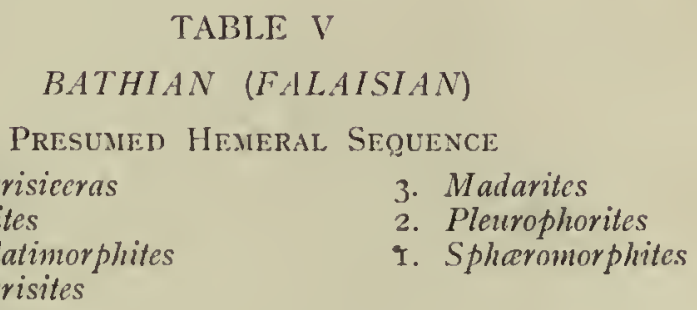


This Ammonite-fauna of the Fullers' Earth Rock-Great Oolite strata is the one sliort and not over-populous break in the remarkable dearth of Ammonites which characterizes--in Great Britain and North France, at any rate-the interval of hemerx post-zigzag to pre-macrocephalus: a dearth all the more remarkable from contrast with the exceeding ricliness in Ammonites of the many preceding and succeeding Ages. This period of Ammonite poverty points to considerable geographical change-more or less it is synchronous with estuarine conditions in East England and in Scotland. But this poverty may not be wholly original: it may have been heightened by wide-spread destruction of ammonitiferous deposits.

The robust character of the genera of the Tulitidæ, their somewhat nautiloid shape, poverty of ornament and rather simple suture-line suggest that they are clecp-sea forms which, at any rate in the case of Tulites of the Minchinhampton Shelly Beds, have drifted into a shallow water deposit, bearing traces of their journcy in the condition of their tests. The Tulitidre are a stock of Coronati, less developed than their predecessors of the Bajocian. The biological order of the genera is somewhat that in which they have now been described, certainly Tulitcs is least, and Spheromorphites is most changed from the original stock. This biological order is not in accordance with their geological succession; but a more changed series is sometimes the first to arrive in a new area; to be followed later by its less changed cousins, not necessarily in order.

Addendum: A Tulitid has been sent by Mr. J. Pringle, F.C..S., from Oxfordshire: it falls between Madarites calvus and $M$. pravus, see p. 46 .

Madarites glabretus, n. "Teloceras subcontractum." [Cadicone to] incipient serpenticone, only outer whorl preserved, body-chamber (cast) just short of a whorl in length, finished by "plain mouth and no constriction. No ornament. Geol. Surv. Engl., No. Pl. 866 ; from Railway "cutting between Bucknell and Ardley Wood," N.W. of Bicester, Oxfordshire, "found loose, probably from Bed 3I, Fullers" Earth Rock, of Mr. M. Odling, F.G.S. (Quart. Journ. Geol. Soc., I.XIX, I9I3, p. 490), who quotes Teloceras subcontractum from this bed " (Mr. J. Pringle) : matrix hard, grcy, non-oolitic stone; S. $79,38,59^{\circ} 5,(34$ ?) ; $107,37,46.5,36.5 ; \max$. II6, somewhat ellipticone.

According to the statements of the quarry foreman, during operations subject to the making of the line, a large Ammonite was obtained from Bed 26 (Odling), that is 4 beds, or about 6 feet above Bed 3I : it was handed over to an official of the Great Western Railway. The damaged impression which the foreman slowed to Mr. Pringle and myself suggested some relative of what is now named Rullatimorphites, but much larger-some IO-I2 inches $(250-300 \mathrm{~mm}$.) -than anything known at present from Great Oolite-Fullers' Earth Rock strata. Mr. Pringle's attempts to trace the whereabouts of this specimen were not snccessful; but it is to be hoped that it may be found.

If the suggested relationship be correct, Bed 26 may be of Bullatimorphites date, and if Bed $3 \mathrm{I}$ be of Madarites date, as there is good reason to think, then Bed 28 is left as, possibly, of the date of Morrisites. The beds superior to Bed 26, up to, say, Bed 2I, are, therefore, possibly of the date of Tulites and Morrisiceras-that is, synchronous with part of the Minchinhampton Shelly Beds. Bed 3I of Ardley, 4 fect thick, could contain all the Ammonite horizons ascribed to the Thornford Beds, for, at Troll, they are not much thicker. 


\section{Family KOSMOCERATIDA, Hyatt}

Onati, Runcinati, Auctt. Cosmoceratide, Hyatt (Ceph.; ZittelEastman Pal. 1, Igoo, 587-Kosmoceras is Waagens' original spelling: nomenclatorial rules forbid alteration of generic and trivial nanes; but a family name must agree with that of the genus). Hyatt placed in Kosmoccratidie, Cosmoccras representing the Ornati, and created Sigaloceras for the Runcinati. He also united with them his genus Phricodoceras, but this is far removed in date: in that respect and in suture-linc it associates with Liparoceratidie (see T.A., 1I, p. B and 1II, Pl. CXLIX).

Mostly scrpenticones and platycones (ex coronate cadicones?) with a specialized venter (see later) and liberally tuberculate on lateral and latero-peripheral areas-the most developed forms carrying two rows of tubercles on cacl of these areas, that is, six rows on the conch. Often with very long lateral prolongations to mouth-border. Transition in one circction to rounded venter and forms with Macroccphalites aspect; in another direction to almost inornate, amblygastric oxycones, and possibly in another direction to uncoiled forms: the so-called Ancylocerates of the Callovian latve the ornaments of the Ornati, and are possible developments of Ornati serpenticones. Suture-line nut elaborate, retraction and reclination of umbilical lobes fecble.

Date of cxistence: Bathian? Callovian, Divesian; maximum in Callovian : some of their strata preserved over wide areas in Europe.

The venter, which may be called the Kosmoceratid venter, prescuts itsclf in varions styles :-

(I) Runcinate-ornate : a median tabulate area, crossed by straight coste or subcoste, bordered by promincnces, from swellings to long spines.

(2) Ornate: median band more or less smooth to quite smootll, tabulate to sunken, bordered by spines, alternate, opposite or intermittent. The spines being septate, and the specimens being usually found as pyritized casts, the length of the spines may fail to be appreciated.

(3) Runcinatc: median band tabulate, crossed by straight costec, which have no prominences at the angle of junction with lateral area. (Runcinate stage-Neumayr \& Uhlig, Kaukasus Jurafoss. ; Denkschr. Math. Nat. Cl. K. Akad. Wiss. LIX, I892, 54).

There are many forms of venter included in the above headings. Some of them are due to change during developments; but others arise from the differential development of characters in distinct lineages.

The Kosmoceratid venter is one feature distinguishing Kosmoceratidx from Parkinsonidx. The runcinate-ornate and the runcinate stages, with ribs rumning straight and strong across venter, are not found in the Parkinsonida: in the true Parkinsonian venter, when ribs are on the median band, they are alternatc and curve forwards to fade away in the mid-line. The ornate venter, however, is comparable witl that in Strenoceras, Garantiana etc. ; but is not to be directly connccted, as it is not a prinitive fcature in Kosmoceratida: it is, presumably, a modification of certain phases of the runcinate-ornate-therefore, it is of independent origin from that of Strcnoceras etc. Proof of this is also found in the associated suturc-line: it is more elaborate than that of Strenoceras and allies. 
Further distinction from Parkinsonide is the failure of Kosmoceratidie to produce Perisphinctean forms. The rounded venter crossed by ribs, attained as a late phase by many Kosmoceratids, is the analoguc of the I'crisphinctean venter; but, in the Kosmoceratidie, inclusion lias by then become too great to produce Perisphincteans: platycones or Nacroccphalitoids are evolved. Distinction from Macrocephalites is the passage through Kosmoceratid venter, however mucl this may be masked by later whorls: Macrocephalites has no such pliasc.

KOSMOCERAS, Waagen I869, (Am. subradiatus ; Geogn.-Pal. Beitr., II $(2), 248)$, Cosmoceras, Auctt. Proposed for the Ornati, all of which named up to that date are therefore genosyntypes. No genolectotype has been chosen. Take as such Ammonites ornatus rolundus, Quenstedt, Cepl., I846, Ix, I9, p. I33, = Kosmoccras rotundum, Qucnstedt sp. The genus is thus to be distinguished by somewhat intermittent, rather fecble tuberculation of lateral. arca; by smooth, subsulcate venter, bordered by strong spines in alternate position; by suture-line with short EL, rather highly developed and broad LI, fairly long but narrow L2. Gcrmany, England, France, Russial.

KEPPLERITES, Neumayr \& Ulilig, I892 (Kalukasus, p. 53), "Typus Kepplerites Keppleri Oppel [sp.]" (p. 55). This leaves it uncertain whether Oppels types or Neumayr \& Uhlig's specimen or specimens identified therewith are to be the genoholotypes. Taking all as genosyntypes, advisable to choose Oppel's large measured cxample as lectotype of his species and genolectotype of Kepplerites. Though it las not been figured, its dimensions are given: they read as ' $T$. I43, 3I, 35, 35, From them and the description (Pal. Mitth. III, I862, I57), his specics is near to Am. macrocephalus cvolulus, Quenstedt, (Amm. Schwäb. Jura, I887, Ixxvir, I, F. 133, 36, [38], 33), but loses its runcinate stage earlier. [Lobes broad and short according to this identification.] There are possibly several lineages with somewhat similar characters. Germany ; "Zone des Amm. macrocephalus." England, Cornbrash.

SIGALOCERAS, Hyatt, Igoo (Op. cit. p. 587) "Type S. (Amm.) calloviense, d'Orb. sp." [Terr. jur. Céph. I847, CLXI, IO, II, non $A m$. calloviensis, Sowerby]. A runcinate with fine ornament, costulæ sinuous : change over to Macrocephalitoid stage not known. [Suturc-line not given, but, presumably, highly devcloped, with a particularly long ELabout the most florid s.l. of any Kosmoceratid, sce T.A. CCLV]. England; France.

GULIELMICERAS, S. Buckman 1920, Legend of Pl. CXCIV; Genoholotype, the example of $G$. gulielmi there figured. A lighly ornatc platycone, with two rows of lateral tubercles and two rows of short spines bordering a smooth narrow venter. [S.1. simple, with broad, shallow lobes]. Passes into forms with rounded venter, losing ornament. England ; Scotland ? France ; Germany ; Russia?

In anamorphs and brephomorphs a venter costate or subcostate between spines is to be expected. Also, in the former, the stage of development of inner row of lateral spines might not be reached.

GOWERICERAS, n. Kepplerites Auctt. Am. gowerianus group. Genotype, Gowericcras metorclum, n., T.A. I92I, CCLIV. Distinct from Kepplerites by suture-line-lobes somewhat long and narrow, EL longer than L.I-by earlicr loss of runcinate stage, by not passing into a Macroceplralitoid stage, but having rather the aspect of an involute Stepheoceras. England, Scotland; Kellaway's Clay (a), majesticus. Continental occurrence doubtful: to be expected in Deux Sc̀vres and at Balin. 


\title{
$a^{\circ}$
}

\section{TYPE AMMONITES}

S. S. BUCKMAN, F.G.S.

The illustrations from photographs by

J. W. TUTCHER

and

ThE AUTHOR

\section{Part XXX}

Pp If 55-64; I6 Plates

\author{
Published By the Author \\ SOLD BY \\ WHELDON AND WESLEY, LTD. \\ INCORPORATING \\ WILLIAM WESLEY AND SON
}

28 ESSEX STREET, STRAND, LONDON, W.c. 2

Decemher, 192 I 


\section{CONTENTS}

\section{PART XXY}

Text:-

Title p. to Vol. III

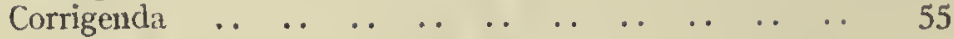

\section{Illustrations :-}

Plate

133. Ammonites lumphriesianus

(Docidoceras cylindroicles) $\ldots$. . $\quad$ CXXXIII B

257. Ammonites giganteus

(Briareites polymeles) . . $\quad \ldots \quad \ldots \quad \ldots \quad$ CCI,VII B, c

258. Sphæroceras brongniarti

(Sphæroceras tutthum) _. . . . . CCLVIII

259. Ammonites sub-contractus

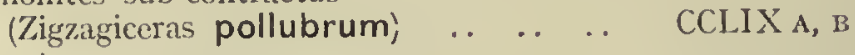

260. Ammonites omplaaloides

(Sagitticeras sagitta) $\quad \ldots \quad \ldots \quad \ldots \quad \ldots \quad \ldots$ CCLX

26r. Ammonites binatus

Binatisphinctes binatus .. $\quad \ldots \quad \ldots \quad \operatorname{CCLXI~A,~} \mathrm{B}$

262. Ammonites binatus

(Hamulisphinctes hamulatus) $\quad$. CCLXII A, B

263. Ammonites binatus

Hamulisphinctes auricula $\quad . \quad \ldots$ CCLXIII

264. Cf. Perisphinctes inglos
(Docidoceras planulatum
.. $\quad$ CCI.XIV

265. Stephanoceras of bayleanum-type

(OEcostephanus dolichœcus) . . . CCLXV

266. Phylloceras aff. vilpum

(Xeinophylloceras xeinus) $\quad \ldots \quad \therefore$ CCLXVI A, B 


\section{CORRIGENDA.}

Page 6, line II, before 'flavum' read 'Oxynoticeras'

P. 7. 1. 30, for 'elliptocone ' read 'ellipticone"

P. I0, for 'Loch Staffin Beds' read 'Loch Staffiı (Argovian) Beds

I. I8, 1. I5 down and lines I, 2 up, for 'pavlovi' read 'pavlowi

P. I9, Sagitticcras. The prior, unfortunately overlooked Sagittoceras, does not invalidate Sagitticeras. Nomenclatorial rules state that the distinction of a letter is sufficient; therefore, change is not allowed.

P. 22, 1.8 up, for 'well-marked cutting' read 'well-marked, cutting '

P. 26, 1. I8 up, for 'holotype' read 'lectotype'

P. 30, 1. Io down, for 'HASElbubGites' read 'HASElbuRgites'

P. 3I, 1. + down, for 'Congres' read 'Congrès'

P. 3I, 1. I2 up, for 'ou' read 'où'

P. 32, 1. 15 down, for 'kranker' read 'kranke'

P. 34, 1. 33, for 'Am. könighi' read 'Perisph. känighi'

P. 50, 1. 5, delete ';' at end

P. 50, 1. 22 up and p. 5I, 1. Io up, for 'isidopliorus ' read 'isidophorous '

I'. 50, 1. I7 up, for 'anisidoplorus ' read 'anisidoploorous '

l'. $50,1.3$ up, for 'Tables $1 \mathrm{~V}, \mathrm{~V}$ ' read 'Tables $I I I-V$ '

Il. CXXXVIII A. Alter 'Hildoceras serpentinum, Reinecke sp.' to 'Hildoceratoides serpentinus, Reinecke sp.' 'The sharp swing backwards of the ribs in Hildoceratoides propeserpentinus (PI. CCXVIII) shows the rib-character which Reinecke depicted: it was wrongly tliought to be an exaggeration. Therefore Argonauta serpentinus, Reinecke, may be expected to lave the rather long, narrow LI of Hildoceratoides and so to belong to that genus.

Hildoceratoides lias been recognized by Dr. L. F. Spath, F.G.S., as denoting a date somewhat later than that of Harpoceras falciferum.

Pl. CXXXVIII B. Alter 'Hildoccras serpontinum Reinecke sp.' to 'Hildaites serpentin iformis, nov., Holotype.' The broad and somewhat sliort LI agrees witl that of Hildaites subscrpontinus, S. Buckman, Pl. CCXVII. Alter the number of "Pl. CXXXVIII B" to 'Pl. CCLXVII A': it is loped to give a further study of this species.

The title of Pl. XII (Vol. I) should be altered from 'Hildoceras levisoni, Simpson sp.' to 'Hildaites levisoni, Simpson sp.' The ribs of II ildaites are not simple as in Hildoceras and Hildoceratoides, but are connate towards inner part of lateral area. Absence of a longitudinal lateral furrow distinguishes Hildaites and Hildoceratoides from Hildoceras.

Dr. Spath writes that Hildaites marks a date somewhat earlier than that of Harpoceras falciferum.

Pl. CXXXIX c, for 'Fig. $2, \times 2$ ' read 'I Iig. 2, Nat. Size'

Pl. CL B, for ' $28(24)$ ' read ' $23(2 \mathrm{I})$ '-

Pl. CLIV, for 'Lamberticeras' read 'Bourkelamberticeras'-see p. I7

Pl. CLV, for 'Prionoceras' read 'Prionodoceras'-

Pl. CLXI, 1. 3, for ' 3 ' read ' 23 '

Pl. CLXV A, for 'Fig. I $\times \cdot 2$ ' read 'Fig. $I \times 2$ '

Pl. CCXIV, after 'S. B. Coll.' add ' $33 \mathrm{I} 4$ '

Pls. CCXVII, CCXVIII, for 'cit. sp. (species) read 'cit. spec.' (specimen)

Pl. CCL A, for " "near' read " near"

PI. CCLVIIA, 1. 4, for ' month' ' read ' nouth' 


\section{EDITORIAL}

Volume III is now completed in 12 parts, containing 193 plates, illustrating 137 species: there are also 3 portraits. Some 50 pages of letterpress deal with chronology, classification and descriptions of many more species: those which have been described, but not illustrated, in the present volume will, it is hoped, find places in the next ; but the mass of type-material which has accumulated is very great-much of it is due to the activities of those geologists who take a keen interest in the progress of this work. Where there is so much interesting material, choice as to which should come for illustration is not easy: those specimens which require little labour in the removal of matrix stand the best chance, but specimens of new genera also have strong claims. It is for this reason that the number of gencra in the present volume is largethe aim has been to illustrate genera, so as to lay a nomenclatorial foundation, lcaving till a later date the building up of the supcrstructurc with the various species of these genera. Already, what has been accomplished in this way in the three volumes is having an appreciable effect on nomenclature: it is not so often necessary to give the unsatisfactory designation, Gen. nov. aff. But much remains to be done, for the persistent richness of British Jurassic deposits in regard to Ammonites is a most remarkable phenomenon : in some cases there are preserved in Great Britain certain strata, with rich ammonite faunas, which do not seem to be found anywhere on the Continent of Europepresumably, these strata have been wholly destroyed there.

To all scientific friends who have kindly aided and encouraged this study of Ammonites, and particularly to Mr. Tutcher, with his valued photographic assistance, the Editor again tenders his hearty thanks. To the subscribers who have so ably supported this work he is equally grateful: he trusts that they will accord the same favour to the fourth volume. To the Council of the Royal Society he would also express kind thanks for material assistance in the shape of grants, which allowed an increase in the number of plates. The author's friend and neighbour, Mr. Walter Blaber, helped towards the same end, giving freely the results of his long experience in the technicalities of book-production and publication: with many thanks the author acknowledges his indebtedness. As the sale of the work in various European countries is greatly hampered by the problem of exchange, all such help is of the greatest value. 


\section{INDEX}

abbas .. . . . Pages \& Plates Abbasites $\cdots \quad \ldots \ldots$ ccxxxvi abbas

cCXXXVI

Abbreviations

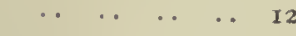

Acanthopleuroceras $\quad \ldots \quad \ldots \quad \ldots$ ccV aegrotus

Aitoun $\ldots$. $\begin{array}{lllll}\cdots & \ldots & \ldots & \ldots & \operatorname{ccx} x 11\end{array}$

Agassiccras . . personatum

CLXXXvII

$\begin{array}{lllll}\text { sp. } & \ldots & \ldots & \ldots & \text { CLXXXvir }\end{array}$

$\begin{array}{llllll}\text { Allom } & \ldots & \ldots & \ldots & \ldots & \text { cCXII }\end{array}$

. foceras ..

bersites agrotus

$\operatorname{ćxx\times v11}$

Amblycoceras

- capricornus

amblygastric $\quad \ldots \quad \ldots \quad \ldots \quad 13$

Ammonites albineus

achiles

$\begin{array}{llllll}\text { alligatus } & \ldots & \ldots & \ldots & \ldots & 26\end{array}$

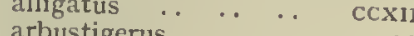

- bakariag $\quad \ldots \quad \ldots \quad \ldots 33$

. $\quad \ldots \quad \ldots \quad \ldots 26$

$41, t^{2}$, CCXXVIII

berlyeri $\quad \ldots \quad \ldots \quad \ldots \quad$ CCXXI

binatus $\quad . \quad$ CCLXi, CCLXI1,

- biplex . . . . 27, cxxxis

- blagdeni $\ldots . . . \quad \ldots \quad \ldots \quad 30$

- braikenridgii $\quad \ldots \quad \ldots{ }^{\circ}$ cLIX

brongniarti $\quad \ldots \quad \ldots \quad$ ccxiv

- buckii .. .. .. .. clxv $a$

- bucklandi .. $\ldots$.. cxxxi

- buckmanii .. .. .. cxcix

- bullatus . $43,47,49,50$

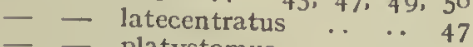

- - platystomus . . . 49

- centauriensis .. 54, cCLV

- centaurus .. .. .. cxLv1

— crassiusculus $\quad \ldots \quad \ldots \quad \ldots \quad$ I5

- crassulus

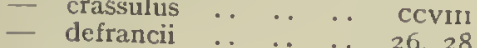

- erratus .. . . C CLxxxvir

- erugatus $\quad \ldots \quad \ldots \quad \ldots \quad$ CLXXXviII

- fabalis .. .. . CCXLIV

- ferrugineus ${ }^{.} \quad \ldots \quad \ldots$ CXLII

- giganteus .. .. " ccxxxi,

CCLVI, CCLVII

- gowerianus .. .. CCLIV

- gracilis .. .. .. cxcin

- guibalianus... ........ I $_{4}$

- heterophyllus numismalis

CCXXXIII

- humphriesianus cxxxiI $b$,

- huntoni ccxxxvil

$\begin{array}{lllll}\text { - huntoni } & \ldots & \ldots & \ldots & \operatorname{ccx} 1 x \\ \text { incrassatus } & \ldots & \ldots & \ldots & \operatorname{ccx}\end{array}$ ingens $\quad \ldots \quad \ldots \quad \operatorname{cLxxxIV}$

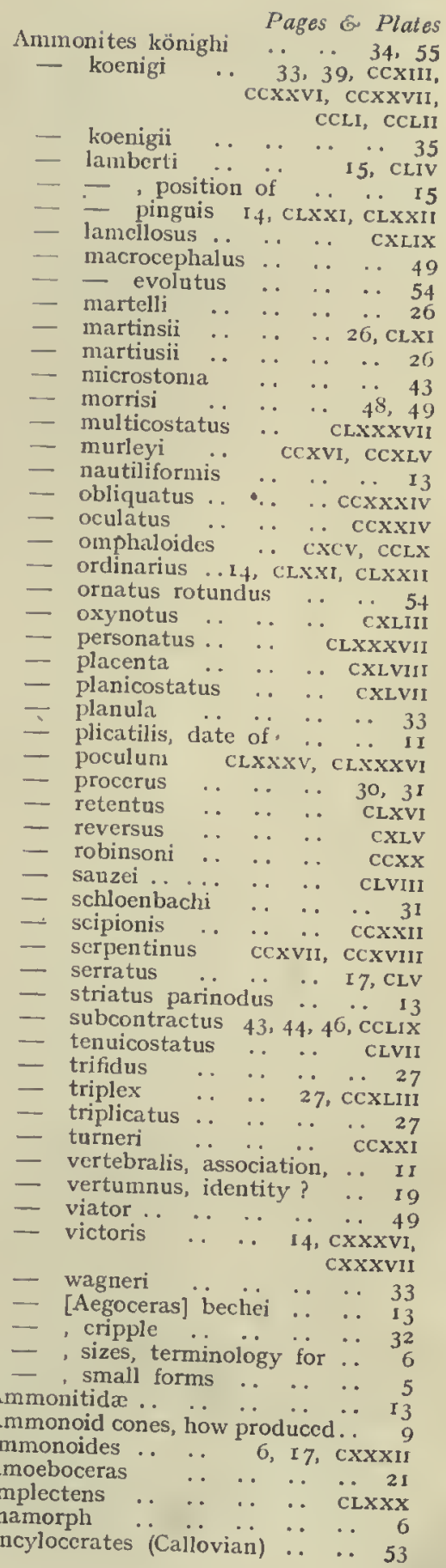

$$
\begin{aligned}
& \text { Ammonites könighi .. . } 34,55 \\
& \begin{array}{l}
\text { 33, 39, cCXIII, } \\
\text { ccxivi, ccxxvil, }
\end{array} \\
& \text { CCLI, CCLII } \\
& \begin{array}{rllllr}
\text { - koenigii } & \ldots & \ldots & \ldots & \ldots & 35 \\
\text { - lamberti } & \ldots & \ldots & & 15, & \text { CLIV }
\end{array} \\
& \text { - - position of } \ldots \text { pinguis I } 4, \mathrm{CLXX}, \ddot{\mathrm{CLXX}} \text { I5 }
\end{aligned}
$$

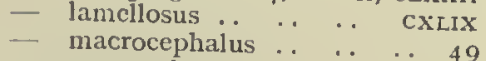

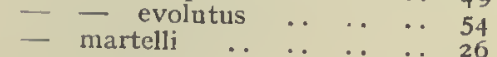

$$
\begin{aligned}
& \text { - martinsii .. } \ldots \text {. } \text { 26, clxI }
\end{aligned}
$$

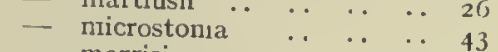

$$
\begin{aligned}
& \text { - multicostatus } \quad \ldots \quad \cdots \quad 48,49 \\
& \text { - murleyi .. cexvi, CCXLV } \\
& \text { — nautiliformis } \quad \ldots \quad \ldots \quad \ldots \quad \text { I3 } \\
& \text { - oculatus .. .. . . ccxxiv } \\
& \text { - omphaloides .. CXCV, cCLX } \\
& \text { - ordinarius ... }
\end{aligned}
$$

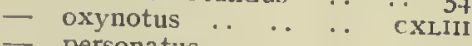

$$
\begin{aligned}
& \text { - placenta .. } \quad \ldots \quad \ldots \quad \text { CLXXXVII } \\
& \text { - planicostatus .. .. cxlvir } \\
& \text { plicatilis, date of . } \\
& \text { retentas } \quad \cdots \quad \cdots \quad \ldots \quad 30,3 I \\
& \text { reversus } \quad . \quad \ldots \quad \ldots \quad \ldots \quad \text { CXIV } \\
& \text { robinsoni } \quad . \quad \ldots \quad \ldots \quad \operatorname{ccxx} \\
& \text { sauzel . ... } \quad \ldots \quad \ldots \quad \text { CLVIII } \\
& \text { schloenbachi } \quad . \quad \ldots \quad \ldots \quad 31
\end{aligned}
$$

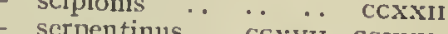

$$
\begin{aligned}
& \text { - serratus .. .. .. I7, CLV } \\
& \text { striatus parinodus .. . . } 13 \\
& \text { subcontractus } 43,44,46, \text { CCLIX } \\
& \text { trifidus }
\end{aligned}
$$

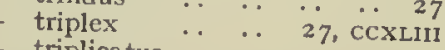

$$
\begin{aligned}
& \text { triplicatus .. } \quad . . \quad \ldots \quad \ldots 27 \\
& \begin{array}{lllll}
\text { turneri } & \cdots & \cdots & \cdots & \operatorname{ccxxi}
\end{array} \\
& \text { - vertumnus, identity ? ... I } \\
& \text { - viator .. .. . . . . . } 49 \\
& \text { — wagneri cxxxvil }
\end{aligned}
$$

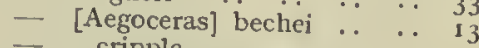

$$
\begin{aligned}
& \text { - cripple . . . . . } 32 \\
& \text { — small forms .. } \\
& \text { Ammonoid cones, how produced.. }
\end{aligned}
$$$$
\text { ammonoides .. .. 6, } 17, \text { CXxxis }
$$$$
\text { Amoeboceras } \quad \ldots \quad \ldots \quad \ldots \quad \ldots 2 \text { 2 }
$$

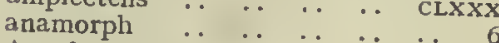$$
\text { Ancyloccrates (Callovian) } \ldots \begin{array}{rrr}
\ldots & \ldots & 53
\end{array}
$$ 
Pages \& Plates

anglica $\ldots \quad \ldots \quad \ldots \quad \ldots \quad \ldots \quad$ ccxxv anisidophorous (-us) $\quad \ldots \quad \ldots 5$ 50, 55

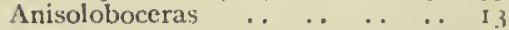
Aperture (ocular and brachial) cixxii

- sealed .. .. .. . . cLxxiv - , sec Mouth

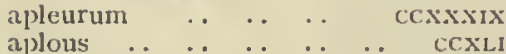

Apoderoceras $\quad \ldots \quad \ldots \quad \ldots$ ccxxxv lobulatum

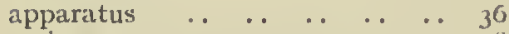

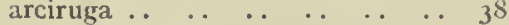

Ardley, Great Oolitc, dates of .. 52

Argonauta serpentinus cxxxviII

Argovian chronology .. .. . . 10

$\begin{array}{lllllll}\text { Arictidie } & \ldots & \ldots & \ldots & \ldots & \ldots & \text { I }_{3}\end{array}$

Arictites $\ldots \ldots \ldots$. . . . . turneri

Arnioceras miserabile .. .. .. 6

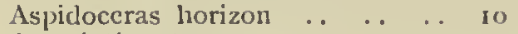

Association term $\quad \ldots \quad \ldots \quad \ldots$ I I

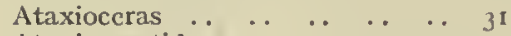

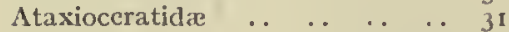

auricula . $\quad \ldots \quad \ldots \quad \ldots \quad \ldots$ CCLXH

auricularis $\quad . \quad \ldots \quad \ldots \quad$ CLXXXVi

$\begin{array}{lllllll}\text { auriculatus } & \ldots & \ldots & \ldots & \ldots & \ldots & 37\end{array}$

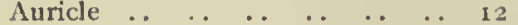

— , node on ........ . CxL

Auricles, incompletely grown ? $\mathrm{cl} J$

Baculatoceras $\quad \ldots \quad \ldots \quad \ldots \quad \ldots 29$

Basement Bed ..

basileus .. . . . . . 34, cri.II

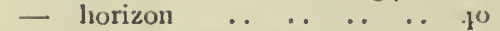

Batlian, hemeral sequence .. 5 I

bathyomphalum .. .. I8, cxevi

Beaniceras .. .. cxlvi, cxLVII centaurus, crassum

Becheiceras ..

biarmatum lıorizon $\ldots$.. $\quad \ldots$ I0

bifurcus . $\quad \ldots \quad \ldots \quad \ldots \quad \ldots \quad$ c.sc11

$\begin{array}{lllllll}\text { Bigotellal } & \ldots & \ldots & \ldots & \ldots & \ldots & 29\end{array}$

- haugi ..

- petri ..

$\begin{array}{lllll}\text { Bigotitean venter } \quad \ldots & \ldots & \ldots & 29\end{array}$

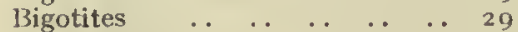

Binatisphinctes .. .. . . c cLxI binatus

binatus . $\quad \ldots \quad \ldots \quad \ldots \quad \ldots \quad$ CCLXI

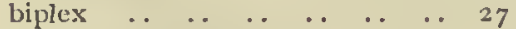

Biplices . . $\quad \ldots \quad \ldots \quad \ldots \quad \ldots \quad \ldots 3_{1}$

Bourkclamberticcras

lamberti

1 7. 21,55 (CLIV)

Bradypalingenesis .. .. .. II

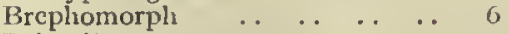

Briareites $\ldots \ldots \ldots \ldots$ CCLVII polymales

buckii $\ldots \ldots \ldots$...

bucklandi .. $\ldots \quad \ldots \quad 6$, cxxxI

buckmanii $\ldots \ldots \ldots$...

Bullatimorphites .. .. $43,47,5$ I bullatimorplius, latecentratus

bullatimorphus .

Cadicone coronoid ... cxxxili

Cadoceras $\quad \ldots \quad \ldots \quad \ldots \quad 7,21,41$

- carinatum . . . . . . . . 20

$\begin{array}{llllll}\text { Cadoceratidae } & \ldots & \ldots & \ldots & \ldots & 14\end{array}$
Pages \& Plates

Cadoceratidx analysis, development, morplology $\ldots \quad \ldots 2$ I

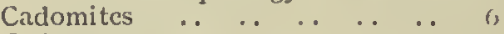

Cadomoceras .. .. G, cLxxxix costatum

Cadomoceras cadomense $\ldots 7.77$

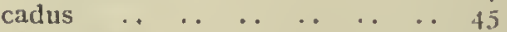

capistratus $\quad . \quad \ldots \quad \ldots \quad 37$, ccsil

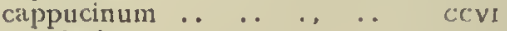

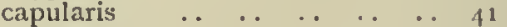

$\begin{array}{llllllll}\text { cardia } & \ldots & \ldots & \ldots & \ldots & \ldots & \ldots & 15\end{array}$

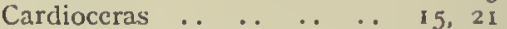
cardia

Cardioceras ammonoides cxxxif $c$

- cardia, horizon .. .. 10

— cordatum $\ldots$..

一 dieneri.. .. .. $\quad . . \quad \ldots \quad 16$

- goliathus .. clvi, cxcvit

— sliuravskii .. . . . . . $\quad 17$

- vertebrale .. .. .. cxcviII

Carina, loss of .. .. cxxxvı $b$

一, septum end ... .. $\operatorname{ccv} b$

$\begin{array}{lllllll}\text { Carination } & \ldots & \ldots & \ldots & \ldots & \ldots & 21\end{array}$

$\begin{array}{lllllll}\text { carinatum } & \ldots & \ldots & \ldots & \ldots & \ldots & 20\end{array}$

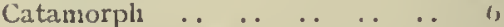

Caumontisplinctes 28,29, CLNi1, cLXix, cXc11, cCXLI, CCXLII

aplous, bifurcus, nodatus,

phaulus, polygyralis

contaurus $\quad \ldots \quad \ldots \quad \ldots \ldots$ CXLVI

Chanoussctia.. $\quad \ldots \quad \ldots \quad \ldots \quad \ldots 2$ I

$\begin{array}{lllllll}\text { Clieltonia } & \ldots & \ldots & \ldots & \ldots & \ldots & 6\end{array}$

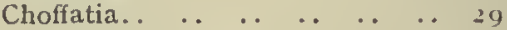

$\begin{array}{llllll}\text { Chondroceras } & \ldots & \ldots & \ldots & \ldots & 22\end{array}$

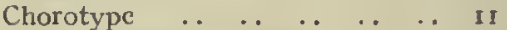

Chronological Sequence .. $\quad . .50$

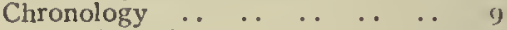

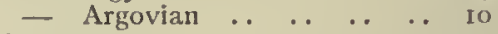

clausum .. $\ldots . . . \quad \ldots \quad$ I 4, CXLIV

clcistus $\ldots \quad \ldots \quad \ldots \quad \ldots \quad \ldots \quad$ CLXI

Coeloceras $\quad \ldots \quad \ldots \quad \ldots \quad \ldots, 44, \operatorname{ccx}$ incrassatum

Colomorph $\quad$. 6, cxxxil b, cxxxiv

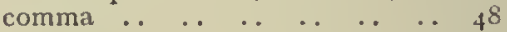

$\begin{array}{lllllll}\text { Cone-terms } & \ldots & \ldots & \ldots & \ldots & \ldots & 7\end{array}$ Contracticone .. .. 7, exxxiv 6 ,

$\begin{array}{llllll}\text { contractus } & \ldots & \ldots & \ldots & \ldots & \text { CLVIII }\end{array}$

Corallian strata $\ldots \ldots \ldots$...

cordatum horizon $\quad \ldots \quad \ldots \quad \ldots$ io

coronarius $\quad \ldots \quad \ldots \quad \ldots \quad \ldots \quad \ldots$ CCII

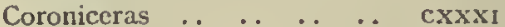
bucklandi

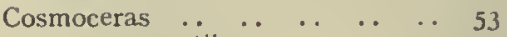

— caumontii .. $\ldots$..

- subfurcatum .. .. cexx.ix

- see Kosmoceras

Cosmoceratida $\quad \ldots \quad \ldots \quad \ldots \quad \ldots 53$

-, see Kosmoceratida

costatum $\quad . \quad \ldots \quad \ldots \quad$ CLXXXix

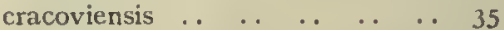

crassicosta $\ldots \quad \ldots \quad 41$, cexxvill

Crassiplanulites .. 33, 41, ccxxvil,

crassicosta, crassiruga,

CCLIII

lalıuseni 
Pages \& Plates

Crassiplanulites horizon ‥ 40, 42 crassiruga $\quad \ldots \quad \ldots \quad \ldots \quad 42$, CCLII crassiusculum $\quad \ldots \quad \ldots \quad \ldots \quad$ ccix crassulum $\quad \ldots \quad \ldots \quad \ldots \quad \ldots \quad$ cCVIII crassum $\ldots \begin{array}{llllll} & \ldots & \ldots & \ldots & \ldots & \text { cxLVII }\end{array}$ crater $\ldots \quad \ldots \quad \ldots \quad \ldots \quad 7$, CLXIV Cripple Ammonites .. .. .. 32 Crucilobiceras $\quad \ldots \quad \ldots \quad$ CLxXVIII crucilobatum

crucilobatum $\quad \ldots \quad \ldots \quad$ cLXXVIII Curvature, how produced .. .. 8 curvus .. cylindroides .. $\quad . \quad \ldots \quad 6$, cxxxin Cyrtosiceras macrotelus . . . 7 Dactylioceras ... CLVII, ceVIII crassulum, tenuicostatum

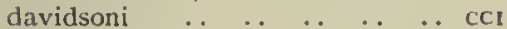
delicatus $\quad \ldots \quad \ldots \quad \ldots \quad \ldots \quad$ cxLI

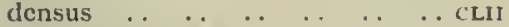
Deroceras leckenbyi .. . ccxxxv Development $\quad \ldots \quad \ldots \quad \ldots \quad \ldots \quad 8$ — Cadoceratida .. .. . 2 I

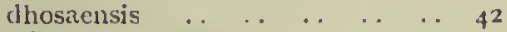
Dichotomoceras .. .. 27, cxxxix, alligatum, dichotomun,

Clxxxiv, ccxil ingens

Dichotomoceras horizon ... .. 10

— variocostatum .. $\quad \ldots \quad \ldots 28$

dichotornum .. $\quad \ldots \quad \ldots \quad \ldots$ cxxxix

Diplesioceras .. . . . 25, CLxxvil diplesiun

cliplesium . . . . 25, CLxxvil

Dipoloceras . . . . . . .

Docidoceras .. .. 22, 28, cxxxill,

cylindroides, planulatum

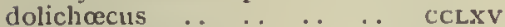
dorsal suturc-line .. cexxxviı dorsalc .. . . . . . 16, cxcvill Dysmorph $\quad \ldots \quad \ldots \quad 32$, cLXXXvil Eboraciceras .. .. If, $21, \mathrm{CLXXI}$, ordinarium, subordinarium

CLXXII

Ebraviceras .. .. .. 22, CLXXili. jactatum, ocellatum, pseudoCLXXIV anceps, rursum, vaschaldi

Ebrayiceras, proportions of spp. of 24

Editorial .. $\ldots . . . \quad \ldots \quad 5,56$

Eichwaldiceras .. $\ldots . . .20,21$ carinatum

Ellipticone (-ocone) 7,55, c LXxxIX

Emileia .. .. $6,7,22,43$, CLXIV crater

Emileia, cadicone stage .. cLxiv

Epalxites ... 12, 21, CLI, CLIX formosus, latansatus

erratum .. $\quad . . \quad \ldots \quad \ldots \quad$ cLXxxvil erugatum $\quad \ldots \quad \ldots \quad \ldots \quad \ldots \quad$ CCXXi1

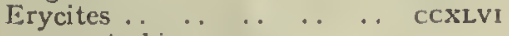
partschi

Erycites gonionotus .. . . CCxLvi

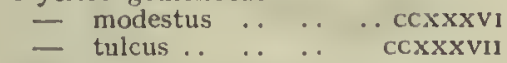

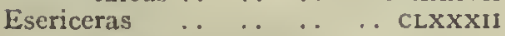
inaequun?
Pages of Plates

Erymuoceras _... .. 21,43

Fudmetoceras .. cixxix, cLXXX amplectens, eudnetum

eudmetum $\quad . . \quad \ldots \quad \ldots \quad \ldots \quad$ cLXXIX

euryodos $\quad \ldots \quad \ldots \quad \ldots \quad \ldots \quad$ CLII

excentricus ..

$\begin{array}{llllll}\text { extensum } & \ldots & \ldots & \ldots & \ldots & \text { ccxiv }\end{array}$

fabale $\quad \ldots \quad \ldots \quad \ldots \quad \ldots \quad \ldots$ ccxilv

fabricatus $\quad \ldots \quad \ldots \quad \ldots \quad \ldots 36$, CCLI

Falaisian, hemeral scquence .. 51

fastigatum $\ldots$. .

Fastigiceras .. .. .. I4, CXLIV clausum

Fauna, Fullers' Earth Kock, Great Oolite $\ldots \ldots \ldots \ldots$. . . 51

Faunal Horizons .. $\ldots . . . \quad \ldots \quad 10$

Females ..

ferrugineum $\ldots \quad \ldots \quad \ldots \quad \ldots \quad$ cxLII

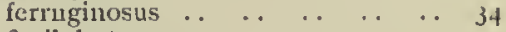

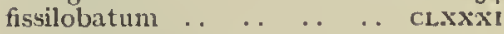

Fissilobiceras $\quad \ldots \quad \ldots \quad \ldots \quad$ CLXXXI fissilobatum

formosus $\quad \ldots \quad \ldots \quad \ldots \quad \ldots \quad \ldots, \mathrm{cLI}$

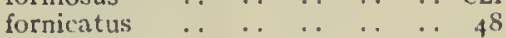

forte $\quad \ldots \quad \ldots \quad \ldots \quad \ldots \quad \ldots \quad c c x L v$

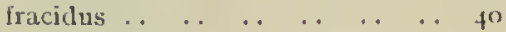

- horizon .. .. .. . . 40

Frogdenites .. .. .. .. ccxv spiniger

Fuller's Earth Rock .. . . . . 43

- — - , sequence... .. 51

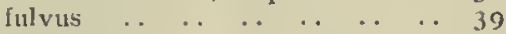

Furcation $\quad \ldots \quad \ldots \quad \ldots \quad \ldots \quad \ldots \quad 13$

$\begin{array}{lllllll}\text { galeatum } & \ldots & \ldots & \ldots & \ldots & \text { CLVI }\end{array}$

Garantiana $\ldots{ }^{\prime} \quad \ldots \quad \ldots \quad \ldots \quad 29,53$

- , latcsulcate sp. .. ccxL

Genolectotype $15,24,25,26,29,30$,

31,54, CCXLVIII

Geological Sequence .. . . . 50

Gerontic swelling $\ldots \quad$ cLxxx $b$

giganteus $\quad \ldots \quad \ldots \quad \ldots \quad \ldots \quad$ CCLVI

Gigantites .. . . . . . . C CLV1 giganteus

$\begin{array}{lllllll}\text { glabretus } & \ldots & \ldots & \ldots & \ldots & \ldots & 52\end{array}$

Gleviceras $\quad \ldots \quad \ldots \quad \ldots \quad \ldots \quad \ldots$ IA

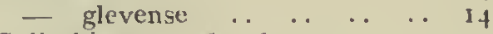

Goliathiceras $6,16,17 ; 21$, cxxxII, ammonoides, galeatum

Goliathiccras horizon .. $\quad . \quad \ldots \quad$ I0

Goniocone $\quad . \quad \ldots \quad \ldots \quad 7$, cLXXVI

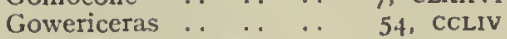
metorchum

gracilis .. .. . . . $\quad 32$, cxcin

Gracilisphinctes .. .. 32, cxcill gracilis

Great Oolite .. .. .. . . . 43

— Ardley, dates of .. .. 52

— Gloucestershire .. .. 51

grossouvrei .. . .. 24, cLXxv

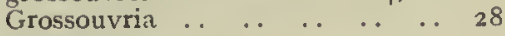

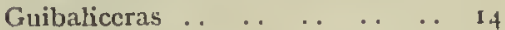

gulielmi .. $\quad \ldots \quad \ldots \quad \ldots \quad 54$, cxciv

Gulielmiceras .. .. 54, cxciv guliclmi

Hammatoceras . . . . . ccvi cappucinum 
Pages or Plates

Hammatoceras amplectens.. CLXXX — insigne $\quad \ldots \quad \ldots \quad \ldots \quad$ CCVI - sp. .. .. cLXXIX, cCVII lramulatus $\quad \ldots \quad \ldots \quad \ldots \quad \ldots \quad$ CCLXII Hamulisphinctes .. ccLXII, cCLXII auricula, hamulatus

Harpoceras falciferum (date) .. 55 fissilobatum ... . CLXXXI

Haselburgites.. . . . . 30, cciII admirandus

Haugia inrequa .. .. CLXXXII

Hemeral Sequence .. $\quad \ldots \quad \ldots 5^{I}$

heterolithous .. $\quad \ldots \quad \ldots \quad \ldots \quad \ldots 50$

heteropetrous.. $\quad \ldots \quad \ldots \quad \ldots \quad \ldots 50$

Hildaites $\ldots$. 55, (cxxxviII b),

levisoni, serpentiniformis subserpentinus

Hildaites, date .

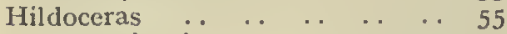

— levisoni $\ldots \quad \ldots \quad \ldots \quad \ldots \quad 55$

- (Hildaites) ... .. cxxxviı $b$

- (Hildoceratoides) cxxxvili $a$

- serpentinum .. 55, cxxxviI

Hildoceratoides .. 55, (cxxxviII a), coxvili propeserpentiuus, scrpentinus

Hildoccratoides, date .. . . . 55

Hlawiceras .. . . . . . CCXL platyrrymun

hollow keel .. $\quad \ldots \quad \ldots \ldots \ldots \ldots$

homceolithous $\quad \ldots \quad \ldots \quad \ldots \quad \ldots 50$

Homoomorph .. cxxxix, cxiII

lromceopetrous $\quad \ldots \quad \ldots \quad \ldots \quad \ldots \quad 50$

homœoticum .. $\ldots \ldots \ldots$... $\quad \ldots 4^{8}$

homolithous .. $\quad \ldots \quad \ldots \quad \ldots \quad \ldots 50$

Horizons, Argovian, .. .. ..

- Faunal .. .. .. . .

— , Kellaways.. .. .. . 40

- , see Hemeral Sequence

lnumplíriesianum .. .. ccxxxvıı luuntoni $\ldots \quad \ldots \quad \ldots \quad \ldots \quad \ldots \quad c c x i x$ Hyponomic sinus $\quad \ldots \quad \ldots \quad \ldots \quad 9$ inzquum $\quad \ldots \quad \ldots \quad \ldots \quad \ldots$ CLXXXII incrassatum $\ldots \quad \ldots \quad \ldots \quad \ldots \quad \ldots$ c $\begin{array}{lllllll}\text { Inflation } & \ldots & \ldots & \ldots & \ldots & \ldots & 21\end{array}$ ingens .. . . . . 28, cLxxxiv injury $\ldots \quad \ldots \quad \ldots \quad \ldots \quad$ cxxxvil $b$, ccxxxvil

interlineatum $\quad \ldots \quad \ldots \quad \ldots \quad \operatorname{cciv}$ intricatum $\quad \ldots \quad \ldots \quad \ldots \quad 6$, cxixv $\begin{array}{llllllll}\text { involutus } & \ldots & \ldots & \ldots & \ldots & \ldots & 36\end{array}$ isidophorous (-us) . . . . . . $\quad 50,55$ jactatum.. jump (in size) $\quad \ldots \quad \ldots \quad \ldots 18, \mathrm{cxcv}$ Kakomorph .. $\quad \ldots \quad \ldots \quad \ldots \quad \ldots \quad 32$ Kallilytoceras .. . . . . ccIV interlineatum

Kallimorph $\quad \ldots \quad \ldots \quad \ldots \quad \ldots \quad \ldots \quad 32$

Kallistephanus $\quad \ldots \quad \ldots \quad \ldots \quad \operatorname{ccxxx}$ kalus

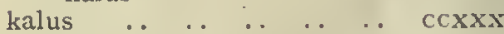

Kellaways Clay, divisions of $\ldots 40$

- Rock, - . . . . 40

Kelloway Rock, - - - $\div 40$

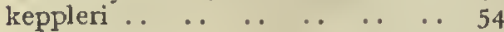

Kepplerites .. $\ldots$.. $\ldots 4$ 4I, 54 keppleri kinkelini

Pages of Plates

Kinkeliniceras $\quad \ldots \quad \ldots \quad \ldots \quad 33,42$ kinkelini, pendambilianum

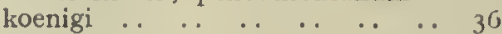

$\begin{array}{lllllll}\text { lorustes } \ldots & \ldots & \ldots & \ldots & \ldots & \ldots & 48\end{array}$

IIosmoceras .. $\quad \ldots \quad \ldots \quad \ldots \quad 53,54$ rotundun

Kosmoceras, sec Cosmoceras

ISosuoceratidae $\quad \ldots \quad \ldots \quad \ldots \quad \ldots 53$

- see Cosmoceratida

Iranaosplinctes .. . . . cCxLIII kranaus

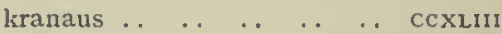

$\begin{array}{llllllll}\text { korys } & \ldots & \ldots & \ldots & \ldots & \ldots & \ldots & 17\end{array}$

Korythoceras $\quad . . \quad \ldots \quad$ IO, I7, 21 korys

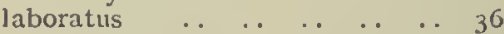

Labyrinthoceras .. $6,7,22$, cxxxiv, extensum, intricatum

cXXXV, cCXIV perexpansum

laevigatus $\quad \ldots \quad \ldots \quad \ldots \quad 34$, c Cxxxir $\begin{array}{llllllll}\text { lahuseni } \ldots & \ldots & \ldots & \ldots & \ldots & \ldots & 42\end{array}$

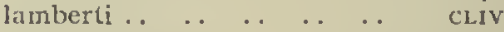
Lamberticctas . . I I, 17, 55, CLIV - lambcrti .. .. .. I4, CLIV

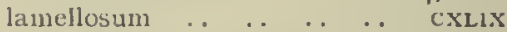
latansatus $\quad \ldots \quad \ldots \quad \ldots \quad \ldots \quad$ CLIX lateral auricle (Perisphinctes) .. 26

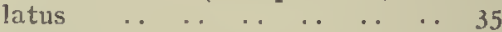
Lectotype ... .. . . 54, cxLIV Legend, explanation of .. .. 5

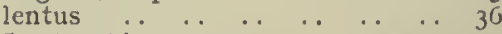
Leptosphinctes $\quad$. 29,3 1 , CLX, CLXI, cleistus, coronarius,

CCI, CCII davidsoni, leptus

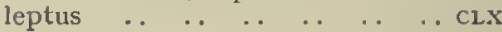

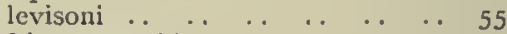

Liparoceratidx $\quad \ldots \quad \ldots \quad \ldots \quad \ldots \quad 13$

Lipogenesis .. . . . . . . . . II

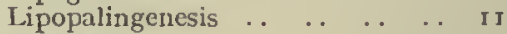

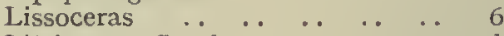

Littlemore Sands... . . ccxum $b$

lobulatum $\ldots \ldots$... ccxxxy

Locality, of Am. cordatus .. I 15

Locli Staffin Beds ... .. 10, 55

- - (Argovian) Beds .. 55

LI, proportion to whorl-breadth 32

Longæviceras ..... 2I, CXLVIII placenta

longilobatum $\quad \ldots \quad \ldots 20$, CLxxxIII

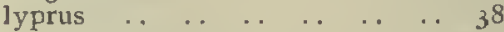
Lytoceras sutneri .. .. ccrv Macrocephalites .. .. 22, 46, 48 — , from Kosmoceratidx .. 54 - morrisi .. 47, 49, clxviI macrum .. .. .. . .

Madarites $\ldots \quad \ldots \quad \ldots \quad 43,45,5$ I calvus, glabretus, madarus, pravus

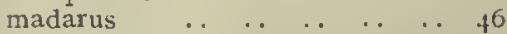
majesticus $\quad \ldots \quad \ldots \quad \ldots 34$, ccxxv1 - horizon $\ldots$.. $\ldots$. 40

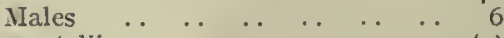
martelli .. .. .. cLxxxiv (3) - horizon $\ldots$.. $\ldots$. . 
Masckeites Pages \& Plates densus

Measurement $\quad \ldots \quad \ldots \quad \ldots \quad \ldots$ I I

Megalomorph $\quad \ldots \quad \ldots \quad \ldots \quad \ldots \quad 6$ - , Proplanulites .. .. . . 34 metorchum $\quad \ldots \quad \ldots \quad \ldots \quad \ldots \quad$ CCLIV

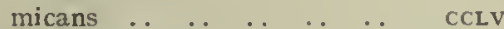
Microceras densinodum CLxxvir Micromorpl .. Milborne Beds .. . . . 43, 5 I Minchinhampton Beds .. .. 5 I — Shelly Beds .. .. .. 43 Morphoceras .. .. . . . . . 22 - pseudo-anceps cLxxill, clxxiv

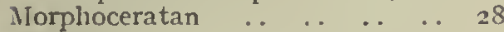
Morphoceratid (defrancii) .. .. 30 Morphology, Cadoceratida .. 2 I morrisi .. . . . . . . . . . 49 Morrisiceras .. . $\quad 22,13,47,49$, comma, homocoticum, 51, CI.XVII korustes, sknipum, sphara, tolmerum

Morrisites $\ldots \ldots 43,48,49,5$ I fornicatus, morrisi

Mouth .. .. .. .. .. cCLXIV - re-opened .. .. .. CLXXIV - see Aperture

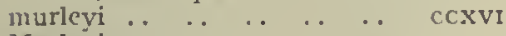
MUurleyiceras .. .. cCXVI, cCXIV forte, murleyi

Nannoids $\quad \ldots \quad \ldots \quad \ldots \quad \ldots \quad \ldots \quad 6$

Natural Order $\quad . \quad \ldots \quad \ldots \quad \ldots \quad 14$

Nautilus ammonoides.. cxxxir $a, b$

Neumayriceras .. $\quad . . \quad \ldots$ ccxxrv oculatum

nodatus .. $\quad \ldots \quad \ldots \quad \ldots \quad \ldots \quad$ CCXIII

Node on auricle .. . . . . . CXI

nodulatum $\quad \ldots \quad \ldots \quad \ldots \quad \ldots \quad$ CCXXII

Nomomorph .. .. . . . . . .

Normannites .. $\quad \ldots \quad \ldots \quad \ldots \quad 6,21$

numismalis .. $\quad . . \quad \ldots \quad$ ccxxxiII

obliquatun $\quad \ldots \quad \ldots \quad \ldots \quad$ ccxxxiv

obtusicosta .

Obtusicostites $\ldots \ldots \ldots 3,42$ dliosaensis, obtusicosta, omplualodes, paramorplius

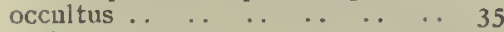
ocellatum $\quad . \quad \ldots \quad \ldots 23$, CLXXIII Ochraceous Lias .. .. .. CXIVII Ocular aperture and parabola .. 3 I oculatum $\quad \ldots \quad \ldots . \quad \ldots \quad \ldots \quad$ ccXXIV Ecoptychius .. .. . . . . refractus

Ecoptychius grossouvrei 7, crxxvI

- refractus .. .. . . . . 7

—, sphrocone stage .. crxxy

Ecoptyclioccras .. .. 24, CLXXV, grossouvrei, subrefractum

Ecostephanus cLXXYI dolichœecus

Oecotraustes genicularis .. .. 25 Oekotraustes .. $\quad . . \quad \ldots \quad \ldots \quad \ldots \quad 25$

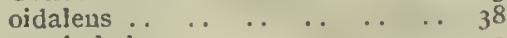
omphalodes $\ldots$.. $\quad \ldots \quad \ldots \quad \ldots 4^{2}$ omphaloides .. .. .. . . I 8, cxcv
Pages \& Plates

opimus . . . . . . .

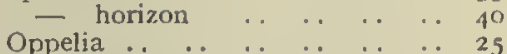
waageni

Oppelia subradiata $\quad \ldots \quad \ldots \quad \ldots 25$

Oppelid, acmic .. . . . clxxvir

- , ellipticone .. cLxxxix

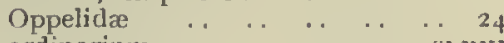

ordinarium $\quad \ldots \quad \ldots \quad \ldots \quad \ldots \quad$ ('Lxxi

ornate venter $\quad \ldots \quad \ldots \quad \ldots \quad \ldots 53$

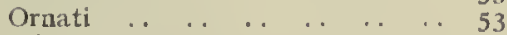

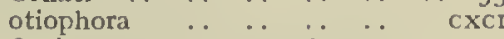

Otoites .. .. . . 6, 6, 9, 12, 22.

contractus, delicatus

CXLI, CLVIII

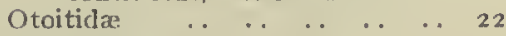

Oxford Clay strata .. $\ldots$.. In

oxygastric $\quad \ldots \quad \ldots \quad \ldots \quad \ldots \quad \ldots 13$

Oxynotes _.

Oxynoticeras. . . 6,6 , cxLII, cxLV buckii, oxynotum

Oxynoticeras, and nat. order $\quad I_{4}$

— flavum ". . " 6,55

oxynotum $\quad \ldots \quad \ldots \quad \ldots \quad \ldots \quad$ cxLIII

Pachammatoceras $\quad . . \quad \ldots \quad$ ccvrI pachu

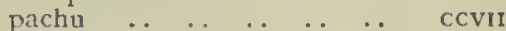

Pachyceratida $\quad \ldots \quad \ldots \quad \ldots \quad 21,43$

Palingenesis .. $\ldots$.

Paltopleuroceras .. $\quad . . \quad \ldots \quad$ cxurx buckmanii

papillatum $\quad \ldots \quad \ldots \quad \ldots \quad \ldots \quad \ldots, C L$ Papilliceras .. $\quad \ldots \quad \ldots \quad \ldots \quad \mathrm{CL}, \mathrm{CCV}$ acantherum, papillatum

Parabolx, and ocular aperture .. 31

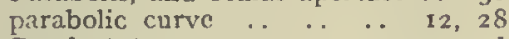
Paralectotype .. .. c c c paramorphus $\quad \ldots \quad \ldots \quad \ldots \quad \ldots 4^{2}$ Parinodiceras $\quad \ldots \quad \ldots \quad \ldots \quad \ldots \quad$ I3 Parkinsonia ...

- caumontii .. clxı, cxlıx

— haugi .. $. . .6 . . . \quad . \quad 20$

- neuffensis ..

Parkinsonian $\quad \ldots \quad \ldots \quad \ldots \quad \ldots 28$

- venter $\quad \ldots \quad \ldots \quad \ldots \quad 29,53$

$\begin{array}{lllll}\text { Parkinsonidx } & \ldots & \ldots & \ldots & 28,53\end{array}$

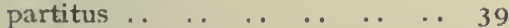

partschi .. $\quad \ldots \quad \ldots \quad \ldots \quad \ldots$ cCXLVI

Prvloviceras .. .. .. I8, 21, CLXX, excv, cxcvi, cxcvil bathyomphalum, omphaloides, pavlowi, roberti, stibarum

pavlowi (-ovi) $\quad 18,19,55$, CLXX Pelecoceras obliquatum

Pel toceras arduennense horizon, .. Io pendambilianuın .. perexpansunı $\quad \ldots \quad \ldots 66$, cxxxiv perfoliatum ... .. 7, 14, cxxxvII Perisphinctean forms, from different

$\begin{array}{cccccc}\text { lines } & \ldots & \ldots & \ldots & \ldots & 28 \\ \begin{array}{c}\text { venter } \\ \text { Perisphinctes }\end{array} & \ldots & \ldots & \ldots & \ldots & 29 \\ \text { biplex, martelli } & \ldots & \ldots & 26, & 27\end{array}$


Pages \& Plates

Perisphinctes and lateral auriclc.. 26

- cobra .. . . . . . . . 29

- congener ..

- davidsoni .. .. CLX, CCI,

cvolutoides cCll, CCXLI

- inglos .. $\ldots \quad \ldots \quad \ldots$ cCLXiv

一 kônighi $\quad \ldots \quad \ldots \quad 34,35,55$

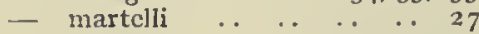

- martinsii CLXı, Cxc, cxCI, cexiviII

- mutans $\ldots \quad \ldots \quad \ldots \quad \ldots \quad 33$

- obtusicosta 34,42, CCXXvI

- omphalodes ...

- pscudomartinsii .. ..

- spirorbis $\ldots \quad \ldots \quad \ldots \quad 4 I, 42$

- subtilis .. .. . . . 28

- tiziani $\quad \ldots \quad \ldots \quad \ldots \quad \ldots \quad 3 I$

- (Ataxioceras) hypselocyclus 3I

Perisphinctida $\quad \ldots \quad \ldots \quad \ldots \quad 25,27$ personatum $\quad \ldots \quad \ldots \quad \ldots \quad$ clxxxvil

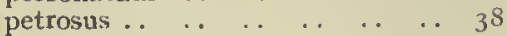

Phanerosplinctes .. .. .. ccxi plianerus

phanerus. . $\quad \ldots \quad \ldots \quad \ldots \quad \ldots \quad, \quad \ldots c x 1$

Phaulomorph 6, 9, $\mathrm{CXL}, \mathrm{CLXXXV11}$

phaulus $\ldots \quad \ldots \quad \ldots \quad \ldots \quad \ldots \quad$ CLXIX

Phricodoceras $\quad \ldots \quad \ldots \quad 53$, CXLIX lamellosum

Phylloceras buvigneri .. .. CXLIV

— vilpum $\ldots \ldots \ldots$ cCLXVI

Phymatoceras $\quad \ldots \quad \ldots \quad \ldots$ ccxLIV fabale

Pictonia .. $\quad \ldots \quad \ldots \quad \ldots \quad \ldots \quad 31,33$

placenta .. $\quad \ldots \quad \ldots \quad \ldots \quad \ldots$ CXLVIII

Plagiomorph . . $\quad \ldots \quad \ldots \quad \ldots \quad \ldots \quad 32$

plagium $\quad . \quad \ldots \quad \ldots \quad \ldots \quad \ldots \quad \operatorname{ccxxix}$

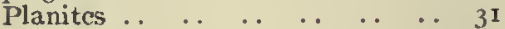

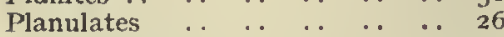

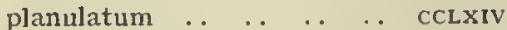

platyrrynum $\quad \ldots \quad \ldots \quad \ldots \quad$ c $\quad \ldots x$

Pleuroceras hawskerensc .. $\mathrm{CxcIx}$

Pleurophorites .. 43, 46, 47, 5I pleurophorus, polypleurus

pleurophorus .. $\quad \ldots \quad \ldots \quad \ldots \quad \ldots \quad 47$

Poculisphinctes 3I, cLXXXv, clXxxvr auricularis, poculum

poculum $\quad \ldots \quad \ldots \quad \ldots \quad \ldots c \operatorname{cxxxV}$

pollubrum $\quad \ldots \quad \ldots \quad \ldots \quad \ldots \quad$ CCLIX

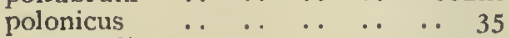

polygyralis .. $\quad \ldots \quad \ldots \quad \ldots \quad$ CLXII

polymeles $\quad \ldots \quad \ldots \quad \ldots \quad \ldots$ cCLVIr

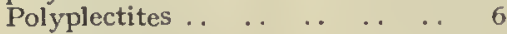

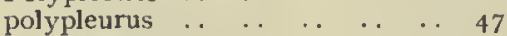

Porpoceras .. . . . . . $\quad$ ccix crassiusculum

pourcandiensis $\quad \ldots \quad \ldots \quad \ldots \quad \ldots 37$

præclarus $\quad \ldots \quad \ldots \quad \ldots \quad \ldots \quad \ldots 45$

pravus ..

pre-cordatum horizons .. .. Io

Prionoceras .. .. .. I 7, 55, CLV 一 prionodes .. .. . . I $7, \mathrm{CLV}$

prionodes $\quad \ldots \quad \ldots \quad \ldots \quad \ldots \quad$ I 7, CLV

Prionodoceras .. I $7,21,55,(\mathrm{CLV})$ prionodes

Procerites ... .. I2, I $8,30 \mathrm{CLIII}$ euryodos
Proccrites schloenbach Pages \& Plates

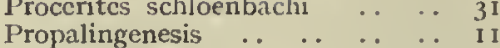

propeserpentinus .. .. 55, ccxvil

Proplanulites 31, 33, ccxiI, ccxxvi,

CCXXvil, CCXXXI, CCLI, CCLII

apparatus, arciruga,

auriculatus, basileus,

capistratus, capularis,

cracoviensis, curvus,

excentricus, fabricatus,

ferruginosus, fracidus,

fulvus, involutus,

kocnigi, laboratus,

laevigatus, latus,

lentus, lyprus,

majesticus, occultus,

oidaleus, partitus,

petrosus, polonicus,

pourcandiensis, rudis,

rufus, stiphrus, subcuneatus,

subcunciformis, teisseyrei,

tornquisti, trifurcatus, tridens

Proplanulites arcigura $\quad \ldots \quad$.. 35

- arciruga $\ldots \ldots \quad \ldots \quad 34,35,39$

- Chronology .. ..

- haugi .. . . . $38,39,4$ I

- kinkelini $\ldots \quad \ldots \quad \ldots \quad \ldots 4^{2}$

— könighi .. . $\quad 33,35,55$,

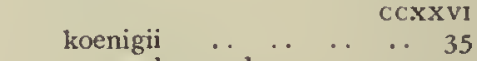

_ megalomorph $\quad \ldots \quad \ldots 343$

— $\begin{array}{lllll}\text { - pourcandiensis } & \ldots & \ldots & \ldots & 39 \\ \end{array}$

CCXXvil

— teisseyrci $\ldots \quad \ldots \quad 34,38,39$

Proplanulitidæ $\quad \ldots \quad \ldots \quad \ldots \quad \ldots 3^{2}$

Proportions, Am. biplex .. $\quad . .27$

— Ebrayiceras spp. .. .. 24

Prorsiceras ..

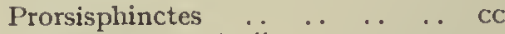
pscudomartinsii

pseudo-anceps .. . . 23, c cxxrv

Pseudobigotella .. .. .2 29, cxCI otiophora

Psendobigotella haugi .. . 29

Pseudocadoccras .. $\quad . . \quad \ldots \quad \ldots 2$ I

Pseudolioceras . . . . clxxxvill erratum

pseudomartinsii $\quad \ldots \quad \ldots \quad \ldots \quad \ldots \quad c c$

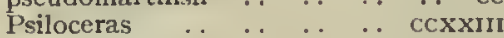
erugatum

Publication details $\quad \ldots \quad \ldots \quad \ldots 64$

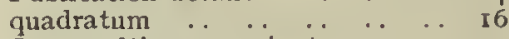

Quenstedticeras carinatum .. 20

— damoni $\ldots$.. $\quad \ldots$..

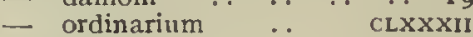

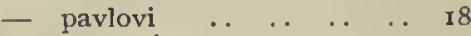

- pavlowi ..

- sutherlandia $\ldots$ I 8 , cxcvi

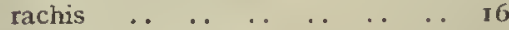

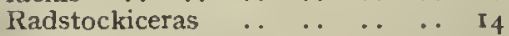

— complicatum .. $\ldots$. I4

Rasenia ..

refractus $\quad \ldots \quad \ldots, \ldots, \ldots, \quad 7,24$ 
Pages \&. Plates

Retenticeras .. .. .. . ckxvi retentum

retentum $\quad \ldots \quad \ldots \quad \ldots \quad \ldots \quad$ CLXVI

reversum $\quad \ldots \quad \ldots \quad \ldots \quad \ldots \quad$ CXLV

Rhytostephanus .. . . . . . CCL rliytus

rhytus $\quad \ldots \quad \ldots \quad \ldots \quad \ldots \quad \ldots \quad \ldots, \mathrm{cc}$

Ringsteadia .. .. . $33, \mathrm{ccxxv}$ anglica

$\begin{array}{rlllllll}\text { roberti }_{1} & \ldots & \ldots & \ldots & \ldots & \ldots & \ldots & 19\end{array}$

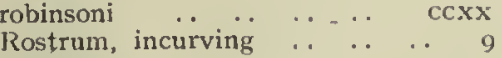

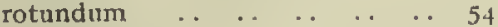

$\begin{array}{llllllll}\text { rudis } & \ldots & \ldots & \ldots & \ldots & \ldots & \ldots & 37\end{array}$

- horizon $\quad . \quad \ldots \quad \ldots \quad \ldots 40$

Rugiferites $\quad \ldots \quad \ldots \quad \ldots \quad 4.3,46,51$ rugifer

$\begin{array}{llllllll}\operatorname{rugifer} & \ldots & \ldots & \ldots & \ldots & \ldots & \ldots & 46\end{array}$

$\begin{array}{llllllll}\text { rufus } & \ldots & \ldots & \ldots & \ldots & \ldots & \ldots & 39\end{array}$

runcinate venter .. $\quad \ldots \quad \ldots \quad \ldots \quad 53$

— -ornate venter .. $\ldots . \quad \ldots 5.3$

Runcinati $\quad \ldots \quad \ldots \quad \ldots \quad \ldots \quad \ldots 53$

Rursiceras $\ldots$. . $\quad \ldots \quad \ldots \quad$ CXLV reversum

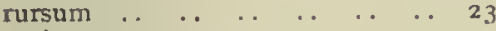

sagitta $\quad \ldots \quad \ldots \quad \ldots \quad \ldots \quad \ldots$ I 9, CCLX

Sagitticcras .. .. 19, 21, 55, CCLX fastigatum, sagitta

Sagittoccras .. $\quad \ldots \quad \ldots \quad \ldots \quad \ldots \quad 55$

Sands, Littlemore $\ldots \operatorname{ccxl}_{11} b$

scarburgense horizon .. . . . 10

Schlotheimia lacunata $\quad \ldots \quad \ldots 6$

septicarina $\ldots \quad \ldots \quad \ldots \quad \ldots$ clXviI

- obsolescent .. cLxXX1b

septum in carinit $\quad . \quad \ldots \quad \operatorname{ccv} b$

serpentiniformis $\quad \ldots \quad \ldots . \quad \ldots \quad \ldots \quad 55$

serpentinus $\ldots$.. 5.5, cxxxvill $a$

Shelly Beds .. . . . . . . 43, 44

Siemiradzkia .. $\quad . . \quad \ldots \quad \ldots, 26,31$

- (gracilis) ..

- (Amm.) lakcrix .. . . 3I

Sigaloceras $\quad \ldots \quad 41,53,54, \mathrm{ccLV}$ micans

Sigaloceras (Amm.) calloviensis.. 54

Skirroceras $\quad \ldots \quad \ldots \quad \ldots \quad 21$, cCXLVIII macrum

Skirroceras macrum .. . . ccxLıx

$\begin{array}{llllll}\text { Skirroceratan } & \ldots & \ldots & \ldots & \ldots & 28\end{array}$

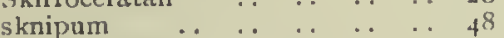

Skolekostephanus $\quad \ldots \quad \ldots$ ccxlrx skolex

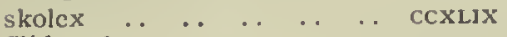

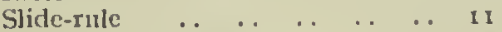

Sonninia (fissilobata) .. cLxxxi a

—, mammillate .. .. .. CL

— , tuberculate .. $\ldots, \ldots, \mathrm{CCV}$

sphara $\quad \ldots \quad \ldots \quad \ldots \quad \ldots \quad 48$, cLXvil

Sphæroccras .. . . . 22, ccLvil tutthum

Spharoccras brongniarti .. ccLvill

- contractun $\ldots$.. CXLI

- perexpansum .. .. cxxxiv,

CXXXV

Spharoccratid, coronate .. C CXV

Sphaeroceratida .. .. $\quad \ldots \quad 22,43$

spharoidalis ..
Pages of Plates

Sphxromorphites .. .. 4 43. $49 \quad 51$ splaxroidalis

sp., Kinkeliniceras _. . . . . 42

-, Proplanulites .. .. .. 34,35

$\begin{array}{llllll}\text { spinifera } & \ldots & \ldots & \ldots & \ldots & \text { CLXVIII }\end{array}$

spiniger .

Stemmatoccras $\quad \ldots \quad \ldots \quad \ldots \quad \ldots 2$ I

Stcphanoceras $\ldots \quad \ldots \quad 44,45,4^{8}$

- bayleanum .. ccxLviı,

CCLXV

- braikenridgii .. CLI, CLII

- coronatum ...

- macrum ... ...

— subcontractun . . . . . 49

一 zigzag .. .. . . . 30 , CLIII

Stephcoceras .. .. 6, 21, ccxxix.

humpliricsianum, plagium

ccxxxvil

Stephcoceras freycincti .. .. CCL

Steplicoccratacea, earliest .. . . 6

Stepheoceratan venter .. .. 29

Stepheoceratida .. .. . . 21, 43

stibarum $\quad \ldots \quad \ldots \quad \ldots \quad 18$, cxcviI

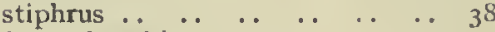

Stomphosphinctes .. . . c $x$ LVII stomphus

stomphus $\quad \ldots \quad \ldots \quad \ldots \quad \ldots$ CCXLVII

Stonesficld Slate .. $\quad . \quad \ldots \quad \ldots 43$

Strata, Argovian .. .. .. .. Io

- Fullers' Eartlı Rock, Great

Oolite .. . . . . 51

Stratal Sequence... .. .. . . 40

Strenoceras .. 29, 53, ccxxxix apleurum

Strigoceras trucllei $\quad \ldots \quad \ldots \quad \ldots 3^{\circ}$

subcontractus $\quad \ldots \quad \ldots . \quad \ldots \quad \ldots 45$

$\begin{array}{lllllll}\text { subcuneatus } & \ldots & \ldots & \ldots & \ldots & \ldots & 37\end{array}$

subcunciformis $\quad \ldots \quad \ldots \quad 37$, ccxxvI

subdivisus $\quad \ldots \quad \ldots \quad \ldots, \ldots, \ldots, c x c$

subordinarium $\quad \ldots \quad \ldots \quad \ldots \quad$ CLXXII

Subparkinsonia $\quad \ldots \quad \ldots \quad \ldots \quad \ldots 29$

subrefractum $\quad \ldots \quad \ldots 24$, CLXXVI

subserpentinus $\quad \ldots \quad \ldots \quad 55$. CCXvII

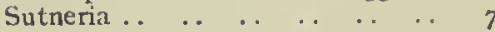

Suture-line, dorsal lobes ccxxxvil Synthetograph $26,43,49, \mathrm{CXXXIV}$ Syntopitc .. Systematic .. $\ldots$. $\quad \ldots, \quad 12,32$ teisseyrei $\quad \ldots \quad \ldots \quad \ldots \quad \ldots \quad \ldots 34$ Teloceras $\quad \ldots \quad \ldots \quad \ldots \quad 2$ I, 43,45

— subcontractum . . $\quad \ldots \quad \ldots \quad 52$

tenuicostatum $\quad \ldots \quad \ldots \quad \ldots \quad$ cLVII

Terminology .. .. $\quad \ldots \quad 5,11,31$

Thornford Beds . . . . . $43,5 \mathrm{r}$

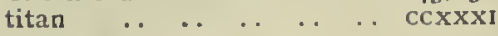

Titanites $\quad \ldots \quad \ldots \quad \ldots \quad \ldots \quad \operatorname{ccx\times x1}$ titan

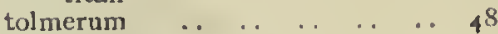

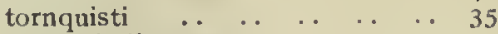

Tragophylloceras .. .. .. ccxix,

$\mathrm{ccxx}$,

$\operatorname{ccxxxI11}$

huntoni, numismalis,

robinsoni

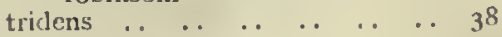


Pages \& Plates

trifurcatus

Trilobiticeras trilobitoides

. . . . 39

$7,9,12,22, \mathrm{CXL}$

trilobitoides...

. 7, I2, CXI

Tuberculation $\quad \ldots \quad \ldots \quad \ldots \quad \ldots \quad$ I 2

— formulas ..

$\begin{array}{llllllll}\text { tula } & \ldots & \ldots & \ldots & \ldots & \ldots & \ldots & 45\end{array}$

Tulites $\ldots \ldots \ldots \ldots$ 43, 44, 5 I cadus, subcontractus, tula

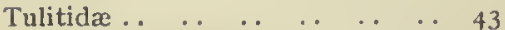

_ , biological characters .. 52

Tulophorites .. .. .. 43, 45, 51 praclarus, tulotus

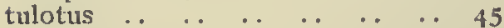

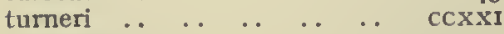

$\begin{array}{lllllll}\text { Turrilites } & \ldots & \ldots & \ldots & \ldots & \ldots & 32\end{array}$

Tutchericeras $\quad \ldots \quad 7,14$, CXXXVII perfoliatum

tutthum .. .. . . . . cCLVIII

Type designation $\quad . . \quad \ldots \quad . . \quad$ I I

$\begin{array}{lllllll}\text { vaschaldi } & \ldots & \ldots & \ldots & \ldots & \ldots & 23\end{array}$

Venter, stages of $\ldots$..

vermiformis .. . . . . . CLXII

Vermisphinctes $\quad . \quad 29,31$, clXII,

subdivisus, vermiformis

$\begin{array}{lllllll}\text { vertebrale } & \ldots & \ldots & \ldots & \ldots & \ldots & 16\end{array}$

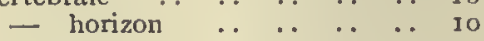

Pages \& Plates

Vertebriccras .. .. 16, 21, cxcVIII dorsale, quadratum

rachis, vertebrale

Vertebriccras horizon .. ... .. I0

- rachis .. $\ldots . . . \quad \ldots \quad \ldots$ Ig

Vertumniceras $\quad \ldots \quad \ldots \quad$ I6, 19,21

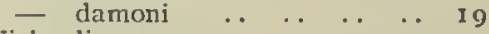

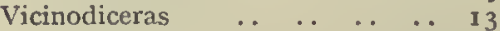

- simplicicosta .. . . . . 13

Victoriceras .. . 7, I4, CXXXVI victoris

victoris $\ldots \quad \ldots \quad \ldots \quad 7, I_{4}, \mathrm{CXXXVI}$

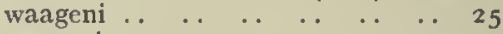

wagneri $\ldots$.

Wagnericeras $\quad \ldots \quad \ldots \quad \ldots \quad \ldots \quad 33$ wagneri

Weatherstones _.

Weissermeliceras .. 20, CIXXXIII longilobatum

Witchellia $\ldots \ldots \ldots$. . cLXvir spinifera

Witchellia laviuscula .. . . clxviu

Xeinophylloceras .. $\ldots$.. xeinus

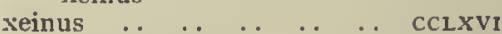

zigzag ornament .. $\quad \ldots \quad \ldots \quad \ldots 28$

- $\begin{array}{cccccc}\text { series .. } & \ldots & \ldots & \ldots & \ldots & \text { I2 }\end{array}$

Zigzagiceras.. $\quad . \quad 30,31, \operatorname{cc} I X$ pollubrum

Zigzagiceratidx $\quad \ldots \quad \ldots \quad \ldots \quad \ldots 30$

\section{Publication Detalls}

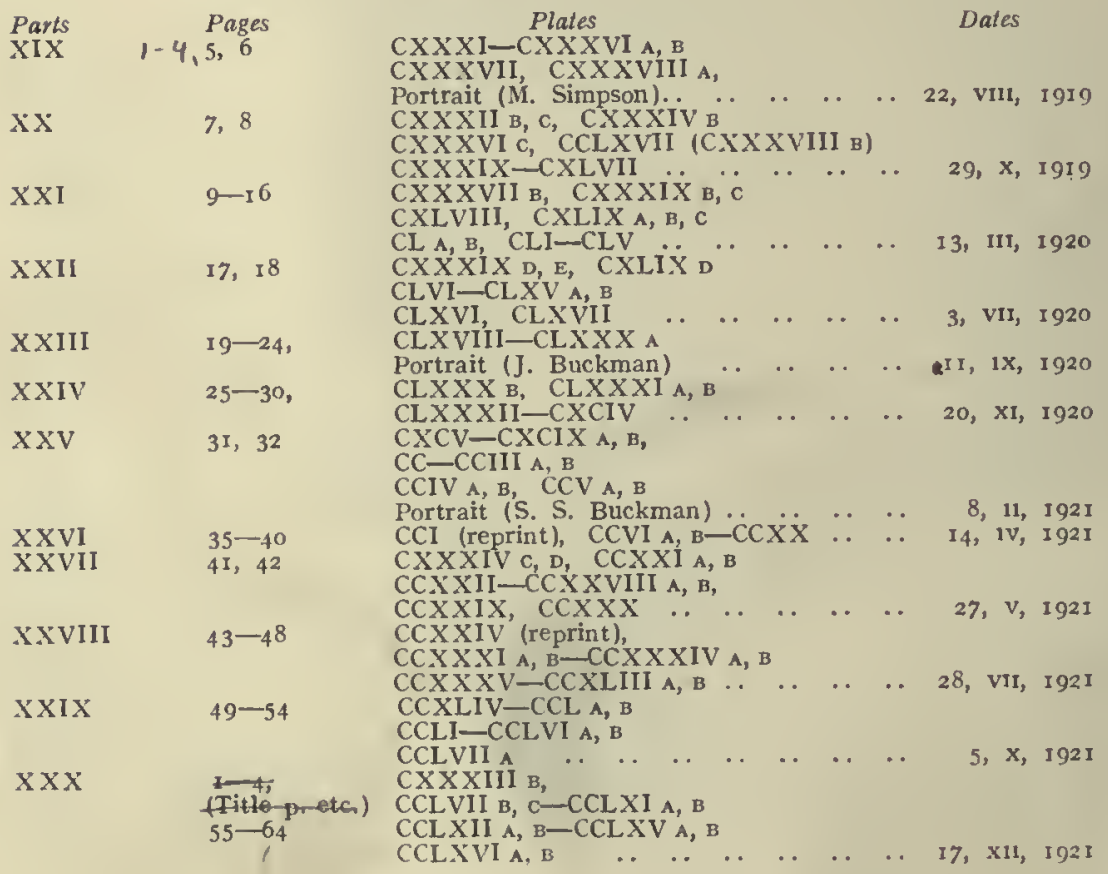


Fig. I, $\times 0.24$

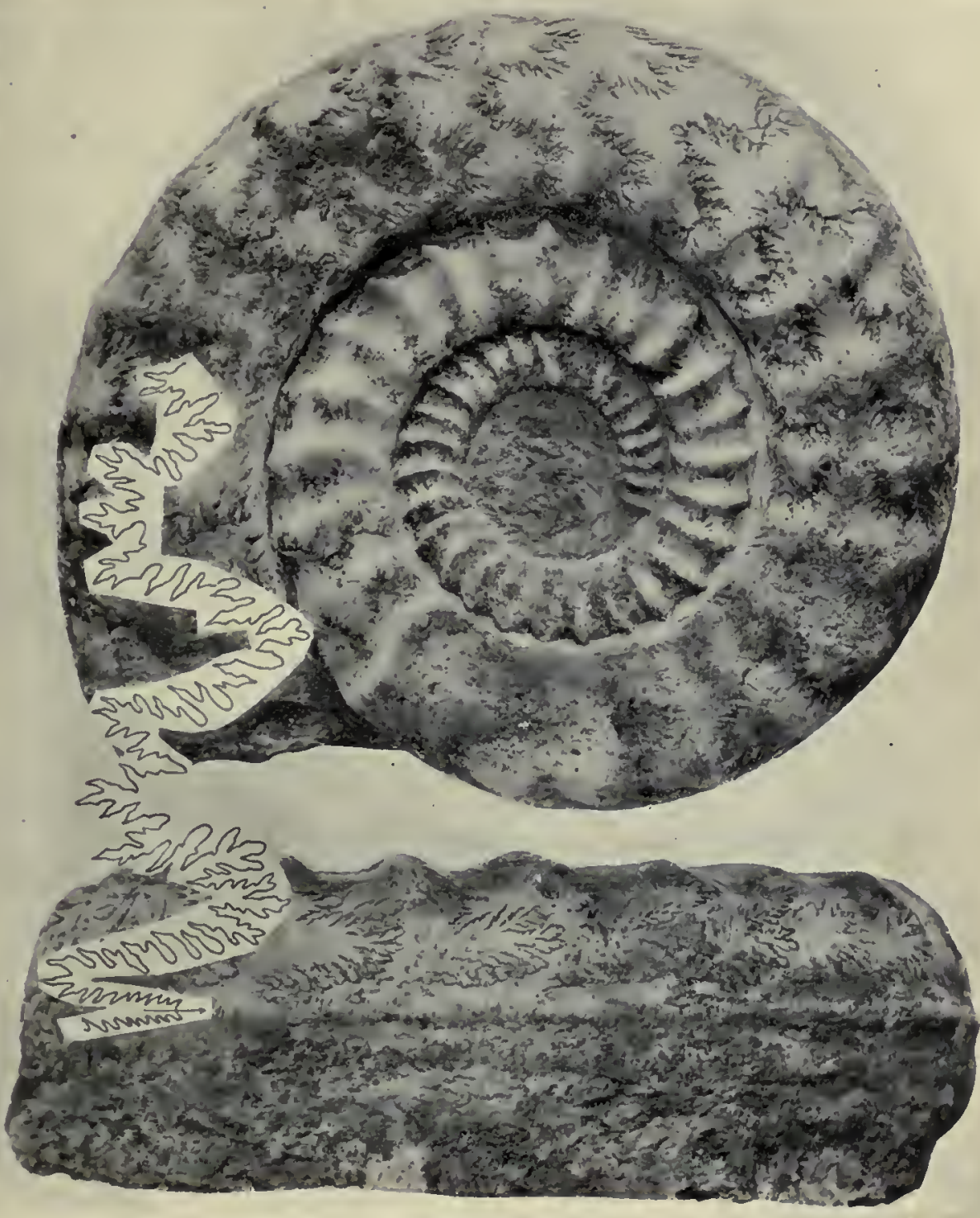

Fig. 2, $\times 0.24$

Ammonities bucklandi, J. Sowerby, i8I6

M.C. II, 69 ; cxxx; Coroniceras, S. B., Q.J.G.S., LXXIII, I9I0, 302";

"Limefield quarry, N. of Rookhill Farm, Keynsham, Somerset; Lower Lias" ; J.IV.T. Coll. ; S. 493, 26, 32, 55 ; max. c. 600

CORONICERAS BUCKLANDI, J. SOWERBY SP. Lymian, bucklandi; Topotype 



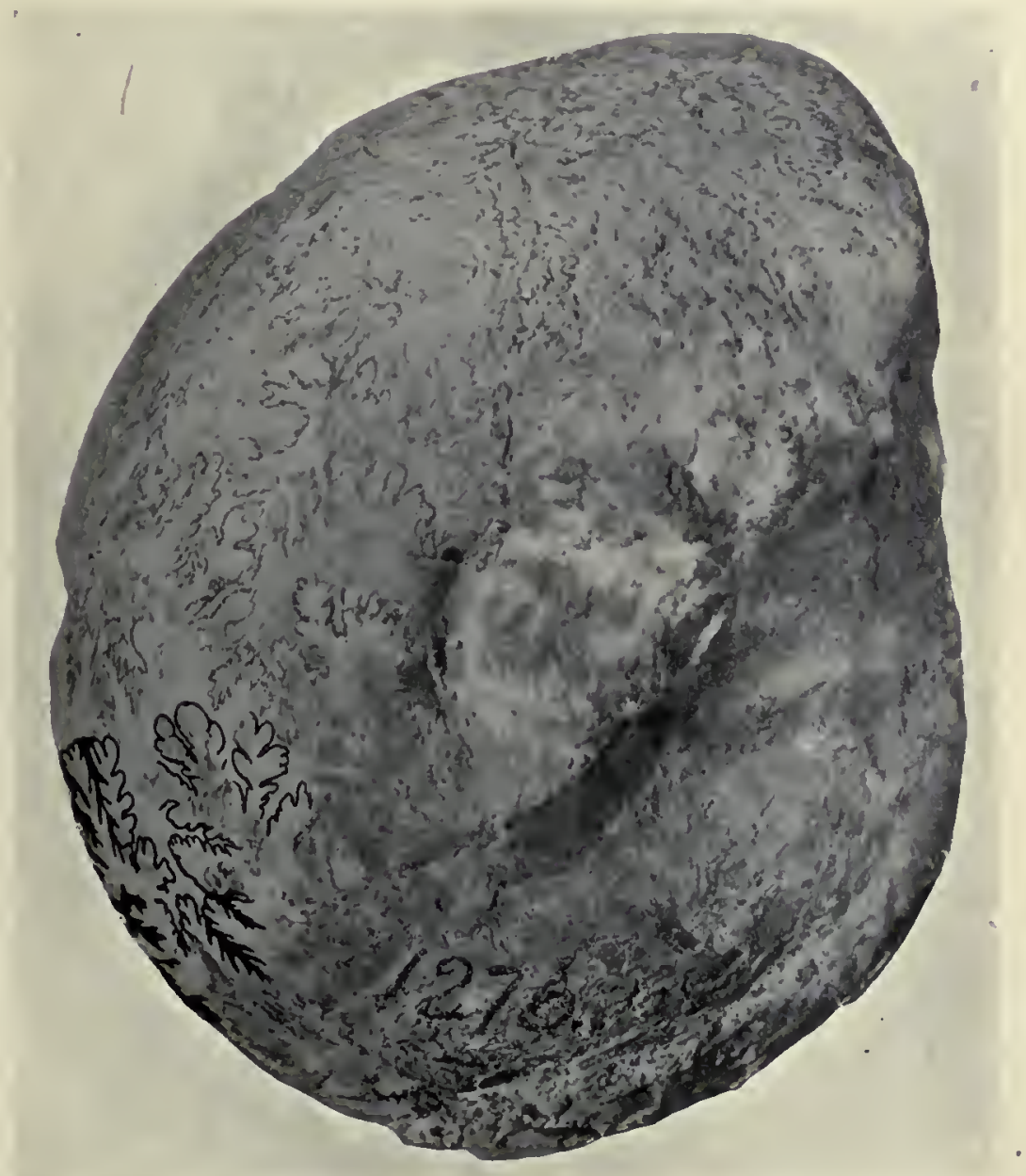

Nautilus Ammonoides, Young \& Bird, I828, Holotype Geol. Yorksh. 27I ; wholly septate, somewhat crushed, another half-whorl with umbilical expansion indicated; S. 205, 57? 76, 13? max. c. 266 

Fig $1 \times 0.62$

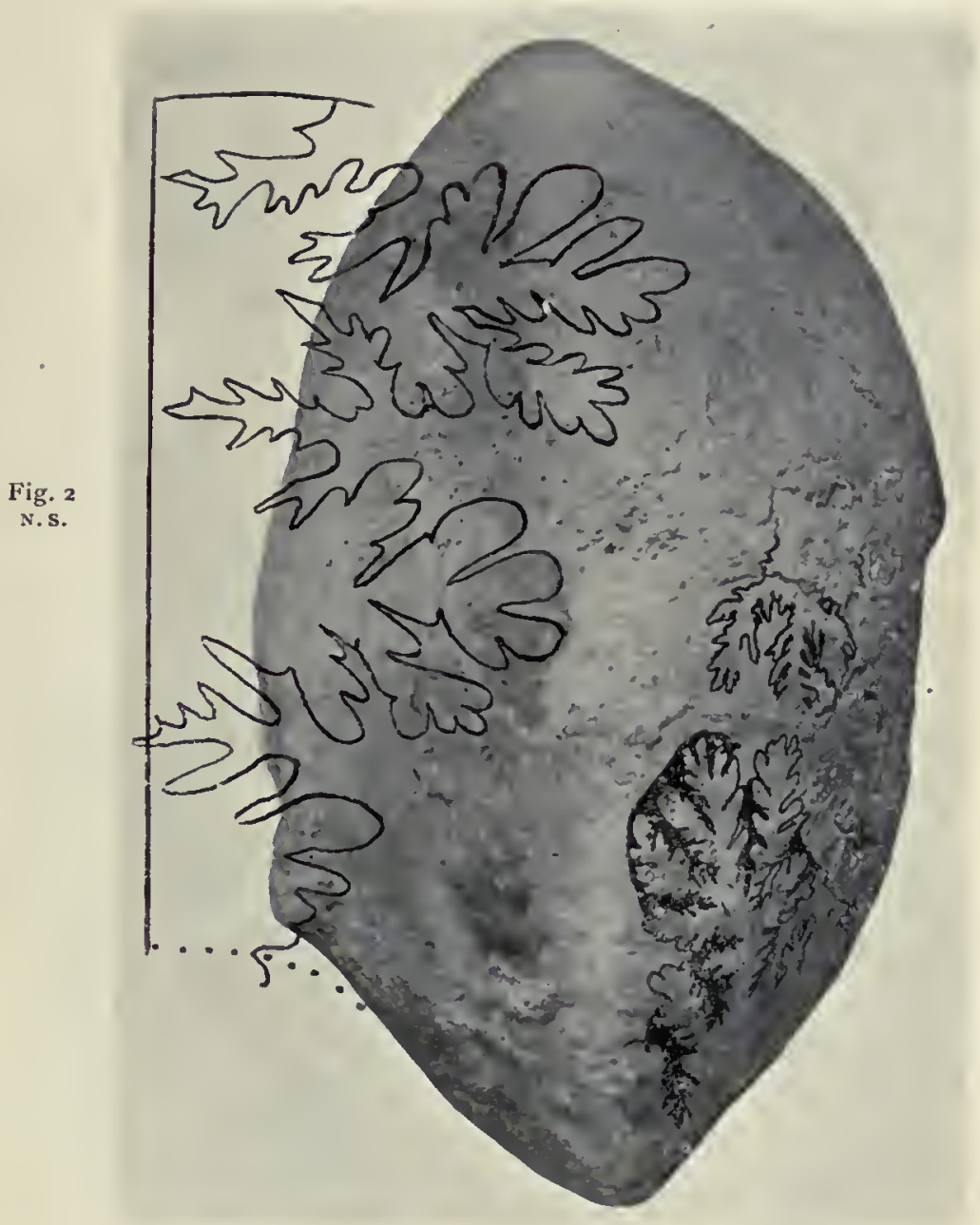

Nautilus ammonoides, Young \& Bird, 1828, Holotype Geol. Yorksh. 271 ; " [Malton], Yorkshire; Oolite [Limestone]; " Whitby Museum, 1276; Fig. 2, Skeleton S.L., Nat. Size

GOLIATHICERAS AMMONOIDES, YOUNG \& BIRD SP. Argovian, vertebrale 

Fig. $4 \times 1.5$

IVig. I

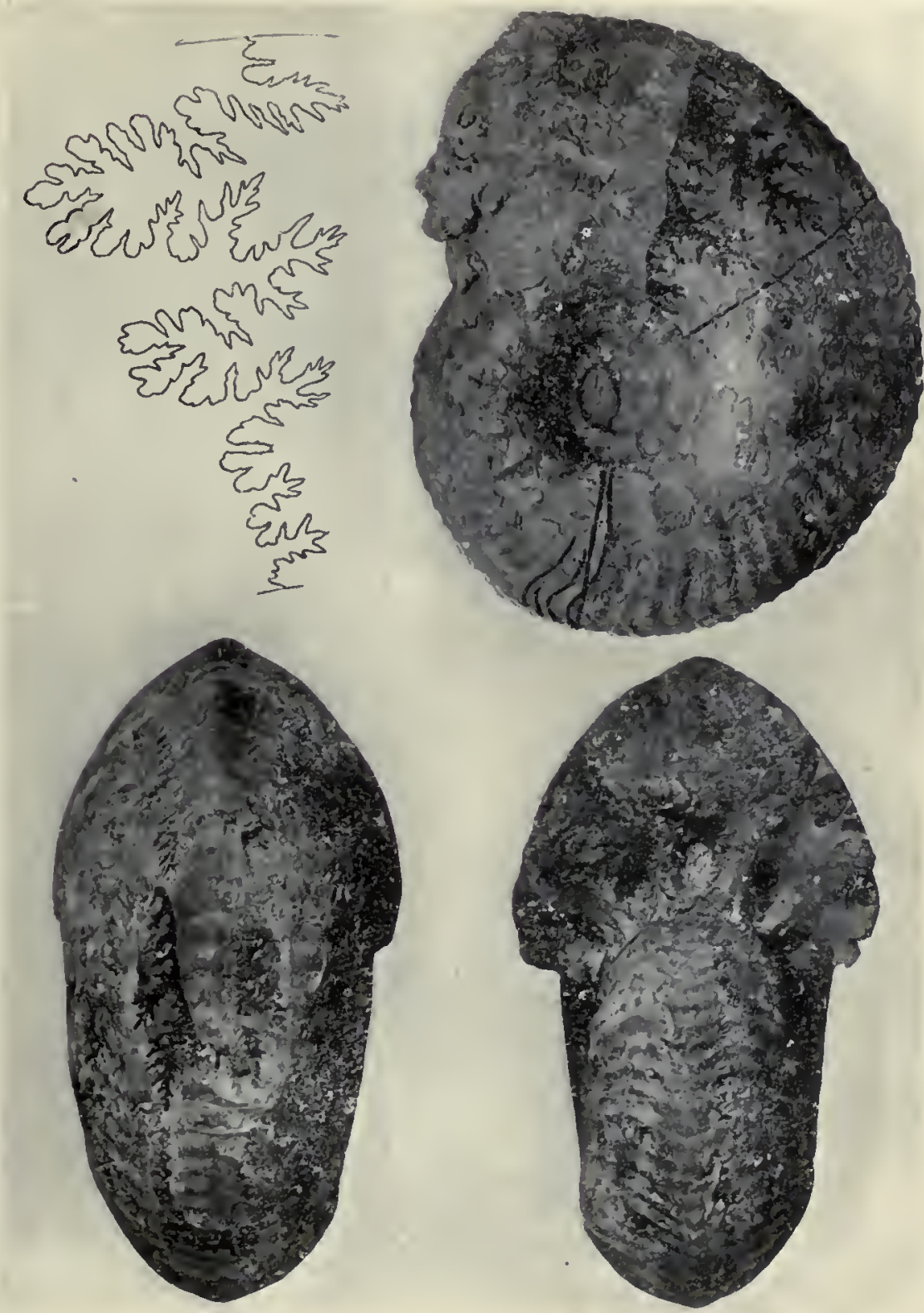

Fig. 3

Fig. 2

"Cardioceras amimonoldes, Young \& Bird sP.

"Cowley, near Oxford ; [Lower Calc. Grit (loose siliceous matrix, top of "Sands) ] ; " S.B. Coll. 2773; S. 43, 43, 56 (50), 3I ; 8I, 47, 54, 25

GOLIATHICERAS AMMONOIDES, YOUNG \& BIRD SP. Argovian, vertebrale; Genotype 

Fig. 2, $\times 0.81$

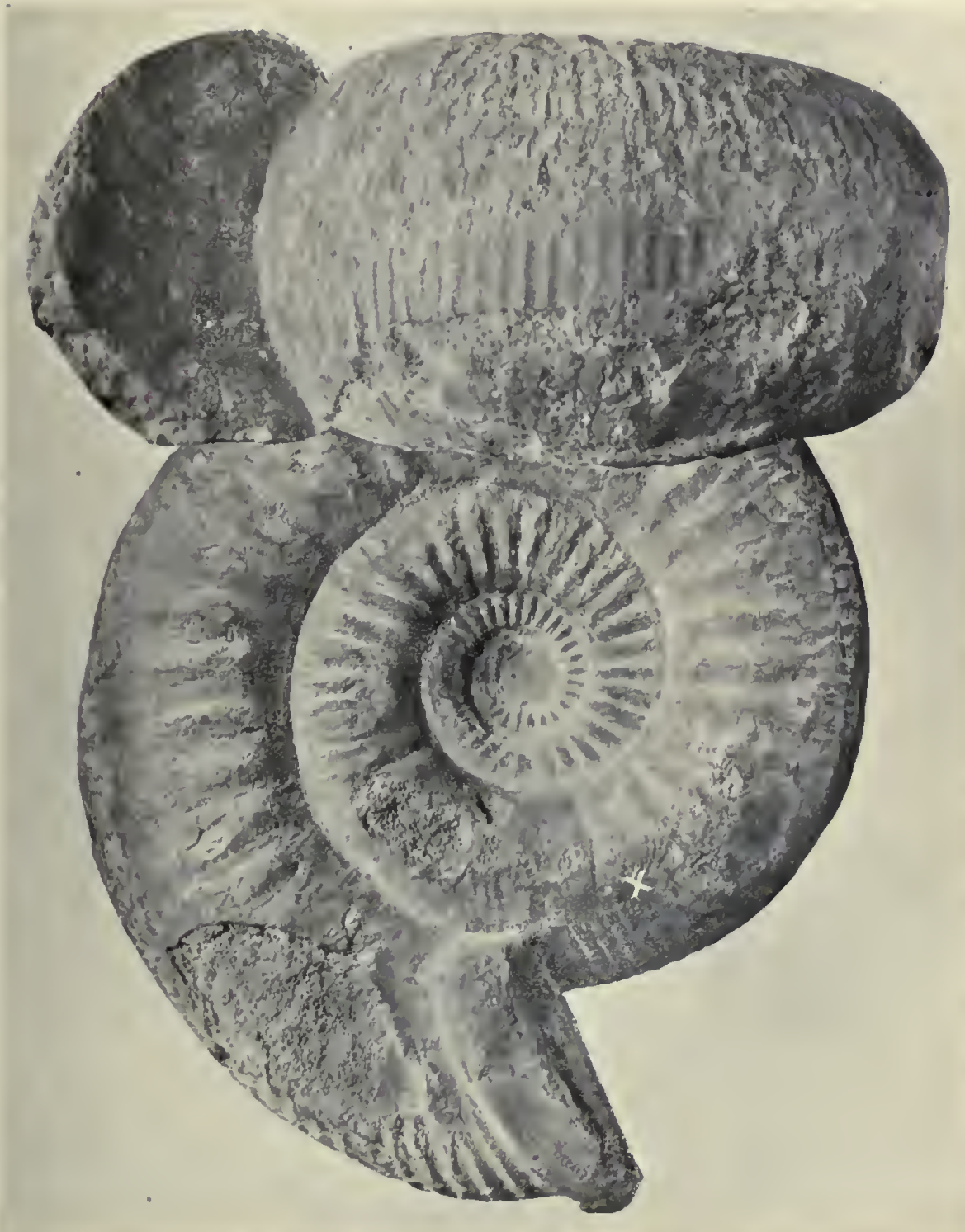

Fig. 1, $\times 0.8 \mathrm{I}$

Cadicone CoRonold, with sharpened bullix

"Bradford Abbas, [Foss. Bed, up. part], Sherborne, Dorset"

S.B., ex Darell, Coll. I243; S. $82,34,70,35$; I 37, 28, 46, 47 ; max. I4I

DOCIDOCERAS CYI.INDROIDES, nov. Bajocian, discites; Genotype and Holotype 

Fig. I

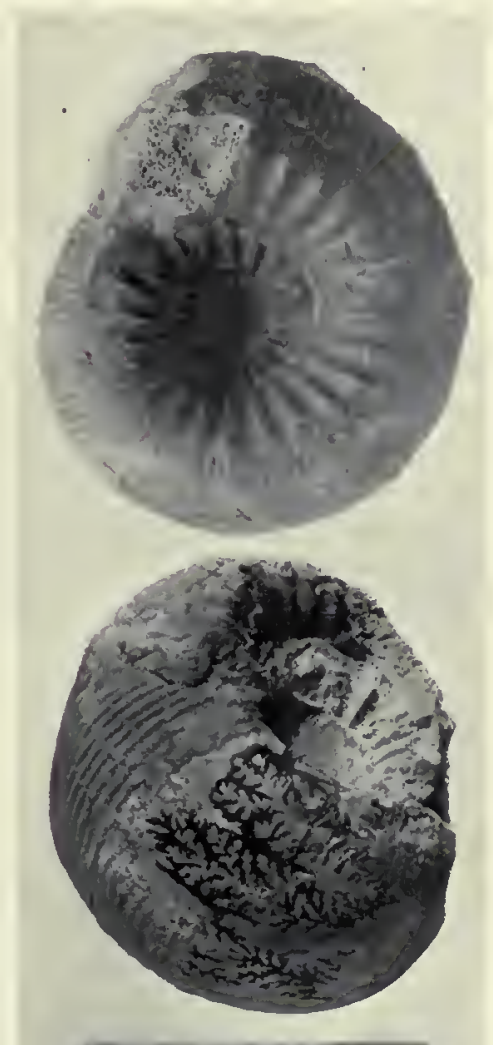

Fig. 2

Fig. 3

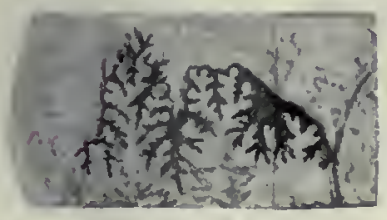

"Aynonites humphriestanus"

"Bradford Abbas, Dorset ; Inf. Ool.," Foss. Bed, [Mid. part]

S.B. Coll. 3062 ; S. $34,34,76,25 ; 49,36,76,32$ A colomorph, wholly septate

DOCIDOCERAS CYLINDROIDES, S. BUCKMAN IgI9 Bajocian, discites, (Eudmetoceras); Paratype 


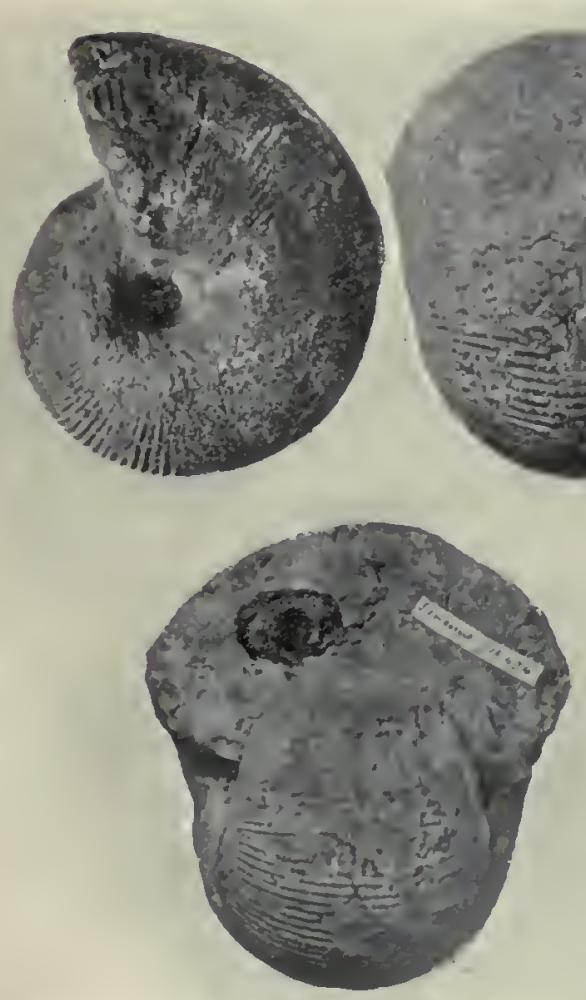
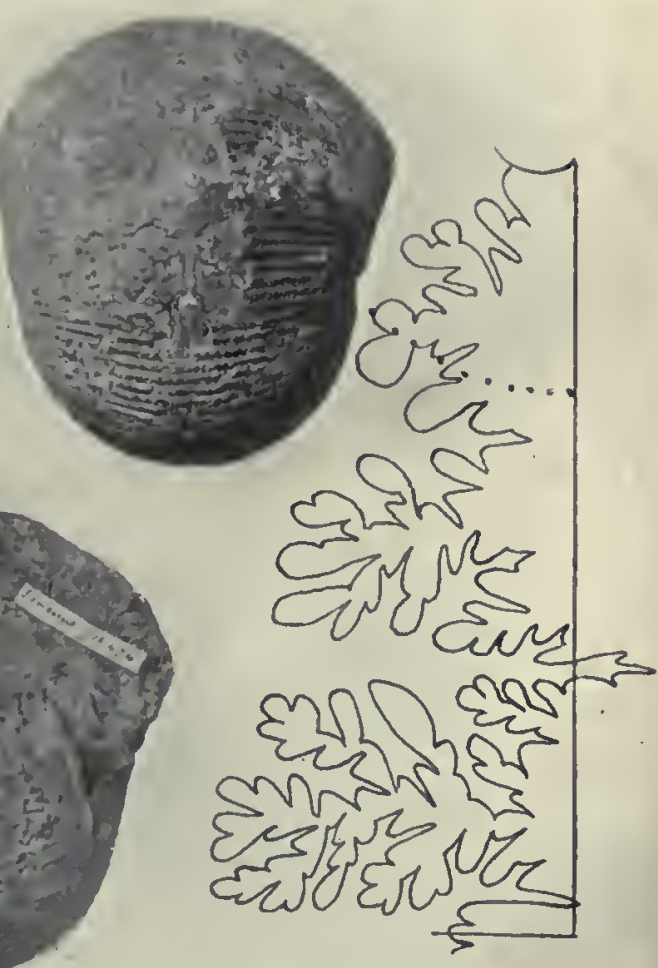

Fig. 4 $\times 2.5$

Spheroceras perexpansum, S. Buckman, i882, Holotype Proc. Dorset N.H. \& A.F.C. IV, I 42 ; II, 4; "Sherborne, Dorset"

S. $36,48,98,15 ; 50,47,87,13$; A colomorph, [max. I34]; Fig. 4; Skeleton S.L., a synthetograph

LABYRINTHOCERAS PEREXPANSUM, S. BUCKMAN SP. Bajorian, sauzei; Genotype 

Fig $I, \times 2.5$
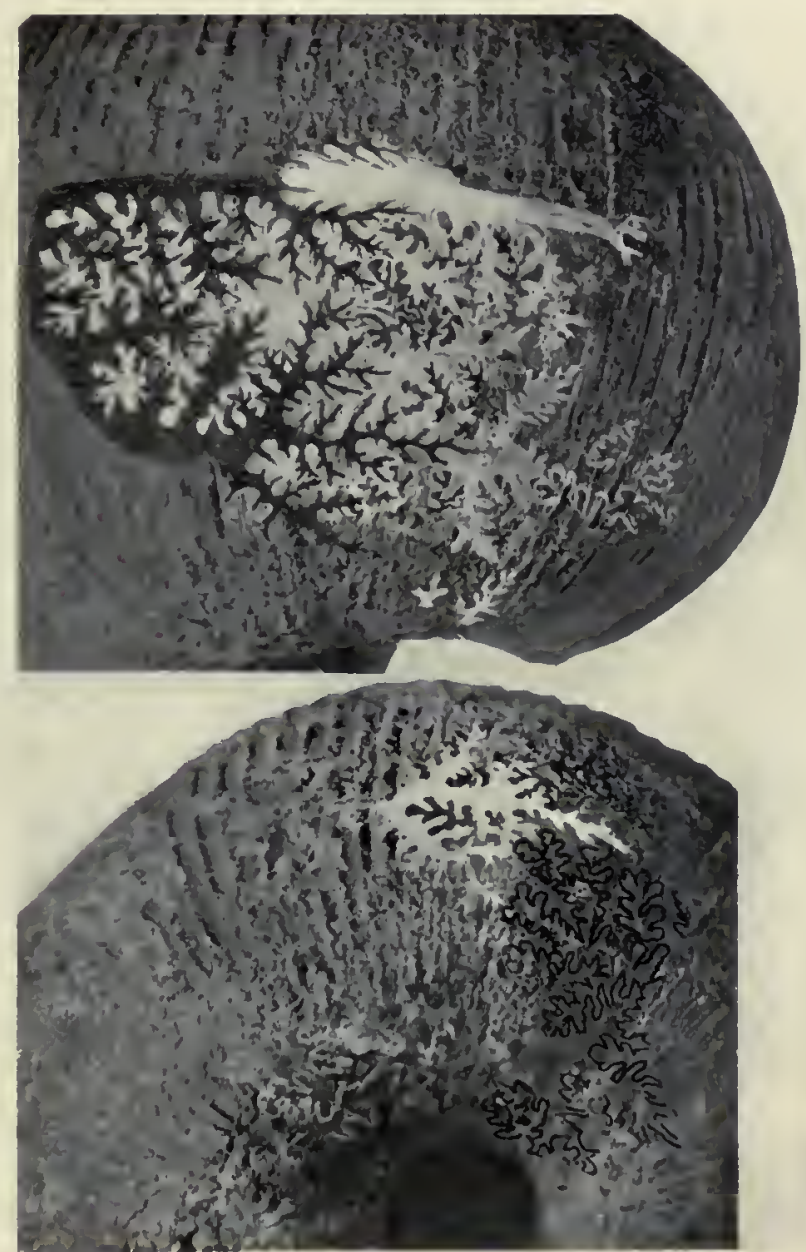

Fig. $2, \times 2.5$

Spharoceras perexpansui, S. Buckinan, i882, Holotype

Proc. Dorset N.H. \& A.F.C. IV, I42 ; II, 4; "Sherborne, Dorset; Inferior Oolite, probably zone of Stephan-Humphriesianum" S. Buckman, ex J. Buckman, Coll. 474

LABYRINTHOCERAS PEREXPANSUM, S. BUCKMAN SP. Bajocian, sauzei; Genotype 



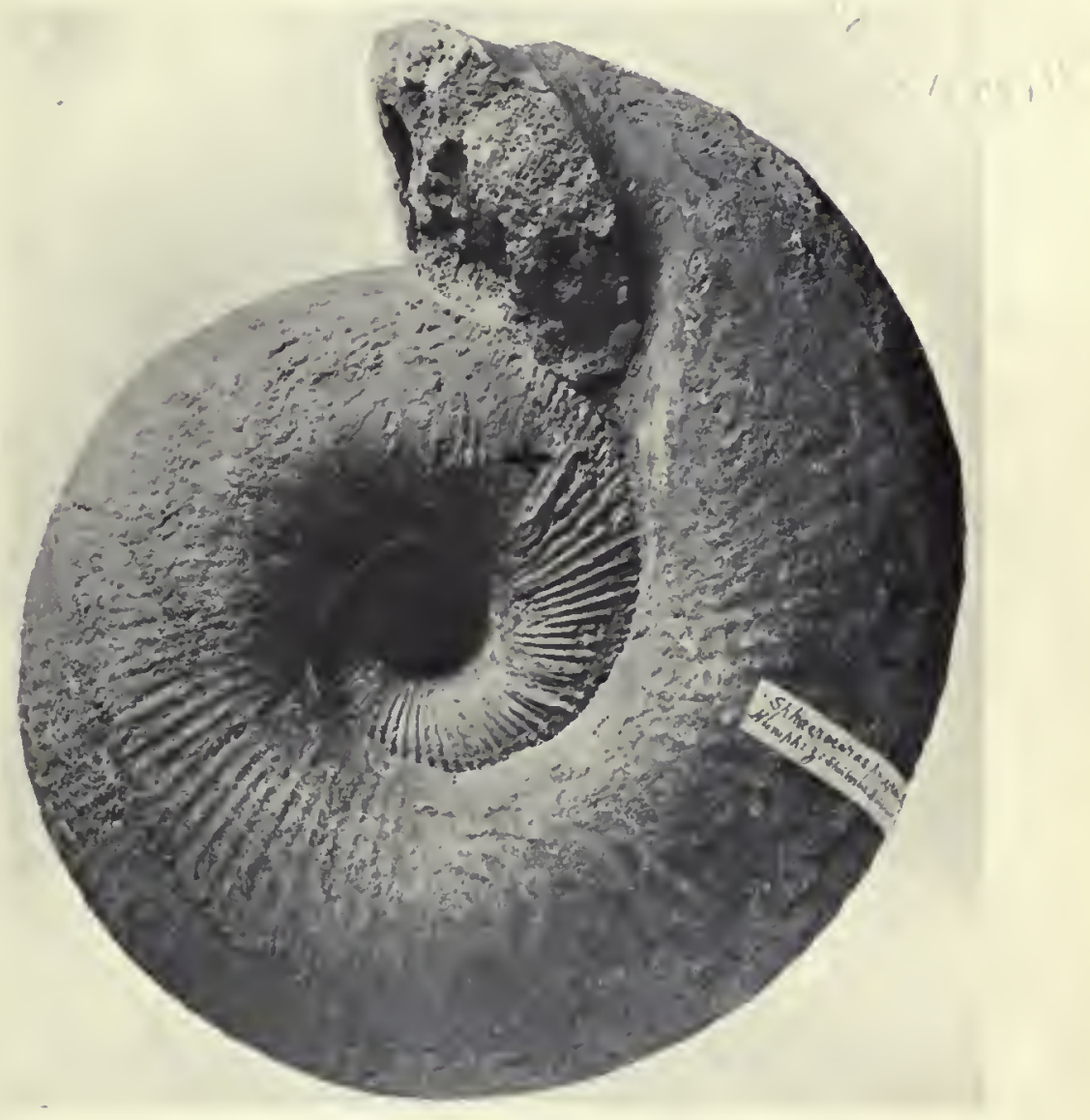

$\times 0.84$

SPHEROCERAS PEREXPANSUM, S. BUCKMAN

[Clatcombe], "near Sherborne, Dorset"

"Inferior Oolite" ; [Humphr. z.] ; S.B., ex Darell, Coll., I 249 S. 8 I , 43, 77, 2 I ; $132,34,5$ I, 34; max. I34; a contracticone

LABYRINTHOCERAS PEREXPANSUM, S. BUCKNAN SP Bajocian ; sallzei 



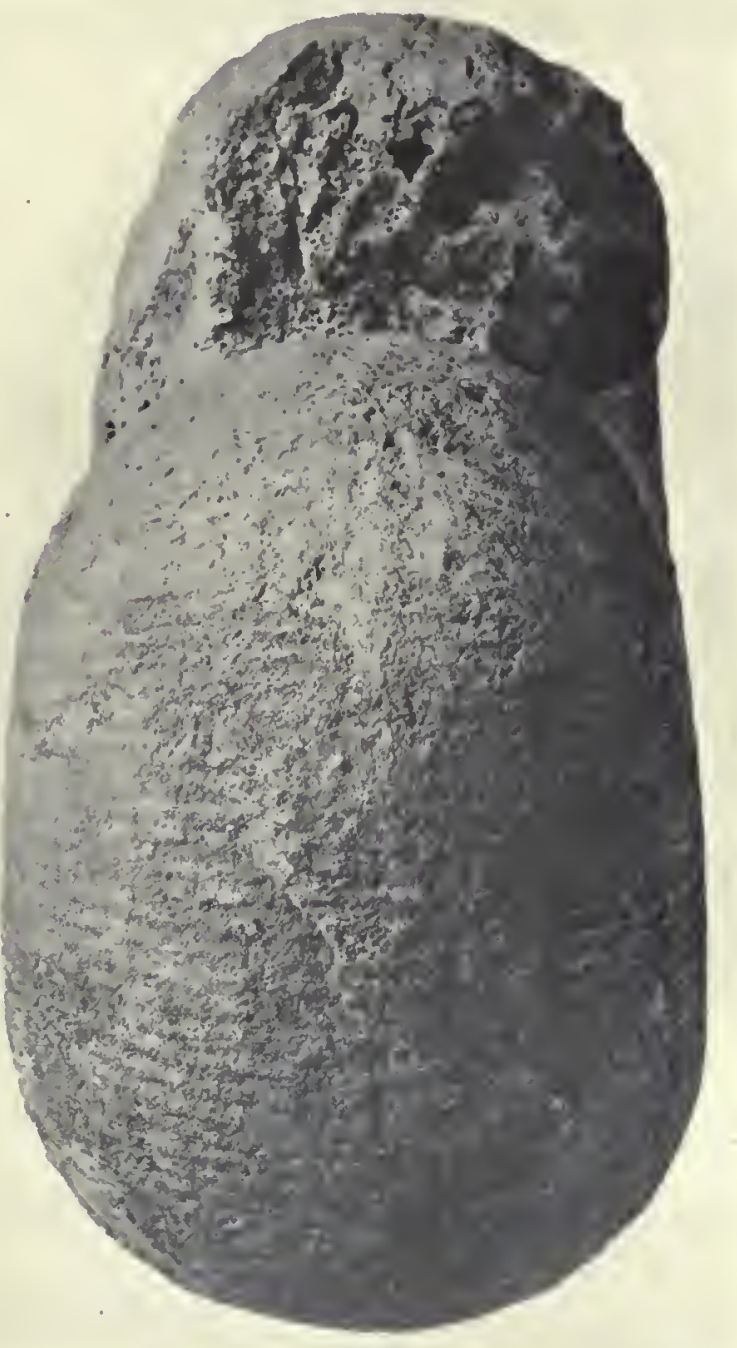

SPIA ZROCER.LS PEREXPANSUM, S. BLCKHAN

S.B. Coll., 1249; part of right side of aperture broken away

LABYRINTHOCERAS PEREXPANSUM, S. BuckMAN SP Bajocian, sauzei 

Fig. $4, \times 2.5$

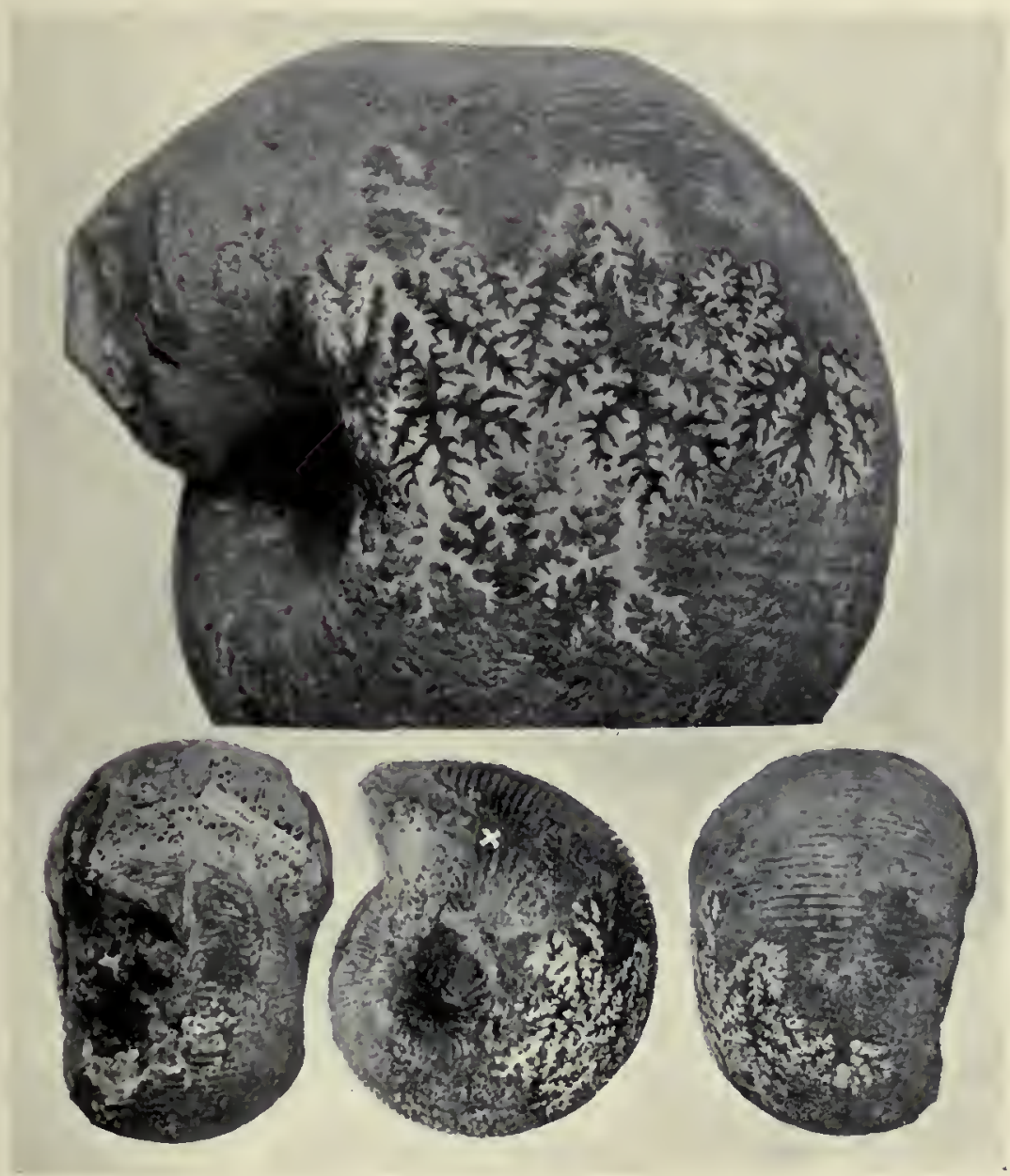

Fig. 2

Fig. I

Fig. 3

Spharoceras perexpansum, S. Buckman, I882, Paratype

Proc. Dorset N.H. \& A.F.C. IV, I42 ; "Sherborne, Dorset:

Inferior Oolite, probably zone of Stephan. Humphriesianum";

S B., ex J.B., Coll. 476 ; S. $34,43,95,20 ; 45,45,73$, I9; $\max$. c. 74 .

LABYRINTHOCERAS INTRICATUM, nov.

Bajocian, sanzei; Holotype 

Fig. $1, \times 0.39$

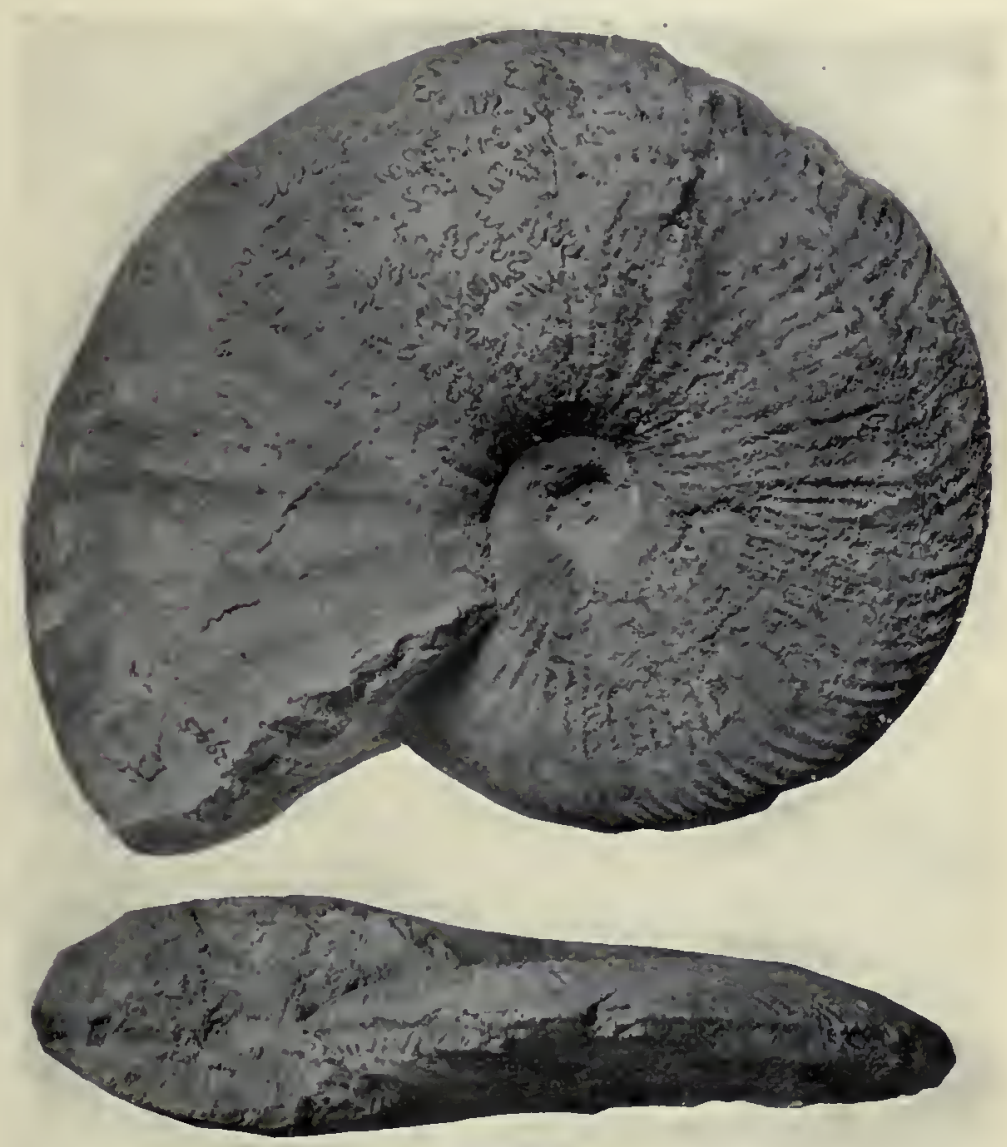

Fig. $2, \times 0.39$

AMnonites victoris, DUMORTIER I867

II, I36 ; XLII ; Victoriceras, S.B., Q.J.G.S. LXXIII, I9I9, 293 ; " Radstock Grove, Radstock, Somerset ; Lower Lias, below raricostatus." S.B. Coll. 2945 ; S. $265,48,29$, I5; $\max$. c. 315 .

VICTORICERAS VICTORIS, DUMORTIER SP. Deiran, Radstockiceras 

Fig. 2,

$\times 3.5$

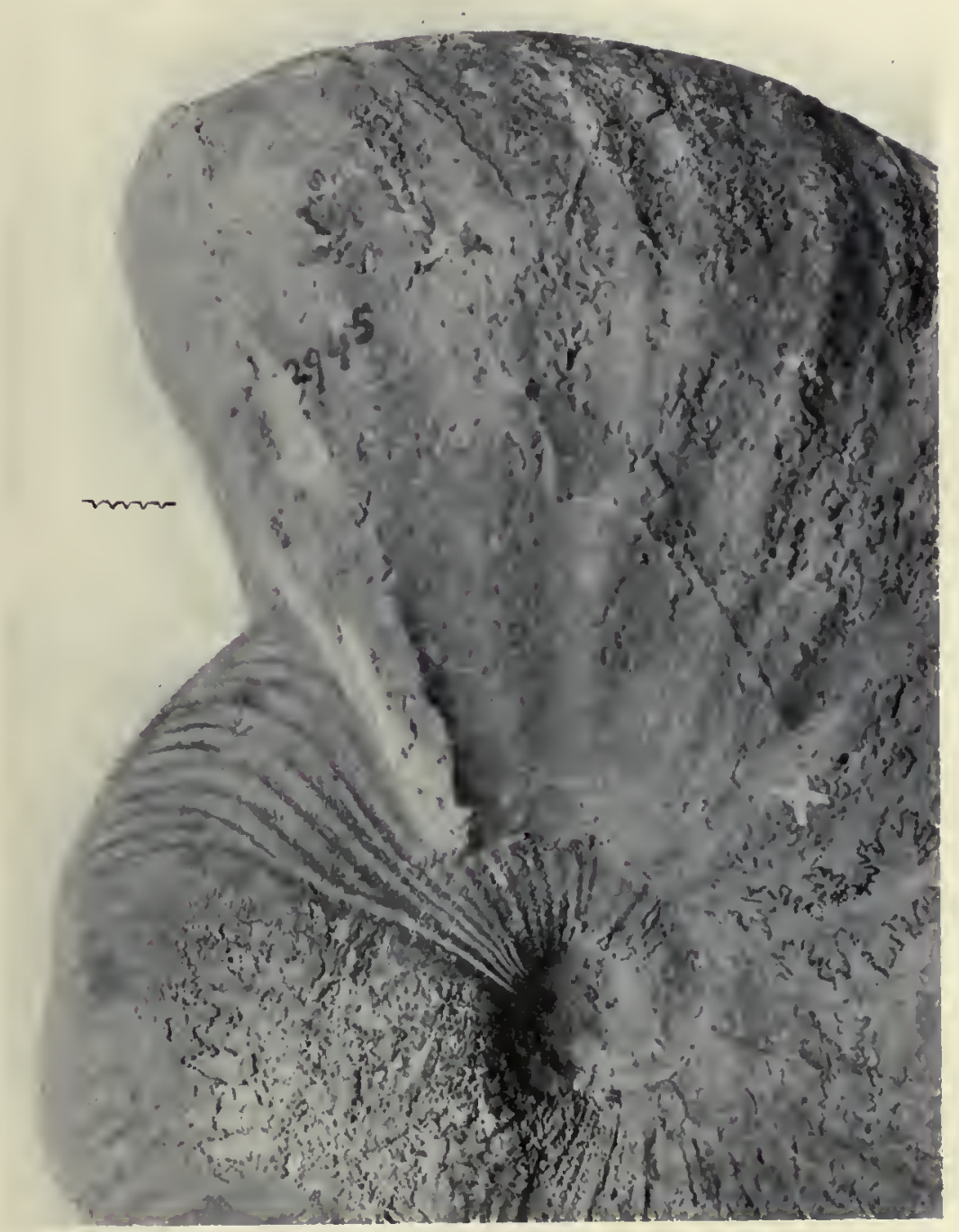

AmMonites Victoris, DUMORTIER I867

II, I36 ; XLII; “ Kilmersdon Colliery, Radstock Grove, Radstock, Somerset"; S.B. Coll. 2945 ; Fig. I, body-chamber, from $\mathrm{x}$; Fig. 2, cross-section intercostal test with strice (grooves), $\times 3.5$

VICTORICERAS VICTORIS, DUMORTIER SP. Deiran, Radstockiceras 

Fig. $2 \times 3.5$

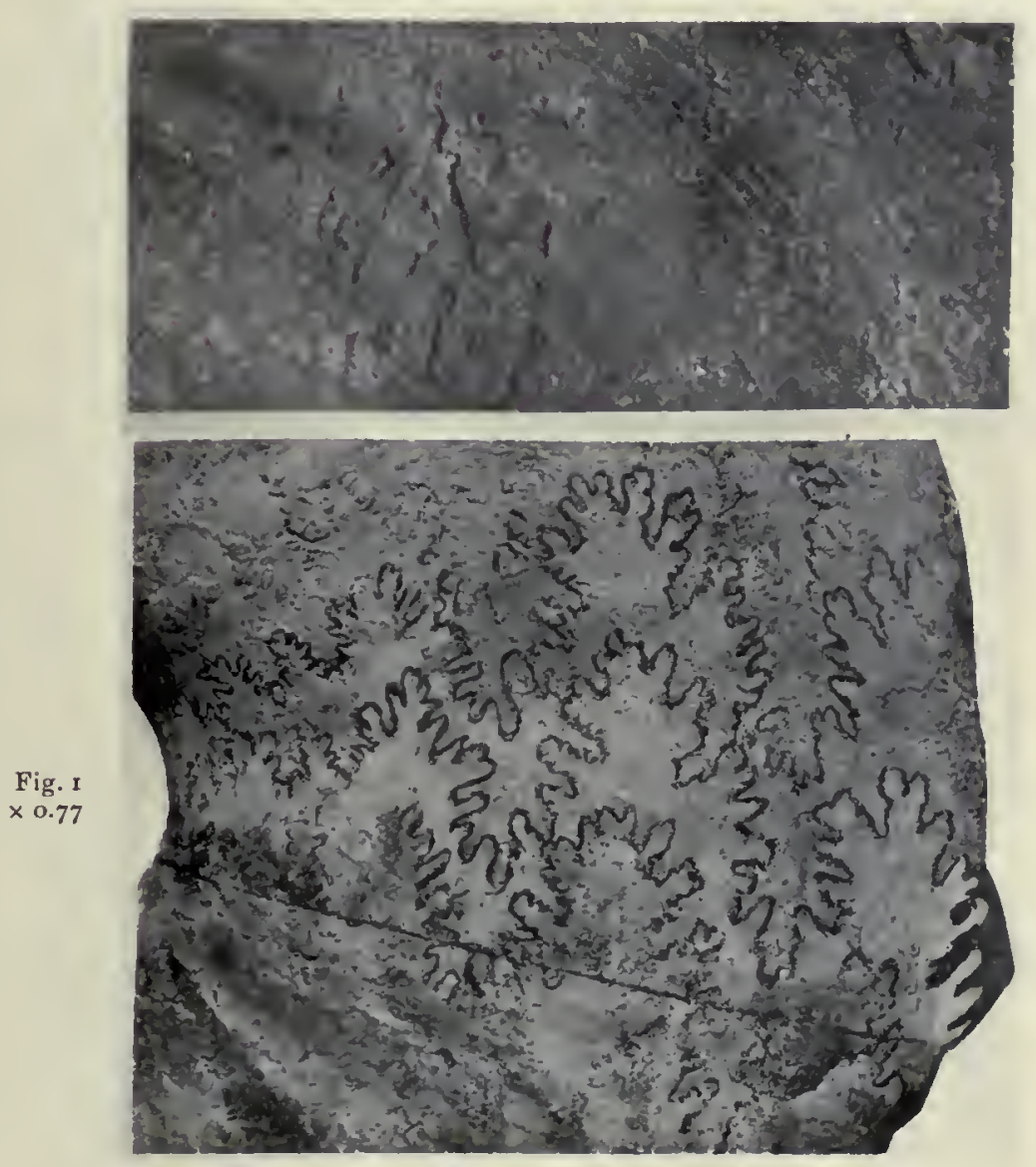

Fig. I

Amionites victoris, Dumortier, i867

Kilmersdon Colliery, Radstock Grove, Somerset; S. B. Coll. 2945 ;

Fig. 2, test with striæ (grooves) and punctre, $\times 3.5$

VICTORICERAS VICTORIS, DUMORTIER SP.

Deiran, Radstockiceras 

Fig. $3, \times 3.5$

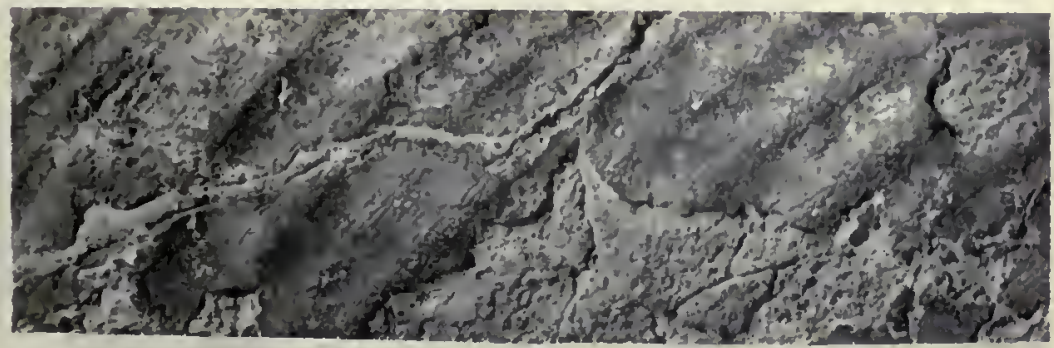

Fig. 4

$\times 3 \cdot 5$

Fig. I $\times 0.53$

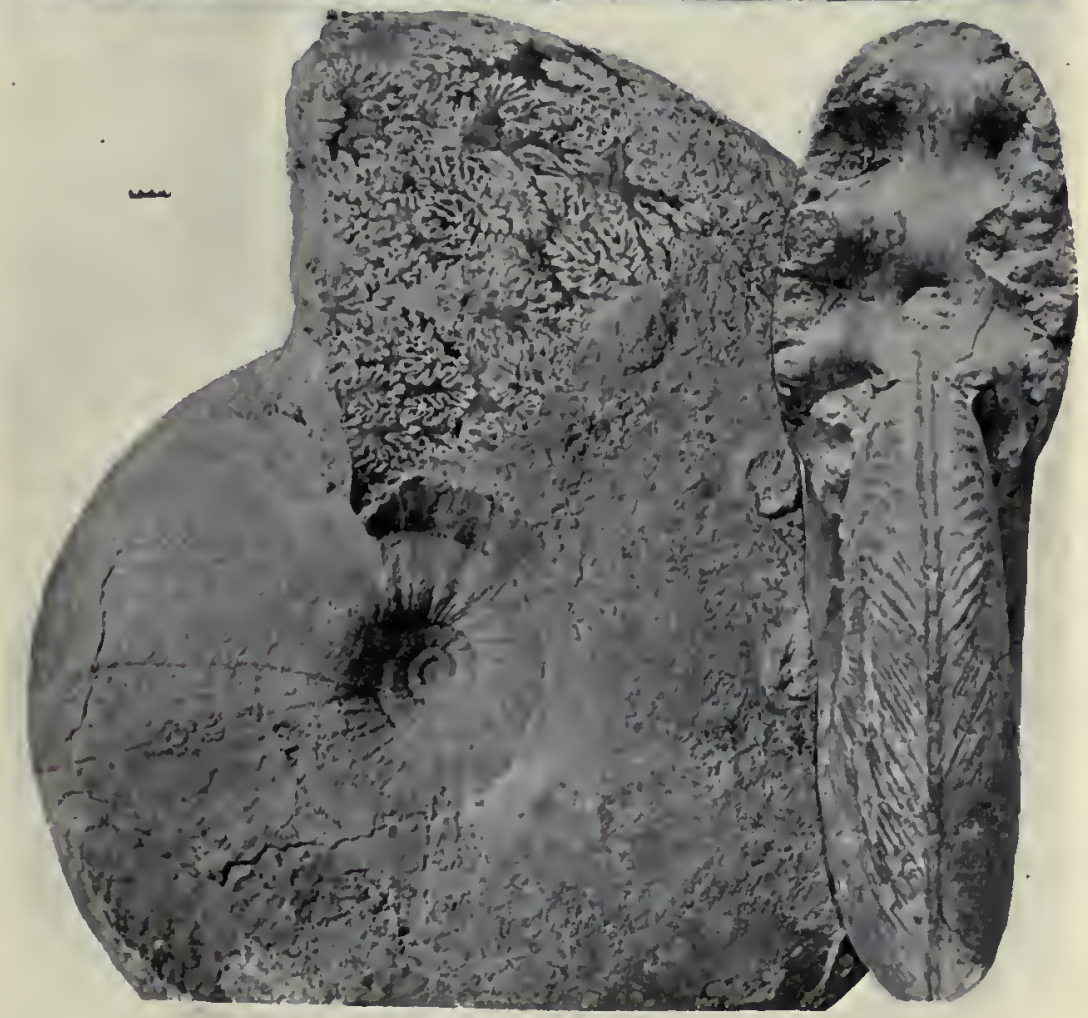

Fig. 2

$\times 0.53$

Ammonites victoris, Homøomorph of

"Radstock Grove, Radstock, Somerset ; Charmouthian, raricostatım" J.IV.T. Coll. ; S. 220, 47, 28, 19 ; max. c. 320 . Fig. 3, test capillate, $\times 3.5$; Fig. 4, sect. intercostal test with capillæ, $\times 3.5$

TUTCHERICERAS PERFOLIATUM, nov.

Deiran, Radstockiceras ; Genotype and Holotype 

Fig. 2

Fig. 1

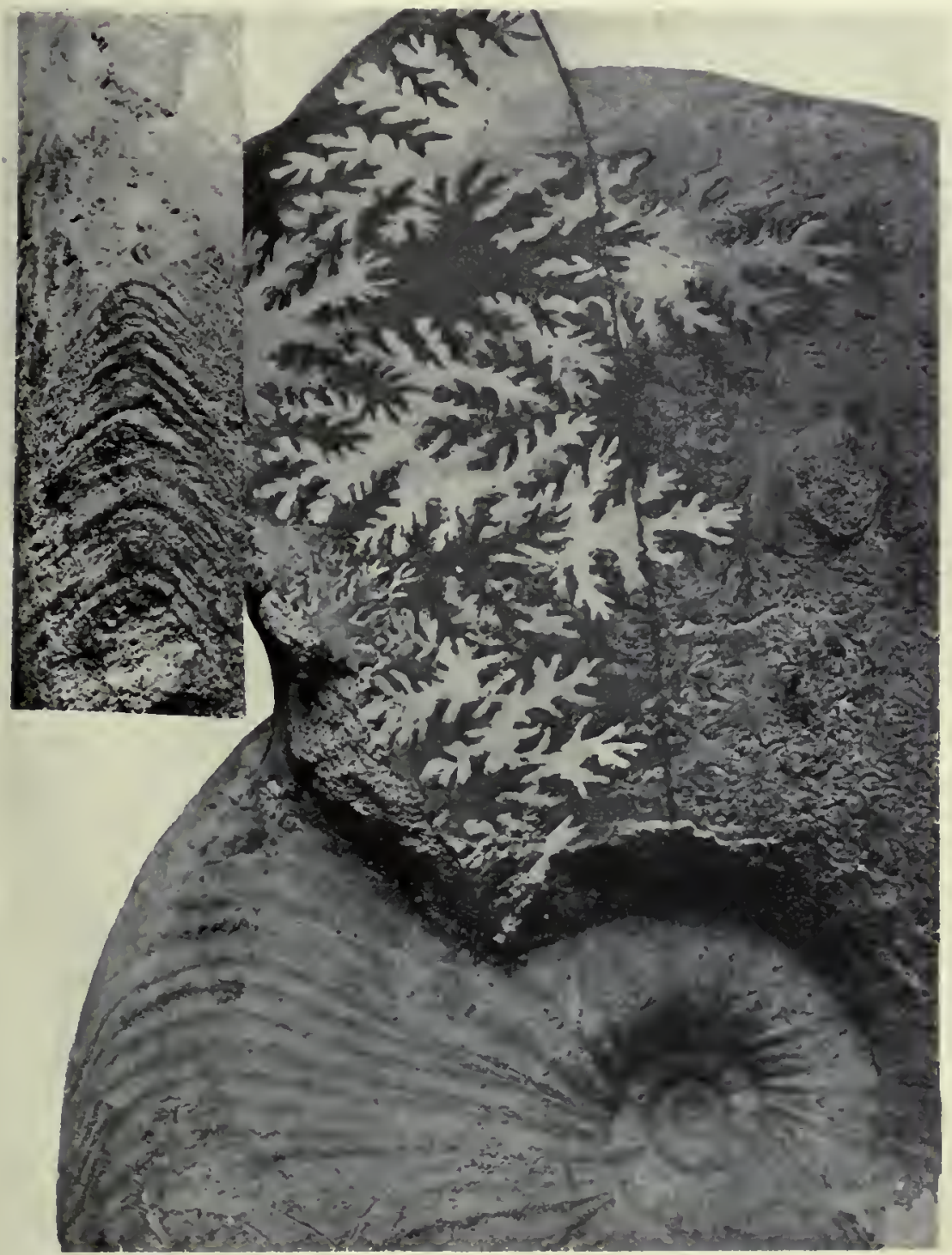

AMmonites victoris, Homoeomorph of lïg. I, Suture-line and radial lines of CXXXVIIA

lïg. 2, Portion of periphery of end of whorl showing loss of carina, possibly due to injury; cf. Q.J.G.S. LXXIII, I9I9, XXXI, 5

TUTCHERICERAS PERFOLIATUM, nov. Deiran, Radstockiceras 



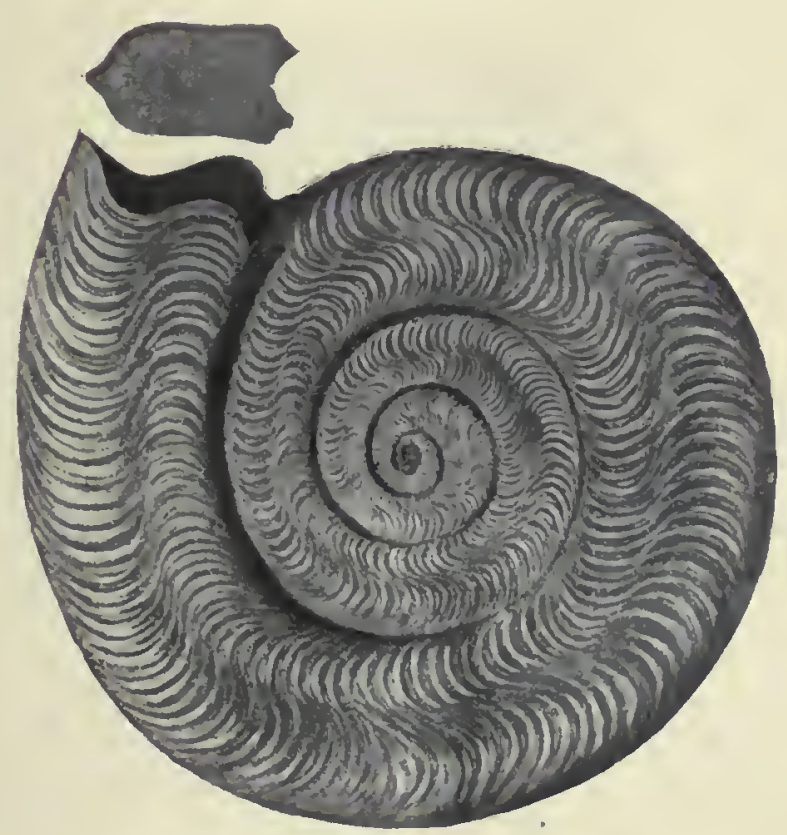

Argonauta serpentinus, Reinecke I8I8, Holotype Maris prot. 89 ; xil1, 74, 75; Copy of Protograph, $\times 0.96$; " Reperitur in marmore solidore [Up. Lias] prope Doeringstadt" F. 80, 28, I6.5, 47. C. Thompson, Natural. I909, XIIr, [I] 



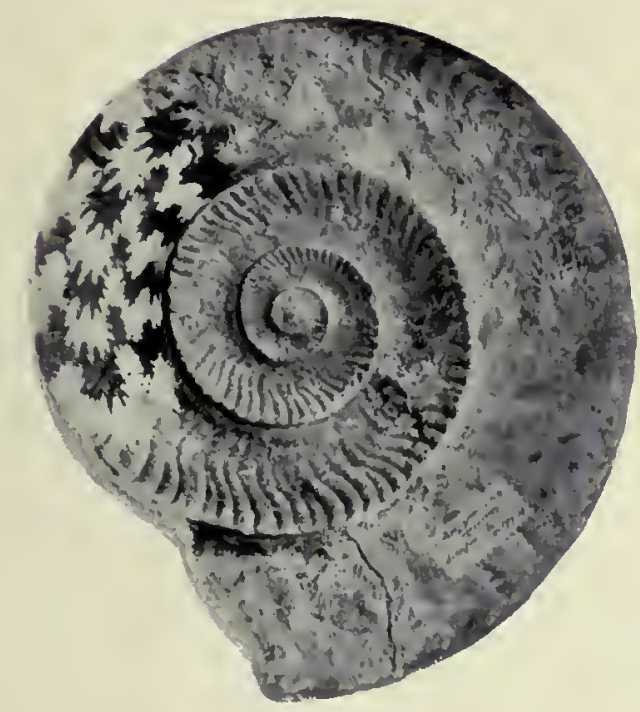

Hildoceras serpentinum, Reinecke SP. ; Plesiotype, $\times 0.56$ S. Buckm. Geol. Mag. (3) VI, I889, 201 ; C. Thompson, Natural. Igog, XIII, [2], 214 ; "South Petherton, Somerset ; Up. Lias" ; Manchester Mus., ex S.B. Coll., L. II305; S. 127, 25, I7, 52.5 



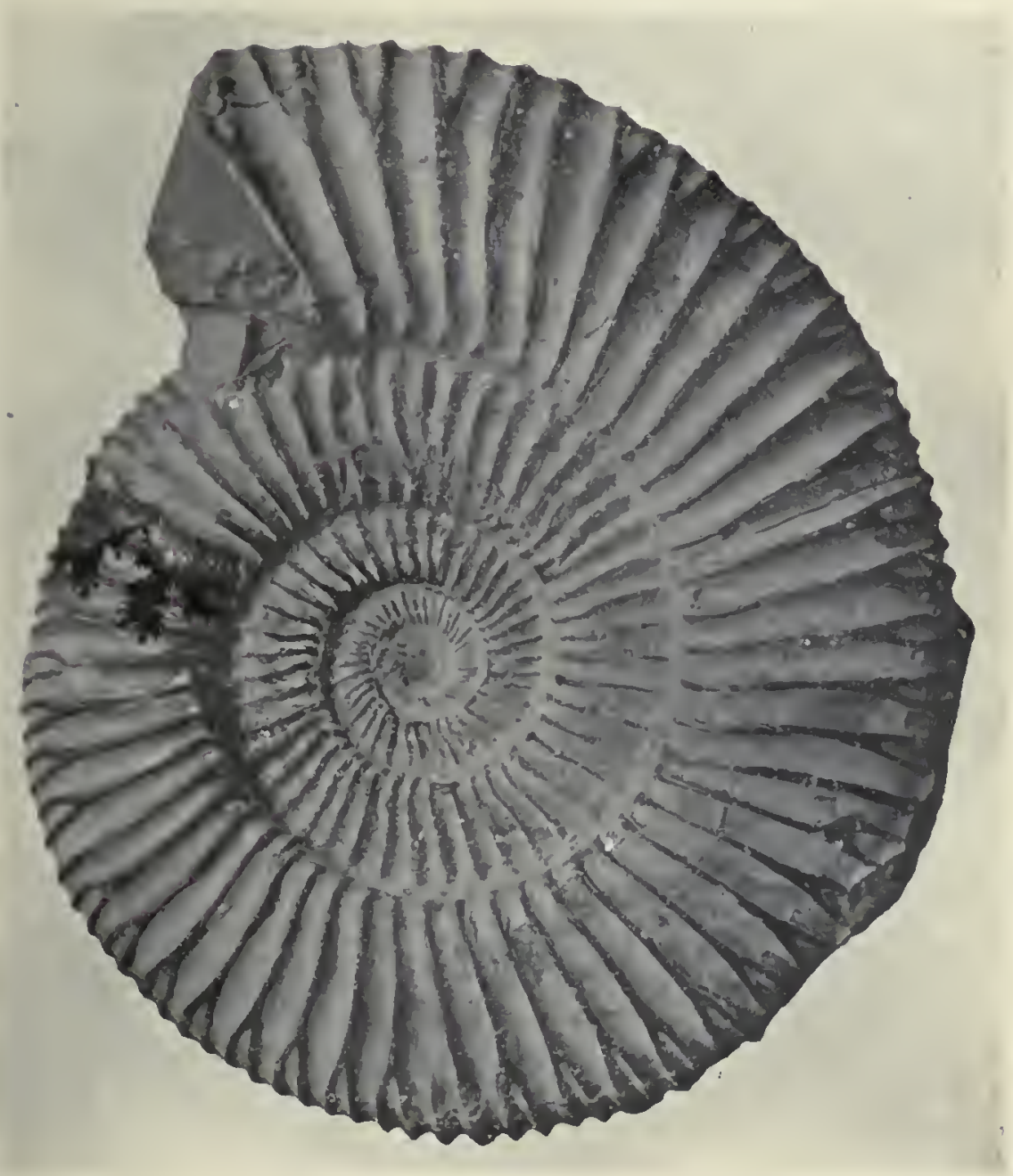

AMmonites BIPLEX, Homœeomorph of

Cf. Perisph. sp., Siemiradzki, I899, 256 ; [Shotover]," near Oxford " Kimmeridge Clay $[=$ Ampthill Clay $]$;. W. Tutcher Coll. S. $90,32,30,41$; I $46,32(30), 28(26), 48$

DICHOTOMOCERAS DICHOTOMUM, S. BuCKMAN, IgI9

Prionodoceratan, dichotomum; Genotype, Holotype 

Fig. 2

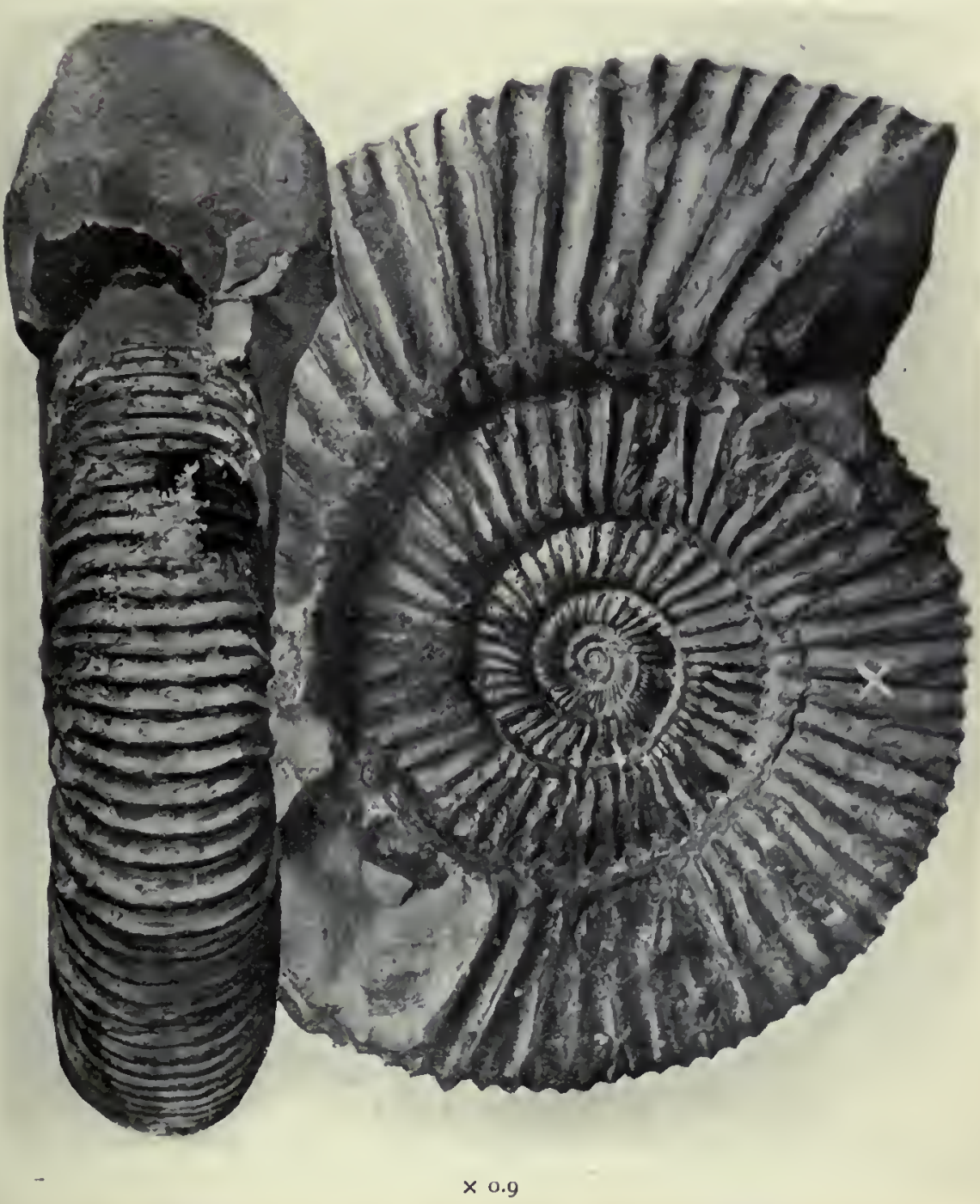

AMmonites BIPLEX, Homœomorph of

Fig. I, Left side of CXXXIXA, with much test, showing stout ribs bordering constrictions; body-chamber from $\mathrm{x}$ complete?

Fig. 2, Peripheral view, ribs strong

DICHOTOMOCERAS DICHOTOMUM, S. BUCKMAN, IgI9

Prionodoceratan, dichotomum; Genotype, Holotype

[Oct. I927] 


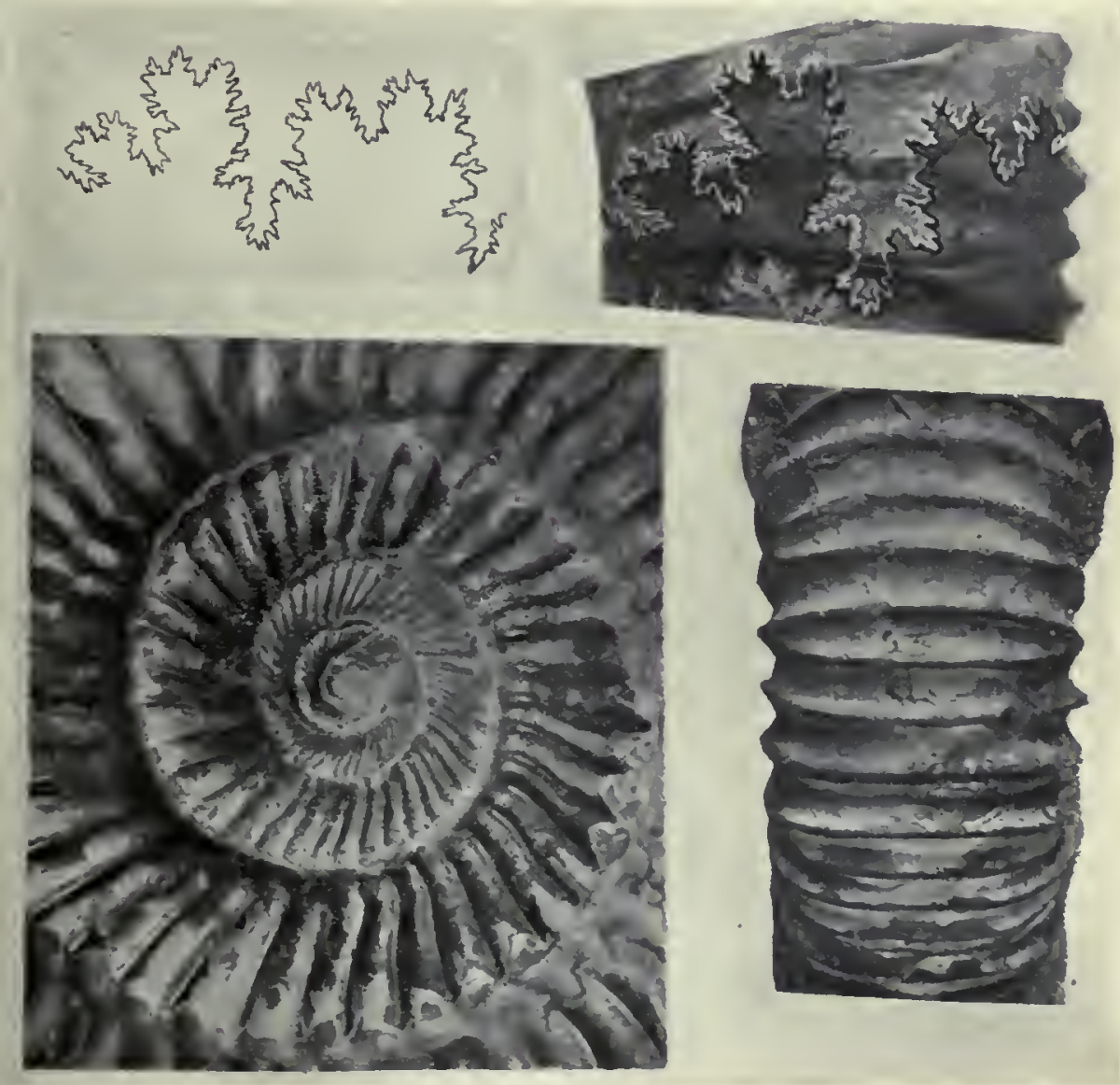

Fig. $1, \times 2$

Fig. $2, \times 2$

Ammonites B1PLEX, Homœomorph of

Fig. I, Inner whorls of CXXXIXB, fine prorsicostæ and constrictions

Fig. 2, Periphery, 2 ribs not divided; Figs. 3, 4, suture-line, nahtlobe short

DICHOTOMOCERAS DICHOTOMUM, S. BUCKMAN, I9I9

Prionodoceratan, dichotomum; Genotype, Holotype

[Oct. 1927] 



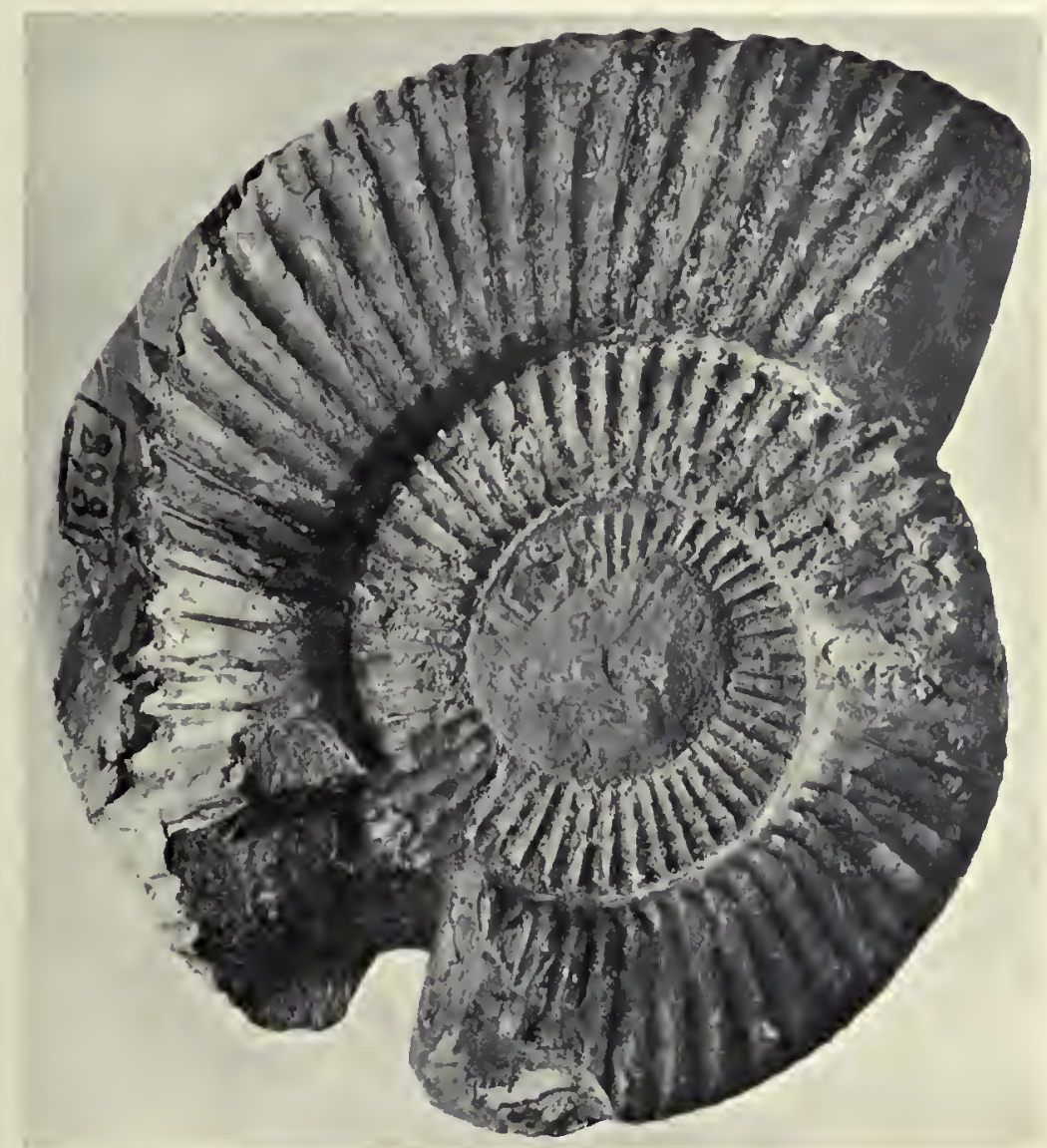

$\times 0.7$

Ammonites BIPLEX, Homœomorph of

"[S.E.] England"; [Boulder Clay, ex Ampthill Clay ?]

Yale Univ. Mus. (U.S.A.) Coll., I868; S. 97, 29, 26, 44 ,

S. I50, 3I, 25, $47 ; 173,30,25,48$

DICHOTOMOCERAS DICHOTOMUM, S. BUCKMAN, IgI9

Prionodoceratan, dichotomum; Paratype 


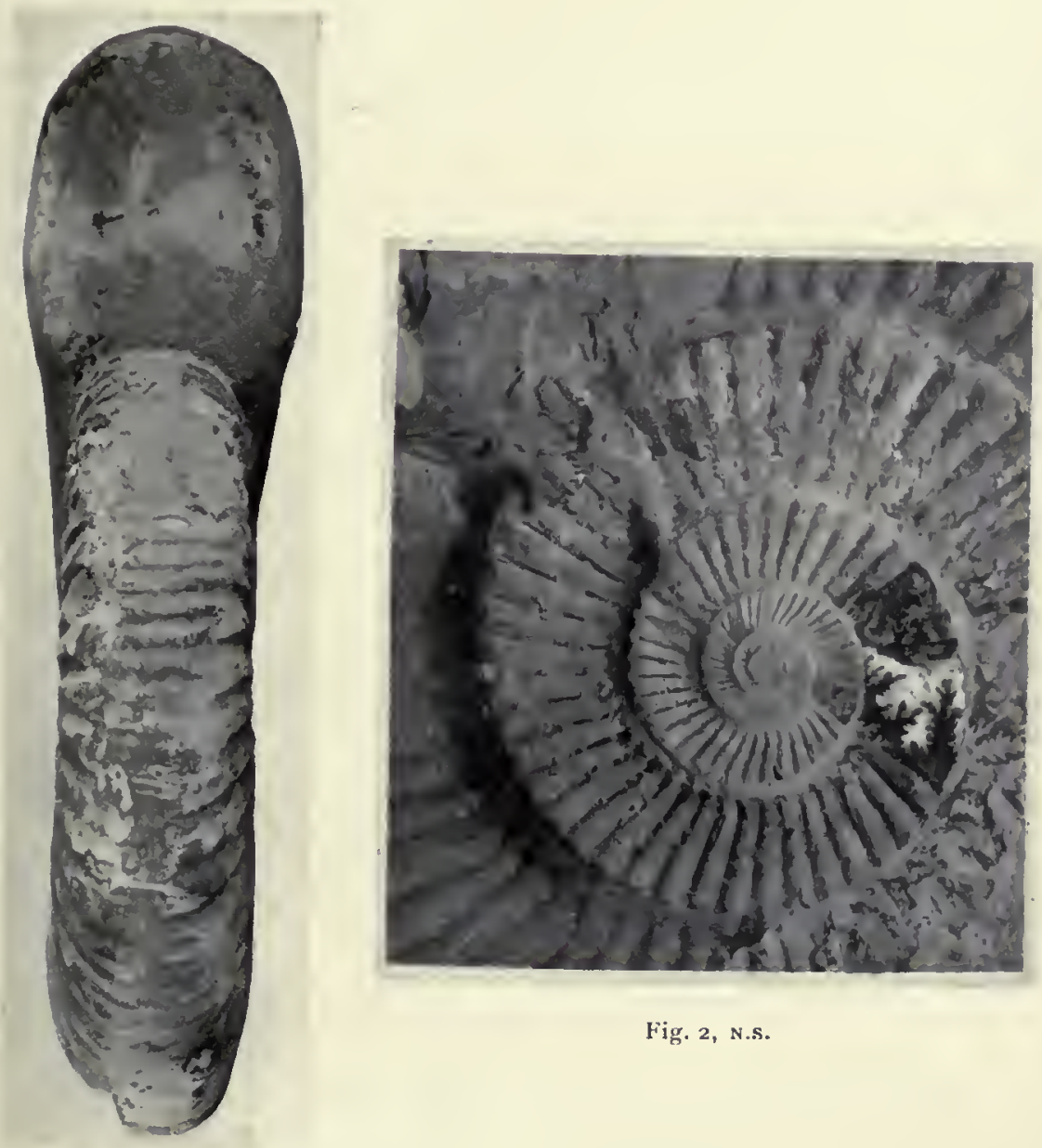

Fig. 2, N.s.

Fig. $1, \times \circ 7$

AMMONITES BIPLEX, Homœomorpl of

Yale Univ. Mus. Coll., No. I868. Fig. I, Peripheral view; Ribs show attrition.-Fig. 2, Inner whorls and suture-line

DICHOTOMOCERAS DICHOTOMUM, S. BUCKMAN, IgI9 Prionodoceratan, dichotomum; Paratype

[Oct. 1927] 

Fig. 2

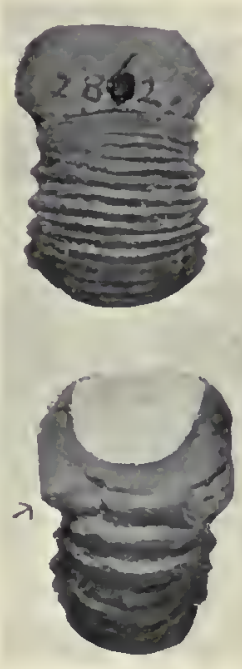

Fig. 3
Fig. I
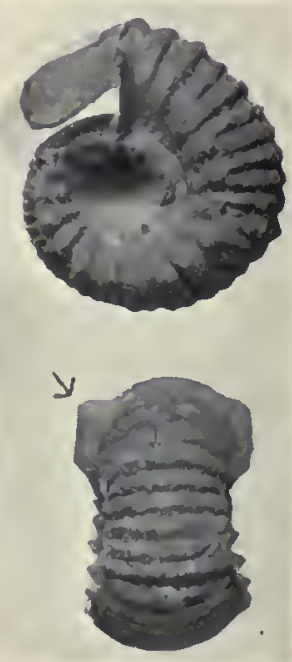

Fig 4

A Docidoceratan phaulomorph $\times \mathbf{r . 2 5}$

" Bradford Abbas, Dorset, Foss. Bed [up. part]; Inf. Oolite;" S. B. Coll. 2862 ; S. I4, 3I, IOI (89), 4I; $23.5 ; 37,46,38$.

$\rightarrow$ Node on auricle. A contracticone.

TRILOBITICERAS TRILOBITOIDES, nov.

Bajocian, discites; Genotype, Holotype 


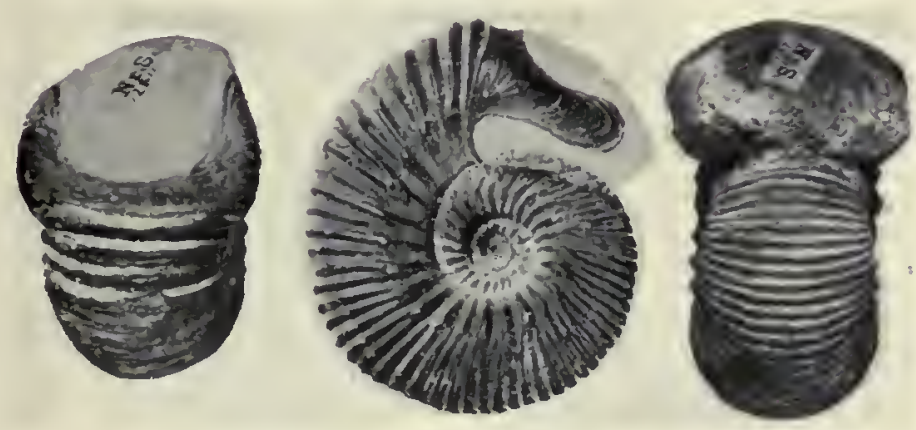

"Spharoceras contractum, J. de C. SOWERbY SP.

" [Sandford Lane (Foss. Bed, Middle part)]. near Sherborne, Dorset"

"Inferior Oolite;" S. B., ex Darell, Coll. I284

S. $24,39,63,23 ; 4 I, 36,46,30$. See IXXXI

OTOITES DELICATUS, nov.

Bajocian, Witchellia; Holotype 



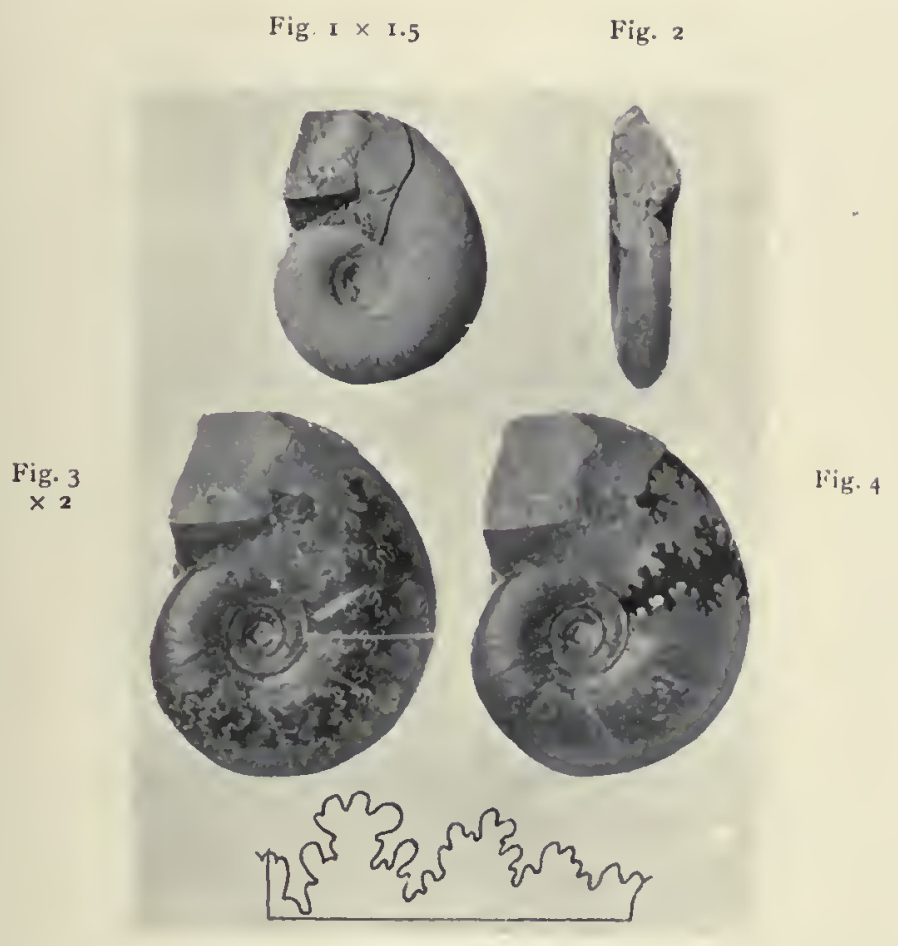

Fig. $5 \times 4$

AmMonites ferRugineus, Simpson I855, Holotype

Pp. 78, 79; Amauroceras, S. B., Y.T.A., II, vii ; " near Whitby, Yorkshire;

Ironstone Beds of Middle Lias " "Whitby Mus. No. 482 ;

S. I8, 47, 26, 22 ; See XX and Homœomorpl I.V

AMAUROCERAS FERRUGINEUM, SIMPSON SP.

Domerian, c. laevis 

Fig. I

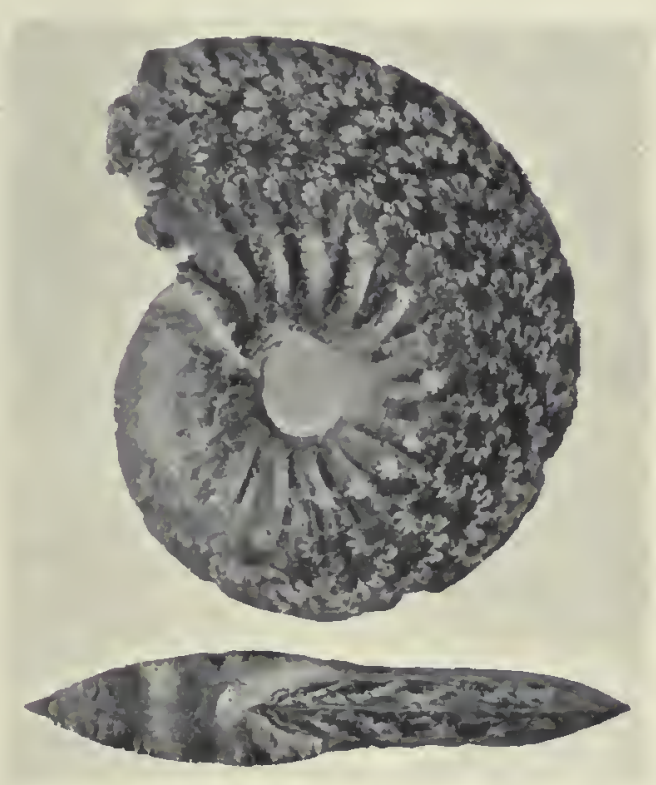

Fig. 2

Ammonites oxynotus, Quenstedt I 843

Flöz.b. Würt. I6I ; I846, Ceph. V, II ; Stonehouse, Gloucestershire :

Lower Lias; J.IV.T. Coll. ; S. 63, 53, I9, I5. See V1ll

OXYNOTICERAS OXYNOTUH, QUENSTEDT, SP.

Deiran, oxynotum 



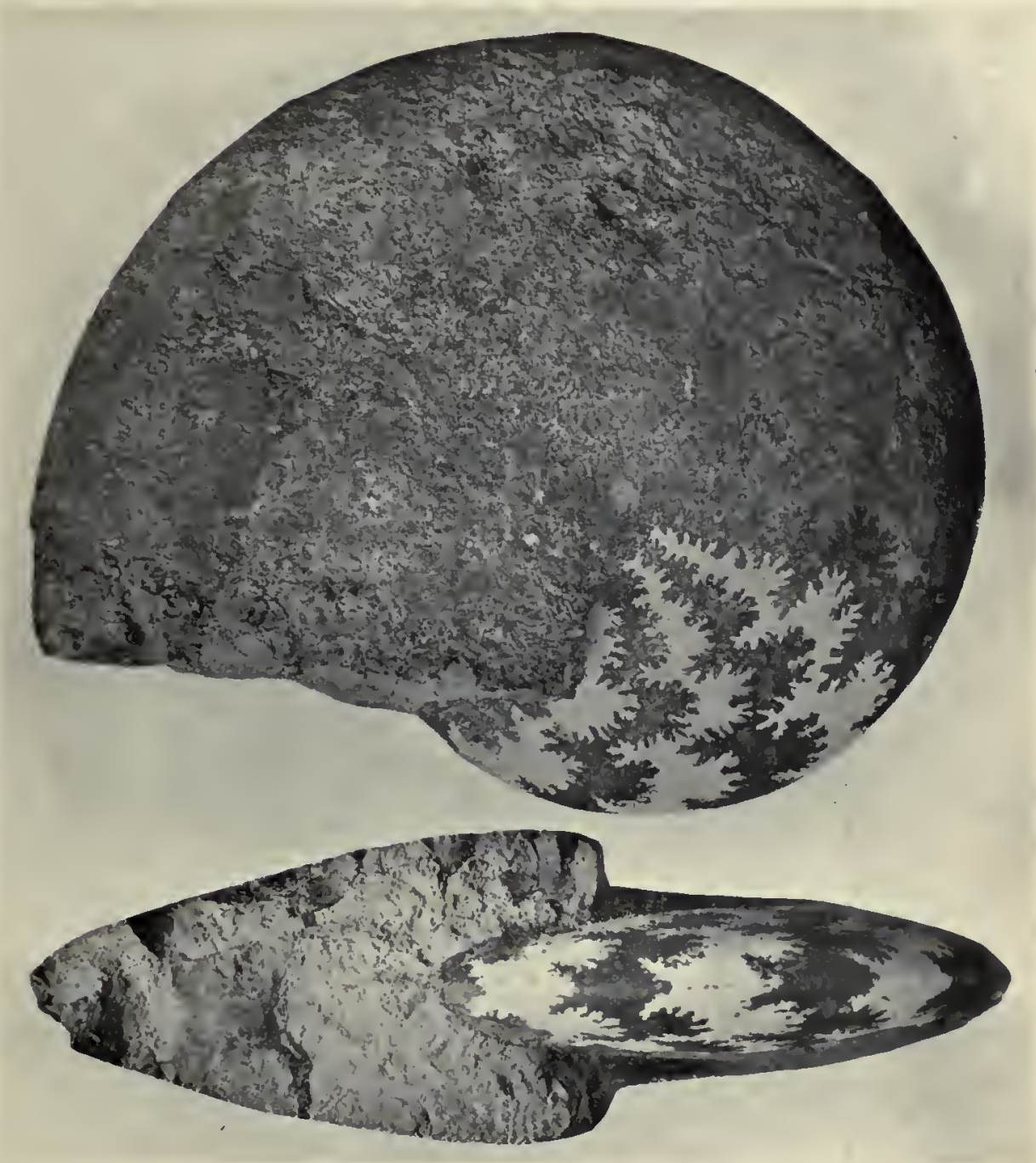

Fivic. $2 \times 0.73$

Cf. Phylloceras Buvigneri ; Wrigitt, i 883 Mon. Lias Amm. LXXvi, I-3 ; "Rockhill, Radstock, Somerset ; Raricost.-armatus" ; J.W.T. Coll. ; S. I62, 60, 32, 3 ; max. 'C. $240+$. In fig. 2 whorl-section as at radius

FASTIGICERAS CLAUSUM, nov. Deiran, Radstockiccras ; Genotype, Holotype 

Fig. I
Fig. 2

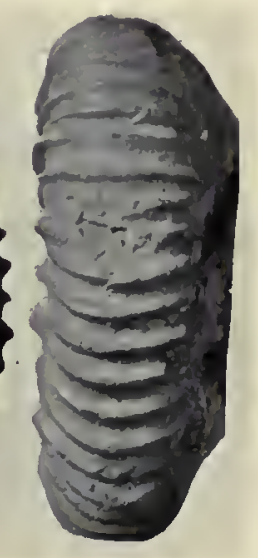

AmMonites REversus (SiMPSON MS.) Leckenib 1859. Holotype Q.J.G.S. XV, 7, 9, 15; 1, 2; The Castle Rock, Scarborough, Yorkshire; Kelloway Rock" (brown ool. calc. with irony sand) ; Sedgwick Mus., Cambridge (Leck. Coll.) ; S. 53, 28, 30, 43. Cf. XCIX

RURSICERAS REVERSUM, SMPSON-LECKENBY SP. Callovian, athleta; Genotype 

Fig. I

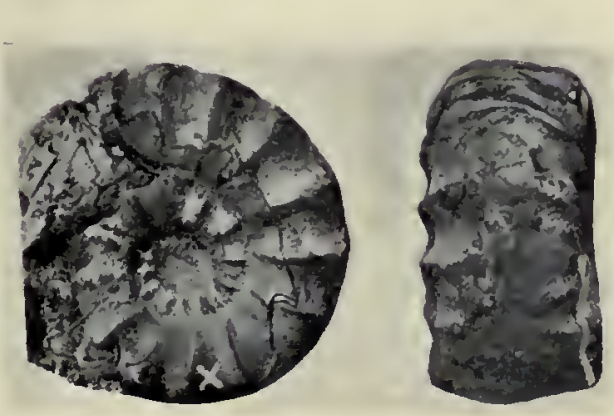

Fig. 2

Amonites planicostatus; J. BuckMan, I 844

Geol. Chelt., New Ed. p. 90 pars; "L[ias] M[arlstone], Glenfall" ; "Cheltenham, Lias" label; Ochraceous Lias; S.B., ex J. B., Coll. No. 2750 ; S. $20.5,36,63(59), 36 ; 28.5,39,42(40), 41$. See CXLVI 

Fig. I

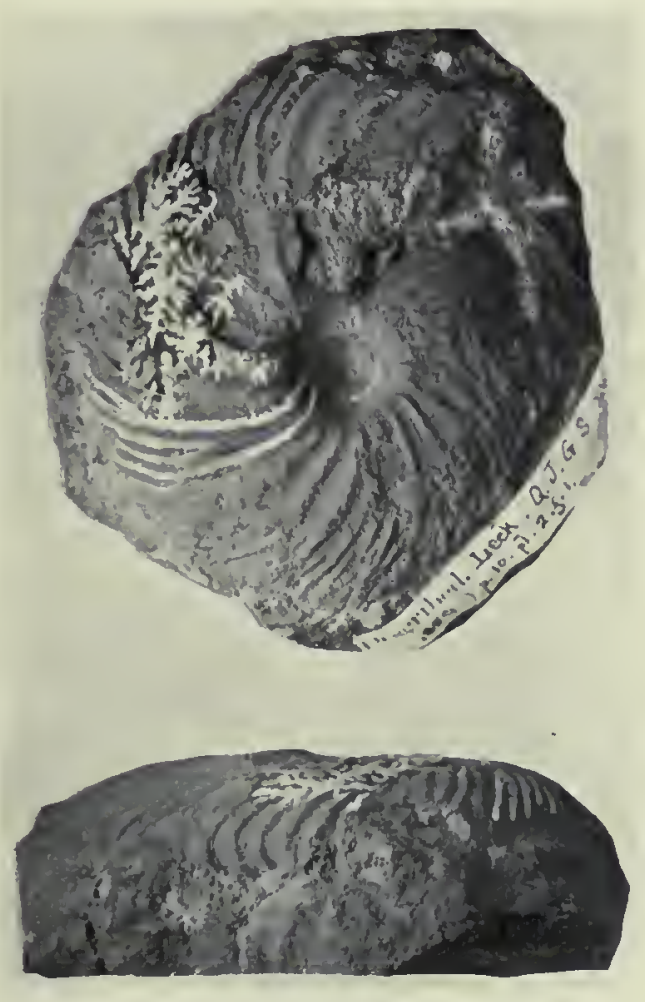

lig. 2

Amanites Placenta, Simpson-I.ecrenby i859, Holotype

Q.J.G.S. XV, Io ; II, I ; "The Castle Rock, Scarborough, Yorks; " Kielloway Rock" ; Grey, coarse ool. ; Sedgwick Mus., Cambridge (Leckenby Coll.) ; S. 58, 52, 34? I9. See CXXIA

LONGAEICERAS PLACENTA, SIMPSON-LECKENBY SP. Callovian, duncani 



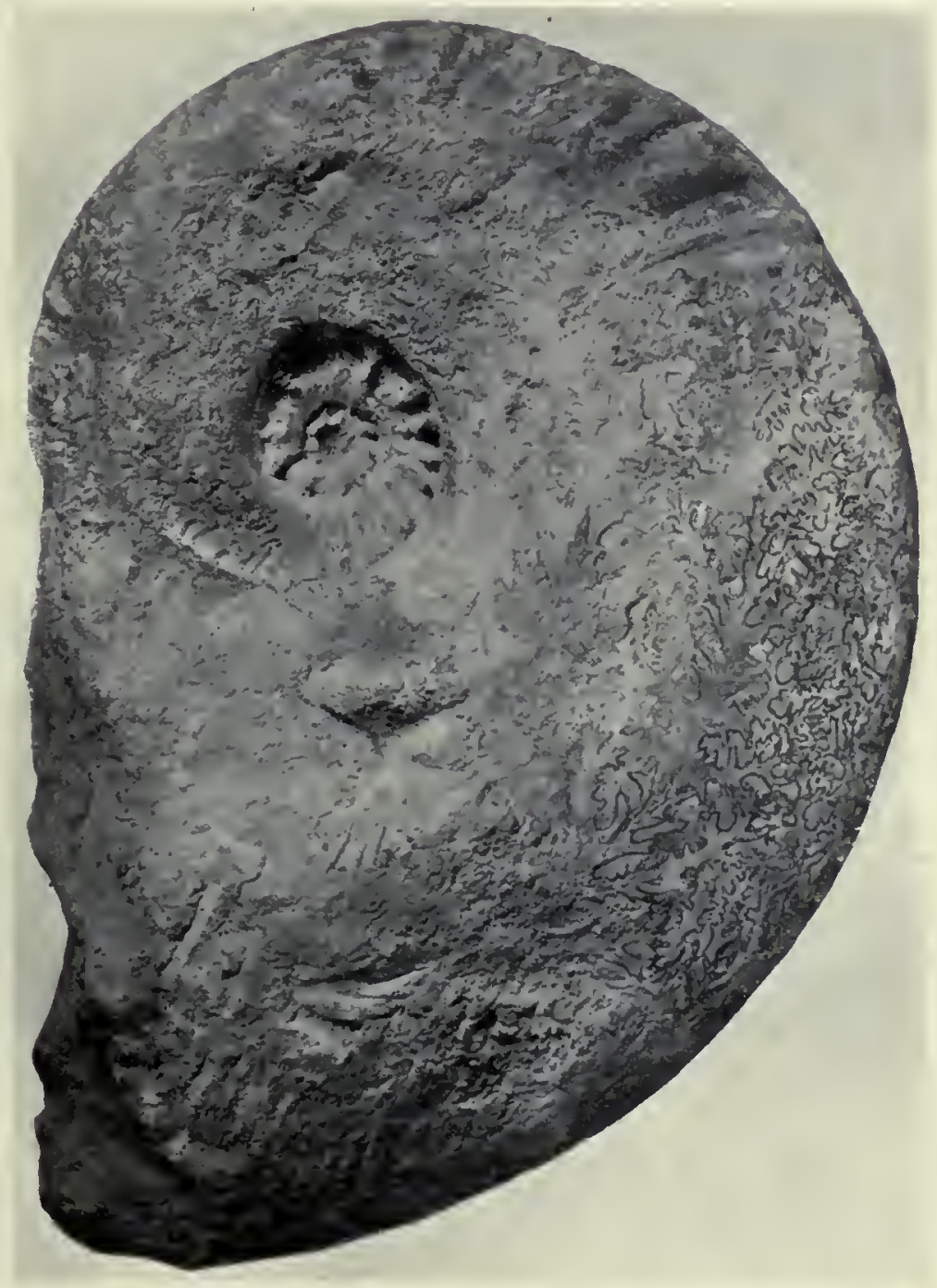

AmMONITES LAMELLOSUS, D'ORBIGNY I844

T.J. Céph. 283; Lxxxiv, I, 2 ; Kilmersdon Colliery, Radstock Grove, Radstock, Somerset; armatum zone; S.B. Coll. 2917 ;

S. $256,55,28,18$; max. c. 428 . See XXXIII

PHRICODOCERAS LAMELLOSUM, D'ORBIGNY SP.

Wessexian, Phricodoceras 

Fig. I

ligig. 2

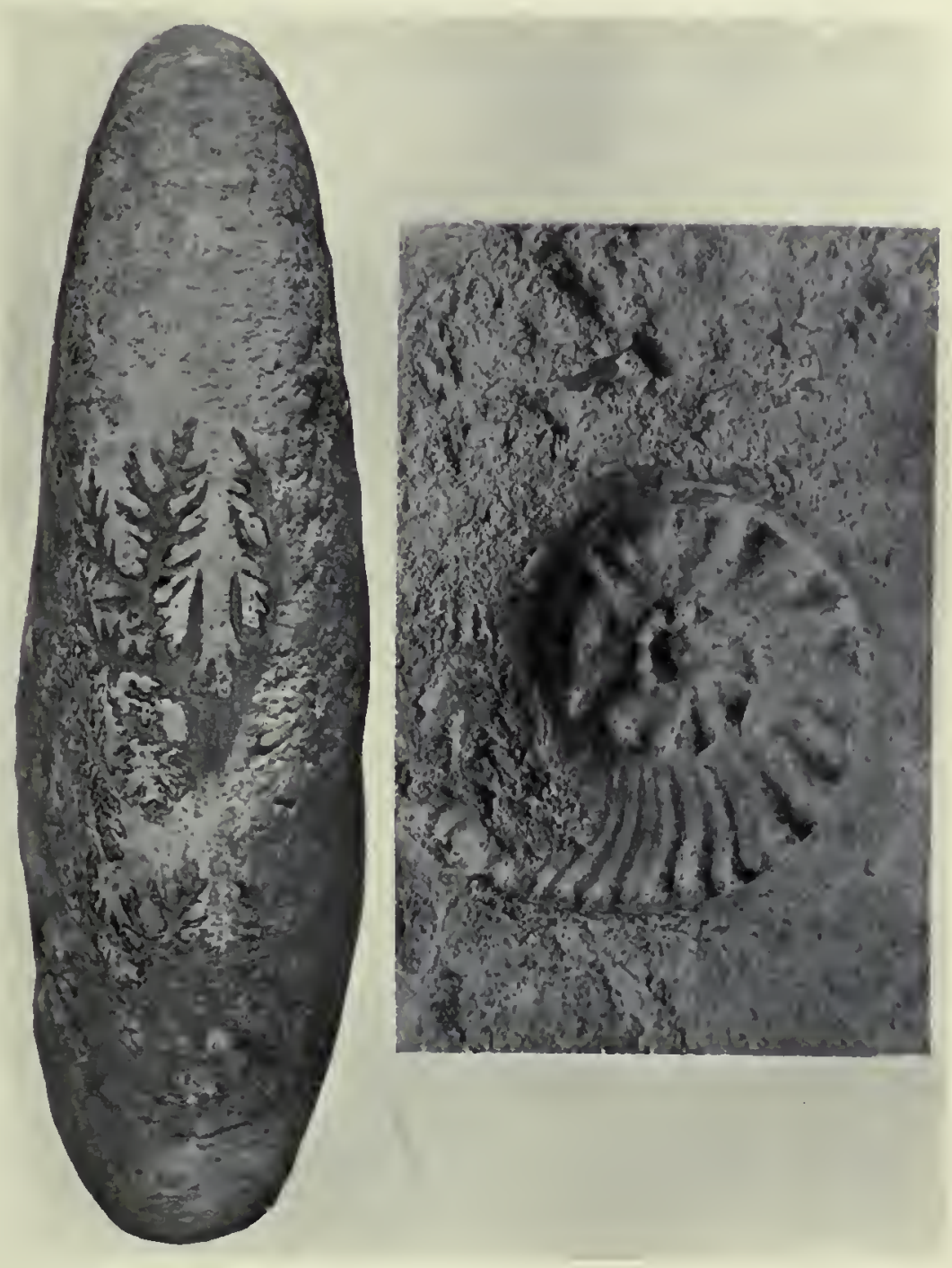

Amanontes lamellosus, D'ORBIGNY

S.B. Coll. 2917 ; Fig. 1, Periphery $\times 0.55$; Fig. 2 , Umbilicus, Nat. size

PHRICODOCEIRAS LAMELLOSUM, D'ORBIGNY SP, Wessexian, Phricodoceras 



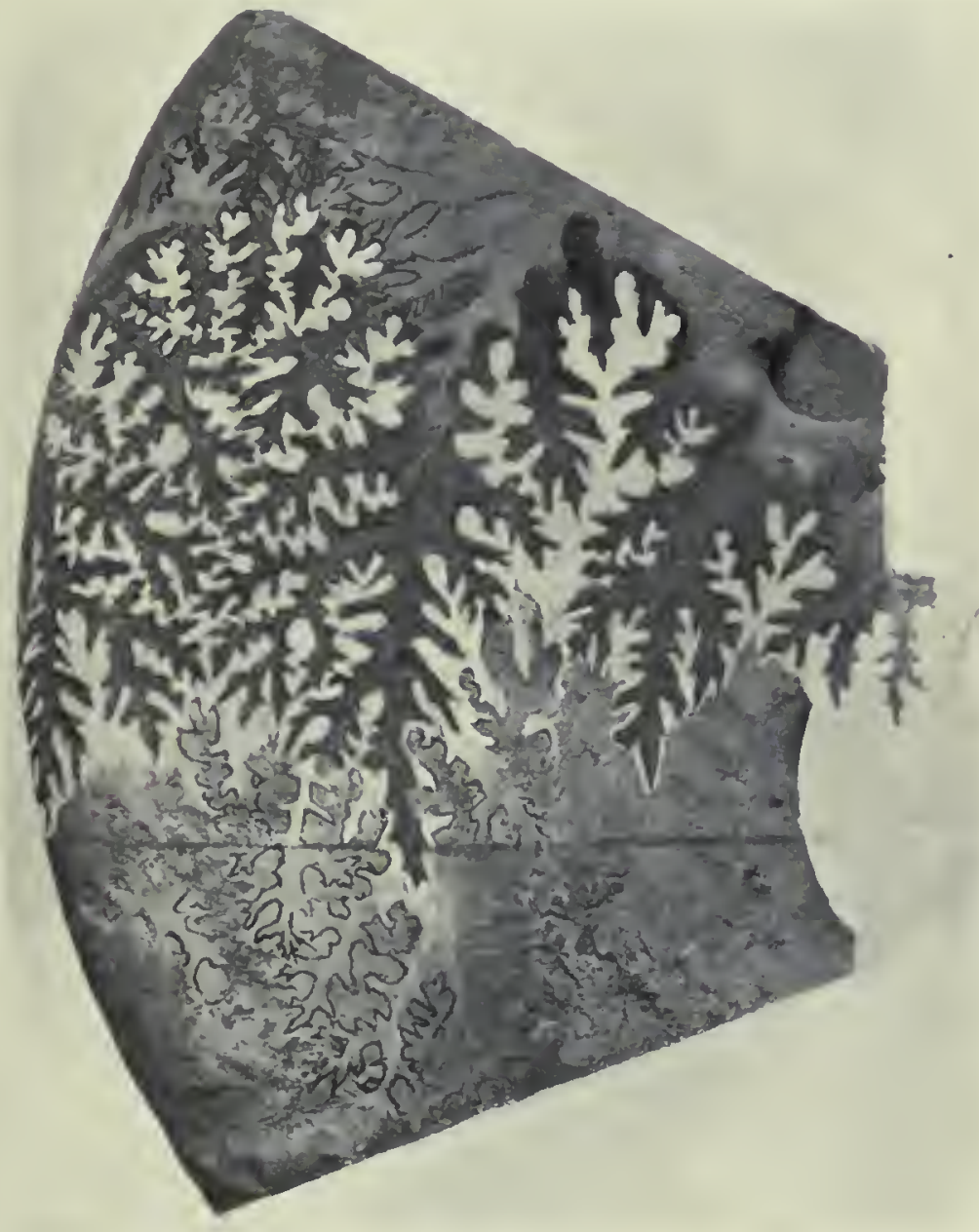

Amanites lamellosus, D'ORBIGNy

S.B. Coll. 2917 ; Suture-line $\times 0.85$

PHRICODOCERAS 1,AMELLOSUM, D'ORBIGNY SP.

Wessexian, Phricodoceras 

Fig. 3

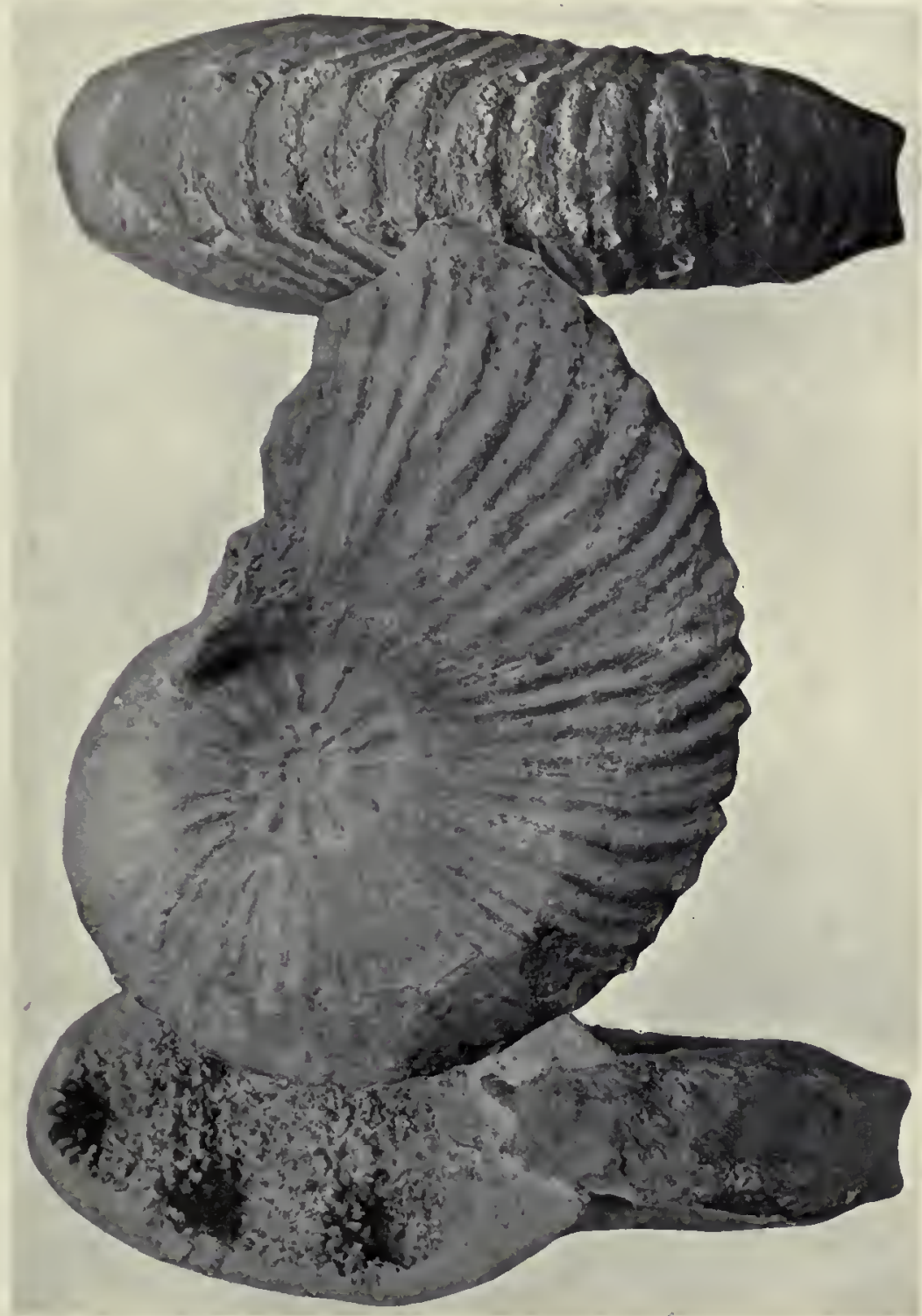

$\times 0.9$

Ammonites lamellosus, d'Orbigny

"Rockhill, Clandown, Radstock, Somerset ; Charmouthian ; armatus ;"

J.W.T. Coll. ; S. I I3, 52, 38, 22, portion shown; with additional part of whorl (not figured), S. $158,55,32$, I 8

PHRICODOCERAS LAMELLOSUM, D'ORBIGNY SP.

Wessexian, Phricodoceras 



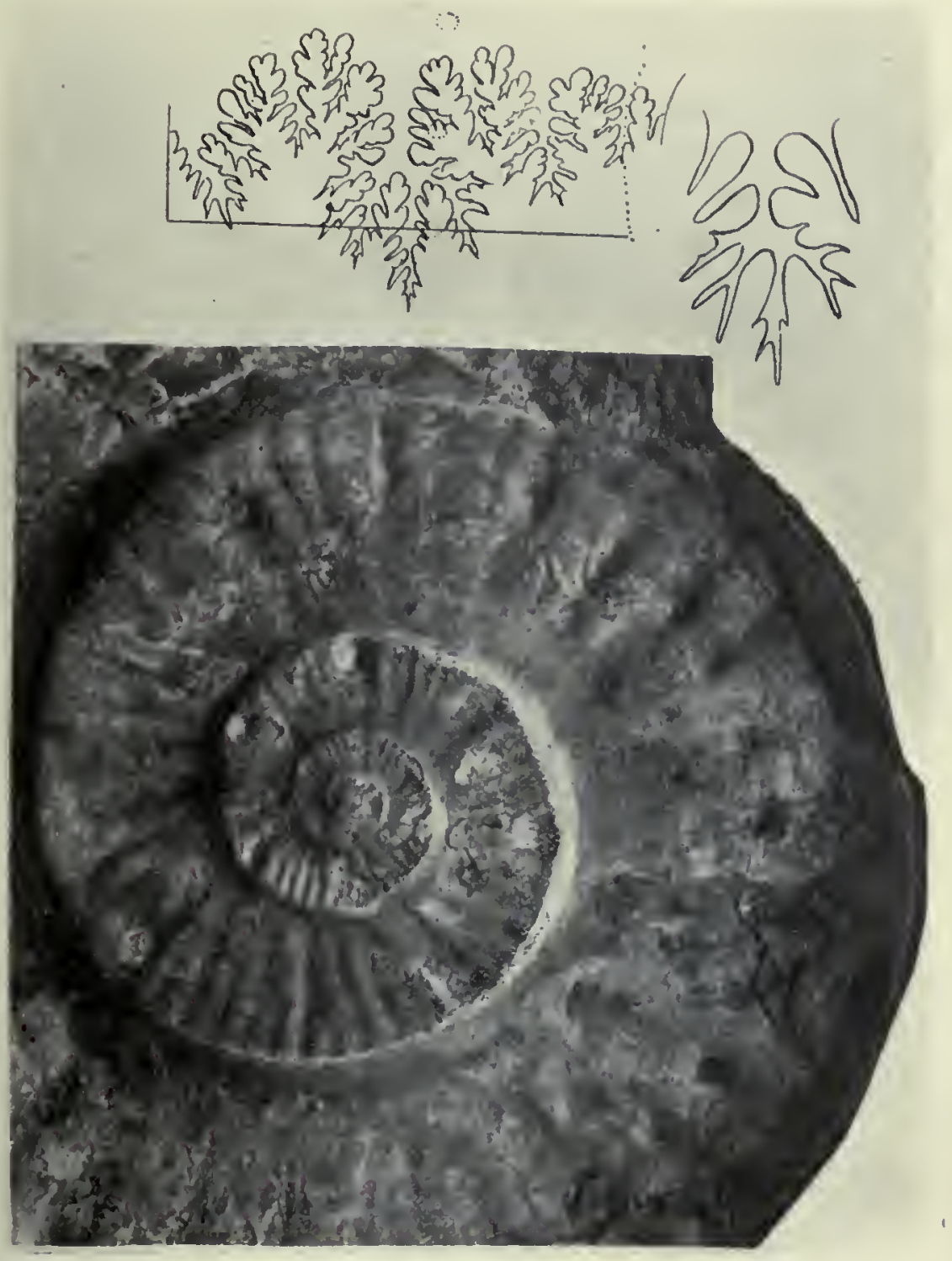

Fig. I

A mammillate Sonvixia

「Sandford Lane], Sherborne, Dorset; Inf. Oolite, [Top of Fossil Bed], Q.J.G.S. XLIX, I893, p. 492 ; Irig. $2, \mathrm{~L}^{1} \mathrm{O}$; Fig. 3, Skeleton I.

PAPILLICERAS PAPIILATUM, nov. Bajocian, sauzei. Genotype, Holotype 

Fig. I

$X \quad$ lìg. 2

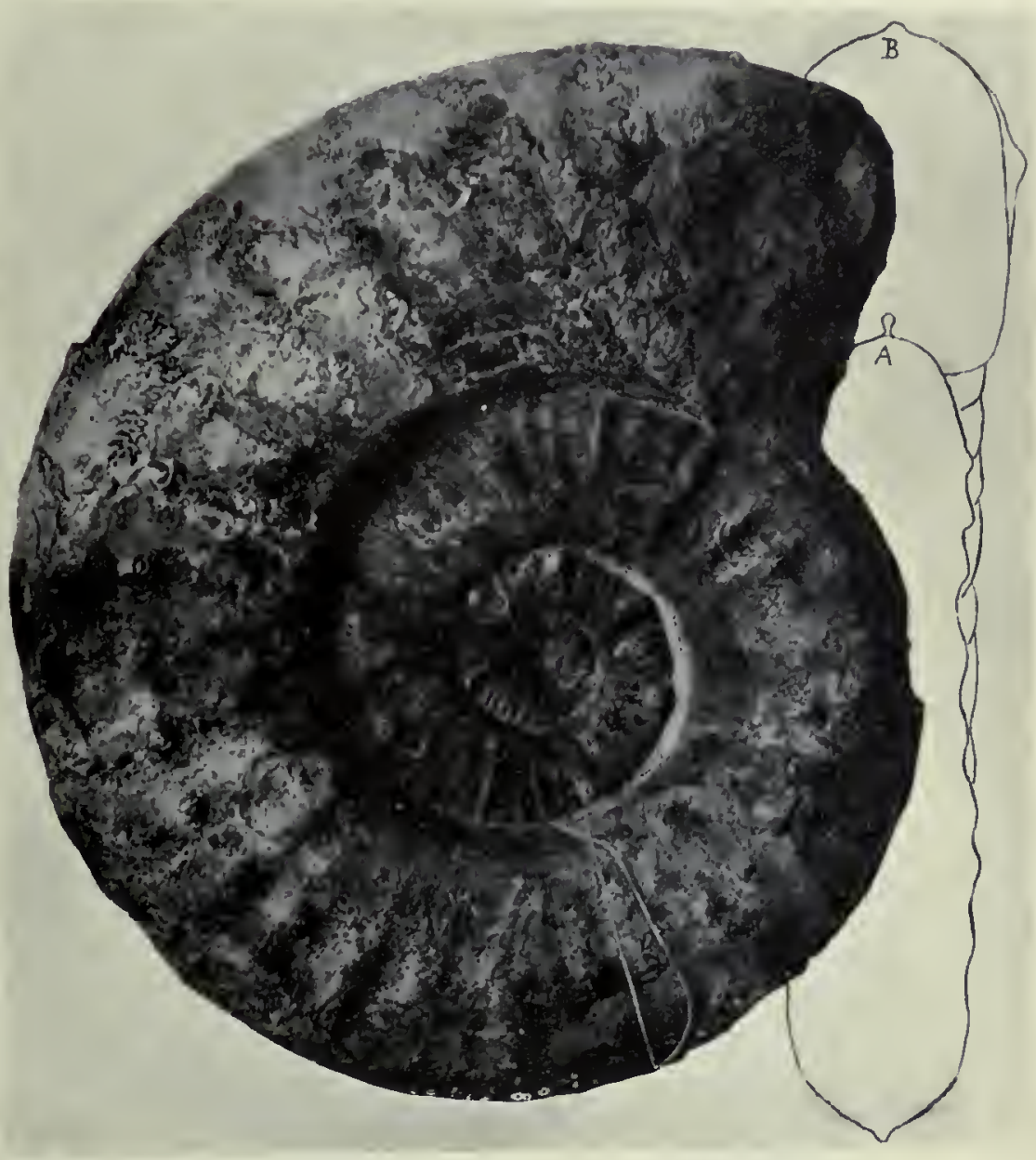

$\times 0 \cdot 6$

A mammillate Sosvisia

Fig. 2. Hollow keel, constricted by lateral grooving, strong at $A$ : a mere ridge of keel at B; S.B., ex J.B. Coll. II8I; S. 202, 33. $28(24), 40$; max. c. 250 . $x$, last s.l. 



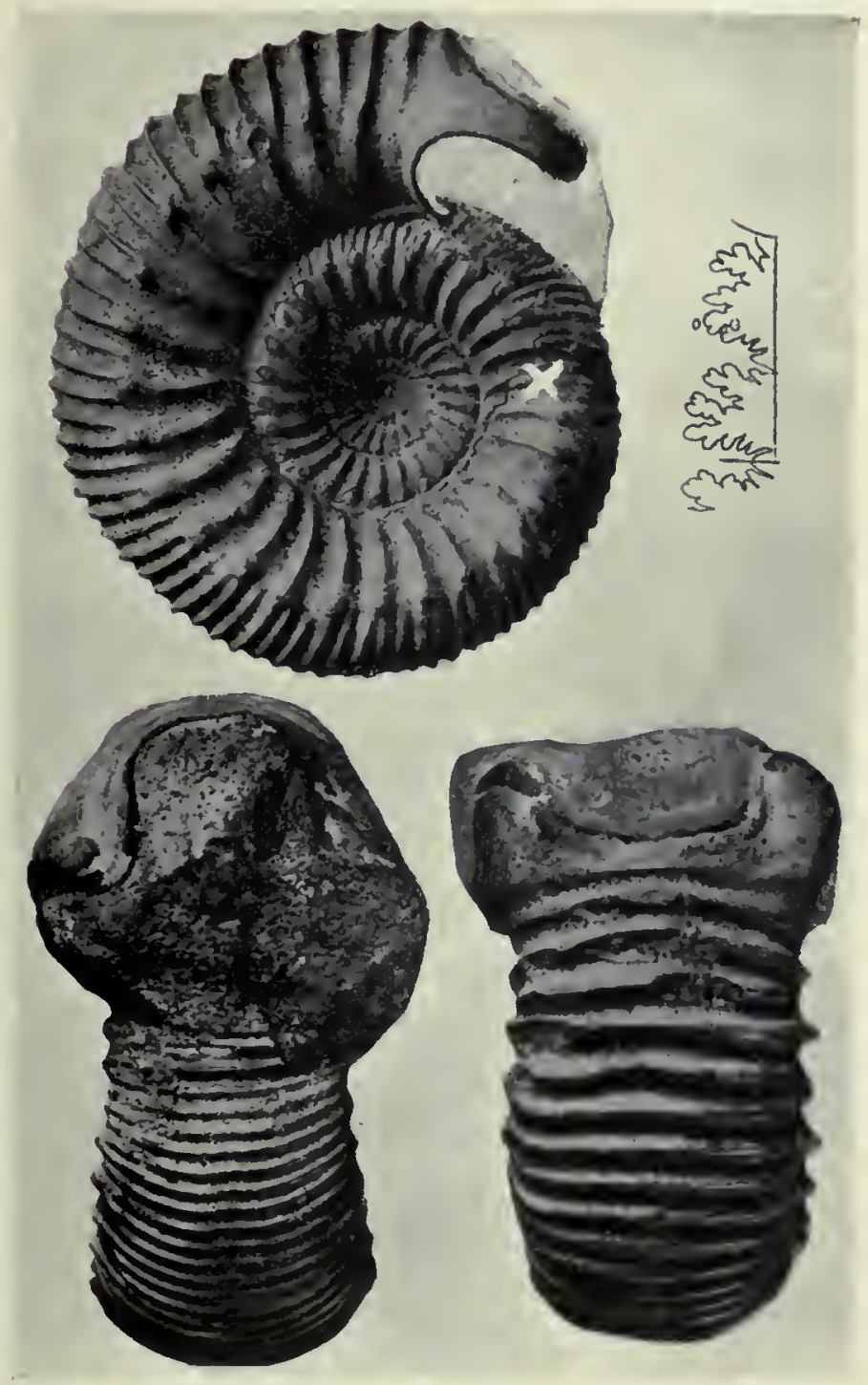

lig. 2

Fig. 3

STEPHANOCERAS BRAIKENRIDGII; S. BUCKMAN

I88I, Q.J.G.S. XXXVII, 596 ; "Frogden Quarry, Oborne, Durset ;

"Inf. Ool. Humph. zone"; Auricles incompletely grown?

S.B. Coll. $2860 ;$ S. $42,33,59,38 ; 73,30.5,41,42$

EPALXITES FORNIOSUS, nov.

Bajocian, blagdeni [Siemmatoceras]; Holotype 

Fig. I

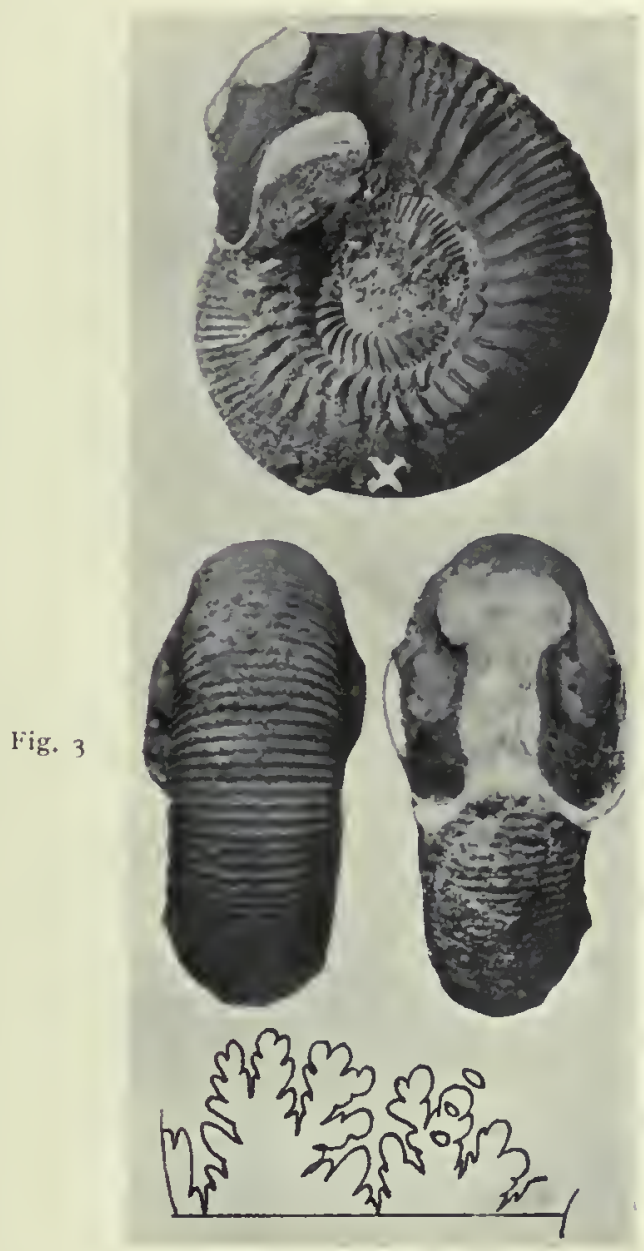

liik. 2

rig. $+\times$ c. 2

STEPHANOCERAS BRAKENRIDGII ; S. BUCKMAN

I88I, Q.J.G.S., XXXVII, 595; " [Clatcombe], Sherborne, Dorset ;

"Inf. Ool, Humphriesianum zone" ; S.B., ex J.B., Coll. 2863

S. $35,36,49,27 ; 50,31,35,40$

MASCKEITES DENSUS, nov.

Bajocian post-sauzei [Masckeites]; Genotype, Holotype 

Fig. 3

Hig. I

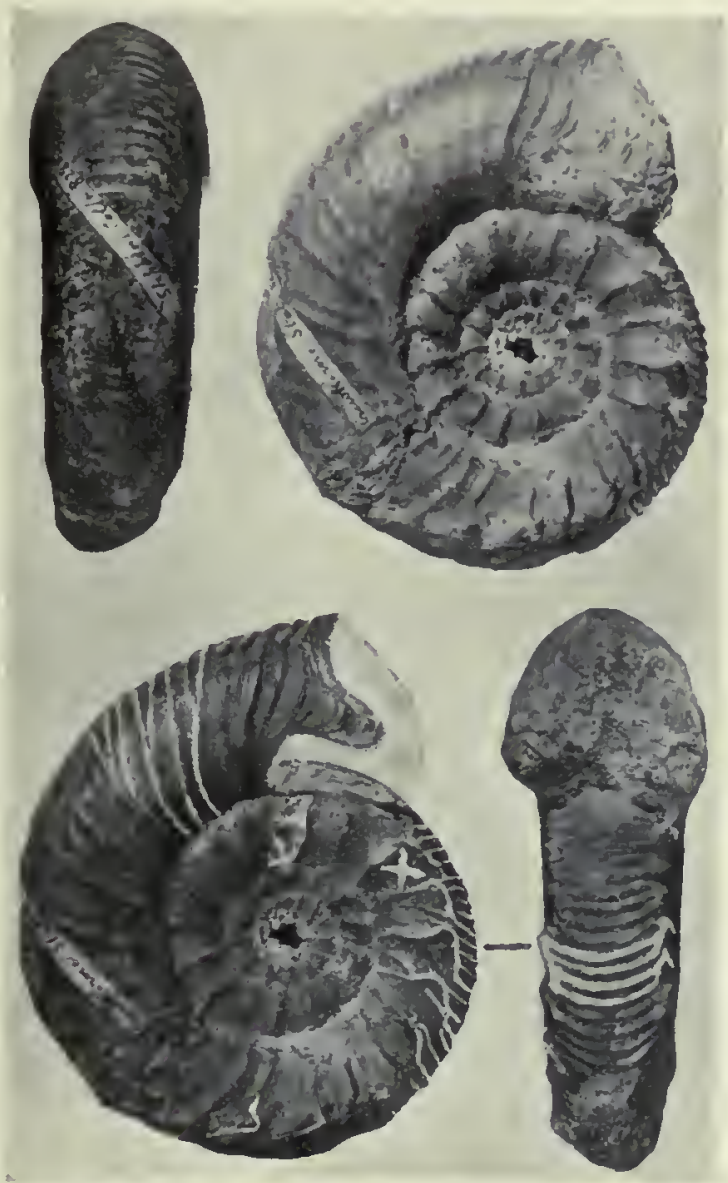

Fig. Ia

Fig. 2

STEPIANOCERAS ZIGZAG; S. BUCKMAN

I889, Q.J.G.S., NLVIII, +48, " with aperture" ; "Crewkene Station, Somerset "; "Top of Inf. Ool." S.B., ex Darell, Coll. 828. S. $34,30,41,44 ; 56,29,30,4+$. Fig. Ia, Details emphasized. 



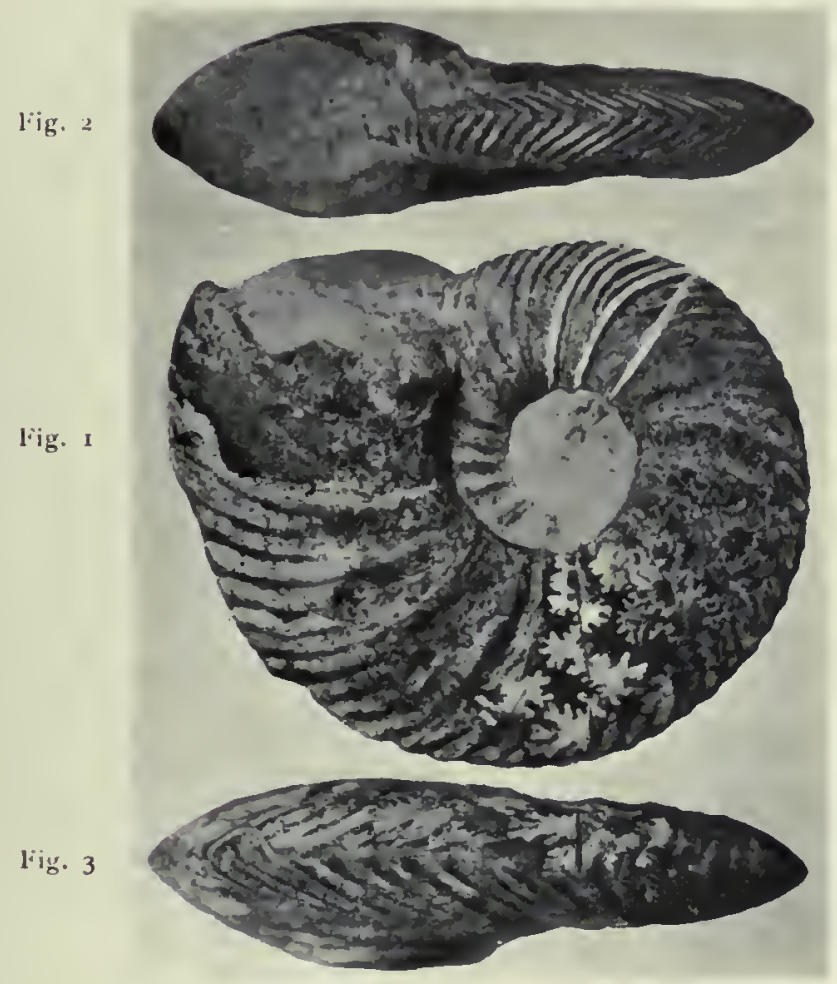

Amyonites Lauberti. J. Sowerby, i8r9; Topotype II.C. 111, 73 ; ccxlı, 3 ; " Weymouth, Dorset ; Oxford Clay " [calcarcous band] ; J.W.'. Coll. ; S. $69,43.5,27,28.5$ 



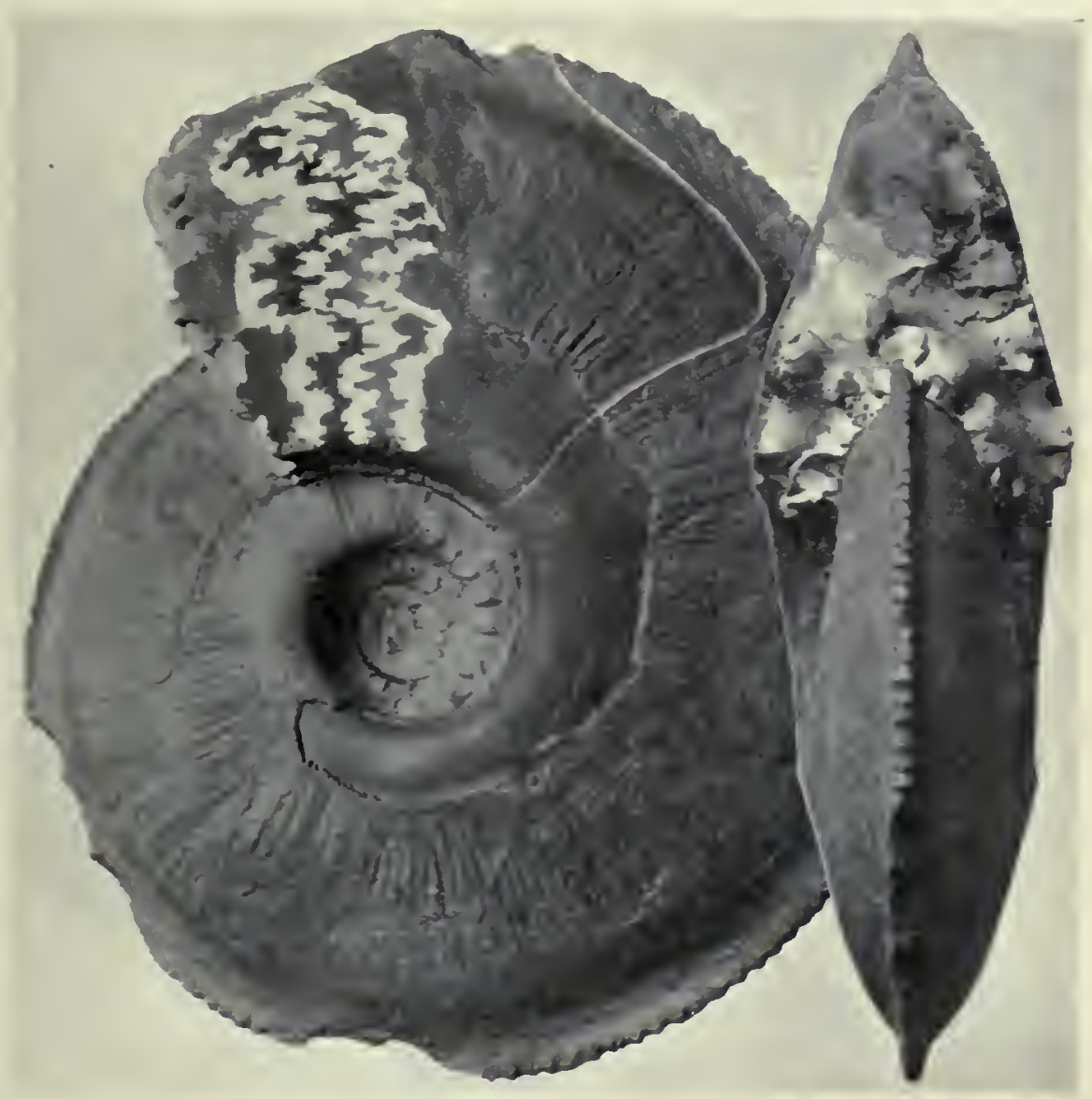

$\times 0.89$

ANMONITES SERRATLS; AUCTT.

ST. Ires, Huntingdonshire; Drift, ex Kimmeridge Clay] J.W:T. Coll. S. $124,43.5,32,22.5$; $\max$. c. I90

PRIONOCERAS PRIONODES. nor: Kimmeridgian, serratum; Genotype, Holotype 

Fig. $4, \times 1.5$

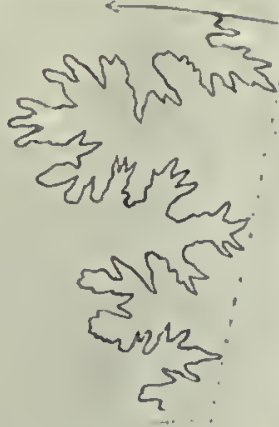

Fig. 5

Fig. I

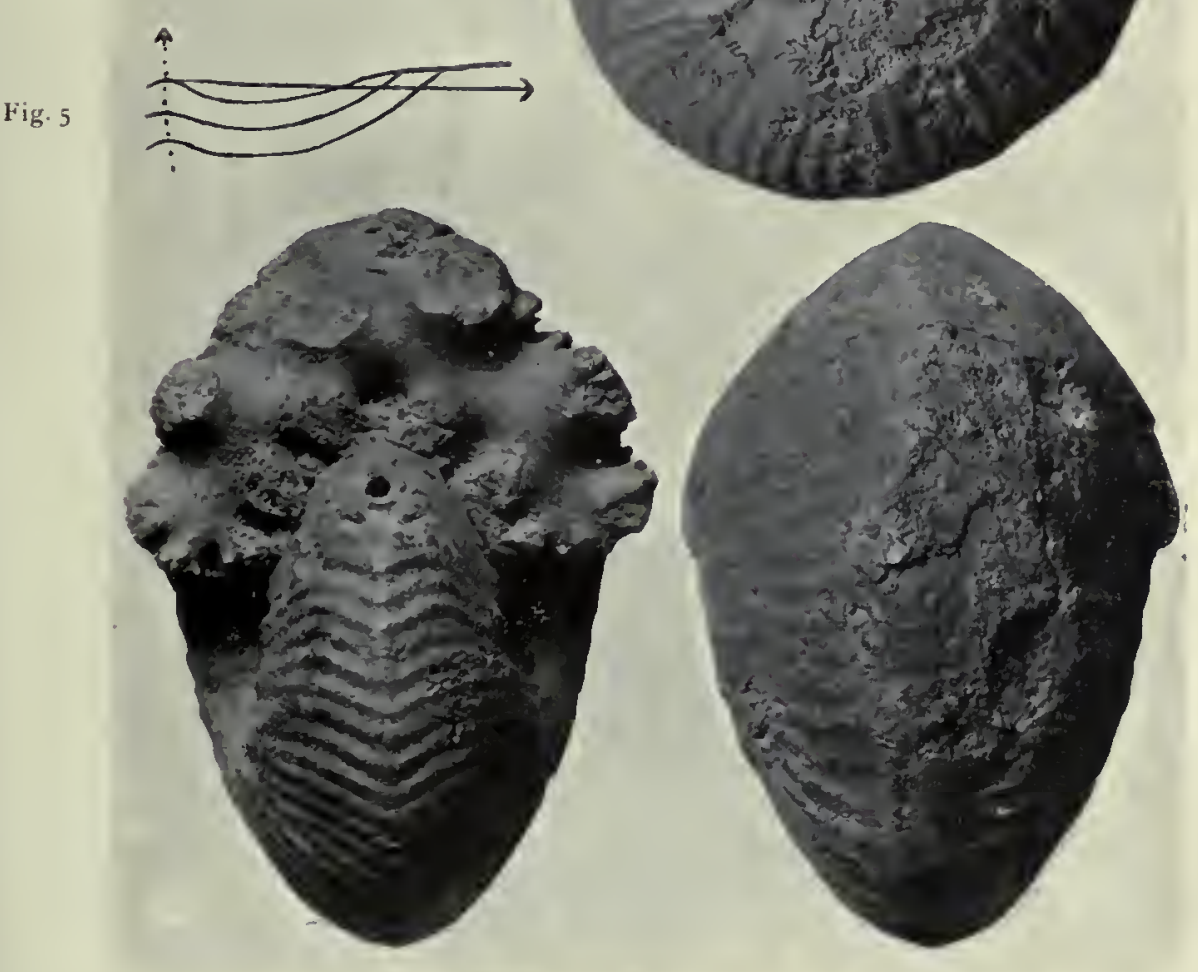

Fig. 2

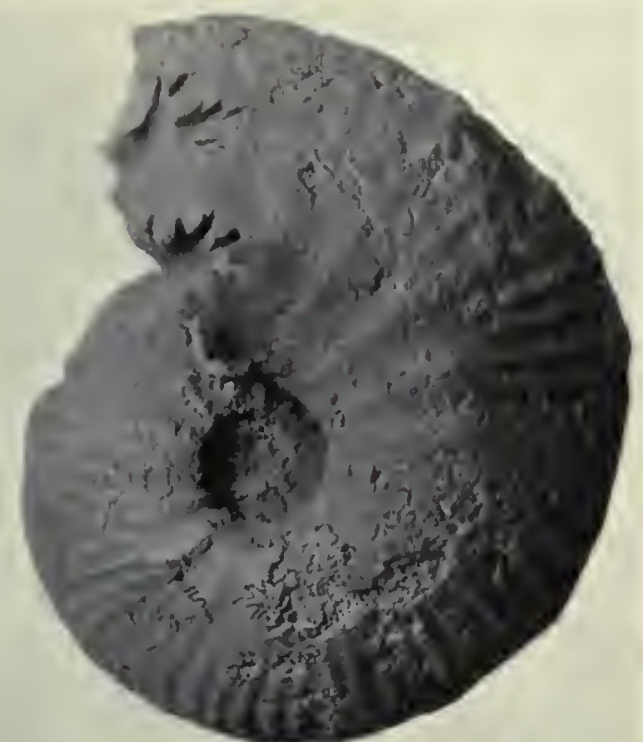



Fig. 1

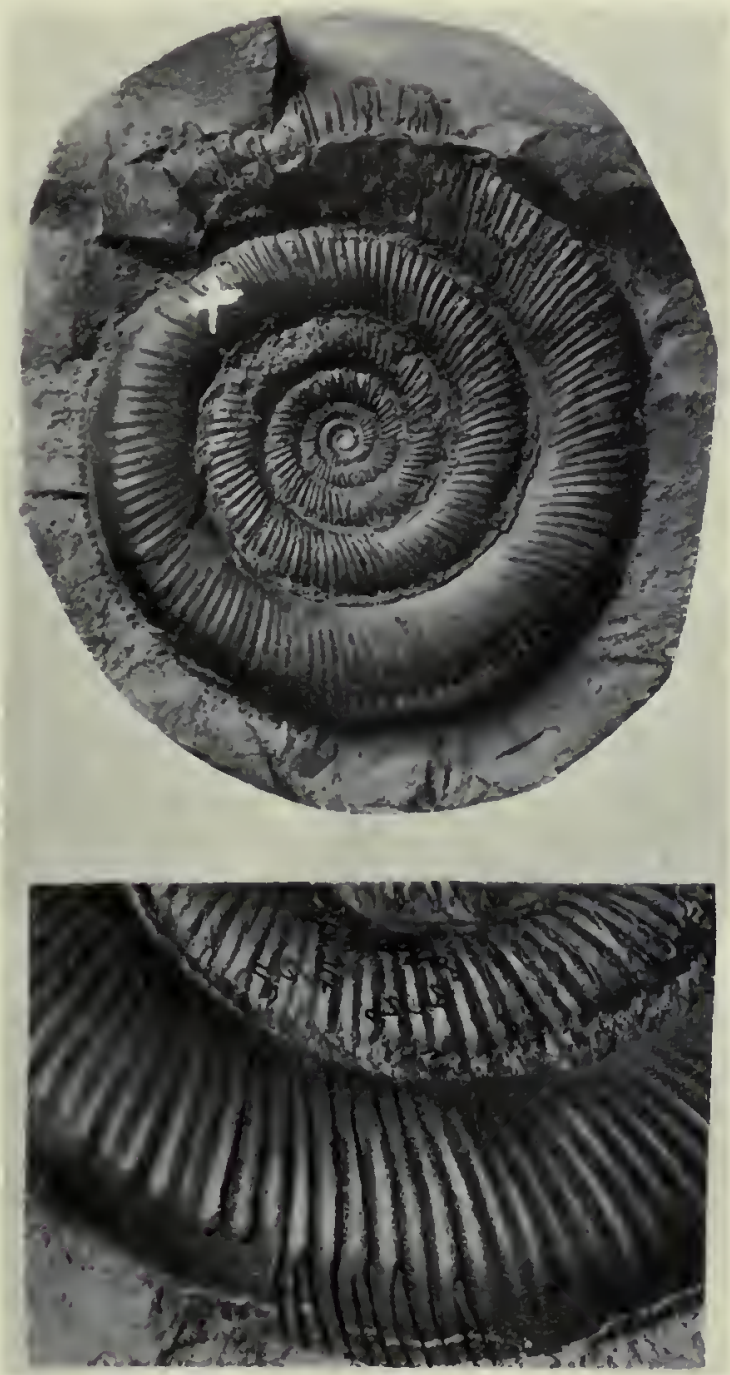

Fig. $2, \times 2$

Ammonites tenuicostatus, Young \& Bird 1822; Topotype Geol. Yorksh. 247 ; xıI, 8 ; [Whitby, Yorkshire ; Upper Lias, Grey Shales] Alice, Lady Fowler Coll. ; S.71, 24, 20?"57; See XXXI

DACTYLIOCERAS TENUICOSTATUN YOUNG \& BIRD SP. Whitbian, tenuicostatum 



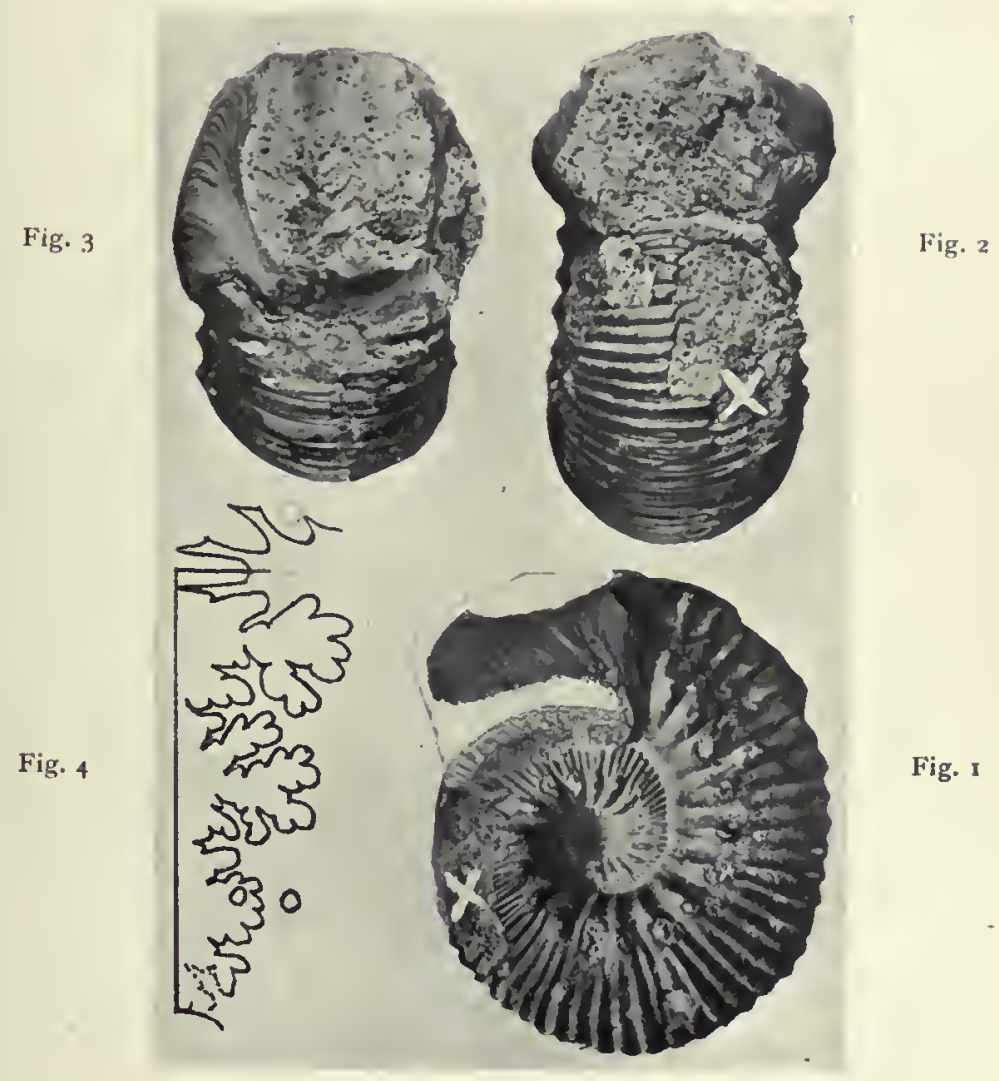

AMmonites SAUZe1; J. BuCkMAN, I88I

Q.J.G.S., XXXVII, 62 ; Spheroceras, S. B., Id., 596 ; [Sandford Lane, (Foss. Bed, top) ], " near Sherborne, Dorset, Inf. Ool."

S. B., ex J. B., Coll. $286 \mathrm{I} ;$ S. $30,4 \mathrm{I}, 78, \mathrm{I} 8 ; 5 \mathrm{I}, 4 \mathrm{I}, 49,28$. See CXLI

OTOITES CONTRACTUS, J. DE C. SOWERBY SP. 1825

Bajocian, sauzei 



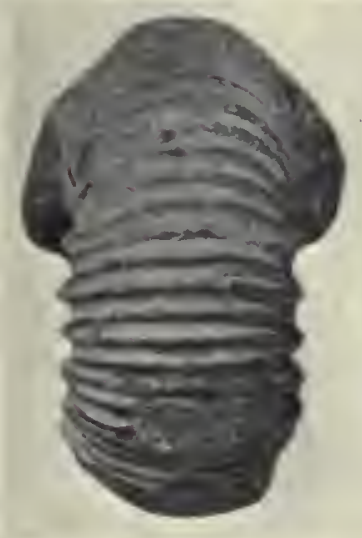

Fig. 3

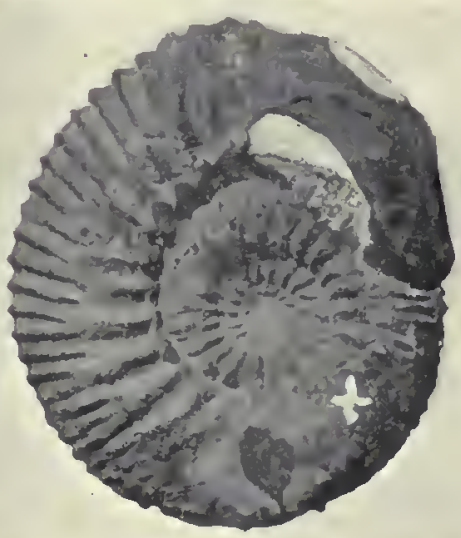

Fig. I

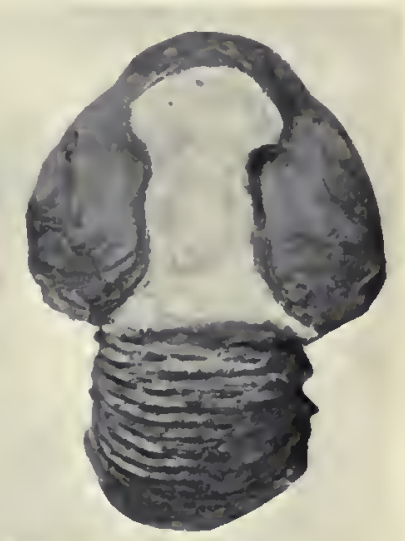

Fig. 2

Ammonites BraikenRIDgil ; J. Buckman, I88I, Plesiotype Q.J.G.S. XXXVII, 62, fig. 3 ; Stephanoceras, S. B., Id., 595 ; Clatcombe, near Sherborne, Dorset; Inf. Ool. "[Humphr. z." S.13.] Manchester Mus. (S. B. Coll.) L. III4I ; S. 54, 3I.5, 4I, 39. See CLI 



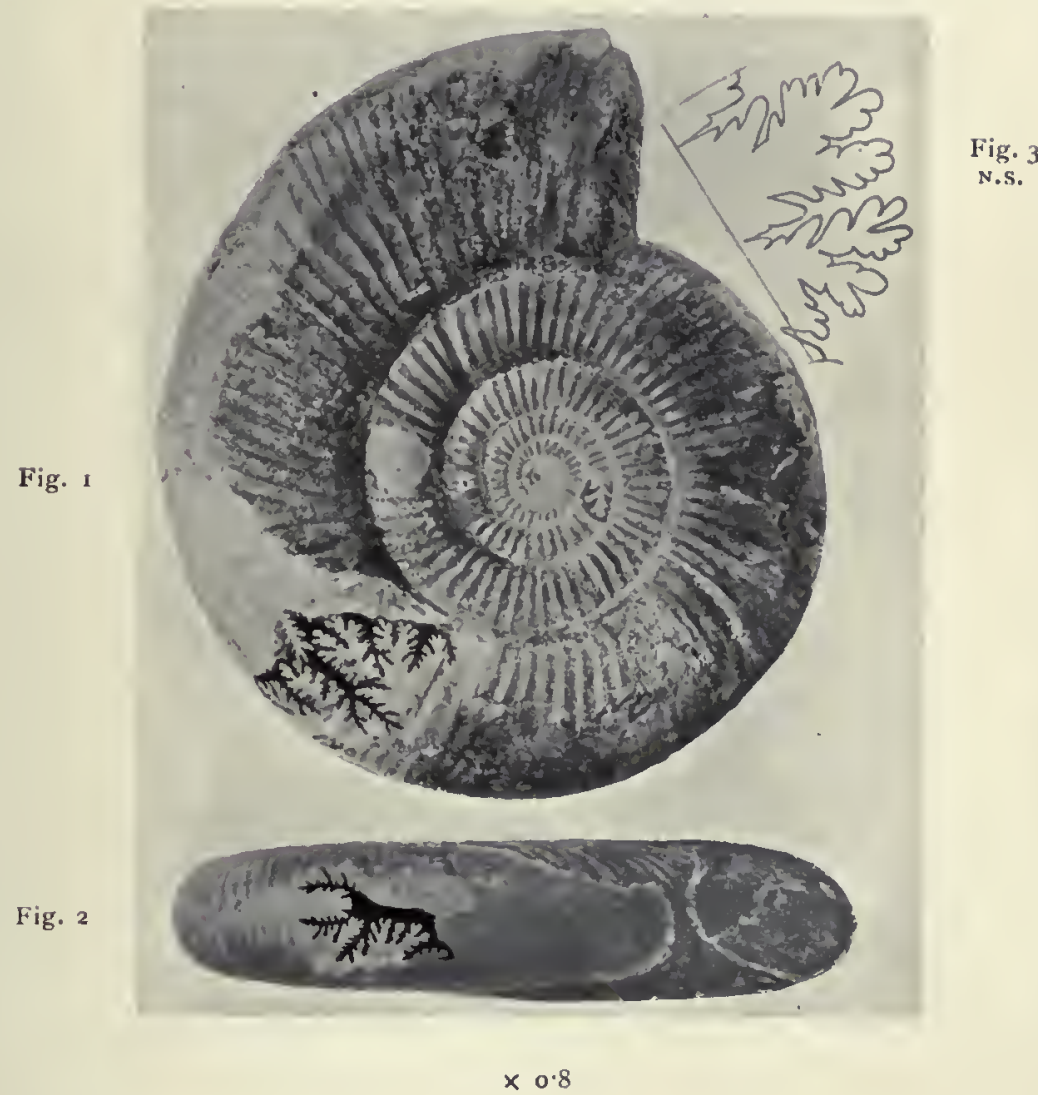

Nig. 3

"Perispintetes davidsoni

[Frogden Quarry], " Oborne, Dorset ; I. O." [Roadstone (up. part] ; S.B., cx Darell, Coll. 884; S. IOI, 32, 2I, 44; 68 ribs; IIax. c. 160

LEPTOSPHINCTES LEPTUS, nov. Bajocian, niortensis ; Genotype, Holotype 

Fig. I

Fig. 3

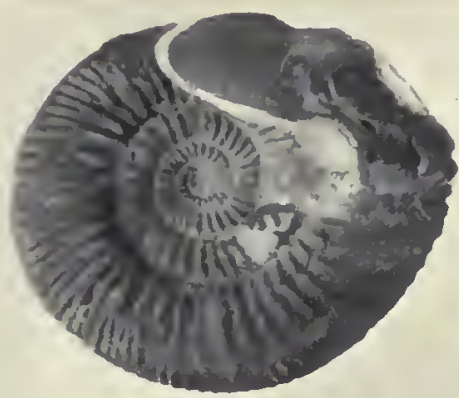

Fig. 2

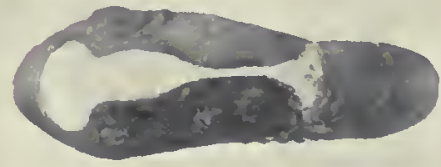

Amionites Martinsil

[Frogden Quarry, Oborne], " near Sherborne, Dorset; I.O." ;

S.B., ex Darell, Coll. 868; S. 44, 3I, 3, 47; 42 ribs.

Fig. I, Lower half of lappet restored; Fig. 2, lappet complete 

Fig. 3

N.S.

Fig. I

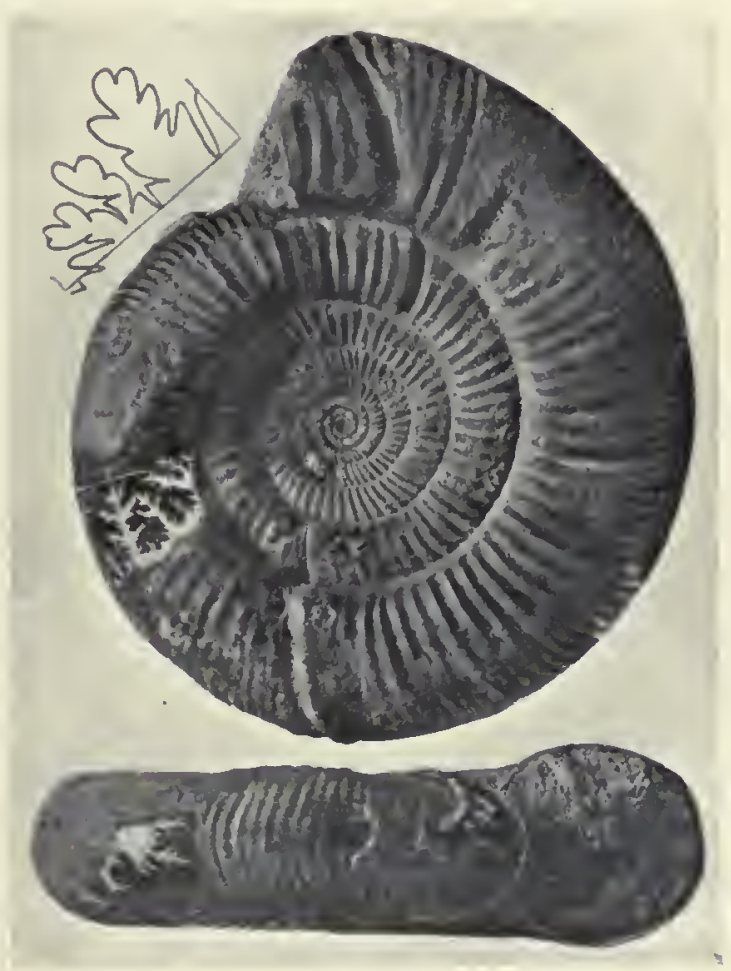

$\times 0.8$

PerisPhinctes MarTINSII; S. Buckman, I88I

Q.J.G.S., XXXVII, 602; " Half-way House, Sherborne, Dorset;

Parkinsoni zone" [Foss. Bed]; S. B. Coll. 3157;

S. $91,27.5,26.5,5$ I $; 62$ ribs; $\max$. C. 150.

VERMISPHINCTES VERMIFORMIS, nOv.

Vesulian (Eningenian); truellii; Genotype; Holotype 



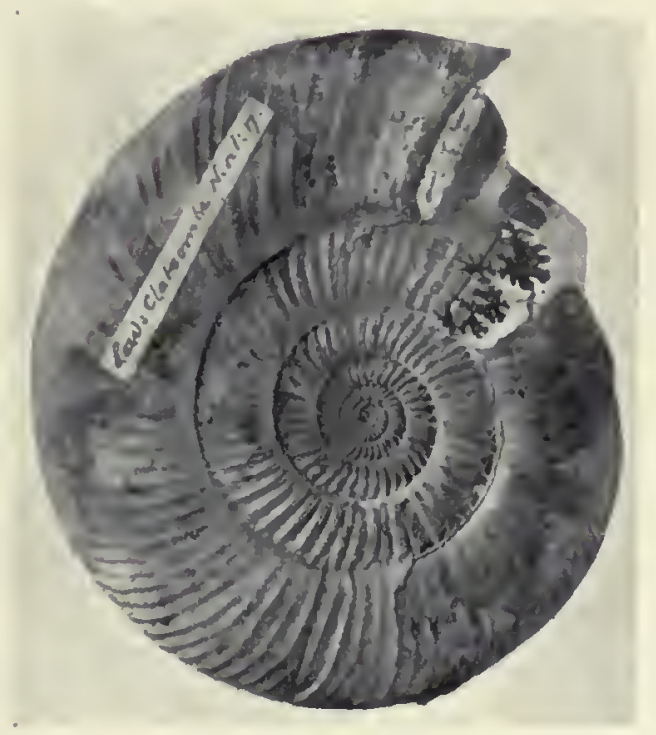

Parkinsonia caunonti, ally of, S. Buckman

I893, Q.J.G.S. XLIX, 497 ; "Lower Clatcombe (\$ xin, 7), Sherborne, Dorset ; Niortensis $\eta . "$ Mouth restored from other side; S. B. Coll., 3274; S. $67,26,20,5 I ; 68$ ribs; tuberculate nearly to body-chamber. 

Fig. 2

Fig. I

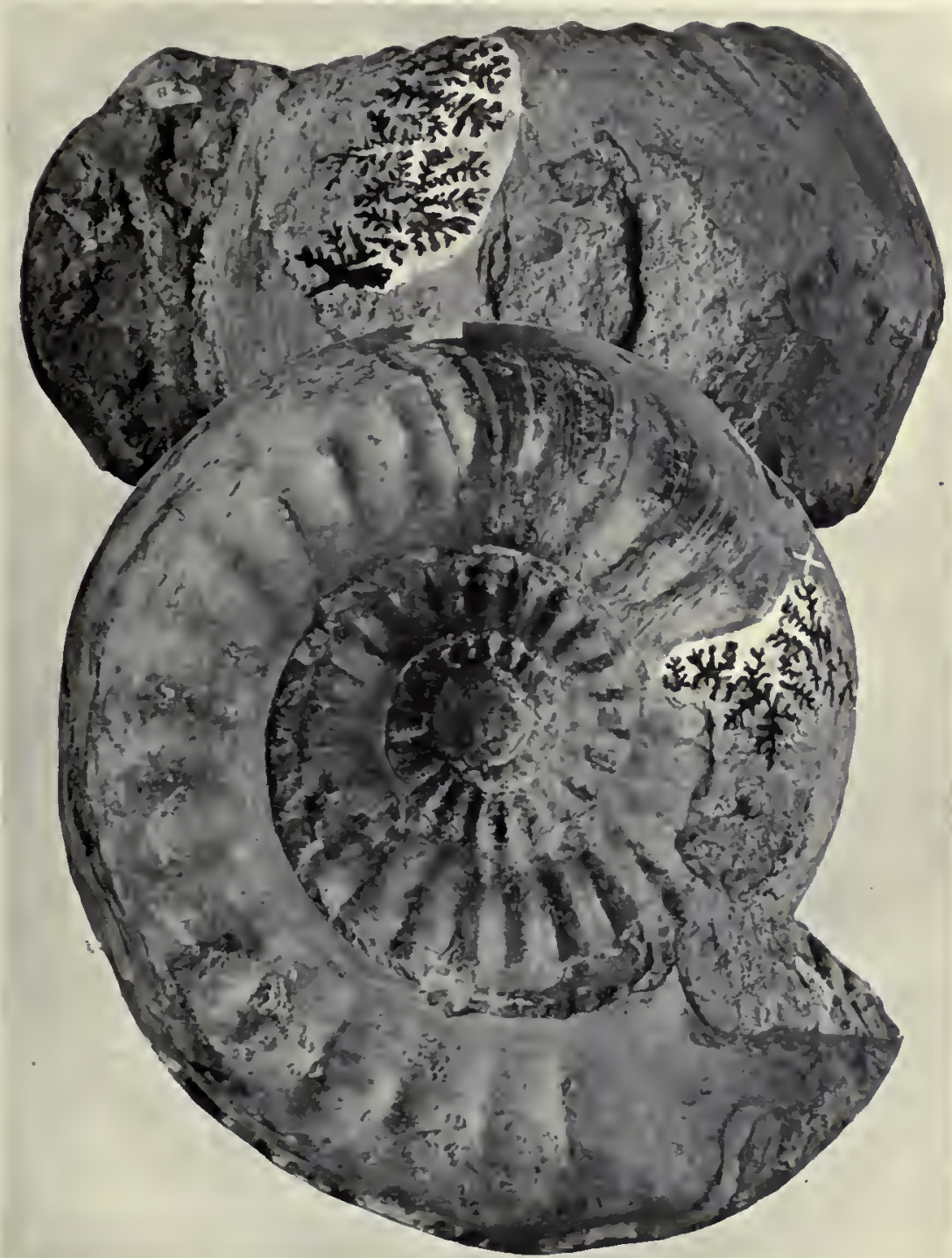

$\times 0.69$

Emrera, cadicone stage

E. crater, S.B., I9I3, Y.T.A., II, ix ; [Sandford Lane, Foss Bd. Low. pt.] "Near Sherborne, Dorset" ; Manchester Mus. (S.B., ex Darell, Coll.) L. II 270 ; S. $103,36,74,34 ; 124,36,67,34 ; 163,34,47,40$

EMILEIA CRATER, S. BUCKMAN Bajocian, Shirbuirnia; Holotype. Cf. CXXXIII 

Fig. I $x \cdot 2$
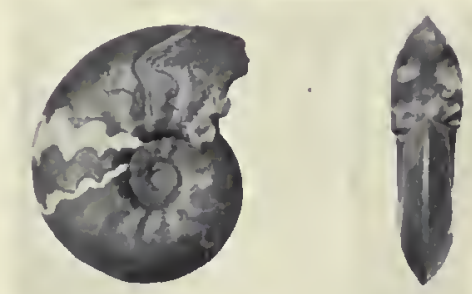

Fig. 2
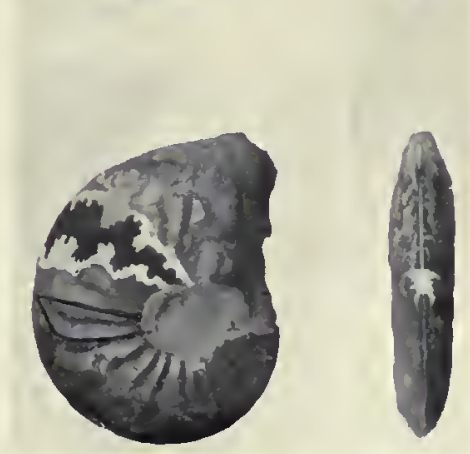

Ammonites buckit, Simpson i 843 , Holotype

Pp. 42, 43, (Fig. I), [Yorkshire] ; "Lower Lias "; " R. H. Bay" (1855, 85)

"L.L. I4" (I 884 , xxi) "Ind. b. I5" (Id. I 2 I). Whitby Mus. 479[a]

S. 13.5, 43, 27, 27. Fig. 2. "Var. a"? (I855, 85), 479[b] ; S. 20, 50, 2I, 2I

OXYNOTICERAS BUCKII, SIMPSON sP.

Deiran, polyophyllum. See CXLIII 



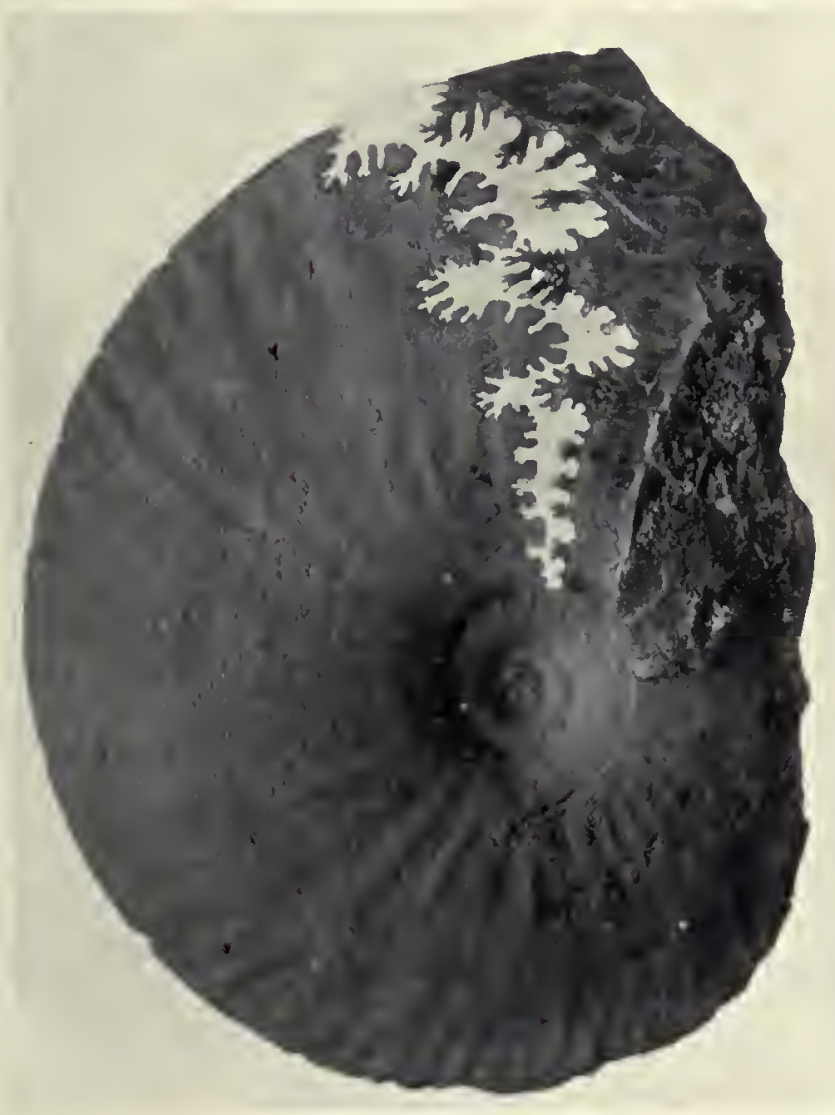

Fig. I

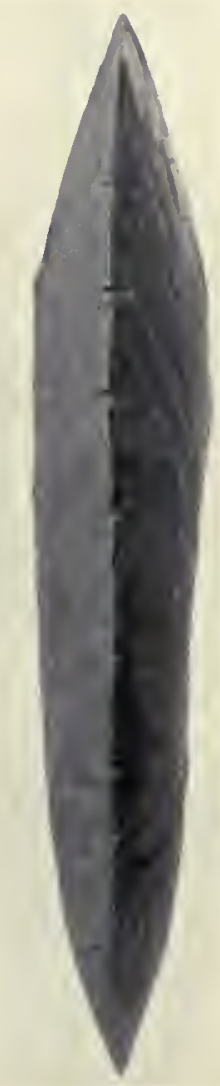

Fig, 2

\section{"OXYNOTICERAS OXYNOTUM}

"Vale of Gloucester; Lower lias, oxynotum zone"

A. Vaughan Coll.; $\phi .108,52,16.5$, I5; max. C. I70\%. See CXLIII.

OXYNOTICERAS BUCKII, SIMPSON SP.

Deiran, polyophyllum 

lig. I

Hig. 2

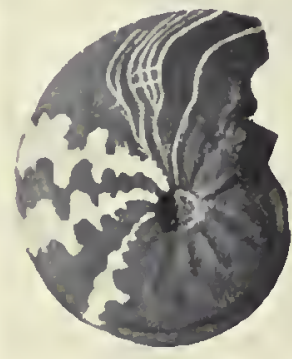

$\times 1.5$

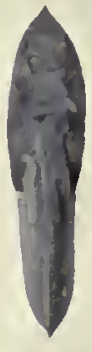

Amonites Retentus, Simpson I855, Holotype

P. 84 ; I884, pp. I20, I2 I R R obin] H[oods] Bay ; Lower Lias ;

Mus. Geol. Surv. Engl. (Clarkson Coll.), No. 2640I;

S. 23,$54 ; 2$, Io. Cf. CXLIV

RETENTICERAS RETENTUM, SIMPSON SP.

Deiran, simpsoni; Genotype 

liig. I

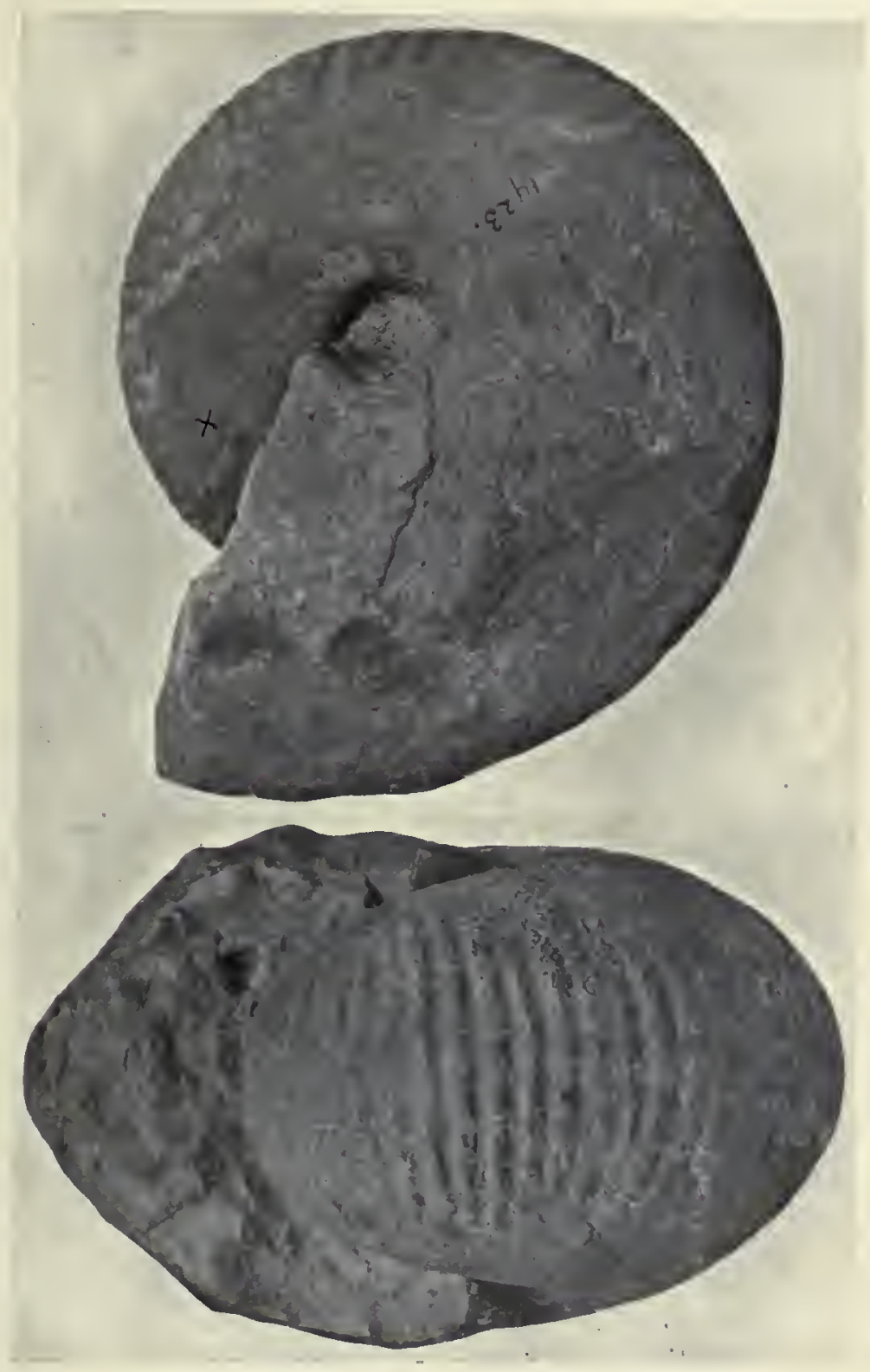

MaCrocephal.ites MORRISi; S. BUCKNAN, I89.3

Proc. Dorset N.H. \& A.F.C. XIV, 43; I895, Q.J.G.S., LI, 440 (pars) ; "Near Sherborne, Dorset" [Milborne Wick, Som.] ; Fullers' Earth Rock [Milborne Beds]; S.B., ex J.B., Coll. I923; S. 99, 51, 66, 10

MORRISICERAS SPHAERA, nov. Bathian (Falaisian), morrisi; Genotype, Holotype 



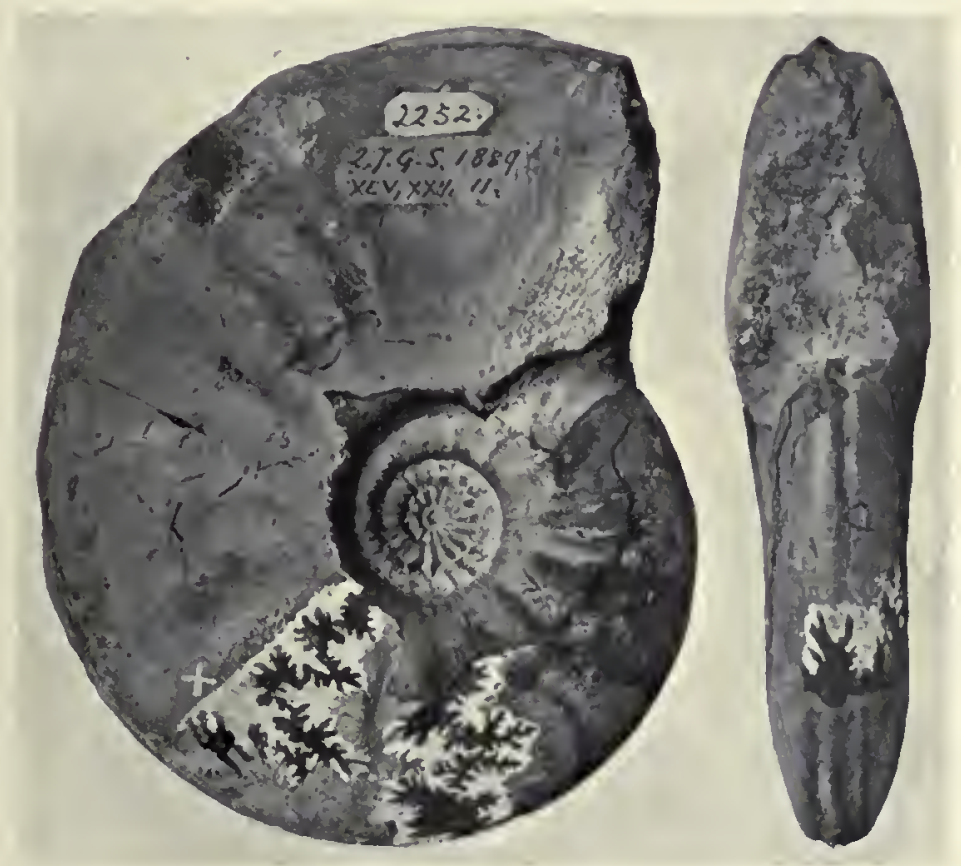

Fig. I

Fig. 2

Witcifflla leviuscula; S. Buckman, 1889, Plesiotype Q.J.G.S., XLV, 658; xxII, II ; Frogden Quarry, Oborne, Dorset (ireen-grained marl (Id. I893, XLIX, 500, § XI, 9); Nanchester 11. (S.B. Coll.) L. II 439 ; S. $85,4 \delta, 25,2$ I. Septicarina lost. Úmb. spinous

WITCHELLIA SPINIFERA, nov. Bajocian, Witchellia ; Genolectotype ; Holotype 



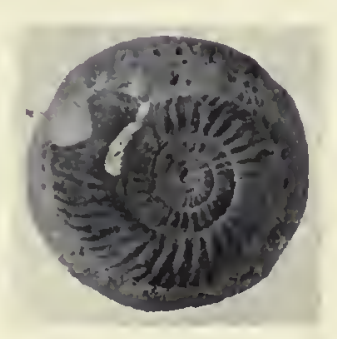

Parkinsonia caumontit

[Lower Clatcombe, (\$ XIII, 7)] "near Sherborne, Dorset"

S. B. Coll. (purch.) 3276 ; S. $24,29,25,46$

Lateral auricle broken at end. Tubercles persistent

CAUMONTISPHINCTES PHAULUS, nov.

Bajocian, niortensis; Holotype 



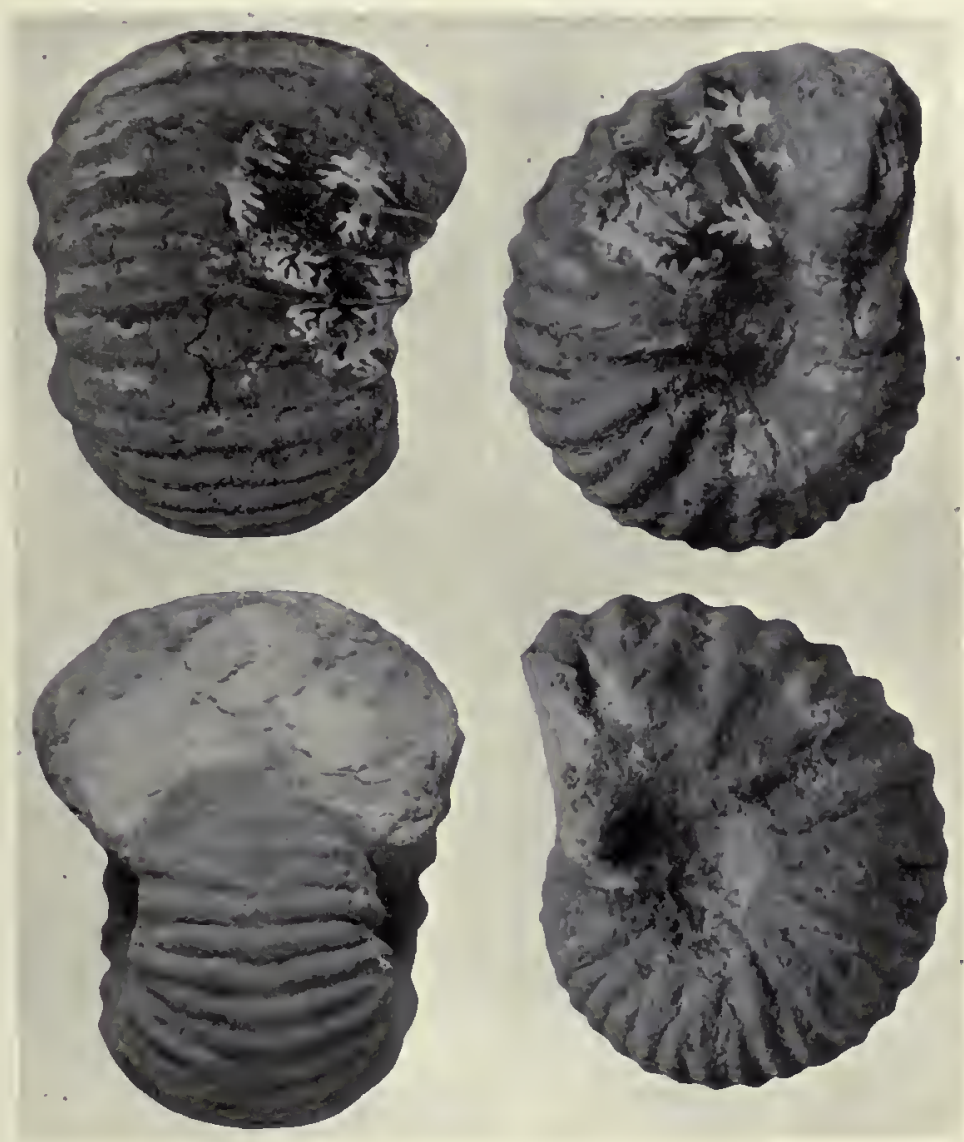

Fig. 3

Fig. 2

Quenstedticeras Pavlowt, R. Douvillé

I912, Cardioc., 74, 75 ; XI, 13; Pavloviceras, T.A., III, I8

"St. Ives, Hunts; Oxford Clay" ; J.W.T. Coll.

S. $35,40 ? 74,23 ? ; 55,43,82,25$

PAVLOVICERAS PAVLOWI, R. DOUVILLE SP.

Divesian, vertumnus; Genotype 

Fig. $I \times 0.9 \mathrm{r}$

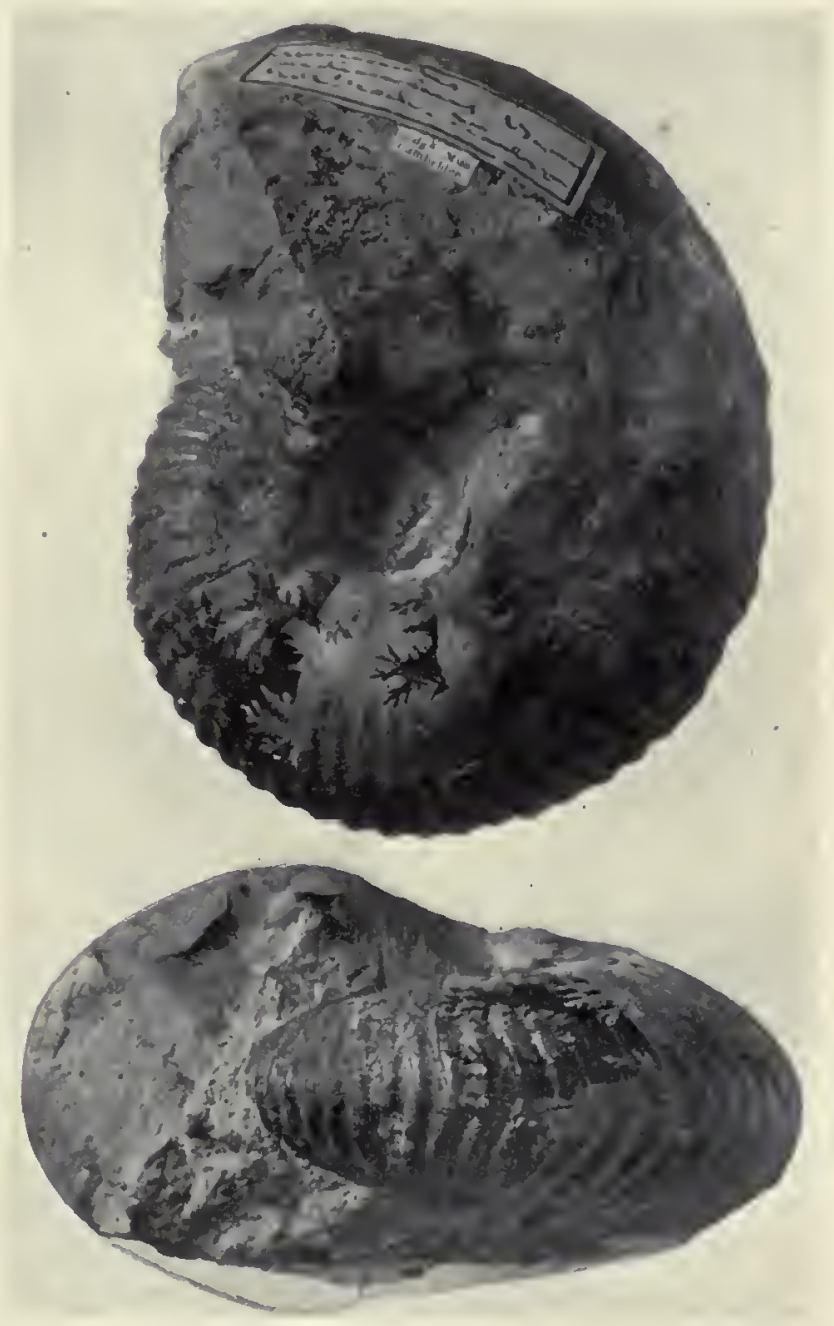

Fig. $2 \times 0.86$

"Ammonites ordinarius, Bean," Chirotype

"Kell. Rock, Scarbro" (Bean's lab.) ; Leckenby, I859, Q.J.G.S., XIV, 9

(A. lamberti pinguis, Qu. I887, xc, I5a); Sedg. M. Cambr. (Leck. Coll.)

S. $66,47,54,19.5 ; 94,50,59$, I9; max. c. 200 . See CXVIIIA

EBORACICERAS ORDINARIUM, BEAN-LECKENBY SP. I859 Divesian, vertumnus; Holotype 

Fig. I

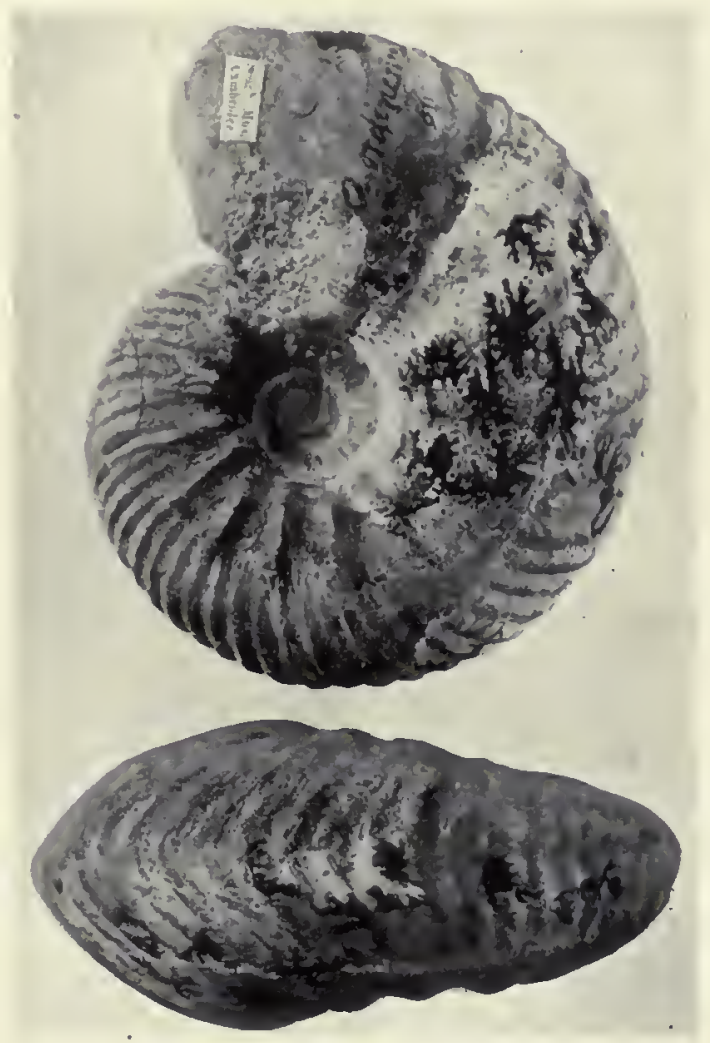

Fig. 2

"Ammonites ordinarius" (Bean) Leckenby I859 (Paratype?) Q. J.G.S., XIV, 9; Gristhorpe Bay, Yorks; Kell. R.; blue argill. (A. lamberti pinguis, Qu. I887, xc, I5) ; Sedg. M. Cambr. (Leek. Coll.) S. $50,46,46,22 ; 66,45,5 I, 2 I ; 15$ ribs; $\max$. e. 95 . Sce CLXXI. 

Fig. $1 b \times 1{ }^{\prime} 3$

Fig. I

Fig. 3

Fig. 2
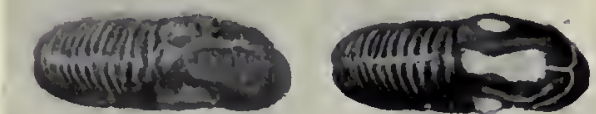

$\times 0.93$
Fig. 32

Fig. Ia

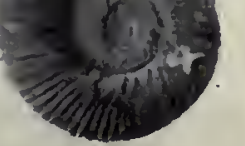

(19)

. 32

Fig. $2 a$

"Morphoceras PSEUdO-ANCEPS"

Broad Windsor, Dorset; Inf. Ool. (top beds)

S.B. Coll. 3272 ; S. 29, 33, 28.5, 40

Mouth with ocular and brachial apertures open

EBRAYICERAS OCELLATUM, nov.

Vesulian (Eningenian), zigzag; Genotype, Holotype 

Fig. $1 b \times 1 \cdot 3$

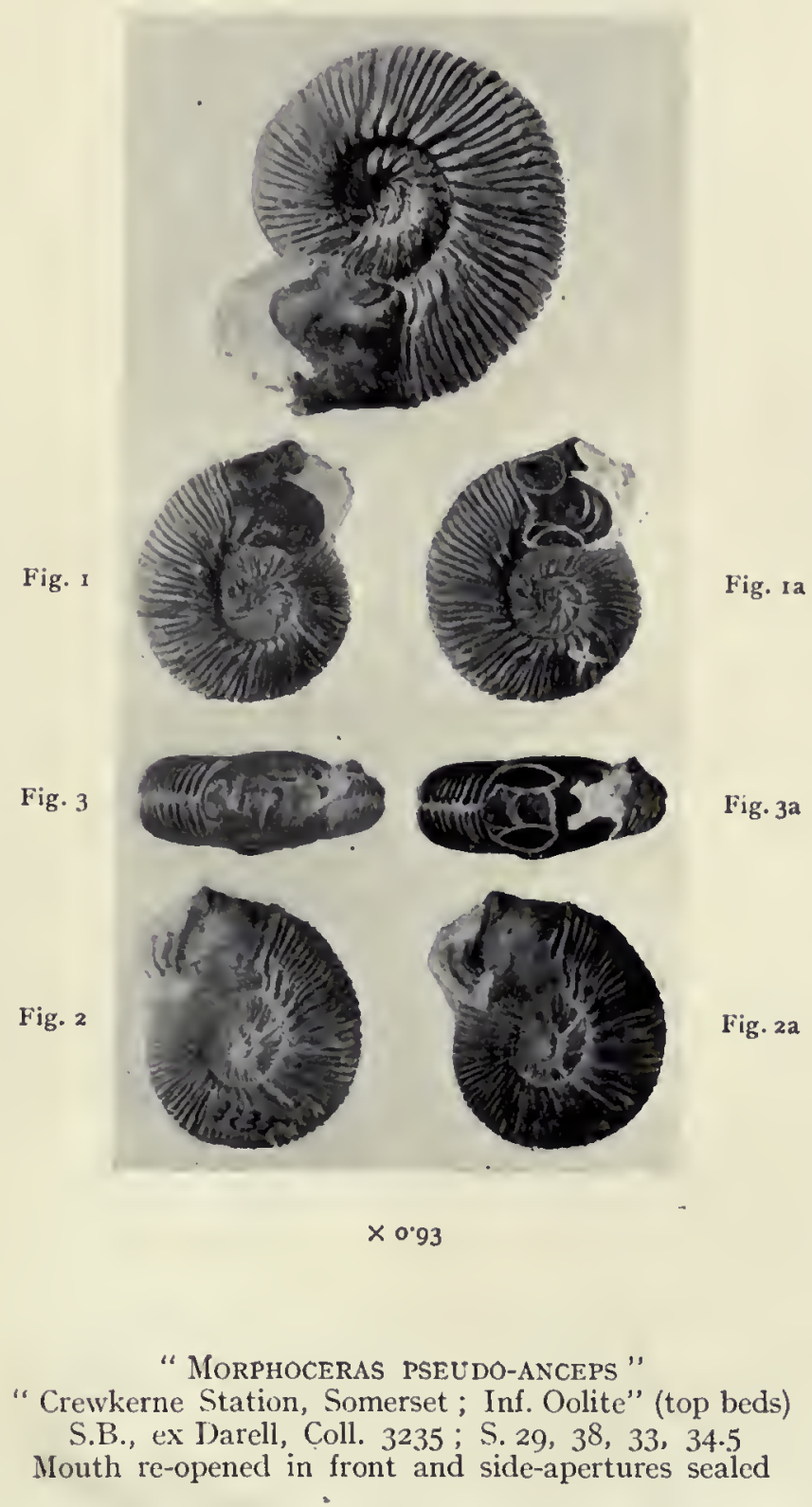

EBRAYICERAS PSEUDO-ANCEPS, EBRAY SP. I864 Vesulian (Eningenian), zigzag. See CLXXIII 

Fig. I

\section{Fig.}

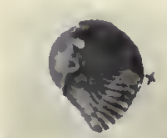

Fig. 2

$\times 1 \cdot 3$

Fig. 3

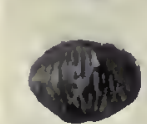

$\times 13$

एक

Oecoptchus (sphærocone stage)

Burton Bradstock, Dorset, Inf. Ool. [Terebratula Bed]

S.B., ex Darell, Coll. I I 5 ; S. $8.5,57,76$, 一.

CECOPTYCHOCERAS GROSSOUVREI, BRASIL SP. I893

Vesulian (Eningenian), tmellei 

Fig. I

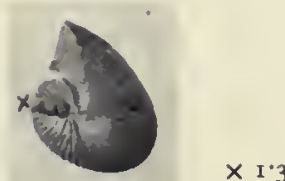

Fig. 2

$\times I \cdot 3$

Oecoptychius grossouvrei; S. BuckMan, i 898 Q.J.G.S., LIV, 456 ; "Cf. O. grossouvrei," S.B., T.A., III, I9I9, 7 Broad Windsor, Dorset; I.O. ; S.B. ex Stubbington, Coll. 382 S. I0.75, 58, 48, - Mainly cast. A goniocone. See CLXXV

ECOPTYCHOCERAS SUBREFRACTUM, S. BUCIEMAN MS. SP. Vesulian (Eningenian), truellei; Genotype, Holotype 

$\begin{array}{lll}\text { Fig. I } & \text { Fig. } 2 & \text { Fig. } 3\end{array}$

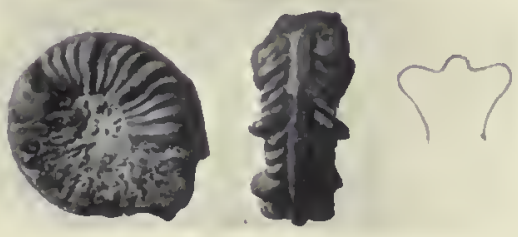

$\times 1 \cdot 3$

An acmic OpPELID

Vetney Cross, Bridport, Dorset; Inf. Dol., (Shell Bed) S.B. Coll. 3265 ; S. $15,40,53(40), 28$ Intermittent large costre bullate latero-peripherally

DIPLESIOCERAS DIPIESIUM, nov.

Vesulian (Eningenian), garantiana; Genotype, Holotype 



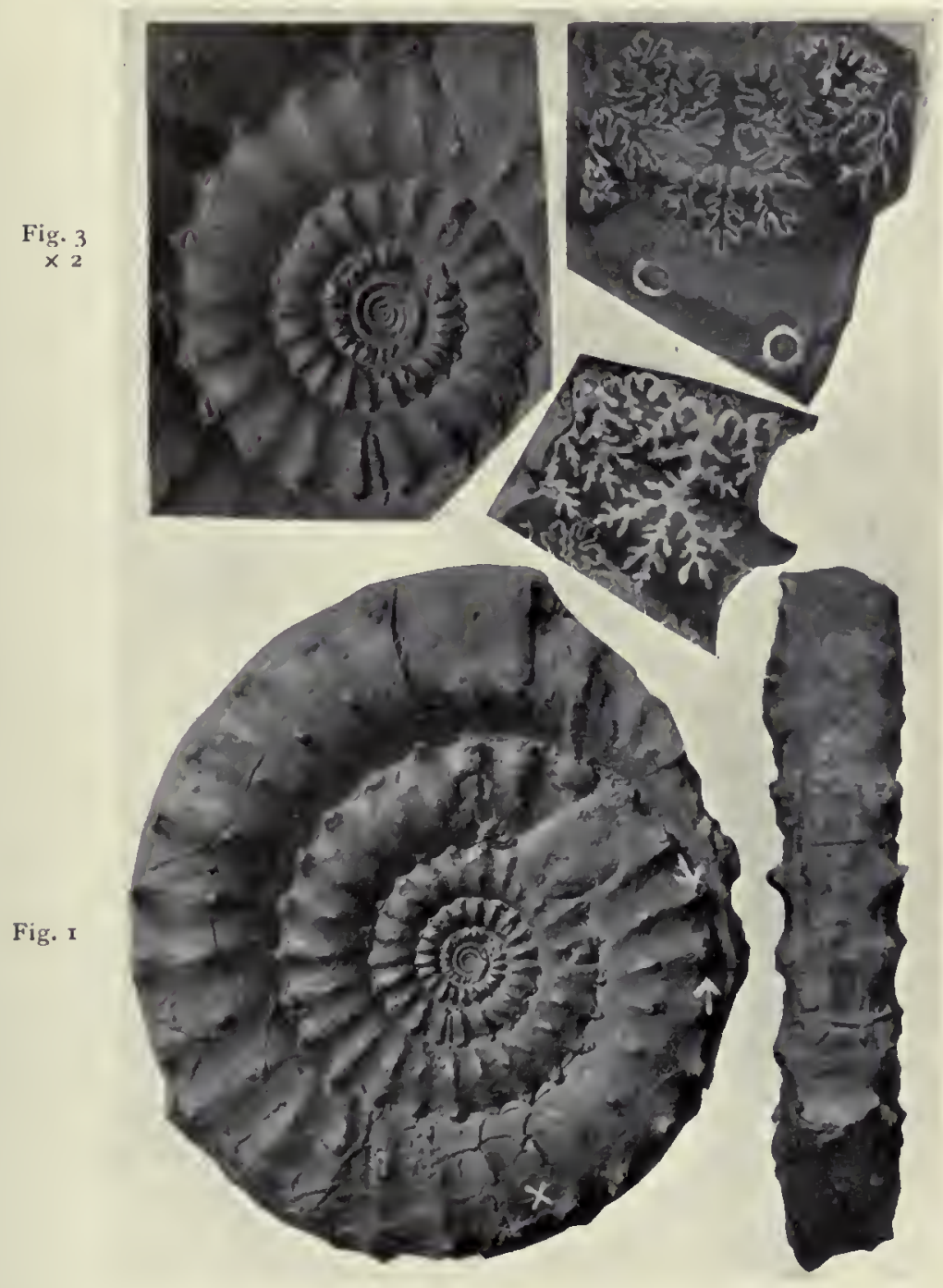

Fig. 4

$\times 2$

IFig. 5

$\times 2$

Fig. 2

"Microceras DENSINODUM"

[Folly I.ane, Cheltenham, Glos; Mid. Lias, armatum]

J.W.T. Coll., S. 79, 24, I9 (I7), 5t; max. c. II 2 ; body-ch. c. I 1 whorl Orn., I to c. 3,2 to c. 5,4 to c. 8,5 to c. I 3 mm. diam.

CRICILOBICERAS CRUCILOBATUM, nov.

Raasayan, densinodum; Genotype, Holotype 



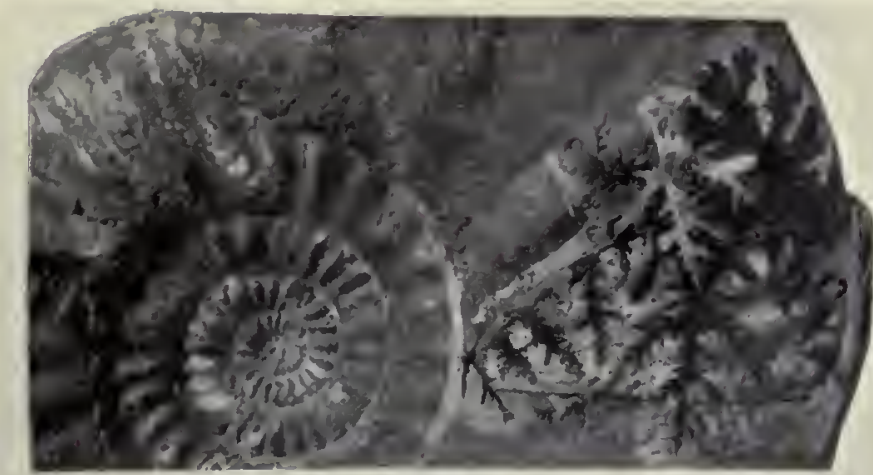

Fig. 3.

N.S.

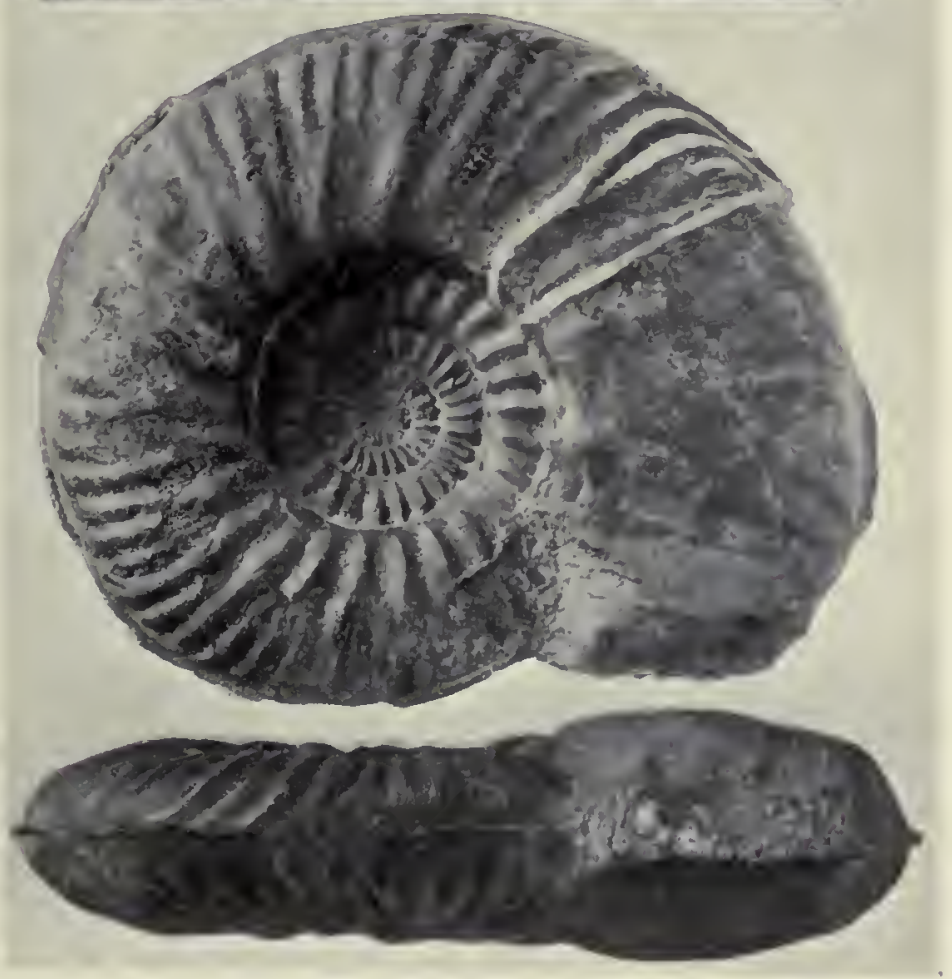

Fig. $x$

$\times 0.77$

Fig. 2

$\times 0 \div 82$

HAMMATOCERAS SP.

Bradford Abbas, Dorset; Inf. Ool. (Foss. Bed [about middle]) S.B. Coll. 3328. S. II5, 39, 27 (24), 32 ; [max. 320, No. I896] Septicarinate. No body-chamber

EUDMETOCERAS EUDMETUM, nov.

Bajocian, discites [Eudmetoceras]; Genotype, Holotype 



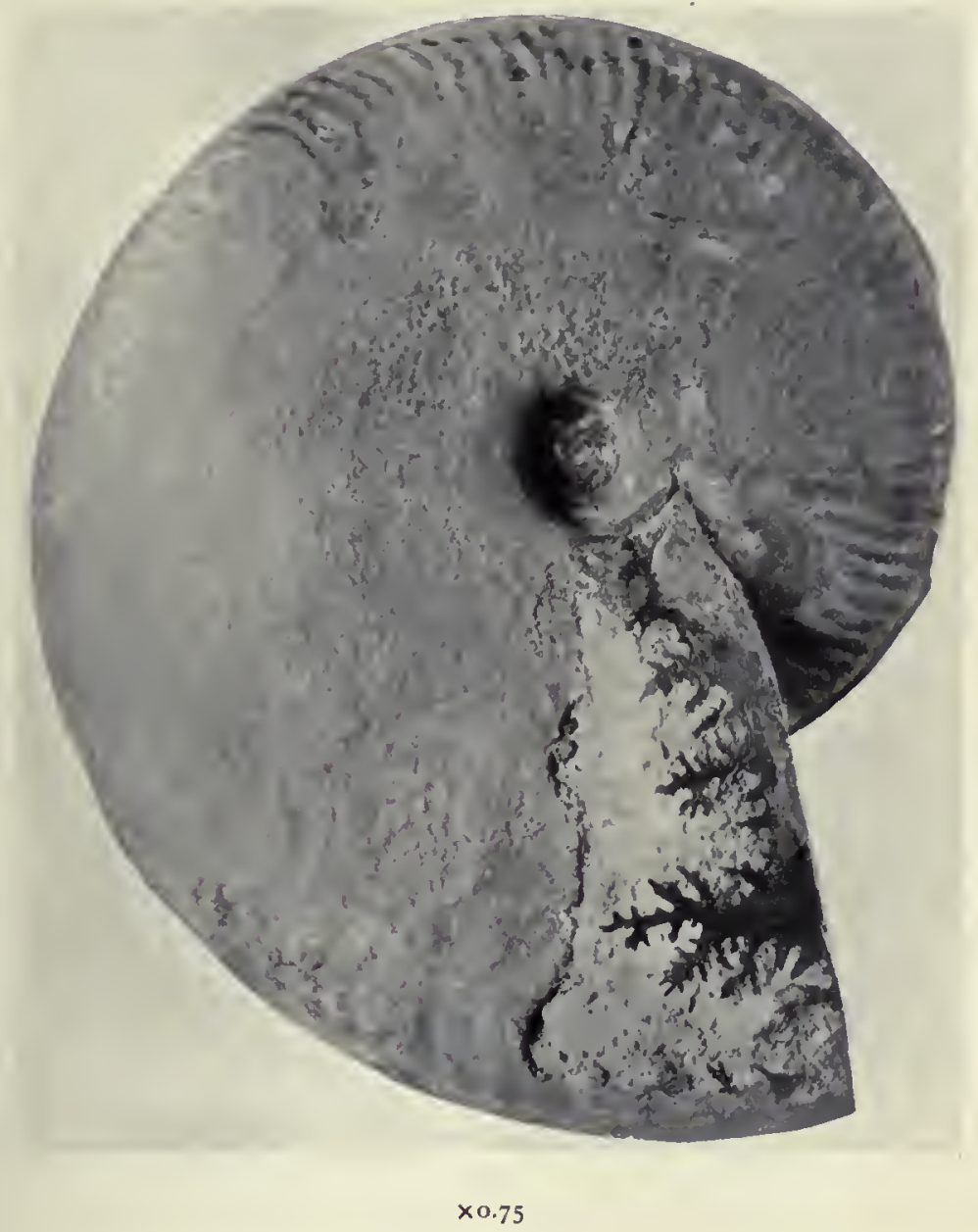

Hammatoceras amplectens, S. Buckman I889, Holotype Q.J.G.S. XLV, 662 ; " Bradford Abbas, Dorset ; Inf. Ool. concavum z." (Foss. Bed, [about middle]) ; Manchester Mus (S.B. Coll. 482) S. I $68,52,27$, II.5; max. c. 260 . See CLXXIX

EUDMETOCERAS AMPLECTENS, S. BuCKMAN SP.

Bajocian, discites [Eudmetoceras] 



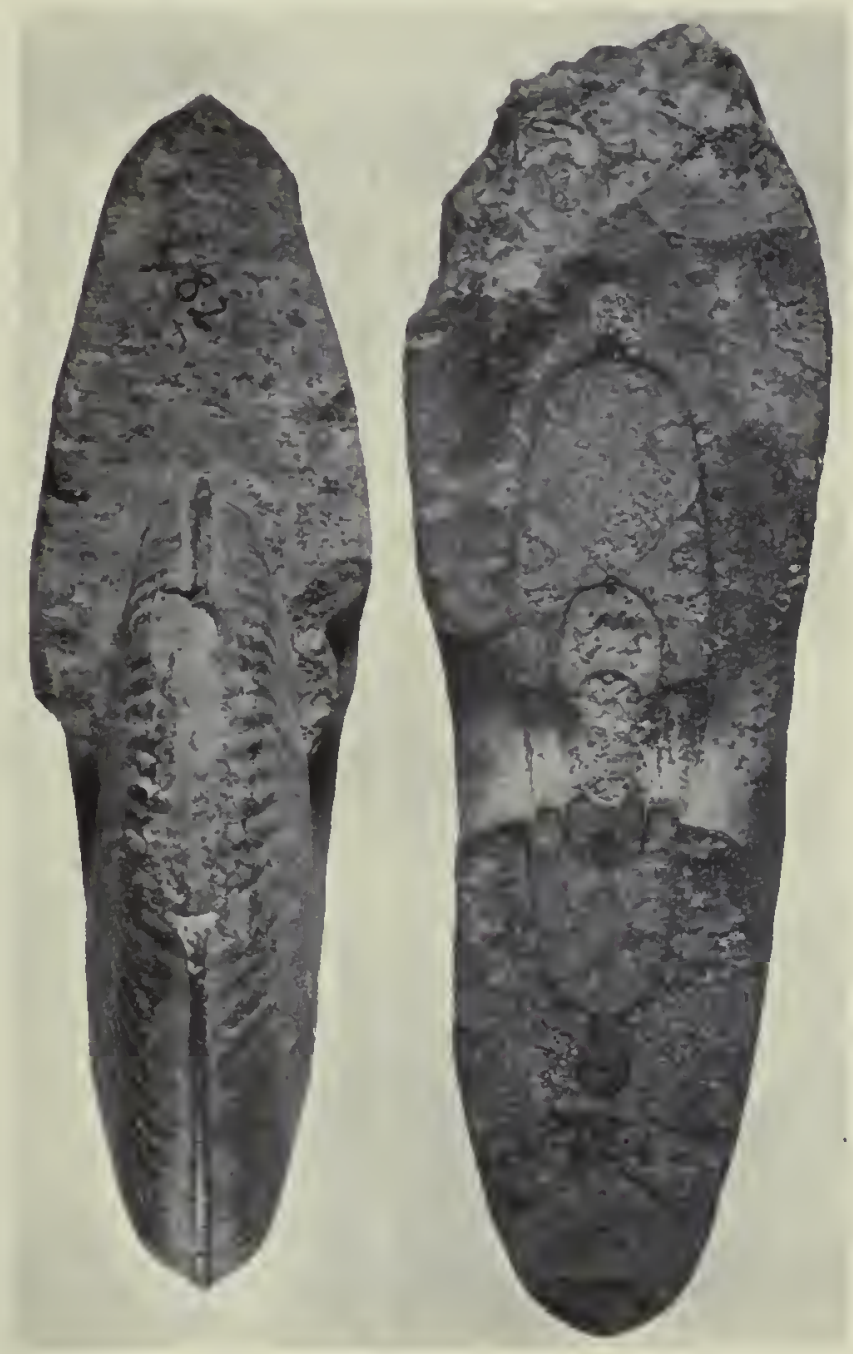

HAMMATOCERAS AMPLECTENS, S. Buckman I889

Fig. I, Holotype. Fig. 2, Paratype; Loc. etc. Id.

S.B., ex J.B., Coll. 3342 ; S. c. $30,43,37,33^{\circ} 5 ; 69,49,29,16.5$ S. I03, 52, 3I, I2.5; $138,48,3 \mathrm{I}$, II $_{5}$. . Gerontic swelling carly

EUDMETOCERAS AMPLECTENS, S. BUCKMAN SP. Bajocian, discites [Eudmetoceras] 



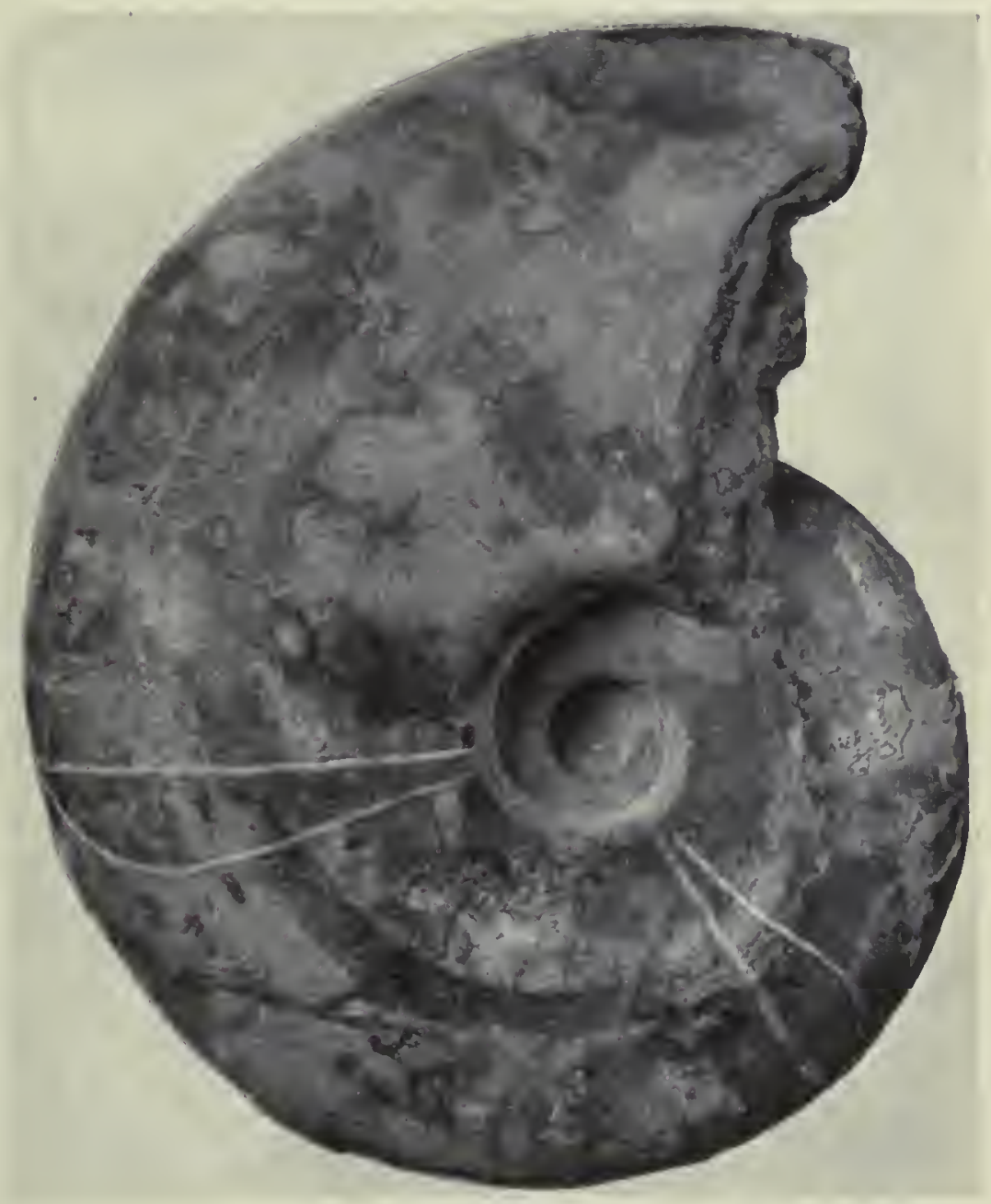

$\times 0.66$

Harpoceras fissilobatum; S. BUCKMAN I 88 I

Q.J.G.S. XXXVII, 603; Sonninia, Id. I893, XLIX, 494

Fissilobiceras, S.B., I9I9, Y.T.A. II, xv; S.B., ex J. B., Coll. 554

FISSII,OBICERAS FISSILOBATUM, WAAGEN SP. I86,7 Bajocian, Shirbuimia; Genotype 



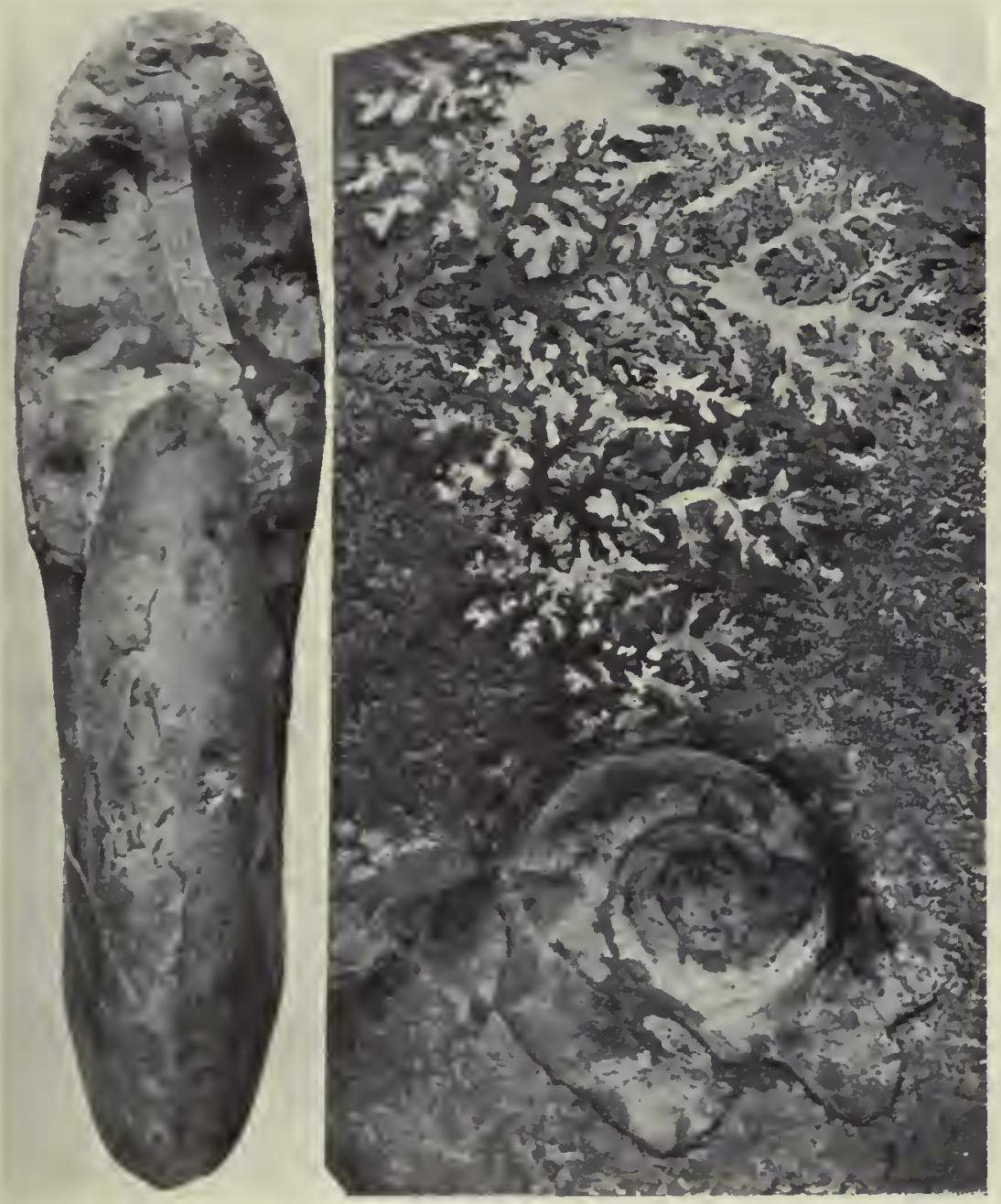

HARPOCERAS FISSILOBATUM; S. BUCKMAN I88I

" [Sandford Lane], Sherborne, Dorset; Inferior Oolite

[Fossil Bed (lower part)]; S. B., ex J. B., Coll. 554

S. 202,5 I 28 , I8; max. c. 420 . Septicarina obsolescent

FISSILOBICERAS FISSILOBATUM, WAAGEN SP. I867 Bajocian, Shirbuirnia; Genotype 

Fig. 2

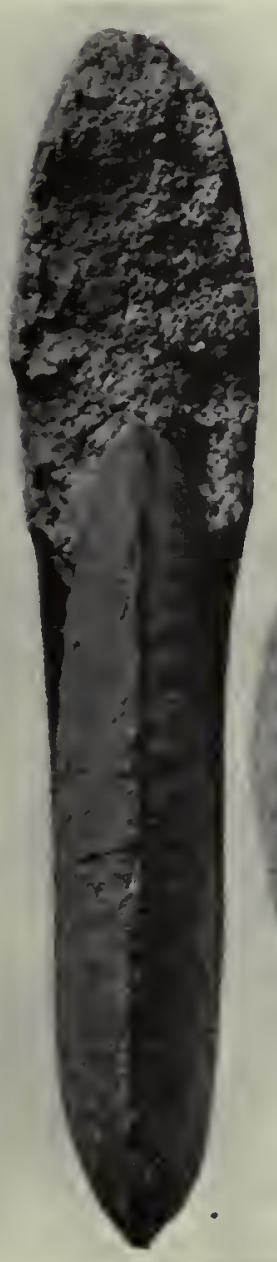

Fig. I

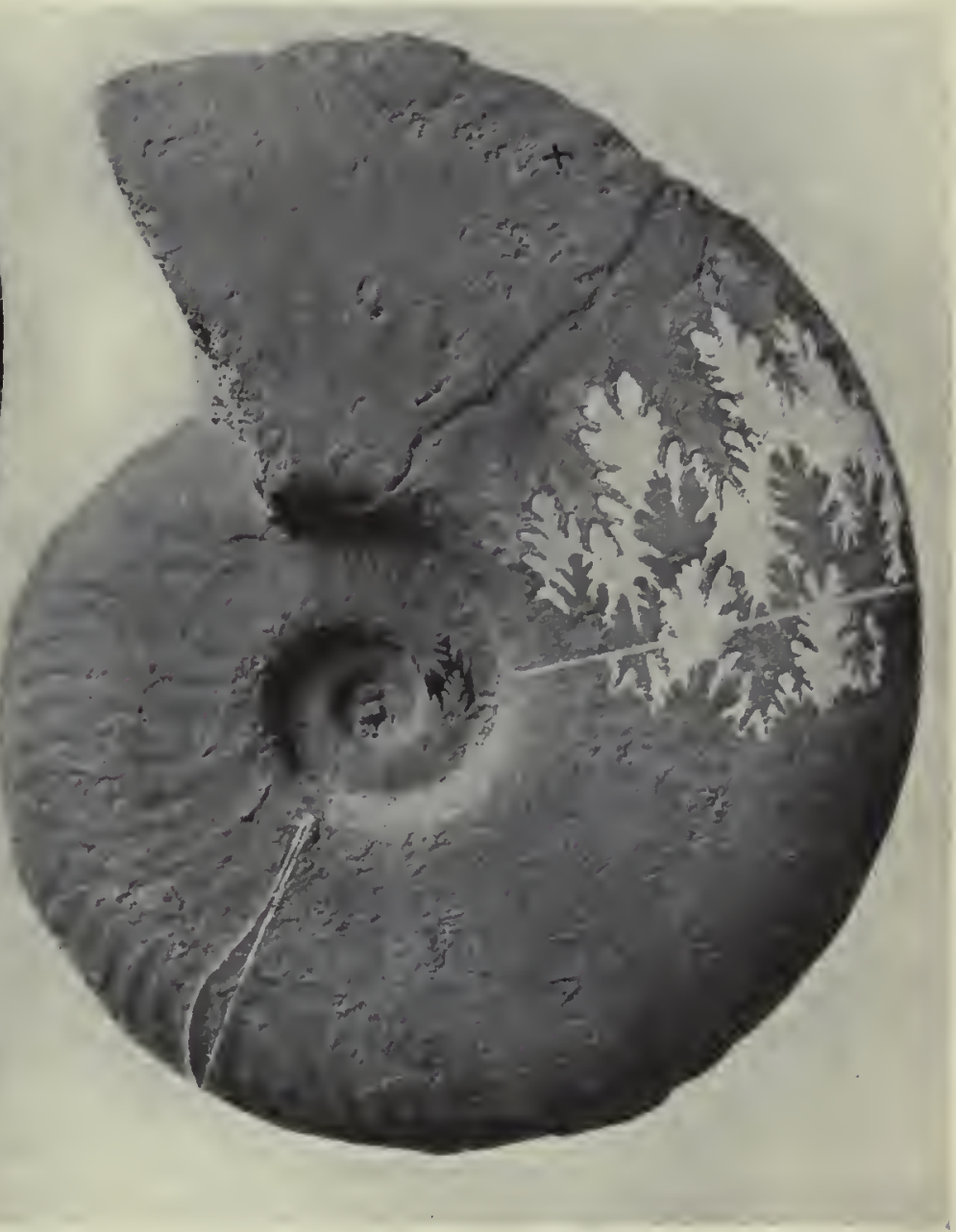

$\times 0.8$

HaUgia INequA, S. BuCKMAN

I808, Mon. I. O. Amm. Sup. p. xxix ; "Timsbury Sleight, Radstock, Somerset; Upper Lias [Ceph. Bed equiv.] " ; J. IV. T. Coll. S. $158,44,20,23$; max. c. 2 Io. Cf. XV

ESERICERAS INAQUUM, S. BUCKMAN SP. Yeovilian, eseri; Genotype 



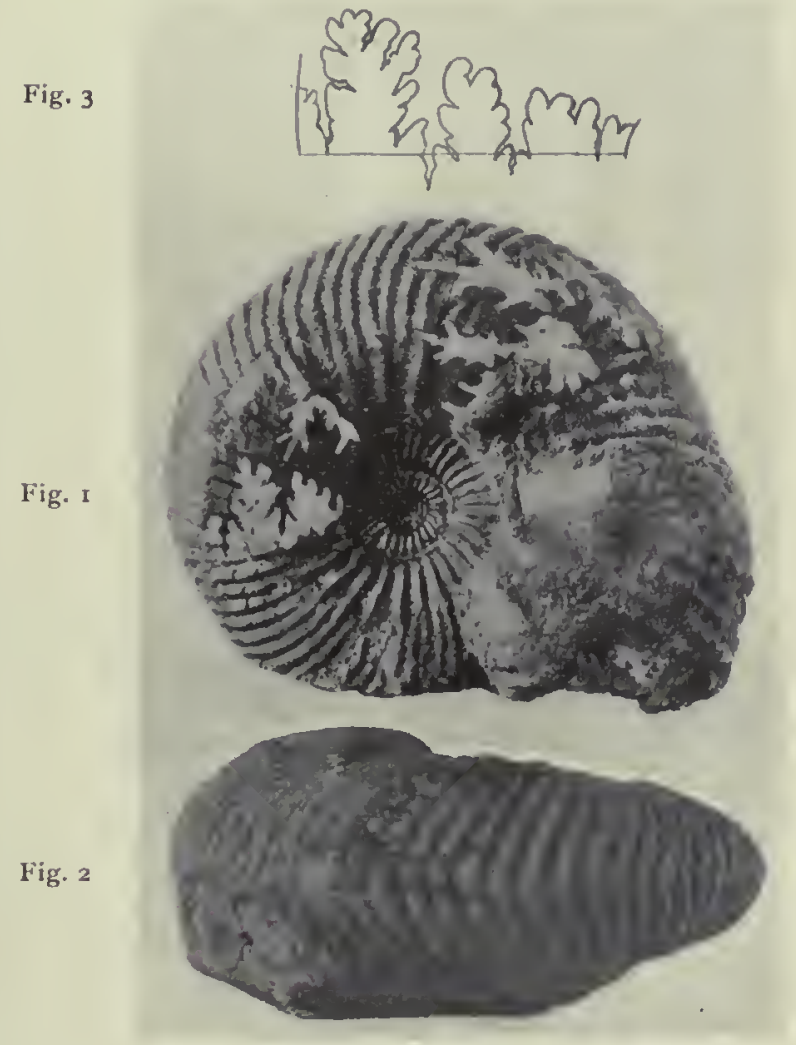

"QURNSTEDTICERAS ORDINARIUM"

" Scarborough, Yorks; Kell. R." Iron-stained sand

Sedg. Mus., Cambridge; S. $53,43.5,45,26.5$

Size of specimen $63 \mathrm{~mm}$.; max. c. $90+; 28$ ribs to $53 \mathrm{~mm}$.

WEISSERMELICERAS LONGIIOBATUM, S. Buckman

Callovian, at/lleta; Genotype, Holotype, p. 20 



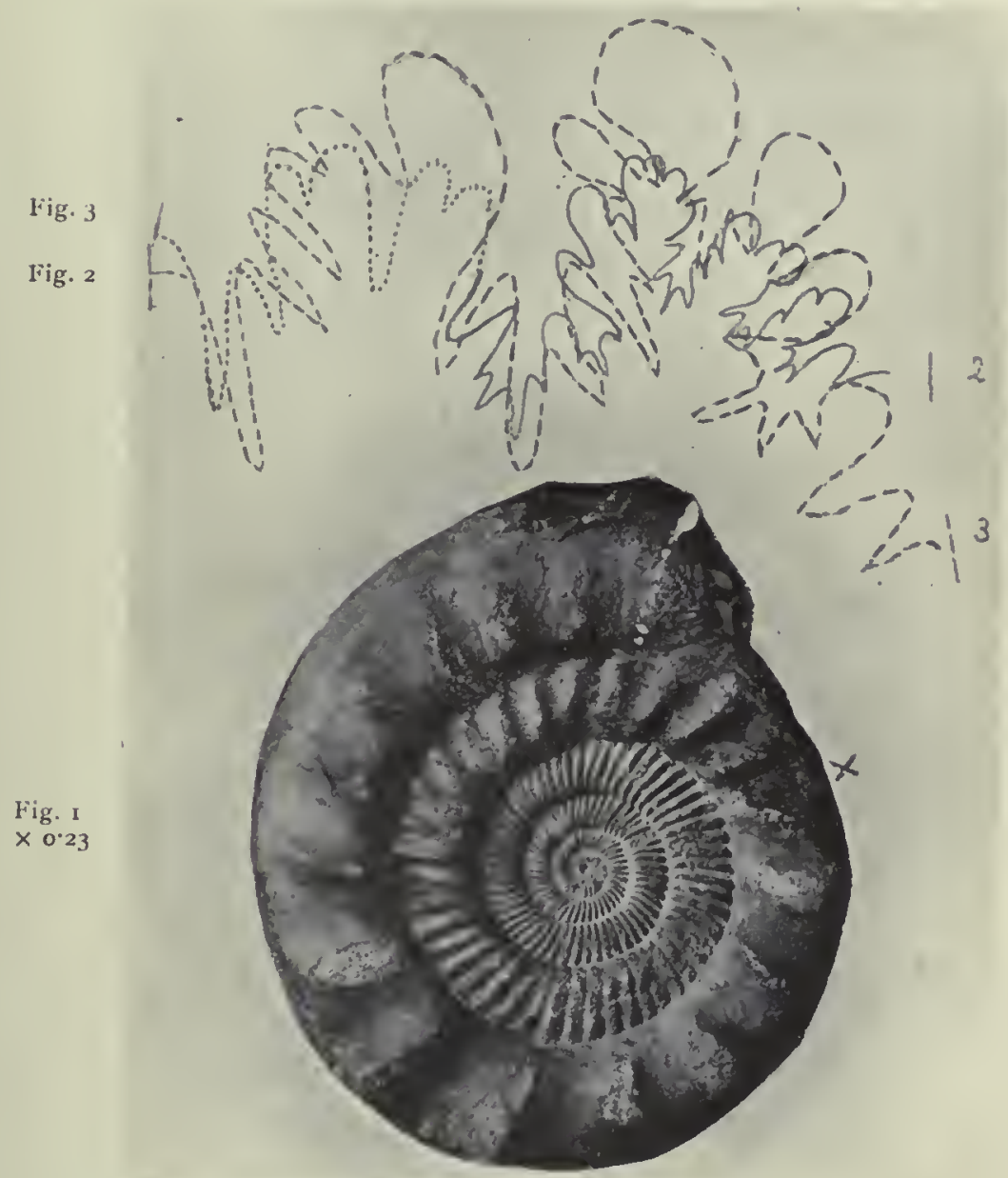

Amonites ingens, Young \& Bird is22, Holotype

P. 247 ; XII, 2 ; "Pickering [Yorks] Oolite" [white ; many cream col. gls.]

Mouth complete; Whitby Mus. I279; S. 222, 27 5, 30(22), 56

S. $264,25,3$ I (23), $55 ; 336,27,20,54$. Ribs, 56,46, IS: [IFigs. I, 2] [Fig. 3, S.1. Derisph. martelli; Siemir. p. 268]

DICHOTOMOSPHINCTES INGENS, YOUNG \& BIRD SP. Perisphinctean, antecedens (ingens). Cf. CXXXIX 



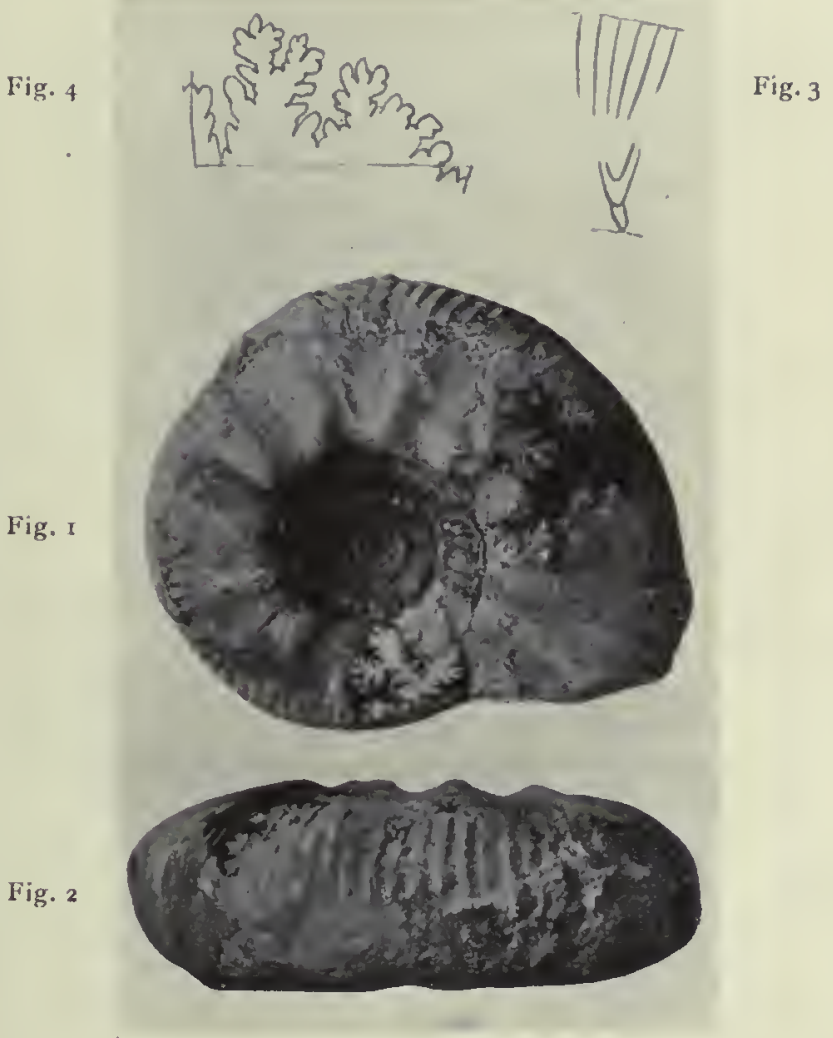

Amonitfs poculum, (Bean MS.) Leckenby I859, "type spec."

Q.J.G.S. XV, $9 ; \mathrm{I}, 4 b, c$; "Near Gristhorpe Bay, Yorkshire

" Kell. R." [Grey, calc., few Iarge ool. gr.]; Sedg Mus., Cambridge (Leckenby Coll.) S. $59,37,37(34), 36$

POCULISPHINCTES POCUIUM, BEAN-LECKENBY SI'. Divesian, vertumnus; Genotype, Holotype 

Fig. I

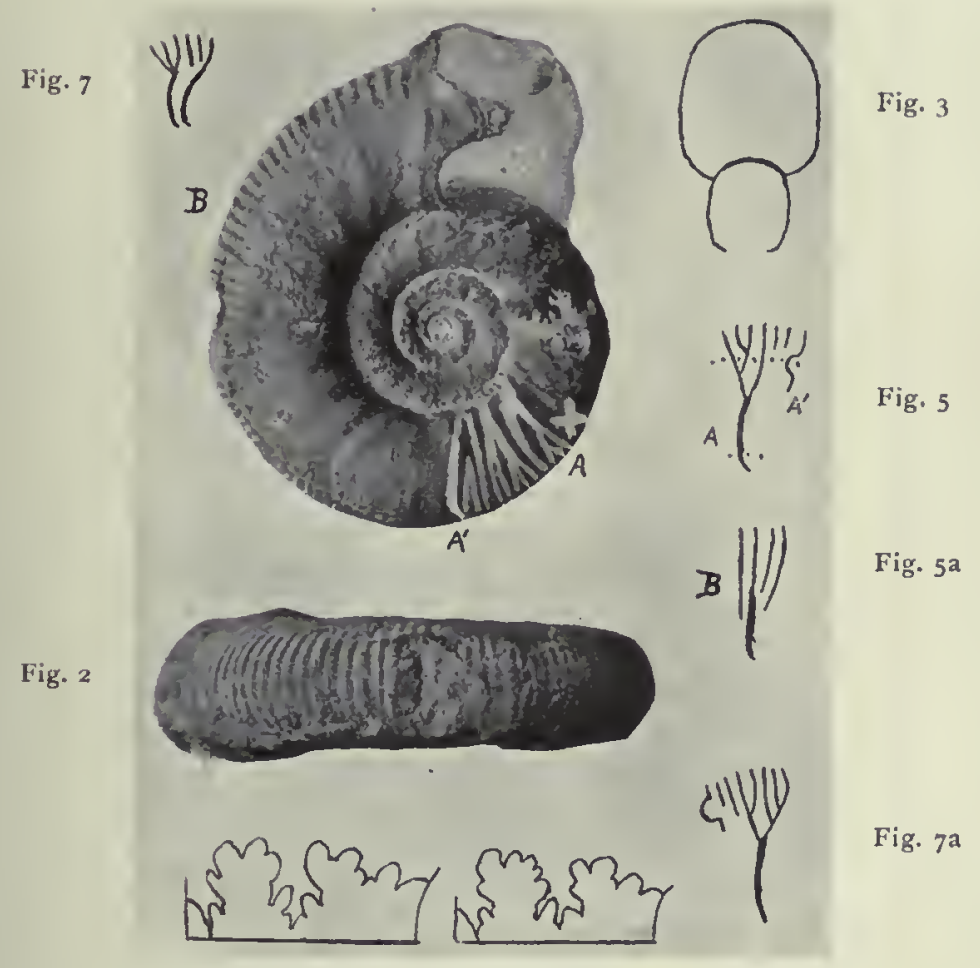

Fig. 4

Fig. 6

Amonites poculum, (Bean MS.) Leckenby 1859 , Paratype

Q.J.G.S. XV, $9 ; \mathrm{I}, 4 a$; "Near Gristhorpe Bay, Yorkshire"

"Kell. R." [grey, calc., few large ool. gr.]; Sedg. M., Cambr. (Leek. Coll.)

S. $47,34,29,42^{\circ} 5$. [Figs. 6,7 , From another ex. Loc. ete. id.]

POCULISPHINCTES AURICULARIS, nOv.

Divesian, vertummus; Holotype. See CLXXXV 

Fig. I

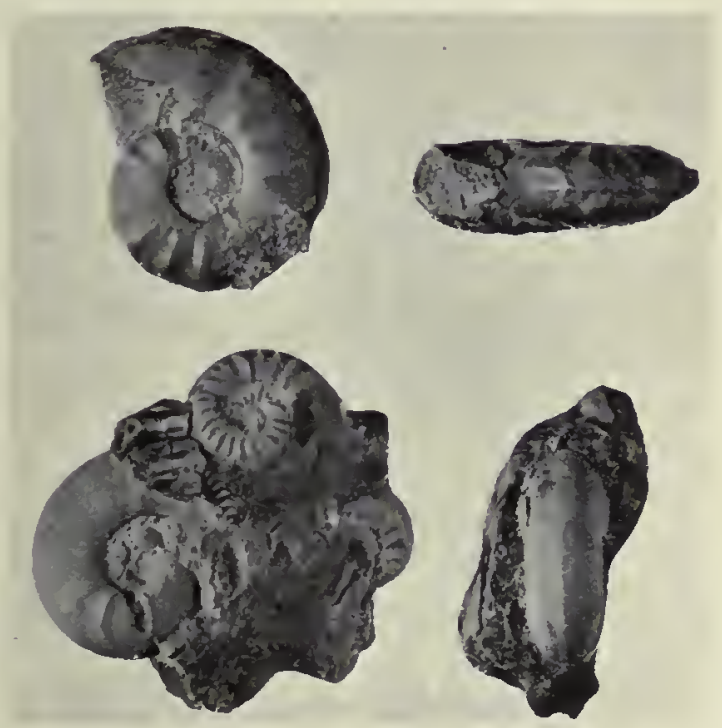

Fig. 3
Fig. 2

Fig. 4

Ammonites personatus, Bean MS. (Simpson, I843, Holotype) P. 9 ; " R[obin] H[oods] Bay ; L.L.," I855, 38. "Ind. Band 26," I 884,66 Whitby M. 2 I $25 ; \phi .28 \cdot 5,35,3$ I, 35. [Figs. 3, 4, Paratype, with "A. multicostatus" [A gass. sp.]; W.M. 67]. See LXXV

AGASSICERAS PERSONATUM, BEAN-SimpSON SP. Lymian, Agassiceras. A phaulomorph 

Fig. I

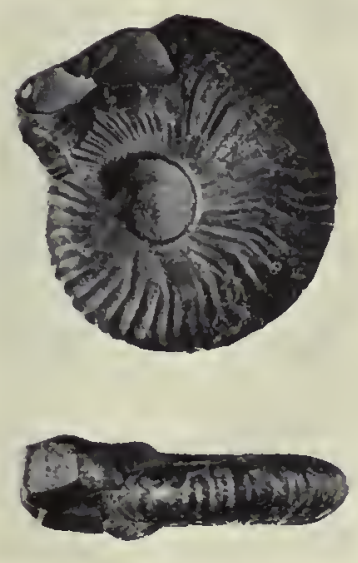

Fig. 2

Amonites erratus, Simison is 43 , Holotype P. 8 ; "South of Whitby, [Yorkshire]; Jet Rock," Upper Lias Whitby Museum, go; $\phi .345,45,26,23$. See XIII A cripple (dysmorph) without keel; cf. Hild. bifrons, CXIV B

PSEUDOLIOCERAS ERRATUM, SimpSON sP.

Whitbian, exaratum 

Fig. I

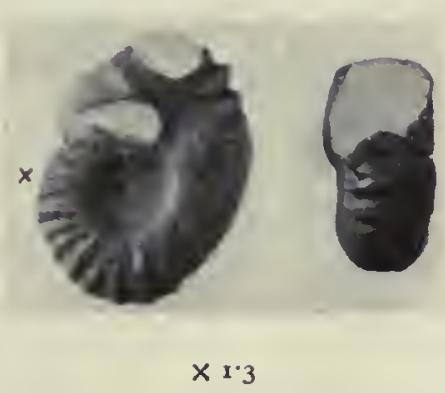

An ellipticone Oppelid

Burton Bradstock, Dorset; Inf. Ool. [White Bed, Q.J.G.S. LXVI, I9I0, 69]; S. B., ex Darell, Coll. 3363

S. $20,4 \mathrm{I}, 35,29$

CADOMOCERAS COSTATUM, nov.

Bajocian, niortensis; Holotype 



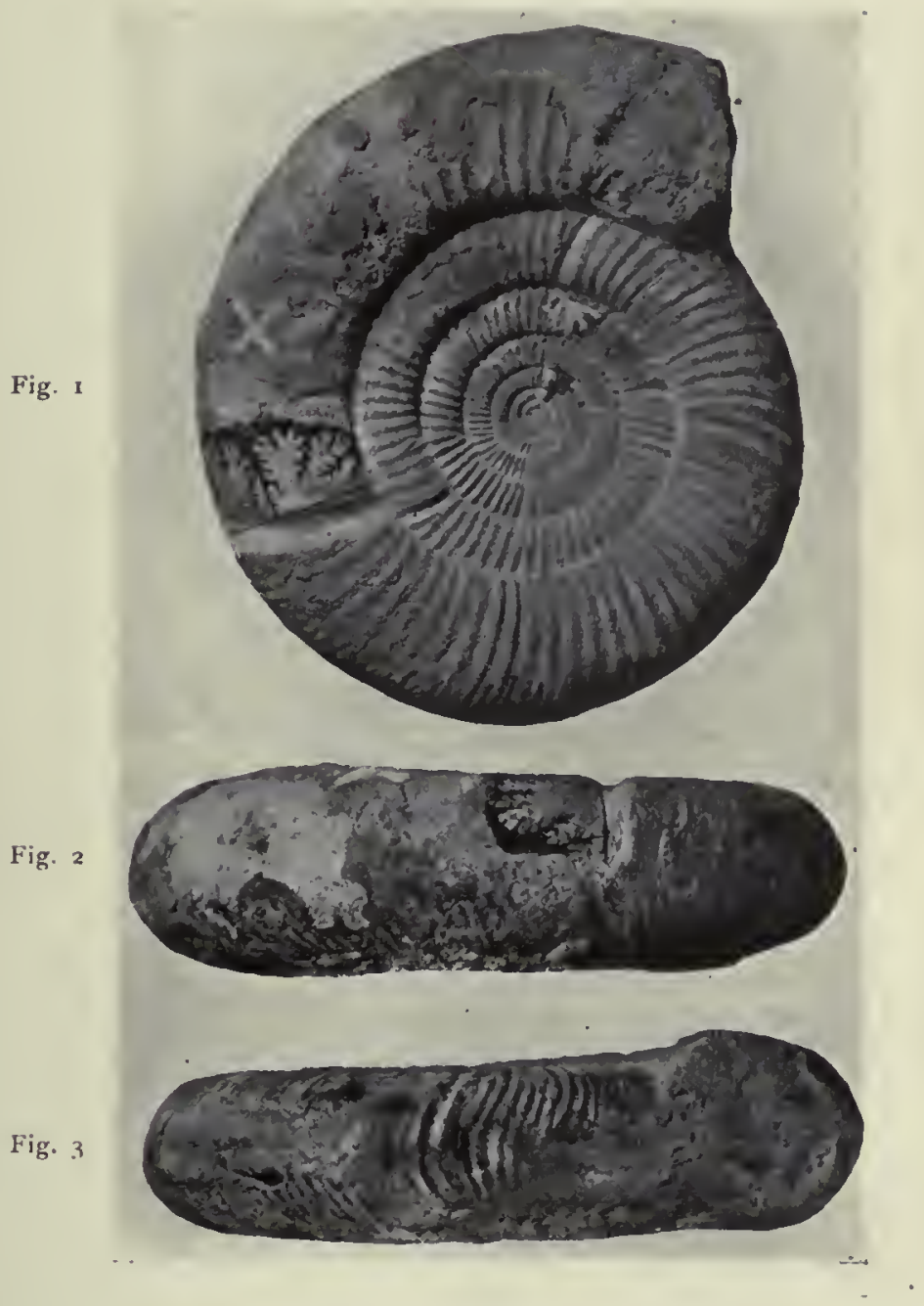

PERISPHINCTES MARTINSII

"Halfway House [Nether Compton, Dorset] : garantiana" J. W. T. Coll. ; S. 76, 26, 27.5, 52; 66 ribs; mas. C. 95 ; See CI.XII

VERIISPHINCTES SUBDIVISUS, nov.

Vesulian [Eningenian], garantiana [truellei?]; Holotype 



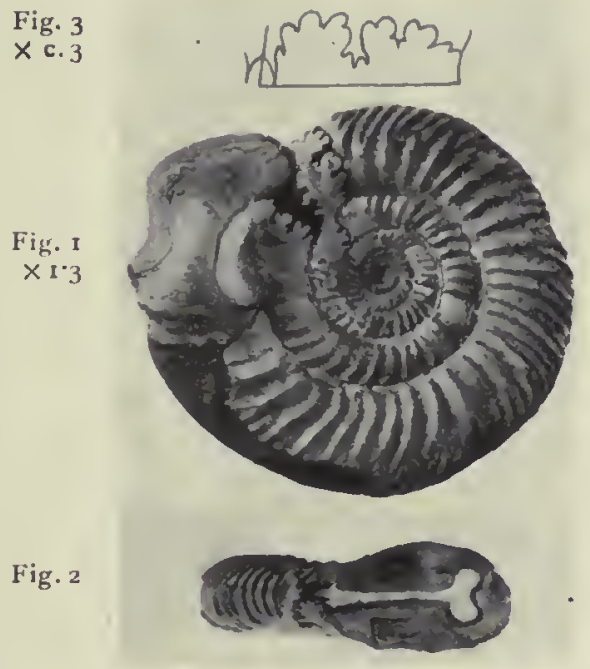

Perisphinctes Martinsil; S. BUCKMIAN I 881 Q.J.G.S. XXXVII, 602; "with the termination" ; Louse Hill Nether Compton, Dorset; "I. O. [above Irony Bed], Cosm. park. z." S. B. Coll. $3175 ;$ S. $34,26 \cdot 5,26 \cdot 5,50 ; 38$ ribs; c. $\frac{1}{2}$ wh. body-ch.

PSEUDOBIGOTELLA OTIOPHORA, nov. Bajocian, niortensis; Holotype. Cf. CLXI 



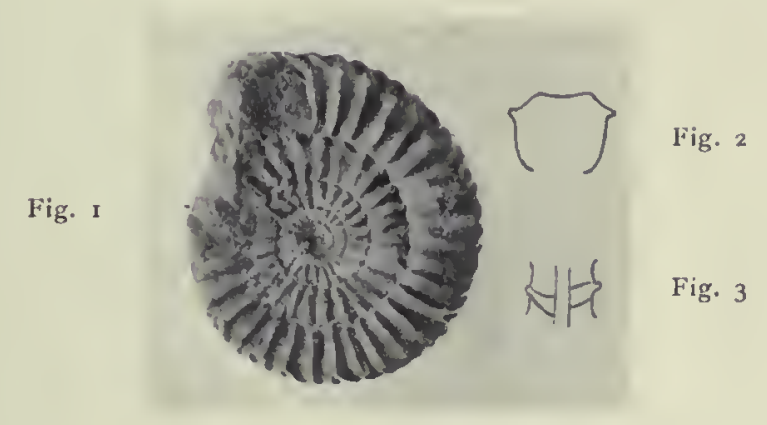

Cosmoceras caumontiI; S. Buckman i $88 \mathbf{r}$

Q.J.G.S. XXXVII, 600; [Frogden Quarry], "Oborne, Dorset" "I. O. [Roadstone (up. part)], Humphr. z.; S. B. Coll. 3273 S. $34,25,28,55$; c. I whorl body-ch. See CIXXIX 



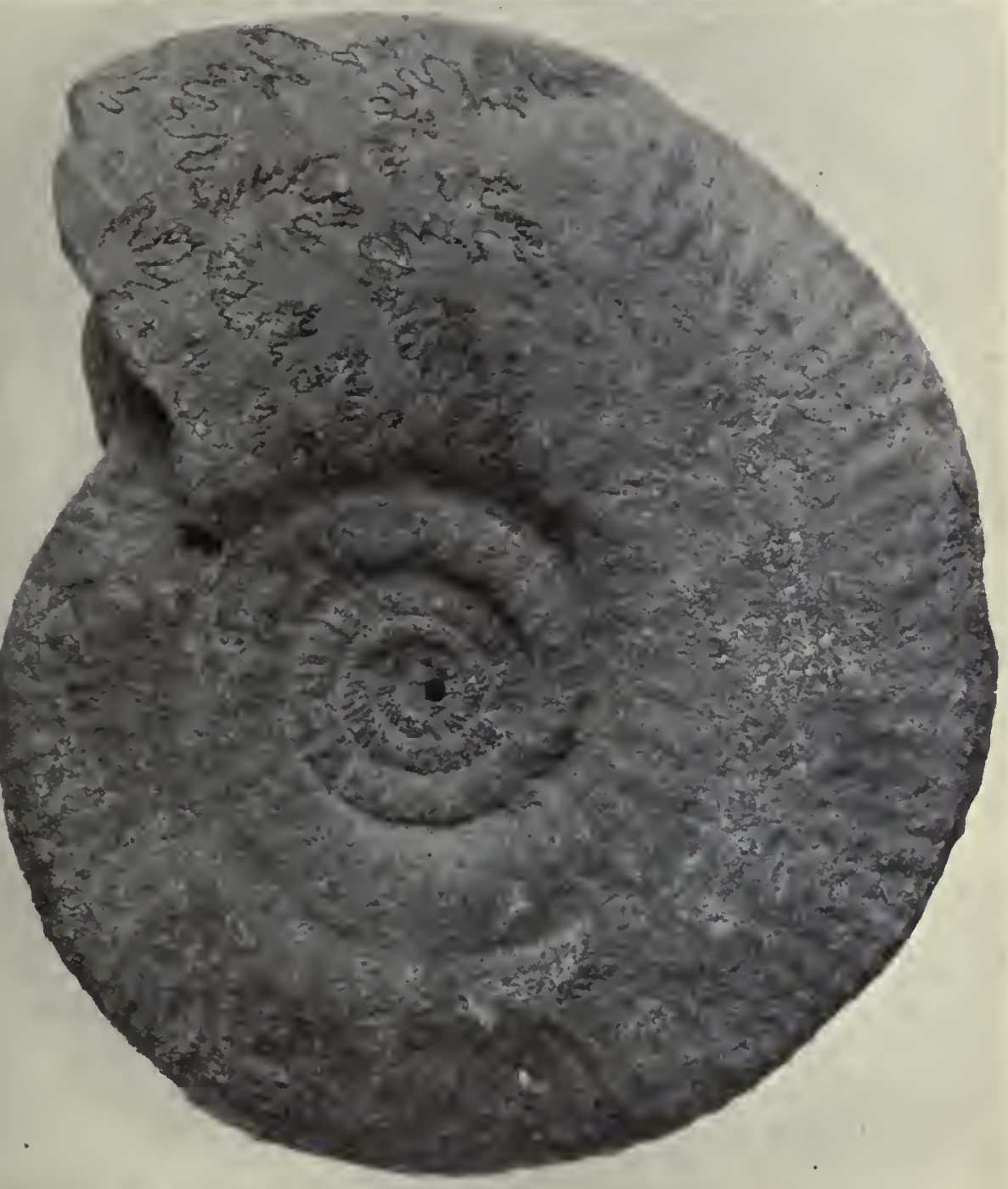

Ammonites gracilis, J. Buckman I8 44 , Holotype Geol. Chelt. 7I, IO4; III, 6 ; Siemiralzkia? S. B. I904, Pal. U. 38 Sevenhampton Common, Glos; Stonesfield Slate; Manchester M. S. I46, 40, I5, 30, flattened; Est. II2, 36, 27, 36; max. c. $210+$

GRACILISPHINCTES GRACILIS, J. BUCKMAN SP. Stonesfieldian, gracilis; Genotype 



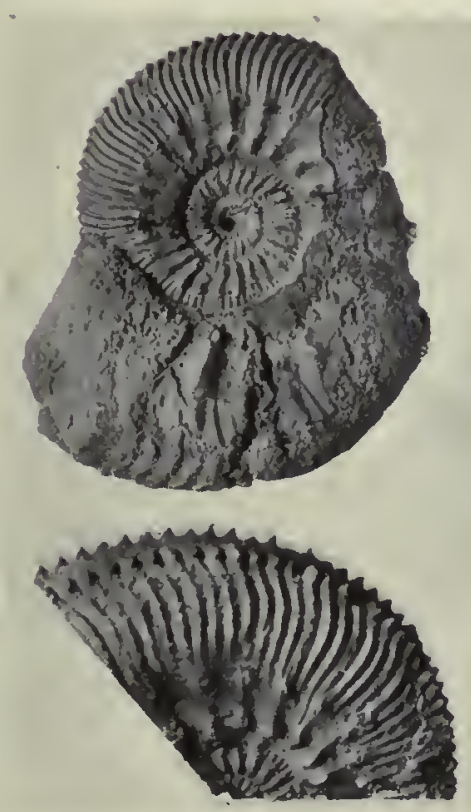

Fig. $3 \times 1 \cdot 5$

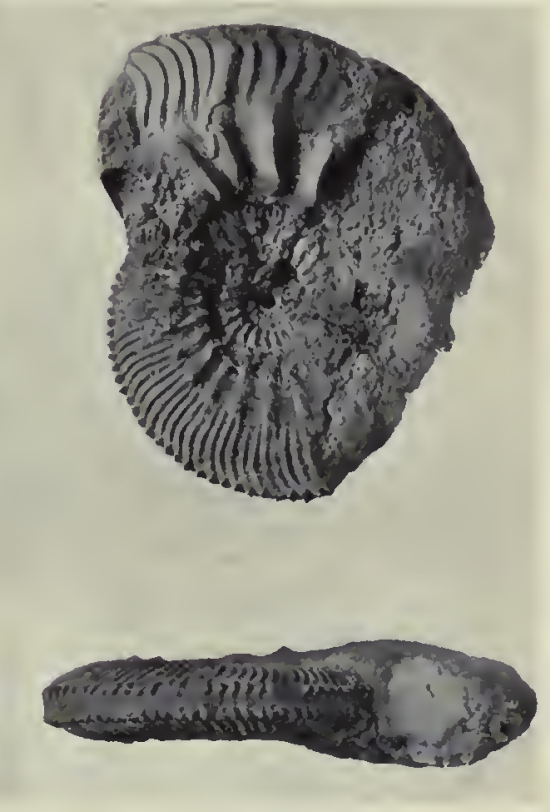

Fig. 4

Ammonites gulielmi, J Sowerry, Topotype? I82I, Min. Conch. IV, p. 5 ; cccxI

[Kellaways, Wiltshire; Kellaway Rock, upper part] J. W. T. Coll. ; S. 49, 39, 26 (22), 32

GULIELMICERAS GULIELMI, J. SOWERBy SP. Callovian, gulielmi; Genotype 



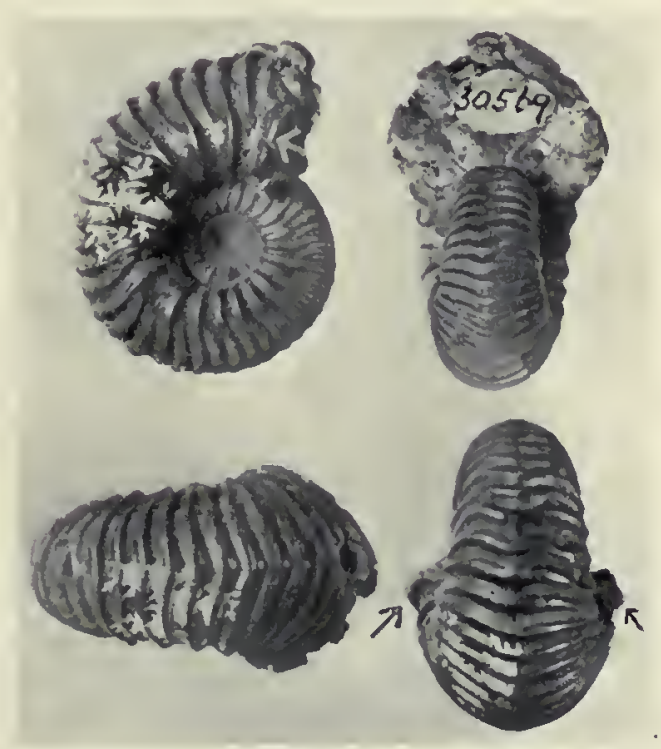

Fig. 3

Fig. $3^{a}$

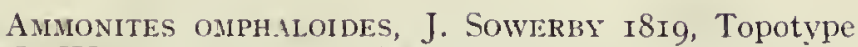
M.C. III, 74 ; CCXLII, 5 ; "Weymouth, Dorset ; Oxf. Cllay " Geol. Surv. Engl. Coll., 30569; S. 26, 42, 57, 31

S. $34^{\circ} 5,4 \mathrm{r}, 57,29 ; 36,47,60,29 ; \rightarrow$ sudden jump. See CLXX

PAVLOVICERAS OMPHALOIDES, J. Sowerry sp.

Divesian, vertumnus; p. I8 

Fig. I
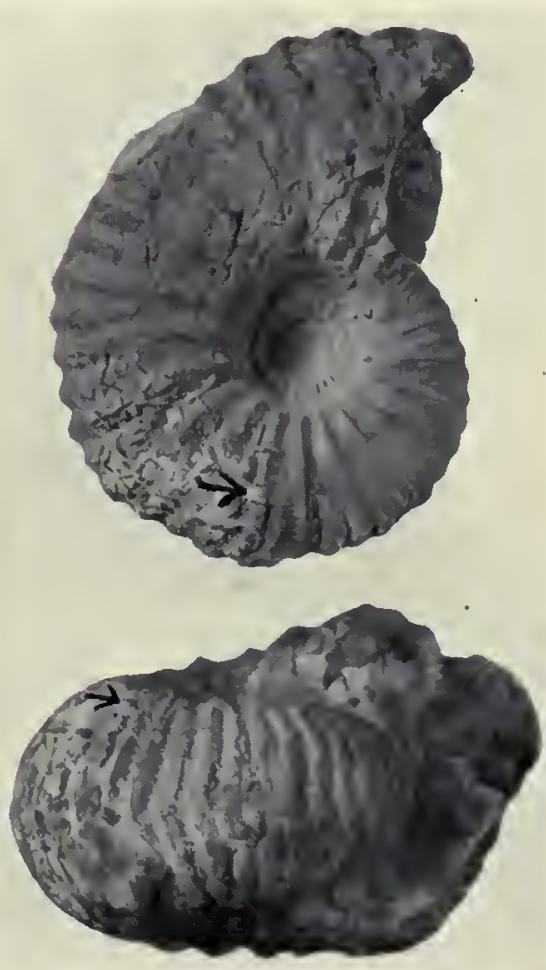

Iig. 2

QUENSTEDTICERAS SUTHERLANDIA

Pavloviceras bathyomphalum, T.A., III, I920, p. 18; Holotype

"St. Ives, Hunts; Oxf. Clay" ; J. W. T. Coll. ; S. 26, 44, 67, 27

S. $34,40,70,26 ; 50,45,65$ ? 24 ; size 59 mm. ; max. c. 90

PAVLOVICERAS BATHYOMPHALUM, S. BUCKMAN

Divesian, vertummus. See Pl. CXCV 

Fig. I

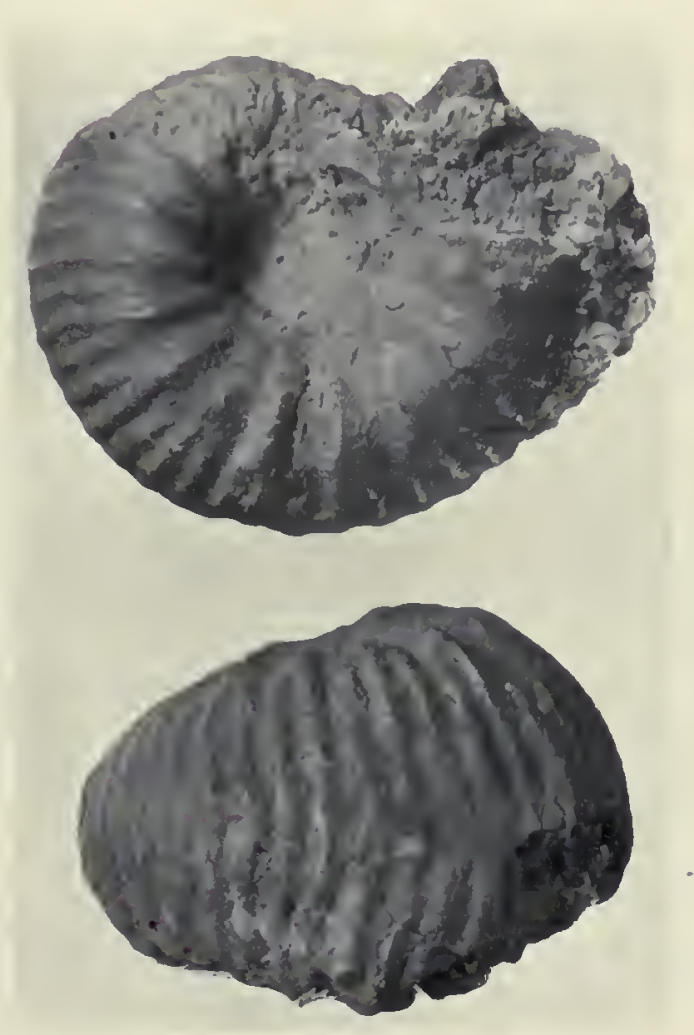

Fig. 2

CARDIOCERAS GOLIATHUS

Pavloviceras stibarum, T.A., III, I920, p. I8 ; Holotype

"St. Ives, Hunts; Oxf. Clay" ; J. W. T. Coll. ; S. 34, 48, 70, 235 S. $59,43,75,25$; size $63 \mathrm{~mm}$. ; max. c. 90. See P1. CXCVI 



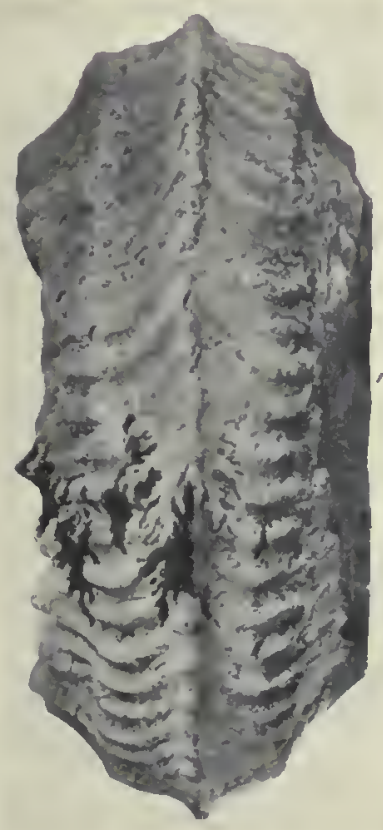

Fig. 2

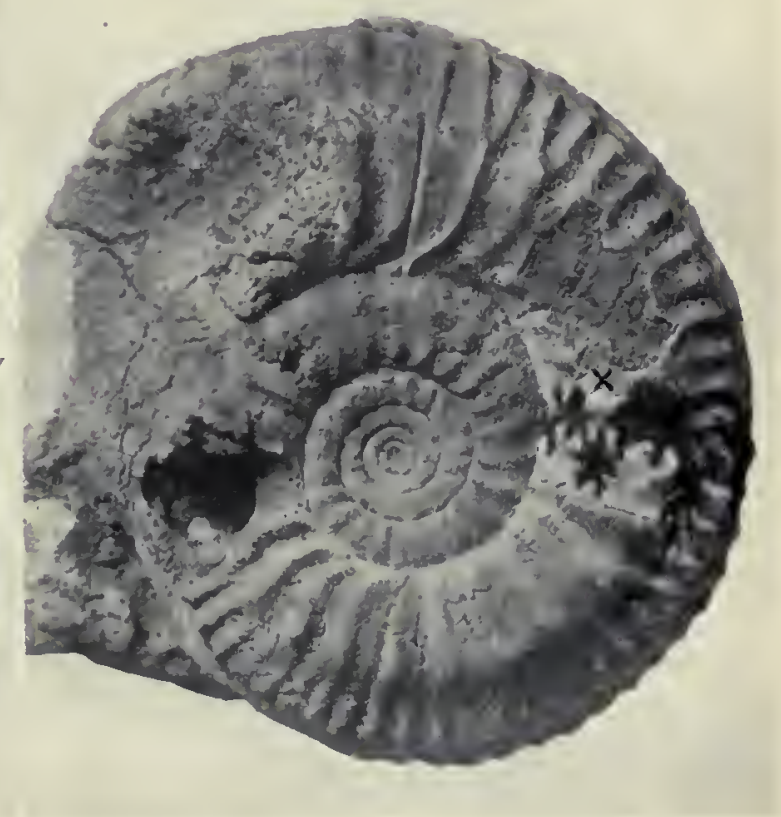

Fin. I

CARDIOCERAS aff. VERTEBRALE

Jertebriceras dorsale, T.A., III, I920, p. I6 Cowley, near Oxford; Lower Calcareous Grit S. B. Coll. 2780 ; S. $80,35,42.5(38), 39$; max. c. 90

VERTEBRICERAS DORSALE, S. BUCKMAN Argovian, Vertebriceras; Genotype, Holotype 



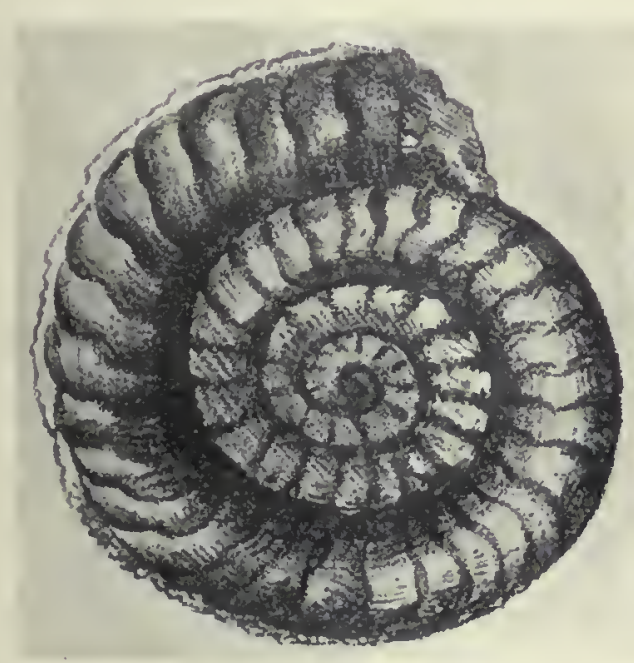

Fig. I

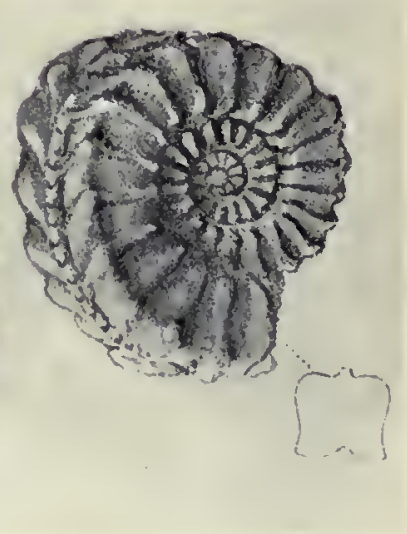

Fig. 2

Ammonites buckManil, Moxon I84I

Foss. British Strata, Pl. xxIv, f. 5 ; copy of Protograph [J. Buckman del.] Fig. 2, Copy of fig. (unnamed) lithographed [by Mrs. Rowe ?] for Geol. Chelt., new Ed., I844; but not published. See L.II 

Fig. 2

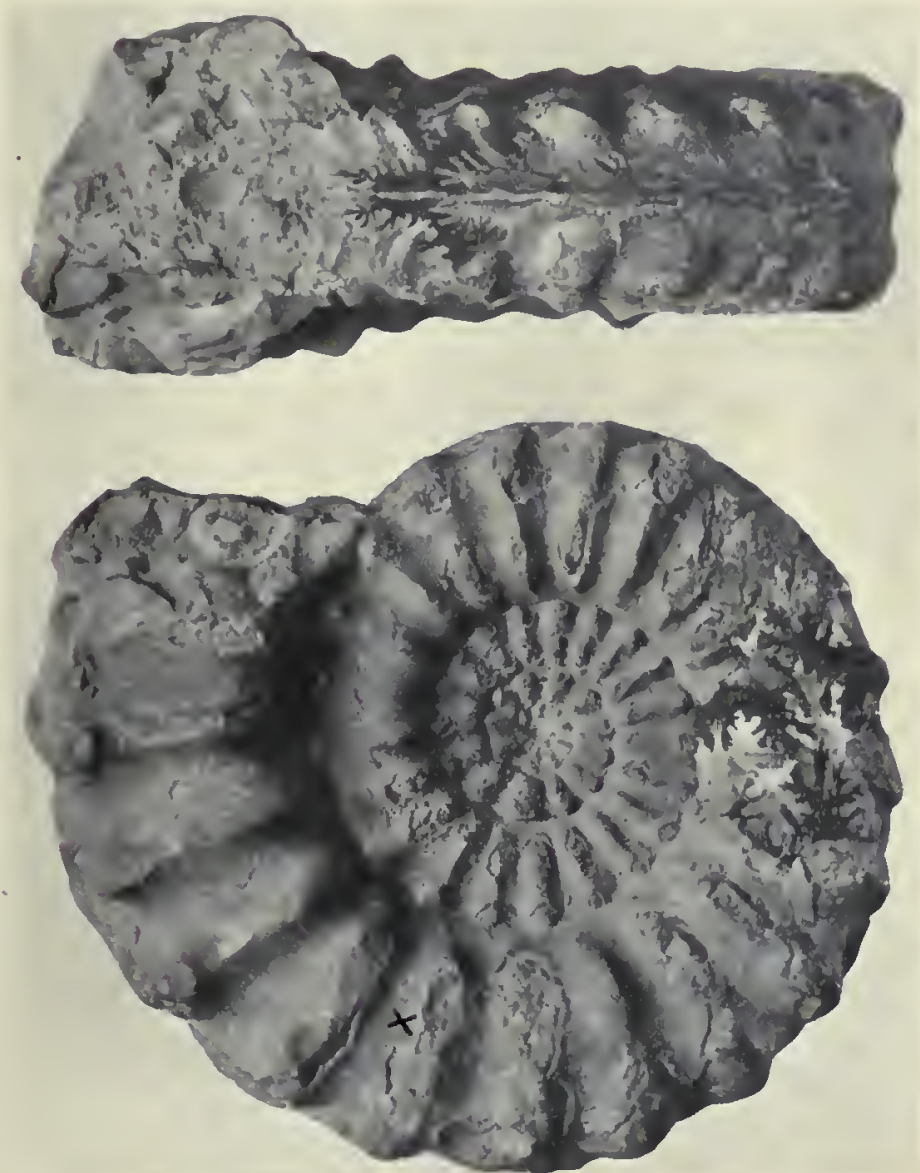

Fig. I

AMmonites BUCKMANII, Moxon, I841, Holotype

"Neighbourhood of .Cheltenham [Alderton Hill, Glos]; Lias Marlstone" Pleuroceras hateskerense, S.B., Q.J.G.S., XLV, I889, 653 ; S.B., ex J.B., Coll. 3310 ; S. $85,33,40(25), 435^{\circ}$; max. c. I20. Orn. $5^{*}$ to c. $13 \mathrm{~mm}$.

PALTOPLEUROCERAS BUCKMANII, MOXON SP. Domerian, spinatum 



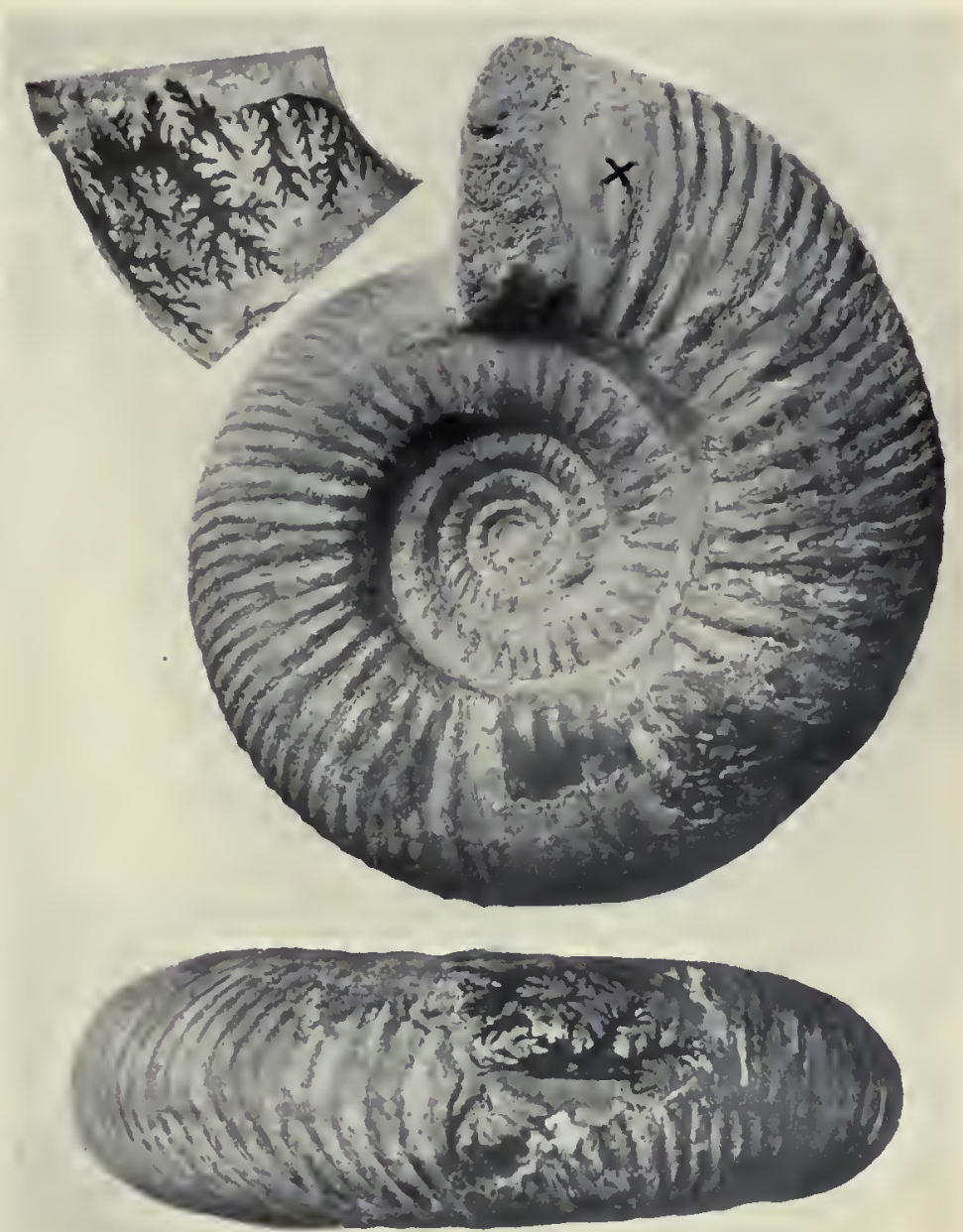

Fig. 2.

Perisphinctes pSeudomartinsi, Stemiradzis

1899, Mon. Per. p. 328 ; XxII, 27 ; [Burton Bradstock, Dorset] Inf. Ool., [Astarte Bed, (Q.J.G.S., L.YVI, I910, 73, Bed 4)]; S. B., ex Darell, Coll. 888 ; S. $87,33,33,38.5 ; 47$ ribs; max. c. I70.

PRORSISPHINCTES PSEUDOMIARTINSI, SIEMIRADZKI SP. Eningenian, garantiana; Genotype Cf. Pl. CLXII 

Iig. 3

Fig. I a
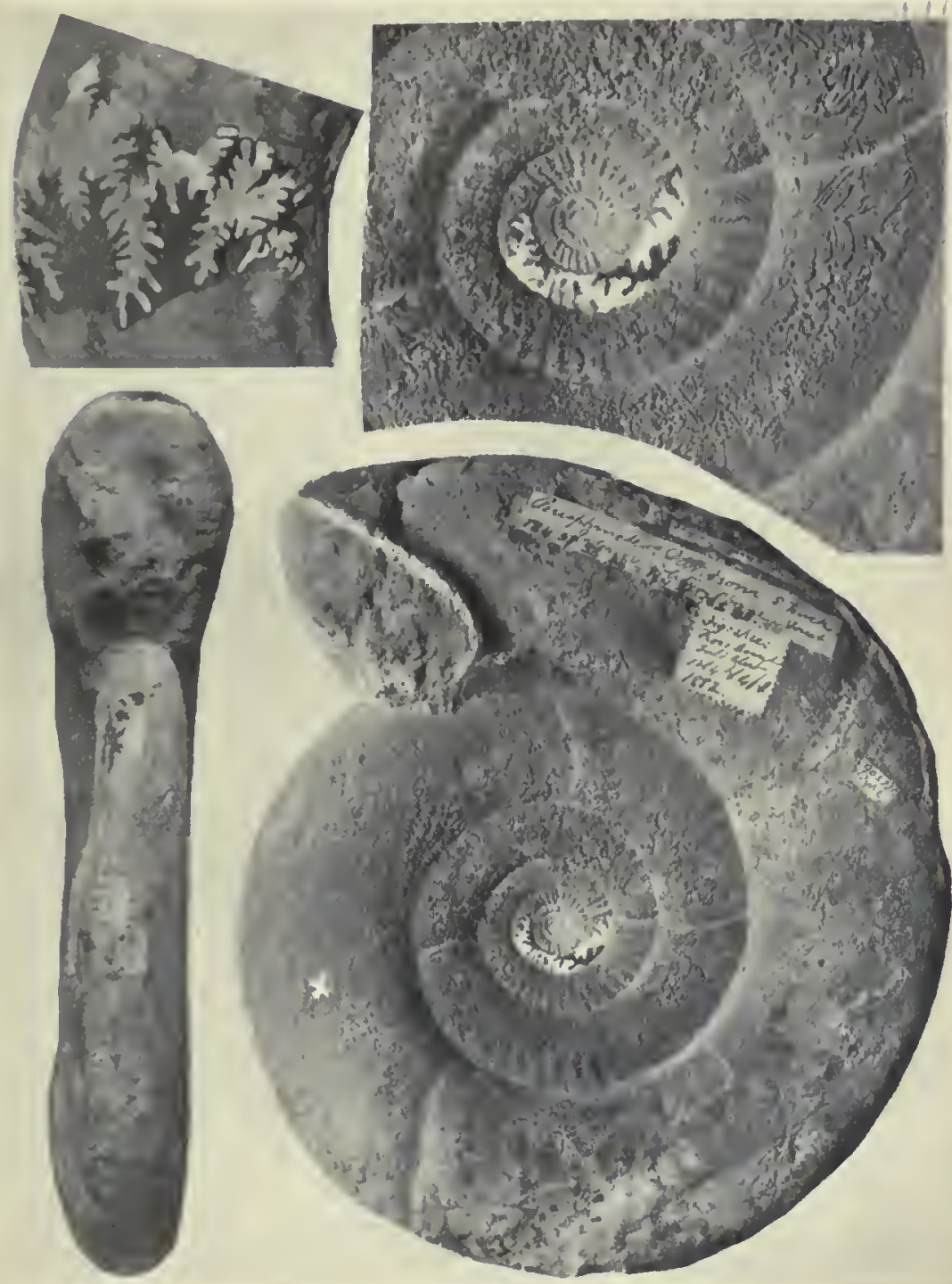

Fig. $2 \times 0.5$

Fig. $1 \times 0.5$

Perisphinctes Davidsoni, S. Buchinan, i88i, Holotype Q.J.G.S., XXXVII, 602; I882, Proc. Dorset I.C., IV, I 44 ; IV, I "Oborne, Dorset ; Humpll. z." [1893, § xv, 4]; Manchester M. (S.B. Coll.) L. II 359 ; S. $\left(42,28 \cdot 5,-, 46\right.$ ? ); $184,27 \cdot 5,20^{\circ} 5,48$. See Pl. CLX

LEPTOSPHINCTES DAVIDSONI, S. BUCKMAN SP. Bajocian, niortensis 

Figr. $1 \mathrm{a} \times 2$

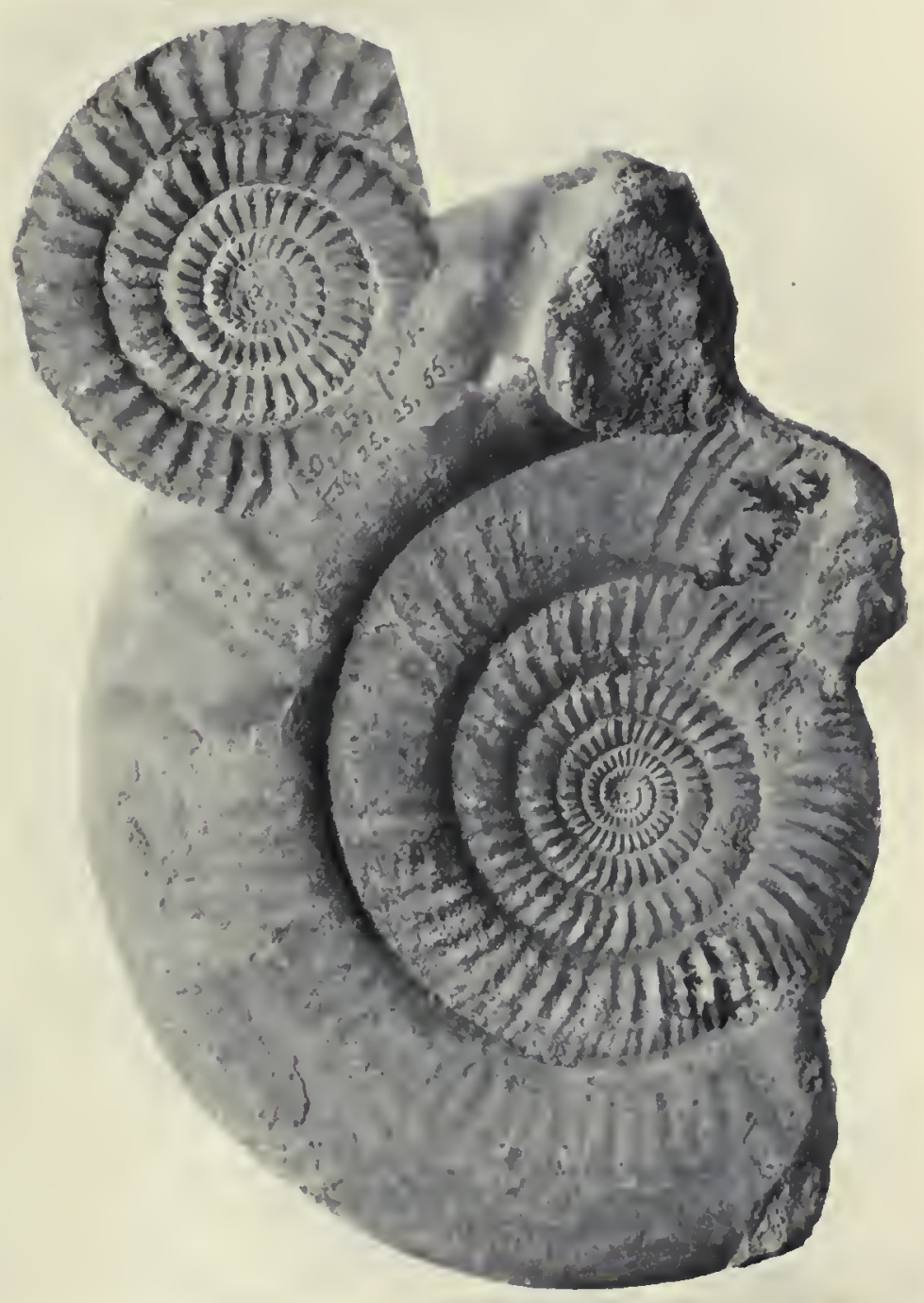

Fig. I

“"Perisphinctes' Davidsoni" ; S. Buckman i893

Q.J.G.S., XLIX, 500, § xv, 4; “Frogden Quarry, Oborne, Dorset

"Inf. Ool.; Niortensis;" body-ch. with aperture; S. B. Coll. 3390 S. $50,25,25,50 ; 120,25, I 7,54$; c. 52 ribs penult. whorl

LEPTOSPHINCTES CORONARIUS, nov.

Bajocian, niortensis; Holotype 



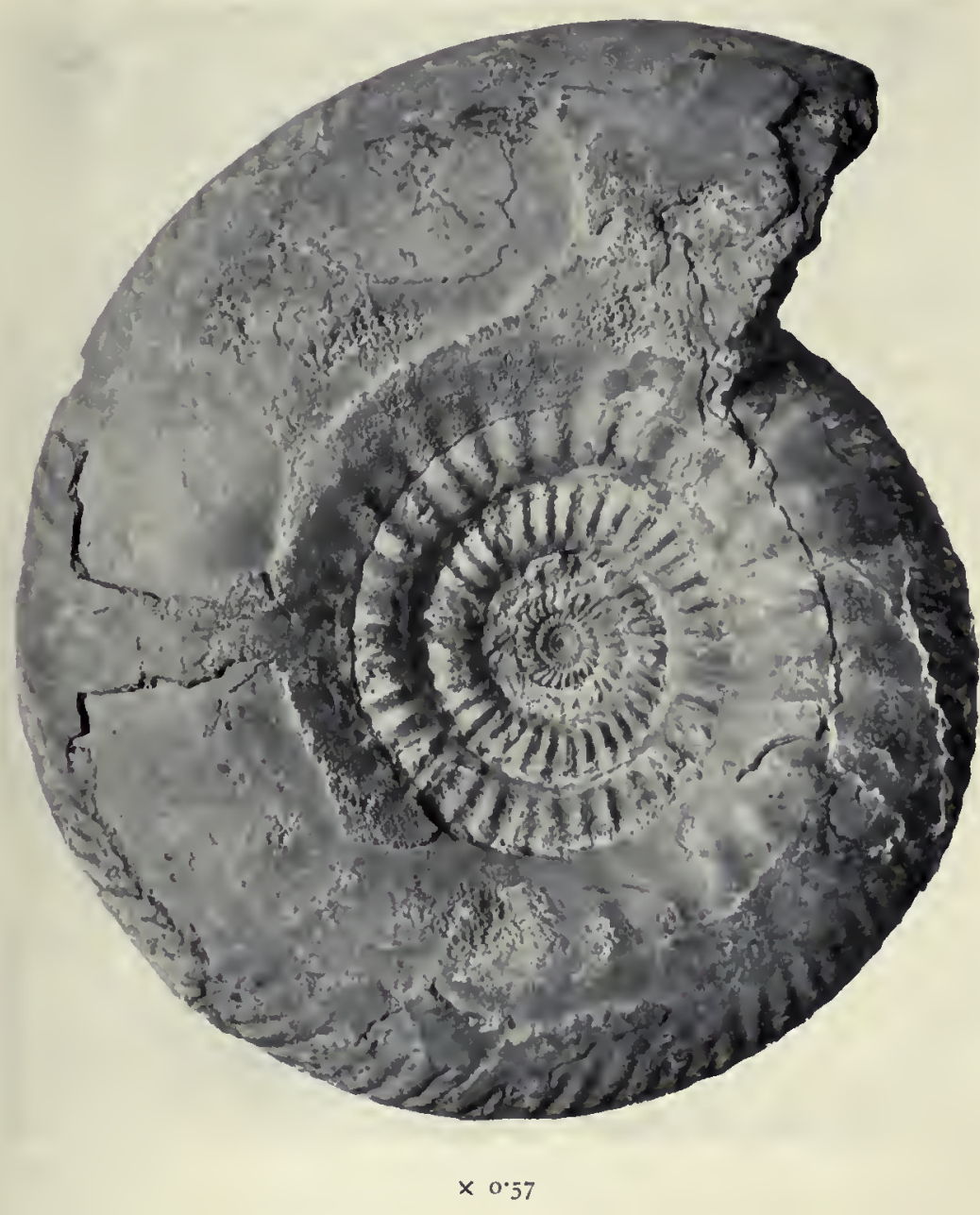

PARKINSONIA NEUfFENSIS

Haselburgites admirandus, T.A., III, I920, p. 30)

"Haselbury, Som." ; [Park. z.] ; S.B. Coll. (purch), 654

S. $129,33,36,42 ; 218,36,29,37 ; \max$. c. $410+$

HASELBURGITES ADMIRANDUS, S. BUCKMAN

Eningenian, truellei; Genotype, Holotype 



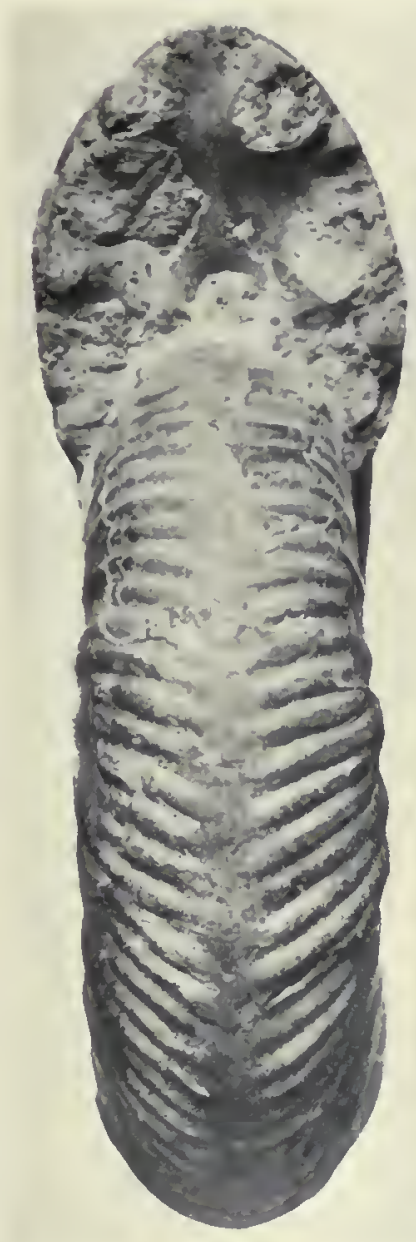

Fig. $2 \times 0.57$

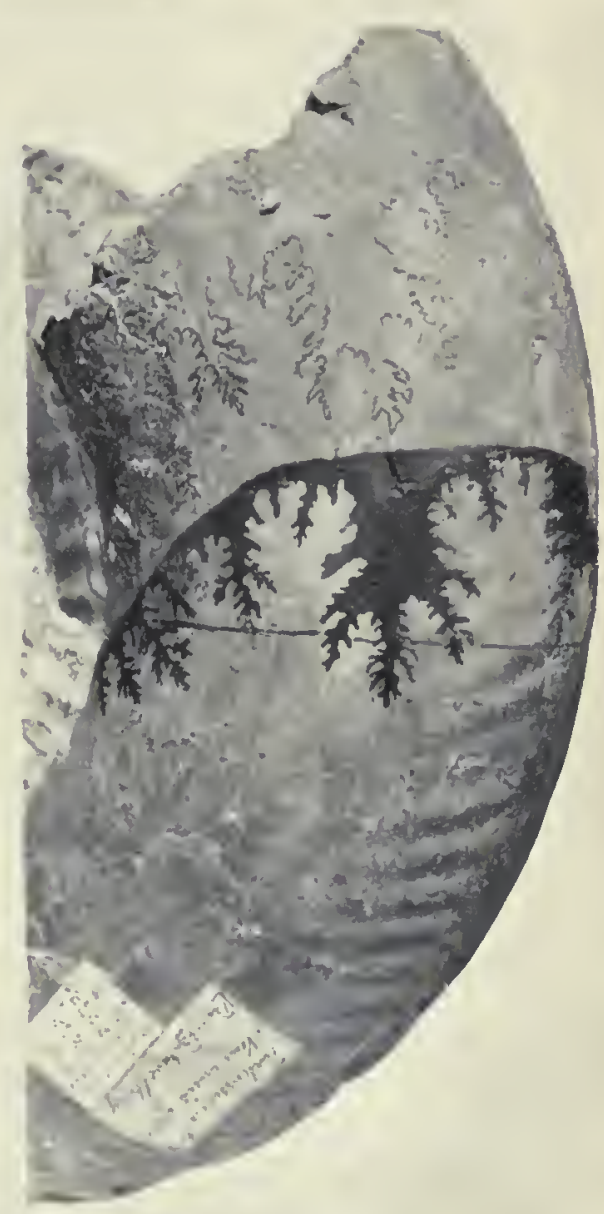

Fig. $2 \times 0.8$

PARIINSONIA NEUFFENSIS

"Haselbury, Somerset" ; [Quarry near Church ; top beds] A light yellow, finely oolitic, soft stone

HASELBURGITES ADMIRANDUS, S. Buckman Eningenian, truellei; Genotype, Holotype 



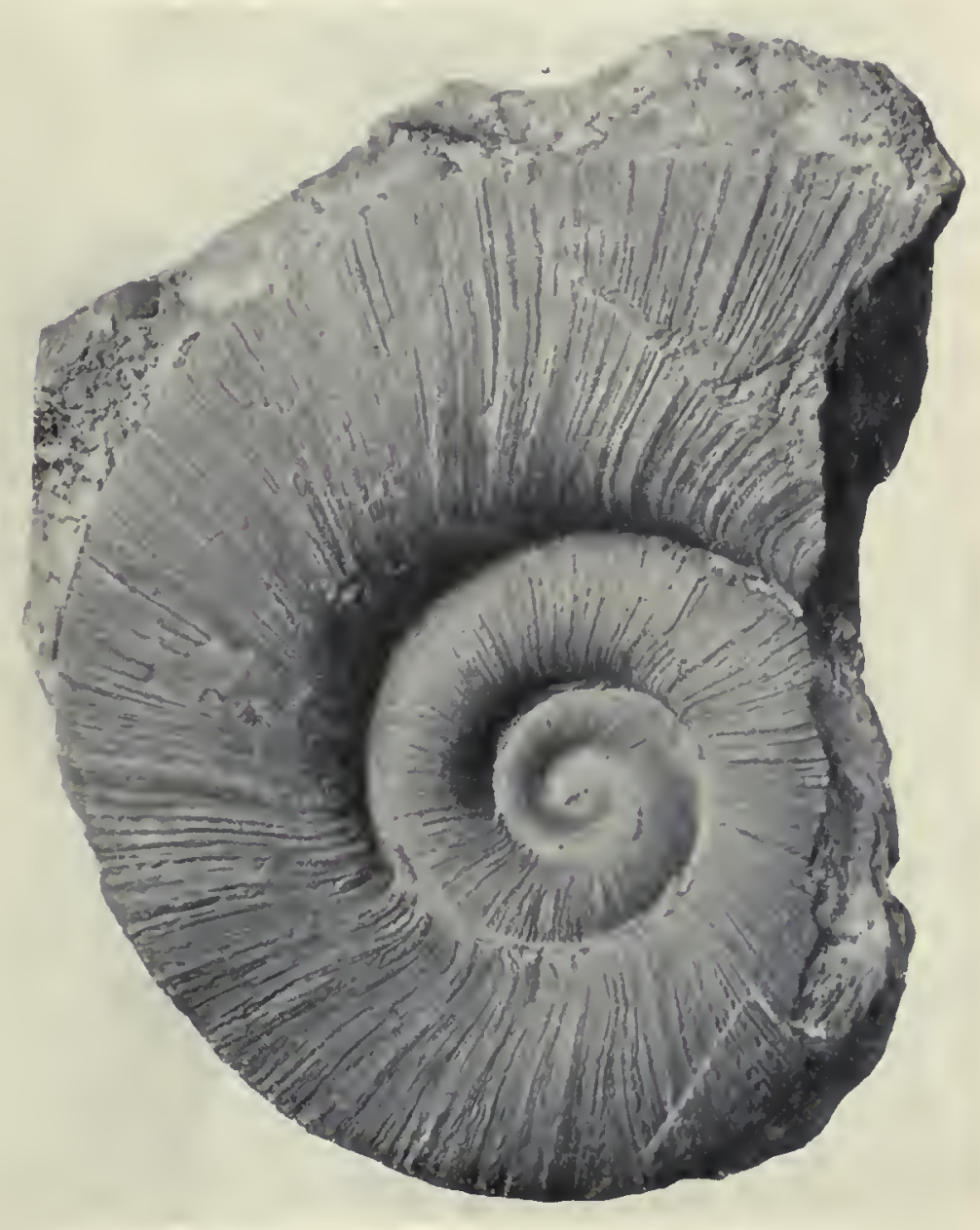

LYTOCERAS cf. SUTNERI, GEYER

"Munger, near Radstock, Somerset

"Charmouthian, valdani" ; J.W.T. Coll. ; S. $197,38,36$ ? 41 Cf. Pl. CXXX

KALLIIYTOCERAS INTERLINEATUM, NOV.

Vessexian, valdani; Genotype, Holotype 

Fig. $3 \times 2$

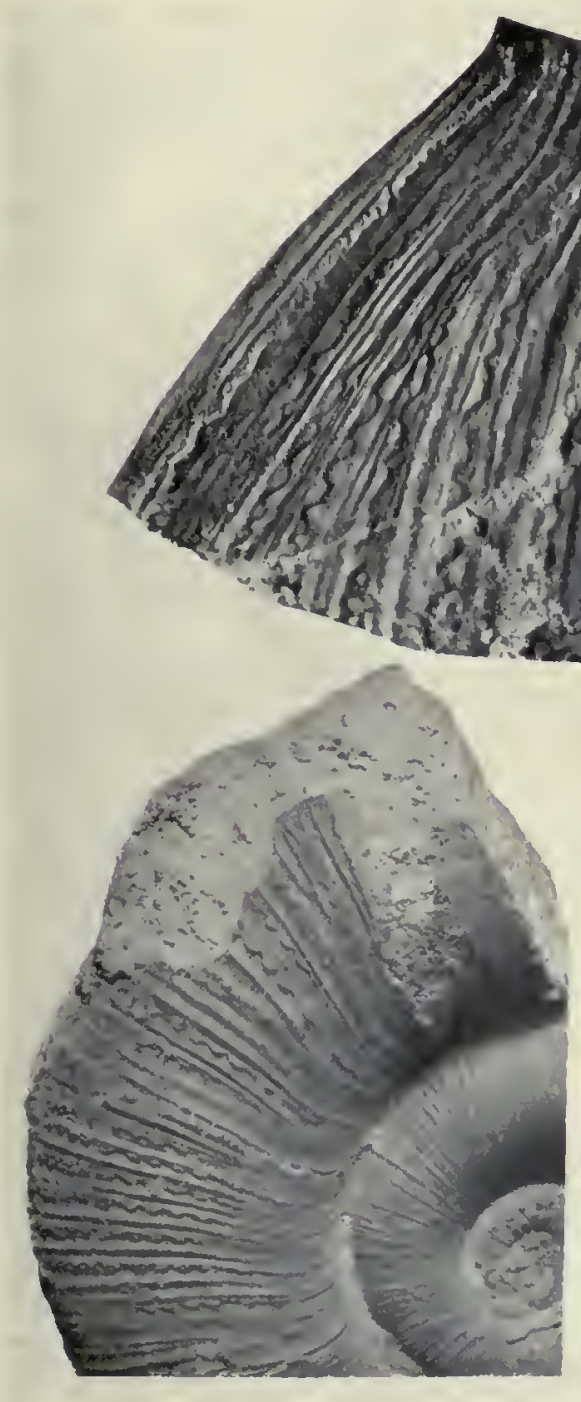

Fig. $2 \times 2$

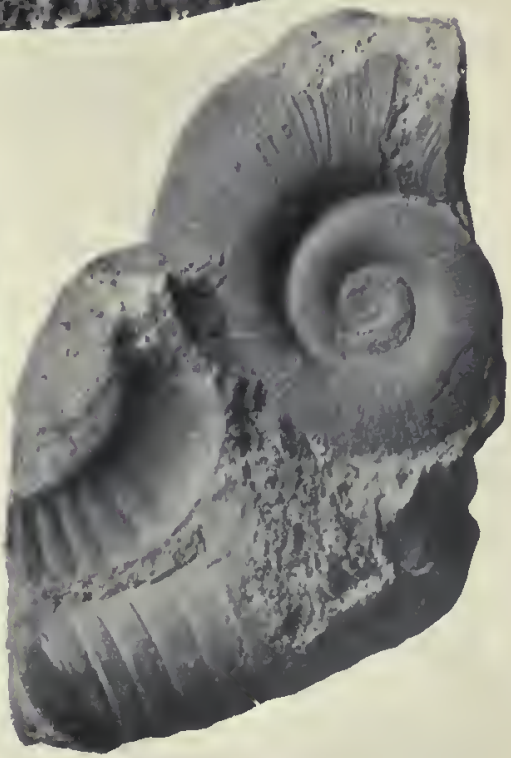

Fig. I

Lytoceras cf. SUTNERI, GEYER

Figs. I, 2, "Old Pit Quarry, Clandown, Radstock, Somerset

"Charmouthian, valdani," Acanthopleuroceras sp. (impression) J.IV.T. Coll. ; S. 46, 40, 32, 4I. Fig. 3, Holotype, test $\times 2$, Pl. CCIVA

KALLILYTOCERAS INTERLINEATUM, NOV.

Wessexian, valdani 

Fig. 3
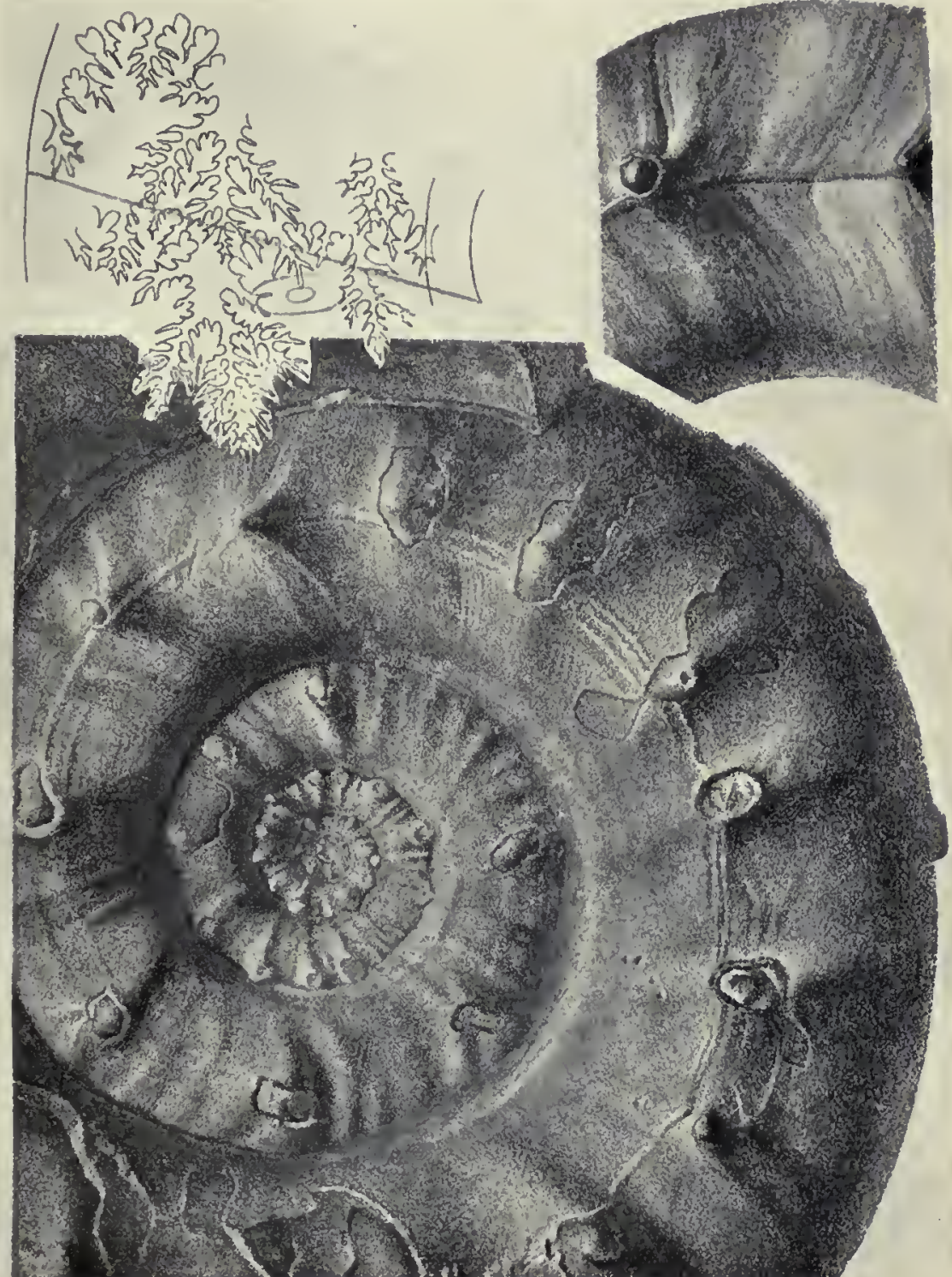

Fig. I

A tuberculate SonNinis

[Sandford Lane], "Sherborne, Dorset; Inf. Ool." ; [Top of Foss. Bed. (Q.J.G.S., XLIX, r893, 492) ] ; S.B., ex Darell, Coll. 995

PAPILLICERAS ACANTHERUM, NOV. Bajocian, sauzei (pre-sauzei ) ; Holotype 



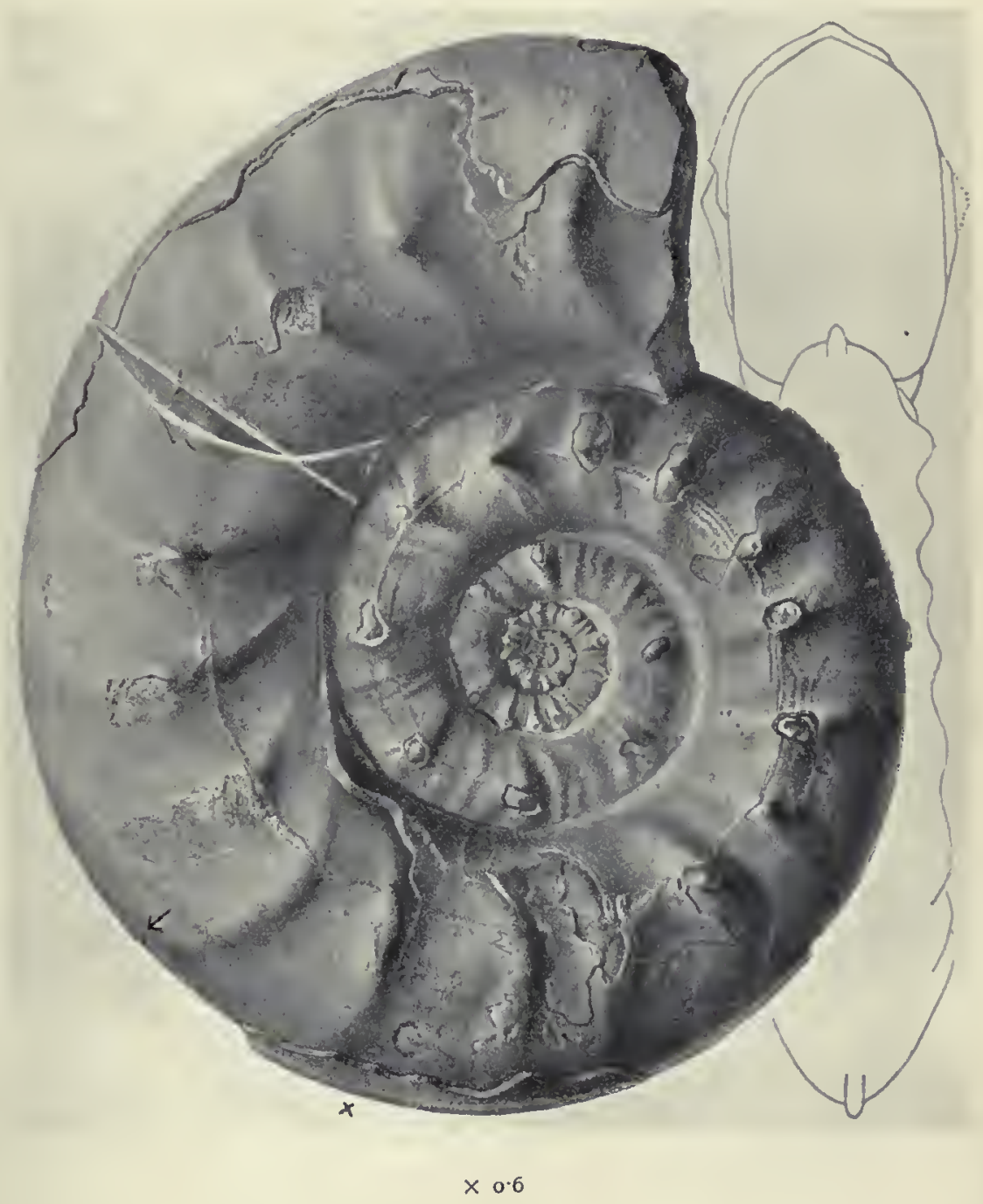

A tuberculate Soxwisis

No. 995 ; S. I I $5,37^{\circ} 5,30^{\circ} 5(245), 37^{\circ} 5 ; 215,345,25(22), 40.5$

NIax. c. $220 . \rightarrow$ End of septum in carina ; $x$, last s.l.

See Pl. CL B and correct there ' $28(24)$ ' to 23 (2I)

PAPILLICERAS ACANTHERUMI, Nov. Bajocian, sauzci (pre-sauzei?); Holotype 



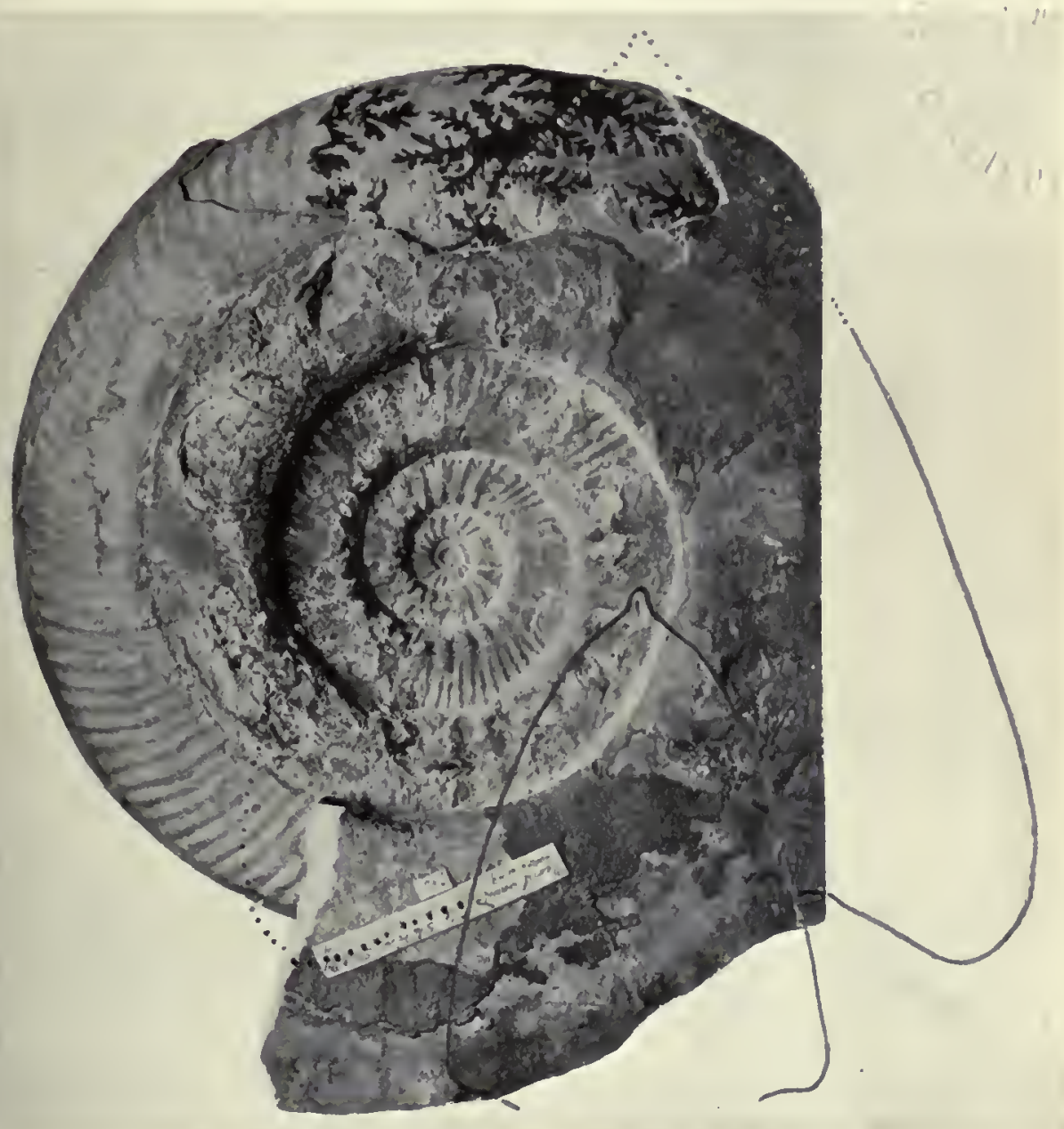

HAMMATOCERAS aff. INSIGNE

Ry. Cutting, Cole, Bruton, Som.; Lias-Ool. (Bruton) Sands

S.B. Coll. (purch.) 783 ; S. $164,33.5,25.5,38$; with further pieces whollyseptate (Fig. 2), S. $275,36^{\circ} 5\left(39^{\circ} 5\right), 33,38\left(35^{\circ} 5\right)$; $\max$. c. $33^{\circ}+$

HAMMATOCERAS CAPPUCINUM, NOV.

Yeovilian, Hammatoceras; Holotype. Cf. CLXXX 

Fig. 1

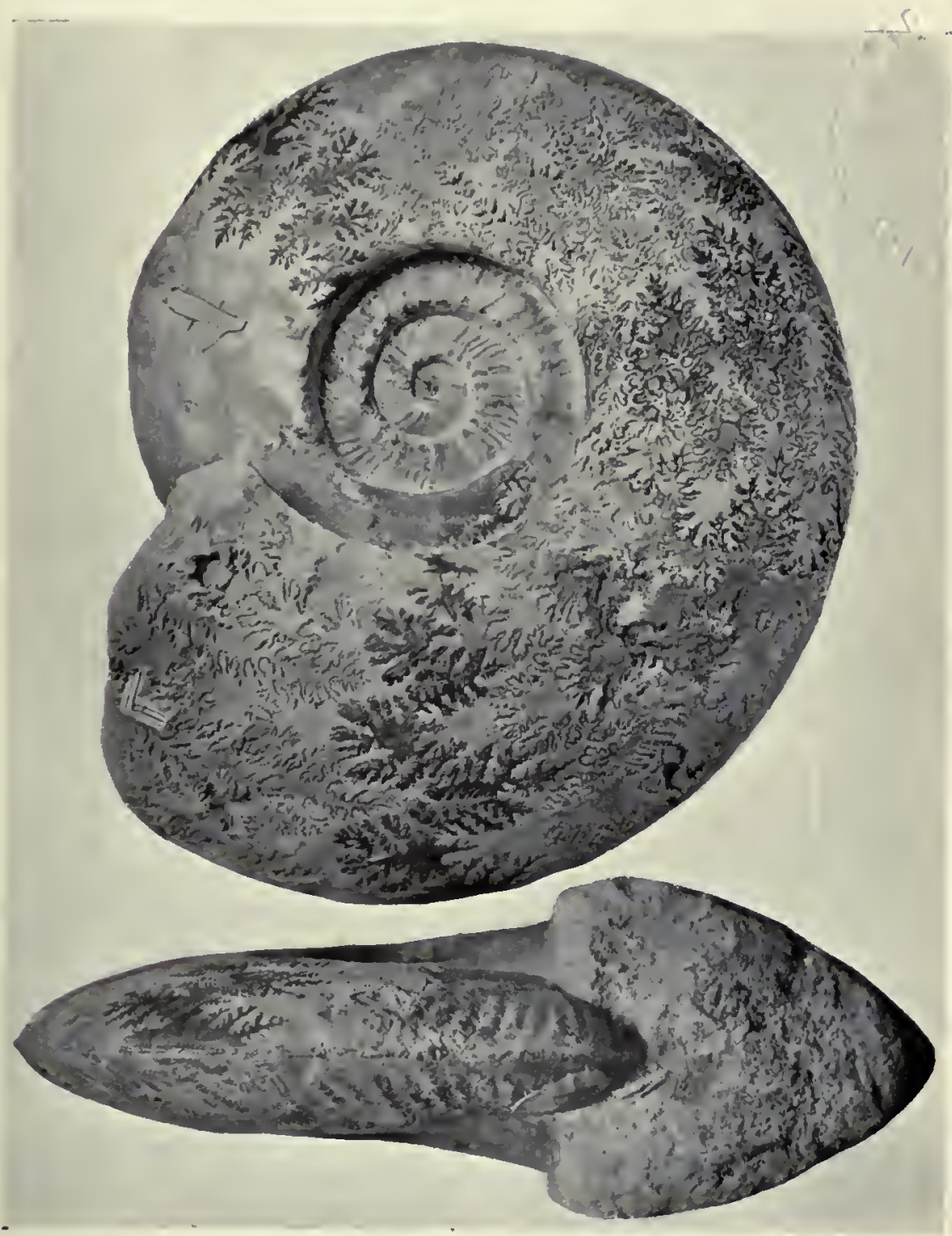

Fig. $2 \times 0.4$

HAMMATOCERAS aff, INSIGNE

[Ry. Cutting, Cole, Bruton, Som.], "England," [Yellow Sands] S.B., Q.J.G.S., I0IO, LXVI, 8I ; Yale Univ. Mus. (U.S.A.) Coll. S. $268,37,33,33.5$; max. c. $380+$

HAMMATOCERAS CAPPUCINUM, NOY. Yeovilian, Hammatoceras; Paratype 

Fig. 1.

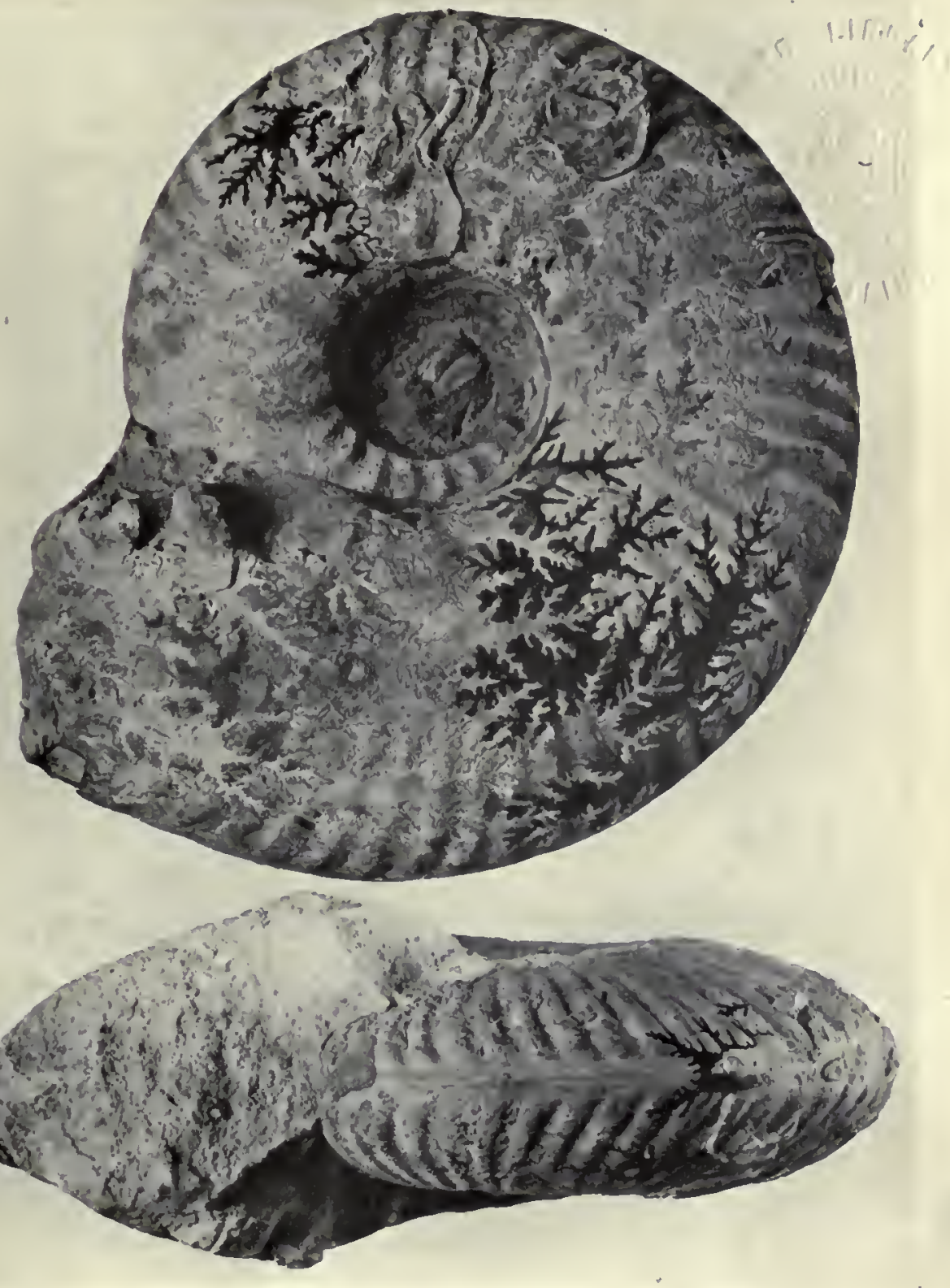

Fig. $2 \times 0.8$

HAMMATOCERAS SP.

"Charolles (Saône et Loire), France"

Yale University Museum (U.S.A.) Coll. No. 45

S. $149,38,36,26$; $\max$. c. $210+$

PACHAMMATOCERAS PACHU, NOV.

Yeovilian, Hammatoceras; Genotype, Holotype 

Fig. I

lig. 3

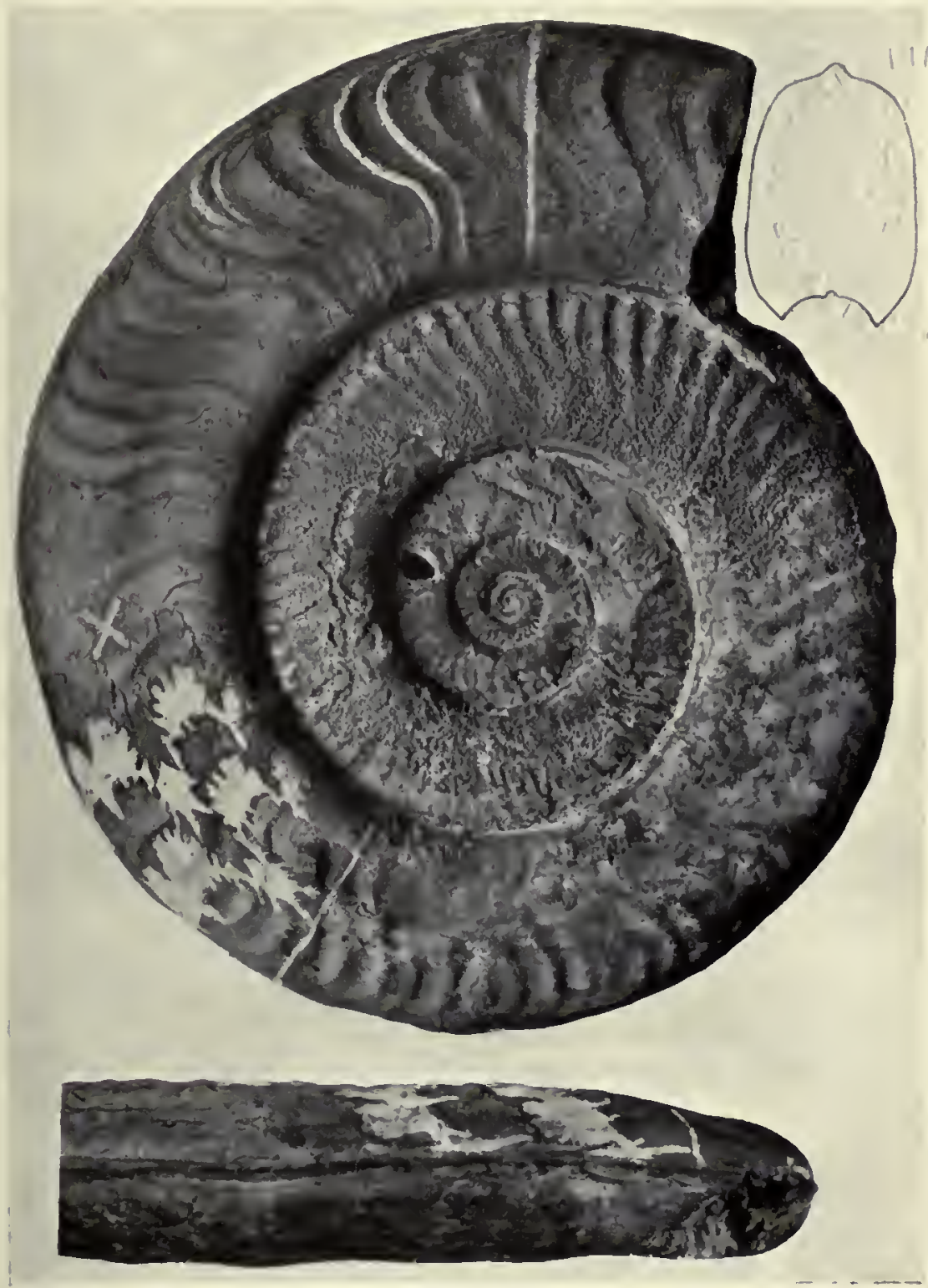

Fig. 2

Amoniti:s SERPEntinus; Moore, I867, (cit. sp. ?)

Proc. Somerset Arch. Soc. XIII, I94; "Ilminster, Somerset

"Upper Lias"; Manchester Mus., ex C. Moore Coll., L. II543

S. $86,30, I 7 \cdot 5,4 I \cdot 5 ; I 24,26, I 6 \cdot 5,55 ; \max . c$. I 40

HILDOCERATOIDES PROPESERPENTINUS, NOV.

Whitbian, falciferum; Genotype, Holotype. See CXXXVIII A 

Fig. 1

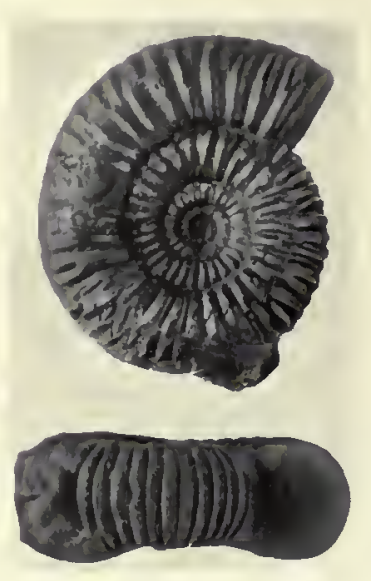

Fig. 2.

Ammonites CRassiusculus, Simpson, I855, Holotype

Pp. 56, 57; "[Whitby], Yorkshire; hard bands of the Middle Lias";

Whitby IIuseum, No. $499 ; \phi .37,25.5,34,49$. See No. 9 I.

PORPOCERAS CRASSIUSCULUM, SimpSON sp.

Whitbian, athleticum 

Fig. I

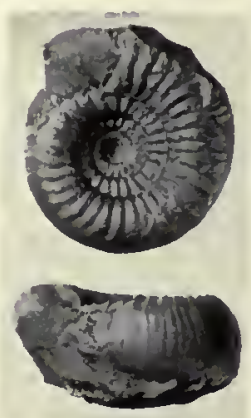

Fig. 2

Amonites incrassatus, Simpson, I855, Holotype P. 5t; " [Whitby], Yorkshire ; U[pper] L[ias]" ; pyritized [Middle Lias, pyritous shales]; Whitby Museum, No. I 49 ; ф. $24,30,48,45$. See No. II9

CCELOCERAS INCRASSATUM, SinPSON SP. Wessexian, pettos 

Fig. I

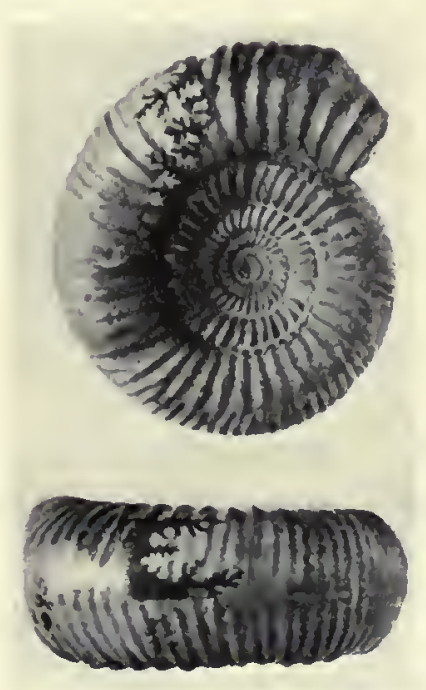

Fig. 2

"Perisphinctes cf. evolutoldes, Siemiradzi " Burton Bradstock, Dorset; Inf. Ool., [3rd. Bed, (truellei)] S.B., ex Darell, Coll. $895 ;$ S. $42,28.5,39,47.5 ; 40$ ribs

PHANEROSPHINCTES PHANERUS, NOV. Eningenian, truellei; Genotype, Holotype 



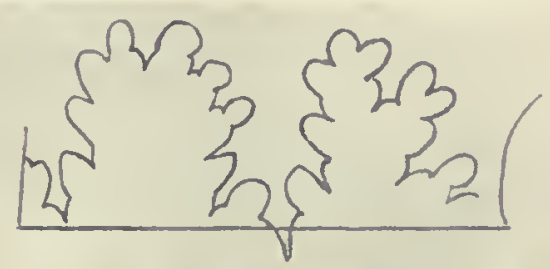

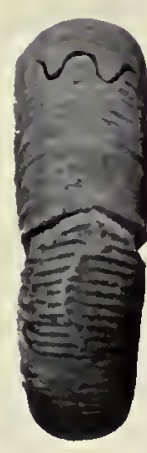

Fig 3

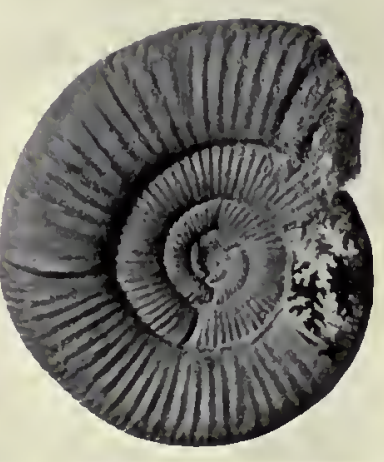

Fig. I

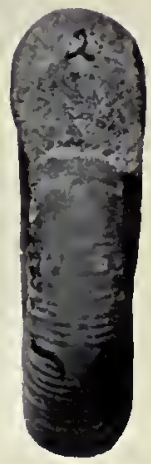

Fig. 2

Ammonites Alligatus, (BEAN MS.) Leckenby, I859, Holotype Q.J.G.S., XV, 9; II, 2 ; Scarborough Castle Rock, Yorkshire Kclloway Rock; bluish-grey calc., ool. grains rare S. $44,28 \cdot 5,29 \cdot 5,48 ; 60$ ribs; $\max$. c. 53 . See Pl. CXXXIX 



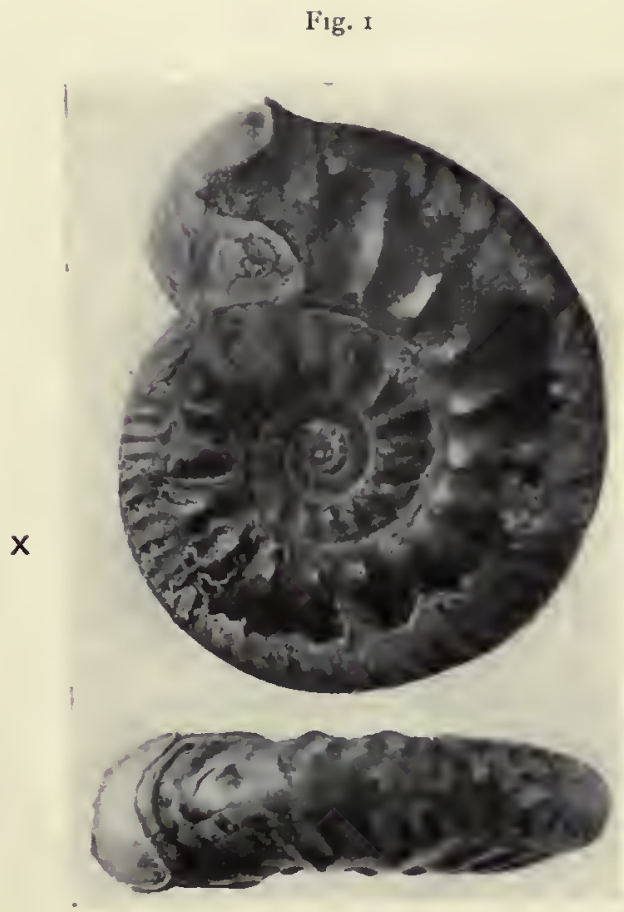

Fig. 2

"Anmonites kolnigi"

"Chippenham, Wiltshire ; Oxf. Clay," [Kellaways Clay (a)] Geol. Surv. Engl., No. 30532 ; S. $61,32,245$ (22), 40 ; 17 ribs

PROPLANULITES CAPISTRATUS, NOV., p. 37

Callovian koenigi (majesticus); Holotype 



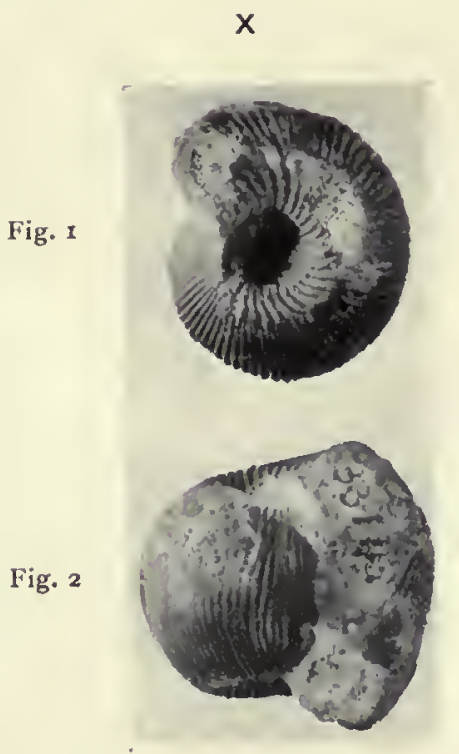

"Amionites brongniarti"

"D[undry, Somerset], $\mathrm{f}[\mathrm{ar}] \mathrm{q}[$ uarry]" = South Main-road Quarry

" Inf. Ool." [Ironshot Ool.], (Q.J.G.S. LII, I896, 69I, § Ix, Bed 4)

S. B. Coll., pres. E. Wilson ; S. 3I, 4I, 97, 2 I ; max. c. 47

LABYRINTHOCERAS EXTENSUI, NOV.

Bajocian, sauzei; Holotype. See CXXXV 

Fig. I

Fig. Ia

Fig. $4 \times$
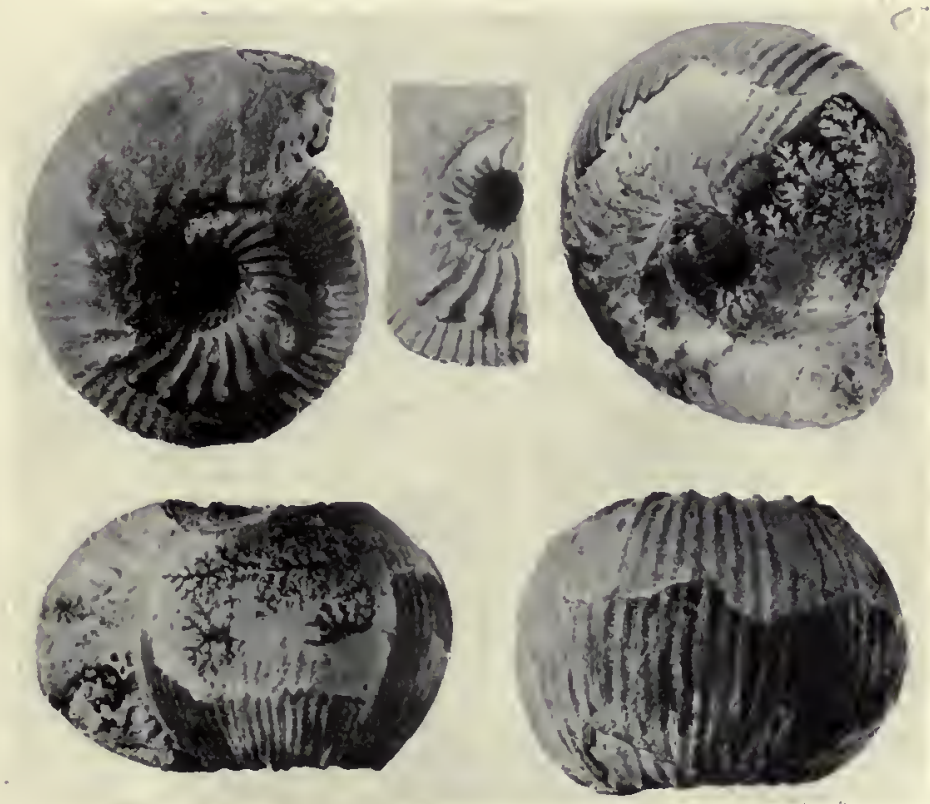

Fig. 2

Fig. 3

A coronate SPH ÆROCERATID

Frogden Quarry, Oborne, Dorset; Inf. Ool., green-granned Marl (Q.J.G.S., XLIX, I893, 500, § Xv, 9) ; S.B., ex Darell, Coll. I228 S $30^{\circ} 5,37,87,2 \mathrm{I} ; 45,33,7 \mathrm{I}, 30$; max. c. 55 . Last s.l. black, fig. 4

FROGDFNITES SPINIGER, NOV.

Bajocian. sauzei; Genotype, Holotype 

Fig. 1

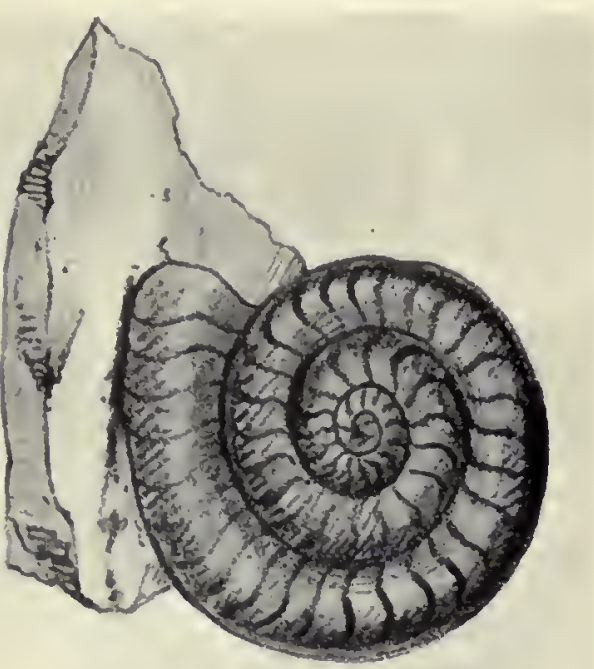

Fig. 2

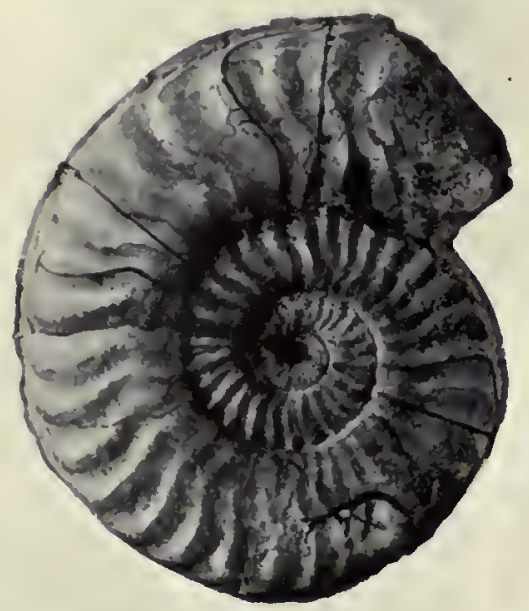

Fig. 3

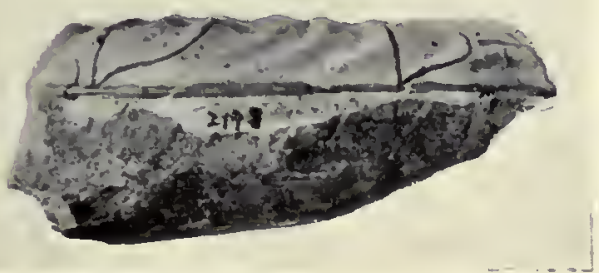

Ammonites Murleyi, J. Buckman in Moxon, I841

Foss. Brit. Str. xxıv, 6; F. r, Protograph, J.B. del. (copy) "Up. lias shale." F. 2, 3, (Holotype ?) Paratype; "Dumbleton, Glos" Geol. Chelt. r844, pp. 36, go ; S.B., ex J.B., Coll. 2178 ; S. 62, 34, 23.5, 40

MURLEYICERAS MURLEYI, J. BUCKMAN-MOXON SP. Whitbian, murleyi ; Figs. 2, 3, Genotype 

Fig. I.

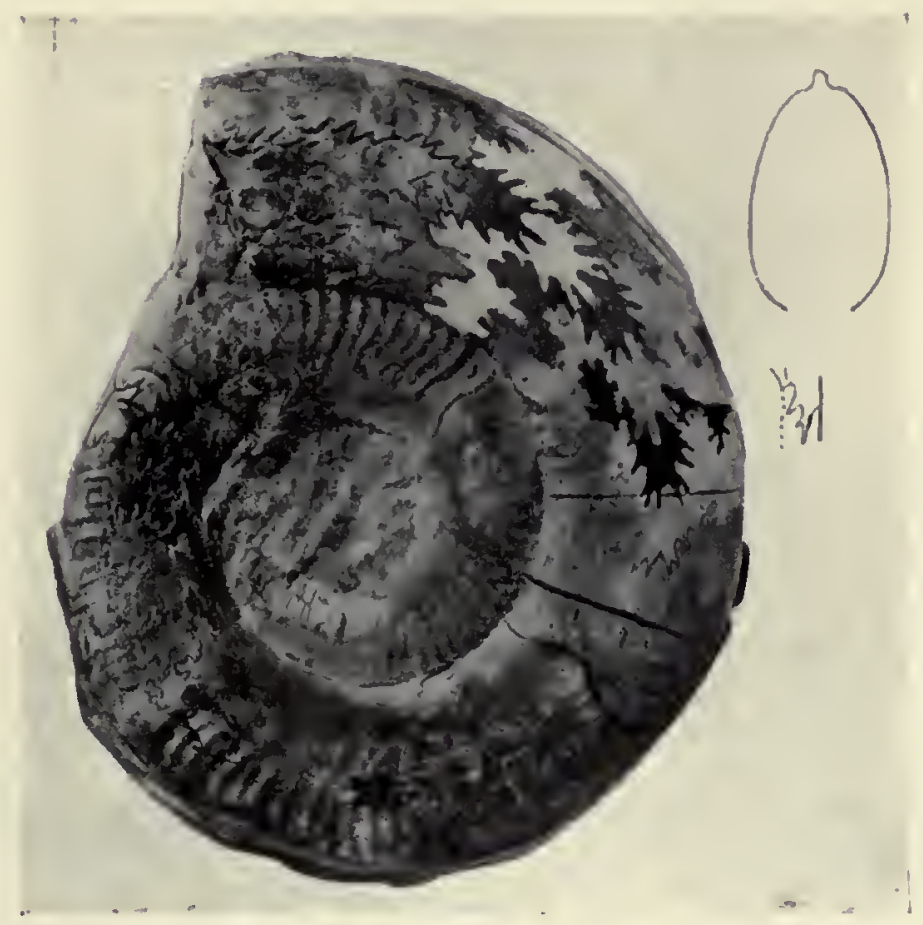

Fig. 2.

Fig. 3

AMMONITES SERPENTINUS ; MOORE I867, (cit. sp. ?)

Proc. Som. Arch. Soc. XIII, 194, "Ilminster, Somerset ; Up. Lias" Manchester Mus., ex C. Moore Coll., L. II544

S. $86,28,17,47 \cdot 5 ; \max$. с. 102 . See CXXXVIII в

HILDAITES SUBSERPENTINUS, NOV.

Whitbian, falciferum; Genotype, Holotype 

lïg. I

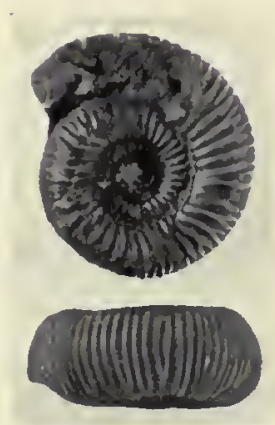

Fig. 2

AmMonites cRassulus, Simpson, I843, Holotype

P. 20; " [Whitby], Yorkshire" ; “U.L. 6," (Simpson, I884, p. 86) Whitby Iuseum, No. $489 ; \phi .23 .5,32,38,47$. See Pl. CLVII 



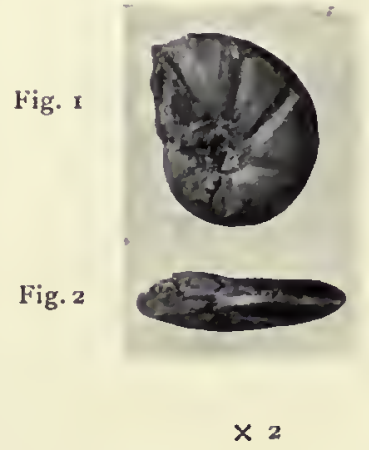

Ammonites huntoni, Simpson, 1843 , Holotype?

P. 4I; "Robin Hood's Bay, Yorkshire; lowest beds of lias ;

“L. L. $y$ ” (I884, p. II9); Whitby Nuseum, No. 477 ф. I0.5 (2I), 45, 26, 26. See No. I6 \& I, viii

TRAGOPHYLLOCERAS HUNTONI, SIMPSON SP.

Wessexian, ibex 



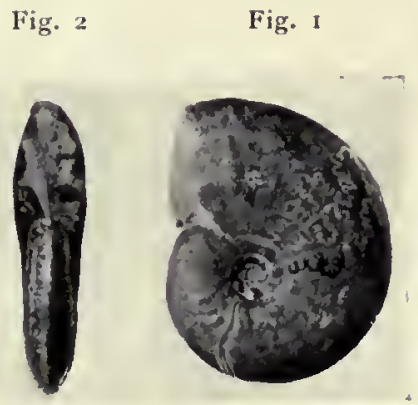

$\times \quad 1.25$

Amonites Robinsoni, Smipson, i843, Holotype P. 42 ; "Robin Hood's Bay, Yorkshire ; lowest beds of lias" A cast of a bronze colour from a grey sandy matrix Whitby Museum, No. 478 ; S. $24,49,23,21$. See Pl. CCXIX

TRAGOPHYLLOCERAS ROBINSONI, SiMPSON SP. Wessexian, ibex 



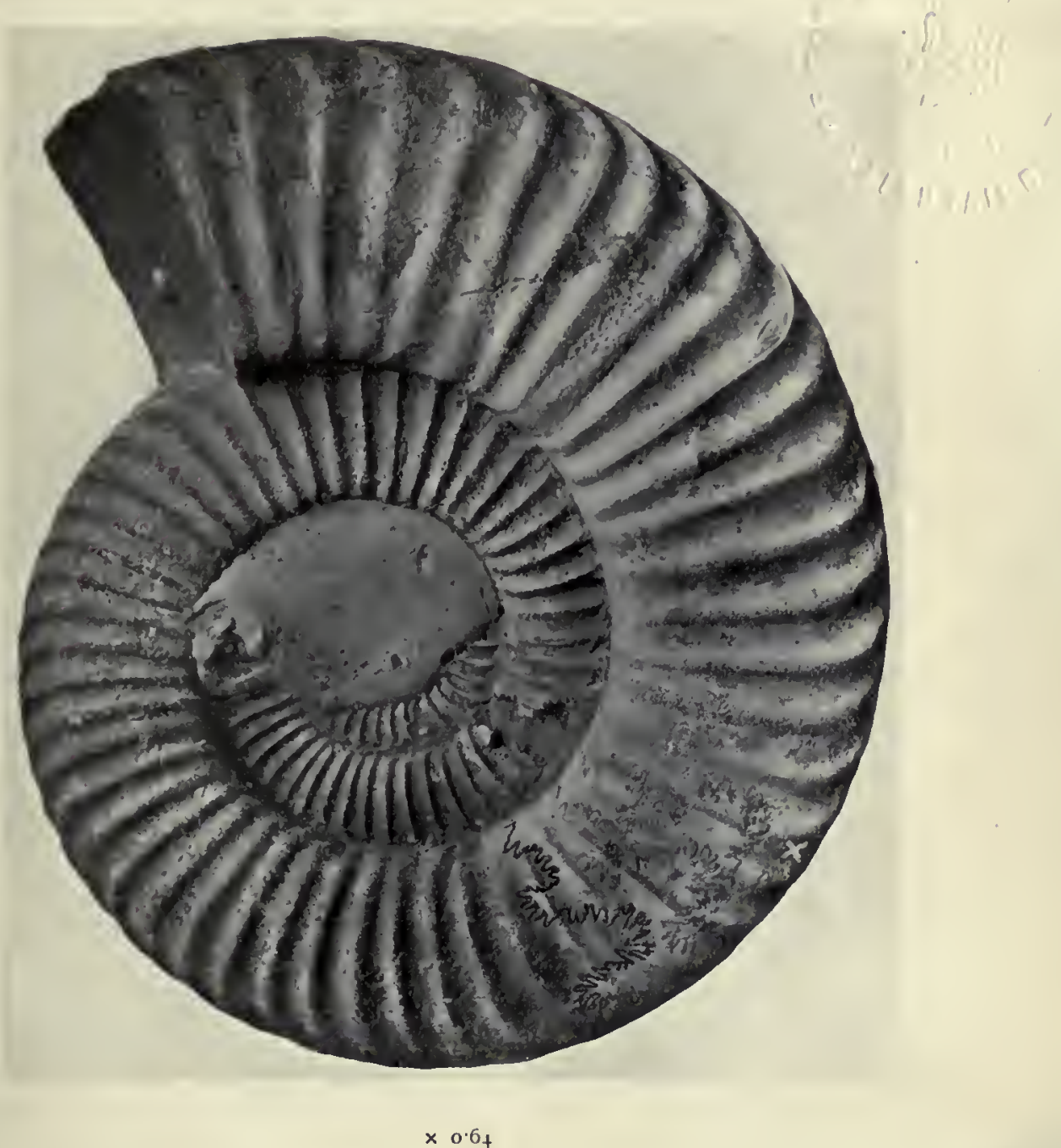

Amionites turneri, J. de C. Sowerby

(I824, Min. Conch., V, 75 ; cCcCLI, upper fig.)

Ex resident Brislington, Som. ; Miss M. G. Horder Coll.

S. $203,32,28,46 ; 49$ ribs; $\max$. c. 220 . See No. I20

ARIETITES TURNERI, J. de C. SOWERBY SP.

Mercian, tumeri 

Fig. I

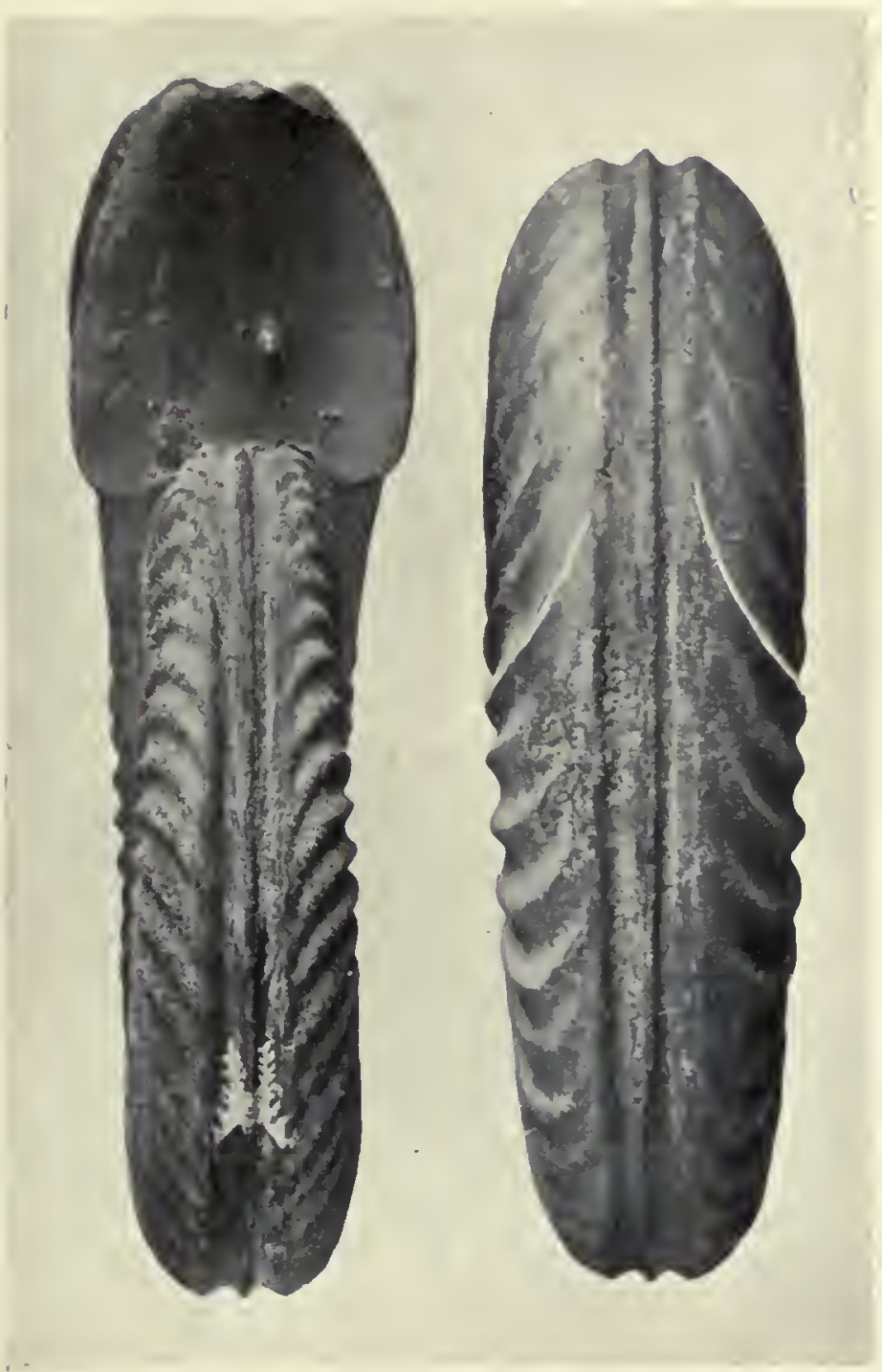

$\times 0.64$

Amonites turneri, J. de C. Sowerby

Ex resident Brislington, Som.; Miss M. G. Horder Coll. ["Kelston, Somerset ; gmuendense-sauzeanum" ; J. W. T.]

ARIETITES TURNERI, J. de C. SOWERBY SP. Mercian, turneri 



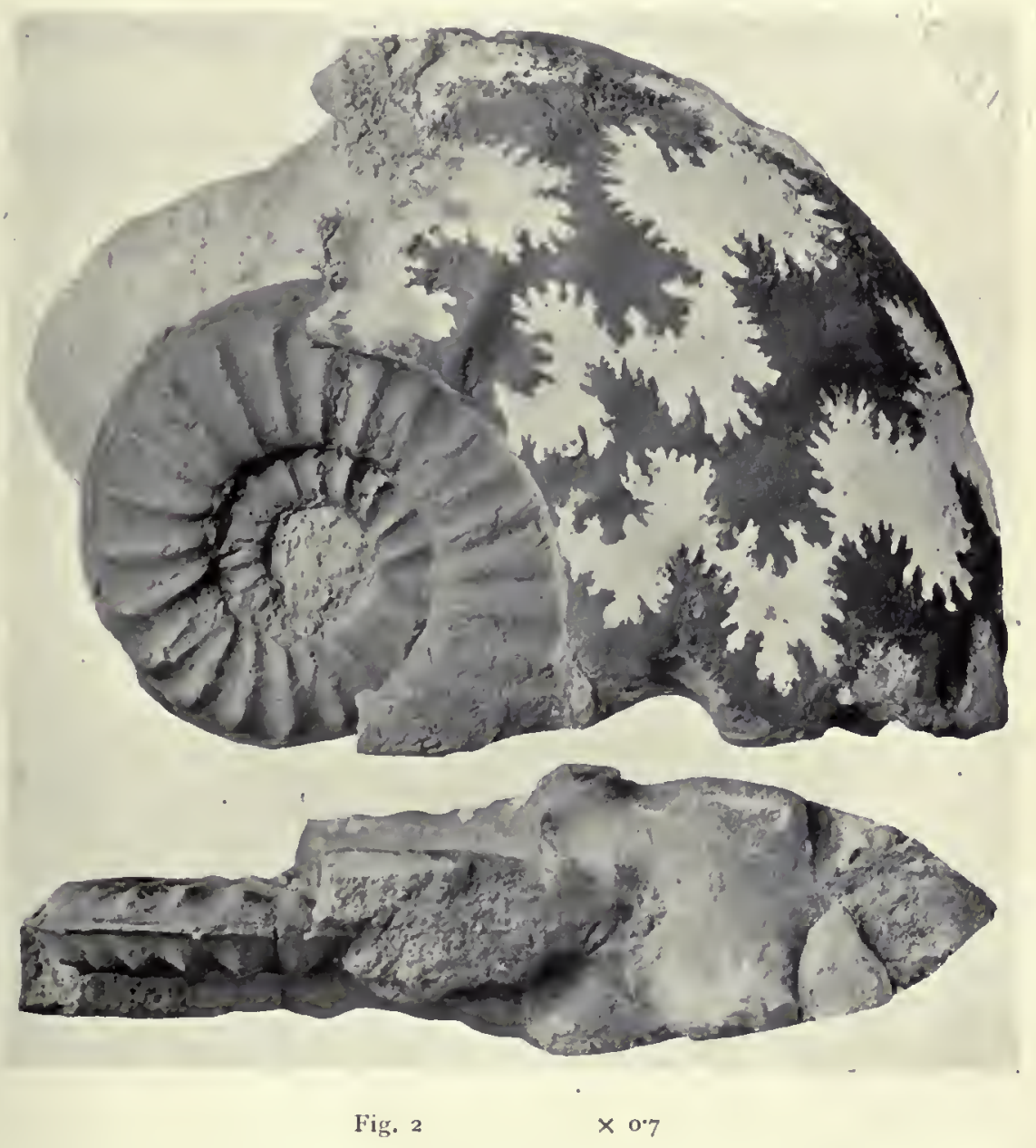

Ammonites scipionis; Reynés

(1879, Mon. Amm., xxvil, 3, 4) ; Newtown, Paulton, Som. ; J.IV.T. Coll. S. $95,37,24,39 ;(190,37,24,40$, est. $)$; max. c. $270+$. See No. 66.

AETOMOCERAS NODULATUM, NOV.

Lymian, scipionianum; Holotype 

Fig. I

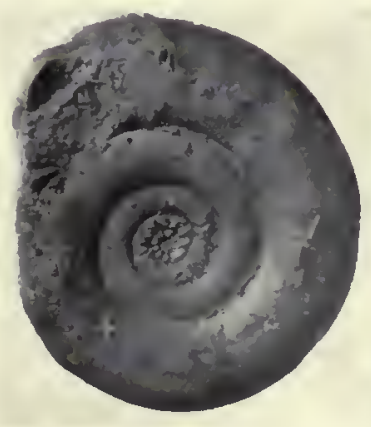

Fig. 2

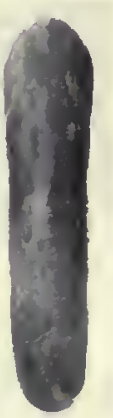

Ammonites erúgatus, (BeAn MS.), Phillips, I829, Holotype Geol. Yorksh., I63, I74, I92 ; XIII, I3; [Robin Hood's Bay], Yorkshire "Upper Lias Shale"; Whitby Museum, No. Ioo; $\phi .42,27,215.49$

PSILOCERAS ERUGATUM, BEAN-Phillips SP. Hettangian, planorbis 



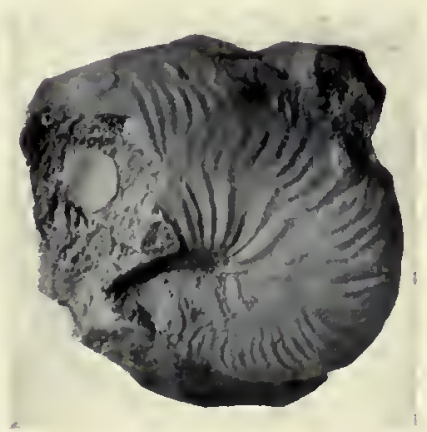

Aymonites oculatus, (Bean MS.) Philitps, I829, Holotype Geol. Yorksh., I38, I75, I88; v, I6; "Scarborough, Oxf. Cl." (blue, sandy) ; Yorkshire Phil. Soc., York, (Bean Coll.) ; "This specimen " figured by Phillips," Bean's lab. ; S. 39, 55, 24 ? 9; crushed

NEUMAYRICERAS OCULATUM, BEAN-PHILLIPS SP. Divesian, vernoni; Genosyntype 

Fig. 2

Fig. I
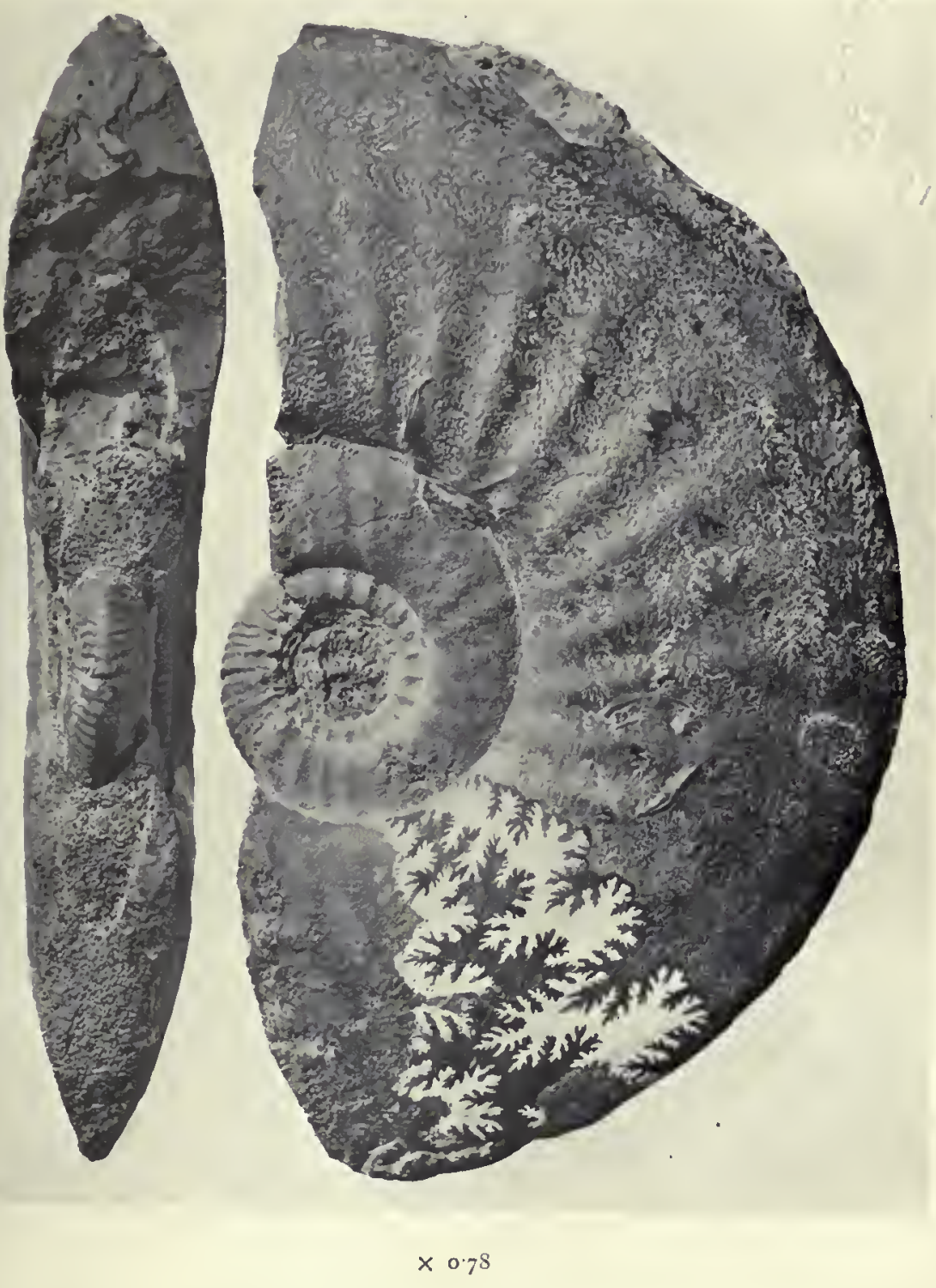

" AMMONITES BERRYERI"

"Westbury, Wilts ; Corallian, [Iron Ore]"

J.II.T. Coll. ; S. 60 ? 44, 25, 27; 100, 42, 23, 28

S. I80, 37, I9, 34; $\max .280+$

RINGSTEADIA ANGLICA, SALFELD

Krimmeridgian (Sequanian), Ringsteadia; Topotype 

Fig. I

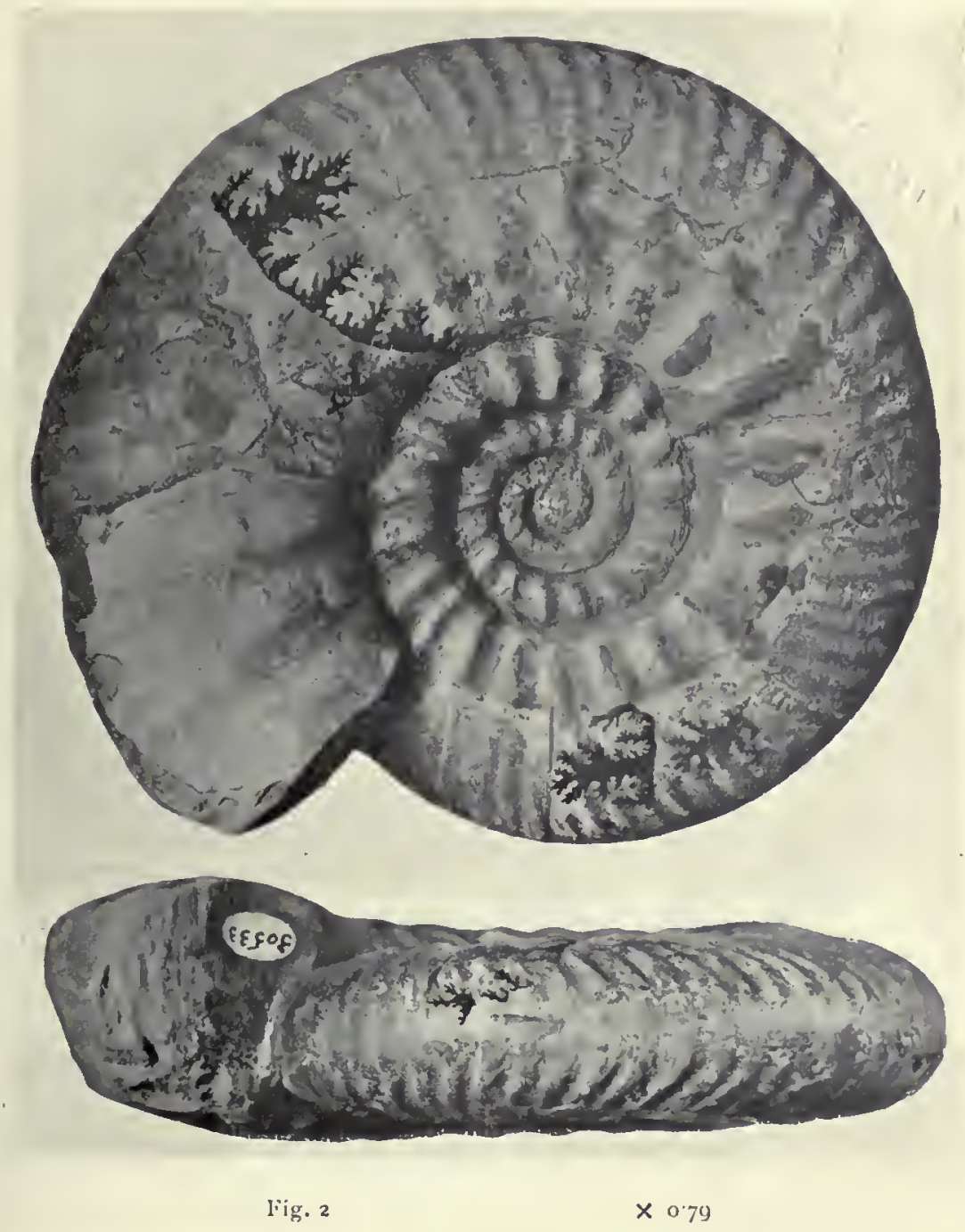

"Ammonites koenigi"

Perisph. könighi; Neum., I87I, xI, 2; P. obtusicosta; Petitclerc, I915, vII, 3 " Chippenham, Wiltshire ; Oxford Clay," [Kellaways Clay $(a)$ ] Geol. Surv. Engl., 30533; S. 133, 37, 27, 35 ; max. c. 2 IO ; LI, $42 \cdot 5$

PROPLANULITES MAJESTICUS, S. BUCKMAN, p. 34 Cillovian, kocnigi (majesticus); Holotype 

Fig. I

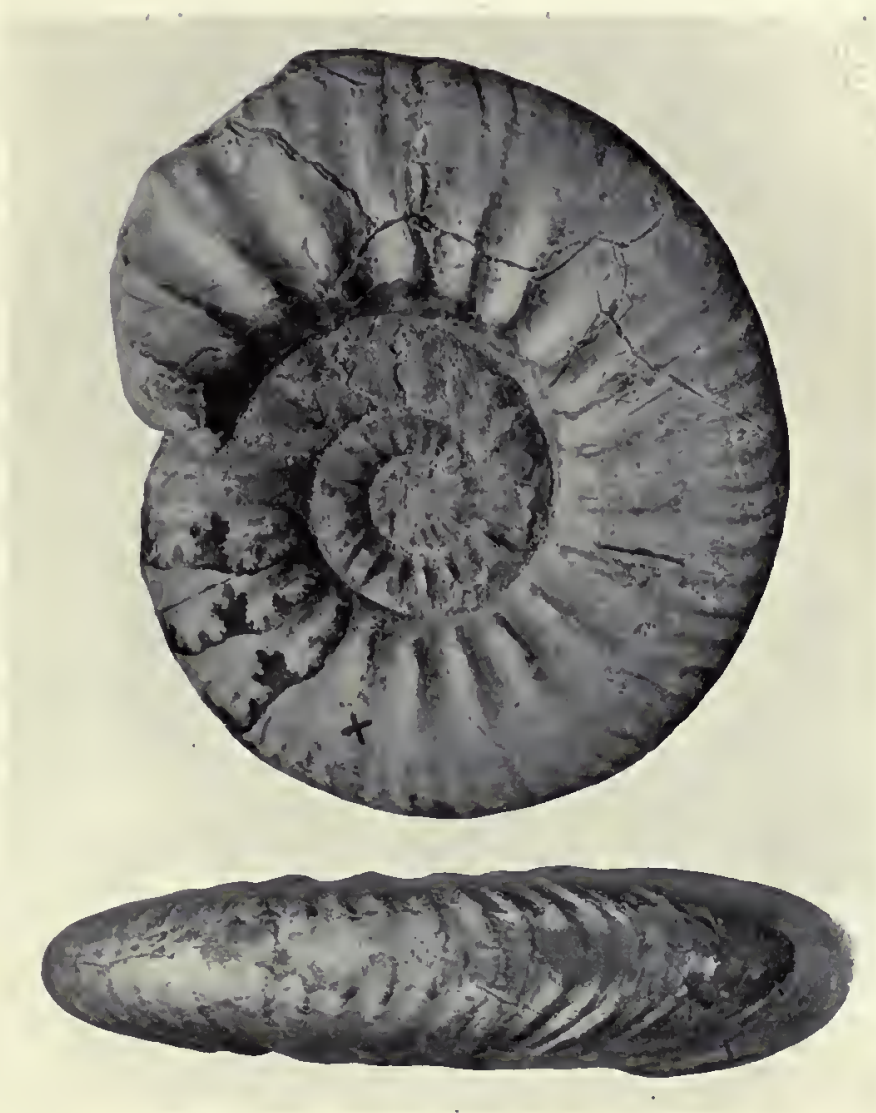

Fig. 2

"AMmonites Koenigi"

Proplanulites subcuncalus, Teiss. I887, Iv, I2; "Christian Malford, Wilts"

" Oxford Clay," [Kellaways Clay $(a)$ ] ; J. W. Tutcher Coll.

S. $71,36.5,26,37 ; 82,36,25,40 ; 22$ ribs; $\max$. c. 94

PROPLANULITES SUBCUNEIFORMIS, S. BLicKMax, p. 37

Callovian, koenigi, (majesticus); Holotype 



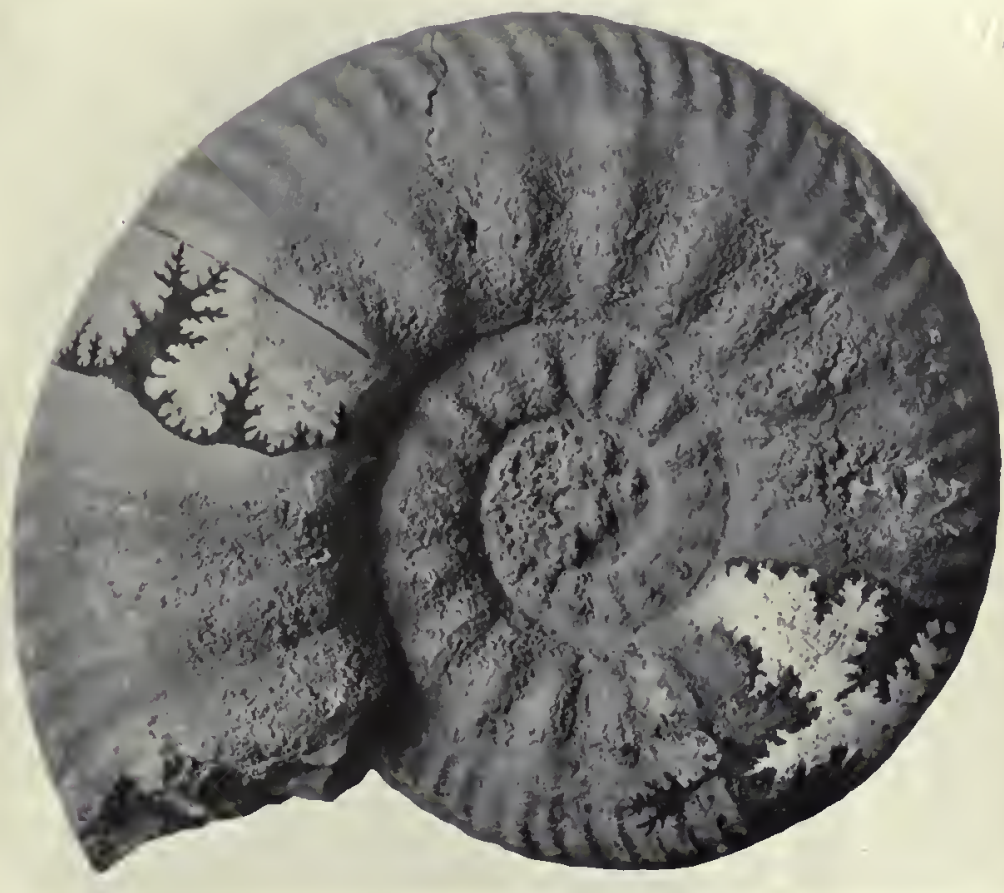

$\times 0.8$

\section{"AMMONITES BAKERIE"}

"Kellaways, Wilts, Kell. Rock [e]"; Geol. Surv. Engl. 25649 S. $65,37,34,35 ; \mathrm{I} 4 \mathrm{I}, 37,34(3 \mathrm{I}), 355 ; 20$ ribs; $\max , \mathrm{c}, 250+$

CRASSIPLANULITES CRASSICOSTA, S. BUCKMAN, p. 4I Callovian, post-koenigi (Crassiplanulites); Genotype, Holotype 

Fig. :

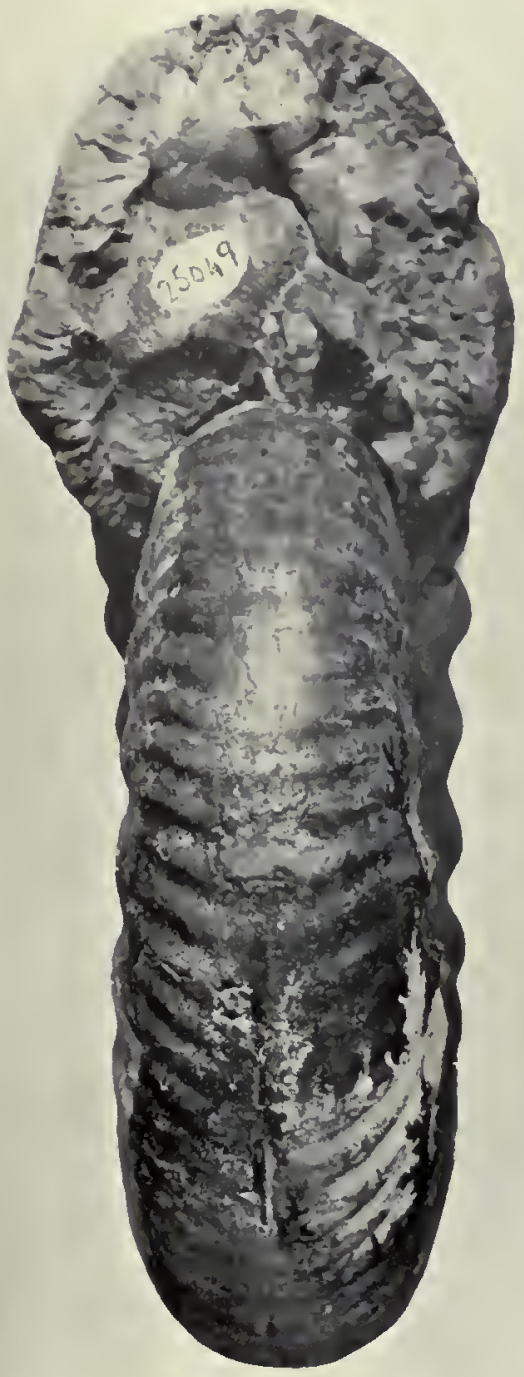

lïg. 2

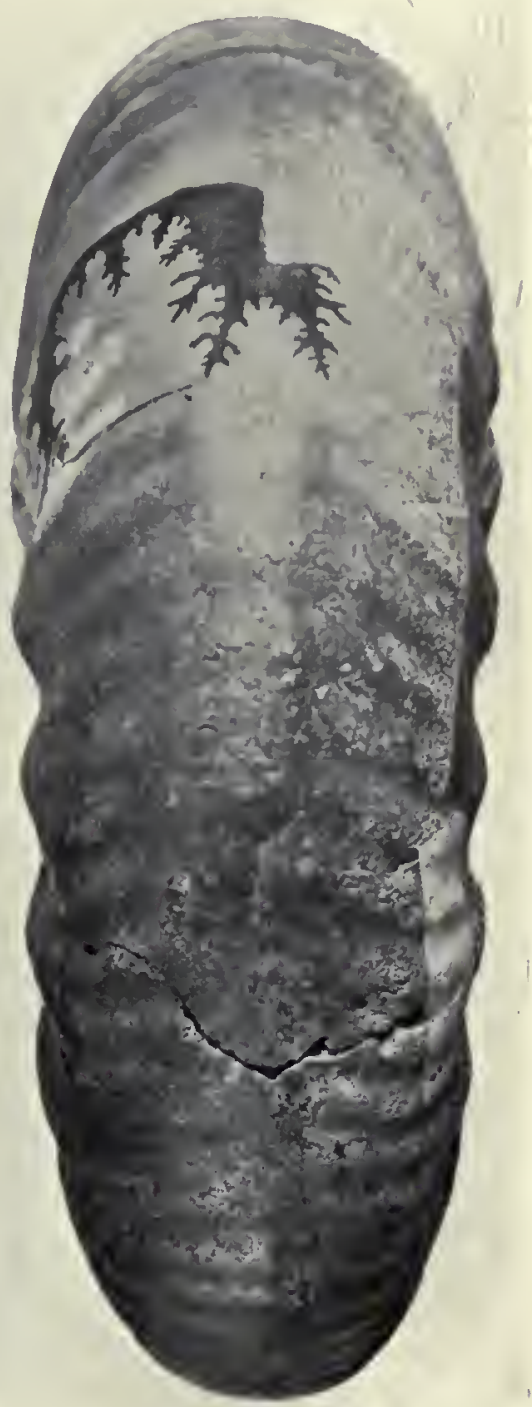

“AMmonites BAKERIE"

"Kellaways, Wiltshire; Kellaways Rock [e]" Geol. Survey England, No. 25649 ; Nat. size

CRASSIPLANULITES CRASSICOSTA, S. BUckMAN, p. 4I Callovian, post-koenigi (Crassiplanulites); Genotype, Holotype 

lïig. I

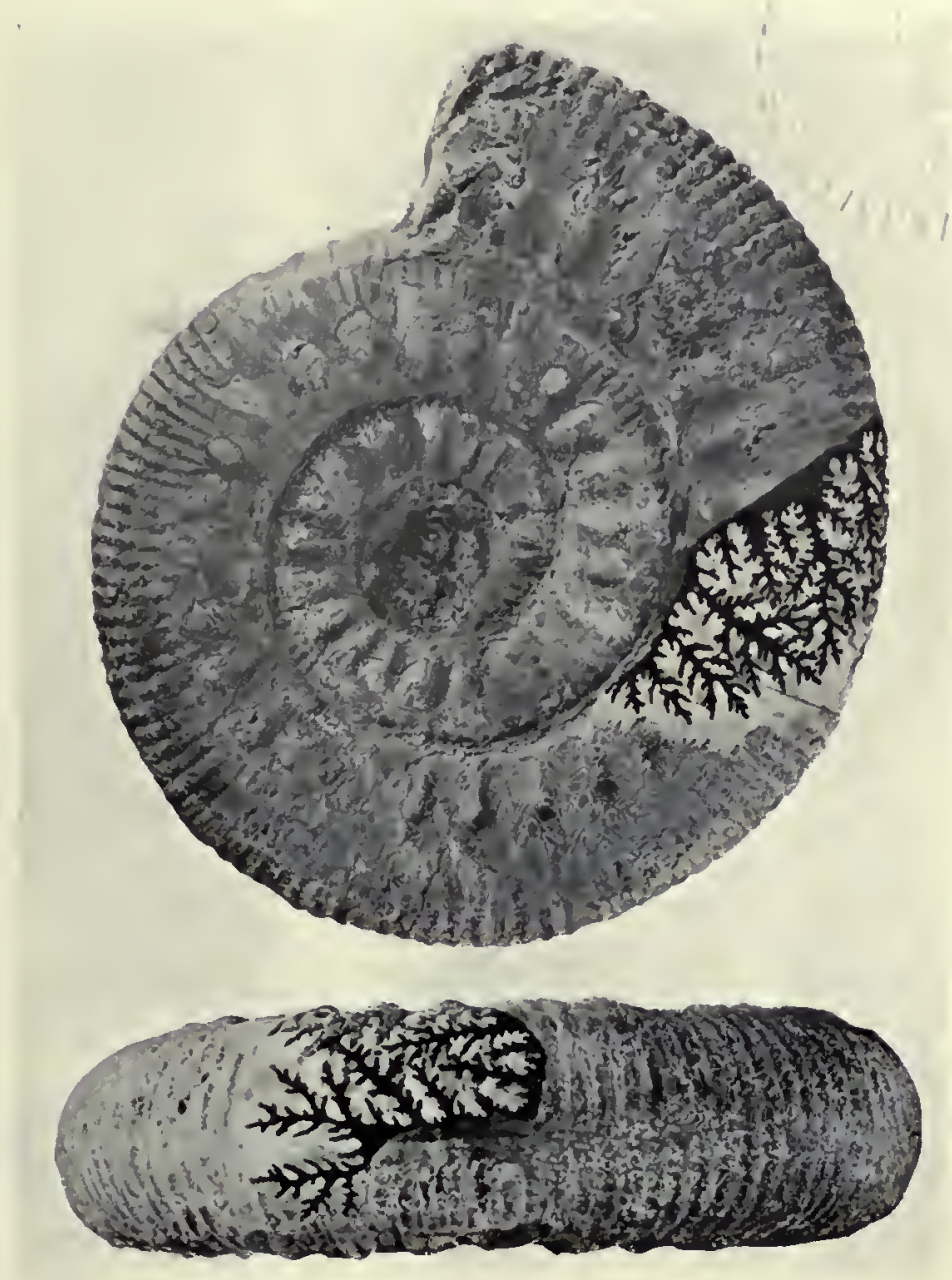

Fig. 2

\footnotetext{
"STEPHANOCERAS HUMPIIRIESIANUM"
}

[Clatcombe], " near Sherborne, Dorset ; Inf. Ool." [lowest pt. Humphlr. z.] S.B., ex Darell, Coll., 347 I ; S. 92, 25, 28.5, 54 ; 28 ribs ; max. c. I75 +

STEPHEOCERAS PLAGIUM, NOv. Bajocian, pre-blagdeni (Masckeites); Holotype 

lig. I $\times$ o.9 I
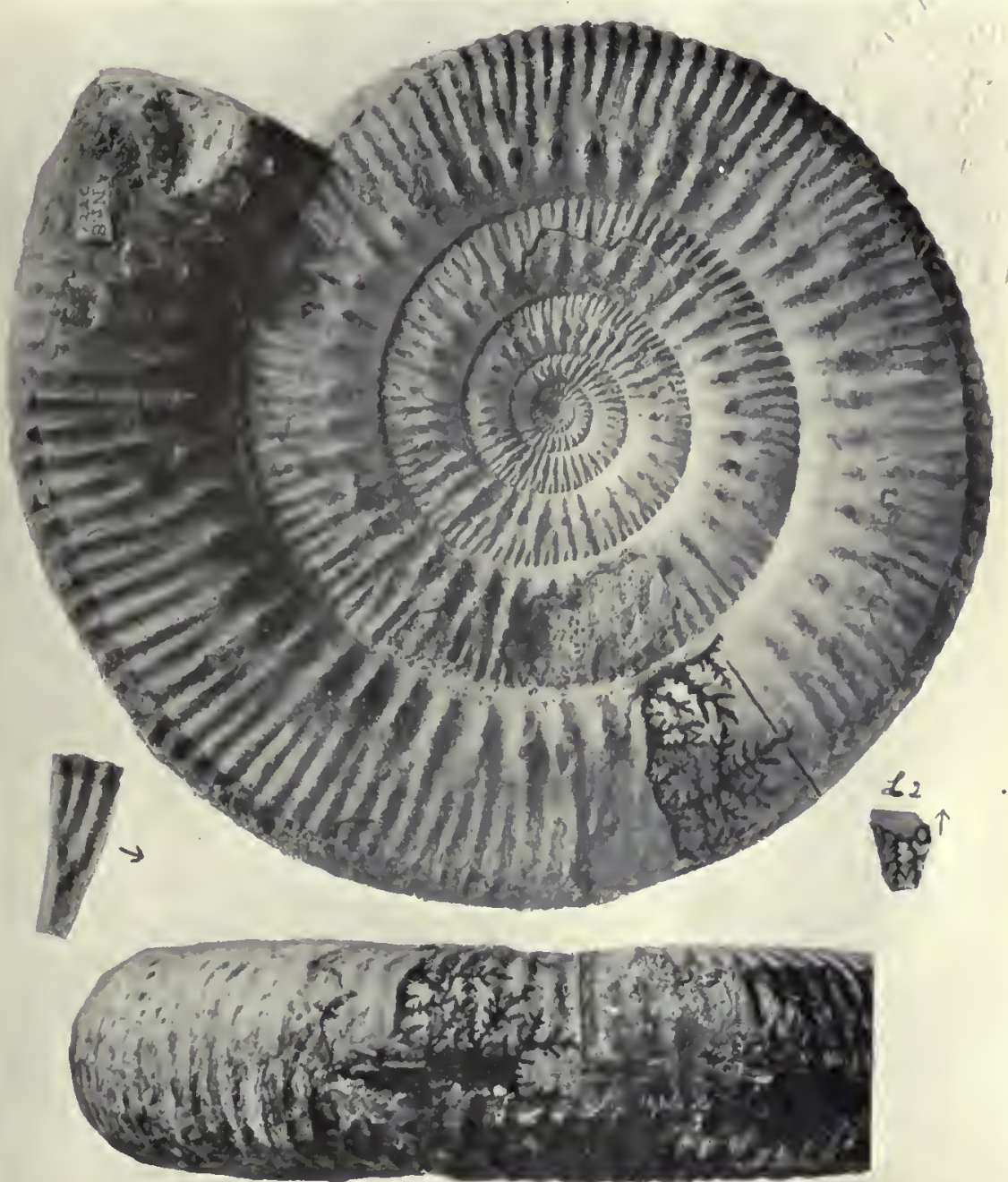

Fig. I a

Fig. 2, N.S

Fig. Ib

" Stepinanoceras MACRUM"

[Sandford Lane], " near Sherborne, Dorset ; Inferior Oolite"

[Foss. Bed, upper part], (Q.J.G.S., XLIX, I893, 494)

S.B., ex Darell, Coll., I220 ; S. I29, 23.5, 24, 57 ; 48 ribs ; max. c. $220+$

KALLISTEPHANUS KALUS, Nov.

Bajocian, sauzei; Genotype, Holotype 



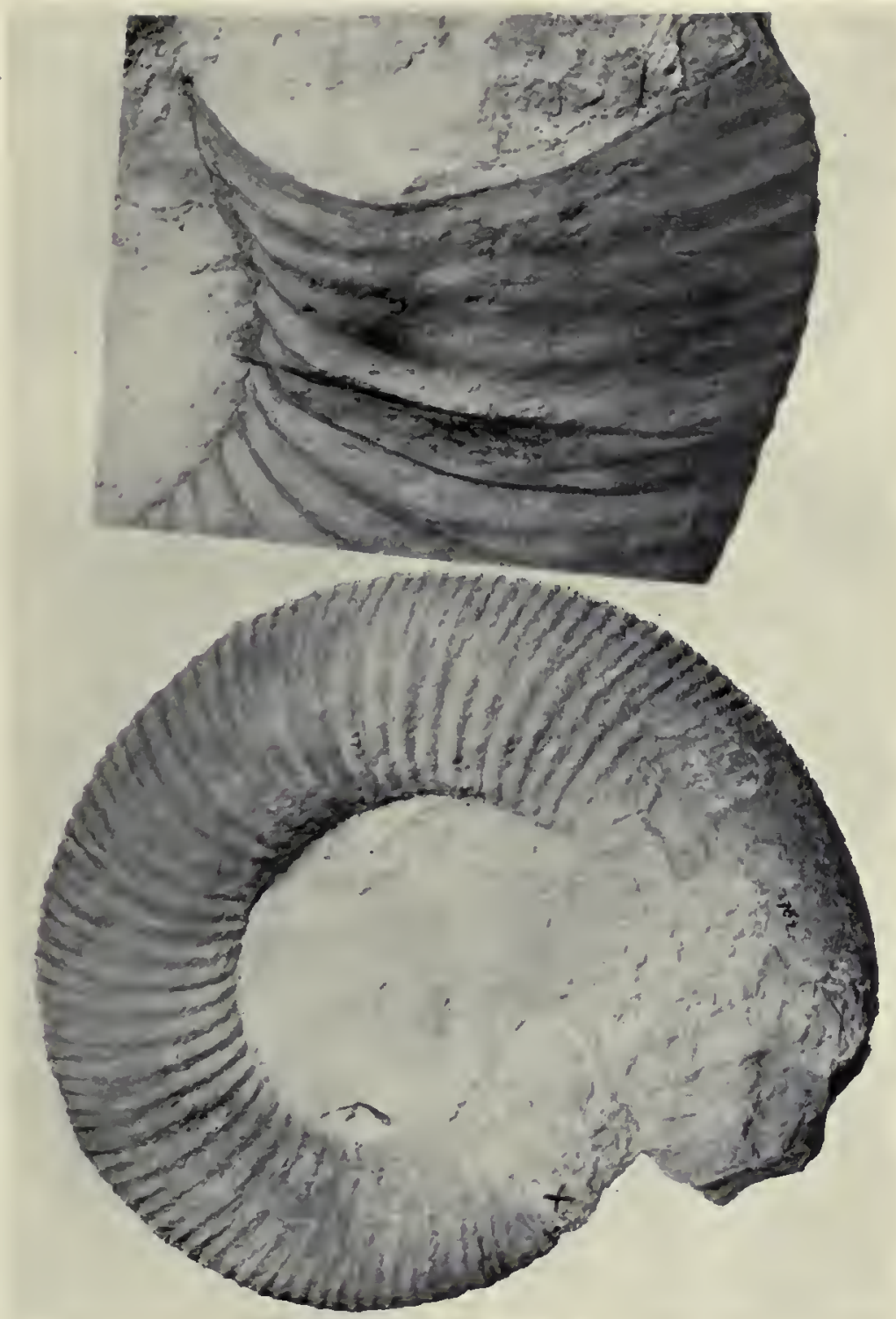

"Amonites giganteus"

Near Baggle Hill, (opposite Notley Abbey), Haddenham, Bucks Portland Stone Beds; S.B. Coll., 2962, pres. Mr. Henry Reynolds S. $640,32,195,47 ; 57$ or 58 ribs; Fig. 2 , mouth and rib-curve

TITANITES TITAN NOV.

Portlandian, Titaniles; Genotype, Holotype 

Fig. I, * $0 \cdot 215$

Fig. $2, \times 075$

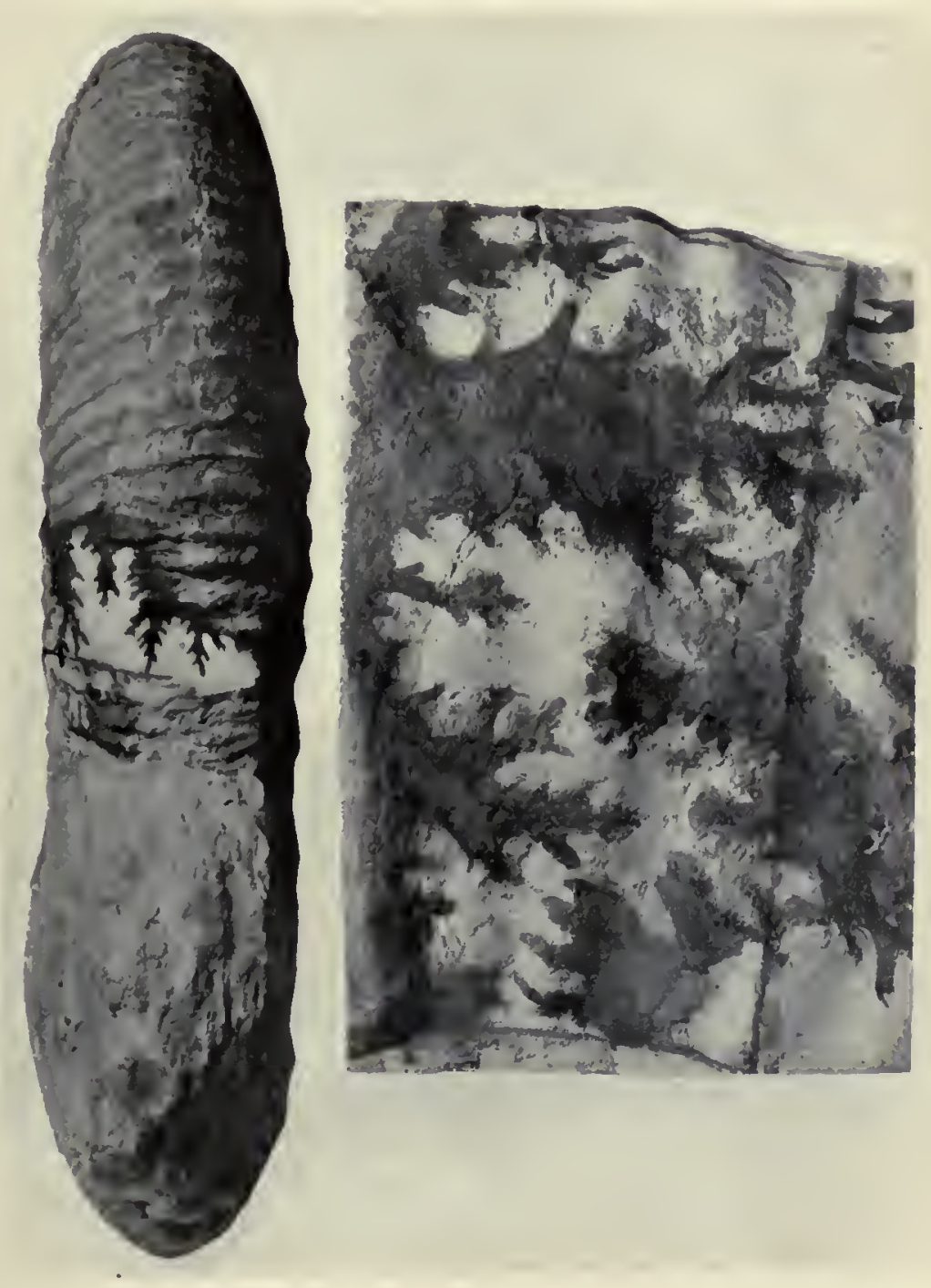

"AnMonites Giganteus"

Portland Stone Beds, "Creamy Limestones" (Blake) [Yellowish Sandstone, "Building Stone," 3rd bed down] S.B. Coll., 2962 ; Fig. 2, L2 short and rather broad

TITANITES TITAN, NOV.

Portlandian, Titanites; Genotype, Holotype 



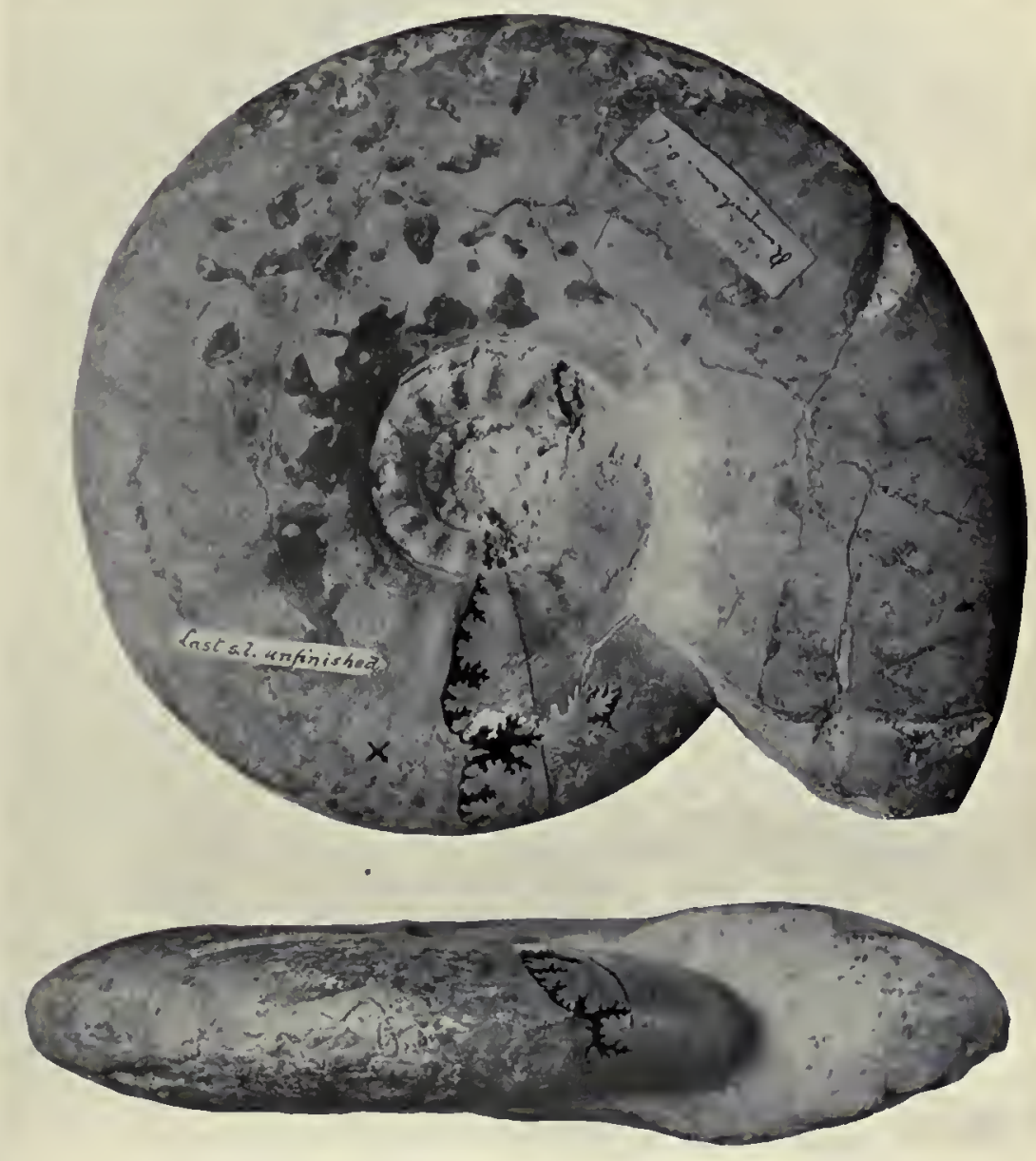

Fig. 2 $\times 0.74$

"Ammonites hoenigi"

"Rampisham, Dorset ; Oxford Clay" [Kellaways Clay (b) ] Geol. Survey England, ex Darell Coll., No. 30686

S. $83,44,26 \cdot 5,26 ; 92,435,25.5,26 ; 147,40,24,29$; max. c. I9o

PROPLANUlites LAEVIGATUS, S. Bucknan, p. 34 . Callovian, koenigi, (basileus) ; Holotype 

Fig. I

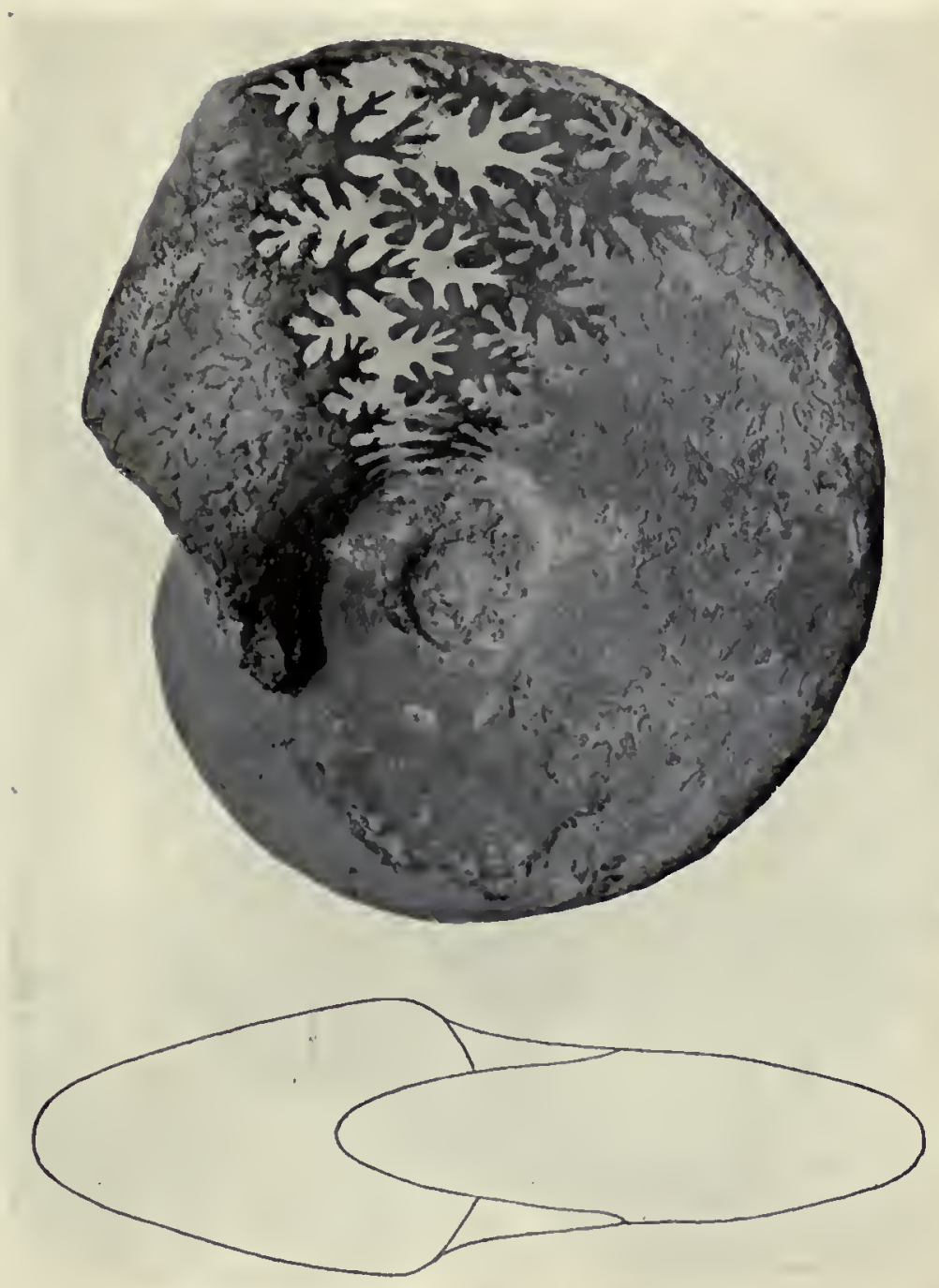

Fig. $2 \times 0.91$

Amonites IETERophyllus Numismalis, QUENSTEdT

(I $\delta_{40}$, Ceph., p. 100, Pl. V1, 5) ; "Radstock, Somerset"; J. IV. T. Coll S. I05, 49, 3I, I9; max. c. $210+$

Fig. 2, Outline, section-end of whorl taken at radius

TRAGOPHYLLOCERAS NUMISMALIS, QUENSTEDT SP.

Wesscxian, ibex. . See I, p. viii \& No. I6 

Fig. 2

Fig. I

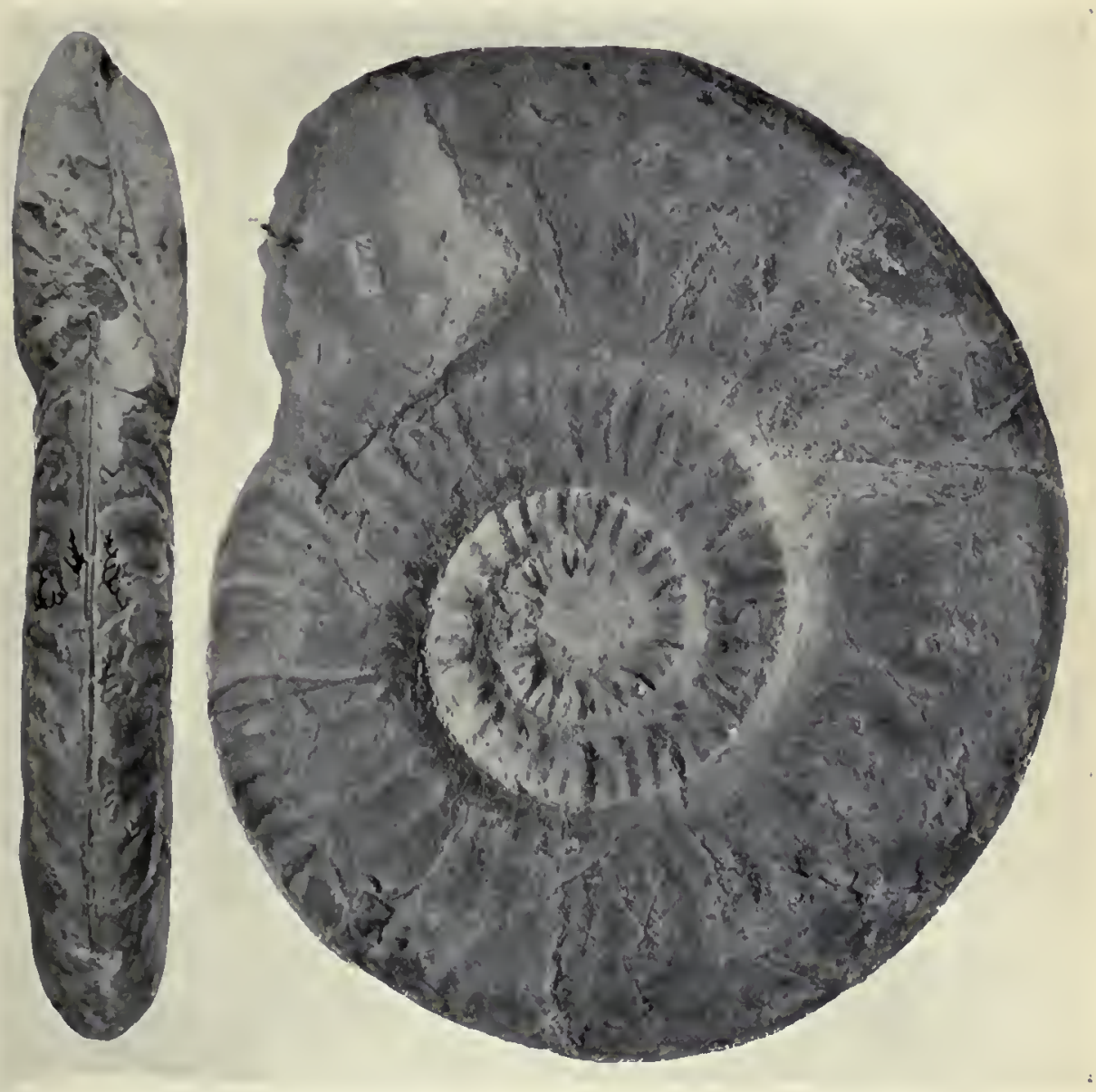

$\times 0.57$

Ammonites obliguatus, Young \& Bird, I828, Holotype

Geol. Yorkshire, p. 265 ; "Hawsker shore; hard bands"

[Peak, near Whitby; U. Lias ; Peak Shales] ; Whitby Museum, No. 222

Ф. 207 (II8), 30, 17, 44, - keel ; max. c. 220

PELECOCERAS OBI.IQUATUM, Young \& BiRD SP.

Whitbian, variabilis. See II, p. $x$ 



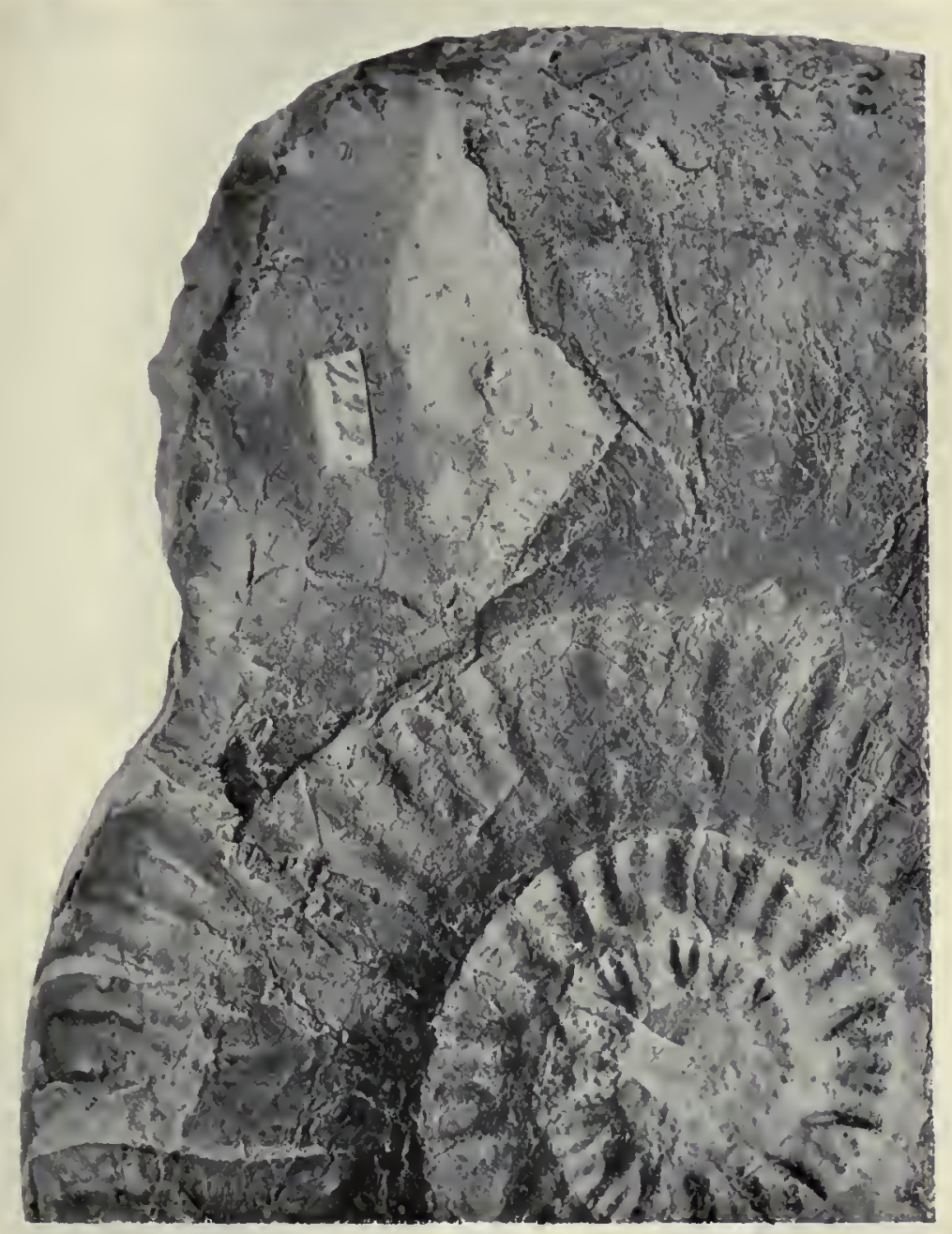

Ammontes obliguatus, Young \& Bird, I828, Holotype

Geol. Yorkshire, p. 265, Whitby Museum, No. 222 Septicarina $4 \mathrm{~mm}$. high beginning of last whorl; reduced to a mere ridge at end of it, nearly end of body-chamber

PELECOCERAS OBLIQUATUM, YOUNG \& BIRD SP. Whitbian, variabilis. Cf. No. I4 

Fig. I
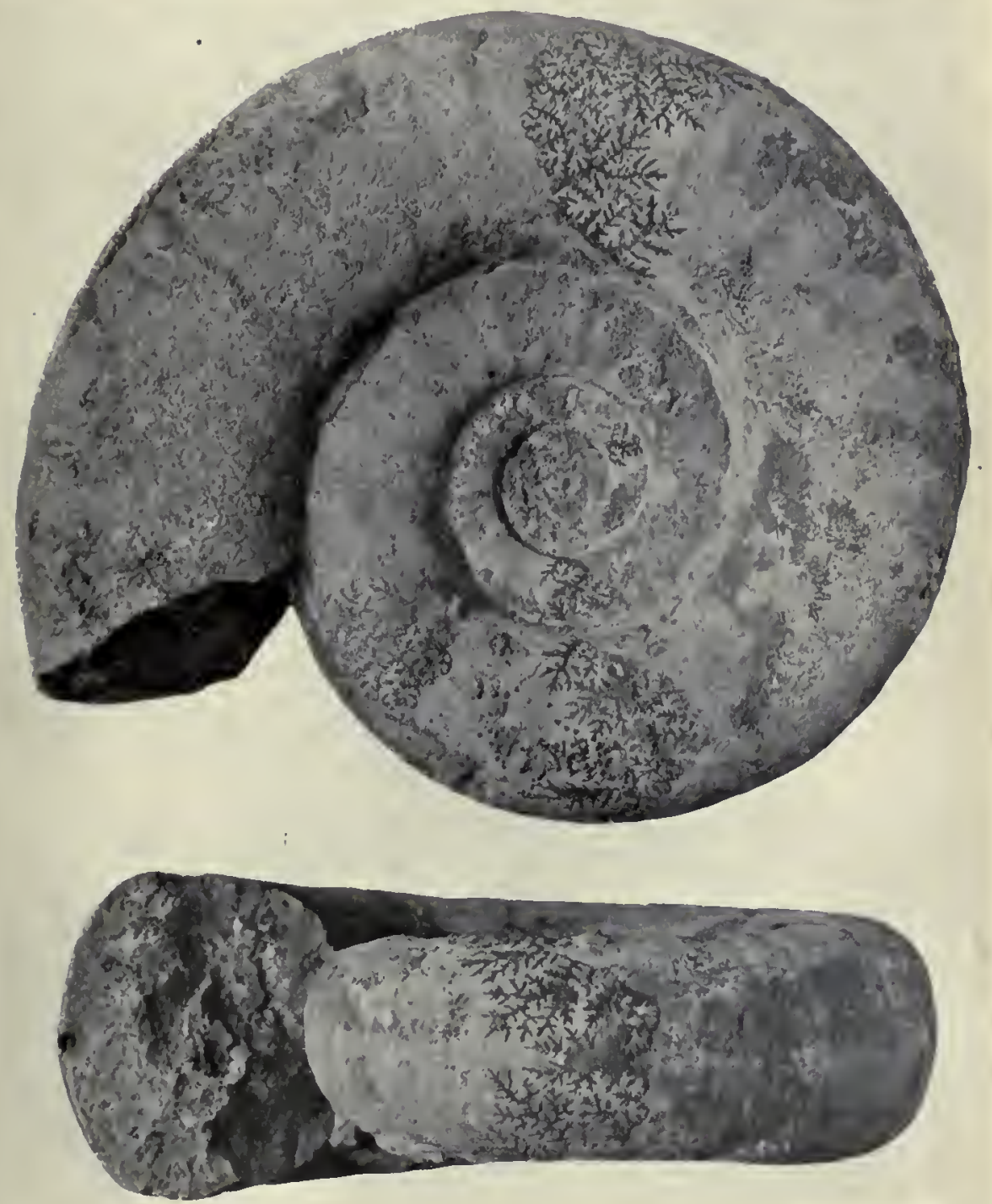

Fig. 2

$\times 0.6$

"DERoceras LECKEnByi"

"Bird's Quarry, Frome Hill, Radstock, Som. ; Mid. Lias, armatus"

J.IT.T. Coll. ; S. 99, 37, 40, 42 ; I $45,34,39,43$

S. $194,31,37,45 ; \max$. c. $35^{\circ}$. See No. 94

APODEROCERAS LOBULATUM, NOV.

Raasayan, leckenbyi (Apoderoceras); Genotype, Holotype 

Fig. I

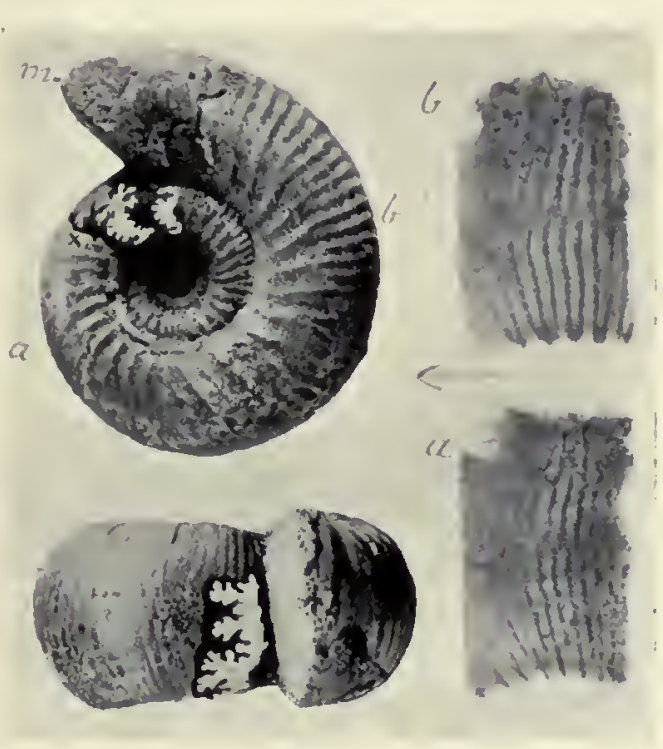

Fig. 2
Fig. $2 b$

Fig. 2a

"ERycites cf. MOdestus, VACEK SP."

"Bradford Abbas, Dorset; Inf. Ool. [Paving Bed]"

S.B., ex Darell, Coll. II 4 I ; S. $28,4 I, 65,36 ; 42,345,45,38$

IF. I, $m$. plain mouth; F. $2 a, 2 b$; ventral ribs broken, alternate,)

\section{ABBASITES ABBAS, Nov.}

Aalenian, bradfordensis (Abbasites); Genotype, Holotype 

Fig. I

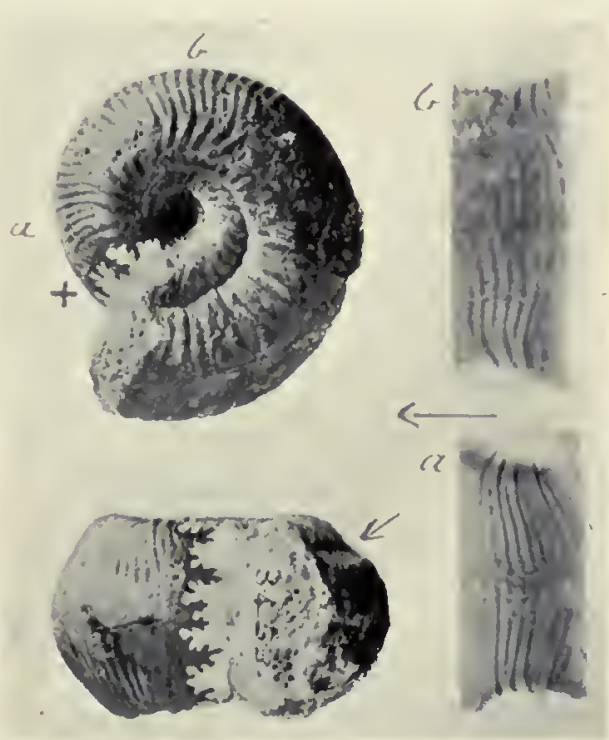

Fig. 2
Fig. $2 b$

Fig. 2a

"ERYcites cf. TUlcus, Gregorio SP."

"Ambers Knoll, Sherborne, Dorset; I.O., [c. ringens beds]" S.B. Coll. 3453 ; S. $21,47 \cdot 5,83,26 ; 36,375,53,36$ Fig. $2, \rightarrow$ injury; Figs. $2 \mathrm{a}, 2 \mathrm{~b}$; ventral ribs entire, (

AMBERSITES AGROTUS, NOV.

Aalenian, bradfordensis (Ambersites); Genotype, Holotype 

Fig, I

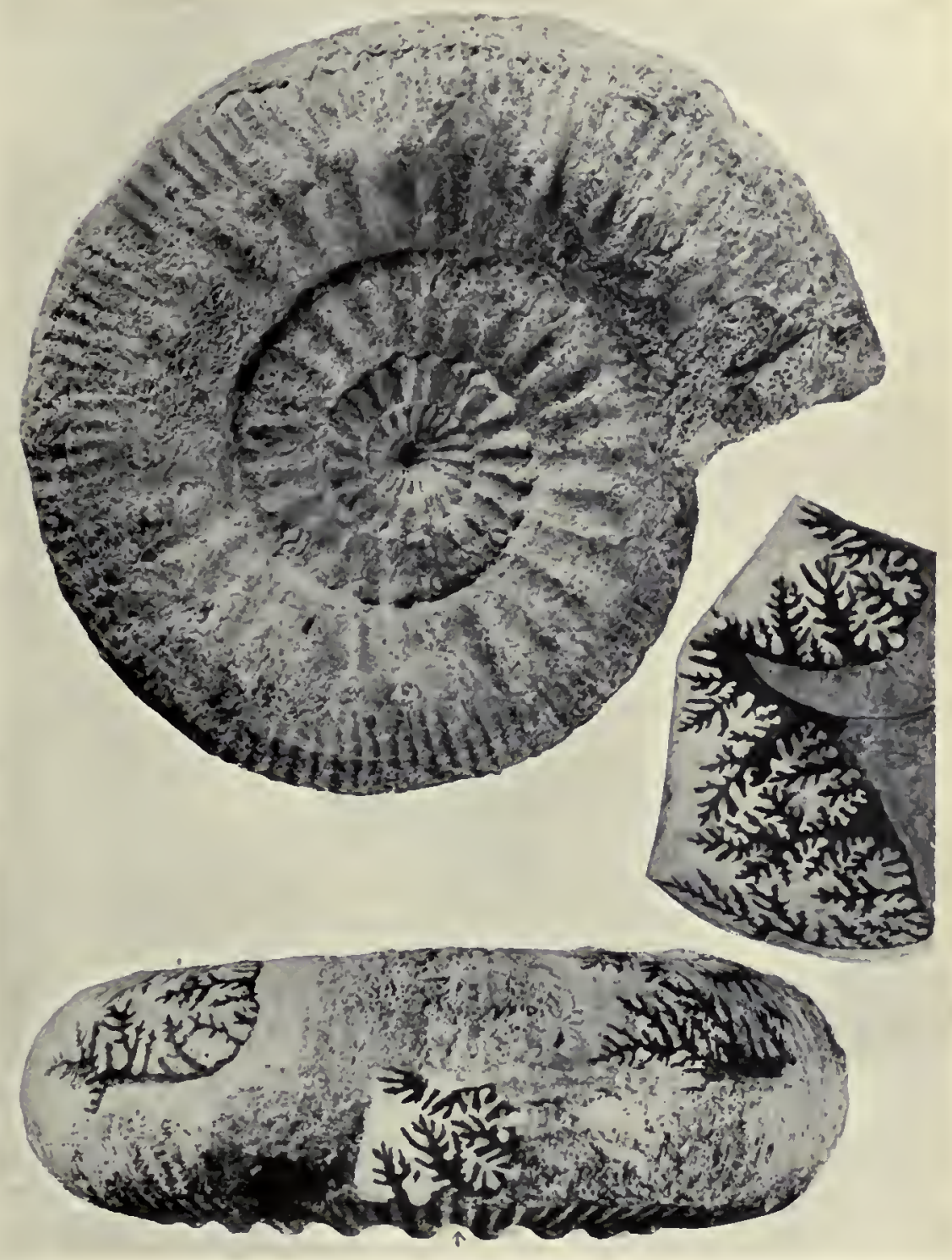

Fig. 2

Fig. 3

Ammonites humphriesianus, J. DE C. SOIVERBy, i825, Topotype (Min. Conch., V, I6I; D, I [b]); Stepheoceras, S.B., I898, see II, xi [Clatcombe], "near Sherborne, Dorset ; I.O., Humphr. z."

S.B., ex J.B., Coll. 3I45; S. 107, 29, 34, 49 ; max. I70 +

F. 2, $\rightarrow$ Dorsal s.l.; Fig. 3, s.l. complete; dorsal part restored

STEPHEOCERAS HUMPHRIESIANUM, J. DE C. SOWERBY SP. Bajocian, Masckeites 

Fig. I

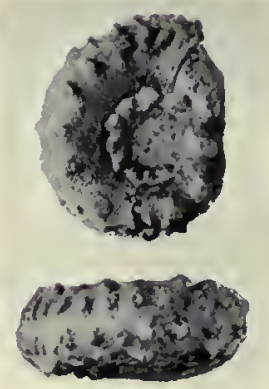

Fig. 2

Cosmoceras subfurdatum, var. ?, S. Buckman, i $88 \mathrm{I}$ Q.J.G.S., XXXVII, pp. 600, 601. "Entirely destitute of ribs "Frogden Quarry, Oborne, Dorset; I.O. ; Humphr. z., higher part" S.B. Coll. 3474 ; S. $22 \cdot 5,35^{\circ} 5,40,42 ; \max .22^{\circ} 5$ 

Fig. I

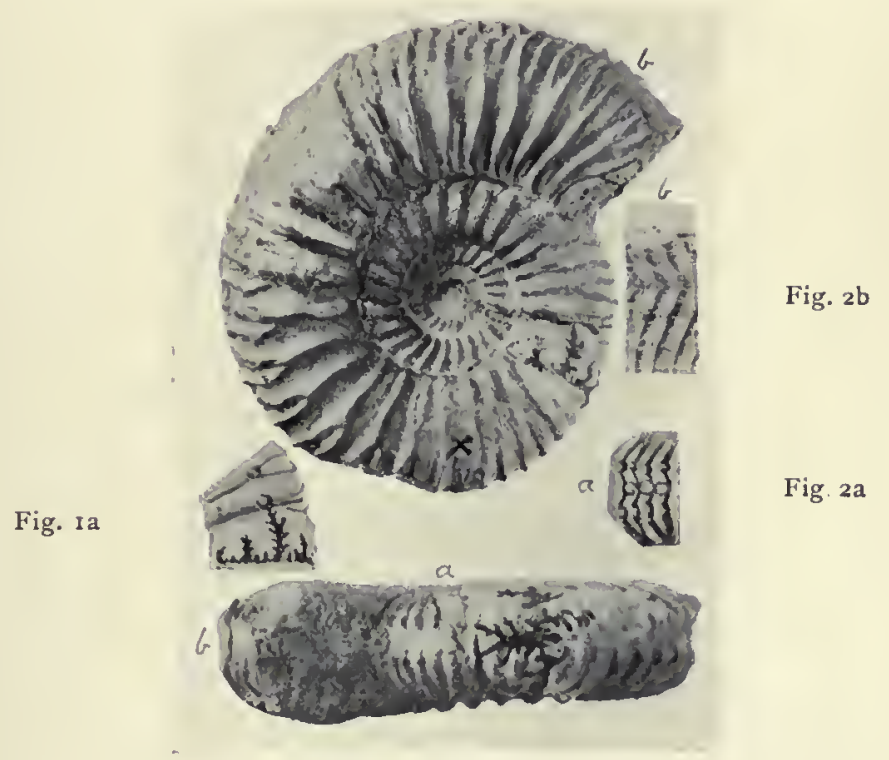

Fig. 2

Garantiana latesulcate sp., S. Buckman, igro Q.J.G.S., LXVI, 71 ; "Louse Hill, Dorset ; I.O., Rotten Bed" S.B. Coll. $3302 ;$ S. $275,33,40,38 ; 50,35,29,4^{1} ; 30$ ribs; $\max .52$ F. $2 a$, Venter, details exaggerated ; F. $2 b$, at b, rubbing, ribs nearly joined 

Fig. I

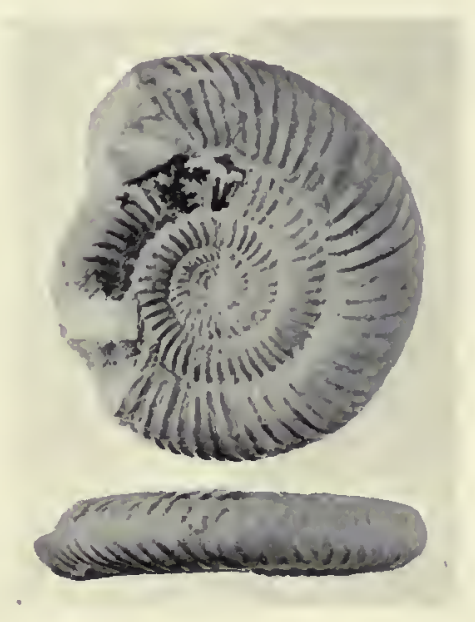

Fig. 2

Perisphinctes Davidsoni; S. Buckman, I88I, Paratype I882, Proc. Dorset F.C., IV, I44 ; IV, 2 ; "Frogden Q., Oborne, Dorset "Humph. z." [Q.J.G.S., XLIX, I893, § XV, 4] ; Manchester M. (S.B. Coll.) L. II 360 ; S. 42, 24, I9, 54 ; c. 53 ribs. Body-ch. complete; mouth plain 



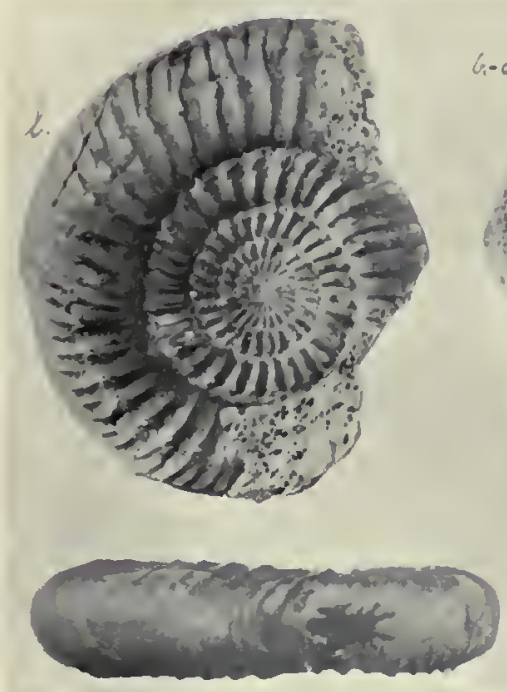

Fig. 2

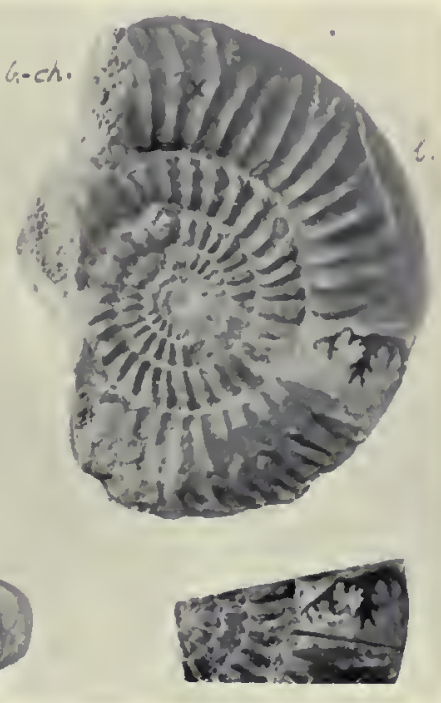

Fig. Ib

Parkinsonia CaUmontir, ally of, S. BuckMan, 1893 Q.J.G.S., XLIX, 497; "Lower Clatcombe (\$ XIII, 7), Sherborne, "Dorset, Niortensis $\eta " ; l$, dorsal lappet of mouth S.B. Coll. 3789 ; S. $50,26,27,50$; c. 36 ribs; $\max$. c. 75 


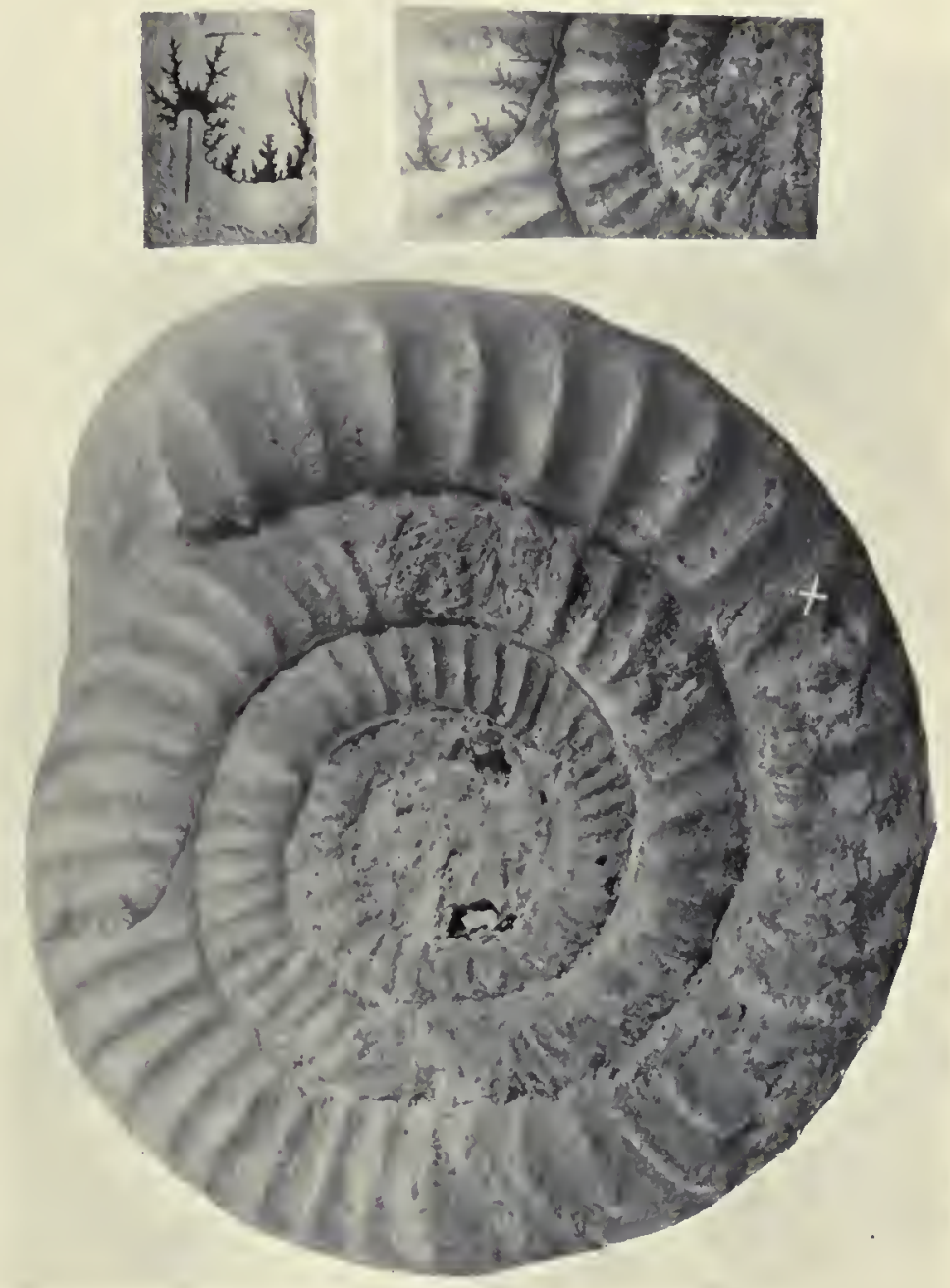

Fig. Ia $\times 0.37$

Ammonites triplex; S. BUCKMLN, I020, p. 27

Non $A$. triplex, Zieten, I83I, vin, 3 ; non $A$. triplex, J. de C. Sow., I835

"Temple Cowley," near Oxford ; Low. Calcareous Grit ; S.B. Coll. 2778

S. $287,21,235(22.5), 6 I^{\circ} 5 ; 37$ ribs; max. c. 460

KRANAOSPHINCTES KRANAUS, Nov. Argovian, c. Goliathiceras; Genotype, Holotype 

Fig, $1, \times 0.35$

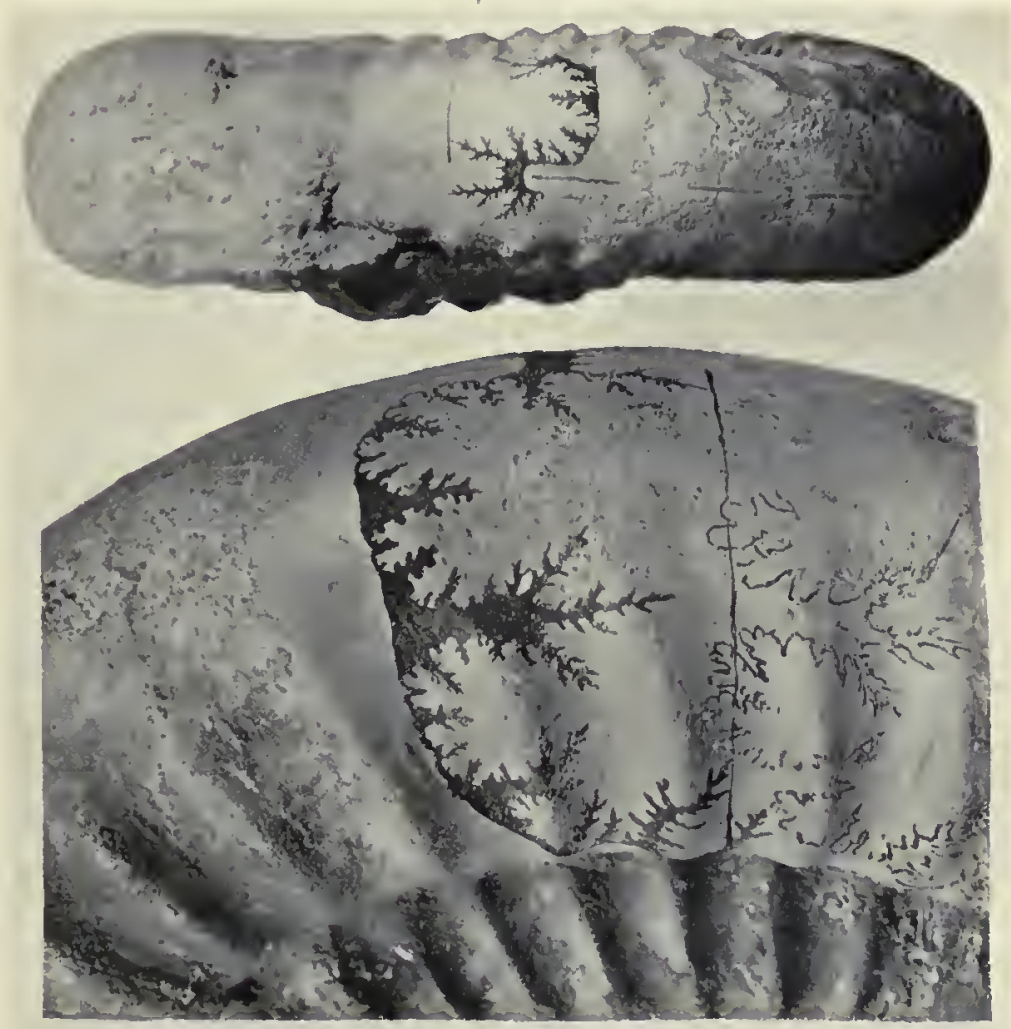

Fig. 2, N.S.

AMMONites TRIPleX; S. BuckMan, I920, p. 27 "Temple Cowley," S.W. of Shotover Hill, near Oxford Lower Calc. Grit (Littlemore Sands, a dogger near top) S.B. Coll. (ex workman) 2778 ; LI at $47 \mathrm{~mm}$, 57 per cent.

KRANAOSPHINCTES KRANAUS, NOV. Argovian, c. Goliathiceras; Genotype, Holotype 

Fig. I
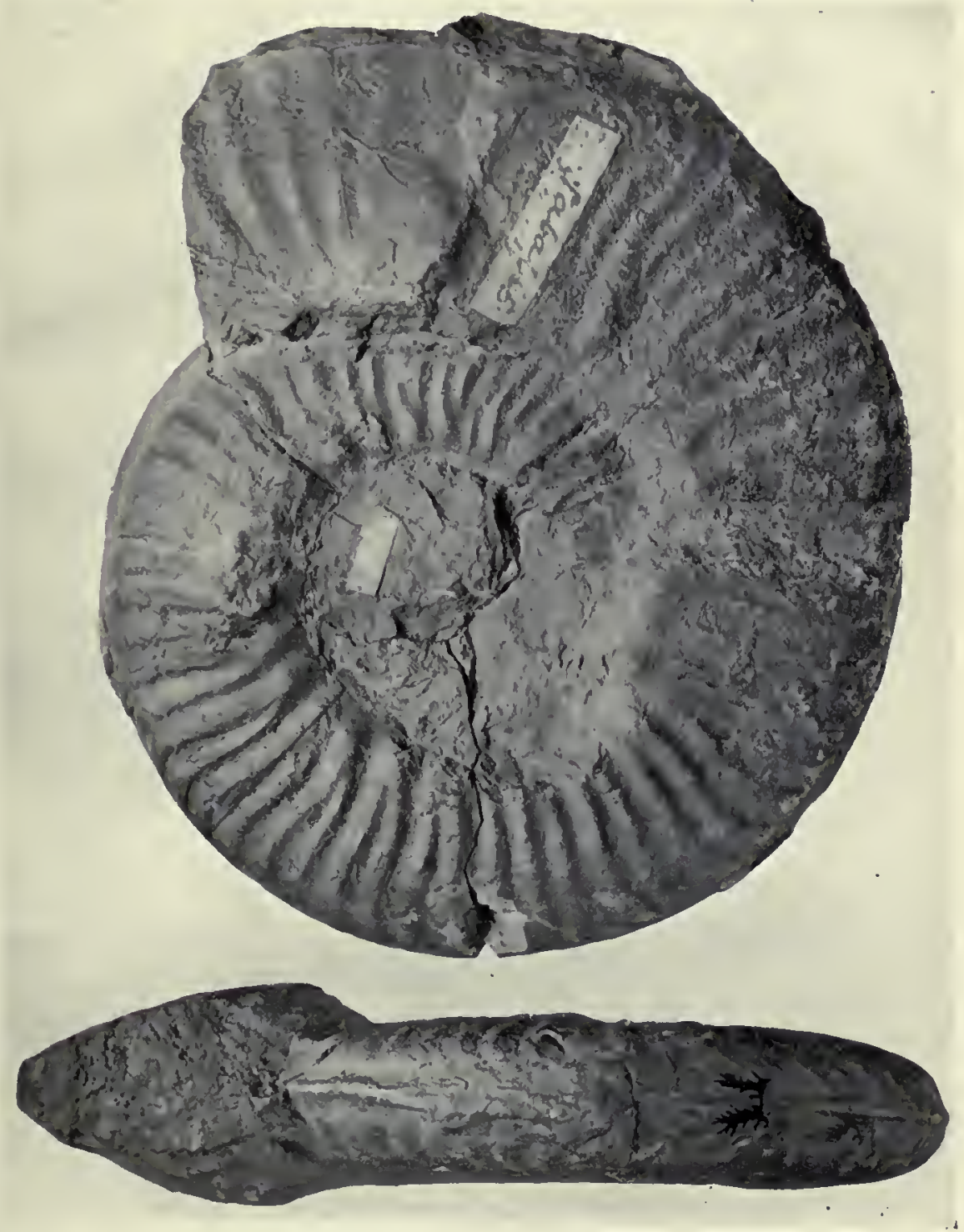

Fig. 2

$\times 0.85$

Amonites fabilis, Simpson, I85.5, Holotype

Pp. 77, 78; "Whitby, [Yorkshire]; Lias" label on specimen

[Peak, near Whitby; U. Lias, Peak Shales]; Whitby Museum, No. 774 I 139 (II8), 32, 24, 43, - keel; max. c. I70

PHYMATOCERAS FABALE, SIMPSON SP. Whitbian, variabilis. See 85 

Fig. I

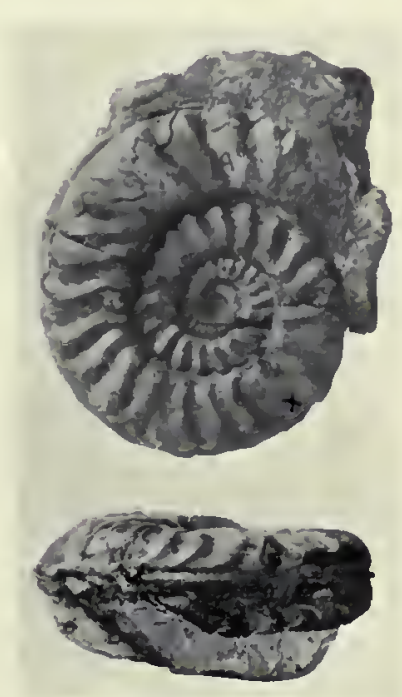

Fig. 2

Ammonites murleyi, J. Buckman in Moxon, Paratype

"Dumbleton, Glos. ; Upper Lias 3, Fissile Marl"

[Fish and Insect Bed], Geol. Chelt., New Ed., I844, pp. 36, 90 S.B., ex J.B., Coll. 2190 ; S. $34,31,32,44$; size 37 ; $\max$. c. 40

MURLEYICERAS FORTE, NOV.

Whitbian, murleyi; Holotype. See CCXVI 

Fig. 3

Fig. I
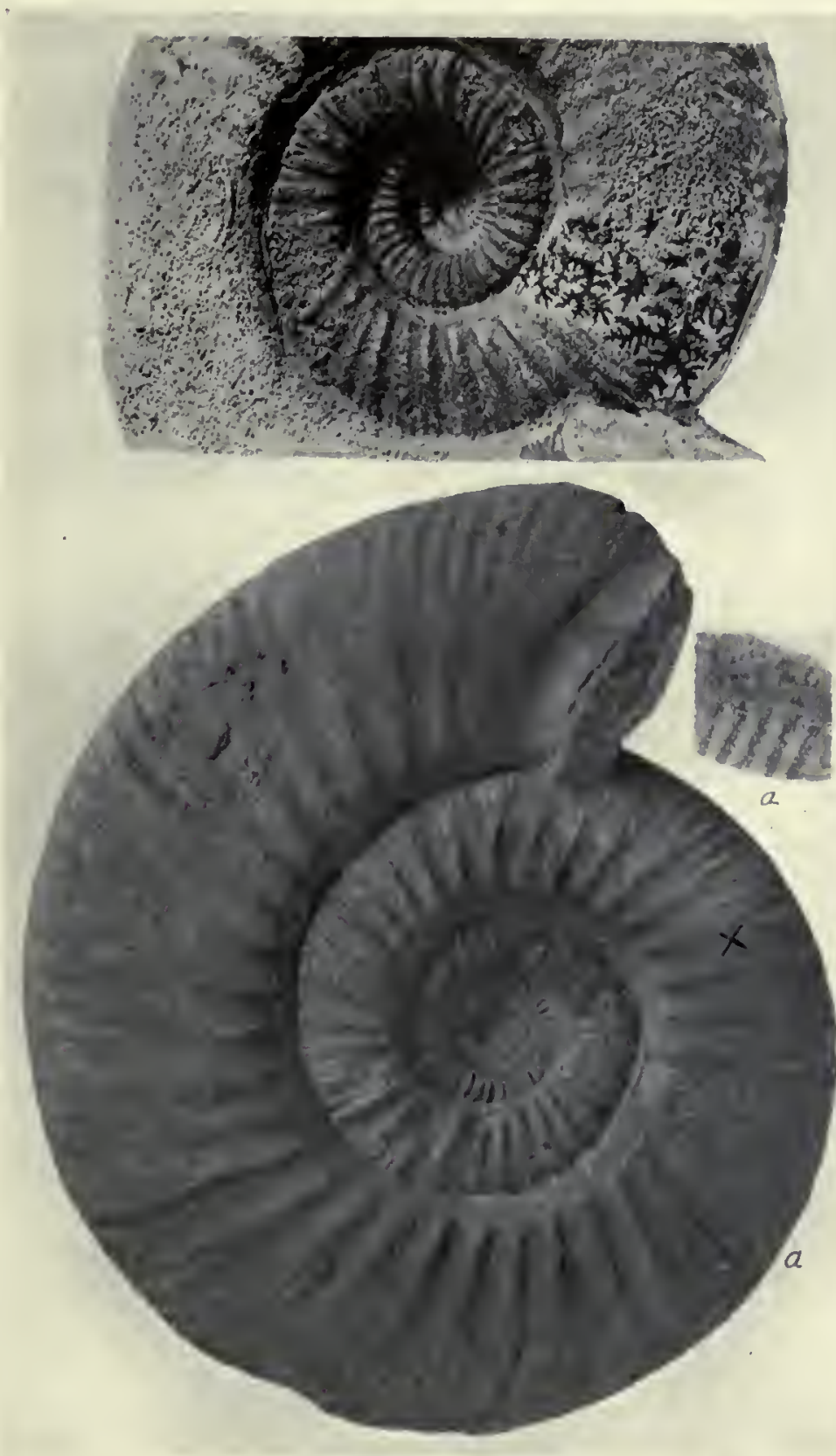

"Erycites cf. Gonionotus"

"Found on Rockery, Bradford Abbas, Dorset [ex Louse Hill ?]

"[Inf. Ool. murchisonce zone ;]" S. B. Coll. 238; Fig. 2, venter (rubbing)

S. $65,34,37,37$; II $4,3 I^{\circ} 5,24^{\circ} 5,43 ;$ max. I 20

Fig. 2

ERYCITES PARTSCHI, PRINZ IOO4

Aalenian, bradfordensis (Erycites). Cf. CCXXXVI 

Fig. 2

N.S.

Fig. I $\times 0.67$

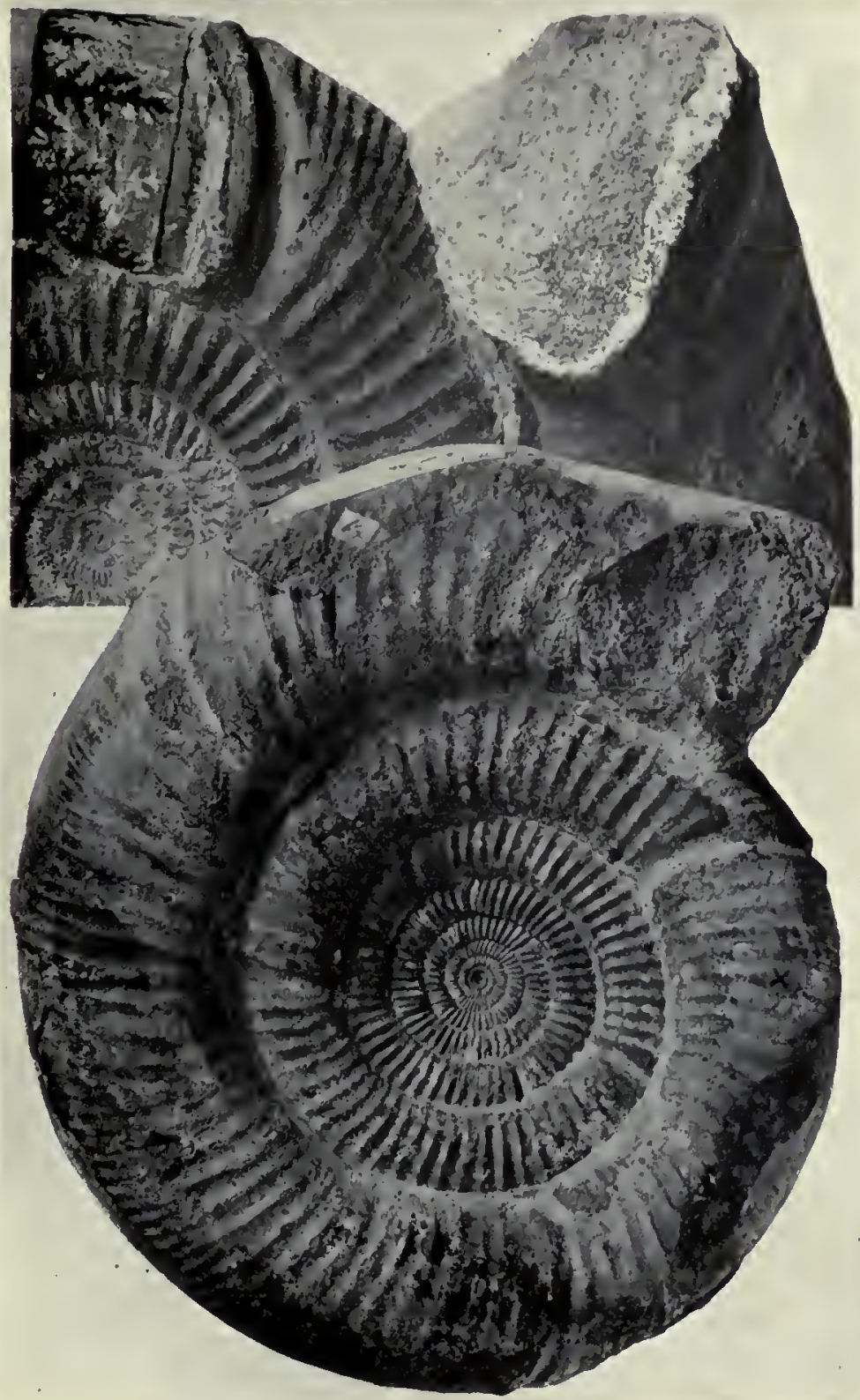

"Perisphinctes martinsil"

"Vetney Cross, Bridport, Dorset ; I.O." [Shell Bed] S.B., ex Darell, Coll. I24I ; S. I05, 28.5, 28.5, $49 \cdot 5$ S. $159,27,22 \cdot 5,51 ; 69$ ribs; $\max$. I66. Cf. CC

STOMPHOSPHINCTES STOMPHUS, NOV. Eningenian, Garantiana; Genotype, Holotype 

Iig. 2

N.S.

Fig. I $\times 0.53$

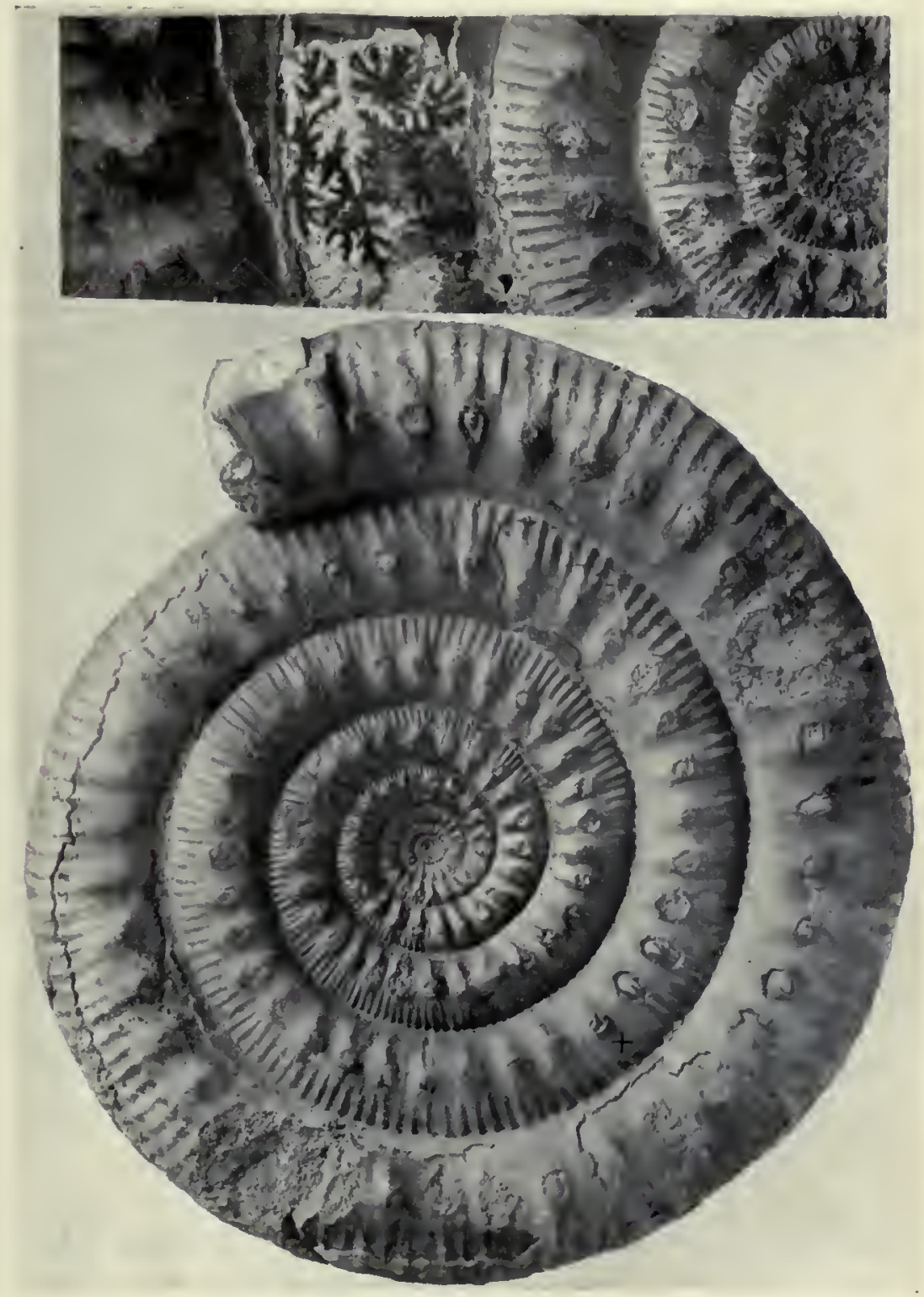

"Stephanoceras Bayleanum"

" [Sandford Lane], near Sherborne, Dorset ; I.O." Cf. CCXXX

[Foss. Bed, upper part], (Q.J.G.S., XLIX, I893, 492, §IX, 6a)

S.B., ex Darell, Coll., I095; S. 2 I9, I9, I8, 66; 38 ribs; $\max .223$

SKIRROCERAS MACRUM, QUENSTEDT SP.

Bajocian, sauzei; [Genolectot., Quen., Schwäb., I.XV, II] 

Fig. I
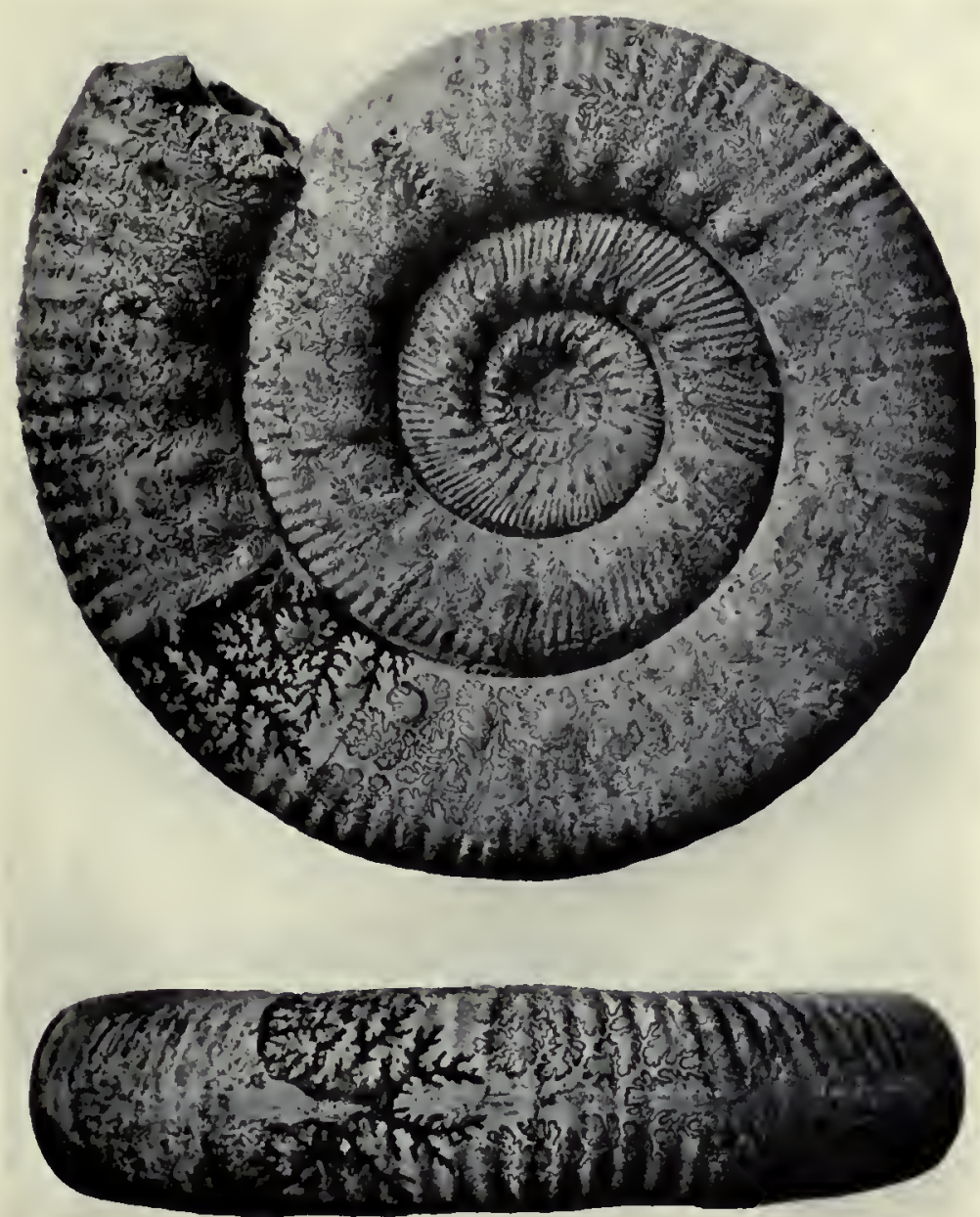

Fig. 2

\footnotetext{
"Shirroceras Macrum"
}

[Sunny Hill, Cole, Bruton, Som. ; I.O., Pecten Bed] Cf. I.. Richardson, Q.J.G.S., LXXI, I916, 497, §36, Bed Io J.W.T. Coll. ; S. IO6, $21.5,235,57 ; 29$ ribs; $\max$. c. $180+$

SKOLEKOSTEPHANUS SKOLEX, NOV. Bajocian, sauzei; Genotype, Holotype. Cf. CCXLVIII 



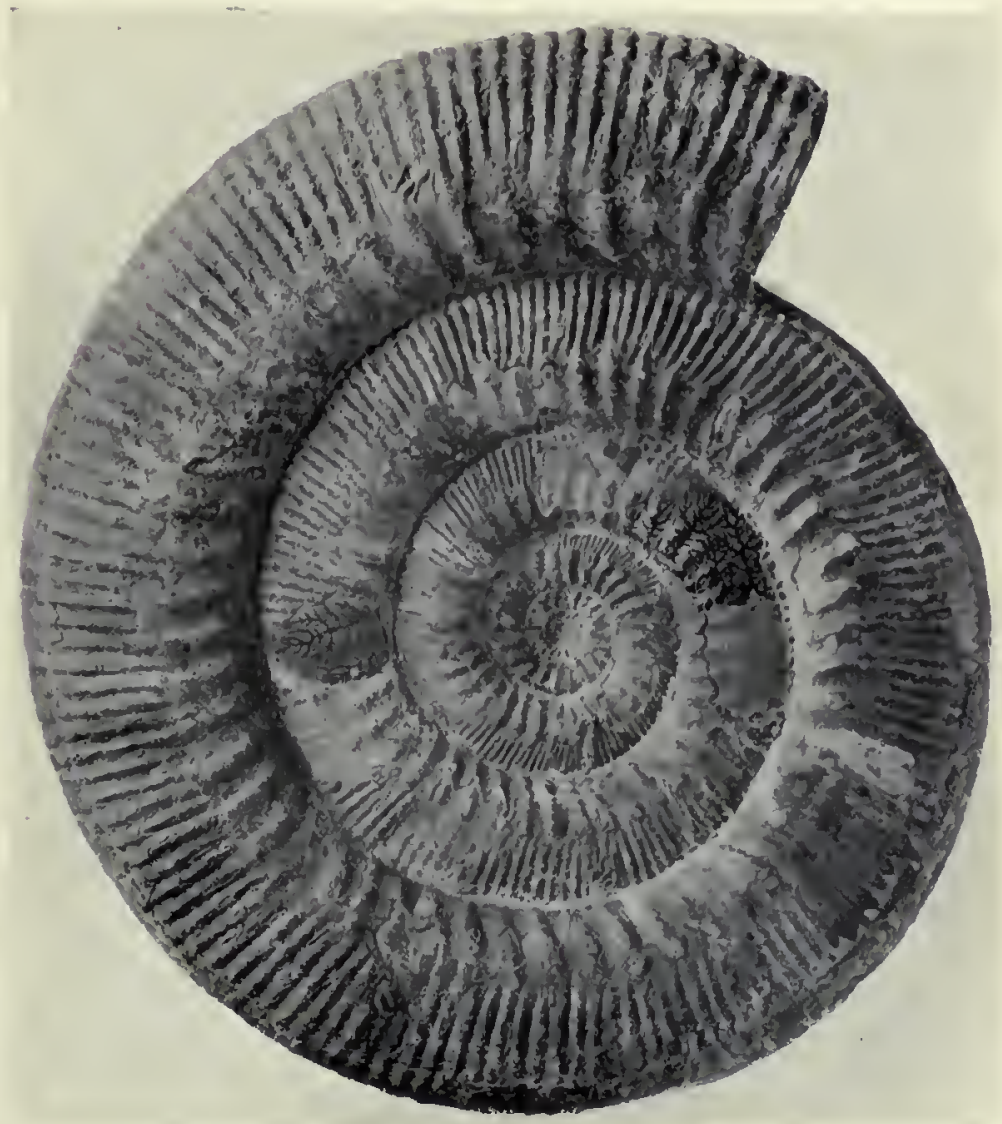

$\times 0.54$

STEPIIEOCERAS FREYCINETI S S. BuCKMAN, 19IO, cit. spec.

'South Dorset'; Q.J.G.S. LXVI, 73, §II, 5

[Burton Bradstock]," near Bridport, Dorset; I.O.," [Red Bed] S.B. Coll. I5Io; S. 208, 29, 22.5, 56; 53 ribs; $\max .290+$

RHYTOSTEPHANUS RHYTUS, NOV.

Bajocian, sauzei; Genotype, Holotype 

Fig. I

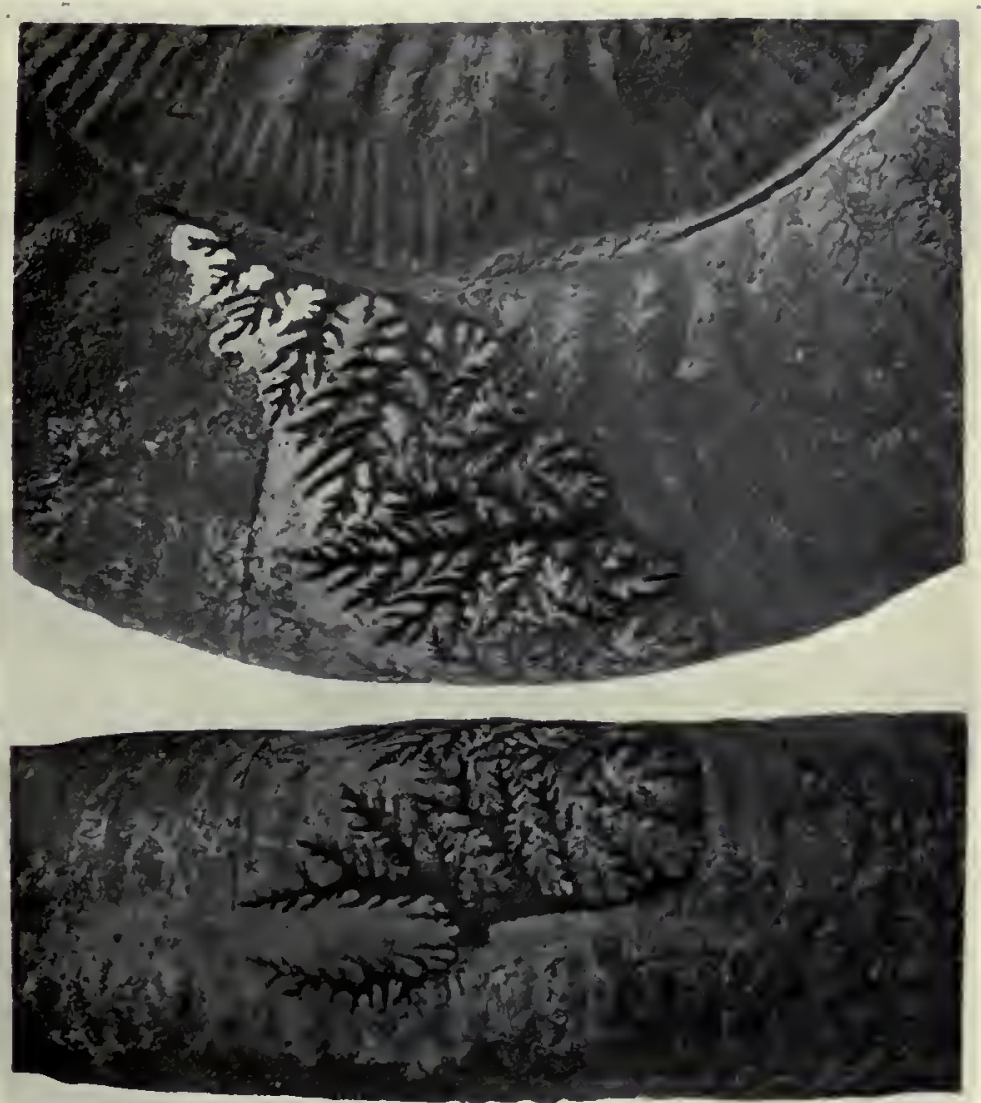

Fig. 2

Stepheoceras freycineti ; S. Buchian, igio, cit. Spec.

[Burton Bradstock] " near Bridport, Dorset; I.O.," [Red Bed] S.B. Coll. (purch.) I5I0; S.1. nat. size. Cf. CCXXXVIII

RHYTOSTEPHANUS RHYTUS, Nov. Bajocian, sauzei; Genotype, Holotype 

Fig. I

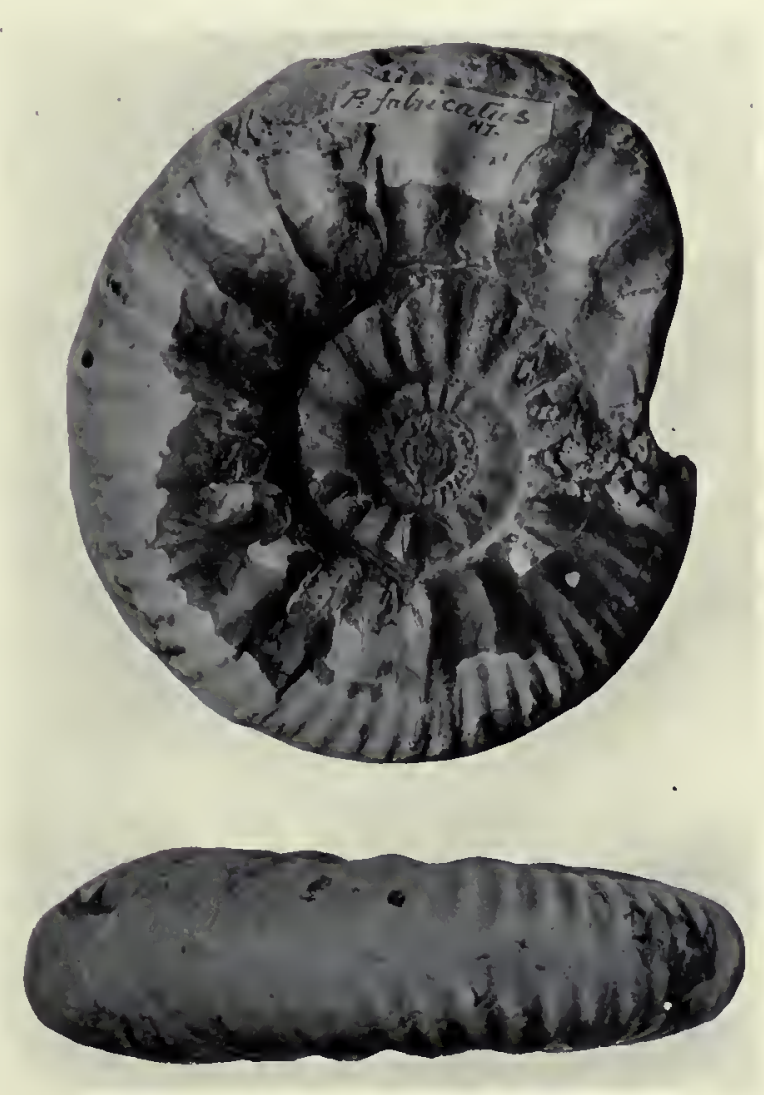

Fig. 2

"Ammonites koenigi"

[Chippenham, Wiltshire; Kellaways Clay (a) ] J.W.T. Coll. ; S. 7I, 38, 29, 42 ; max. c. 95

PROPLANULITES FABRICATUS, S. BUCKMAN, p. 36 Callovian, koenigi (majesticus); Holotype. See CCXXXII 



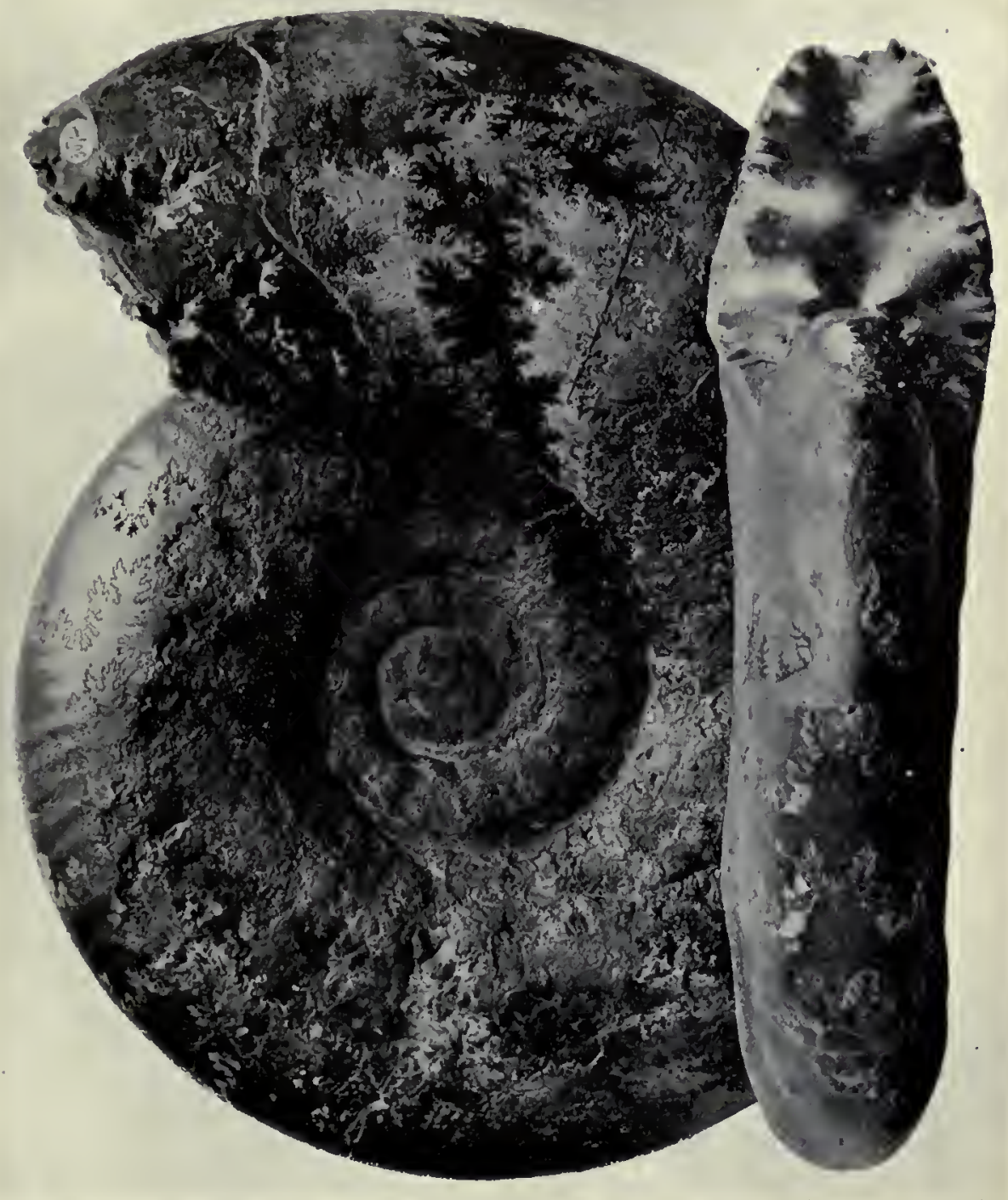

"Amionites rornigi"

"Chippenham, Wiltshire; Oxford Clay" [Kell. Clay (b)] Geological Survey, England, 3074I; S. I 47, 38.5, 25, 30 S. $236,37^{\circ} 5,25^{\circ} 5,35 ; \max$. c. $465+$

PROPLANULITES BASILEUS, S. BUCKMAN, p. 34 Callovian, koenigi [basileus); Holotype. See CCLI 



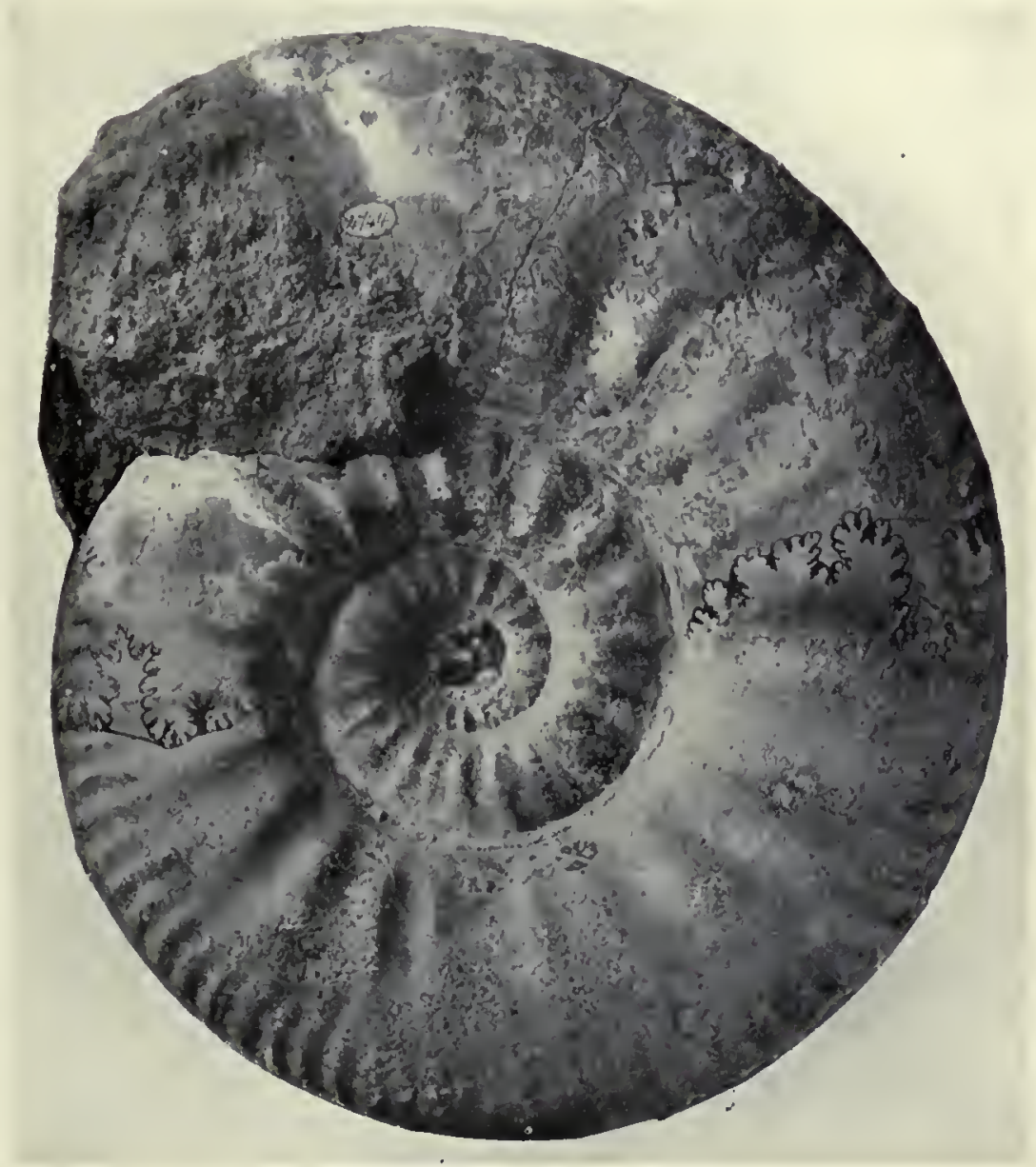

AMMONites BAKERtÆ; H. B. Woodward, I895, cit. spec. Mid. Ool. Engl. ; Mem. Geol. Surv. V, 30 ; " S.W. of Little Somerford, "Malmesbury, Wilts ; Kell. Rock [e]"; Geol. Surv. Engl. 4744 S. I 4 I, $39,27(25), 33 ; 238,36,28,36$; c. 23 ribs ; max. c. 435

CRASSIPLANULITES CRASSIRUGA, S. Buckman, p. 42 Callovian, post-koenigi (Crassiplanulites); Holotype. See CCXXVIII 

Fig. I

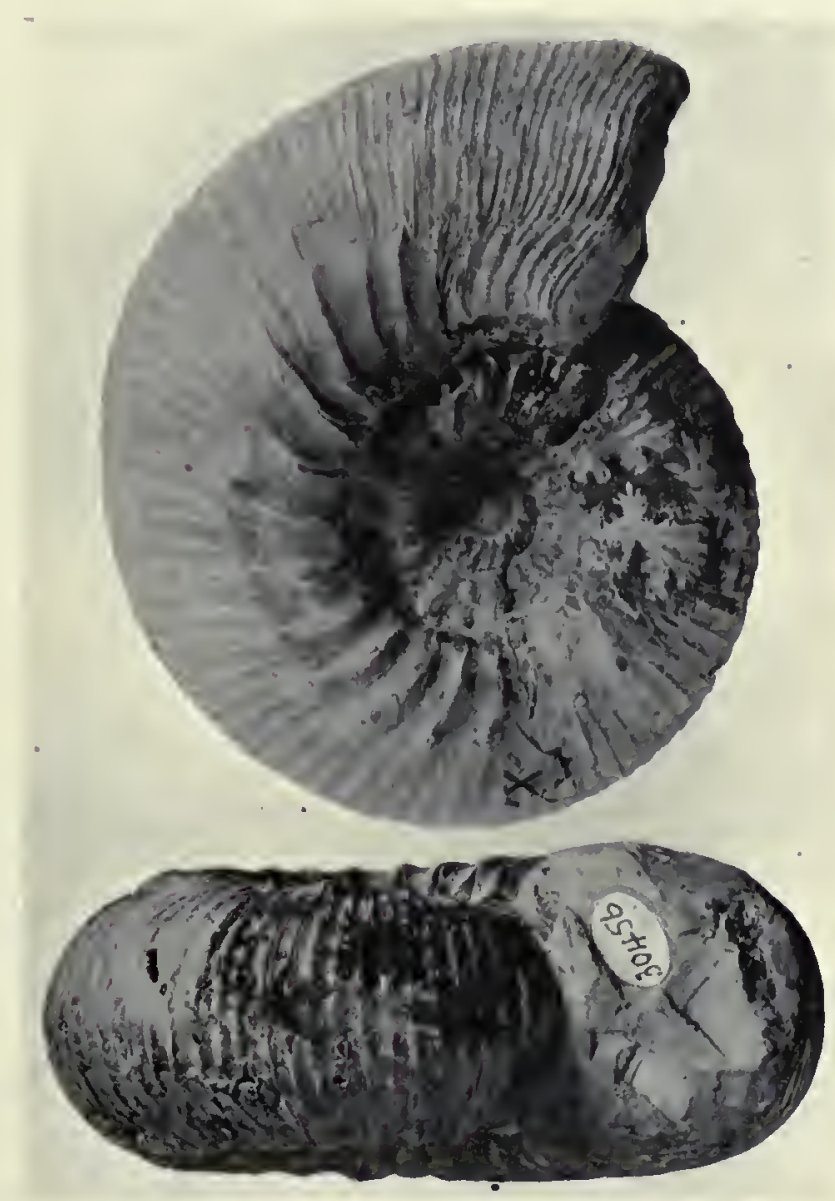

Fig. 2

"Amalonites Gowerianus"

" Chippenham, Wilts ; Oxford Clay," [Kellaways Clay (a) ] Geological Survey, England, $30456 ;$ S. $47,38,53,30$ S. $6 \mathrm{I}, 39^{\circ} 5,54,33 ; \mathrm{S} .85,36.5,39,35 ; \max .85$

GOWERICERAS METORCHUM, Nov. Callovian, koenigi (majesticus) ; Genotype, Holotype 


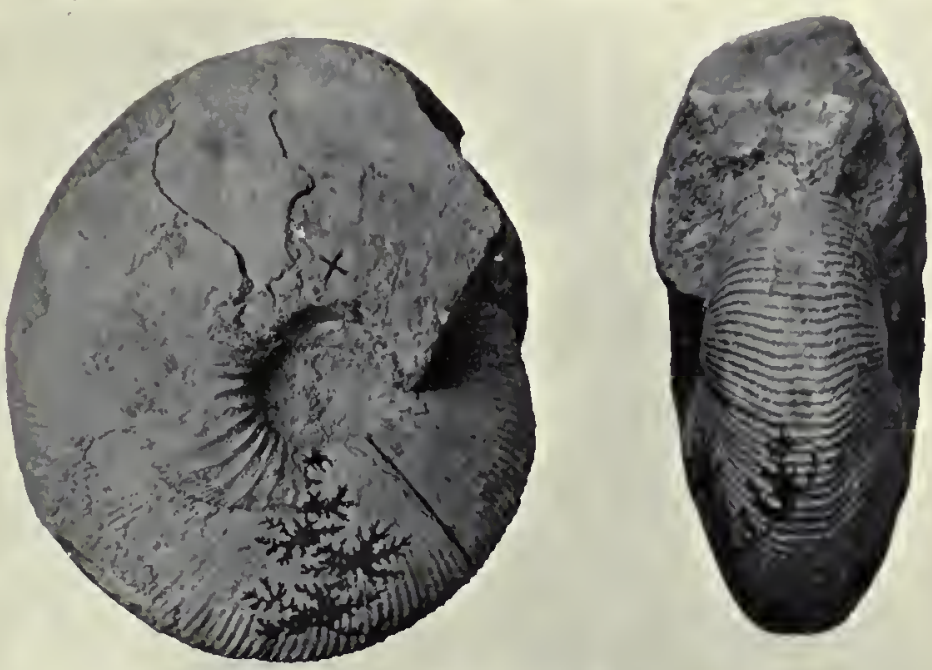

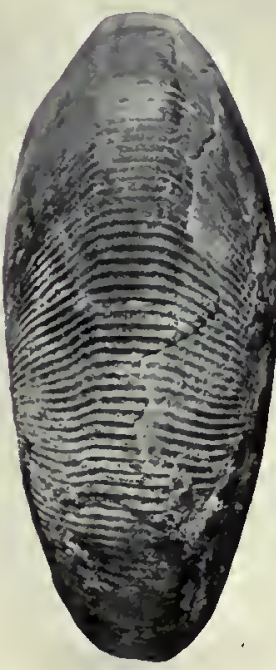

Fig. 3

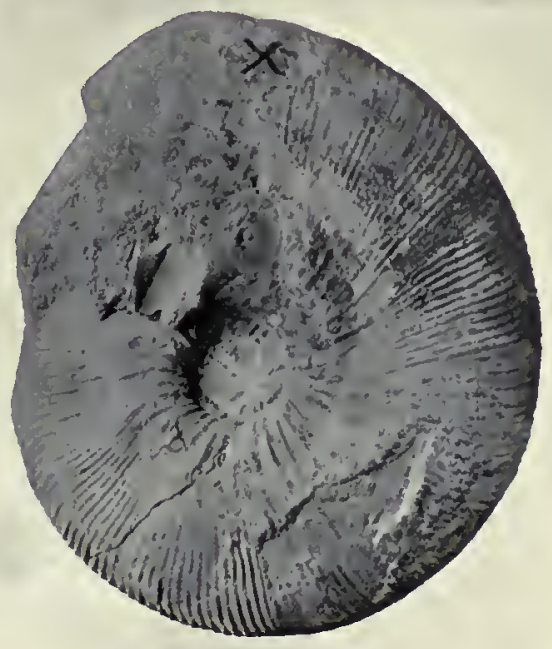

Fig, 1a

"Amonites calloviensis"

[Kellaways, Wiltshire; Kell. Rock], impression of a Rhynchonella J.W.T. Coll. ; S. $38,46,42,21 ; 65,4755,4 I^{\circ} 5,17$; max. c. 85

SIGALOCERAS MICANS, Nov.

Callovian, calloviense (Crassiplanulites); Holotype. Cf. CCLIV 



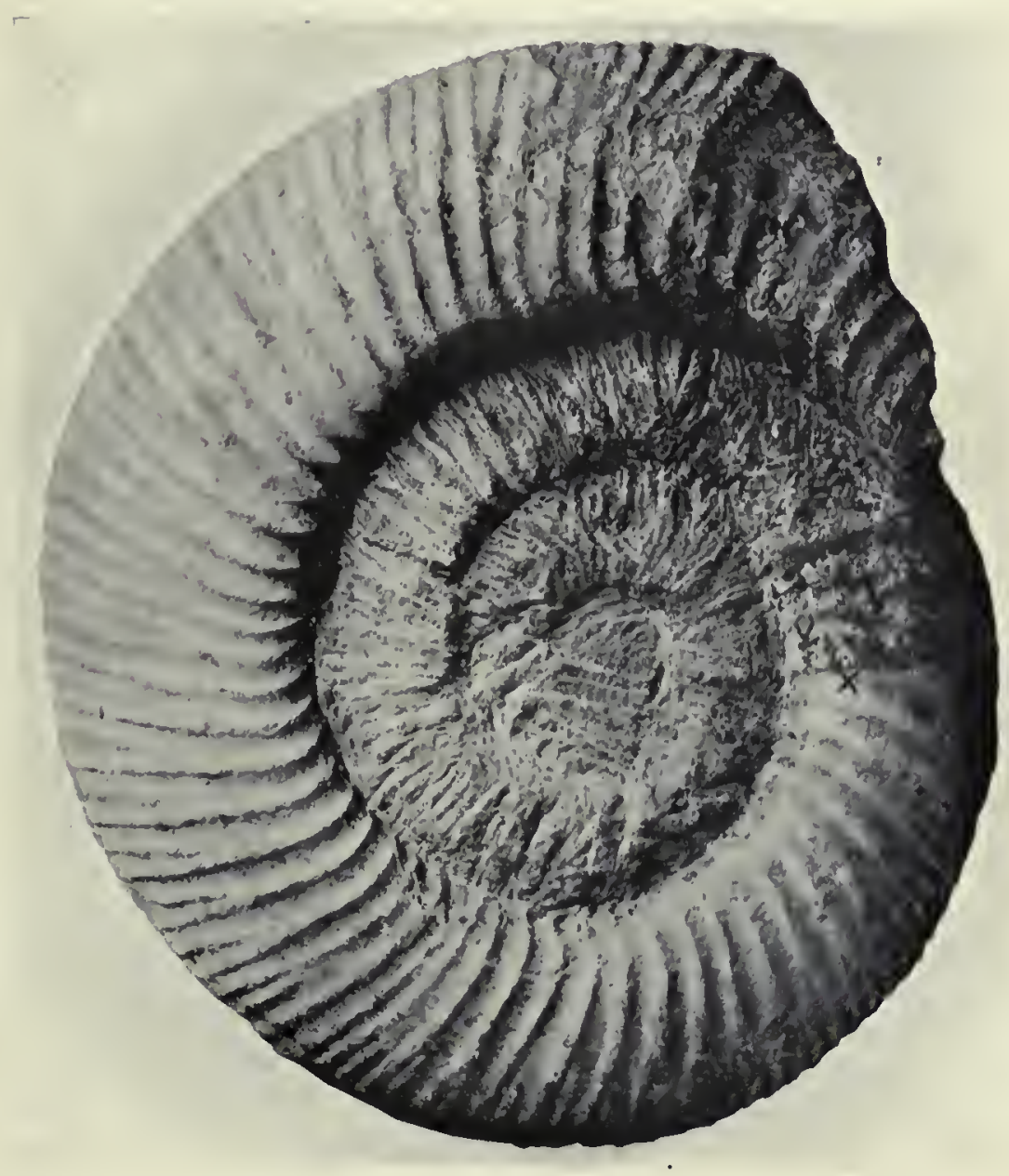

Amonites Giganteus, J. Soweribr, I8I6, Cliorotype (Min. Conch. II, 55 ; CXXvi) ; Barrel Hill, Long Crendon, Bucks Portl. Stone [Lime Bed] ; S.B. Coll. 2957, pres. H. Dodwell, J.P. S. $507,27.5,29,53 ; 60$ ribs; $\max$. c. 540

GIGANTITES GIGANTEUS, J. SOWERBY SP. Portlandian, Gigantites; Genotype. Cf. CCXXXI 

Fig. $1, \times 0.32$

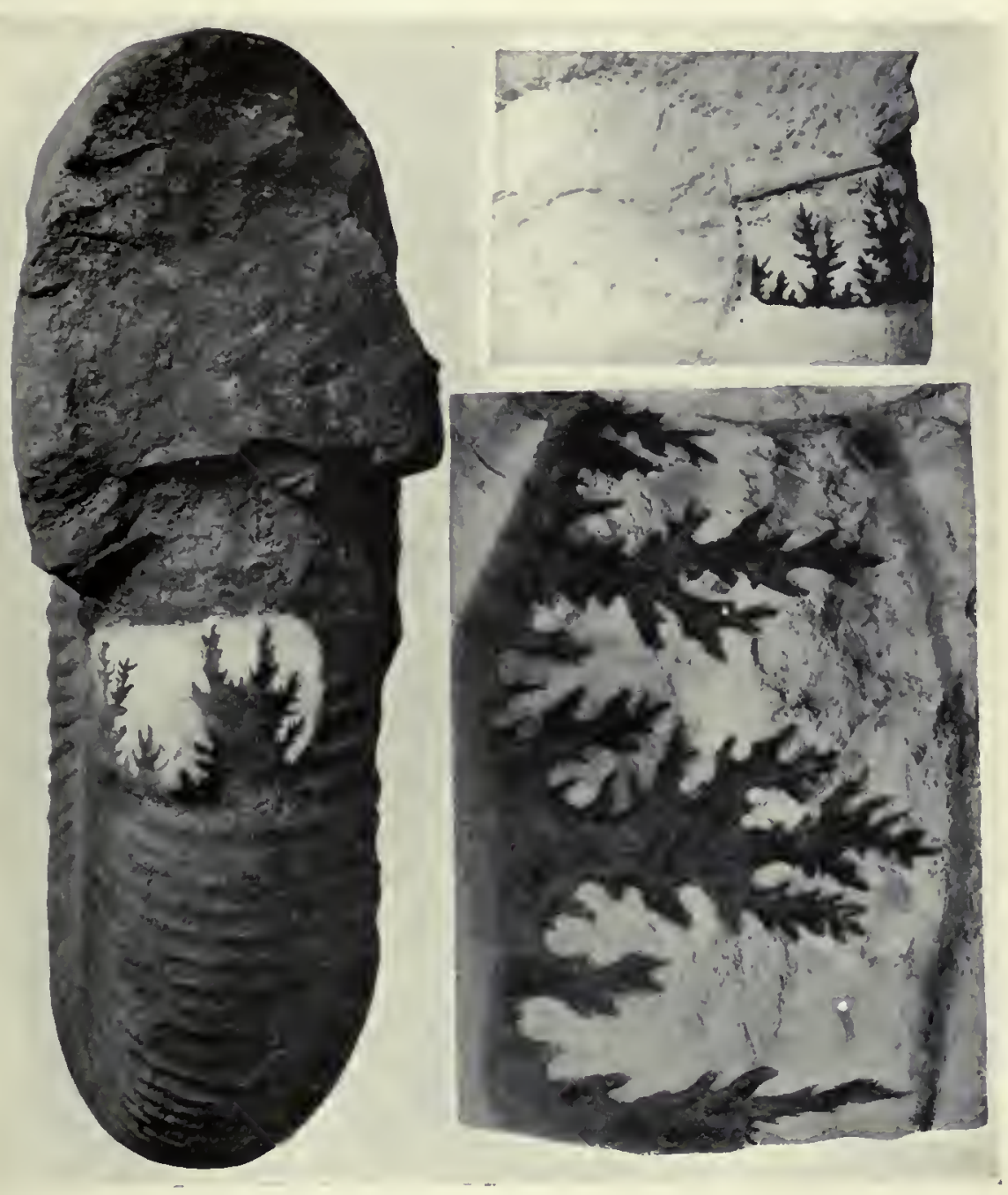

Fig. $3, \times 0.87$
Fig. $2, \times 0.23$

Amonites giganteus, J. Sowerby, i8i6, Chorotype Portland Stone, ["The Hard Lime or Blue Bed"

The 4th Bed down in the "Creamy Limestones"]

S.B. Coll. 2957 ; Fig. 3, EI, LI, L.2 about equal length

GIGANTITES GIGANTEUS, J. SOWERBY SP.

Portlandian, Gigantites; Genotype 



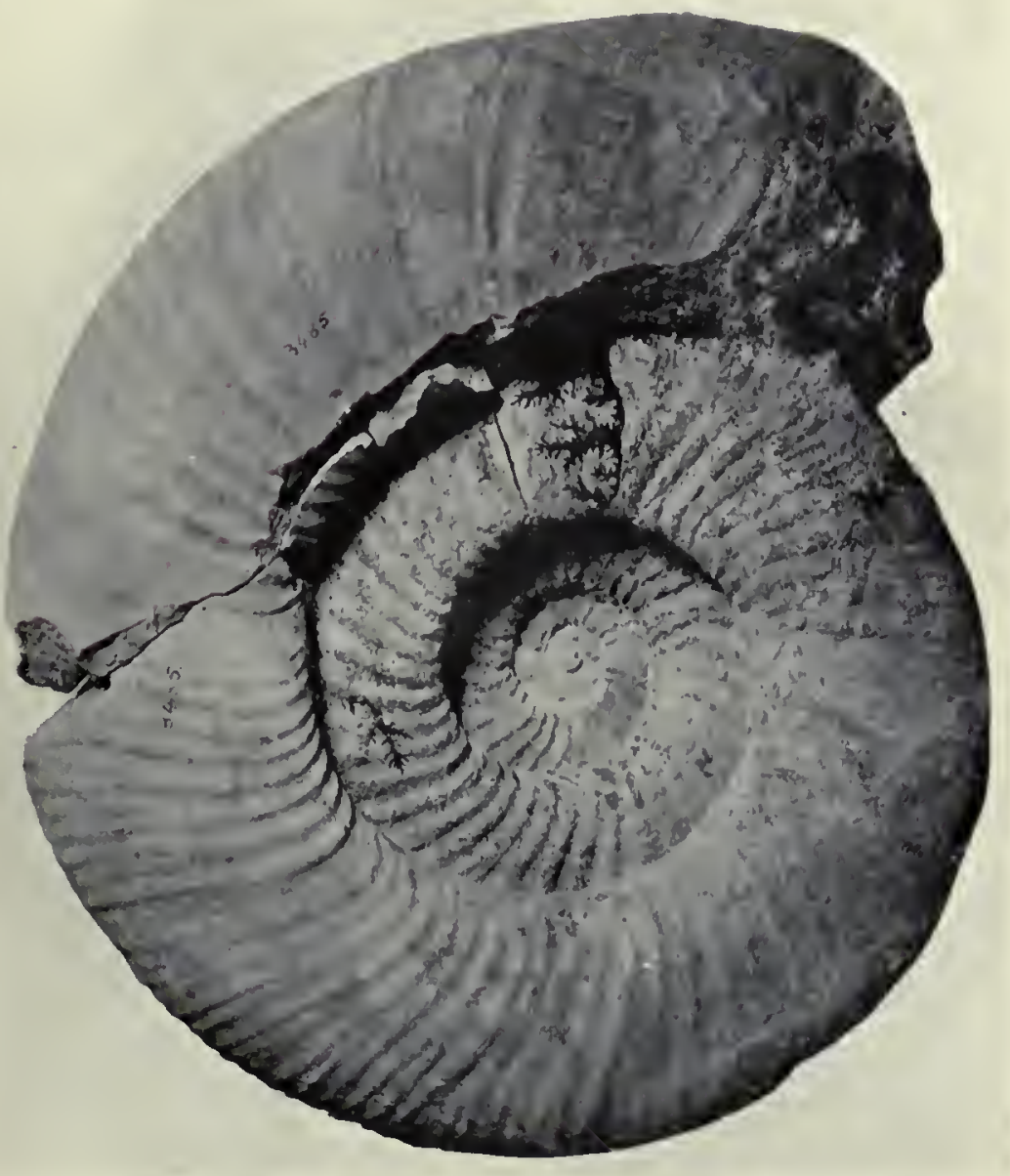

$\times 0.19$

\footnotetext{
"A Amonites giganteus"
}

Scotsgrove, Haddenham, Bucks; Portland Stone

Building Stone; S.B. Coll. 3485 , pres. Capt. Ashton

Body-chamber with signs of month; S. 644, 29, 23.5, 46

BRIAREITES POLYMELES, NOV.

Portlandian, Titanites; Genotype, Holotype. Cf. CCLVI 



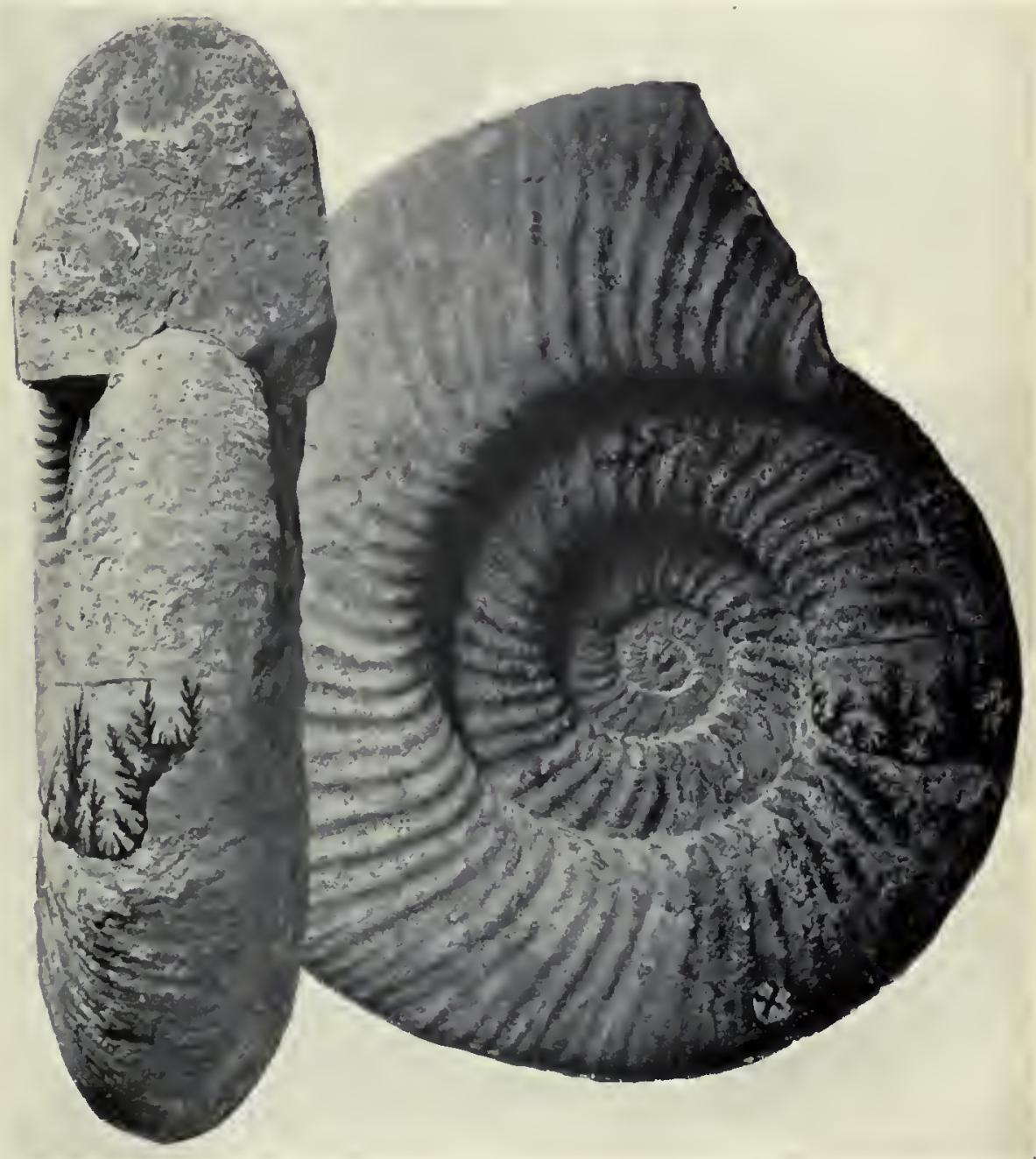

"Amonites Giganteus"

S.B. Coll. 3485 ; without outer quarter whorl

S. $310,35,33,38 ; 527,31,28,44 ; 56$ ribs

S. $644,29,235^{\circ}, 46(\mathrm{Pl}$. CCLVII A). Cf. CCXXXI

BRIAREITES POLYMELES, NOV.

Portlandian, Titanites; Genotype, Holotype 



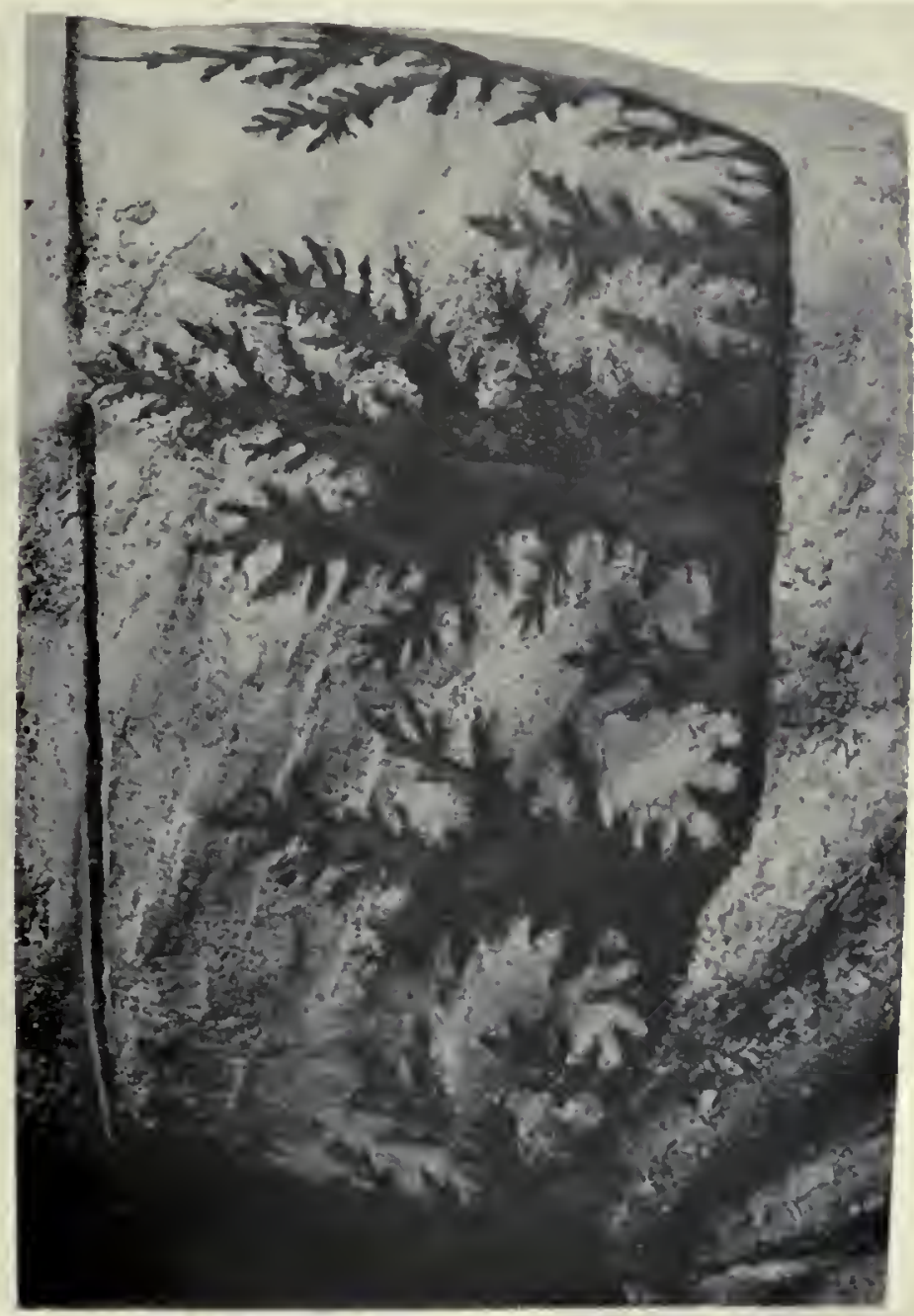

"AMNONITES GigANTEUS"

S.B. Coll. 3485 ; Suture-line with long, florid LI, with rather long $\mathrm{L}_{2}$, but not so long as LI, and recurved umbilical portion. Nat. size

BRIAREITES POLYMELES, NOV.

Portlandian, Titanites; Genotype, Holotype 

liig. I

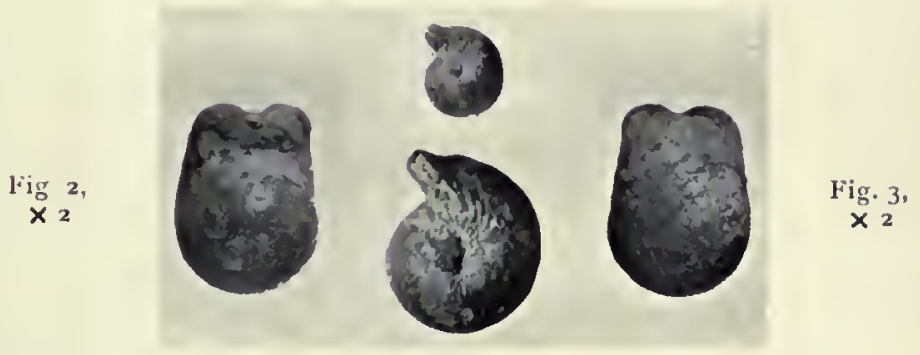

Fig. เa, $\times 2$

SPATROCERAS BRONGNiaRTi; S. BuckMAN, I88I, cit. spec.

Q.J.G.S., XXXVII, 597 ; "Sherborne, Dorset, I.O. Humph. z." S.B., ex J.B., Coll. 3502 ; S. $(575,57,103,-)$ ? ; 8.5, 50, 73, I 7

Mlax. 9. Perhaps one of the smallest Jurassic Ammonites

SPHAROCERAS TUTTHUM, NOV.

Bajocian, niortensis; Holotype 


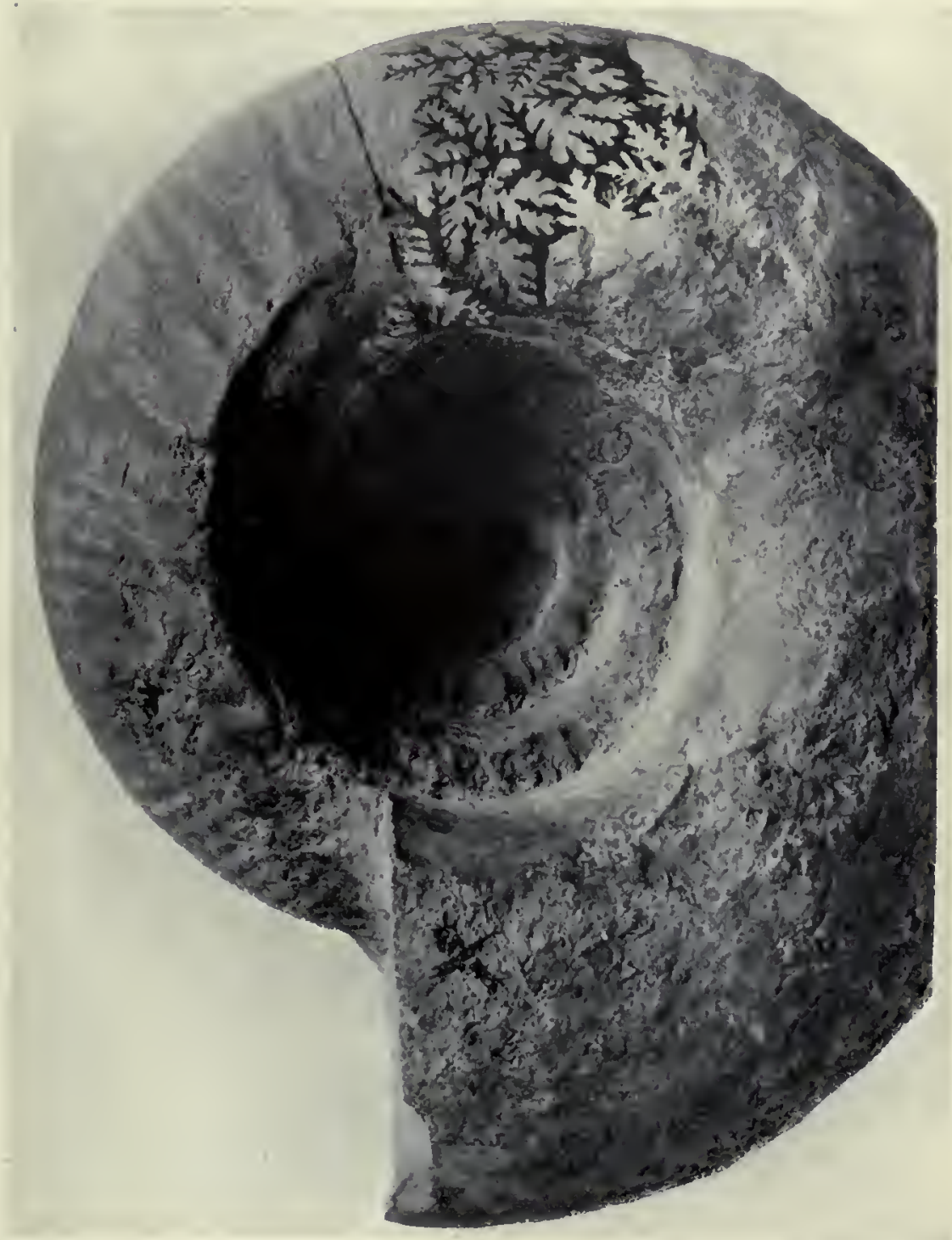

Ammonites sub-Contractus, J. Buckman, 1875, cit. spec. ?

'Ceph. Bed '; Proc. Som. Arch. \& N.H. Soc., XX, I49

"Hall's Quarry, Bradford Abbas, Dorset; Fuller's Earth Rock" Hall's Qy. = Vicarage Qy., S.B., Q.J.G.S., XLIX, I893, 486, § II, [2 ?])

ZIGZAGICERAS POLLUBRUM, NOV. Eningenian, fusca (pollubrum) ; Holotype. Cf, CLIII 

Fig. I

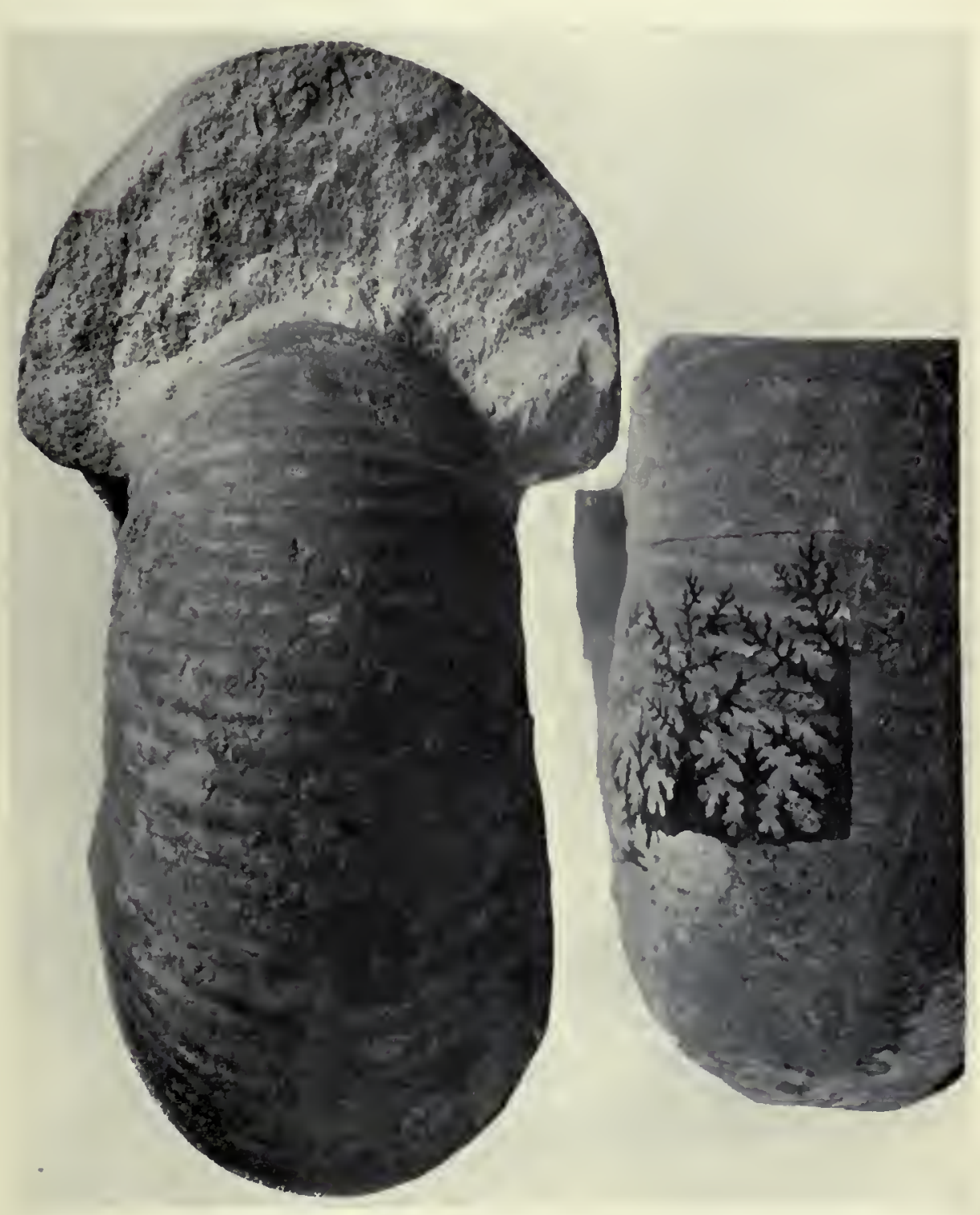

Fig. 2

Amonites sub-Contractus, J. Buckman, I875, cit. spec.?

"Found in B. A. village, from top beds?" Orig. lab.

[Hall's Qy.], Bradford Abbas, Top beds [I.O.] ; S.B., ex Darell, Coll. I I54 S. $91,32,54,43 ;$ I $53,36,54,38$; $\max$. c. 255

ZIGZAGICERAS POLLUBRUM, NOV. Eningenian, fusca, (pollubrum) ; Holotype 

Fig. 2

Fig. Ia

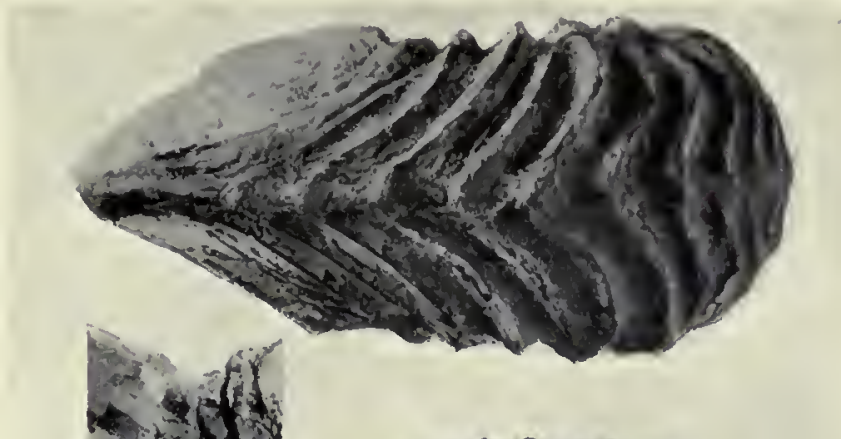

Fig. I
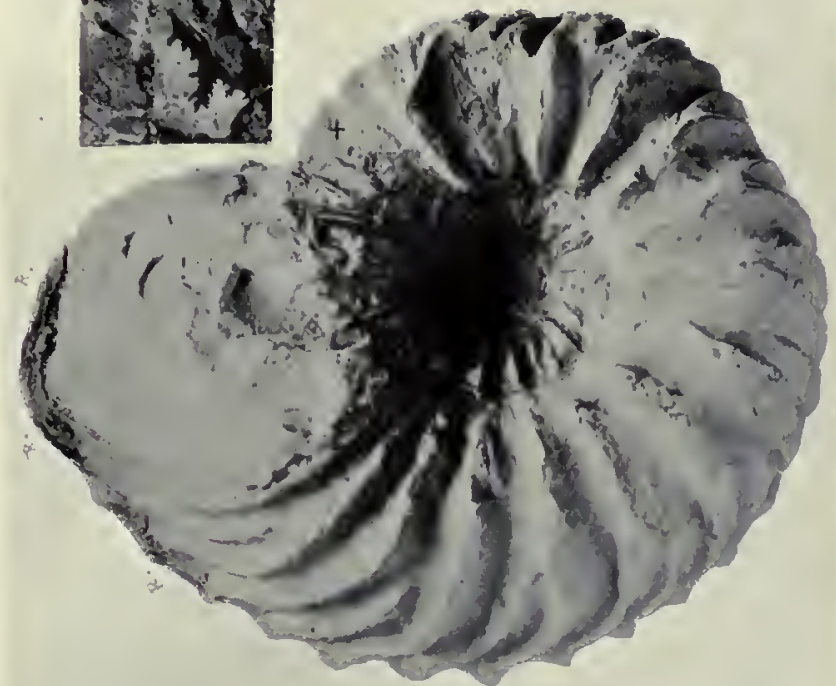

Fig. 3

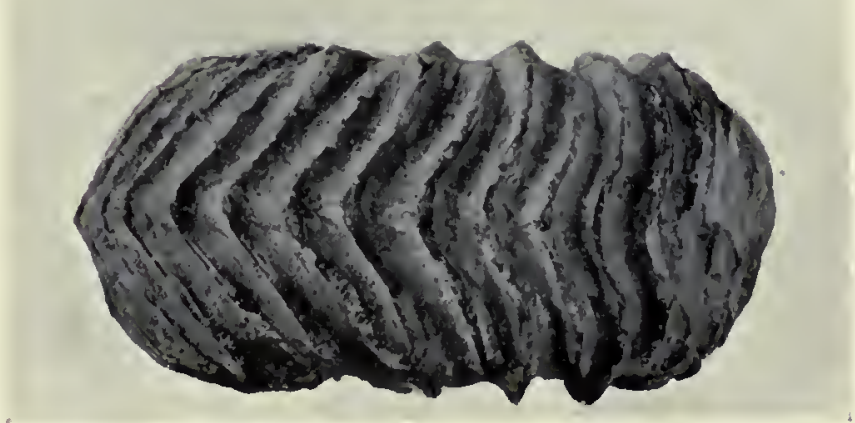

Amonites omphaloides; T. H. Huxley, I865, cit. spec.

Cat. Foss. Coll. Mus. Pract. Geol., p. $24 \mathrm{I}$; "Weymouth, Dorset

" Oxford Clay," bluish calcareous; Geol. Surv. Engl. Coll., 3037 I

S. 5 I , 43, $63(57), 3 I^{\circ} 5 ; 68,43,53(45), 30 ; \max$. c. 79. R., slightly restored

SAGITTICERAS SAGITTA, S. BuCKMAN, I920, p. I9 Argovian, pre-Goliathiceras; Genotype, Holotype. Cf. CXCVIII 
Fig. I

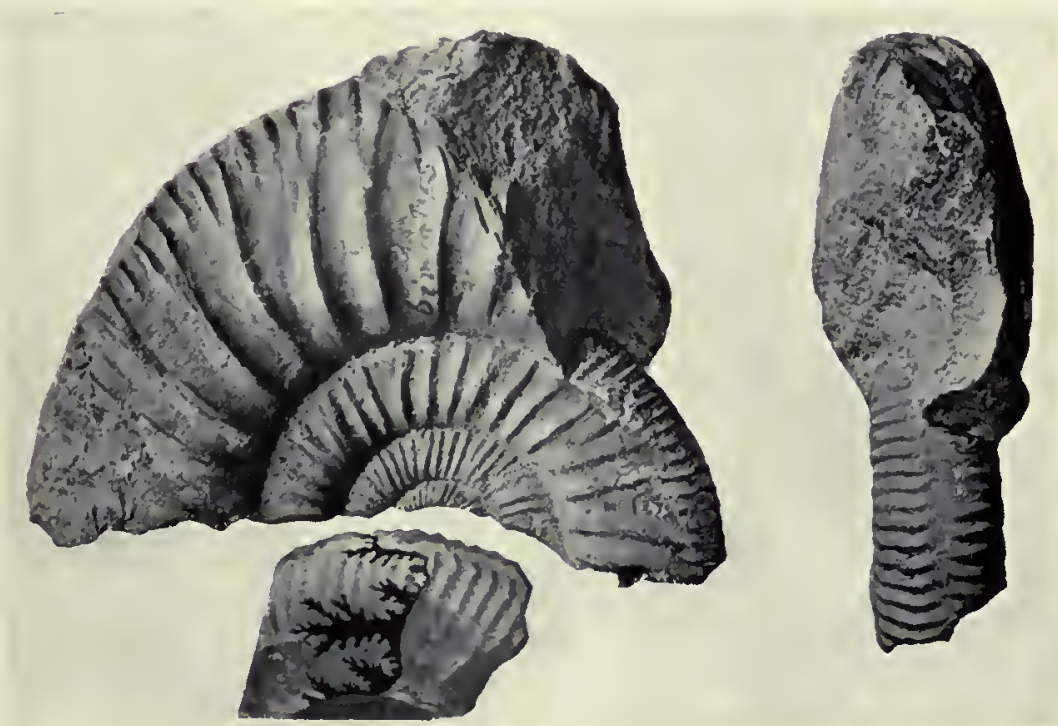

Fig. 3
Fig. 2 
Fig. I

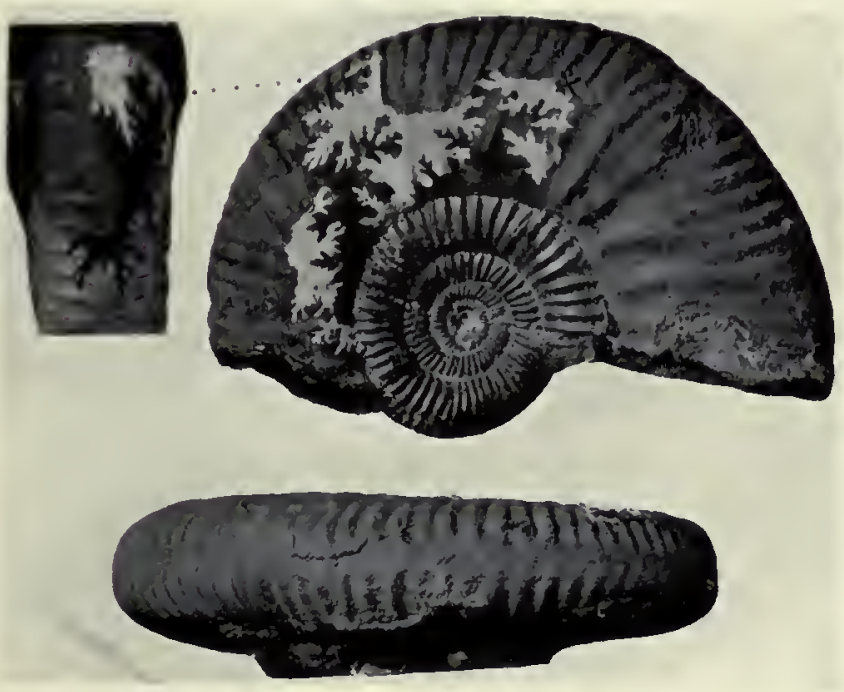

Fig. 2

Amonites binatus, Bean MS. (Leckenby, I859, Syntype) Q.J.G.S., XV, pp. 7, ro ; "The Castle Rock, Scarborough, Yorkshire" "Kell. Rock" ; (grey-brown sandstone) ; Sedgwick Mus., Cambridge S. $33,30,29,44 ; 63,32,25,41$; $\max$. c. II

BINATISPHINCTES BINATUS, BEAN-LECKENBY SP. Callovian, athleta; Paralectotype 

Iig. I

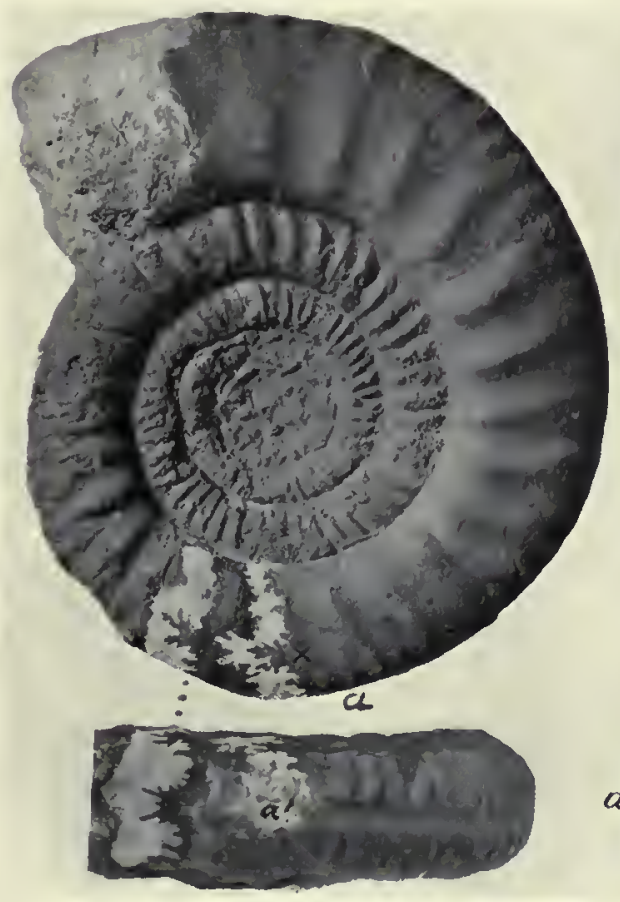

Fig. 2a lig. 2

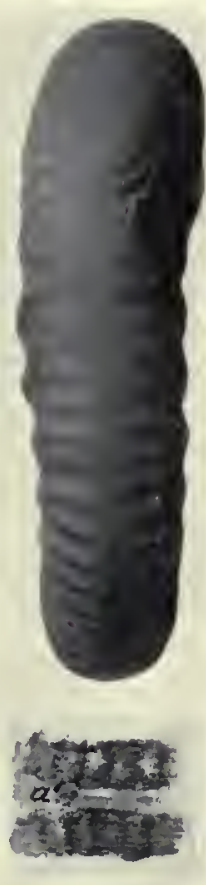

I.ig. $2 b$

Ammonites binatus, Bean MS. (Leckenby, I859, Syntype) Q.J.G.S., XV, 7, 10 ; "The Castle Rock, Scarborough, Yorkshire" "Kell. Rock" (brown and irony, with ool. grs.); Sedgwick M., Cambridge S. $52,24,26,54$, c. 38 ribs; S. $73,29,25,52 ; 28$ ribs; max. c. 85

HAMULISPHINCTES HAMULATUS, NOV.

Callovian, athleta; Genotype, Holotype. Cf. CCLXI 

Fig. I

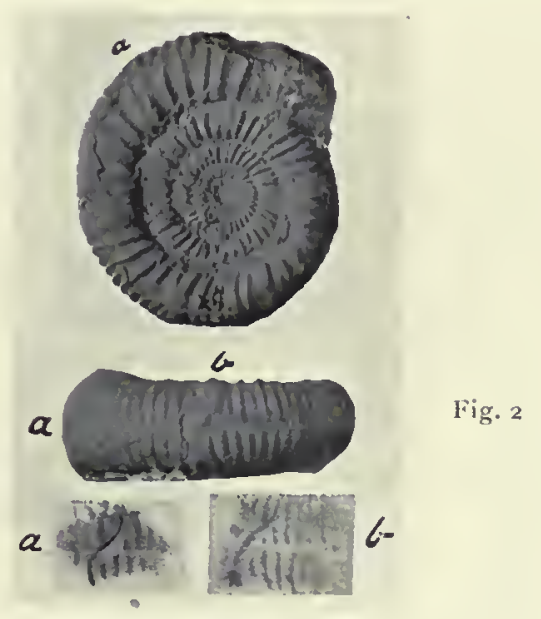

Fig. $2 \mathrm{a} \quad$ I*ig. $2 \mathrm{~b}$

Amonites binatus, BEan MS. (Leckenby, I859, Syntype) Q.J.G.S. XV, 7, Io ; "The Castle Rock, Scarborough, Yorkshire" "Kell. Rock" (grey sandst., with irony pieces); Sedg. M., Cambridge S. $30,25,32,55$; 39 ribs ; 6 parabolic, on last whorl

HAMULISPHINC'TES HAMULATUS, Nov. Callovian, athleta; Paratype 

Fig. 3
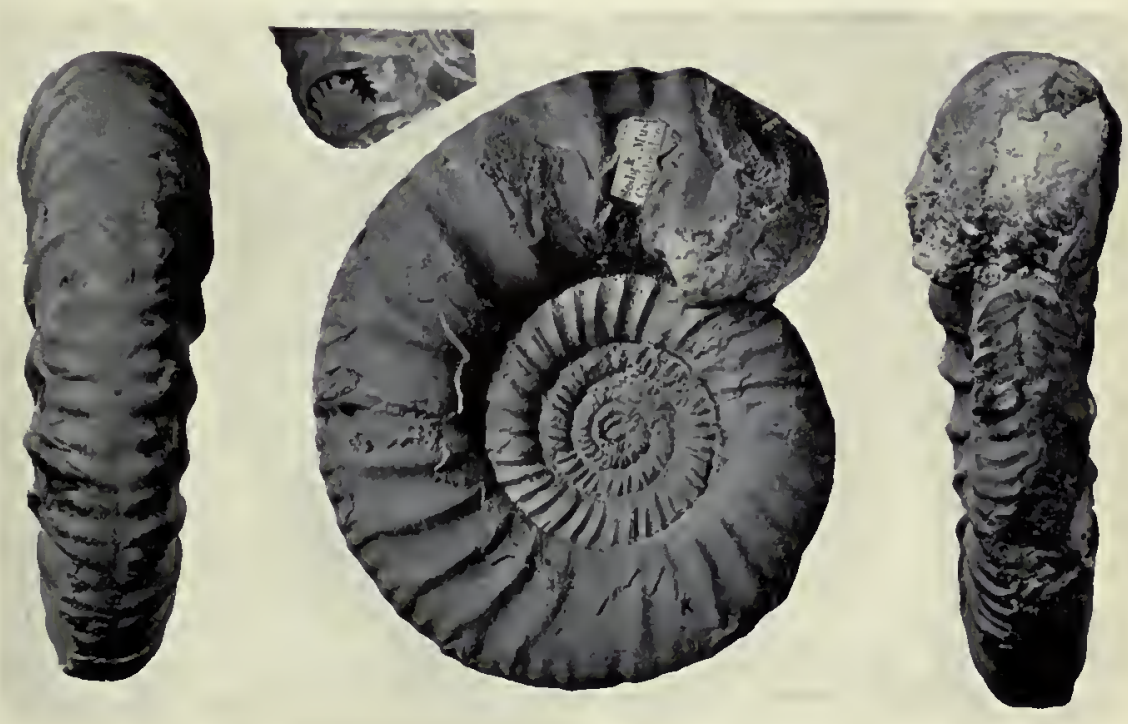

Ammonites binatus, Bean MS. (Leckenby, I859, Syntype) Q.J.G.S., XV, 7, Io ; "The Castle Rock, Scarborough, Yorkshire" "Kell. Rock" (hard grey sandstone) ; Sedgwick II., Cambridge S. $38,27 \cdot 5,26,47 ; 35$ ribs; S. $65,33,29,44 ; 26$ ribs; max. 66

HAMULISPHINCTES AURICULA, NOV.

Callovian, athleta; Holotype. See CCLXII 



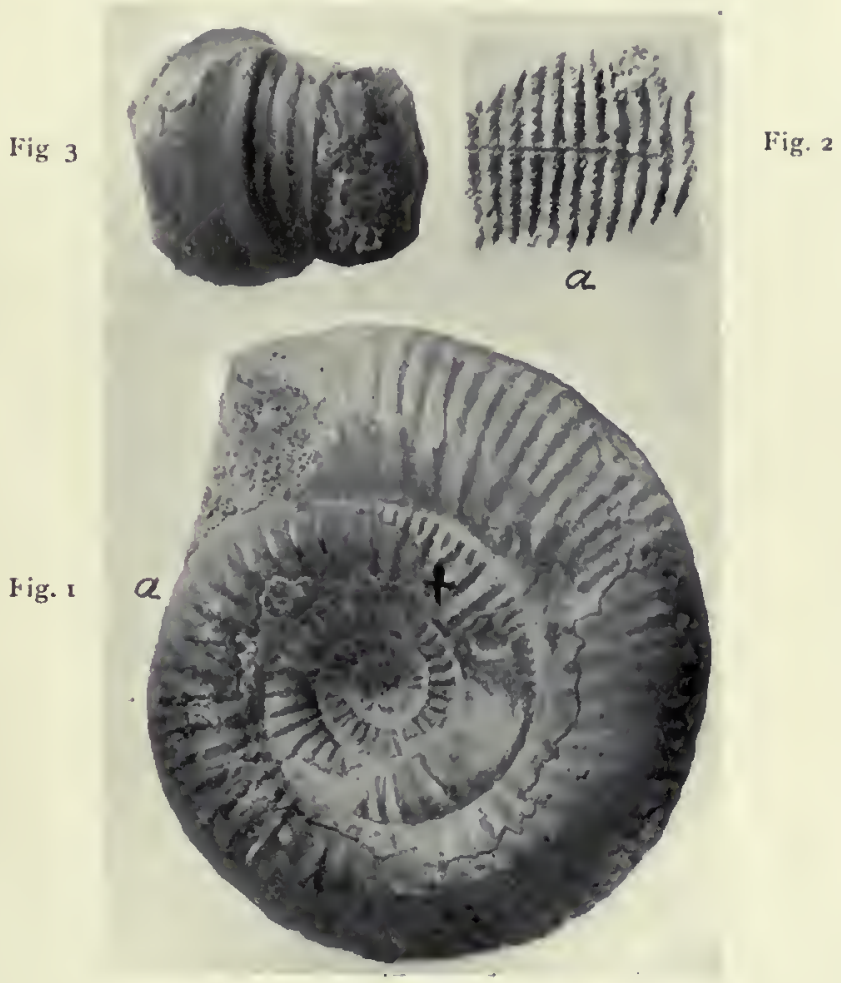

Cf. Perisphinctes inglos, de Gregorio "Bradford Abbas, Dorset. Inf. Ool., Foss. Bed [Mid. part]" S.B., ex J.B., Coll. 3570 ; S. 45 5, 32, 52, $43 ; 67,26.5,36,5 \mathrm{I} ; \mathrm{Max} .72$ F. 3, Id., 357 I, Mouth, raised band. See Perisph. Docid. III, 28

DOCIDOCERAS PLANULATUM, NOV. Bajocian, discites (Eudmetoceras) ; Holotype. See CXXXIII 



\section{Fig. :}

$\times 0.38$

Fig. 2
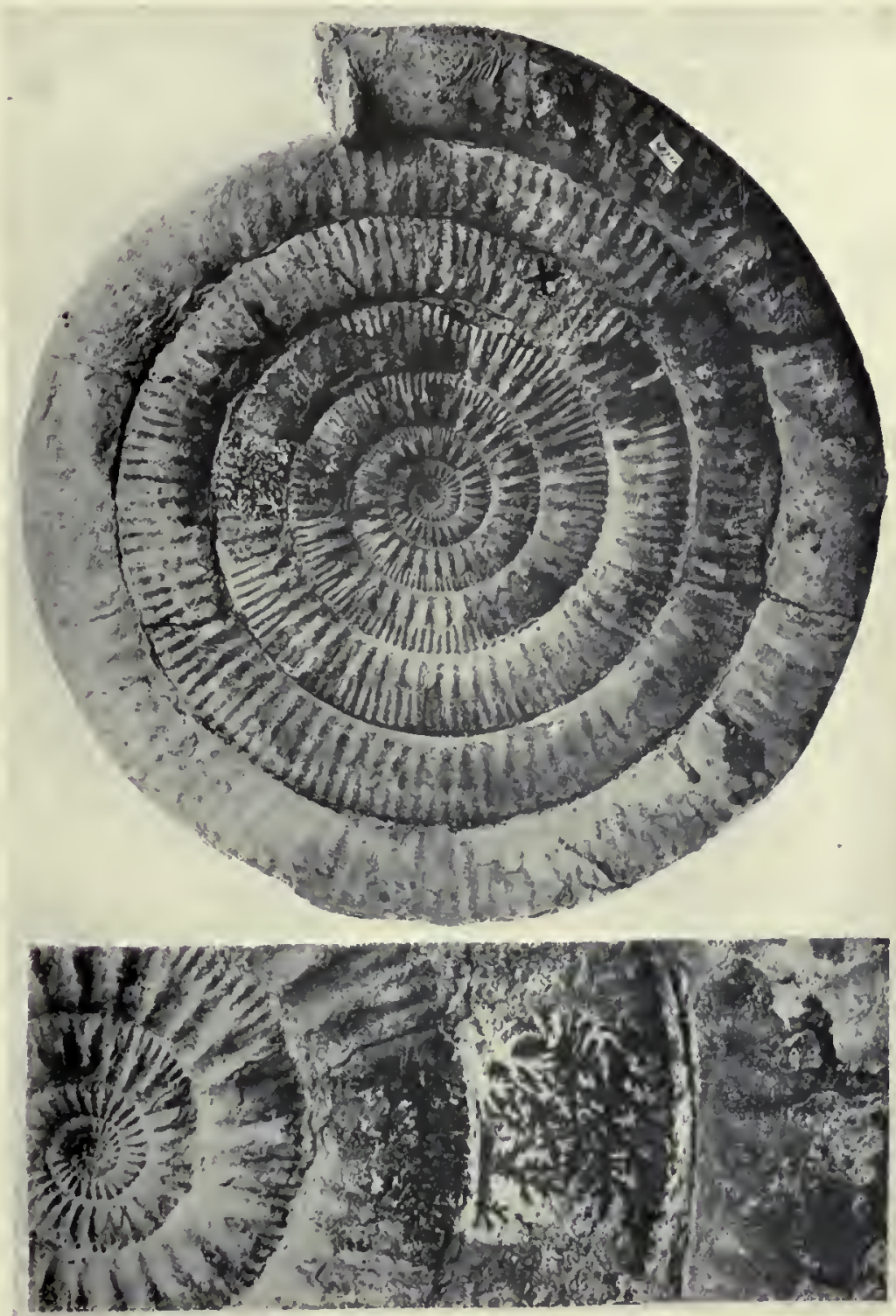

Stephanoceras of Bayleanum-type, S. Buckman, i 896 , cit. spec. Q.J.G.S., LII, 68o, §IV, 5 ; " Dundry, Somerset. I.O., ironshot bed" S. B. Coll. 2174 ; S. I29, 24, 2 I'5, 56 ; 4 I ribs; S. 2 I 8, I3.5, I 5,75 S. $277, \mathrm{I} 4, \mathrm{I} 45,75$; c. 85 ribs; $\max .282$. Body-ch. $2 \frac{1}{8}$ whorls

CECOSTEPHANUS DOLICHCECUS, NOV.

Bajocian, saltze; Genotype, Holotype. Cf. CCL 

Fig. 1, 0.52

Fig. $2 \times 0.62$

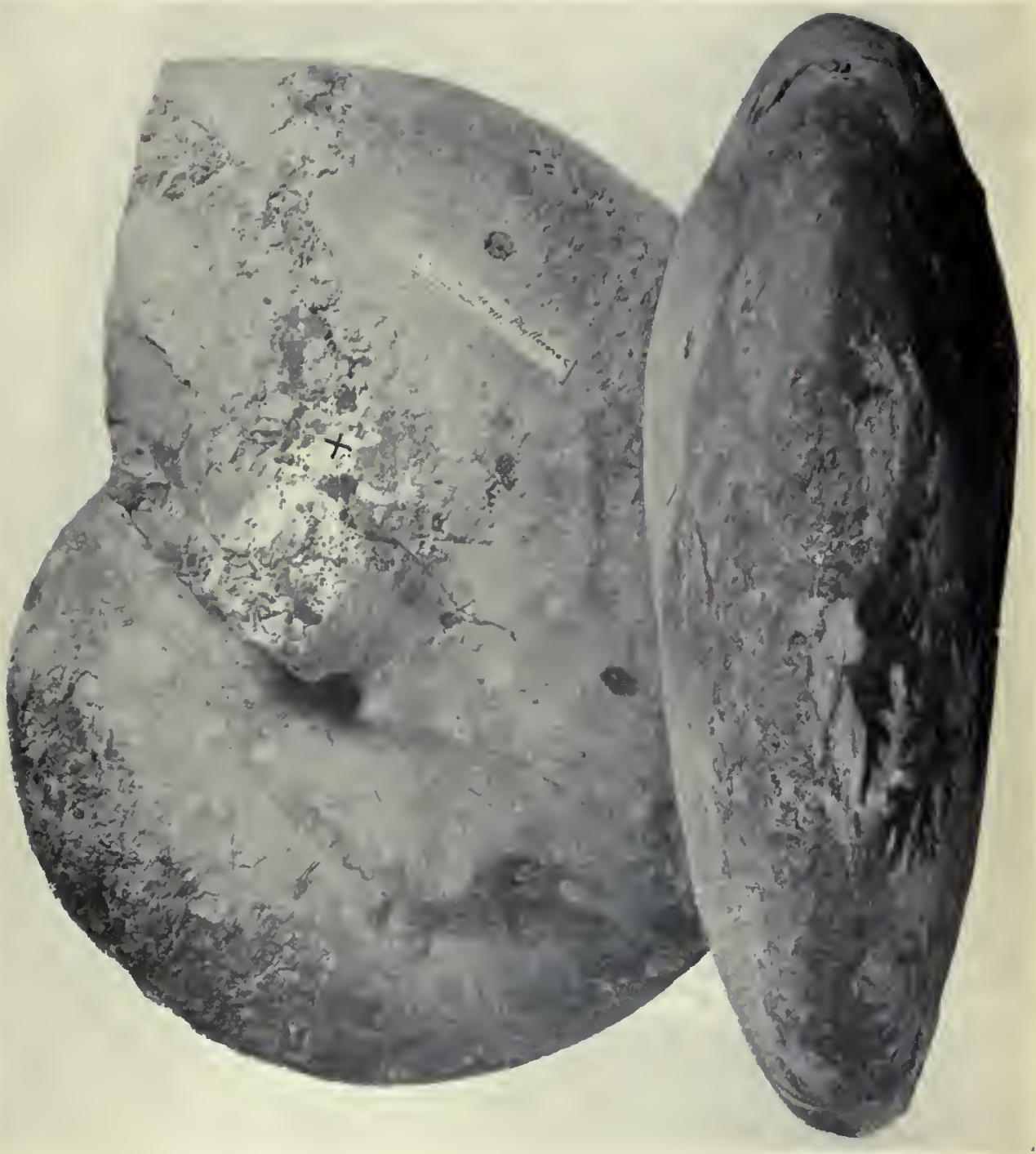

Phylloceras aff. Vilpui, de GREgorio

"Stoford, Somerset ; Sandrock of Yeovil Sands, moorei"

S. B. Coll. 7 II ; S. I $21,59,34,(425$ ?)

S. $252,59,32.5,3$; max. c. 390

XEINOPHYLLOCERAS XEINUS, NOV. Yeovilian, moorei; Genotype, Holotype. Cf. CCXXXIII 


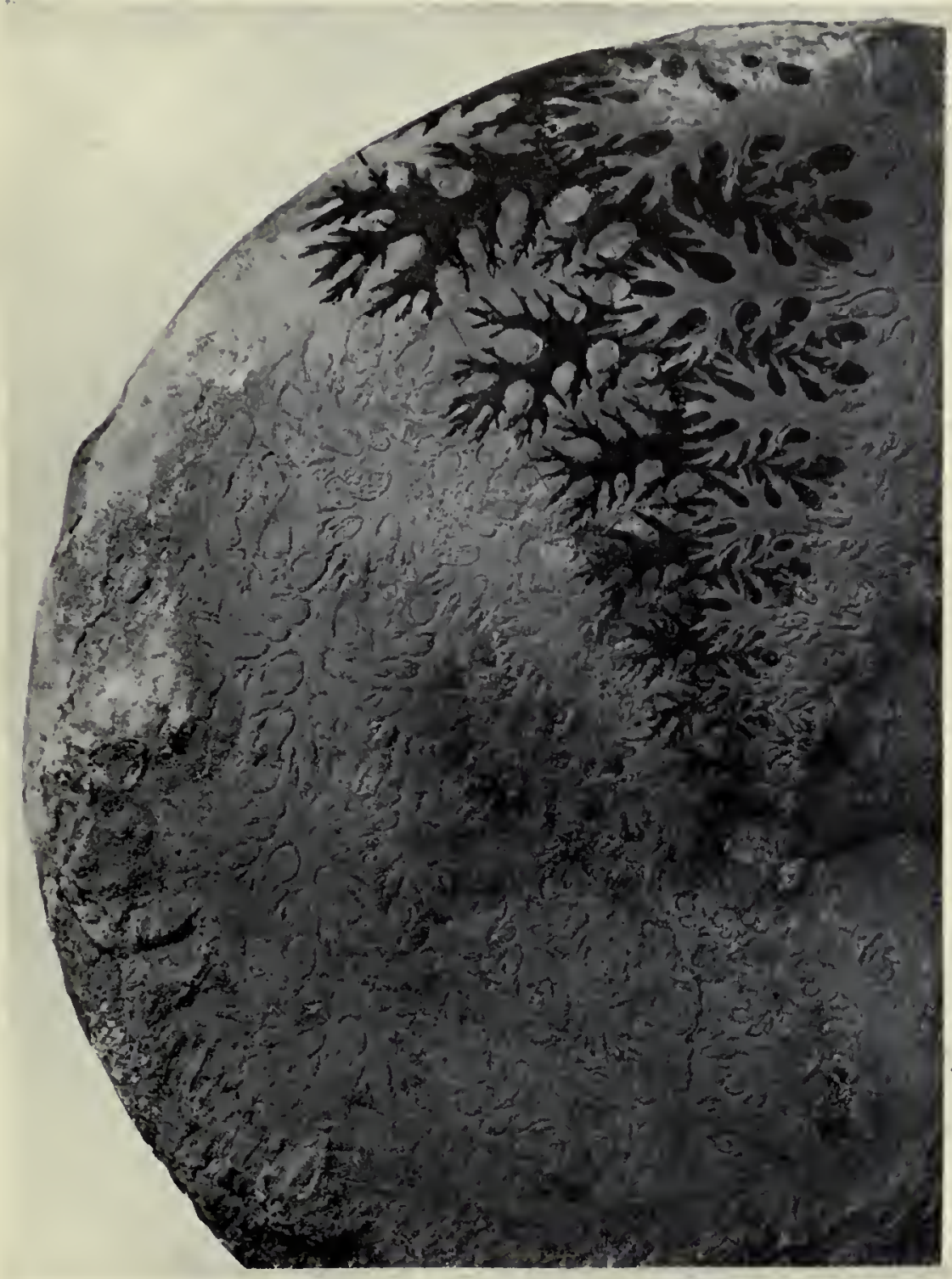

Phylloceras aff. VILPUM, DE GREgorio

"Stoford, Somerset; Sandrock of Yeoril Sands, moorei" (See S. B., "Sands'; Q.J.G.S., XLV, I889, 450, § vil1) Cast shows slight constrictions at intervals. EL very short

XEINOPHYLLOCERAS XEINUS, Nov. Yeovilian, moorei; Genotype, Holotype 





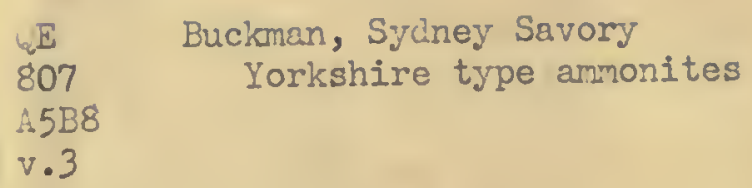

PLEASE DO NOT REMOVE CARDS OR SLIPS FROM THIS POCKET UNIVERSITY OF TORONTO LIBRARY 


